\title{
Percorrer \\ cidade \\ a \\ pé \\ > ações teatrais e performativas \\ no contexto urbano
}

Verônica Gonçalves Veloso

São Paulo 



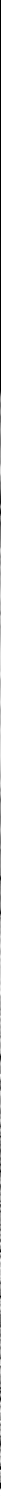

\section{Percorrer cidade \\ pé \\ >> ações teatrais e performativas \\ no contexto urbano}

Verônica Gonçalves Veloso

São Paulo 

UNIVERSIDADE DE SÃO PAULO

ESCOLA DE COMUNICAÇÕES E ARTES

DEPARTAMENTO DE ARTES CÊNICAS

Percorrer a cidade a pé ações teatrais e performativas no contexto urbano

\section{Verônica Gonçalves Veloso}

Tese apresentada ao Departamento de Artes Cênicas da Universidade de São

Paulo para obtenção do título de Doutora em Artes Cênicas.

Versão corrigida (versão original disponível na Biblioteca da ECA/USP)

Área de Concentração: Pedagogia do Teatro

Orientadora: Profa. Dra. Maria Lucia de Souza Barros Pupo

São Paulo 
Autorizo a reprodução e divulgação total ou parcial deste trabalho, por qualquer meio convencional ou eletrônico, para fins de estudo e pesquisa, desde que citada a fonte.

Catalogação na Publicação

Serviço de Biblioteca e Documentação

Escola de Comunicações e Artes da Universidade de Săo Paulo Dados fornecidos pelo(a) autor(a)

Veloso, Verônica Gonçalves

Percorrer a cidade a pé: açōes teatrais e performativas no contexto urbano / Verônica Gonçalves Veloso. - São Paulo:

V. G. Veloso, 2017.

422 p.: 11 .

Tese (Doutorado) - Programa de Pós-Graduação em Artes Cênicas - Escola de Comunicaçōes e Artes / Universidade de Săo Paulo.

Orientadora: Maria Lúcia Bupe

Bibliografia

1. teatro performativo 2. performance 3, daminhar 4 . espectador 5 . cidade I. Pupo, Maria Lúcia II. Títula.

CDiD 2i,ed, - 75: 
FOLHA DE APROVAÇÃO

Verônica Gonçalves Veloso

Percorrer a cidade a pé - ações teatrais e performativas no contexto urbano

Tese apresentada à Escola de Comunicações e Artes da Universidade de São Paulo para obtenção do título de Doutora em Artes Cênicas. Área de Concentração: Pedagogia do Teatro.

Aprovada em:

\section{Banca Examinadora:}

Prof. Dr.

Instituição: Assinatura:

Prof. Dr.

Instituição: Assinatura:

Prof. Dr.

Instituição: Assinatura:

Prof. Dr.

Instituição: Assinatura:

Profa. Dra. Maria Lúcia de Sousa Barros Pupo Instituição: ECA/USP Assinatura: 


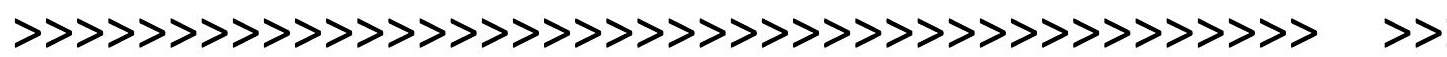



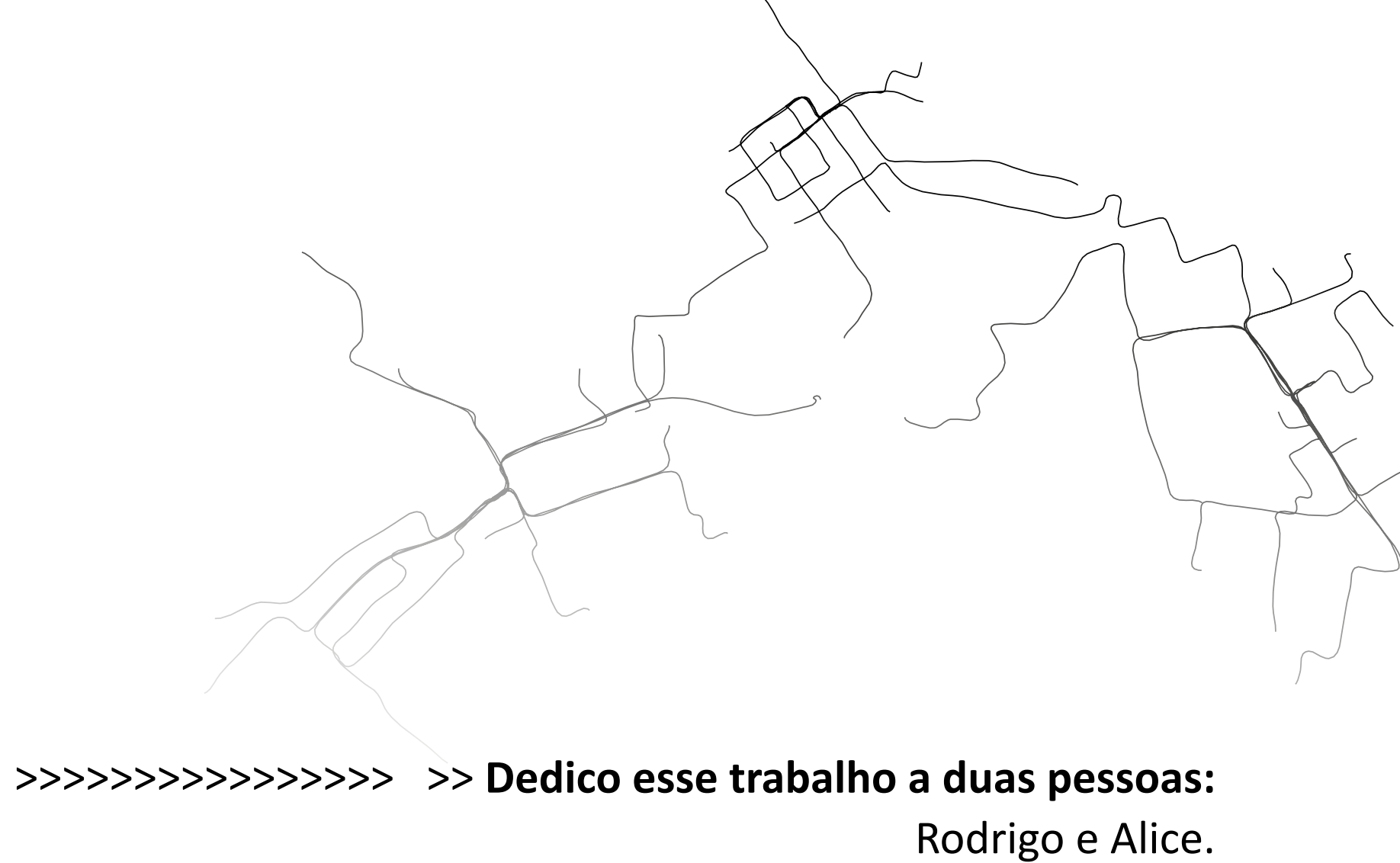

A ele por criar oportunidades para que eu me dedicasse ao estudo, por compreender minha necessidade de isolamento, minhas horas de biblioteca e meu tempo de revisão profunda de diversos aspectos da vida. E ainda assim, mantendo-se firme e inteiramente, ao meu

lado.

A ela por inventar brincadeiras silenciosas, que muitas vezes consistiam em deslocamentos, em idas e vindas, me mostrando o quanto o caminhar se configura também como um disparador de processos do imaginário, um poderoso dispositivo de fabricação de histórias. Por aprender outras formas de viver junto, respeitando generosamente o meu modo de estar presente apenas fisicamente. O corpo de sua mãe foi repetidamente representado em seus desenhos de criança, como um corpo visto atrás de uma cadeira, cercado de livros, e olhando fixamente para um computador. Sua aceitação dessa mãe ausente me ajudou a (re)estabelecer nossos limites e a redimensionar minha entrega aos momentos exclusivamente dedicados a ela.

Sem esses dois retratos do amor, nada disso seria possível. 


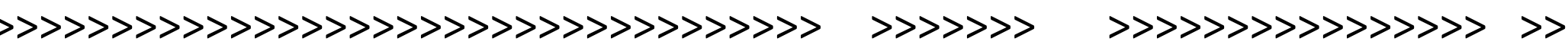




\section{>>>>>>>>>>>>>>>>> $\quad>>>>>>\quad>>>>>>>>>>>>>>>~>>$ Agradeço}

A minha orientadora, Maria Lúcia Pupo, por indicar caminhos e por colocar janelas diante dos meus horizontes tão vastos, por confiar nos meus passos e por me dar a mão nos momentos em que eu me sentia demasiadamente à deriva.

Aos meus pais, meus irmãos e minha família, por me darem suporte para estudar e por acreditarem nos meus sonhos.

Ao Coletivo Teatro Dodecafônico, em especial a Beatriz Cruz e Sandra Ximenez, por experimentar comigo, por caminhar junto ora se perdendo, ora atravessando territórios que chegam a toda a extensão dessa cidade-continente. Lulu Kema, Damyler Cunha, Felipe Julian, Hideo Kushiyama, Monica Galvão, Nathália Imbrizi, Olívia Niculitcheff, Papá Fraga, Vânia Medeiros e todos que derivaram com o Coletivo: vocês convocaram o meu corpo, ouviram os meus chamados e me mostraram tanto, que eu não chegaria a ver se eu não andasse

acompanhada.

A Helena Albuquerque, pelas traduções e correções das minhas traduções do inglês. A Eleonora Fabião e Antonio Araújo, pelas ricas contribuições no Exame de Qualificação.

A Josette Féral, por me receber e orientar meus caminhos em território francês. A Raphaëlle Doyon pelo convite para intervir em seu curso na Paris 8, compartilhando essa pesquisa e transformando a rua em sala de aula.

A Universidade de São Paulo e aos professores do Departamento de Artes Cênicas. A Capes, por financiar essa pesquisa tanto no Brasil como com a Bolsa de Doutorado Sanduíche no exterior.

Aos meus amigos, sem os quais eu não saberia quem sou. A Ana Petta e Paula Klein, pelos nossos sabiás; a Taty Kanter, pelas ajudas incondicionais; a Jorge Wakabara, Katia Lazarini, Paulina Caon e Roberto Borges por nossas redes de suporte e afetos; a André Mourão, Anna Ten, Anne-Sarah Faget, Juliana Jonson, Maria Clara Ferrer, Marina Takami, Regis Mikail Filho e Rodrigo Scalari, pelas derivas parisienses e outras de pensamento; a Andrea Caruso, Julia Guimarães Mendes e Filipe Brancalião, pelas trocas possíveis apenas a quem compartilha dos mesmos caminhos; a Lu Carion e Marcos Bulhões, por me alimentarem sempre; a Ernesto Valença e Joaquim Gama, por me moverem; a Juliana Pugliesi, Marília Rocha e Renata Godoy, por me mostrarem outras formas de estar perto; a Maria Brandão, pelo cuidado; a Rui e Maíra, por me mostrarem o poema do Augusto de Campos. 
A presente pesquisa visa observar o modo de operar da arte contemporânea fundada no caminhar e investigar o quanto ela se faz acessível ao espectador, o quanto ela é inclusiva, relacional e horizontal. Contrariamente a um entendimento de que a arte contemporânea é de difícil acesso, nosso objetivo é relacionar a dissolução de certos estatutos da cena contemporânea com a aproximação do espectador de sua estrutura de funcionamento, a ponto de ele se tornar mais indispensável para sua realização do que o próprio artista.

No primeiro capítulo, apresento esse contexto de dissolução (como linhas invisíveis do mapa), inicialmente no campo do teatro e, posteriormente, na configuração das performances, campo no qual as noções de cena, encenação e espectador já não operam. No segundo capítulo apresento o ato de caminhar em relação ao pensar e ao criar; uma prática estética e política a ser desdobrada nos três capítulos seguintes. Desse modo, do segundo ao quinto capítulo observo modalidades do caminhar: passeios, derivas, fugas, perseguições e travessias realizadas por artistas de diversas procedências (do teatro à land art, da dança à arte conceitual, da performance ao real) e, em alguns casos, por espectadores ou

passantes.

Todas essas ações, sobretudo as performances, resultam em outras materialidades (fotografias, vídeos, desenhos e narrativas) que são igualmente compartilhadas com espectadores ausentes do ato de sua execução. No último capítulo, trato desses rastros ou vestígios - bem como do acesso aos programas dessas ações - como um importante material para os espectadores, que conhecendo os "modos de fazer" dessas modalidades artísticas, compreendem seus "modos de usar". Assim, caminhar como prática estética configura-se como um ato de transgressão do sistema vigente, uma vez que se trata não apenas de uma ação, mas de uma atitude ao alcance de toda e qualquer pessoa. Ao ocupar o contexto urbano por sua dimensão mais baixa, o chão, o sujeito que caminha experimenta outras formas de sociabilidade e outras configurações para o real, inventando micro-poéticas do devir.

\section{palavras-chave:}

teatro performativo - performance - caminhar - espectador - cidade 
> $>>>>>>>>>>>>>>>>>>>>>>>>>>>>\quad>>>>>>\quad>>>>>>>>>>>>>>>$ 


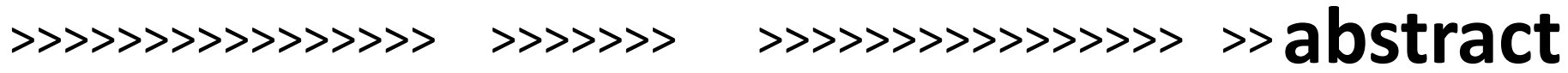

This research aims to observe the way contemporary art founded on walking works and to investigate how much it is accessible to the public, how much it is inclusive, relational and horizontal. Contrary to an understanding that contemporary art is difficult to access, our goal is to relate the dissolution of certain contemporary scenes statutes with the spectator's approach of its functional structure, to the point that he becomes more indispensable for its accomplishment than the artist himself.

In the first chapter, I present this context of dissolution (as invisible lines of the map) initially in the theater field and, posteriorly, in the configuration of the performances, a field in which the notions of scene, staging and spectator no longer operate. In the second chapter, I present the act of walking in relation to thinking and creating; an aesthetic and political practice to be deployed in the three following chapters. Thus, from the second to the fifth chapters, I observe walking modalities: strolls, drifts, escapes, persecutions and crossings by artists of different origins (from theater to land art, from dance to conceptual art, from performance to real) and, in some cases, by spectators or bystanders.

All these actions, particularly the performances, result in other materialities (photographs, videos, drawings and narratives) which are equally shared with spectators absent from the act of its realization. In the last chapter, I deal with these traces or vestiges - as well as the access to the programs of these actions - as an important material for the spectators, who getting to know the "ways of doing" of these artistic modalities, understand their "ways of using". Therefore, walking as an aesthetic practice configures itself as an act of transgression of the current system, since it is not only an action, but an attitude within the reach of any person. By occupying the urban context in its lower dimension, the ground, the subject who walks experiences other forms of sociability and other settings for the real, inventing micro-poetics of devenir.

\section{key words:}

performative theater - performance - walking - spectator - city 



\section{> sumário > passo a passo}

> introdução - cartografias poéticas e itinerários de uma pesquisa $-p .23$

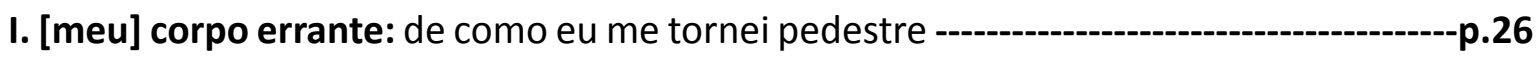

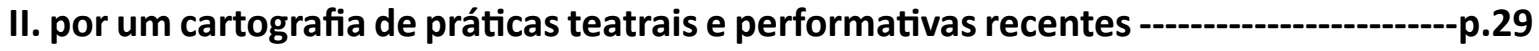

III. algumas noções fundamentais para percorrer esse itinerário ----------------------------p.36

IV. sobre os capítulos que se seguem ou as múltiplas entradas nessa cartografia -------p.38

capítulo um - a cena contemporânea e as linhas invisíveis do mapa ----------p.43

I. encenação em deriva: da instauração do jogo à dissolução da encenação --------------p.45

II. aquele que passa por mim: do espectador como princípio ativo à sua dissolução ----p.69

III. o território do real e o princípio do acontecimento: a dissolução da obra de arte ---p.90

> capítulo dois - o ato de caminhar e o flanar no contexto urbano -------------p.107

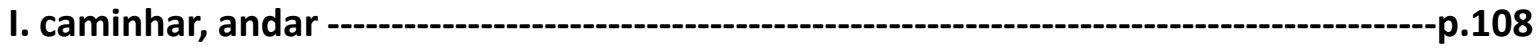

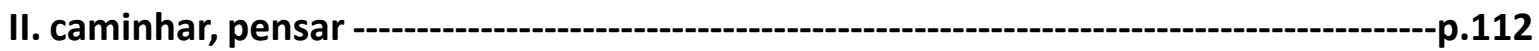

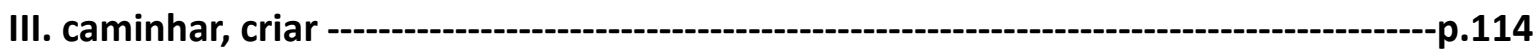

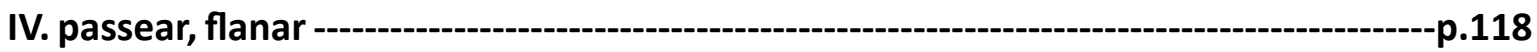

_o flâneur e o Homem da Multidão

_Paris: do passeio ao bulevar, das passagens às lojas de departamento

_o flâneur e a invenção da vida moderna: a cidade como literatura

_quando os artistas levam tartarugas pra passear

_quando se passeia no nível baixo

_quando flanar acontece no feminino

capítulo três - derivas situacionistas e outras formas de perder-se -----------p.151

I. derivas situacionistas e a exploração do acaso ---------------------------------------------p.152

_a deriva como ato estético e político [primeiro estudo sobre a participação]

_Guy Debord e a superação da arte: do Movimento Letrista ao Movimento Situacionista 
_situação construída: a prática (performática) dos Situacionistas

_deriva como prática dadaísta ou surrealista

jogos situacionistas como práticas cotidianas: escândalo, festa e encontro amoroso

_deriva como ação improdutiva: uma interface com o tempo

_deriva como táticas para perder-se ou um modo cinematográfico de olhar a cidade

II. derivas dodecafônicas e outras derivas artísticas

III. fugas e perseguições

_seguir pessoas para explorar outros itinerários

_entre fuga e perseguição: um jogo duplo

_seguir pessoas com o Coletivo Teatro Dodecafônico: uma questão de gênero

>> capítulo quatro - percursos cotidianos e o flanar com fones de ouvido ----p.229

I. quando os artistas se valem de percursos para compor ações

p. 230

_percursos como linhas que atravessam o espaço

_inscrições artísticas como interferência no percurso

_performances que descrevem percursos

_eis-me aqui, metrópole intensa: sobre meus percursos por São Paulo e Paris

II. audiotour: quando passear acontece com fones de ouvido ou quando o artista programa o percurso sonoro

_Janet Cardiff e o efeito de presença

_os percursos sonoros de Janet Cardiff: escrever em três dimensões

_cinema para os ouvidos

_trajetórias guiadas pelo som

> capítulo cinco - travessias de grandes territórios: maneiras poéticas de (con) viver

I. land art: caminhada que se inscreve na terra

II. travessias: recortar a cidade com os pés

_atravessar ou circundar a cidade como um Stalker

_travessia como encontro e despedida

_uma travessia amorosa e outra coletiva com o Dodecafônico 
III. caminhar junto: festa de rua, cortejo, manifestação

_no carnaval e no futebol, a festa é na rua

_protestos, marchas e manifestações

_ocupações, marchas cidadãs e rituais públicos

capítulo seis - depois de caminhar: rastros, vestígios e desdobramentos da prática performativa $-p .345$

I. quando a performance resulta em outras materialidades p.348

_a fotografia como documento primário da performance

_quando a ação performativa se destina para um espectador ausente

_quando a performance resulta em fotografia

_quando a performance resulta em vídeo

_quando a performance resulta em desenhos, textos e outras narrativas

II. quando a performance provoca um efeito de acontecimento $-p .381$

III. quando a performance se desdobra e depois se multiplica [segundo estudo sobre a participação]

considerações finais: caminhar no contexto urbano, um ato de transgressão $-p .399$

I. pequeno ato íntimo contra o embrutecimento $-p .400$

II. um pequeno desvio e os assuntos convergem: a cidade e os seus espaços públicos p.301

III. sobre o espectador e o potencial pedagógico presente nas ações teatrais e performativas $-p .403$

IV. entre a superação da arte e o que queremos, contemporaneamente, que a arte seja $-p .408$ 
Cidade

Augusto de Campos

1963 
atrocaducapacaustiduplielastifeliferofugahistoriloqualubrimendi multipliorganiperiodiplastipublirapareciprorustisagasimplitenave loveravivaunivoracidade

city cité 



\section{Cartografias poéticas e itinerários de uma pesquisa}

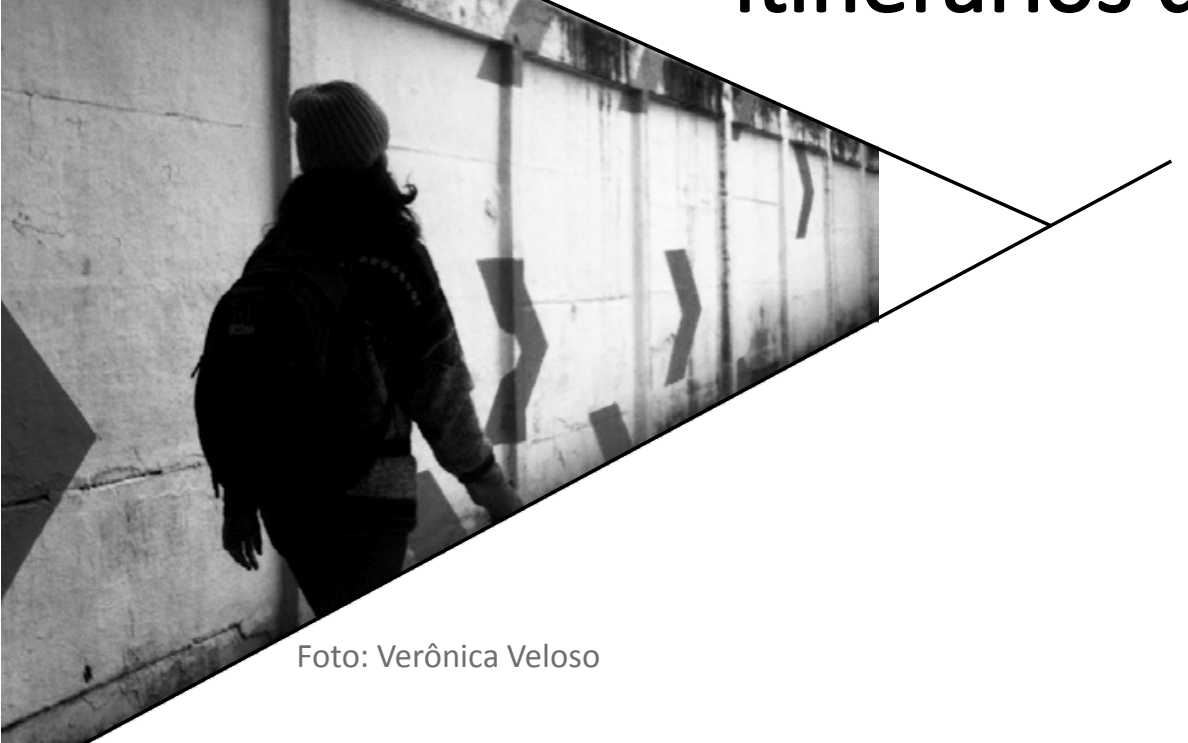

La poésie est dans la rue [A poesia está na rua] Slogan de Maio de $1968^{1}$

Em 1963, o visionário Augusto de Campos retrata em seu poema um projeto moderno de cidade, que atingiu a sua mais perfeita tradução depois dos anos 2000. Nesse projeto, as operações são simultâneas²; um organismo vivo, multifuncional, em rede. As grandes metrópoles do mundo se organizam em torno do capital, dos espaços estriados, da alta velocidade, da conectividade, da continuidade. Se você experimentar ler e reler algumas vezes o poema de Augusto de Campos citado anteriormente em voz alta, terá a exata medida da pluralidade presente na cidade contemporânea. Ela é multifacetada; um espaço de trocas, de fuga, de saga, para destacar algumas palavras que saltam aos meus olhos durante a leitura do poema. Quando o leio, penso em São Paulo. Acontece que as subjetividades que emergem dessa cidade produzem poéticas que questionam tais princípios, reagem a eles e convocam seus habitantes a experimentar outros modos de atravessá-la. "O urbano se distingue da cidade precisamente porque ele aparece e se manifesta no curso da explosão da cidade" (LEFEBVRE, 2016, p. 79). Muitos artistas e espectadores percorrem a cidade a pé, num ato de recusa à velocidade, de apropriação do espaço público, de exploração de outras táticas de sobrevivência e de outros modos de convívio. É adotar uma postura nômade. É traçar rotas descentralizadas, que se contrapõem à métrica da cidade. É inscrever-se no espaço de maneira rizomática.

É possível ler a cartografia de uma cidade e reconhecer o processo de urbanização que ela viveu, pois ideias e ideologias se inscrevem em suas ruas e avenidas. Muitas cidades

\footnotetext{
${ }^{1}$ Localizado na rue Rotrou, próximo ao Théâtre de l'Odéon em Paris.

2 "Enquanto forma, o urbano tem um nome: é a simultaneidade. Essa forma coloca-se entre as formas que se pode estudar discernindo-as de seu conteúdo. Pode ser muito diverso o que a forma urbana reúne e torna simultâneo. Tanto são coisas quanto pessoas, quanto signos; o essencial é a reunião e a simultaneidade" (LEFEBVRE, 2016, p. 80).
} 
brasileiras ainda guardam em seus centros históricos uma estrutura pedestre, com calçadas espaçosas, que conduzem para uma grande praça arborizada. Penso em cidades do interior de São Paulo, como Ribeirão Preto, Bauru, Sorocaba e penso também em Rio Verde - GO. Com o passar do tempo, o casario é progressivamente transformado em estabelecimentos comerciais, escondendo as fachadas antigas e, nos melhores casos, ruas são fechadas para a circulação dos carros. Em cidades de porte médio, como Campinas, Uberlândia e Goiânia, as áreas de urbanização mais recentes apresentam largas avenidas, com escassas faixas de pedestres ou passarelas aéreas, sobre as quais devem atravessar aqueles que ainda insistem na atividade pedestre. Curiosamente, as três cidades citadas são quentes, o que desencoraja essa atividade. Tais avenidas são destinadas para a circulação de veículos particulares, uma vez que o investimento em transporte público não acompanha o nível de expansão das vias de alta velocidade.

Ao expulsar o pedestre da rua, essas novas estruturas urbanísticas visam o máximo controle sobre o espaço público. Longe dos centros empresariais e financeiros, quem não se des-

Figura 1: Slogan Maio de 68

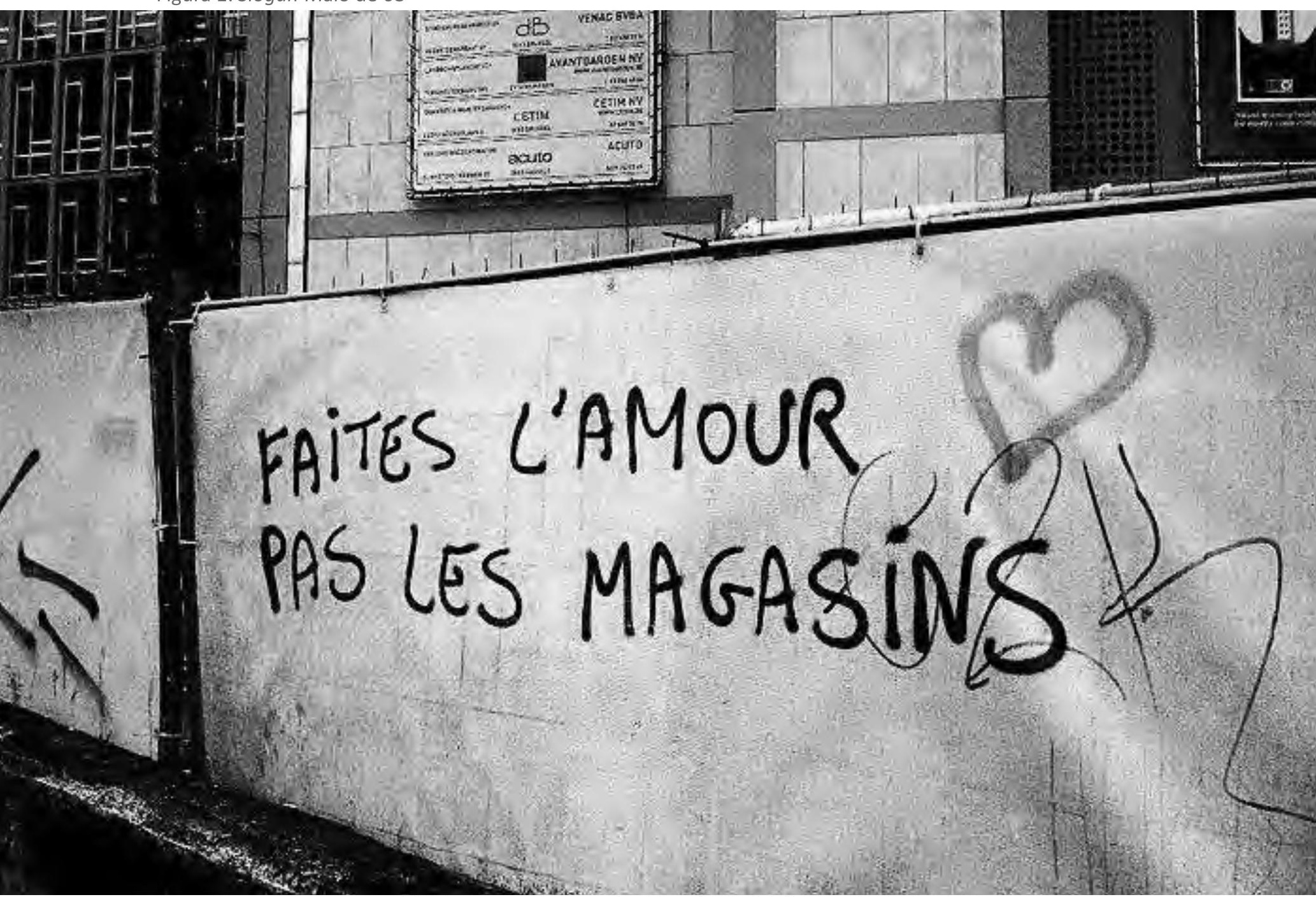

Foto: Disponível em: <http://bichau.canalblog.com/archives/2012/01/13/23233380.html>. Acesso: em 08 mar. 2017. 
loca em veículos particulares acaba confinado em meios de transporte coletivos morosos e precários. Geralmente, essa população que depende do transporte público já não consegue mais viver no centro da cidade, sendo obrigada a deslocar-se por longas distâncias, impossíveis de serem transpostas com a força das próprias pernas. Ao restringir as possibilidades deambulatórias do cidadão, o Estado conduz todo pedestre potencial para dentro dos centros comerciais ou shopping centers, onde os pensamentos evocados durante a caminhada são facilmente convertidos em desejos de consumo. Cada vitrine apresenta ou vende uma promessa de aquisição de um sonho. Identidades e futuros promissores são oferecidos como produtos, num tempo em que educação e saúde são amplamente mercantilizados. Todo cidadão é elevado à categoria de consumidor, à medida em que se perde a noção e o costume com a coisa pública, com o bem comum, com o espaço de livre circulação. Penso em São Paulo, em Goiânia, em Sorocaba e outras cidades do Brasil, nas quais templos do consumo são erguidos com maior frequência que escolas, hospitais, bibliotecas e casas de cultura.

O que se apresenta no Terceiro Mundo é o que Guy Debord imaginou que se tornaria a chamada sociedade do espetáculo, um lugar onde "tudo o que era vivido diretamente afastou-se em uma representação" (2006 p. 766) 33. Um cenário composto pela "tomada de posse do ambiente natural e humano" pela dominação absoluta do capitalismo, e é essa tomada de posse que Debord entendia como urbanismo. Na década de 1960, o autor vislumbrou que o fruto desse urbanismo seriam cidades como essas, que de certo modo seguem um padrão norte-americano, onde impera a lei da mercadoria. Paris talvez tenha sofrido menos com a premonição de Debord, provavelmente por terem sido inscritos sobre aqueles muros, slogans como: "quem consome mais, vive menos" ou "faça amor, não lojas" (como aparece na figura 1). Não que Paris não tenha seus templos do consumo, mas eles ocupam diferentemente o espaço urbano, de uma maneira menos ostensiva que os shopping centers. Penso nas passagens públicas e nas grandes lojas de departamento, além da avenida Champs Elysées e do Quartier Latin. Sem entrar na discussão sobre os espaços cobertos ou fechados, a referida avenida é uma passarela do consumo, porém pedestre, assim como as ruas tortuosas do Quartier Latin. De algum modo, a arquitetura se mantém voltada para o sujeito e não para o transporte em quatro rodas. Diz-se que Paris foi construída para ser observada a cavalo, um ponto de vista que não coincide com andar de bicicleta, nem de ônibus (eles são mais próximos do chão que os nossos), nem mesmo a pé. Porém, foi nessa cidade, onde hoje é possível se deslocar de todas essas maneiras, menos a cavalo, que se disseminaram os pensamentos situacionistas. Eram muitas as pichações contrárias à mercantilização do corpo e da vida.

Caminhar unifica os homens, pois a ação pedestre é inicial, não depende de nenhuma pos-

\footnotetext{
${ }^{3}$ Tout ce qui était directement vécu s'est éloigné dans une représentation (tradução minha).
} 
se, apenas da plenitude do corpo. Caminhar coloca a todos na mesma posição, sem herói, sem espectador e sem autor. Caminhar na cidade é misturar-se nela, sem enxergá-la e ainda assim, colaborando com os fluxos humanos que a constituem. O emaranhado de itinerários de cada habitante da cidade se configura como seu pulso constante; ele está para a cidade, como o sangue está para o corpo humano. São as formigas que tornam um formigueiro visível; sem elas, o formigueiro não passa de um monte de terra oco, perfurado por entradas e saídas imperceptíveis. A rua como espaço de circulação e como principal via desses fluxos não existiria caso os pedestres se ausentassem dela. Vale ressaltar que a exclusão dos pedestres do espaço público compromete gravemente o exercício coletivo da democracia.

$>$ I. [meu] corpo errante: de como eu me tornei pedestre

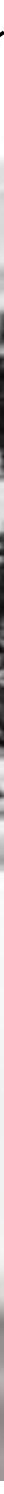

Figura 2: Intervenção urbana Coletivo Teatro Dodecafônico

Foto: Cacá Bernardes

Caminhar na cidade faz corpo, toma corpo e dá corpo às ambiências urbanas. Para falar da relação estreita entre corpo e cidade, das múltiplas implicações que esses dois agentes provocam um no outro, não posso deixar de me colocar como corpo. Ao estudar diferentes 
modos de caminhar, presentes nas mais diversas práticas teatrais e performativas, o meu próprio corpo foi colocado em questão. Qual a relação do meu corpo com essa prática? 0 quanto caminho ou me proponho a caminhar? Quais escolhas, afetos e construções presentes na minha vida me impedem de me tornar um corpo errante? Onde está o descompasso ou o desconforto em relação à pesquisa intelectual e à vida praticada? Poderia esse corpo, sujeito dessa escrita, assumir-se ou conduzir-se nômade algum dia? Com quais tabus estaria rompendo? Pode alguém sedentário discorrer sobre os errantes, os nômades?

\footnotetext{
Se estais pronto para deixar pai e mãe, irmão e irmã, esposa e filho, e amigos, e a nunca mais vê-los - se haveis saldado vossas dívidas, feito vosso testamento, deixado em ordem os negócios e se sois um homem livre, então estais pronto para uma caminhada (THOREAU, 2003, p.5)
}

A radicalidade do discurso de Thoreau nos leva a crer que, na verdade, nunca estaremos inteiramente prontos para a caminhada e que assim ela se faz: imperfeita. Esse homem livre de Thoreau, que tem negócios e testamento em ordem, é um homem no masculino, abastado, romântico e idealizado, portanto inadequado para esse estudo. Quando se refere às mulheres e sua impossibilidade de caminhar, ele diz: "como podem as mulheres, que permanecem em casa muito mais que os homens, tolerar tal situação, eu ignoro. Mas possuo fundamentos para conjecturar que a maioria não a tolera de modo algum" (Ibid., p. 8). Mais de cem anos depois de Thoreau escrever essa frase, a condição das mulheres não deveria ser mais a mesma. Se eu optasse por falar apenas na primeira pessoa, falaria a partir de um lugar onde se reconhece as conquistas relacionadas à emancipação feminina. Entretanto, tais conquistas não são socialmente homogêneas, elas dependem do contexto, do grupo social, da etnia, da localização geopolítica, da orientação sexual. Nesse sentido, espero compreender através do exercício da escrita como me tornei pedestre, porque optei por caminhar e passei a observar essa ação. Torno-me a cada dia uma mulher lenta e atenta a todo um espectro de vozes dissonantes que inclui histórias de outras mulheres que não podem ser esquecidas. Aqui eu me refiro ao homem lento de Milton Santos, colocado propositadamente no feminino.

Ao longo de todo o texto, farei breves retrocessos autobiográficos para entender porque fui capturada por esse tema e tenho me ocupado dele nos últimos anos. Segue abaixo a primeira dessas narrativas:

Quando pequena, eu morava numa cidade no interior de Goiás. Embora ela se chamasse Rio Verde, nela ninguém via o rio. Passávamos sobre o Rio Verdão pela estrada, em alta velocidade, sem nunca nos aproximarmos dele. É um rio caudaloso, com águas fortes $e$ amarronzadas, misturadas com uma terra vermelha e revolta. Eu nunca me aproximei desse rio. Mesmo morando numa cidade no interior de Goiás, que pode parecer algo bastante remoto e provinciano, os moradores da cidade não se aproximam do rio. Lembro apenas de relatos de morte relacionados ao rio. Um primo distante que ao atravessar uma pinguela, 
escorregou e afogou-se no Rio Verdão.

\begin{abstract}
Minha cidade era a terceira maior do estado, o que significava naquela época que não era uma cidade tão pequena assim. Era uma cidade de uns cem mil habitantes. Nasci e vivi nela até os 10 anos, numa casa em uma grande avenida, muito movimentada para os padrões locais, onde eu não podia brincar. As brincadeiras estavam reservadas ao quintal, o lugar de infinitas descobertas, muitas invençöes, cachorros, coelho, pé de ata e pessoas. Vim de uma casa cheia.
\end{abstract}

Em Rio Verde, atravessar os portões da casa só era possivel em companhia da minha avó, que morava na mesma casa que a gente. Ela se chamava Tereza, era uma senhora de testa grande, fartos cabelos brancos, pernas fortes e aparentemente velha. Ela morreu aos 84 anos quando eu tinha 13, mas para mim ela sempre foi octogenária. O trajeto que geralmente fazíamos juntas, às vezes acompanhadas de um de meus irmãos, levava de casa ao armazém do seu Pedro Honório. Lá, ela comprava doces para as crianças enquanto cheirava fumo e conversava com conhecidos. Um dia, ganhei um bambole. o mais longe que eu ia era quando me autorizavam a dar a volta no quarteirão de bicicleta - um movimento circular - uma volta no próprio eixo, tendo a casa como referência central

\begin{abstract}
Caminhar nesse contexto era perigoso e proibido. Só podia caminhar acompanhada de uma velha senhora, lenta. Para ela, era um jeito de cuidar da saúde e, como nunca se tornou motorista, quando não era levada por alguém tinha que ir a pé. A geração de minha avó vivia com muita simplicidade, mesmo as pessoas que dispunham de alguma posse. Não havia bens de consumo, nem estudo, nem o hábito de se deslocar, de viajar. Naquele tempo, nesse Goiás profundo, ninguém tinha ânsias de ver o mundo. E como as distâncias eram mais dificeis de serem transpostas, quem vinha de longe, vinha de Minas Gerais.
\end{abstract}

Diferente de minha pesquisa de mestrado, na qual eu me colocava como encenadora e professora, aqui meu corpo se encontra imerso na pesquisa de campo, não olho de fora. Seja por experimentar as proposições de diferentes artistas como espectadora, seja por performar com o Coletivo Teatro Dodecafônico, encontro-me em deslocamento, caminhando dentro de ações deambulatórias entre os limites da arte e da vida.

Um dos desafios que me coloco ao revelar trechos de minha cartografia poética tem a ver com a seguinte investigação: o quanto as cidades nas quais habitei (ainda) me habitam? Discorro nessa tese sobre duas cidades onde vivi enquanto desenvolvia a presente pesquisa: São Paulo e Paris que, de modos diferentes, me convocaram a percorrê-las. E nesse convite, essas duas cidades também me ensinaram a caminhar com as minhas próprias pernas. Os trechos da cartografia poética evocam as cidades goianas que me habitam, mais do que aquelas que habitei. Nelas, poucas chances me foram dadas de caminhar. Desejo percorrer o meu estado a pé, sentindo em minha pele o sol que não dá folga, o céu em for-

4 Fruta do conde, em algumas regiões do país. 
ma de abóboda celeste; o azul, o vento e a poeira tão próprias de Goiás. Um sentimento de reapropriação, para talvez reapaixonar-me por um lugar onde escolho a cada dia não viver.

O primeiro estágio do amor urbano é aquele do mapa: ele se produz quando você sente que a cartografia da cidade amada se sobrepõe a todas as outras. Apaixonar-se por uma cidade é sentir, quando a percorremos, dissipar-se os limites materiais entre seu corpo e suas ruas, quando o mapa torna-se anatomia. $O$ segundo estágio é aquele da escrita. A cidade se prolifera sob todas as formas possíveis do signo, ela se faz, de início, prosa, depois poesia e torna-se, finalmente, evangelho. ${ }^{5}$

No texto acima, Paul Beatriz Preciado discorre sobre três cidades que amou. Aqui falo sobre as cidades que habitei e não necessariamente amei. Foi curioso perceber como o meu amor é diretamente proporcional ao quanto pude percorrê-las a pé. Parece que de outro modo, eu não conseguiria sentir essa sobreposição de que fala Preciado, entre o meu corpo e a cartografia da cidade. Quando a autora menciona a cidade se fazendo prosa e poesia, a cada passo, ela conclui com sua transformação em evangelho, que do grego, significa "boa nova" ou "boa notícia". É assim que anuncio para vocês o texto que se segue, como uma boa nova, uma boa notícia, meu evangelho pessoal. Convido o leitor a me dar as mãos e deixar-se ser levado. Não pretendo guiá-lo completamente, você poderá fazer as suas escoIhas. Inclusive pensar em outra ordem para a leitura dos capítulos dois, três, quatro e cinco, a depender de seu interesse. Sugiro que o primeiro e o último capítulos sejam lidos para iniciar e fechar o texto, respectivamente.

\section{> II. por um cartografia de práticas teatrais e performativas recentes}

Tomando como ponto de partida o método cartográfico formulado por Gilles Deleuze e Felix Guattari, que visa investigar um processo de produção e não definir um objeto previamente, algumas peças e performances que atravessaram meu caminho ao longo desses quatro anos de pesquisa são analisadas nesta tese. Ou seja, elas poderiam certamente ser substituídas por outras. Todas têm em comum o fato de serem deambulatórias e acontecerem no contexto urbano. Algumas tive a oportunidade de experimentar presencialmente, e em relação a outras, sobretudo as performances que ocorrem nas décadas de 1960 e 1970, tive acesso apenas aos vestígios deixados por elas. Seja presencialmente, seja navegando

\footnotetext{
${ }^{5}$ Le premier stade de l'amour urbain est celui de la carte : il se produit quand tu sens que la cartographie de la ville aimée se superpose à n'importe quelle autre. Tomber amoureux d'une ville, c'est sentir, quand on la parcourt, s'estomper les limites matérielles entre ton corps et ses rues, lorsque la carte devient anatomie. Le deuxième stade est celui de l'écriture. La ville prolifère sous toutes les formes possibles du signe, elle se fait d'abord prose, puis poésie et devient, finalement, évangile (tradução minha). Excerto do artigo Aimer une ville [Amar uma cidade], disponível em: <http://www.liberation.fr/debats/2015/12/04/aimer-uneville_1418398>. Acesso em: 20 jan. 2017.
} 
por livros ou pela internet, essa cartografia que aqui se apresenta não se assemelha a um decalque, uma cópia ou um conjunto de regras a serem aplicadas; juntos, esses exemplos se configuram como um mapa que dispõe de múltiplas entradas.

\footnotetext{
O mapa é aberto, é conectado em todas as suas dimensões, desmontável, reversível, suscetível de receber modificações constantemente. Ele pode ser rasgado, revertido, adaptar-se a montagens de qualquer natureza, ser preparado por um indivíduo, um grupo, uma formação social. Pode-se desenhá-lo numa parede, concebê-lo como obra de arte, construí-lo como uma ação política ou como uma meditação (DELEUZE \& GUATTARI, 1995, p.22).
}

O caminhar retrata uma condição móvel daquilo que não se fixa, que não é estável, nem definitivo. Nesse sentido, compor uma cartografia de ações teatrais e performativas deambulatórias caracteriza-se como uma tarefa fluida, cujos conceitos e definições vão sendo estabelecidos ao longo do processo. Nessa forma de deslocamento se inserem desde aqueles que passeiam ou derivam pelas cidades, até aqueles que atravessam territórios e ainda aqueles que não têm lugar na terra, os andarilhos, os refugiados e os nômades. Não se trata apenas de ações solitárias, mas coletivas, que colocam em relevo o ato de caminhar como forma de pensar, de criar, de se desterritorializar e de se reterritorializar. A história do caminhar se confunde com a história da humanidade, que avança ao reconfigurar seus espaços de (con)viver, questionando e reformando seus usos do espaço dito público. Por tratar de um assunto móvel e, portanto, instável, essa cartografia será necessariamente imprecisa. Ela se configurará como um exercício de reflexão a partir dos caminhos de inúmeros artistas que se deslocam no espaço urbano, sem pretender, no entanto, abarcar a globalidade dessas produções.

Apresentarei algumas categorias porosas da caminhada, analisando o modo pelo qual elas contribuíram ou inspiraram a invenção de modalidades artísticas diversas. Mantendo o foco da investigação em práticas teatrais e performativas no contexto urbano, tal tipologia revela o quanto o sujeito que coloca seu corpo em deslocamento a pé pelas grandes cidades pode inventar outros modos de ocupar o espaço e de usar o tempo, tornando estética e política indissociáveis. A arte, desse modo, se apresenta a partir de processos fluidos, não institucionais, ambulantes e cada vez mais próximos das esferas do real. É por isso que as ações a serem apresentadas e analisadas neste estudo estão situadas nas fronteiras entre diversas disciplinas artísticas. Estão situadas nas margens entre teatro, dança, intervenção e performance urbana, assim como nos seus desdobramentos em outras materialidades como fotografias, vídeos, desenhos e textos disseminados pela internet.

São proposições em diálogo com o real, com as estruturas políticas e sociais e com as práticas urbanas contemporâneas. Tais ações têm um caráter inacabado e ao mesmo tempo inapreensível, pois são manifestações não apenas efêmeras, como precárias. E tal precarie- 
dade não advém apenas de suas materialidades, mas de sua realização recente historicamente. Por esse motivo, nosso recorte coloca lado a lado ações realizadas a partir da década de 1960 até os dias atuais. Como se tratam, muitas vezes, de formas líquidas, apostamos que a observação de ações com alguma estabilidade temporal, com maior distanciamento histórico, seria um interessante contraponto às ações que vêm sendo criadas recentemente.

O nosso interesse é observar os modos de operar dessa arte contemporânea deambulatória e investigar o quanto ela é acessível ao espectador, o quanto ela é inclusiva, relacional e horizontal. Contrariamente a um entendimento de que a arte contemporânea é de difícil acesso, nosso objetivo é destacar o quanto a dissolução de certos estatutos da cena contemporânea pode aproximar o espectador da estrutura de funcionamento da arte, a ponto de ele se tornar mais indispensável para a execução da ação que o próprio artista. Então, pergunto: é possível reconhecer nas manifestações artísticas contemporâneas um potencial pedagógico, político, poético e transformador não apenas dos estatutos artísticos, mas também de comportamentos e práticas sociais?

Desse modo, minha primeira hipótese é de que à medida em que se reconhece um potencial pedagógico nessas modalidades artísticas contemporâneas, elas se configuram como dispositivos relacionais e dialógicos capazes de colocar a figura do espectador no primeiro plano da discussão. Muito tem se discutido a respeito da figura do espectador nos últimos anos, de modo que esse assunto tem alimentado a produção de inúmeras pesquisas sobre o tema. Se o espectador do edifício teatral sabe como deve se portar quando vai ao teatro, é porque essa ação já foi repetida por ele inúmeras vezes e não só por ele, mas está socialmente instaurada.

[...] como a mimese, a teatralidade tem relação fundamental com o olhar do espectador. Esse olhar identifica, reconhece, cria o espaço potencial no qual a teatralidade será identificada. Ele reconhece esse outro espaço, espaço do outro onde a ficção pode surgir. Esse olhar é sempre duplo. Ele vê o real e a ficção, o produto e o processo. [...] a teatralidade diz respeito, sobretudo, e antes de tudo, ao espectador. Sem ele, o processo mimético e teatral não tem nenhum sentido (FÉRAL, 2015, p.107).

Se a teatralidade pertence, sobretudo, ao espectador e se a criação é também resultante da ação do espectador, é preciso investigar o que tem sido oferecido a ele pelos artistas como dispositivos para lidar com esse novo estatuto dentro das artes cênicas e performáticas. Nas modalidades artísticas aqui analisadas, o "modo de usar" não é previamente conhecido, há margens para sua compreensão e exploração. Frequentemente, elas retiram o espectador de seu espaço/tempo habitual. Quando utilizo o termo "uso", eu me refiro ao sentido dado por Michel de Certeau, para quem "o ato de falar é um uso da língua e uma 
operação sobre ela" (2014, p.91). Ao opor usos e consumos, o autor interroga a ação do telespectador de TV, da seguinte forma: "o que o consumidor fabrica com essas imagens e durante essas horas" (Ibid., p. 88). Certeau afirma que esse espectador não inscreve nada na tela da TV; trata-se portanto de um sistema que o mantém afastado; o espectador encontra-se totalmente excluído dessa manifestação. A referência à TV nos permite compreender o quanto as expressões artísticas analisadas aqui não se constituem como produtos para serem consumidos, mas dispositivos para serem usados. E mais ainda, tais ações podem ser desdobradas a partir de suas próprias fabricações, na medida em muitas vezes não interessa ao artista manter-se como o único fazedor de arte.

É importante salientar que o foco da presente pesquisa não está na recepção, mas na proposição do artista, que de modo mais ou menos radical interpela o espectador. Sendo assim, aproximo a tarefa acadêmica ora da minha atividade como espectadora, ora da minha prática artística. Busquei incluir minha experiência como espectadora nas análises realizadas em todos os capítulos, pois as reflexões tecidas aqui são fruto da frequentação dessas encenações e do estudo dessas performances. No entanto, não pretendo generalizar minhas impressões particulares como espectadora para todo um conjunto dissonante de pessoas, que, de maneiras muito distintas, são atravessadas pelas provocações de todos esses artistas. Tomo como referência a prática de análise de manifestações cênicas contemporâneas adotadas por três pesquisadoras: Silvia Fernandes, Josette Féral e lleana Diéguez Caballero. As duas primeiras se valem da ideia da crítica genética (amplamente difundida por Cecília Almeida Salles no Brasil), preconizada, de certa forma, pelo tipo de análise empreendida por Josette Féral ao observar os processos criativos do Théâtre du Soleil e pelos inúmeros volumes da série Voies de Création Théâtral (editada pelo CNRS), dedicada ao estudo da obra de artistas relevantes da cena teatral desde 1972, na França. Todas essas formas de análise pretendem "derrubar as barreiras que separam a análise do espetáculo do estudo dos processos de criação", segundo a pesquisadora Silvia Fernandes ${ }^{6}$.

O movimento de análise que pretendo experimentar nas páginas que se seguem bebe nessa fonte, tendo como principal inspiração a pesquisa realizada por Silvia Fernandes, uma das maiores estudiosas da cena teatral contemporânea brasileira. Ileana Diéguez Caballero desenvolve suas análises dos territórios expandidos e liminares da cena latino-americana sempre acompanhada de uma profusão de imagens, que de maneira bastante consistente complementa suas narrativas sobre as criações artísticas e cidadãs. Dessa forma, procurando observar as ações para além do seu produto final, dispondo de uma extensa documentação visual e tendo como referência minha experiência como espectadora presencial e virtual (desenvolverei esse assunto no primeiro capítulo), sedimentei as análises que figuram

\footnotetext{
6 Dados obtidos no texto "Gêneses do real no teatro: experiências de performatividade na cena brasileira contemporânea", da professora e pesquisadora Silvia Fernandes, disponibilizado pela autora como material didático da disciplina "Teatros do Real", oferecida na ECA/USP no primeiro semestre de 2013.
} 
em cada um dos capítulos dessa tese. Vale ressaltar que as ações que compõem o corpus dessa pesquisa raramente se aproximam da ideia de obra acabada, constituindo-se como proposições de imersão e de experiência para os espectadores e não de visões a serem decodificadas. Em alusão aos estudos de Erika Fischer-Lichte sobre o desvio performativo que o teatro experimentou a partir dos anos 1960, Silvia Fernandes afirma que o teatro não é mais a representação do mundo ficcional que o público deve observar, interpretar e compreender. Vivemos um tempo de crise da representação, no qual a representação da realidade dá lugar à ideia de presença, de instauração de acontecimentos, de "um teatro sem referencial", no qual o "sentido seria mantido em suspensão" (FERNANDES in GUINSBURG e FERNANDES, 2009, p.26). Como herança da performance, esse teatro se apoia na materialidade das ações e na corporeidade dos atores, fazendo com que a experiência ultrapasse o simbólico.

Nesse sentido, não caberia à análise interpretar os significados impressos nos signos, desvendar as mensagens submersas nas combinações de imagens e sons; ao contrário, como pesquisadora, proponho-me a iniciar as análises descrevendo as ações, tendo como referência a minha experiência como espectadora (sendo que em alguns casos, não assisti presencialmente à ação, tendo acesso ao vídeo ou a relatos da experiência), a pesquisa sobre o material genético correspondente à ação e os vestígios produzidos em decorrência dela. Ao analisar também como 'uma' espectadora, que vive 'uma' experiência ímpar, tecida com um manancial de referências próprio, tal análise se aproxima da produção de uma narrativa, que não poderia ter sido realizada por outra pessoa. Ou seja, não cabe à análise realizar uma leitura definitiva, correta ou abrangente, mas apresentar um ponto de vista, que envolve certo grau de criação por parte do espectador particular. Josette Féral, cujas pesquisas têm contribuído para atenuar a oposição entre teatralidade e performatividade, privilegia "uma definição que apresenta a teatralidade antes de tudo como o resultado não somente de um 'ato de reconhecimento' mas também de 'criação' por parte do espectador" (2012a, p.10) ${ }^{7}$. Recorro ao artifício da descrição como primeiro movimento da análise, operação esta que além de contextualizar o leitor, também revela os fios do raciocínio que gerou tais reflexões. Sendo assim, ao apoiar-me também na subjetividade da minha percepção como espectadora, não apresento um modelo de boa recepção, mas uma leitura possível. Trata-se do ponto de onde avisto, ou melhor, do corpo através do qual experimento tais manifestações cênicas contemporâneas.

Quando opto por analisar dezenas de ações nas quais a mobilidade está em jogo, investigando os dispositivos articulados pelos artistas para o jogo dos espectadores, não pretendo associar o espectador sentado, que não participa de ações deambulatórias, à passividade.

\footnotetext{
${ }^{7}[$ [...] une définition qui présente la théâtralité avant tout comme le résultat non seulement d'un 'acte de reconnaissance' mais aussi de 'création' de la part du spectateur (tradução minha).
} 
Busco observar de que modo o ato de caminhar opera na fruição do espectador e o pré-dispõe para a experiência, seja pelas possibilidades inerentes ao caminhar, seja pela recusa imediata de certos espectadores a caminhar. Assim se coloca minha segunda hipótese: 0 ato de caminhar pré-dispõe o espectador a se relacionar diferentemente com as manifestações artísticas, na medida em que mobiliza o corpo e organiza as ideias. Caminhar torna o espectador um "vivenciador" de uma ação e ainda possibilita que ele se aproxime do espaço do real de modo não funcional, não objetivo e improdutivo, como só pode ocorrer numa situação de jogo. Essas condições permitem a toda e qualquer pessoa relacionar-se com a cidade, ampliando as margens de seu imaginário, o primeiro passo na construção de outras possiblidades de vida.

Francesco Careri, em palestra na cidade de São Paulo, afirmou que "saber provocar uma reação é mais interessante do que ser participativo". Nesse sentido, acredito que o fato de as ações estudadas aqui serem deambulatórias não faz com que elas se configurem como participativas. Colocar-se em deslocamento não é o mesmo que participar, significa colocar-se em processamento, acionar-se inteiramente para determinada operação. Ou então, fazer uso da caminhada para que se fabrique pensamentos, ideias, e sobretudo, para que se exercite o imaginário, território das maiores disputas na contemporaneidade. Verificar o desdobramento pedagógico de uma encenação ou performance inscrita no espaço público é um modo de observar o quanto ela incorpora o espectador dentro do jogo, deixando brechas para que ele reaja aos estímulos produzidos pela prática artística.

Procurarei apontar ao longo das análises que se seguem a presença do que nomeei como potencial pedagógico na primeira hipótese apresentada e o quanto ele permite a expansão da noção de arte enquanto campo que se aproxima cada vez mais da esfera da vida. É certo que quando os artistas se posicionam na fronteira entre arte e vida, eles se posicionam justamente nessa brecha, nesse intervalo entre uma coisa e outra. Contudo, esse posicionamento não significa a dissolução da arte, mas a ampliação de seus domínios de tal modo que a arte possa não só tornar a vida possível, mas se tornar um espaço de experimentação de outros modos de vida. As questões relacionadas à superação da arte foram amplamente debatidas pelos situacionistas franceses (esse assunto será tratado no terceiro capítulo), como podemos notar nos slogans inscritos em Paris em maio de 1968. Dentre eles: "L'art est mort. Godard n'y pourra rien" [A arte está morta. Godard não poderá fazer nada.].

Para a presente pesquisa, interessa menos endossar a perspectiva anti-arte bastante difundida pelos situacionistas, do que questioná-los a partir de reflexões também tecidas por eles, que poderiam no entanto ter tomado outros rumos. Por exemplo, ao afirmarem "Changez la vie, donc transformez son mode d'emploi" [Transforme sua vida, então transforme seu modo de usar], os situacionistas propõem uma mudança efetiva na esfera da vida - uma alteração nos modos de operar dos cidadãos - que deveriam lutar por uma vida 
e não pela mera sobrevivência. Tal constatação, contudo, não implicaria necessariamente a supressão da arte, mas certamente sua alteração. Lendo isso hoje, entendo que sem essas esferas de exercício do imaginário, as fronteiras do possível não serão nunca tensionadas. $E$ assim, nenhuma transformação política, ética e social terá lugar no tempo em que vivemos e teremos que nos contentar com o exercício permanente da sobrevivência, em uma terra arrasada e sem nenhuma pulsão de vida.

Quando afirmo que o referido potencial pedagógico possibilita a expansão da noção de arte, isso se deve ao fato de essas ações problematizarem o papel, a função e o modo de operar dos espectadores. Desse modo, os processos que possibilitam a emergência dessa implicação pedagógica e, por vezes política, são complexos e não dependem apenas do artista, mas do contexto, da formação do espectador, das condições culturais e sociais em que os sujeitos dessa experiência se encontram. Dependem tanto dos dispositivos organizados pelos artistas, quanto da disponibilidade do espectador para experimentar determinada proposição artística. Para discorrer um pouco sobre a abertura que se espera desse espectador, penso em uma situação hipotética na qual uma pessoa se depara com a obra Cosmococa 5, de Helio Oiticica, ao visitar a Galeria dedicada ao artista no Inhotim, em Minas Gerais. Trata-se de um espaço com diversas redes dependuradas em paredes usadas também para a projeção de vídeos. Se repararmos com atenção, não há barreiras entre a instalação e o frequentador da galeria e nenhum aviso ou segurança o impede de se aproximar. Porém, se a pessoa em questão chegar ao espaço e observar as redes, mantendo uma distância segura para não encostar em nada - seguindo perfeitamente as convenções sociais que nos ensinam como devemos nos comportar em um museu - ela tentará em vão se relacionar com a proposição de Oiticica. O exemplo de Cosmococa é esclarecedor, pois esse artista articula suas composições de modo a romper com padrões e convenções pré-estabelecidas. O que Oiticica espera do espectador é que ele se entregue corporalmente para aquelas redes, que ele se dê esse tempo, que ele usufrua daqueles vídeos a partir de uma posição de repouso bem específica, possível apenas para quem se permite esse nível de entrega a uma rede alheia. Acontece que essa disponibilidade decorre de muitas instâncias, que passam por todos os processos educacionais vividos desde a infância até às convenções sociais incorporadas pelas pessoas de diferentes culturas. Além disso, essa questão toma outras proporções quando se trata de práticas teatrais ou performáticas.

Alterar o estatuto do espectador corresponde a uma alteração na postura do artista, que se coloca como um criador de dispositivos ou propositor de experiências, e não como alguém que dispõe de capacidades extraordinárias. Ele abdica do papel de virtuose e categorias frequentemente consideradas indispensáveis para a produção artística, como a ideia de talento, são diluídas. O foco se desloca da exibição para o compartilhamento, que pode acontecer em múltiplas instâncias, seja no ato mesmo do acontecimento cênico, quando os 
espectadores também acionam a criação, seja a posteriori, por meio de outras materialidades decorrentes do ato performativo. Desse modo, todos podem usufruir e experimentar proposições artísticas que se configuram abertas, inclusivas e inacabadas, por serem altamente dependentes do encontro com o outro.

À medida em que o artista se distancia do papel de autoria, sua função se transforma em propositor de experiências alheias; o artista se torna provocador. Sophie Calle inicia seu livro de fotografias Les Dormeurs [Os adormecidos], com a seguinte inscrição: "provocação de situações arbitrárias que tomam a forma de um ritual". Dessa forma, o artista propõe ao mesmo tempo um processo artístico e de aprendizagem, que envolve descobertas e reformulações de acordo com os encontros que se produzem. Trata-se, portanto, de um processo de exploração ou experimentação de materialidades, percursos, sensações, leituras. Menos preocupado com a questão da autoria, o artista pode alçar voos mais arriscados na direção da invenção de outros mundos, de estruturas nas quais a operação ou a ativação da arte esteja ao alcance de toda e qualquer pessoa.

\section{>> III. Algumas noções fundamentais para percorrer esse itinerário}

Apresentarei a seguir algumas noções sobre as quais se baseou a presente pesquisa; sem elas dificilmente os caminhos trilhados seriam os mesmos. As primeiras são as noções de tática e estratégia cunhadas por Michel de Certeau, como duas lógicas para a ação. A partir delas, podemos afirmar que as encenações e performances aqui analisadas são táticas que respondem à organização do contexto urbano, ele sim estrategicamente definido pelo poder público. A tática, ao contrário, "é determinada pela ausência de poder", é "a arte do fraco" (CERTEAU, 2014, p.95). "A estratégia é a ciência dos movimentos bélicos fora do campo de visão do inimigo" (VON BULLOW apud CERTEAU, 2014, p. 94), enquanto a tática é movimento "dentro do campo de visão do inimigo"(Ibid.). Desse modo, a tática é uma ação dentro do campo controlado, é ação temporária no terreno do outro. Se por um lado, a estratégia é uma ação que define, que delimita espaço, por outro, a tática é um procedimento que propõe usos para o tempo. Essas duas noções serão frequentemente evocadas nas análises das encenações e performances urbanas ao longo do texto. Veremos, contudo, que em alguns casos artistas adotam lógicas de ação estratégicas, ainda que suas práticas possam ser consideradas apenas táticas, pois uma vez que se encontram em deslocamento pelas ruas, sua ação é da ordem da imersão. Isso significa que os espaços dos artistas são prioritariamente lisos (para Deleuze e Guattari), opacos (para Milton Santos) e vazios (para Careri).

De acordo com Francesco Careri, as primeiras tentativas de considerar o ato de caminhar 
como forma de arte foram realizadas como um campo expandido da literatura. Embora os dadaístas, os surrealistas e os situacionistas realizassem suas deambulações como forma de antiarte, todos eles propunham uma expansão do campo da literatura para as artes visuais e, eu acrescentaria, para o que futuramente se tornaria o campo da performance. As deambulações dadaístas, suas formas de visitas, as práticas do flâneur, as errâncias surrealistas e as derivas situacionistas nasceram no âmbito literário. Como herdeiros das vanguardas históricas, os artistas interessados em incluir seus corpos em suas criações passaram a realizar performances e happenings urbanos e dando continuidade a essas explorações, ganharam as ruas a partir da década de 1970 . Posteriormente, à medida em que se paramentaram de tecnologias de registro de imagem (fotografia e vídeo), passaram também a prolongar suas criações na forma dessas outras materialidades. Desse modo, não é possível posicionar o caminhar dentro de uma única linguagem; trata-se de uma modalidade híbrida e múltipla, que migra entre linguagens, sem se deixar fixar em nenhuma delas.

É Francesco Careri quem vai expandir a noção de percurso da maneira mais legítima, considerando-o como uma forma de arte, como uma prática estética, em seu livro "Walkscapes: caminhar como prática estética" (Ed. G. Gili, 2013) ${ }^{8}$. Trata-se de um compêndio sobre o caminhar, dos primeiros nômades, passando pela land art até as ações realizadas pelo grupo Stalker, que ele integra na década de 1990. O autor italiano defende a ideia de que caminhar cria arquitetura e paisagem e desse modo admite três acepções para a palavra "percurso": a ação, o objeto arquitetônico e o relato da experiência.

Com o termo "percurso" indicam-se, ao mesmo tempo, o ato da travessia (o percurso como ação do caminhar), a linha que atravessa o espaço (o percurso como objeto arquitetônico) e o relato do espaço atravessado (o percurso como estrutura narrativa). Pretendemos propor o percurso como forma estética à disposição da arquitetura e da paisagem (CARERI, 2013, p. 31, grifos meus).

Desse modo, o percurso como performance do caminhar, ou seja, como simples execução dessa ação já pode ser considerado uma prática estética. Dito de outro modo, ações centradas no ato de caminhar, ainda que invisíveis para um espectador convidado ou deliberado, podem se configurar como uma prática estética. Constituem-se como intervenção temporária no espaço público, resultando assim em objeto arquitetônico, em construção simbólica no território. Nesse sentido, o percurso como linha traçada, como rastro de um caminho percorrido configura um objeto arquitetônico. Contrariando a ideia de que as sociedades nômades não produziam arquitetura, sendo opostas às sociedades sedentárias - conhecidas por se fixarem e construírem territorialidades - o autor retorna aos menires, como primeiros marcos dos territórios deixados por essas sociedades móveis, justamente para defender a ideia de que um percurso é um objeto arquitetônico. E por fim, o percurso

8 Publicado em 2002 na Itália e traduzido para o português em 2013. 
também pode ser definido como estrutura narrativa, tanto como relato de uma experiência vivida - em forma de texto produzido a posteriori - quanto como espaço de enunciação.

No contexto dessa pesquisa, essas três acepções atribuídas ao percurso por Careri - ação do caminhar, objeto arquitetônico e estrutura narrativa - nos ajudarão a olhar para essas ações de modo amplo. No campo expandido do caminhar é que se encontram as encenações e performances urbanas escolhidas como exemplos para as discussões que se seguem. São ações que se encontram no limiar entre vida e arte e rompem com os estatutos que distinguem aqueles que fazem daqueles que veem, assim como se afastam da noção de obra para se aproximar da noção de acontecimento. Algumas dessas ações podem se constituir como objetos arquitetônicos ou percursos invisíveis. Outras se constituem como resquícios da caminhada, linhas no mapa, conjunto de fotografias, um vídeo ou um relato produzido a partir de um deslocamento. Nesse caso, a ação ganha um caráter de rastro, de vestígio a ser lido por interlocutores ausentes do momento mesmo de sua execução.

\section{> IV. sobre os capítulos que se seguem ou as múltiplas entradas nessa cartografia}

Se oriente, rapaz, pela constelação do Cruzeiro do Sul. Gilberto Gil

No primeiro capítulo apresento um cenário de dissoluções instaurado no campo das práticas teatrais; trata-se da dissolução da encenação, do espectador e da obra de arte. Quando as análises se voltam para o campo da performance, tal dissolução já se configura como característica dessa linguagem. Exemplo disso é a ausência da figura do encenador ou qualquer olhar de fora. Ainda que alguns artistas proponham que outras pessoas executem seus programas, não se diz que esses performers encenem ou dirijam uma performance. A figura do espectador também aparece diluída, sobretudo quando a ação tem lugar na rua; raramente há a convocação de público em performance urbana. Os espectadores se restringem aos passantes que fortuitamente se deparam com a ação na rua ou aos espectadores virtuais, que terão acesso à ação posteriormente via internet. Quando me refiro à dissolução da obra de arte, trato da invisibilidade de certas ações, que inevitavelmente são confundidas com a vida cotidiana, mas cuja potência é forte o suficiente para mobilizar modificações não apenas no campo da arte, mas também da vida. Nesse mesmo capítulo desenvolvo a noção de "encenação em deriva", ao me referir a experimentações teatrais deambulatórias que simulam uma situação de deriva para os espectadores e a noção de “instauração de jogo" (mise en jeu), que se opõe à encenação (mise en scène).

Nos capítulos dois, três, quatro e cinco discorro sobre diversas ações teatrais e performativas segundo uma divisão em diferentes categorias do caminhar. O propósito dessa divisão 
em categorias porosas distintas não é o de classificar as ações de acordo com qualidades específicas, criando compartimentos rígidos que não se misturam; esse foi um modo de criar pontos de aproximação e de distanciamento entre experiências diversas nas quais os corpos envolvidos se deslocam, criando tensões e reflexões sobre as múltiplas possibilidades do caminhar. Dessa forma, no contexto desta pesquisa, o caminhar não pode ser observado como simples deslocamento, mas como ato físico, ecológico, filosófico, artístico e político. Algumas vezes, essa deambulação se aproxima mais da ideia de deriva ou errância, outras, de passeio ou da prática do flâneur (em francês, esses termos são mais difundidos: promenade e flânerie, respectivamente). Acontece também dessa deambulação ser observada como fuga ou perseguição, assim como travessia de um território. Há ainda os percursos traçados cotidianamente, que também podem ser explorados enquanto materialidades artísticas.

Sendo assim, na primeira parte do segundo capítulo, discorro sobre o caminhar como ação distinta da fisicalidade do andar e como propulsor de pensamentos e inúmeras experimentações artísticas em diferentes linguagens. Como prova disso, retraço a passos largos a história do caminhar dentro da história da arte, desde o momento em que se passa a retratar a figura humana em deslocamento, até o momento em que tal ação deixa de ser representada e passa a configurar a ação central da criação artística. Na segunda parte desse capítulo, abordo o ato de caminhar na perspectiva de quem passeia. Nesse sentido, a principal referência é a figura do flâneur descrita com precisão por Charles Baudelaire e posteriormente retomada por Walter Benjamin. Em seguida, dedico-me a analisar ações de diferentes artistas que passearam ou convidaram o espectador para um passeio, retomando os passos do flâneur. Há exemplos de performers solo (dentre eles, um acionista vienense) e de performers que exploram em seus passeios uma proximidade extrema com o chão. Nestes últimos, o ato de caminhar é substituído pelo rastejar-se, um deslocamento no nível baixo, produzindo aquilo que pode ser considerado uma "política do chão" (segundo Paul Carter via André Lepecki).

No terceiro capítulo, dedicado ao caminhar sem rumo decorrente da prática da deriva, apresento as teorias situacionistas, especialmente as ideias preconizadas pelo jovem Guy Debord. Em um retrospecto histórico, retomo as deambulações surrealistas e dadaístas, que marcam a rua como o único campo legítimo da experiência, de acordo com André Breton. Entre as vanguardas artísticas e a prática revolucionária, outras práticas situacionistas também são evocadas como complementares à teoria da deriva, como por exemplo: a psicogeografia, a construção de situações e o desvio ou apropriação. Coloco em evidência, nesse estudo, a proximidade da deriva da prática do jogo, igualmente improdutiva e antifuncional. Trata-se de uma exploração das ambiências da cidade, na qual o sujeito se deixa levar ao sabor dos acontecimentos e dos encontros que se efetivam pelo caminho, como 
se olhasse a cidade de um modo cinematográfico. Apresento derivas realizadas pelo Coletivo Teatro Dodecafônico em São Paulo, outras realizadas com parceiros diversos em Paris, além de uma peça na qual tanto atores quanto espectadores realmente derivam, definindo juntos o percurso a ser traçado a cada nova sessão. Para além da ideia de perder-se, o que tais derivas permitem a quem se dispõe a experimentá-las é a ousada permissão de perder tempo, o artigo de ouro da era do capital.

Ainda no terceiro capítulo, como forma alternativa de perder-se, toda uma parte é dedicada a modalidades associadas às fugas e perseguições. Em ambos os casos, trata-se de deslocamentos realizados em relação a um outro. Quando se foge de alguém, desloca-se rapidamente e nem sempre com um destino definido; o objetivo de quem foge é distanciar-se o máximo possível de alguém ou algo. Em contrapartida, quando a ação é perseguir, o deslocamento é sorrateiro, sinuoso e discreto; o objetivo de quem persegue é não se deixar ser percebido. Seguir alguém é um modo frequente de colocar-se em deriva, sendo que inúmeros artistas realizaram performances cujos programas consistiam basicamente em realizar essa ação. Sophie Calle seguia pessoas quando voltou para Paris, depois de sete anos no estrangeiro, para se apropriar de itinerários alheios, pensando que assim ela se reaproximaria das ambiências de sua cidade natal. Nessa mesma parte, uma série de derivas de gênero realizadas por mim, sozinha ou acompanhada pelo Coletivo Teatro Dodecafônico, serão igualmente apresentadas.

No quarto capítulo há uma aproximação da esfera do real, pois o tipo de mobilidade evocada é aquela que se apreende dos percursos cotidianos, ou seja, deslocamentos objetivos que têm ponto de partida e de chegada bem definidos. Inspirada em um mapa produzido pela aluna do sociólogo urbano Paul-Henri Chombart de Lauwe marcando os percursos realizados por ela ao longo de um ano, percebi que muitas criações artísticas repetiam trajetos definidos ou demarcavam elementos ao longo de um caminho, de modo que as pessoas que realizassem determinado percurso pudessem percebê-los. Há casos, inclusive, de demarcações tão sutis que os passantes só conseguem perceber pela repetição de determinado trajeto algumas vezes. Tal capítulo divide-se em duas partes. Na primeira, apresento uma série de ações nas quais o percurso está em primeiro plano, seja por aparecer como uma trajetória fisicamente demarcada, seja pela repetição de um percurso por parte do artista ou do espectador. Em última instância, o que o estudo dos percursos cotidianos possibilita é uma ampliação da percepção estética da vida, pois quanto mais se percorre um mesmo caminho, mais se conhece e mais condições se tem de percebê-lo e de perceber-se a si mesmo ao cumprir esse trajeto.

Na segunda parte desse mesmo capítulo, os percursos são cumpridos de fones de ouvido, de modo que o flanar é sempre impulsionado por uma trilha sonora. Discorro então sobre a modalidade cênica conhecida como audiotour, assim como sobre os áudio walks (e pos- 
teriores vídeo walks) preconizados por Janet Cardiff, que influenciaram uma quantidade significativa de artistas de diferentes países. Tratam-se de explorações sonoras e deambulatórias do espaço urbano que se apoiam sobre estruturas ficcionais ou contextuais, dependendo do caso. Geralmente, os audiotours promovem experiências imersivas, colocando os espectadores em contato com uma escrita em três dimensões ou um filme para os ouvidos.

No quinto capítulo, parto de um breve estudo sobre a land art, modalidade em que a terra se torna a superfície onde os artistas inscrevem seus percursos, para depois voltar a atenção para travessias de grandes territórios e para caminhadas realizadas em conjunto. No primeiro caso, trata-se de cortes ou contornos de territórios pré-estabelecidos, como se ao caminhar fosse possível traçar uma linha demarcando a trajetória percorrida. Travessias podem ser realizadas individualmente ou em conjunto e, com frequência, são ações que passam completamente despercebidas pelas pessoas encontradas ao longo do caminho. No sentido oposto a esse, no segundo caso, tratam-se de caminhadas que se pretendem visíveis. São as marchas, os protestos, os cortejos e as manifestações realizadas em defesa de uma causa, como forma de comemorar ou reivindicar algo. Nesse sentido, o comportamento festivo ou contestatório dá o tom do tipo de ação que se inscreve nas ruas e avenidas de uma cidade, mas em ambos os casos ela se configura como uma ação conjunta.

Para ilustrar o estudo das travessias, apresento as caminhadas desenvolvidas pelo coletivo Stalker, do qual fez parte Francesco Careri, certas travessias realizadas individualmente por alguns artistas, além do famoso encontro entre Marina Abramovic e seu companheiro Ulay em algum ponto no meio da Muralha da China. Outras travessias em dupla são evocadas, nas quais se cortou as cidades de Nova York e Paris com os pés, bem como a grande travessia de dois dias na qual o Coletivo Teatro Dodecafônico percorreu o eixo oeste-leste da cidade de São Paulo a pé. Ao analisar o caminhar junto, trato de uma peça de teatro e de uma intervenção urbana realizadas em São Paulo, além de uma grande ocupação realizada no México, as passeatas da Mães da Plaza de Mayo e os escraches organizados pelos H.I. J.O.S. em Buenos Aires. Nestes últimos exemplos, observa-se tanto o modelo do protesto alimentando as criações artísticas, quanto as manifestações políticas tornando-se cada vez mais performáticas, numa interface clara entre arte e política.

No último capítulo da tese, o foco se volta para as materialidades que se compõem a partir da execução das ações, sobretudo performances, pois é nesse campo que o prolongamento da ação na forma de fotografia, vídeo, desenho e texto se configura de maneira mais evidente. Dentro da história do performance, a partir do momento em que os artistas se apropriam das técnicas de registro e documentação de suas ações, muitas delas passam a ser endereçadas para as câmeras. Ou seja, as performances não preveem um encontro com o público, mas se destinam a um espectador ausente ou virtual. Inicialmente, o espectador teria acesso à documentação da ação pelos vestígios produzidos em decorrência dela nas 
galerias ou publicações a respeito dessa linguagem. Mais recentemente, o espectador ausente pode estar presente virtualmente, acompanhando a desenrolar da performance de sua casa ou, de fato, observar os resultados de uma ação posteriormente pelo intermédio de imagens ou relatos a respeito do ocorrido.

Há casos também nos quais as ações instauram acontecimentos no espaço público. Levando em conta que um acontecimento é um evento não planejado, considero acontecimento uma eventualidade que se concretiza em decorrência de uma situação construída por um artista. Desde a Guerra dos Mundos, narrada no rádio por Orson Welles, passando por um boato criado por Francis Alÿs em uma pequena cidadezinha do México, até a discussão de gênero instaurada pelo Coletivo Teatro Dodecafônico, diferentes modalidades artísticas se confundem com o real, promovendo ações concretas no âmbito social e intervindo diretamente na esfera da vida. Exacerbando essa aproximação entre arte e vida, esse capítulo se encerra com desdobramentos e multiplicações de performances que passam a ser realizadas por toda e qualquer pessoa. À medida em que os artistas disponibilizam seus programas de performance e convocam as pessoas em geral para se apropriarem deles, muitas operações artísticas se infiltram na vida cotidiana. Trata-se de um compartilhamento de "modos de fazer", que em uma perspectiva microscópica promovem alterações em modos de vida.

É importante destacar ainda que ao longo de todos os capítulos, compartilho imagens da internet e de livros aos quais tive acesso, convidando o leitor a enxergar as mesmas imagens que eu, visualizando o que procuro descrever em minhas análises. Pode-se dizer que essa escrita se produz a partir de pesquisa textual, imagética e audiovisual e que, em certa medida, coloco em prática a proposta de détournement [desvio ou apropriação] praticada por Guy Debord. Como a materialidade na qual essa tese se inscreve é o papel - e talvez, algum dia, ela chegue a uma plataforma capaz de criar hiperlinks, citando vídeos, sonoridades e até projeções em 3D - a apropriação que se apresenta aqui se restringe ao campo das imagens. Essa atitude coloca em relevo a discussão sobre autoria e também sobre a transformação dos materiais de estudo em mercadorias. Na era da internet, em que se tem acesso a grande quantidade de informações sem que elas sejam necessariamente arquivadas, utilizar tais imagens com os respectivos endereços, datas de acesso e referências bibliográficas não me parece um desvio ético. Ao contrário, trata-se se divulgar trabalhos, de promover discussão e contribuir para a reflexão e a familiarização com a arte contemporânea. Como se trata de um trabalho acadêmico, opto por usar a universidade como um lugar de experimentação, de exercício do livre pensamento, de possibilidade de erro e um dos raros espaços de liberdade que ainda nos restam. 


\section{> capítulo um: a cena contemporânea e as linhas invisíveis do mapa}

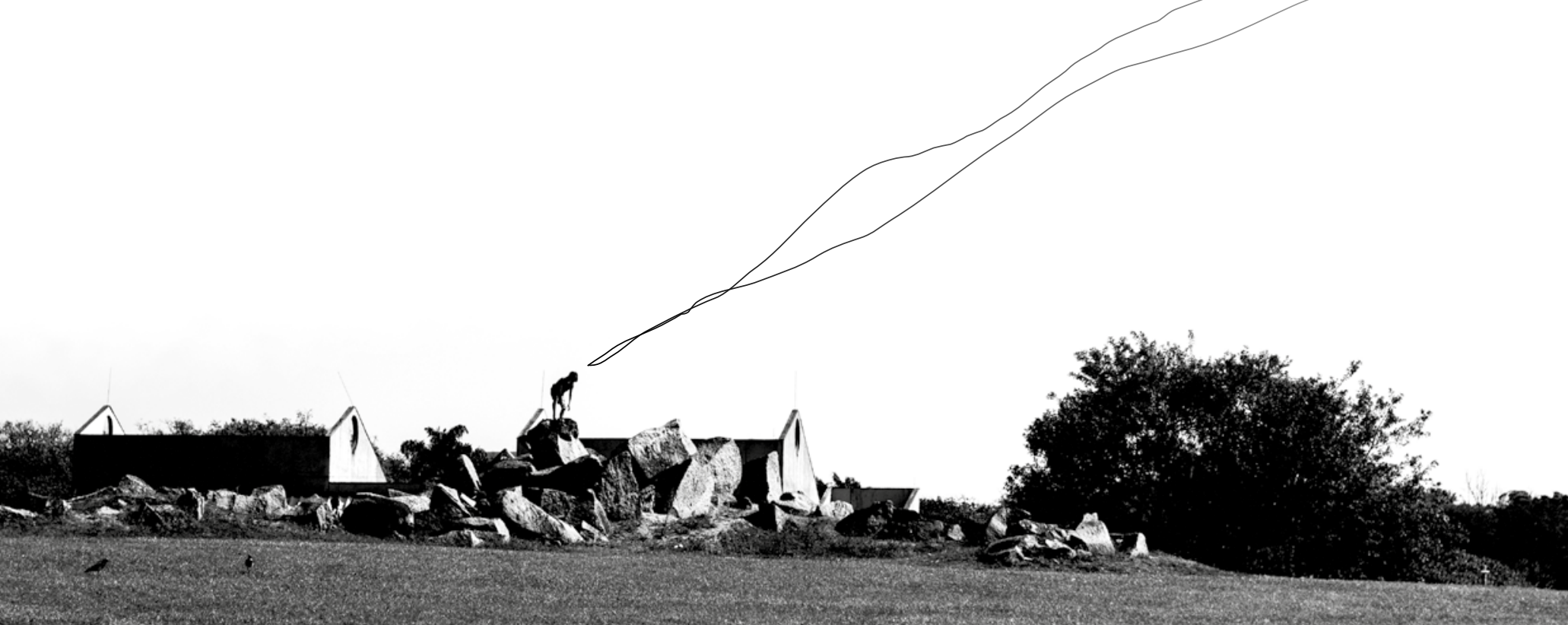

Foto: Papá Fraga

[nota sobre o capítulo: a ideia é apresentar alguns aspectos da cena contemporânea a partir da análise tanto de encenações teatrais quanto de performances urbanas nas quais se nota um questionamento (e em muitos casos, um esfacelamento) desses aspectos considerados inerentes ao que se entende por cena. A encenação, o espectador e a obra de arte são colocados em contínua revisão; são testados, modificados e, não raramente, se dissolvem na cidade. Quando o teatro ou a performance se inscrevem como acontecimento no contexto urbano, a noção de encenação se torna instauração do jogo, os espectadores passam a ser voláteis (ninguém em especial e, ao mesmo tempo, todo e qualquer passante) e a manifestação artística se (con)funde com o real. Os exemplos analisados para discorrer sobre cada um desses aspectos poderiam ser substituídos por outros, assim como cada exemplo poderia servir para discutir mais de um desses aspectos. No entanto, esses são exemplos possíveis para se analisar a cena contemporânea, mas certamente não são os únicos.] 
A crise contemporânea é basicamente a crise do ato ético contemporâneo. Tem-se aberto um abismo entre o motivo de um ato e o seu produto.

Mijail Bakhtín

Pode parecer estranho começar o primeiro capítulo de uma tese que pretende investigar práticas teatrais e performativas no contexto urbano, apresentando aspectos da "cena", uma vez em que raramente esta palavra é usada quando o assunto é performance. Ao longo do capítulo, o leitor poderá constatar o quanto estamos cientes dessa questão, ainda que se tenha optado por manter a palavra "cena" no título do presente capítulo. Não é minha intenção defender um caminho que leva do teatro à performance, ou seja, afirmar que a performance seja uma digressão ou um desvio de certas práticas teatrais. Meu foco de interesse sempre esteve voltado para práticas teatrais posicionadas à margem, um teatro fora do edifício teatral, no qual não há hegemonia do texto, onde os corpos configuram-se como presenças e raramente como personagens; um teatro quase sem teatro, um teatro em fuga, um teatro que escapa de si mesmo ${ }^{1}$.

\begin{abstract}
Tornou-se uma banalidade dizer que a sociedade contemporânea está em mutação. A palavra "mutação" só tem conteúdo preciso na biologia. Quando empregada com um sentido sociológico trata-se menos de um conceito que de uma imagem, uma metáfora. Essa imagem pode mascarar a questão essencial: para onde vamos?

Não é menos certo que essa "mutação" é caracterizada por crises múltiplas que se imbricam umas nas outras, desde as crises econômicas e as crises da economia política, até as crises na arte, na literatura, no cinema, no teatro, na universidade, na juventude etc (LEFREBVRE, 2016, p.75).
\end{abstract}

É interessante notar como o filósofo e sociólogo francês Henri Lefrebvre contextualiza a crise na arte a qual me refiro aqui dentro de um espectro mais amplo: o das crises múltiplas da sociedade contemporânea. A arte, no sentido atribuído pelo autor, seria mais uma manifestação dessa crise. Lefebvre ainda atesta que o urbano aparece e se manifesta no curso da explosão da cidade, ou seja, de sua dissolução. Desse modo, o cenário de dissoluções identificado na arte contemporânea constituiria uma reação à ideia de urbano e não à cidade propriamente dita. Como todos os nossos exemplos se referem ao contexto urbano, vale investigar, como sugere o autor, para onde vamos. O que gera a cena contemporânea deambulatória que se inscreve na cidade, como arte urbana?

[...] trata-se, antes, de uma forma, a do encontro e da reunião de todos os elementos da vida social, desde os frutos da terra [...] até os símbolos e as obras ditas culturais. No próprio seio do processo negativo da dispersão, da segregação, o urbano se manifesta como exigência de encontro, de reunião, de informação (Ibid., p.80).

\footnotetext{
${ }^{1}$ Ver artigo da autora "O teatro em fuga ou Quando o teatro escapa de si mesmo", publicado na Revista Sala Preta v. 13, n. 2 (2013), disponível em: <http://www.revistas.usp.br/salapreta/article/view/69080/71525>.
} 
À medida em que passei a me identificar com práticas mais performativas no contexto das artes cênicas, pensei em recusar a nomenclatura "teatro" e afirmar que meu interesse se voltava para experiências que não poderiam mais ser chamadas assim. Por um lado, percebo um interesse crescente pelo campo da performance e por todas as possibilidades de interface com as artes visuais, com o cinema, com a arquitetura e com a cidade. Por outro lado, meu interesse por esse teatro fora do teatro, em fuga, não desapareceu. Então, concluí que ao negar o "teatro", ou seja, afirmar que as criações que me interessam não podem ser consideradas teatro, e sim de "experiências" por exemplo, eu estaria colaborando para a delimitação da linguagem teatral dentro de parâmetros conservadores. Desse modo, ao associar esse estudo à área do teatro, eu poderia colaborar para sua modificação, endossando as alterações presentes na cena contemporânea como ampliadoras de possibilidades. Não me interessa, portanto, categorizar rigidamente as linguagens artísticas, pois pretendo transitar entre o teatro e a performance com certa liberdade, deixando o ato de caminhar e o espaço urbano serem os elementos comuns a ambas as linguagens.

As manifestações analisadas nessa tese se encontram, portanto, num campo liminar, entre o teatro, a performance, a dança, a arte conceitual e o real. Como em todos os casos o deslocamento físico está presente, há a preponderância do corpo, não apenas do artista como também do espectador, o que nos leva a enxergar nessas experimentações outras formas possíveis de teatro, de performance ou de vida. Resolvi aceitar o desafio de contribuir para a expansão da noção de teatro, bem como para a expansão da noção de arte, e afirmar que tais criações estão afinadas com o ar do seu tempo e se constituem como reações à espetacularização do real, como instauração do jogo, reinventando-se como acontecimento e aproximando-se cada vez mais da esfera da vida. Neste capítulo, portanto, será importante usar os termos: "cena", "encenação", "espectador" e "obra", mesmo sabendo que talvez eles já não sirvam como ferramentas para a análise e discussão desse teatro expandido, assim como já não atendem às solicitações dos estudos da performance. De uma maneira ou de outra, as modalidades artísticas analisadas a seguir respondem à atual crise da representação, questionam os modos de funcionar da arte e sugerem outros modos de agir.

\section{>> I. Encenação em deriva: da instauração do jogo à dissolução da encenação}

O primeiro aspecto que gostaria de destacar é a ideia de encenação em deriva. Ainda que mais adiante meu foco se volte para a desconstrução da noção de encenação, desenvolver essa ideia ajudará a definir com maior precisão o recorte de modalidades cênicas que serão discutidas aqui. Mas por que falar em encenação em deriva e não em encenação itinerante ou em deambulação? Inicialmente, porque o termo 'itinerante' revela a possibilidade de determinada peça de itinerar, ou seja, de ser apresentada em diferentes lugares, 
adaptando-se facilmente às mais diferentes condições e não à presença de deslocamento em sua composição. Logo, o termo 'itinerante' não se aplica, por exemplo, às criações em site specific tratadas neste estudo. $O$ uso do termo 'deambulação' também serviria para desenvolver essa ideia, pois ele se refere ao deslocamento, a uma cena construída sobre o movimento, geralmente produzido pela caminhada a pé. Porém, quando se fala em deriva, há um aspecto de experimentação, de imprevisibilidade e de liberdade, que aproxima o enquadramento dessas produções do campo da performance. Além disso, ao afirmar que se trata de uma encenação em deriva, defendo de modo indireto, que ela está em deriva, que ela erra em busca de novos formatos e possibilidades, como se buscasse outros modelos de mundo, de vida, de existência. Não pretendo assim afirmar que a encenação contemporânea está perdida, nem que haja um descrédito nos seus descaminhos; ao contrário, considero o ato de errar um valor. Permanecer na fronteira se configura como um desafio, uma opção por existir em estado de risco, na liminaridade.

As errâncias são definidas pelos dicionários como desvio, afastamento ou como vagar, andar sem destino, perder-se no caminho, cometer erro. O verbo errar também tem definições parecidas, que vão do cometer erro ao enganar-se, vagabundear, vagabundar, percorrer. A desorientação, ou o perder-se, faz parte da própria definição da errância (e do errar), assim como a ideia do erro, o errar de caminho, errar o itinerário, que também está relacionado a uma desorientação. Na errância não se anda de um ponto a outro, a errância está no próprio percurso, nos entres e erros dos caminhos. [...] A errância é o entre, ou seja, é o próprio trajeto, o percurso, o itinerário. O errante é o itinerante, o ambulante, aquele que erra e se perde. (JACQUES, 2012, p.273-274).

Embora eu dedique um capítulo inteiro para o estudo da deriva (capítulo três), é fundamental antecipar a apresentação desse termo para discuti-lo como um aspecto recorrente nas encenações contemporâneas. Ao procurar a palavra deriva no dicionário², as definições apontam para universos distintos: do marítimo à teoria de formação dos continentes. Fala-se em "desvio de rota de um navio ou aeronave", em "medida do desvio em relação ao funcionamento normal que um aparelho ou instrumento passa a apresentar com o decorrer do tempo", em "medida do desvio que ocorre entre o momento em que se abre o paraquedas e o instante em que atinge o solo" e na "teoria segundo a qual os continentes seriam constituídos por fragmentos de blocos da crosta terrestre superior boiando sobre 0 sima". O que há em comum entre todos esses universos é o fato de navios, aeronaves e blocos da crosta terrestre se deslocarem sem rumo, ao sabor dos ventos e das correntes, sem governo. Nenhuma referência ao ato de andar ao sabor dos acontecimentos preconizado por Guy Debord nos anos 1950.

A noção de deriva, criada pelo jovem Debord, se configura como uma grande inspiração

2 Dicionário Huaiss da Língua Portuguesa. Rio de Janeiro: Ed. Objetiva, 2007, p. 944. 
para inúmeros artistas que adotaram a "caminhada como prática estética" (CARERI, 2013), ainda que para ele, as derivas não tivessem uma finalidade artística. Ela se constitui como um deslocamento sem rumo, que não prevê um local de chegada, apenas um ponto de partida. Tal prática é frequentemente associada ao ato de perder-se, o que não é falso, pois as pessoas podem se perder - mesmo em locais conhecidos - ao praticar uma deriva. Entretanto, Debord afirma que a deriva está mais associada à perda de tempo do que ao perder-se, uma vez que ela não produz um deslocamento objetivo, não produz nada, nem deixa rastros.

Entre os diversos procedimentos situacionistas, a deriva se define como uma técnica de passagem apressada através de ambiências variadas. $O$ conceito de deriva é indissociavelmente ligado ao reconhecimento de efeitos de natureza psicogeográfica, e à afirmação de um comportamento lúdico-construtivo, o que se opõe em todos os pontos às noções clássicas de viagem e passeio (DEBORD, 2006, p. 251). ${ }^{3}$

Segundo Debord, a deriva é uma técnica de deslocamento praticada por uma ou mais pessoas, geralmente a pé ${ }^{4}$, cujo percurso é definido pelas "solicitações do terreno" e pelos "encontros" que acontecem ao longo do caminho. O campo espacial da deriva pode ser preciso ou vago, pois essa atividade visa, ao mesmo tempo, o estudo de um terreno e dos afetos provocados por ele. Esses dois aspectos da deriva apresentam múltiplas interferências, sendo impossível isolar um do outro. Por isso, a psicogeografia é tão importante para a prática da deriva, ela é considerada sua metodologia. Ela se refere aos efeitos que o meio geográfico produz sobre os afetos dos indivíduos. No número 20 da revista Potlatch ${ }^{5}$, Debord fala sobre uma unidade de ambiência presente num recorte do quinto arrondissement de Paris - região da Rua Mouffetard ao lado da Place de Contrescarpe, recorrente em seus textos. A percepção de uma ambiência similar nesse conjunto de quarteirões é resultado de uma fina observação dessa região, que foi bastante frequentada pelo autor.

É importante destacar que a deriva é um acontecimento quase invisível aos olhos da cidade, sem nenhum traço de teatralidade e quase sem registros por parte dos Situacionistas (os responsáveis pela Internacional Situacionista, organização revolucionária que publicou uma revista de 1957 a 1972). Há apenas dois relatórios a respeito de derivas realizadas em

\footnotetext{
${ }^{3}$ Entre les divers procédés situationnistes, la dérive se définit comme une technique du passage hâtif à travers des ambiances variées. Le concept de dérive est indissolublement lié à la reconnaissance d'effets de nature psychogéographique, et à l'affirmation d'un comportement ludique-constructif, ce qui l'oppose en tous points aux notions classiques de voyage et de promenade (tradução minha).

${ }^{4}$ Em Teoria da Deriva (texto publicado na Revista Les Lèvres Nues no 9), Debord assume a possibilidade de se tomar um taxi no meio de uma deriva, seja para se chegar a uma destinação precisa, seja para se deslocar 20 minutos a oeste (DEBORD, 2006, p. 254).

${ }^{5}$ Revista publicada entre 1954 e 1957, por participantes da Internacional Letrista, que após algumas dissidências daria origem à Internacional Situacionista. A redação do primeiro número, em 1954, apresenta a revista como "a publicação mais engajada do mundo: nós trabalhamos para o estabelecimento consciente e coletivo de uma nova civilização" (DEBORD, 2006, p. 133, tradução minha).
} 


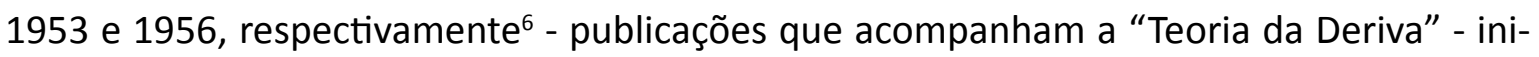
cialmente na revista belga Les Lèvres Nues $\mathrm{n}$ 9 e posteriormente no $\mathrm{n} \div 2$ da revista Internacional Situacionista ${ }^{7}$. O pesquisador Gabriel F. Zacarias, cuja tese se configura como uma genealogia da arte e do pensamento de Guy Debord, a partir da experiência e da representação do sujeito, menciona algo bastante recorrente a respeito do situacionista, o paradoxo que se resume à seguinte equação: ser o último revolucionário ou o último artista de vanguarda (2014, p. 13). Nesse sentido, Debord não chegou a se afastar totalmente das artes, embora tenha se alinhado em diferentes momentos a correntes que pregavam o fim ou a superação das artes. $\mathrm{O}$ autor produziu colagens de imagens e textos muito próximos da arte pop, que inspiraram sua teoria do desvio ou da apropriação (détournement), além de ter realizado diversos filmes. Para Jacopo Crivelli Visconti, que publicou um livro em 2014 sobre as novas derivas, ao longo dos anos 60 - um período marcado pela ruptura entre artistas e revolucionários - "a prática da deriva como ação de cunho artístico começava a afirmar-se [também] como tipologia autônoma e reconhecida" (2014, p. IX). Seu estudo leva a crer que a partir dessa matriz situacionista, inúmeros artistas produziram derivas como ações artísticas, proporcionando uma grande contribuição para a arte contemporânea.

A ideia de encenação em deriva remete a criações que promovem o deslocamento, aleatório ou não, de artistas e público por ambiências diversas. Tais ambiências podem ser percebidas e reveladas pelos artistas ao longo do percurso ou podem ser artificialmente produzidas por eles. Existem muitas maneiras de alterar uma ambiência: por meio do som, da inscrição de intervenções no espaço e também pela instauração de uma presença mais visível do artista no espaço. Nesse sentido, ao optar pelo termo encenação em deriva reforçamos também a ideia de que se trata de uma criação ou da revelação de ambiências no contexto urbano. De fato, quem experimenta uma deriva são os espectadores. São eles que vivenciam o percurso pré-definido pelos artistas, que por sua vez já o terão explorado inúmeras vezes. Mesmo que eles tenham explorado certo território por meio de derivas ao longo do processo de criação, quando a ação é realizada publicamente, a maioria dos artistas já conhece o percurso, o que não poderia se configurar como uma deriva. Entretanto, para os mais variados tipos de espectadores, tanto de encenações quanto de performances urbanas fundadas na caminhada, o percurso será sempre desconhecido.

Não se trata, portanto, de uma percepção objetiva, pois alguns espectadores têm a impressão de estarem perdidos, de serem levados ao sabor dos acontecimentos, e outros não. Há até quem considere que uma vez que somos levados, conduzidos por alguém, não estamos em deriva. Acontece que dificilmente ao longo de uma peça o espectador será conduzido o tempo todo por uma mesma pessoa. Na verdade, quem o conduz não é 'alguém', mas uma

\footnotetext{
${ }^{6}$ Deux comptes rendus de dérive (DEBORD, 2006, pp. 257-263).

7 O primeiro número da revista saiu em Paris, em junho de 1958, sendo Guy Debord seu editor até o último número dessa publicação, que data de setembro de 1969.
} 
série de circunstâncias, compostas por diferentes estímulos e convites. O que a encenação em deriva apresenta é uma sequência de ambiências, um jogo com aspectos da realidade que parecem suspensos e temporariamente ressignificados.

É como se o artista recriasse o contexto urbano, modificasse a experiência de caminhar pela cidade, criando trilhas sonoras, alterando lógicas e propondo reflexões. Dependendo da ambiência, fruto de mais ou menos intervenção do artista, o espectador será mais ou menos atraído para ela. Frequentando as mais diferentes modalidades artísticas instaladas na cidade, sabemos que os espectadores podem ou não se deixar captar pelo que está sendo apresentado. Não há um controle absoluto sobre sua atenção (aliás, em nenhuma criação artística) e, sem grandes dificuldades, a pessoa pode recusar ou se abster de viver tal experiência. Se a deriva é uma passagem rápida por ambiências diversas, uma encenação em deriva é uma criação cênica que joga com essas ambiências, incitando o espectador a imergir numa sequência de imagens e sons, percorrendo um trajeto previamente definido, porém, sem ser objetivo, sem ser funcional (assim como em uma deriva). Dessa maneira, podemos afirmar que tais espectadores ou participantes da ação (quando são os próprios espectadores que acionam a ação) partem em deriva pela cidade, passando por caminhos desconhecidos, enquanto os artistas percorrem um caminho conhecido e de maneira objetiva, pois têm o intuito de apresentar sua criação.

Nesse sentido, a problemática que vem à tona é a seguinte: em que o ato de caminhar pode modificar o estado corporal e a relação dos indivíduos com o ambiente urbano? O espaço público não pode ser desassociado dos cidadãos que o habitam, pois são esses cidadãos que o constroem (ou tentam fazê-lo) todo o tempo. Percorrendo as cidades a pé, os artistas praticam um exercício simples que permite (re)descobrir o espaço público, devolvendo, ainda que temporariamente, esse espaço para os pedestres. Tais ações fazem dessa atividade elementar - o caminhar - uma comunicação coletiva, potente e profundamente vinculada à ideia de urbanidade. Caminhar, desse modo, assume um caráter tanto estético quanto ético.

Andar a pé representa tanto uma recusa à aceleração do tempo, quanto uma valorização do caminho percorrido. Num tempo em que os valores dos cidadãos se caracterizam pelo aumento da velocidade e o aproveitamento máximo do tempo - frequentemente associado ao dinheiro - uma das grandes aspirações coletivas para o futuro é o encurtamento das distâncias. Tal aspecto evidencia o quanto os caminhos percorridos não são considerados importantes, são considerados "passagem inútil”, um modo de suprimir o espaço em favor do tempo. O que as encenações em deriva proporcionam aos seus frequentadores é justamente o contrário: uma mobilidade lenta, um convite à observação detalhada do percurso

\footnotetext{
${ }^{8}$ Mais uma referência ao modo pelo qual Debord escreve sobre a deriva.
} 
e uma permissão para se 'perder' tempo, ou seja, desfrutar do tempo de maneira subjetiva. Resta, portanto, a seguinte questão: será que essas abordagens artísticas são capazes de interferir diretamente no imaginário do cidadão? E elas são suficientemente potentes para fomentar a produção de outros mundos possíveis?

A partir de agora o texto será entremeado por análises de encenações e performances sedimentadas no ato de caminhar no espaço público como forma de aprofundar as discussões apresentadas. A partir do passeio pelos exemplos que considero mais inspiradores, convido o leitor a refletir sobre o estado atual da cena contemporânea, que se configura de maneira impermanente, movediça e profundamente vinculada à esfera do real. Nessa interface entre arte e vida, entre construção e percepção, entre intervenção na realidade e aproveitamento dos fluxos cotidianos é que desenvolvemos os três eixos desse capítulo, que versam respectivamente sobre o esfacelamento da encenação, da figura do espectador e da própria arte enquanto obra. Ao explorar modos de usar mais abrangentes, a arte se confunde com a vida e nem por isso ela será menos arte, mas com certeza, ela já não será mais a mesma. Por esse motivo, ao elencar os estatutos em dissolução nas artes cênicas e performáticas, não pretendo anunciar o fim da arte, já tão anunciado desde o início do século passado. $\mathrm{O}$ que pretendo anunciar é o quanto a arte se modifica à medida em que ela se propõe a ser móvel, pois tal desterritorialização corresponde a uma extensão do seu território e não à sua extinção.

_ O Farol - uma contemplação da velocidade, de OPOVOEMPÉ: o jogo instaurado em diferentes meios de transporte. Uma reflexão sobre a mobilidade urbana.

O experimento cênico $O$ Farol integra a trilogia A Máquina do Tempo (ou Longo Agora), na qual OPOVOEMPÉ se propôs a discutir o tempo em três experiências distintas. Nesse experimento tal discussão conduz para uma reflexão sobre a mobilidade nos grandes centros urbanos: quanto tempo se leva de casa até o trabalho, que meios de transporte são utilizados, quanto tempo se espera. A estrutura do tempo na vida das pessoas revela graus de liberdade e de poder; quanto mais dinheiro, mais velocidade. Tal proposta resultou em um formato de encenação em deriva bastante interessante.

O Farol foi inspirado nas ideias acerca da velocidade de Paul Virilio e na imagem de uma

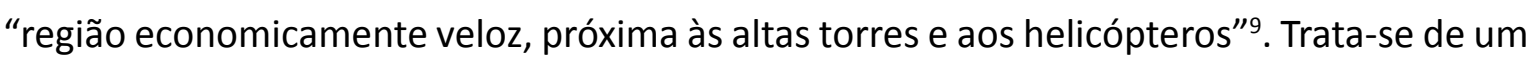
"percurso sonoro ou um documentário ao vivo". A princípio, a cidade foi o ponto de partida para a definição da "dramaturgia pós-dramática, não ficcional, que incorporava elementos

\footnotetext{
9 Os trechos entre aspas desse parágrafo são citações da publicação organizada pelo grupo OPOVOEMPÉ, intitulada "A Máquina do Tempo (ou Longo Agora)", de 2012.
} 
o poeta (ou o artista) contemporâneo de Giorgio Agamben. Para ele, "contemporâneo é aquele que mantém fixo o olhar no seu tempo, para nele perceber não as luzes, mas o escuro" (AGAMBEN, 2009, p.62). Em resposta à velocidade, ao trânsito e aos helicópteros, o experimento propõe pausas para ouvir reflexões sobre o tempo. Nessas velocidades diversas, representativas das luzes e das trevas da contemporaneidade, o experimento convida a olhar através de janelas que enquadram desigualdades, diferentes fluxos e dinâmicas presentes nos aglomerados urbanos.

A cidade pode ser considerada como o primeiro eixo dramatúrgico, uma vez que o percurso dos espectadores foi o ponto de partida para a articulação da trilha sonora. Tal percurso foi resultado de uma experiência de errância pela cidade. Ao se perder em São Paulo, uma das integrantes do grupo chegou a um antigo estacionamento de trens abandonados na Estação Presidente Altino. Diante de tal visão de imobilidade, a artista encontrou o que seria a imagem do "escuro da contemporaneidade", uma oposição singular ao sentimento de velocidade, fluidez e transitoriedade impregnado no corpo de quem habita ou frequenta um grande centro urbano. A fim de revelar o quanto a velocidade do indivíduo é diretamente proporcional ao poder econômico do cidadão, O Farol convida os espectadores a se deslocarem de diferentes maneiras (a pé, de carro e de trem), partindo da Berrini, uma região empresarial de São Paulo, e chegando à periferia da cidade. Quanto mais próximo se está do mundo dos negócios, mais rápido e mais eficiente é o deslocamento; na medida em que o cidadão se aproxima da periferia, mais tempo se espera e mais se desacelera.

Para assistir $O$ Farol, o espectador deve agendar sua participação antecipadamente por telefone. Ao chegar ao ponto de encontro - a portaria de um grande hotel situado nessa área empresarial da cidade - o espectador é recebido como se fosse pegar um voo: tem que apresentar seu número de reserva e responder um questionário. As saídas acontecem de dez em dez minutos. Com apenas dois espectadores por sessão, eles são guiados a partir de proposições mínimas por alguém que porta uma mala vermelha. Essa pessoa não atua em um sentido teatral, não assume uma personagem; ela simplesmente faz uma mediação entre o espectador e a cidade, levando-o a experimentar diferentes velocidades. Trata-se, portanto, de uma criação contextual, pois emerge de determinado contexto e propõe uma interação com os elementos, os modos de vida e de mobilidade encontrados nele. Não há nessa criação uma camada ficcional que se sobrepõe ao que a realidade apresenta. OPOVOEMPÉ convida o espectador a refletir sobre as condições de vida e as organizações sociais observadas ao longo desse percurso, que se fizesse parte de outra cidade, de outro contexto, evocaria outras questões.

Ao longo do percurso sonoro, distintos performers conduzem os espectadores. Cada um é responsável por uma parte do trajeto, mostrando placas - onde se lê: "A partir de agora, observe se a velocidade do outro é a mesma que a sua" - ou mensagens na tela de um 
tudo fica mais lento. No final do percurso proposto pela peça, o espectador - que se encontra sobre uma longa passarela suspensa - se detém diante de uma visão da imobilidade: um cemitério de trens abandonados. Essa última visão, composta de vagões parados sobre os trilhos da CPTM, sintetiza uma oposição singular entre a velocidade, a fluidez, a pressa e a impaciência presentes nos corpos que habitam um grande centro urbano.

Nesse percurso sonoro, os espectadores são considerados atuadores sutis que se relacionam apenas visualmente com os atores. A cena, no entanto, permanece invisível no corpo da cidade, avessa à espetacularização do cotidiano, escoa por São Paulo sem se deixar perceber. Como não há atuação, não há cena no sentido mais convencional do termo, o que se observa é a teatralidade do próprio espaço urbano. O experimento se destaca da vida real porque artistas pensaram previamente esse percurso, escolheram recortes da cidade para serem observados e compuseram uma trilha sonora especialmente para ser ouvida ao longo desse trajeto. Justamente pelo caráter exclusivo do áudio, que se refere precisamente a determinado recorte geográfico da cidade (ou seja, ele não funcionaria caso decidíssemos ouvi-lo ao longo de outro percurso), que $O$ Farol se constitui como uma criação em site specific. Na verdade, o que é visível aos "praticantes ordinários da cidade" ${ }^{10}$ são duas pessoas portando fones de ouvidos, seguindo uma terceira, cujo ritmo de caminhada varia entre muito depressa e muito devagar, dependendo do lugar onde se encontra.

Em algum ponto entre o hall do hotel e a parada de trens, uma voz pergunta ao espectador: Como reduzir as distâncias entre centro e periferia? O esgotamento, a fadiga - que promovem "preguiça de ler e de raciocinar" - produzem cidadãos anestesiados, numa eterna corrida contra o tempo e a favor do capital. A equação do homem contemporâneo passa a ser "penso, logo produzo". Assim, O Farol se configura como um convite a (re)pensar nossa organização do tempo (em relação ao trabalho, à família, o tempo de ócio, o lazer, ...) e as consequências do processo de aceleração vivido nesse último século.

Por mais que visões da cidade sejam apresentadas em diferentes momentos do experimento cênico, elas não são criadas por um encenador, que cria peças como quem cria visões. Nesse caso, as visões são cuidadosamente recortadas do contexto urbano e oferecidas ao olhar do espectador em momentos específicos. Há ainda as visões que cada um recolhe da cidade, o tempo todo, montando uma faixa de imagem particular. Entretanto, nessa proposta, por se tratar de um percurso sonoro, a visão perde seu protagonismo e o caminhar é colocado em primeiro plano, pela exploração de trajetórias diferentes daquelas praticadas cotidianamente. A cidade, assim, passa a ser observada e explorada de maneira não usual. Ela se torna um espaço lúdico, de experimentação de diferentes velocidades e de trans-

\footnotetext{
${ }_{10}$ Os trechos entre aspas, nesse parágrafo e no próximo, são citações da dramaturgia do experimento cênico. Neste caso, as artistas de OPOVOEMPÉ usam a mesma nomenclatura usada por Michel de Certeau ao se referir aos habitantes da cidade.
} 
formação do uso do tempo, que deixa de ser produtivo e passa a ser ocioso. A experiência propiciada aqui é menos de consumo de um espetáculo e mais de exploração de um território, uma atividade improdutiva (como o jogo) e antifuncional (como uma errância urbana).

$<<>>>$

O segundo aspecto que gostaria de destacar - após desenvolver a noção de encenação em deriva - notável em grande parte das manifestações artísticas analisadas, é o deslocamento da noção de mise en scène para a noção de mise en jeu. A primeira noção pode ser traduzida por "encenação". O verbo mettre, do qual deriva o particípio mis, significa colocar, dispor elementos em cena: os que são e os que não são visíveis. Patrice Pavis associa esse ato de por em cena à transformação do texto em ato. Segundo esse ponto de vista, a encenação se refere necessariamente a um texto prévio. Muitos autores, entretanto, associam a prática de mise en scène à criação de visões, ressaltando o rompimento com uma hierarquia textual. Esses autores reforçam a ideia de que a encenação define espacialidades e pontos de vista, sem excluir a temporalidade dessas visões, uma vez que elas se constituem a partir de uma permanência no tempo. A definição dos tempos (durações, pausas, as reincidências e repetições), a ordem da apresentação dos fatos e das personagens, assim como a escolha do posicionamento do público cabe ao encenador. Em suma, a encenação pode ser definida pela organização de uma estrutura que será vista e ouvida, ao mesmo tempo, pelo espectador. Vem dessa prática da mise en scène, a afirmação do diretor norte-americano Bob Wilson (célebre criador de visões) de que suas composições são uma combinação de um filme mudo com uma peça radiofônica.

Béatrice Picon-Vallin retoma os estudos desenvolvidos por Edward Gordon Craig e Vsevolod Meyerhold, no início do século XX, ao discutir a mise en scène moderna e suas relações com a visão e a imagem. Craig imagina o teatro do futuro, no qual o encenador teria se tornado o "artista do teatro"; Meyerhold, por sua vez, o considera "o autor do espetáculo". Para ambos, o encenador "não é somente aquele que dirige, organiza, reúne, orquestra os elementos, os objetos e os atores (...), mas aquele que passa a escrita à espada do olhar e apreende da peça a ser encenada uma visão por vezes precisa e sugestiva" (PICON-VALLIN, 2004, p. 12). A criação de uma visão por parte do encenador corresponde, portanto, à "luta contra a dominação do texto escrito" ou ao "tornar visível o invisível". Nas palavras de Meyerhold, seria preciso "parar de ser ilustrador" para tornar-se encenador (Ibid., 2004, p.15). Desse modo, percebe-se que o questionamento à hegemonia do texto surge no teatro ao mesmo tempo em que aparece a figura do diretor.

Para a noção de mise en jeu, que pretendo desenvolver aqui, a tradução mais adequada é instauração do jogo. Neste caso, a criação de uma visão observada de determinado ponto de vista é substituída pela proposição e subsequente instauração de um jogo. Não são 
necessariamente os elementos da cena que são organizados, mas alguns dispositivos apresentados com a intenção de que um jogo seja experimentado. Ainda que elementos cênicos tais como espaço, tempo e corpos sejam ordenados pelo jogo, as finalidades dessas ações são distintas. Uma visão é uma imagem para ser observada esteticamente e um jogo é uma forma de convívio. A diferença também está no endereçamento das regras, pois no caso do jogo, elas podem não ser destinadas apenas para os atores ou performers. Elas podem, em certos casos, ser direcionadas para todos e envolver a todos, sem distinguir atores de espectadores, espaço dentro e fora da cena, realidade e ficção. Dentro desse mecanismo de instauração do jogo, o dispositivo pode ser descolado do artista, pode ser acionado por uma pessoa qualquer que assume seu lugar, ou pode ser explorado pelo espectador, prescindindo da presença do artista.

A substituição da palavra cena pela palavra jogo (da mise en scène à mise en jeu) explicita a passagem da ação do especialista da cena para toda pessoa que, num dado momento, se reconheça como jogadora. De acordo com Johan Huizinga, o jogo pode ser definido como uma atividade livre, supérflua, circunscrita em um espaço- tempo e definida a partir de suas próprias regras. $\mathrm{O}$ jogo teria a capacidade de trazer para o primeiro plano a dimensão não utilitária da existência humana. Por esse motivo, ele escolheu estudar o homo ludens, característico por saber jogar e não por saber criar (homo faber) ou por saber trocar (homo oeconomicus). Ele se refere ao jogo como uma função primitiva, uma vez que ele já estava presente na natureza; os animais também jogam. Em seu ensaio sobre a função social do jogo, o autor explica que o jogo é anterior à cultura e não o contrário. Trata-se de uma atividade cujo isolamento espacial e cuja delimitação temporal a separam da vida corrente. Tal característica separaria o jogo da moral e o aproximaria da ficção.

No primeiro número da revista Internacional Situacionista, provavelmente Guy Debord ${ }^{11}$ marca uma diferença entre a definição de jogo de Huizinga e a definição situacionista de jogo. O autor insiste no desaparecimento de todo elemento de competição e reivindica uma ideia de jogo mais coletiva, embasada na criação de ambiências lúdicas ${ }^{12}$. Huizinga acentua a função primitiva do jogo, marcando a passagem do jogo à cultura e revelando que esta última seria estruturada para dar sentido a nossa necessidade de jogar. Debord, no entanto, pretende superar a distinção entre jogo e vida corriqueira, preconizada por Huizinga. Para o situacionista, o jogo é percebido como ficção por sua existência marginal (ele se estabelece num espaço e tempo distintos da vida corrente), ao ser comparado com a realidade estafante do trabalho. Entretanto, nos ideais situacionistas, marcados por frases como "Ne travaillez jamais" [Não trabalhe nunca] - escritas nos muros de Paris em maio

\footnotetext{
${ }^{11}$ Os textos publicados nos primeiros números dessa revista não eram assinados pelos integrantes da I.S., porém segundo o pesquisador Gabriel Zacarias, tudo indica que esse texto tenha sido escrito por Guy Debord.

${ }^{12}$ A partir do texto "Contribution à une définition situationniste de jeu", I.S., n. 1, p. 9-10, 1958.
} 
de 1968 - o trabalho consistia em preparar futuras possibilidades lúdicas e não em manter a máquina capitalista, interessada apenas na produção e no consumo de mercadorias. Para Debord, a liberação do trabalho era a única condição possível para que a vida pudesse ser confundida com o jogo e a saída para isso era a mecanização do trabalho, que liberaria todo o conjunto da sociedade da obrigação de trabalhar.

Traçando paralelos entre essas duas noções de jogo, Gabriel Zacarias afirma que enquanto Huizinga considerava a delimitação espacial mais importante que a delimitação temporal, Debord considerava o tempo o verdadeiro elemento de delimitação do jogo. Por considerar o jogo uma atividade supérflua, Huizinga acreditava que o jogo não estava vinculado a um dever moral e o que o distanciaria da moral era justamente o seu isolamento da vida corrente. Por outro lado, Debord transformava as regras do jogo de uma convenção arbitrária a um fundamento moral. Ele queria fazer a vida ser invadida pelo jogo, aproximando-se do pensamento de Huizinga, que não excluía em absoluto a possibilidade de mergulhar atentamente no terreno do jogo com muita seriedade. Se para Huizinga "o jogo é uma luta por alguma coisa, ou a representação de alguma coisa"; para Debord, o jogo "é também luta e representação: luta por uma vida à altura do desejo, representação concreta dessa vida" (JACQUES, 2003, p. 61). Segundo Zacarias, o jogo e a noção de situação - que dará o nome para o grupo situacionista - são as principais armas da vanguarda situacionista, pois elas podem dar às pessoas a oportunidade de abandonar a passividade e tornar-se "um agente ativo da própria vida"13.

Essa noção de jogo interessa ao presente estudo por dois motivos. Primeiro, para dar corpo à instauração do jogo, como movimento correlato à encenação, uma atividade supérflua, porém séria. Depois, a radicalidade de Debord ao colocar o jogo como luta por uma vida à altura do desejo, que não ocorre apenas no recorte espaço-temporal da experimentação artística, é fonte de transformação das relações humanas e do modo de estruturar o espaço-tempo do trabalho, do lazer, da vida. Tal expansão da abordagem de jogo, imbricada na vida, será retomada ao final do presente capítulo quando discutiremos a passagem da obra para o acontecimento e a construção de situações.

Por não estar vinculada à configuração de visões, de um espaço e um tempo objetivos ou de pontos de vista claramente definidos, a instauração do jogo potencializa a performatividade do evento. Tal exploração é mais subjetiva, sujeita ao envolvimento dos jogadores, que se organizam no espaço e no tempo não somente em função das regras do jogo, mas também em função da experiência lúdica do momento. Patrice Pavis desenvolve a noção

\footnotetext{
${ }^{13} \mathrm{~A}$ palavra usada por Debord é viveur, cuja tradução no Dicionário on line Michaelis é "homem que leva uma vida de prazeres, pessoa que só pensa em se divertir". Optei, no entanto, por "agente ativo da própria vida" para enfatizar sua ação sobre a vida, sua tomada de decisão, sem evidenciar a busca exclusiva pelo prazer e opondo-se a um estado de passividade.
} 
de mise en jeu de forma diferente. Para ele essa noção pode ser definida como a "primeira etapa do trabalho com os atores, consistindo em fazê-los falar, jogar e deslocar-se no início do processo de ensaio" (PAVIS, 2010, p.317) ${ }^{14}$, o que não corresponde ao uso do termo apresentado neste texto. Esse mesmo autor defende que a encenação é a transposição da escrita dramática para o ato, de modo que a cena seria uma espécie de explicação do texto.

Nesse sentido, a mise en scène resultaria em uma estrutura mais fixa, definida por um olhar de fora, assumido pela figura do encenador. A mise en jeu, por sua vez, resultaria em uma estrutura mais aberta, centrada no jogo, na qual o performer se ocupa de um "fazer", que seria facilmente apreendido pelo espectador, que por sua vez, pode ser convidado a integrar ou a desenvolver, ele próprio, o jogo. Voltaremos à discussão sobre a centralidade do espectador mais adiante. A função atribuída ao encenador responsável por essa instauração do jogo seria, portanto, a proposição de uma sequência de jogos, de um dispositivo relacional (de convívio ou de envolvimento das pessoas presentes) ou, simplesmente, de um dispositivo de passagem do tempo, em detrimento da criação de uma sequência de visões, como acontece na mise en scène. Acontece que a figura do encenador que se ocupa de instaurar um jogo fica enfraquecida, instável e oscilante. Essa função entra em colapso e corre risco de extinção. Desse modo, a hegemonia do olhar do encenador, que garantiria a construção de uma visão exata e, por conseguinte, de um discurso, passa a ser menos fundamental. De certa forma, qualquer participante, mesmo alguém que integra o jogo, participando efetivamente dele, poderia se ocupar dessa tarefa.

_Home Visit Europe, Rimini Protokoll (2015): o teatro dentro de um apartamento, sem atores e na forma de um jogo instaurado.

Para explicar a noção de instauração do jogo como substituta à noção de encenação, optei por incluir nesse texto a análise da peça Home Visit Europe, do coletivo alemão Rimini Protokoll ${ }^{15}$. Tal criação foge às premissas iniciais das peças analisadas nessa pesquisa por não se passar na rua, nem em deslocamento, mas dentro de um apartamento de um cidadão comum, que oferece sua casa como espaço para a instauração desse experimento. Embora não aconteça no espaço público, ela propõe uma experiência errante pela cidade e inspirou

\footnotetext{
${ }^{14}$ Mise en jeu: première étape du travail avec les acteurs, consistant à faire dire, jouer et se déplacer les acteurs au début du processus de répétitions (tradução minha).

${ }^{15}$ Rimini Protokoll é um coletivo formado pelos encenadores Helgard Haug, Stefan Kaegi e Daniel Wetzel. O coletivo trabalha no limiar entre a realidade e a ficção, desenvolvendo pesquisas sobre situações existentes, dialogando com espaços reais e convidando não atores para suas encenações. Maiores informações no site: $<$ http://www.rimini-protokoll.de>.
} 
muitas reflexões sobre a ideia da instauração do jogo (mise en jeu $)^{16}$. Cada apresentação acontece em um endereço diferente. De acordo com a data e o horário, o espectador deve se dirigir à casa de um morador diferente de Aubervilliers cadastrado previamente para receber em torno de sua mesa até 15 desconhecidos. Quando me vi, em um domingo cinzento, caminhando na periferia de Paris em busca de um endereço de uma pessoa que eu não conhecia, numa região onde eu nunca tinha estado, pensei imediatamente nas experiências de deriva, especialmente aquelas realizadas com o Coletivo Dodecafônico nas quais exploramos estratégias para perder-se. Um corpo que caminha numa cidade em busca de um teatro que nunca frequentou, sabe que chegará a uma instituição chamada teatro, onde terá um hall, no qual outros espectadores se concentram; verá informações sobre a peça, localizará rapidamente um café e uma livraria, onde poderá esperar o início do espetáculo. Ou seja, esse corpo saberá exatamente como agir, como distrair-se ou passar seu tempo. As ações e as expectativas presentes no corpo desse espectador são conhecidas, já exploradas e, de certa forma, assimiladas por um espectador habitual de teatro.

Acontece que, buscar o endereço de um desconhecido, caminhando alguns quarteirões nas imediações de um metrô fora da cidade, entrar na casa dele e passar algumas horas em companhia de outros tantos desconhecidos se constitui como uma experiência totalmente distinta daquela de chegar em um teatro e suas dependências. Esse corpo, que era o meu, caminhava pela cidade como um corpo desejante, um corpo que em pouco tempo experimentaria algo novo e inusitado. $O$ trajeto do metrô ao apartamento foi povoado de percepções sobre esse estado corporal, sobre o papel do acaso nos fatos que se sucedem e no fato de que a experiência proposta pelo Rimini inicia-se antes mesmo que o endereço seja encontrado. Pelo tipo de experiência com a cidade que essa ação suscita, optei por incluir a análise dessa peça, que sintetiza de maneira bastante didática a ideia de instauração do jogo em detrimento da noção de encenação.

Assim que cheguei ao conjunto de prédios correspondente ao endereço que buscava, encontrei uma senhora, muito velhinha, que aparentemente se encontrava ali pelo mesmo motivo que eu. Nós nos olhamos e nos reconhecemos como espectadoras errantes. Nós duas nos surpreendemos no ápice dessa aventura: a busca por uma peça escondida dentro de um daqueles pequenos apartamentos de antigos operários, localizados ao norte de Paris. A pergunta que me ocorreu foi: que tipo de gente se propõe a visitar um desconhecido em busca de viver uma experiência teatral? E a primeira resposta que me ocorreu, antes mesmo de entrarmos apertadas em um elevador minúsculo que nos levaria até a casa de uma anfitriã simples e sorridente, foi: qualquer pessoa. Dentro do apartamento se encontravam quase todo o público daquela sessão, por volta de 15 pessoas, de idades e ori-

\footnotetext{
${ }^{16}$ A produção foi instalada na França com o apoio do Théâtre de la Commune, um teatro nacional situado ao norte de Paris, em Aubervilliers. Os ingressos eram vendidos na bilheteria do teatro, assim como a peça era divulgada dentro de sua programação, ainda que nenhuma apresentação acontecesse no teatro.
} 
confrontar suas opiniões e experiências de vida. Ninguém assume nenhum papel, a não ser o próprio. Mesmo nas produções do coletivo alemão onde há participantes convidados que criam uma cena observada por espectadores (penso em Lagos Business, encenação apresentada no Festival de Avignon em 2013), os atuadores são tratados como 'especialistas do cotidiano'. No caso de Home Visit Europe, onde os espectadores acionam o jogo e a ação de assistir se resume a uma observação mútua tal qual acontece na vida cotidiana, quando um grupo de pessoas se reúne ao redor de uma mesa, para jogar, comer, conversar e conviver.

Nesse sentido, não se trata de uma encenação de algo para ser visto e ouvido, mas da instauração de um jogo, da criação de uma situação real. Não seria suficiente afirmar que há uma anexação do real (segundo Paul Ardenne), nem uma irrupção do real (segundo Hans-Thies Lehmann), mas a proposição de um momento de partilha, a experimentação de um momento de vida, como se se tratasse da invenção de um jogo de tabuleiro. A situação é de tal modo construída que cada apartamento recebe apenas uma sessão da peça e os anfitriões desconhecem o desenrolar dos fatos. Há regras e diferentes maneiras de apresentá-las: desde a orientação inicial para marcarmos os três pontos no mapa até as instruções impressas por uma engenhoca posicionada no centro da mesa. Esse dispositivo é passado de mão em mão. Cada espectador que o recebe apoia sobre um botão que dispara a impressão de uma instrução (consigne). Ela pode se apresentar como pergunta ou como sugestão de ação endereçada a uma ou mais pessoas. Por exemplo, há perguntas endereçadas aos anfitriões como "desde quando você habita aqui e por que esta região?"18 ou "Quantas pessoas vivem aqui? e outras, a todos: "Quem é ou já foi membro de um partido?", "Quem ao redor dessa mesa tem um trabalho cujo salário o permite viver?" ou "Quem tem medo do futuro?". Há ainda perguntas que serão respondidas por apenas uma pessoa, porém será o grupo, em consenso, que decidirá quem responderá. Para isso, lê-se na instrução: "apontem para a pessoa de quem gostariam de saber de onde vêm seus avós e como eles se encontraram", por exemplo. Tal questão coloca não só uma ação, mas uma decisão a ser tomada pelo público em conjunto. $O$ jogador que lê a instrução conta até três e, aos poucos, as mãos vão mudando o alvo até que todos apontem para a mesma pessoa.

O jogo é apresentado em 4 níveis distintos, nos quais se apresentam decisões importantes como tratados, convenções ou compromissos que também foram assinados em torno de uma mesa (como a Convenção de Dublin de 1990). Cada fato histórico revela um aspecto do viver junto, numa coletividade, que será questionado na forma de uma pergunta ou uma ação. Uma das instruções relata o fato de alguns estados europeus, em 1966, terem negociado no Compromisso de Luxembourg que questões controversas seriam decididas por meio do consenso e não pela vontade da maioria. A seguir, lê-se a pergunta: "quem foi representante de classe?". A engenhoca com um botão que aciona uma pequena impres-

18 Todas as perguntas citadas foram traduzidas do francês por mim. 
sora é, em dado momento, substituída por um pequeno tablete para cada jogador. Esse dispositivo permite que respostas mais pessoais possam ser computadas por um aplicativo que será capaz de agrupar os participantes por afinidades de respostas. No fundo, o que a série de perguntas propõe é uma reflexão sobre o modo de se organizar e de se posicionar politicamente, por isso no último nível do jogo, duplas e depois quartetos são pontuados, instaurando-se uma competição. A trinta e cinco minutos do fim do jogo, o dispositivo da impressora solicita que a anfitriã coloque um bolo de chocolate para assar. Com os sentidos atraídos pelo aroma do bolo, os grupos passam, literalmente, a disputar pela maior fatia do bolo. $O$ aplicativo que controla o jogo chega a imprimir um organograma redondo, nas mesmas dimensões do bolo, que permite dividi-lo nas porcentagens reais alcançadas por cada subgrupo.

O jogo instaurado convida o espectador a refletir sobre os modos de se posicionar politicamente em diferentes escalas: da esfera pessoal à Comunidade Europeia. Não restam dúvidas de que o jogo se instaura; os participantes resgatam suas histórias, questionam-se e tentam interpretar as escolhas de seus oponentes, numa transposição simbólica do jogo político para uma mesa na periferia da cidade. Caso se tratasse de um jogo instaurado na vida real em torno de uma roda de verdadeiros amigos, é possível que se chegasse em uma verdadeira discussão sobre posicionamentos políticos, as escolhas e os ideais de cada um. Mas não é isso que acontece. Nenhuma questão é realmente debatida; se houvesse um real enfrentamento de ideias, o sistema criado para o jogo entraria em colapso. No fundo, há um controle do tempo, há um acordo com os proprietários do apartamento que recebem a ação e também um aspecto mercadológico embutido no evento. O Coletivo vendeu certo número de apresentações, definiu a duração de cada ação e tem contas a prestar. A experiência é mais próxima ou mais distante da noção de acontecimento na medida em que se reconhece mais ou menos performativa. Radicalizar seu coeficiente de performatividade significaria liberar o tempo de discussão, permitir que os participantes derivassem por temas da atualidade ou por histórias que as perguntas suscitassem. Se essa fosse a opção do Rimini não haveria como prever uma duração e o mestre de cerimônias teria um papel muito mais complexo, pois caberia a ele conduzir a sequência de jogos, mediando a conversa e propondo cortes e mudanças de tema em momentos oportunos. Tudo isso inviabilizaria o próprio modo de operar desse coletivo, além de solicitar mais especificidades aos aparatos tecnológicos.

Diferente de uma encenação, essa proposta do Rimini instaura um jogo entre os espectadores e deixa rastros das discussões iniciadas que poderão ser continuadas em torno de outras mesas. Independentemente da impressão de que o coeficiente de performatividade poderia ser elevado, é interessante destacar a implicação dos corpos dos jogadores na ação. Eles são convocados a agir, a se posicionar visivelmente diante de questões que no fundo 
revelam quem eles são. Esse engajamento do corpo, que se levanta, que entra embaixo da mesa ou que se debruça sobre ela e que toma decisões, coloca o participante numa posição radicalmente diferente de um espectador convencional. Essa pessoa integra a situação e se expõe, de um modo parecido com a experiência de participar de um jogo em uma aula de teatro. Ao sugerir que uma pessoa cochiche no ouvido da outra ou que alguém escolha, a partir da observação dos sapatos dos outros, a quem perguntar sobre a caminhada mais longa já empreendida na vida, o jogo aproxima os espectadores. Do mesmo modo, ao convidar o grupo a sentar-se tranquilamente em silêncio e decidir, por meio dessa (não) ação quanto tempo permanece assim, o Coletivo propõe práticas de sensibilização do corpo, da escuta e desse agrupamento de pessoas ali reunidas. No final do encontro, algumas conversas se prolongam, informações são trocadas e contatos se estabelecem.

A instauração do jogo acontece a partir do momento em que saímos em busca de um endereço de uma pessoa desconhecida e se prolonga até o momento em que comemos juntos um bolo de chocolate. Assim, a noção de instauração do jogo ajuda a dissolver a noção de encenação, uma vez que por mais que haja uma elaboração prévia do evento por parte do artistas criadores, são os participantes que agem e que articulam do seu modo a ação. Nem encenadores, nem atores, o que está colocado em questão é o estatuto do artista, em especial, do encenador. Digo isso pois, em última instância, poderíamos afirmar que os espectadores assumem o papel de atores. Nesse caso, os espectadores são encarregados da execução da ação, são eles os operadores do jogo, aqueles que inscrevem seus corpos no espaço, sem responder, no entanto, às prerrogativas de alguém que os dirigisse de fora da cena. A quebra do modelo de recepção baseado na existência de um espaço cênico e uma audiência, assim como a profunda modificação do processo de criação de tais eventos, alteram significativamente o modo de operar desses eventos. Os processos criativos não mais se constituem pela realização de ensaios que visam a repetição, mas da programação das ações, técnica e dramaturgicamente, para serem finalmente experimentadas. É claro que tais alterações nos modos de fazer variam de acordo com a peça ou a performance, no entanto, ao observar de maneira mais abrangente, é possível notar uma instabilidade nos estatutos da cena, do espectador e da obra. São esses aspectos que serão desenvolvidos nos subitens a seguir.

$$
<<>>>
$$

No campo das performances e intervenções urbanas há uma dissolução da encenação, como olhar de fora, como organização do espaço/tempo para ser visto e ouvido. Nos casos em que a performance é realizada por um(a) artista só, a autoria se mantém vinculada a esta pessoa, porém quando se trata de uma ação conjunta, é comum notar-se a dissolução também da ideia de autoria. Não consegue-se identificar quem está no comando, de onde surgiu a ideia inicial e quem está por trás do que acontece. O que importa é o ação, o mo- 
mento exato em que alguém se propõe a realizar algo na cidade que não estava programado. Ou melhor, estava, pois o que resta de preparação é o que Eleonora Fabião nomeou de programa performativo, pois a preparação no formato 'ensaio' é cada vez mais rara quando o assunto é performance.

\footnotetext{
Sugiro que a desconstrução da representação, tão fundamental na arte da performance, é operada através de um procedimento composicional específico: o programa performativo. Chamo este procedimento de "programa" inspirada pelo uso da palavra por Gilles Deleuze e Félix Guattari no famoso ensaio "28 de Novembro de 1947 - Como Criar Para Si um Corpo sem Órgãos. Neste texto os autores sugerem que o programa é o "motor da experimentação". (...) Programa é motor de experimentação psicofísica e política. Ou, para citar palavra cara ao projeto político e teórico de Hanna Arendt, programas são iniciativas. (FABIÃO, 2013, p. 4) $)^{19}$
}

O programa não se confunde com dramaturgia, porque não organiza palavras para serem ditas; usa palavras para descrever ações. O programa também não se confunde com o planejamento de um ensaio ou com uma síntese da encenação. Ele tem um parentesco com o argumento de um filme, embora o argumento suscite a escrita de um roteiro; o que também não acontece a partir da construção de um programa. Ele é roteiro de ação, algo que revela intenções, ou como diz Eleonora, com palavras de Hanna Arendt, iniciativas. Ela também usa o termo enunciado, algo que é dito ou escrito, talvez admitido, antes de se colocar em movimento uma experimentação. É interessante pensar em enunciação quando o assunto é performance, pois o termo remete aos atos de fala, que inauguraram na teoria literária o estudo de enunciados performativos. Pensando em enunciados como palavras que performam, Eleonora continua: "o programa é o enunciado da performance: um conjunto de ações previamente estipuladas, claramente articuladas e conceitualmente polidas a ser realizado pelo artista, pelo público ou por ambos sem ensaio prévio" (Ibid.).

No fazer teatral não há correspondentes para o programa; trata-se de um dispositivo para o artista organizar sua iniciativa e ordenar as ações que compõem sua performance. Nesse sentido, a cena está para o teatro, como a ação está para a performance. Por se tratar de uma proposição concisa - sem adjetivos e com verbos no infinitivo, segundo consideração de Fabião - ela não poderia ser tomada como uma substituta da encenação, mas a prova de seu esfacelamento. Quando Eleonora ressalta que as ações poderão ser realizadas tanto pelo artista, quanto pelo público - retirando das mãos do artista o privilégio do fazer artístico - ela reforça o aspecto político do fazer performance. É a esse aspecto abrangente e inclusivo da performance que me refiro quando penso no potencial pedagógico de cada uma das experimentações analisadas; é sua capacidade de se auto explicar, de apresentar

\footnotetext{
${ }^{19}$ FABIÃO, Eleonora. Programa Performativo: o corpo-em-experiência. ILINX Revista do LUME, Campinas, n. 4, 2013. Disponível em:<http://gongo.nics.unicamp.br/revistadigital/index.php/lume/article/view/276/256>. Acesso em: 01 jun. 2016.
} 
seu modo de usar, sem depender de terceiros (mediação ou explicação externa à ação), e de se fazer ser experimentada pelo outro. Trata-se de um ato capaz de desprogramar o cotidiano, mexer na ordem das coisas, inscrever no imaginário do cidadão a criação de outros possíveis. Parece que a ampliação das possibilidades no imaginário coletivo caminha ao lado da desconfiguração da arte, ou pelo menos, da arte como instituição, como atividade direcionada a pessoas escolhidas e favorecidas socialmente.

Para Antonio Araújo, o olhar de fora contamina a atitude do performer, transformando-o "no encenador da [sua] obra". Ele se apoia nas ideias de Renato Cohen ao afirmar que o performer acumularia as funções de autor e encenador. Segundo Araújo, "na medida em que a função precípua do diretor não é mais a passagem do texto à cena, o campo de experiência do próprio encenador se abre também como material cênico". O autor se concentra no estudo de encenações performativas, nas quais a vida pessoal do diretor também interfere em suas escolhas temáticas e pode, eventualmente, espelhar os fatos apresentados em cena: “(...) a encenação passa a ser, em certa medida, a encarnação, a mise en chair do diretor" (ARAÚJO, 2008, p.254). Essa relação carnal do encenador com a obra revela seu engajamento, um investimento de si mesmo, como postula Josette Féral ao analisar as principais ideias do que nomeia teatro performativo. "Não se trata necessariamente de uma intensidade energética do corpo no modelo grotowskiano, mas de um investimento de si mesmo pelo artista" (FÉRAL, 2008, p. 207).

Contudo, no âmbito da performance o papel do encenador é operado pelos próprios performers, que se tornam protagonistas e "receptores do enunciado", nas palavras de Jorge Glusberg (2003). Independente do nível de visibilidade que uma ação promove, de mais invisível a mais perceptível do corpo na cidade, o que se percebe é uma passagem da criação de uma cena para a execução de ações. O programa revela a iniciativa do performer, que parte em deslocamento pela rua atento à realização e à materialidade das ações. Muitas vezes não há significado escondido por trás da ação, o que não impede que ela provoque questionamentos, crie turbulências e deixe inquietações presentes nas pessoas que a presenciam, como vestígios da performance.

Para citar um exemplo de performance individual, evoco os Experimentos Gramíneos, desenvolvidos por Maicyra Leão, desde 2006, em diferentes cidades ${ }^{20}$. Nessa performance, a artista cobre todo o seu corpo, inclusive o rosto, com uma roupa feita de grama artificial e caminha por centros urbanos carregando um regador de plantas. Por onde vai, a criatura-grama não passa despercebida: um corpo estranho num território conhecido. Geralmente, ela parte de um canteiro da cidade, onde permanece deitada durante um tempo, camuflada à grama real. Descalça, desloca-se com certa dificuldade, realizando ações simples e co-

${ }^{20}$ Maicyra Leão realizou a performance no Rio de Janeiro e em Recife em 2006, em Buenos Aires em 2007, em diferentes cidades do Sergipe em 2010 e circulou pelo Palco Giratório do SESC em 2016. 
ou para onde vai, abre as brechas da qualquer coisa. Hoje, na Gardênia Azul, comunidade bem tranquila por onde percorri essa manhã, à tarde, como grama, as recepções foram outras. Não apenas o jogo lúdico de uma grama de plástico regando uma outra viva ou a si mesma, mas desconfianças que trancam as portas ou que ativam o alarme de segurança geral da vila. Por pouco, eu-grama, não fui confundida com inimigos disfarçados. Carro parando do meu lado e um alvoroço pelos celulares se questionavam se eu era o Cipó ou o Pará. É teatro!!! (trecho de relato de Maicyra sobre as intervenções realizadas na comunidade Gardênia Azul, no Rio de Janeiro, dia 27 de maio de 2016).

Há nessa ação um aspecto crítico à lógica urbana contemporânea, como se de repente um tufo de grama criasse vida e saísse andando por aí, reivindicando mais áreas permeáveis em meio a tanto concreto e asfalto. A opção pela artificialidade do material, somada à ação de regar, que indica cuidado e dedicação a um ser vivo, revela a ironia contida na performance. A crítica de Isis Costa McElroy ${ }^{22}$ produzida no âmbito do Festival Hemispheric (2007) aborda a performance a partir de um fato histórico que merece atenção. Ele se refere à chegada na década de 70 de um tipo específico de grama no Brasil: a brachiária ou brachiarinha, considerada como uma grama imortal, tamanha a capacidade de resistir à seca, pois suas longas raízes sugam toda a água do terreno, matando todas as outras espécies gramíneas que poderiam conviver com ela. Deriva desse fato a destruição do cerrado brasileiro em benefício da criação de ótimas pastagens para gado e a cobertura de vastos terrenos de Brasília com grama (numa substituição urbana do cerrado), que até hoje é mantida pela mesma empresa criada por Juscelino Kubitschek, em 1956. Desse modo, o corpo manifesto de Maicyra denuncia a impossibilidade de sobrevivência de outros representantes vegetais no contexto urbano. O que ela apresenta é um cartão postal do futuro, uma terra arrasada, onde humanos, sem entender muito bem porque, regarão suas plantas artificiais como se fossem vivas.

Tal exemplo retrata essa estrutura de criação bem comum no campo da performance: a mesma pessoa que realiza, cria as ações. Em casos de ações mais coletivas e em território urbano, os performers "proponentes" integram a performance, juntamente com os convidados. É o que acontece com a intervenção urbana Cegos, criada pelo Desvio Coletivo, realizada inicialmente em São Paulo (2012) e depois em diversas capitais brasileiras e estrangeiras. Quem propôs a ação foi Marcos Bulhões, a partir de uma visão que teve quando se encontrava hospitalizado: pessoas vestidas de executivos e cobertas de argila circulam pela cidade em câmera lenta com os olhos vendados com uma fina gaze. Bulhões não encena a situação, embora dite os tempos para a execução das ações do programa, participando como performer.

\footnotetext{
${ }^{22}$ Crítica disponível em: <http://hemisphericinstitute.org/journal/4.2/eng/en42_pg_mcelroy.html>. Acesso em: 02 jun. 2016.
} 
Quando se trata de uma ação coletiva, até a elaboração do programa pode estar distribuída entre os participantes da ação. Além disso, no ato da experimentação do programa há uma liberdade de escolhas, decisões podem ser tomadas por cada um dos integrantes da performance. As propostas são decididas coletivamente e confiadas aos corpos que performam e às interações que acontecem. Há uma perda de controle. Na medida em que a ação é repetida, sua proposição inicial, seus efeitos e a qualidade da presença dos performers podem ser revistos e alterados. Por isso, pode-se afirmar que não há repetição em performance, pois cada vez que uma série de ações é repetida, ela é modificada pelo ambiente, pelo fluxo de passantes, pelo trânsito, pelas condições climáticas, pela presença da polícia, para citar alguns elementos. Ou seja, no ambiente urbano, os passantes não serão os mesmos, os performers estarão afetados por condições diferentes a cada dia. Mesmo que, em última instância, essa característica também possa ser percebida em todo tipo de teatro, o índice de performatividade no ambiente urbano atinge seu grau máximo.

Em todos os exemplos citados fica nítida a centralidade do corpo na organização da experiência, que pode ser vivenciada somente pelo performer ou em conjunto com o espectador. A dissolução da encenação nesse contexto é consequência dessa implicação do corpo, pois não é possível manifestar-se por um viés performático sem colocar o [próprio] corpo em estado de experimentação. Silvia Fernandes fala do performer como um sujeito desejante, que se expõe por meio de dados autobiográficos e busca fugir à representação.

\footnotetext{
Atenção: esse passo deve ser dado com os quatro lados do seu corpo. (...) sinta o campo aberto e fique frente a frente com o que você quer e com o que tem. Quando o que quiser e o que tiver estiverem equilibrados, aproveite. Atenção: nunca transforme isso num objetivo. Dissolva objetivos longos e cultive os curtos. Saboreie o confronto entre um lado e outro. Depois que permanecer por tempo suficiente, o tempo pode não ser suficiente. Aceite. (depoimento de Beatriz Cruz, do Coletivo Teatro Dodecafônico sobre situação de performance na rua)
}

Por fim, no que se refere ao trabalho desenvolvido com o Coletivo Teatro Dodecafônico, onde sempre ocupei a função de encenação, organizando os pontos de vista, a relação com a arquitetura e a preparação dos atores, essa função também foi dissolvida. Na medida em que se iniciou o trabalho de pesquisa com performance urbana parecia não fazer sentido meu posicionamento fora das ações. Mesmo que isso tenha acontecido eventualmente, eu sentia uma grande necessidade de experimentar também, de me colocar à prova, de incluir meu corpo como elemento desejante. Algumas ações realizadas pelo Coletivo Teatro Dodecafônico serão evocadas nos próximos capítulos. 


\section{$>$ II. Aquele que passa por mim: do espectador como princípio ativo à sua dissolução}

Todas as modalidades cênicas aqui investigadas ocupam o espaço urbano de maneira poética, colocando os espectadores em deslocamento e incorporando-os como elementos constituintes do evento. A inclusão do espectador não significa sua exposição desnecessária, como acontece em peças ditas interativas, nas quais apenas um espectador é escolhido e não raramente ridicularizado. Tal inclusão configura-se aqui de outro modo. Sophie Lucet $^{23}$ afirma que o espectador teria se transformado no "princípio ativo" da obra. Sem aprofundar essa metáfora, a autora se interessa pela memória do espectador ao discutir as criações e os pensamentos de artistas de estéticas muito diferentes entre si como Jean Vilar, Jérôme Bel e Joël Pommerat.

A ideia de transformar o espectador em princípio ativo da ação parece servir muito bem para refletir sobre os modos de operar propostos a ele em diferentes modalidades cênicas observadas. Ao meu ver, isso não significa afirmar que este espectador seja ativo, em detrimento de uma possível passividade de outro espectador que permanece sentado ao longo de sua fruição artística. Associar a 'atividade' (em oposição à passividade) ao deslocamento físico reforça a dicotomia corpo e mente, como se a mente de um corpo em estado de pausa não funcionasse. Nesse caso, atividades como a leitura, a meditação, o estudo, uma ida ao cinema não poderiam ser consideradas 'ativas' para o espectador contemporâneo. No mesmo sentido, Jacques Rancière afirma que ser ativo ou passivo diz respeito a divisões sociais antes de serem tomadas como qualidades para as ações do corpo.

\footnotetext{
Durante séculos e milênios, a humanidade foi dividida em homens ativos e homens passivos. Homens ativos eram aqueles que não tinham necessidade de trabalhar para ganhar sua vida. E os passivos não eram pessoas que permaneciam de braços cruzados, mas, ao contrário, que produziam, se reproduziam e ganhavam sua vida, fechados no universo da necessidade imediata. Eu tentei recolocar o que parece ser evidente: a oposição ativo/passivo se inscreve em uma partilha do sensível, o que quer dizer que são posições sociais e simbólicas antes de serem posições reais do corpo. E tentei, também, dizer que o que se passa quando alguém vê um espetáculo, um filme ou não importa qual coisa... não pode se definir em termos de passividade. Olhar é uma atividade. (RANCIÈRE, 2013, p. 10 , grifo meu $)^{24}$.
}

\footnotetext{
${ }_{23}$ Mémoires et pouvoirs du spectateur. Théâtre Public - Penser le spectateur, Montreuil, n. 208, p. 98-102, avril/juin 2013.

${ }^{24}$ Durant des siècles et des millénaires, l'humanité a été divisée en hommes actifs et hommes passifs. Les hommes actifs étaient ceux qui n'avaient pas besoin travailler pour gagner leur vie. Et les passifs n'étaient pas des gens qui restaient les bras croisés mais, au contraire, qui produisaient, se reproduisaient et gagnaient leur vie, enfermés dans l'univers de la nécessité immédiate. J'ai essayé de resituer ce qui a l'air d'être des évidences : l'opposition actif/passif s'inscrit dans un partage du sensible, c'est à dire que ce sont des positions sociales et symboliques avant d'être les positions réelles des corps. Et j'ai essayé, aussi, de dire que ce qui se passe quand quelqu'un regarde un spectacle, un film, ou n'importe quelle chose... ne peut pas se définir en termes de passivité. Regarder est une activité (tradução minha).
} 
Desse modo, afirmar que o espectador pode ser transformado em "princípio ativo" da ação nada tem a ver com ser ativo ou passivo. O que pretendo afirmar é que o espectador pode ser considerado, metaforicamente, como um dos elementos (ou substâncias) que consegue ter ação sobre o acontecimento cênico (ou organismo). Assim como um medicamento, uma planta ou um alimento tem diversas substâncias em sua composição e apenas uma ou algumas delas podem agir sobre o organismo, o espectador seria esse princípio ativo do acontecimento cênico, pois é dada a ele a capacidade de exercer determinado feito, definição de rumo ou até mesmo reunir em seu corpo uma quantidade específica de informações que, juntas, se configuram como a experiência artística em si.

Muitos autores têm se voltado ao estudo do espectador na contemporaneidade. Jacques Rancière, cuja intenção inicial era investigar o espetáculo na sua acepção mais ampla, ideológica, e acabou escrevendo sobre teatro, tornou-se uma referência no campo das artes sobre o assunto. Ele escreveu o artigo $O$ espectador emancipado em resposta a um convite feito por um grupo de artistas que queria refletir sobre o espectador, depois de ter lido seu livro $O$ mestre ignorante. Segundo Rancière, a emancipação do homem acontece quando se questiona a oposição entre agir e olhar. Nas palavras do autor, do mesmo modo pelo qual não cabe ao professor transmitir conhecimentos, "o mesmo ocorre com a performance. Ela não é a transmissão do saber ou do sopro do artista ao espectador" (RANCIÈRE, 2012, p. 19). O autor não defende, entretanto, uma condição "participativa" para o espectador, no sentido específico que se dá a uma arte considerada "interativa". O que esse autor enfatiza é a atividade intrínseca ao espectador, "o papel de intérprete ativo", um sujeito capaz de tecer relações com seus próprios referenciais, sejam eles quais forem, e de elaborar traduções, ou seja, de construir suas próprias narrativas.

Marie-Madeleine Mervant-Roux, por sua vez, afirma não ser possível falar do espectador como se ele fosse uma figura atemporal. A pesquisadora francesa parte da perspectiva da antropologia histórica. Segundo ela, o termo 'espectador', comumente usado para designar quem se coloca do lado de fora da cena, tornou-se comum na França nos séculos XVII e XVIII. Utilizava-se também a palavra auditeur para se referir à mesma figura, uma vez que seu foco estava mais associado à escuta do que à visão. Vem daí a designação ainda hoje usada, porém com menos frequência: 'audiência', para se referir ao público. Atualmente esse termo é mais usado para referir-se ao público do rádio ou da televisão. De acordo com Mervant-Roux, por volta dos anos 1930, o espectador foi tomado como figura teórica e nos anos 1970, ele passou para o primeiro plano. Apoiada na visão de Elie Konigson sobre a Idade Média, período histórico ao qual ele atribui a origem do teatro europeu, a autora defende que a figura que melhor representa o espectador é a do guardião, como um pastor de ovelhas, que permanece estático, geralmente sentado. $O$ pastor experimenta com seu olhar, sua audição e com todo o seu corpo, a visão das ovelhas; ele também experimenta 
sensações e pensamentos, sem, no entanto, expressá-los. Nesse sentido, a autora considera importante manter o espectador separado da cena, como aquele que vem de fora, um viajante noturno, um guardião do real ${ }^{25}$.

Independentemente da visão do espectador como figura imóvel e discreta, que permanece na sombra, o que chama a atenção nesse caso, é a ênfase na atividade daquele que aparentemente não se move, apenas cuida, vela e reflete. Novamente, a imobilidade física não denota imobilidade mental. Estar atento é um modo de agir, cujo controle depende do espectador, é ele quem decide qual o grau de sua atenção. Outro aspecto trazido pela pesquisadora a partir da Antropologia Histórica de Elie Konigson é a associação do fenômeno teatral ao contexto urbano. Para o antropólogo, é impossível analisar o teatro sem analisar a cidade, que tem na casa sua primeira célula. Tecendo relações entre essas três esferas - cidade, teatro e casa - essa abordagem investiga os modos de apropriar-se física e simbolicamente das cidades. Desse ponto de vista, o teatro rompe historicamente com a ideia de rito e se vincula definitivamente à cidade.

Por tomar a Idade Média como contexto de seu estudo, essa visão aproxima o teatro da cidade, porém mantém o espectador separado da cena e só considera espectador aquele que se pré-dispõe a essa função. Ou seja, a pessoa que se dirige a um edifício teatral ou a um recorte urbano, onde uma peça será apresentada, tendo conhecimento de que se colocará nessa função. O espectador, nessa acepção, é caracterizado por aceitar o pacto ficcional, não podendo ser confundido com um transeunte volátil. Desse modo, o presente estudo se distancia dessa perspectiva, pois na medida em que a cidade é tomada como território de jogo e o espectador é considerado o princípio ativo da ação, toda e qualquer pessoa pode ser considerada uma espectadora em potencial. Ao "tomar a cidade de assalto", para usar uma expressão empregada por André Carreira, o público alvo não é o espectador que aceita o pacto, mas todos as pessoas que cohabitam determinado território. O transeunte volátil, o pedestre apressado, o trabalhador aborrecido, o subempregado, o desempregado e todas as pessoas que na maior parte do tempo não são espectadores, são cidadãos. Muitos deles não têm acesso aos espaços oficiais do espetáculo, porém todos eles estão merguIhados na espetacularização da cidade, que se torna o campo de disputa do imaginário das pessoas. Mesmo quando a ação recebe espectadores convidados que aceitaram o pacto, como ela acontece no espaço público, estará ao alcance de todos. Desse modo, considero importante destacar que o espaço associado ao surgimento do fenômeno teatral não pode se tornar campo exclusivo da publicidade, da mercadoria e da incitação ao consumo.

De fato, o teatro de rua é concebido pelos seus atores como um teatro acessível a um grande público, e visa constituir-se como tal. Michel Crespin definiu o público

\footnotetext{
${ }^{25}$ Dados recolhidos na disciplina "Aquele que vem de fora", ministrada por Marie-Madeleine Mervant-Roux em agosto de 2013 no PPGAC da ECA/USP.
} 
de teatro de rua como um "público-população", "que se encontra na rua, naturalmente, caso um espetáculo aconteça ou não" e que representa então "a maior banda passante cultural, sem distinção de conhecimento, de papel, de função, de idade, de classe social". O teatro de rua busca então resolver a difícil questão do público invertendo o dado: ao invés do público vir ao teatro, é o teatro que vem ao público, e mais precisamente que vem à rua constituir a população em público (HAMIDI-KIM, 2013, p.370-371, grifos meus) ${ }^{26}$.

Embora o enquadramento dessa investigação não contemple o teatro de rua na sua acepção mais tradicional, as manifestações cênicas tratadas nos estudos de caso compartilham das mesmas questões quanto ao acesso de públicos variados. Muitas delas porém, têm limite de público e/ou ingressos pagos, o que não impede que novas relações sejam construídas. Desse modo, seria possível destacar pelo menos três categorias para a atividade do espectador: o convidado ou deliberado (alguém que foi convidado para a apresentação previamente e por isso já organizou sua percepção para o encontro ficcional), o passante ou fortuito (pedestre mergulhado na realidade, que provavelmente caminha pela cidade com algum objetivo e tem seu fluxo interrompido pelo evento $)^{27}$ e o espectador ausente ou virtual (aquele que tem acesso ao acontecimento cênico mesmo sem tê-lo presenciado; pelo intermédio da internet, ele encontra fotografias, vídeos e narrativas produzidas a partir dos eventos).

Assim como a encenação e a obra de arte, a figura do espectador encontra-se em oscilação. Modalidades artísticas distintas deixam de funcionar na base do mostrar/ver, do promover/ receber. Elas estão fundadas sobre proposições dialógicas, interessadas em troca, em fricção e em desestabilização dos meios. Ou ainda, em proposições pedagógicas, uma vez que elas anunciam aos espectadores os modos de operar da criação contemporânea. Por esse motivo, não mais se espera que alguém assuma a posição de quem está fora. Por mais que os passantes testemunhem eventos que ocorrem no espaço público, eles não se atêm necessariamente a eles, sendo que a ação de ver aparece, muitas vezes, deslocada para os espectadores ausentes, que acessam posteriormente esses eventos. Em diferentes medidas, qualquer pessoa seria um ator em potencial. É o que pensa Denis Guénoun ao afirmar que "não há em nosso tempo, em nosso mundo, espectadores de teatro que não sejam jogadores em potencial" (GUÉNOUN, 2004, p.150). No campo da performance, essa é a ideia ope-

\footnotetext{
${ }^{26}$ De fait, le théâtre de rue est conçu par ses acteurs comme un théâtre accessible à un large public, et vise à constituer comme tel. Michel Crespin a défini le public du théâtre de rue comme un "public-population ", "qui se trouve dans la rue, naturellement, qu'un spectacle s'y produise ou pas ", et qui représente donc "la plus large bande passante culturelle, sans distinction de connaissances, de rôle, de fonction, d'âge, de classe sociale ». le théâtre de rue entend donc résoudre la difficile question du public en inversant la donne : au lieu que le public vienne au théâtre, c'est le théâtre qui vient au public, et plus précisément qui vient dans la rue constituer la population en public (tradução minha).

${ }^{27}$ Philip Auslander considera esse espectador passante desinformado, pois encontra-se no mesmo espaço tempo da ação ao acaso. Conforme o autor, esse seria apenas o público inicial das performances que se destinam às câmeras. Voltarei a essa discussão no capítulo seis.
} 
rante. Geralmente, os espectadores são todos passantes, não há convocatória na imprensa com data, hora e local do evento e, muitas vezes, a ação não se configura com o objetivo de ser assistida, mas se aproxima da ideia de encontro, de momento compartilhado.

Nicolas Bourriaud, por sua vez, afirma que a aura da arte de hoje deslocou-se para o público, pois ela "leva em conta, em seu processo de trabalho, a presença da microcomunidade que irá acolhê-la. Assim, uma obra cria uma coletividade instantânea de espectadores-participantes, seja em seu modo de produção ou no momento de sua exposição" (BOURRIAUD, 1998 , p. 82). Atento à importância do encontro e da dimensão relacional presente nas obras atuais, o autor recorre a exemplos bastante significativos nos quais os artistas apelam ao senso de responsabilidade dos espectadores, convocando seus corpos como forma de exposição da realidade. Retomo, portanto, dois exemplos oferecidos por Bourriaud para desenvolver em seguida o meu estudo de caso. Em todos eles o corpo do espectador é o disparador da obra. Bourriaud afirma que esse tipo de arte "não deriva da simples percepção ocular: o que o espectador traz é todo o seu corpo, sua história e seu comportamento, e não mais uma simples presença física abstrata" (Ibid., p. 83).

No primeiro exemplo, o cubano Felix Gonzalez-Torres delimitou um quadrilátero de luzes acesas e disponibilizou um par de walkmans para que os espectadores pudessem dançar, em aparente silêncio, no meio da galeria [Untitled, na galeria Jennifer Flay, Paris, 1993]. No segundo, o dinamarquês Jens Haaning [Turkish Jokes, 1994], criou uma ação na qual transmite histórias engraçadas em turco, por alto-falantes, em uma praça de Copenhague. Essa ação concentrou na praça dinamarquesa uma pequena comunidade de estrangeiros que saiu de sua situação de exílio por alguns instantes. Em ambos os casos a ação oferece dispositivos para serem usados pelos espectadores. No primeiro exemplo, o espectador é quem decide expor-se ou não, colocar ou não o seu corpo em estado de dança no meio da galeria, sozinho ou acompanhado. Mesmo dançando só, a presença do segundo walkman, em espera, está disponível para alguém ausente. Esse modo de inscrever mensagens nos fatos é uma marca desse artista que apostou com frequência em duplas de objetos (dois relógios, em sua obra mais conhecida). Certamente, muitos não se dispuseram a usar o walkman e exibir seu corpo dançante, no entanto essa obra depende não só do corpo do espectador para ser acionada, mas também de seu tempo. É ele quem decide o tempo de permanência não diante, mas em obra, como princípio ativo da ação. $O$ espectador tem poder de decisão, de execução e de fruição. Aquele que observou o espaço vazio com dois pares de walkman num quadrado luminoso viu uma instalação, enquanto cada pessoa que resolveu dançar criou sua própria narrativa a partir de sua experiência.

Nos dois exemplos, os corpos dançando ou reunidos em torno dos alto-falantes constituem-se como eventos a serem também observados. A micro-comunidade turca reunida numa praça em Copenhague, rindo, desfrutando de histórias que somente ela entende, 
evidencia a presença desses imigrantes numa esfera mais ampla, na qual são mantidos longe dos holofotes. Se o áudio fosse emitido em um local sem o traço dessa imigração, nada aconteceria, pois não haveria o encontro. As histórias isoladas, nesse caso, não configuram a obra, uma vez que ela só acontece quando essa micro-comunidade é colocada em destaque e observada pelos outros cidadãos.

Nas palavras de Bourriaud: "o espectador, então, oscila entre o papel de consumidor passivo e o de testemunha, associado, cliente, convidado, coprodutor, protagonista"(Ibid., p. 81). Assim sendo, mais importante do que responder à pergunta: "que espectador é esse?", seria questionar, o que é proposto a ele? Observando o modo de organizar esteticamente dos artistas, vale refletir sobre o alerta de Bourriaud, para quem "as atitudes se tornam formas" e "as formas induzem modelos de sociabilidade".

_ Remote X, Rimini Protokoll (2013/15): o espectador em ação e a cidade como protagonista

Tive a oportunidade de presenciar a montagem do audiotour Remote $X$ realizado por Stephan Kaegi em três cidades diferentes, entre 2013 e 2015. Em cada uma dessas localidades, a fórmula criada pelo artista se repete, inventando uma modalidade artística capaz de viajar pelo mundo, sem a necessidade de transportar atores, cenários e figurinos. Para tanto, Stephan Kaegi se instala em cada país com uma equipe constituída de dramaturgo, desenhista de som e produtores locais para desenvolver uma pesquisa de campo. Nela, tem-se como objetivo selecionar um recorte no mapa da cidade onde será traçada a trajetória dos espectadores, que por sua vez será articulada com uma dramaturgia pré-definida. Nas três localidades - Avignon (2013), São Paulo (2014) e Paris (2015) - a peça começa em um cemitério e termina em um edifício alto, de onde o público tem uma vista panorâmica da cidade. Com algumas variações entre as situações que se instauram, as linhas gerais da dramaturgia se mantêm, as ações destinadas aos espectadores e o assunto tratado também. Pode-se questionar a apropriação ligeira, por vezes superficial, que tal estrutura proporciona em cada cidade na qual Remote $X$ se instala. Em um primeiro momento, tem-se a impressão de se tratar de uma criação em site specific, o que agregaria a essa criação outras camadas de complexidade, relacionadas ao contexto escolhido. Mas o que se configura é justamente o contrário, uma vez que se trata de um modelo que se repete e que teoricamente comporta toda e qualquer cidade. Esta é a base, portanto, das críticas mais contundentes ao trabalho de Stephen Kaegi: o fato de compor em larga escala, como se seus percursos sonoros fossem criados em série, permitindo que eles sejam instalados em diferentes cidades. Contudo, o aspecto experimental da ação (e não inaugural, tendo em vista os áudio walks desenvolvidos por Janet Cardiff, que serão discutidos no capítulo quatro) e o impacto de 
seu dispositivo na subversão da função do espectador e na instauração de uma atmosfera de acontecimento no espaço público merecem ser observados com mais cuidado.

O ' $X$ ' que acompanha o título do audiotour é a variável substituída pelo nome da cidade de referência e traduz com precisão o recurso usado para adaptar-se a diferentes localidades. Cerca de cinquenta pessoas recebem um receptor e um par de fones de ouvido, de onde ouvem comandos que orientam seu deslocamento, suas ações e seu olhar para a cidade. Essas pessoas participam de um jogo com ares de ficção científica, no qual se vislumbra o que poderá acontecer entre homem e computadores em um futuro não muito distante. Em certo sentido, essa proposta se aproxima das práticas situacionistas, pois transforma a cidade em espaço de jogo, sem distingui-lo da vida corriqueira, podendo também ser considerada uma encenação em deriva. O jogo de Stephan Kaegi se resume, inicialmente, a contemplar e, aos poucos, convocar o público a fazer junto, colocando-se em situação em lugares inusitados e também colocando-se à prova dentro do grupo. Antes de entrar nos pormenores dessa proposição, é importante separar os espectadores dessa peça entre espectadores portadores ou não de fones de ouvidos. Os que portam fones de ouvido são os espectadores convidados, que se deslocaram deliberadamente até o local para assistir, ou melhor, participar do evento. Os que não portam fones de ouvido são os passantes, que se deparam fortuitamente com a peça enquanto são apenas usuários da cidade. Acontece destes também estarem de fones de ouvido, mas isso é papel do acaso e só acontece por-

Disponível em: <http://www.rimini-protokoll.de/website/media/remotex/pressebilder/Remote\%20Ber-

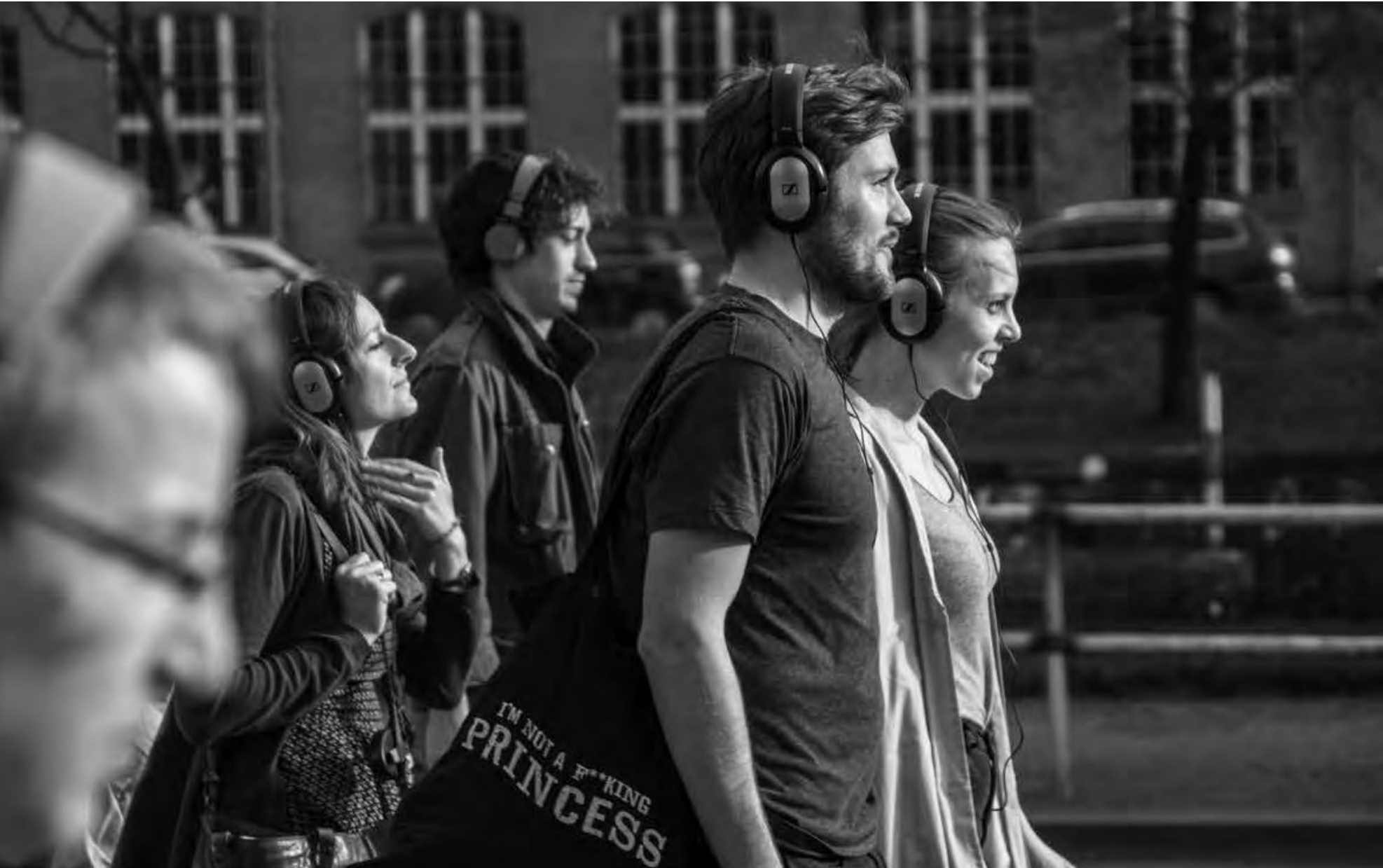


que fones de ouvidos são dispositivos frequentemente usados por pedestres no contexto urbano. Então, os que portam fones estão em bando e vieram para o evento, não são passantes de fones de ouvido.

Trata-se de uma caminhada coletiva, na qual cada espectador pode ter a sensação de estar sozinho, pois os fones de ouvido proporcionam um fechamento sonoro que distancia a pessoa do espaço real - que ela ouve apenas sumariamente - e a aproxima dos sons ficcionais, que ativam suas percepções sensoriais. Com os corpos modificados pela mudança de ambiente sonoro, os participantes (portadores de fones de ouvidos) praticam uma errância coletiva, deslocando-se sem saber exatamente para onde, a partir do comando de uma voz mecanizada. Essa voz de comando não convida, ela 'controla', 'faz' os participantes se deslocarem, propõe questionamentos, aproveitando-se do fato de ter-se tornado uma voz que fala dentro dessas cabeças simultaneamente, ocupando o lugar de seus próprios pensamentos. Cada recorte observado pelos olhos desse espectador, portanto, passa a ser filtrado pela interferência de uma voz instalada dentro do seu ouvido.

A princípio uma voz feminina conduz os espectadores com fones, uma voz sem corpo, que toma emprestado o corpo do público para perambular pela cidade. Ela não pertence a uma mulher real, mas a um software. Trata-se de uma voz produzida por um computador, semelhante àquelas montadas para os GPS, resultantes da combinação de fonemas gravados por pessoas diferentes. No meio do percurso, a voz feminina é substituída por uma voz masculina. Além do texto dito por essa voz artificialmente fabricada e de algumas músicas, há ainda uma ambiência integrando a composição. Na faixa de som desse audiotour, algumas sonoridades ambientes que não procedem do lugar onde o espectador com fones se encontra são utilizadas, criando uma ilusão de que se escuta um espaço outro. É constante o jogo entre o que se vê e o que se ouve, sendo que inúmeras vezes ouve-se sons que remetem a situações que não estão acontecendo no mesmo espaço/tempo que os espectadores se encontram. Como a faixa sonora é montada com a ajuda de um software que reproduz o processo de escuta humano, dividindo a recepção do som nos dois ouvidos (um sistema binaural), os sons parecem chegar "naturalmente" em nossa cabeça, reproduzindo distâncias e profundidades. Isso causa a impressão de que os sons vêm do espaço real, enquanto eles são produzidos artificialmente ou captados do próprio local em momento anterior e reproduzidos na trilha sonora como se acontecessem no momento mesmo em que o público percorre a cidade. Voltarei ao estudo do som quando me aprofundar na discussão sobre audiotour, no capítulo quatro, como um percurso pré-definido pelo artista para um espectador que passeia.

O que esse programa de computador visa é reproduzir a percepção auditiva para criar um efeito de presença, por exemplo, faz com que seja possível ouvir um jogo que não está acontecendo. Ouve-se jogadores se comunicando, uma bola quicando, mas nada disso se 
encontra ao alcance de olhar do espectador. Trata-se de um falso evento e de um jogo que desestabiliza o espectador com fones de ouvido, pois apresenta pistas falsas, embaralhando sua percepção. A espacialização do som confunde de tal forma o ouvinte, que os espectadores com fones de ouvidos buscam com o olhar a bola que ouviram quicando à direita ou à esquerda e riem ao se darem conta de que a bola não existe, o que existe é apenas a sugestão de sua presença. Assim como se ouve uma bola ausente, integra-se uma manifestação, da qual se ouve os gritos de ordem e a movimentação de manifestantes que não estão ali. Quem está de fone de ouvido é convidado a agitar um objeto escolhido que cada um traga consigo, como se participasse dessa manifestação. Sem nada falar, essas pessoas ouvem sons de manifestantes registrados anteriormente e, mesmo em silêncio, têm a sensação de estar no meio de uma manifestação barulhenta. Do lado de fora, para os espectadores fortuitos, sem fones de ouvido, é possível observar a passagem de uma estranha manifestação silenciosa.

Aos poucos, o grupo vai se reconhecendo e apropriando-se do espaço urbano. $\mathrm{O}$ ato de caminhar configura a experiência, pois coloca o espectador em contato com seu próprio corpo e com a realidade mutante da cidade (refiro-me aqui a quem porta fones de ouvidos). Aos poucos os participantes se reconhecem e, por fim, localizam suas coordenadas a partir de uma vista panorâmica. Ao mesmo tempo em que há uma tomada de consciência do corpo, há o reconhecimento dos outros corpos e do espaço onde se está, como se esse corpo passasse a se perceber como matéria do tecido urbano. $O$ trajeto poderia ser descrito assim:

- enquanto percebe-se como corpo, o espectador entra em contato com a finitude de sua existência, partindo de um cemitério. Depois observa corpos atléticos e percebe a própria mobilidade ao visitar uma quadra esportiva. Em Avignon, essa passagem foi substituída por uma visita à universidade, de onde o público sai aplaudido, como se fosse uma turma de formandos. Em São Paulo, é convidado a refletir sobre a vulnerabilidade do corpo diante de um hospital, onde ironicamente é levado a usar seu tecnocorpo (ou seja, seu celular), para tirar uma foto do grupo todo espelhado na fachada do edifício. A fotografia pode ser compreendida como o ponto de virada, da percepção do próprio corpo para o reconhecimento do conjunto de espectadores. Nas duas cidades francesas também havia o momento da fotografia, mas ele não estava posicionado nesse ponto do roteiro, nem tampouco nas paredes espelhadas de um hospital.

- enquanto reconhece o grupo, o espectador coloca-se em marcha, interagindo gradativamente com os outros. São ações simples, mas capazes de quebrar a barreira que impede os cidadãos de se olharem nos olhos, reconhecendo-se enquanto um agrupamento temporário, uma coletividade. Dentro da quadra (em São Paulo e Paris) ou dentro do auditório (em Avignon), esse agrupamento ganha função simbólica: torna-se um conjunto de torcedores 
que experimenta a realização de uma 'ola'. Quando se acostuma à condição de pedestre, esse conjunto é confrontado com uma imensa quantidade de carros em uma movimentada avenida. Em Avignon, esse momento é marcado pela entrada na parte murada da cidade, deixando para trás o último vestígio de uma cidade cosmopolita.

Em São Paulo e em Paris, o modo de vida da cidade é questionado. Na primeira localidade, acentua-se a incoerência da opção pelo transporte particular: vários carros comportando apenas um passageiro, e provavelmente se deslocando na companhia de um GPS. A reflexão sobre a mobilidade urbana se estende até o trecho percorrido por metrô, saindo da Zona Leste em direção ao centro. Nesse contexto, o grupo se reafirma, mas a proposta de ação conjunta é frágil, a música que se ouve não tem força suficiente para embalar os corpos e fazê-los, de fato, dançar. Há ainda o confronto com a vida real pelos problemas de mobilidade enfrentados diariamente por uma parcela significativa da população. Sem grandes questionamentos, a ação praticamente não interage com esses corpos "embrutecidos" e não tem força suficiente para os atingir, nem para os potencializar. O corpo do público como coletividade se constitui como uma bolha na esfera urbana, transforma a paisagem sumariamente e não provoca nenhum efeito poético nos usuários do metrô. Como esse trajeto também é longo, a realidade supera a ficção: o que fica em primeiro plano é a preocupação em não perder o sinal do áudio. De um modo ou de outro, os participantes se reconhecem, pois todos têm fones de ouvidos parecidos e compartilham da mesma trilha sonora.

Já em Paris, a proposição funcionava de um modo mais fluido. Isso se deve às condições do transporte público. Paris possui uma das dez maiores redes metroviárias do mundo, destacando-se não pela extensão dos trilhos, mas pela quantidade de linhas e estações. A linha na qual circulamos, na região norte de Paris, é distante do centro turístico da cidade e não apresenta um fluxo muito grande de pessoas; o contrário do que acontece no trecho percorrido em São Paulo ${ }^{28}$. Todas essas condições, somadas ao fato de o trajeto ser menor e da atmosfera do vagão ser mais acolhedora, possibilitou que a proposição contagiasse com mais facilidade os corpos com e sem fones de ouvidos que se encontram no metrô francês.

- enquanto ocupa a cidade, em São Paulo, na descida do metrô Sé, os portadores de fones são convidados a assumir uma postura mais performática, como se fossem "um grupo que realiza um flashmob", dizia uma das críticas sobre o audiotour. Juntas, essas pessoas se agacham para amarrar o sapato e se levantam em plena estação, organizam e dissolvem filas, dançam balé nas escadarias do metrô e perscrutam a polícia no centro da praça. Desse momento em diante, os corpos permitem-se cada vez mais experimentar movimentos

\footnotetext{
${ }^{28}$ São Paulo é a cidade do Brasil com maior malha metroviária $(78,4 \mathrm{Km})$, contando com 6 linhas, 67 estações, nas quais circulam 4,6 milhões de passageiros por dia. Ainda assim, a capital francesa (10a colocada dentre as maiores redes do mundo), uma cidade com um terço da população de São Paulo, conta com uma malha metroviária de $213 \mathrm{~km}, 16$ linhas, 303 estações, nas quais circulam diariamente 4,5 milhões de passageiros (dados recolhidos no site wikipedia, em junho de 2016).
} 
e comportamentos inusitados, chegando ao ponto de apostarem uma corrida em uma das ruas de pedestres localizadas na região. Na cidade do sul da França, ao final dessa corrida, os participantes eram presenteados com garrafas d'água gelada para amenizar o calor do verão. Ao final do percurso, Avignon, São Paulo e Paris são vistas do alto. A partir da visão aérea de cada cidade, os participantes reconhecem sua dimensão humana de cima da Opéra Grand Avignon, do Edifício Martinelli e da antiga sede do Partido Comunista francês, um belo edifício projetado por Oscar Niemeyer.

Inicialmente, o percurso sonoro afeta o corpo de quem se coloca na situação de espectador com fones, como convidado para viver essa experiência. À medida que a percepção vai dando espaço para a realização coletiva de algumas ações simultâneas, ainda que sutis, o evento cria turbulências no cotidiano. Muitos passantes colocam-se em estado de atenção, notando que alguma engrenagem saiu do lugar nessa máquina contínua que é a realidade.

Em cada cidade, uma proposição se destaca. Em Avignon, foi bastante interessante integrar o coro dos manifestantes que fazia referência à grande greve dos profissionais do espetáculo que ocorreu em 2003, resultando na anulação do Festival ${ }^{29}$. Em São Paulo, merece destaque o momento em que todos os integrantes do audiotour se aproximam dos círculos formados por pastores evangélicos que pregam nos arredores da Praça da Sé. A ação promove uma confusão na esfera do real, uma vez que os pastores podem ter a ilusão de que seu discurso começa a fazer efeito, no entanto, repentinamente, aquelas pessoas se viram de costas e dispersam o círculo. Com a repetição das apresentações, tanto os pastores quanto os comerciantes dos estabelecimentos por onde o grupo de fones de ouvido passa, reconhecem o evento. Ele se torna, então, esperado por esses espectadores casuais que observam repetidamente o audiotour sem ter acesso à sua trilha sonora. $O$ jogo que se configura para essa camada de espectadores - que tem seus cotidianos atravessados pela intervenção de um grupo de espectadores munidos de fones de ouvidos - tem caráter coreográfico, uma vez que, para eles, o que se apresenta são diferentes configurações de um coro que se comporta sempre da mesma maneira. O prazer desse olhar está na ação de quase adivinhar os passos desse coletivo, tentando entender o que todos ouvem e do que se trata aquele evento.

Em Paris, onde o audiotour foi realizado na região de Belleville, pouco frequentada por turistas, a ação revela uma visão da cidade que não está nos cartões postais. Trata-se de um antigo bairro operário, habitado por muitos imigrantes, onde se desenha uma Paris reterritorializada. Pelas ruas, é possível seguir a rota dos grafites, um espaço de grande profusão

\footnotetext{
${ }^{29}$ Desde então, essas reivindicações estão presentes, com maior ou menor intensidade, resultando na anulação da abertura do festival em 2014, seguida de uma série de protestos e leituras de manifestos antes da apresentação de cada espetáculo, nesse mesmo ano. Em 2016, uma nova onda de protestos contra a modificação dos direitos trabalhistas espalhou-se por toda a França.
} 
de arte urbana. Há ainda um mirante de onde se vê uma das vistas mais bonitas da cidade, sendo comparada às panorâmicas da Notre Dame e da Torre Eiffel. Seguindo esse percurso nada óbvio - tanto pelo recorte da cidade quanto pela visão da cidade que Stephan Kaegi escolhe compartilhar ao final da experiência - os espectadores são convidados a cantar uma canção de amor, acompanhando a música veiculada em seus ouvidos. Trata-se de uma canção conhecida pela maioria dos espectadores.

Algo que acontece nesses três territórios é a proposição da inversão do jogo. Depois que os espectadores com fones já se tornaram corpos visíveis, ou seja, já realizaram ações coletivas significativas pelas ruas - passando a ser observados como os performers da ação - eles enquadram a cidade a partir de um ponto de vista em profundidade. Essa inversão faz com os espectadores com fones passem a observar os trabalhadores e transeuntes da região como agentes da teatralidade presente no cotidiano. $O$ atendente do bar vira personagem, os sons das casas vizinhas preenchem o quadro, assim como a moça que atravessa a praça vagarosamente imprime uma temporalidade na cena. Quem experimentou o percurso mais de uma vez na mesma localidade, garante que a cada dia uma situação diferente se estabelece.

O que Stefan Kaegi propõe ao público é uma prática que desvenda seu modo de fazer. O artista caminha pela cidade buscando capturar - e não criar - visões particulares, situações inusitadas e acontecimentos que remetam a fatos históricos que precisam ser revistos. Acontece que a relação pessoal e a apropriação de cada espaço por parte do artista varia, depende de sua história de vida, das pessoas com quais se relaciona como produtoras locais e que, de certa forma, apresentam suas visões da cidade, e depende igualmente do acaso. Isso faz com que, para o artista, Remote Berlim e Remote Moscou sejam as versões mais interessantes desse jogo.

O fator mais curioso dessa experiência, que faz com que ela fuja das premissas para a configuração do fenômeno teatral, é a ausência de atores. Em Remote $X$, nem mesmo a voz que conduz os participantes possui algum resquício de aura artística, por ser excessivamente mecanizada. Além disso, a ausência da obra como objeto concreto marca a radicalidade da proposta, uma vez que não existe texto prévio e o roteiro gravado não se sustenta a posteriori. De nada serve o texto sem a visão da cidade; e a visão da cidade, sem a presença dos fones e do receptor de áudio, pode não se configurar como experiência artística. O que Kaegi propõe é uma experiência, um exercício de fruição da cidade, nos moldes apresentados por Patrice Pavis em seu texto sobre o ponto de vista do espectador. "Segundo um crítico de arte contemporânea como Yves Michaud, a experiência se substitui à produção da obra, ela troca sua realidade sólida por uma experiência comparável a uma arte em estado gasoso" 
$(2012, \text { p.8 })^{30}$. O que Remote $X$ promove é a dissolução todas as categorias estudadas aqui: o artista, o espectador e a obra de arte.

$$
<<<>>
$$

Do estudo do espectador como princípio ativo do jogo chega-se às performances que prescindem dessa figura, promovendo sua completa dissolução e colocando também a noção de obra artística em questionamento. As performances urbanas que se realizam com baixo grau de visibilidade, convivem com os habitantes da cidade mas não se exibem, não se dão em espetáculo. Elas se infiltram como situações inesperadas, manifestações fronteiriças, outras maneiras de (con)viver. A metáfora da 'dissolução' confere à figura do espectador um aspecto oscilante, uma vez que não há espectador convidado, ninguém chega deliberadamente ao encontro da performance. Porém, nada impede que um cidadão qualquer a atravesse, que seu fluxo seja interrompido por ela. Quem assume a atividade do espectador é o passante, mas não qualquer um, somente aqueles que decidem interromper seu cotidiano em favor de uma experiência casual. A abertura para esse encontro é definidora do jogo, pois alguns performers - de um modo diferente das encenações analisadas aqui também deslocam para essa relação com o outro a operação do ato performativo. É o caso de algumas performances realizadas por Eleonora Fabião dentro da Série Precários, e por Laurie Anderson, em sua performance Fully Automated Nikon (1973).

Dentre as ações desenvolvidas por Eleonora Fabião na Série Precários (2011/13) realizada no Rio de Janeiro, há uma intitulada Toco tudo ${ }^{31}$. Nessa proposta, ela sai de um ponto escolhido da cidade, de olhos fechados, com a intenção de chegar a um segundo ponto, previamente definido. A simplicidade de seu programa traduz a delicadeza de seus passos: "Com local de partida e de chegada preestabelecidos, caminhar com olhos fechados. Aceitar a ajuda de estranhos. Tocar e ser tocada" (FABIÃO, 2015, p.140). Alheia a toda possibilidade de espetacularização de suas ações, ela caminha calmamente pela calçada, tocando fachadas de prédios, esbarrando em obstáculos e, principalmente, expondo-se de maneira frágil. Ao fechar os olhos, ela ativa sua percepção corporal, tornando ouvidos e pele mais sensíveis. A performer corre pequenos riscos e se entrega aos cuidados de passantes desconhecidos. Pelas fotos que ilustram seu livro Ações é possível observar pessoas que a ajudam a atravessar ruas e multidões. Há quem a observe de longe, quem lhe estenda a mão e quem a leve para um passeio de braço dado. Há curiosidade, diversão e ofensa. Trata-se de um corpo receptivo, performativo, estranhamente exposto para quem frequenta o espaço

${ }^{30}$ Selon un critique d'art contemporain comme Yves Michaud, l'expérience se substitue à la production de l'oeuvre, elle en remplace la réalité solide par une expérience comparable à un art à l'état gazeux (tradução minha).

${ }^{31}$ Essa ação também foi realizada em São José do Rio Preto (2012), no quadro do Festival Internacional de Teatro (FIT) e em Montréal, no Canadá (2014), no IX Encontro do Instituto Hemisférico de Performance e Política. 
performance realizada por Laurie Anderson em espaços públicos na década de 70, também seguia essa premissa. Em Fully Automated Nikon (1973), a performer propõe um passeio pela cidade de Nova York, durante o qual ela fotografa homens que fazem comentários quando ela passa ou quando passam por ela. A ideia para a performance surgiu quando uma mulher a confundiu com uma atriz de televisão. Embora ela negasse, a mulher respondia que entendia o fato de ela negar, mas que tinha certeza de que se tratava da tal atriz. Quanto mais ela negava, mais a mulher se convencia de que se tratava da atriz que se parecia com a performer. Para se livrar da situação que já se alongava, a performer pergunta para a suposta fã se poderia tirar uma foto dela. A mulher consentiu. A partir desse momento, Laurie Anderson se deu conta de que uma fotografia pode ter o efeito de um assalto. Com essa descoberta em mente, ela resolve inverter o jogo com os homens que a assediam verbalmente, situação que a deixava indignada.

Anderson revela que a primeira vez que saiu pelas ruas andando com sua câmera fotográfica Nikon, ela se sentiu como se estivesse armada. Quando algum homem a assedia, ela Ihe pergunta se ele realmente disse aquilo e começa a fotografá-lo. Segundo Laurie Anderson, assim que ela se vira, após a cantada a maioria dos homens tem reações similares: ao serem questionados, eles se fazem de inocentes e até mesmo de ofendidos. Quando ela começa a fotografá-los, eles fazem poses, se sentindo lisonjeados. Alguns sentem-se coagidos e perguntam se ela é policial ${ }^{32}$. Nessa performance, os participantes resultam de encontros fortuitos e se tornam alvo de uma câmera fotográfica, não podendo ser considerados 'espectadores'. Os demais usuários da cidade que, por ventura passem na rua naquele exato momento, e que percebem que uma mulher reagiu diferentemente a uma cantada habitual, podem se constituir como espectadores fortuitos. Porém, não se têm notícias, ao menos na bibliografia consultada, de que outros transeuntes tenham passado no momento exato em que a performer 'captura a alma' dos assediadores.

Os homens que se relacionam com essa Laurie Anderson armada com uma câmera funcionam como operadores de um jogo socialmente praticado, comum até os dias de hoje, que a performer se encarrega de transformar em jogo perfor-

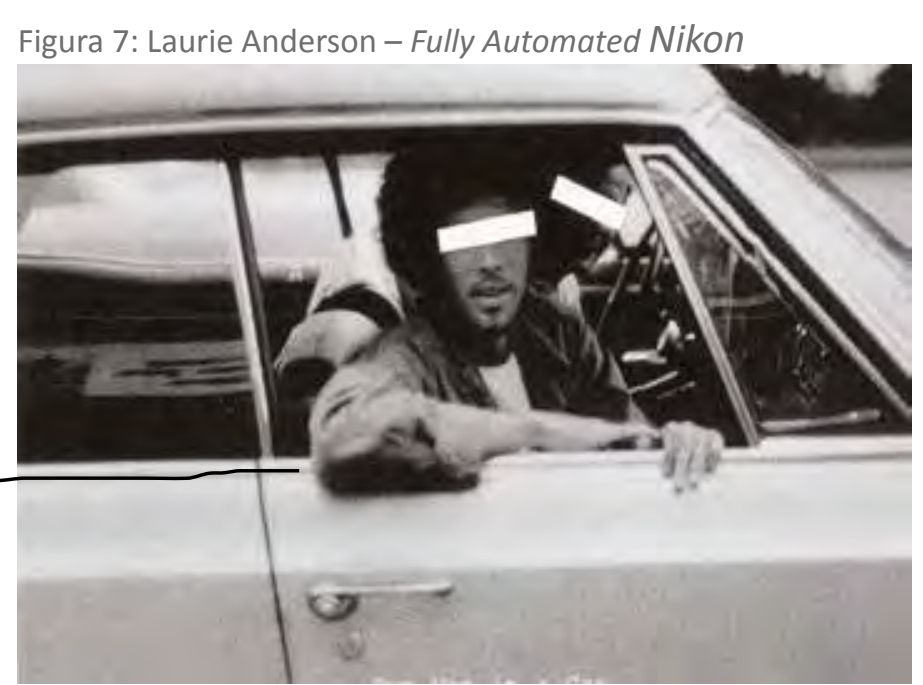

Foto: Laurie Anderson (YEE; URSPRUNG, 2011, p. 45)

\footnotetext{
32 Informações retiradas do catálogo da exposição Laurie Anderson, Trisha Brown, Gordon Matta-Clark: Pioneers of the Downtown Scene, New York 1970s, London: Prestel / Barbican Centre, 2011.
} 
mático. Ao invés de aceitar o papel da vítima, ela parte para a ofensiva, usando sua câmera como dispositivo de produção de provas, de denúncia. Nessa passagem de objeto para sujeito, a mulher ameaça a figura masculina que, na maioria dos contextos sociais, se sente segura, protegida por uma estrutura de sociedade machista e conivente com esse tipo de atitude. Na maioria das vezes, as próprias mulheres são responsabilizadas pelo assédio, associado a sua atitude ou a sua vestimenta.

Até então não há indícios de atividade artística; toda essa situação poderia se resumir a militância feminista e experimentação de novas configurações de comportamento para as mulheres. $O$ fato da performer ampliar as fotografias, posicionando uma tarja branca sobre os olhos dos homens capturados - para preservar minimamente sua identidade - e realizar uma exposição com esse material é o que posiciona essa prática da vida cotidiana dentro da esfera artística. É nesse mesmo movimento de transformação do ato em fotografia que percebo o potencial político dessa ação. Trata-se de um caso complexo, pois a performer troca de lugar com o homem que a assedia, passando a ser ela a detentora do olhar intimidador. Mesmo a ação tendo sido deflagrada e não performada para ser fotografada, essa troca de lugar com o agressor se concretiza. E no fim das contas, pode-se dizer, em primeiro lugar, que o espectador está ausente ou entrará em contato com a ação posteriormente. Em segundo, que a artista se torna espectadora ao adotar ela mesma a ação de olhar através da câmera e, em terceiro lugar, que o espectador é o último a chegar, configurando assim essa outra categoria de espectadores (ausentes). Eles chegam quando as fotos já estão expostas com suas legendas, contando detalhadamente onde ela estava, o que cada homem disse e como reagiu ao ser surpreendido pela arma-Nikon de Laurie Anderson. Naquele momento, tais espectadores acessam a ação em uma exposição de fotografias e, atualmente, esse contato se daria pela internet.

Nessa performance, Laurie Anderson propõe uma inversão, um outro modo de sociabilidade; uma outra forma, que propõe mudanças de atitude, outros valores. Por esse motivo, em última instância, reconheço que o desdobramento pedagógico dessa ação está no fato de seu programa se tornar acessível a toda e qualquer mulher. Nesse sentido, o que está em jogo não é a autoria da ação, mas a quantidade de mulheres que aderem a essa prática. Não tenho conhecimento do quanto essa ação foi reperformada desde a década de 70 , mas percebo que as cidades de hoje pedem para que essa ação seja retomada.

Em abril de 2016, o Coletivo Teatro Dodecafônico retomou essa performance na Ocupação Mulheres, Performance e Gênero. Com pequenas alterações, realizamos a ação em conjunto, num grupo de três mulheres pelo Bairro do Bom Retiro, em São Paulo. Propusemos a alteração do título para Spray de Pimenta - uma referências às feministas italianas que na década de 70 andavam pelas ruas carregando spray de pimenta como uma arma que permitia que elas transitassem livremente. Realizamos a ação em dois momentos da ocupação, 

Figura 9: VALIE EXPORT - Action Pants: Genital Panic.
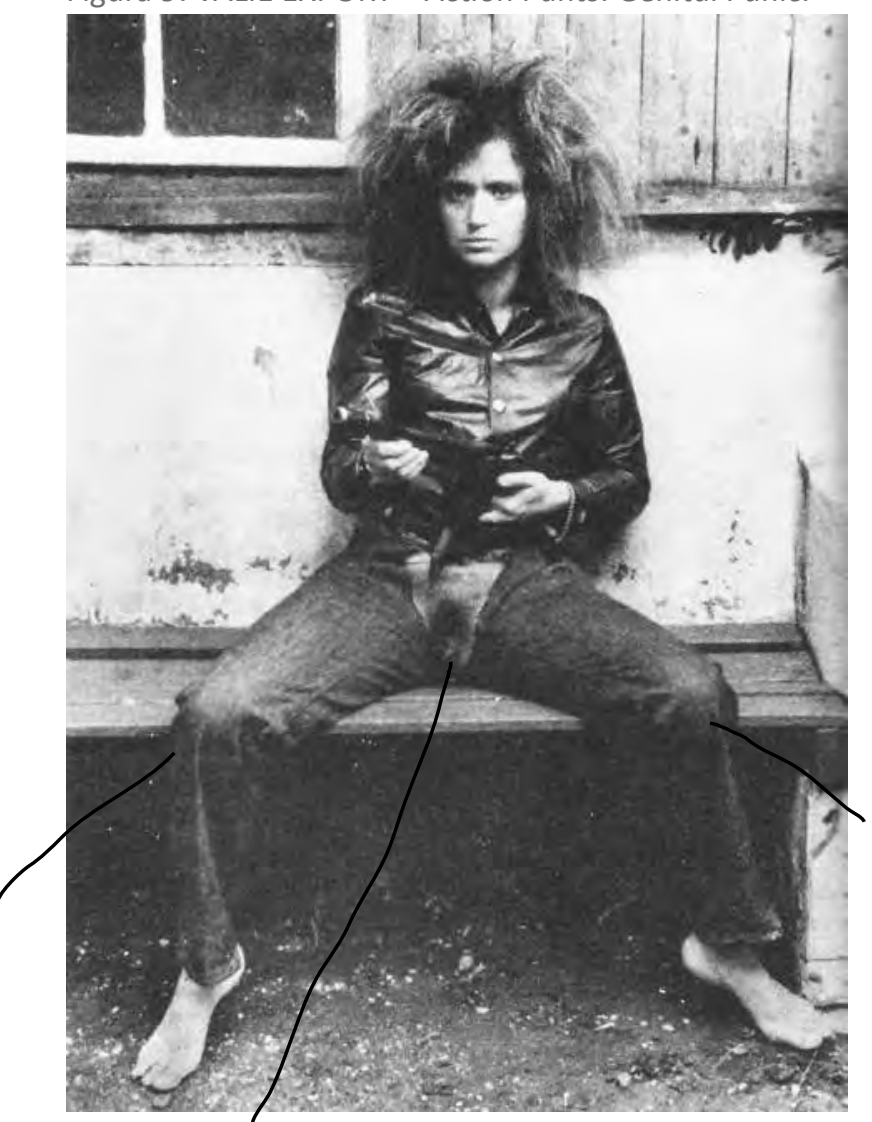

Foto: DELPE $\$ X, 2010, p. 140

${ }^{33}$ Nome artístico da performer, criado como um logotipo, por isso deve ser escrito em letras maiúsculas. A escolha desse nome em 1967 veio acompanhada de um autorretrato no qual a artista aparece fumando no plano de fundo e mostra, em primeiro plano, um pacote de cigarros de uma marca popular (EXPORT) no qual se lê a inscrição de seu nome no rótulo. A ação, representada pela fotografia, busca legalizar a troca de nomes, que também revela o processo de questionamento de sua identidade. Tal mudança de nome representa uma revolução não somente artística como política, além de representar uma crítica à crescente mercantilização da arte, que em última análise, significa a reificação do artista. A então Waltraud Höllinger (nascida Waltraud Lehner) tornou-se VALIE EXPORT eliminando seus vínculos com o patriarcado, a família de nascença (que havia compactuado com a ideologia nazista) e com o marido, de quem se separou, depois de ter se tornado mãe (algumas dessas referências foram pesquisadas na Wikipedia).

34 Um dos grupos mais radicais de performance dos anos 60, conhecido pela busca por transgredir tabus numa Áustria profundamente marcada pela guerra, composto por Günter Brus, Otto Muehl, Rudolf Schwarzkogler e Hermann Nitsch. Sua prática envolvia o uso de sangue, excrementos e outros fluidos animais, automutilação, nudez, sexo, orgia, abate de animais de médio a grande porte, resultando muitas vezes em rituais que podiam durar vários dias.
As performances da austríaca VALIE EX$\mathrm{PORT}^{33}$ são bastante conhecidas e discutidas, justamente pelo fato dessa performer ter sido uma pioneira na área no que diz respeito à experimentação de ações e sua consequente documentação. No final dos anos 60, a artista desenvolveu um importante trabalho sobre performances coletivas, em parceria com Peter Weibel. A dupla editou o Vienna Book, como ficou informalmente conhecida a importante publicação intitulada "Bildkompendium Wiener Aktionismus und Film" (1970), que reúne uma grande quantidade de imagens produzidas pelos e sobre os Acionistas vienenses ${ }^{34}$ e onde aparece a primeira descrição da conhecida performance de EXPORT: Action Pants: Genital

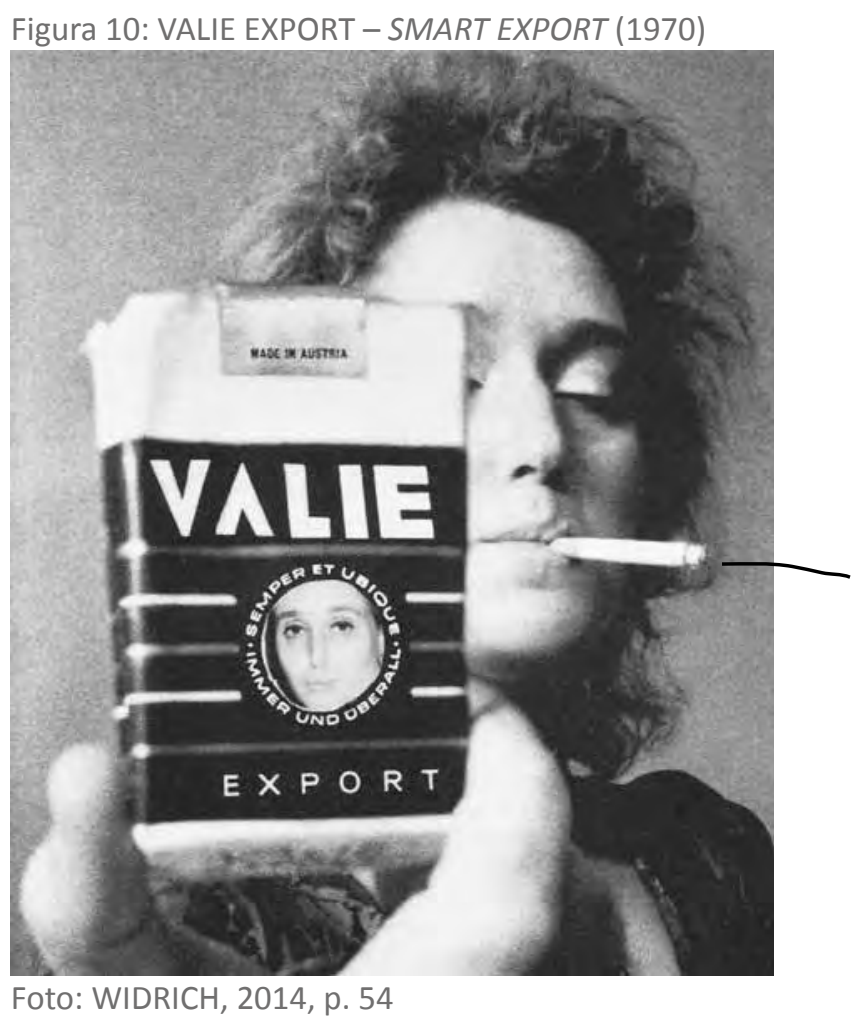


Panic $^{35}$. Graças a essa publicação, o movimento tornou-se mundialmente conhecido como parte significativa da história da arte no pós-guerra austríaco. Nessa época, ela aderiu aos Acionistas vienenses, participando apenas indiretamente de suas ações (operando a luz de uma ação, por exemplo). No início da década de 70, no entanto, conflitos com o grupo a levaram a afirmar que seu movimento se constituía como um acionismo feminista, o que distinguiu definitivamente o trabalho de EXPORT do caráter machista presente nas ações do grupo (WIDRICH, 2014, pp. 53-55).

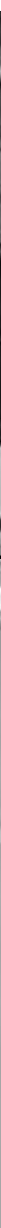

Figura 11: VALIE EXPORT - Portfolio Doggedness

Foto: Disponível em: <http://www.nytimes.com/imagepages/2008/09/12/arts/12streCA02ready.html>. Acesso em: 15 jan.2017.

A performer VALIE EXPORT em Portfolio Doggedness (1969) caminha pelas principais avenidas do centro de Viena, vestida de casaco de pele e levando Peter Weibel como se fosse seu cachorro. A performance pode ser considerada como o passeio de uma flâneuse, uma vez que sua ação se restringe a caminhar sem objetivo preciso, vestida elegantemente,

35 Aktionshose: Genitalpanik (1968) foi realizada por VALIE EXPORT em um cinema de arte de Munique, usando uma calça que deixa seu sexo aparente, enquanto carrega uma metralhadora. Ela caminha pela plateia de modo que seu sexo permanece na altura do olhar do público. No ano seguinte, uma fotografia da performer com a mesma indumentária, sentada de pernas abertas foi realizada por Peter Hassmann em Viena. A imagem consagrou a performance. Em 2005, Marina Abramovic reperformou a ação de EXPORT dentro de sua Exposição Seven Easy Pieces, no Museu Guggenheim de Nova York . 
levando um homem pela coleira. Trata-se de uma ação que não depende da ativação ou participação direta de alguém para que aconteça. A interação que se estabelece é entre a mulher e o homem, sendo que os espectadores passantes ou fortuitos testemunham $o$ ato. Ela caminha de cabeça erguida, trocando olhares com os passantes; em algumas fotografias, Valie aparece sorrindo. Ele permanece de cabeça baixa, olhando para o chão. Ela não se contenta em andar pelas calçadas, perto das vitrines; atravessa uma grande avenida na diagonal, puxando seu parceiro. Ele a acompanha, andando de quatro; ela escolhe não passar pelas faixas de pedestres.

Portfolio Doggedness não é apenas a visão de uma mulher dominatrix subjugando um homem que age como um cão, nem a visão da liberação feminina em oposição à opressão masculina; configura-se como um portfólio. Não se trata somente de promover uma inversão de valores socialmente aceitos, de uma crítica à uma sociedade machista; trata-se da composição de uma sequência de fotos que denunciam o caráter público da ação. $O$ título evidencia que a fotografia se sobrepõe à ação. Sobretudo se levarmos em conta o que Mechtild Widrich nomeia de plateia mal informada ("uninformed audience"): "pessoas que se constituem como público simplesmente por estar em uma dada locação em um dado momento, o oposto de ser convidado"(MIDRICH, 2014, p. 55-56) $)^{36}$. Esses passantes desinformados não apenas presenciam tal ato, mas compõem junto com os performers os retratos desse acontecimento. Suas reações de espanto, de curiosidade, de indignação e de vergonha integram tal portfólio que, em uma de suas versões, foi composto por 5 imagens escolhidas pela performer. Essa sequência está endereçada para um espectador $\operatorname{tardio}^{37}$, que venho nomeando aqui como ausente, que será convidado a refletir sobre as reações dos espectadores fortuitos que também foram capturados pela câmera. Quando a ação foi realizada, esse momento posterior acontecia em uma galeria de arte; atualmente, ainda que ele continue acontecendo em uma exposição, certamente a ação encontrará o maior número de interlocutores na internet. $O$ enfoque nesse corpo expandido, que acessa a ação fora do contexto do real, aumenta as proporções da ação; ela se torna dissociável de um contexto específico e ganha uma dimensão política mais eficiente, pois desterritorializa a reflexão. A intervenção deixa de ter acontecido somente naquele espaço-tempo de sua execução (Áustria, 1969) e passa a provocar efeitos em outros territórios, durante um tempo igualmente prolongado.

Ao contrário de EXPORT, as performances realizadas por Tehching Hsieh são características por sua invisibilidade, elas não se oferecem à observação no momento da ação propriamente dita, porém elas também se destinam a um espectador ausente. $O$ artista taiwanês radicado nos Estados Unidos é bastante conhecido por realizar performances de longa du-

\footnotetext{
${ }^{36}[. .$.$] persons who constitute an audience simply by being in a given location at a given time, as opposed to$ the invited (tradução minha).

${ }^{37}$ belated viewer : outra expressão empregada por Midrich (p. 64).
} 
ração. Entre 1978 e 1986, ele realizou uma série de cinco performances com duração de um ano cada, sendo que cada performance é apresentada com uma declaração de intenções. Em ordem cronológica, a terceira delas, chamada Outdoor Piece consiste em permanecer um ano perambulando pelas ruas de Nova York sem entrar em edifícios ou qualquer tipo de abrigo, como carros, trens, lojas ou moradias. Dormindo em parques ou sob marquises ou pontes, o artista levou ao extremo sua condição de habitar o exterior, em um movimento oposto à primeira ação da série, na qual viveu um ano dentro de uma jaula montada em seu ateliê (Cage Piece). Ele se desloca pela cidade carregando apenas uma mochila nas costas e um saco de dormir. Ao longo desse período, o artista não realizou nenhuma ação que pudesse ser assistida por alguém; ele viveu em condições adversas, exposto às variações climáticas, dormindo, comendo e realizando todas as suas necessidades na rua. Muito raramente usou um telefone público ou encontrou al-
Figura 12: Cartaz exposição Tehching Hsieh

ONE YEAR PERFORMANCE by TEHCHING HSIEH

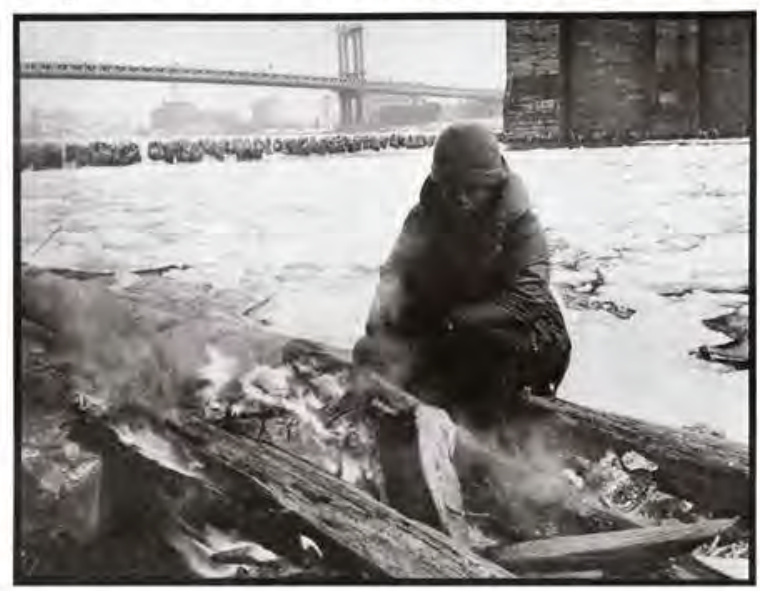

26 Sept 1981 - 26 Sept 1982

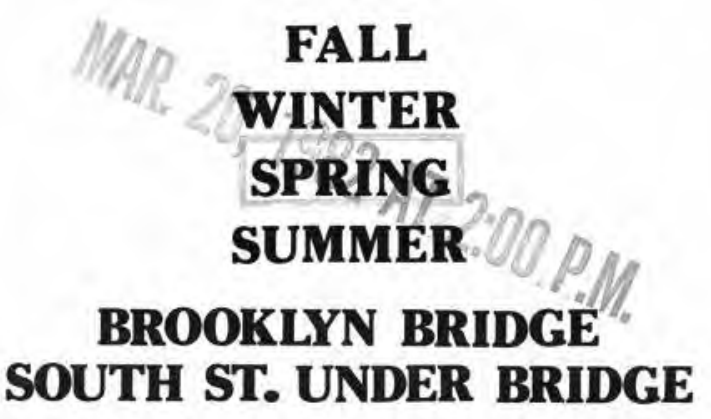

Foto: Disponível em: < http://lingerlongers.tumblr.com/ page/3>. Acesso em: 20 fev. 2017. gum amigo. Antes de sair como um nômade em deriva, no dia 26 de setembro de 1981, Hsieh fez uma declaração, registrada em cartório, responsabilizando-se por sua ação.

Com tal ação, Hsieh pretende comprovar como, sem um lugar, a pessoa se torna invisível. A ideia do artista não é interpretar um personagem sem teto, mas converter-se em um. Ao colocar-se na pele do outro e experimentar seu sofrimento, o performer recusa a performance como metáfora. Segundo Iria Candela, performances como essa falam das formas de alteridade existentes na sociedade e que o espaço público é o lugar onde se experimenta os limites do social, onde se encontra o outro e se experimenta o antagônico, para poder debater e negociar os fundamentos essenciais da identidade democrática (2004, p. 139).

Mas Hsieh ia um pouco além. Em sua performance, por algum desses misteriosos mecanismos da arte, a radicalização do individual o permitiu alcançar o social, a fim de examinar, mais em termos foucaultianos que de "democracia radical", as versões mais extremas dos fenômenos de exclusão experimentados na sociedade. (...). Sua obra implicava uma crítica feroz à América da desproporção criada pela administração do presidente Reagan. Outdoor Piece falava de um exclusão 
social, econ6omica, psicológica desproporcional... a mesma que havia gerado a crise dos sem teto em Nova York. Tehching Hsieh foi um dos primeiros artistas a detectar, no início da década de 1980, quem seria o grande outro na cidade nos anos que seguiriam (Ibid., pp. 139-140) ${ }^{38}$.

Muitos aspectos podem ser discutidos a partir desse feito. Mesmo não sendo um morador de rua, as pessoas que eventualmente passavam por ele durante esse ano perambulando por Nova York não tinham condições de reconhecê-lo ou de distingui-lo de outros moradores de rua. Não havia situação construída na qual ele pudesse ser observado, nem ação proposta que visasse algum tipo de relação com alguém com quem ele encontrasse casualmente. Não havia local, nem hora marcada, assim como não havia convocatória para possíveis espectadores. Mais do que uma ação artística, o performer instaura uma ação política na qual coloca seu próprio corpo à prova, em situação de risco, vivendo na rua, como tantos outros. Com sua Outdoor Piece, Tehching Hsieh tensiona a noção de arte, ampliando seus domínios, pois suas condições de vida como morador de rua ao longo de um ano não poderiam ser consideradas arte. O que dá valor artístico à sua ação é justamente a transformação dessa vivência em narrativa, assim como a presença de um programa performativo - um desafio de sobrevivência - e o acompanhamento dessa ação por um único cúmplice: Robert Attanazio, o fotógrafo que registrou essa peregrinação.

\section{O território do real e o princípio do acontecimento: a dissolução da obra de arte.}

Quando a teórica francesa Maryvonne Saison articulou o termo 'teatros do real' ela pensava no estreito laço que unia a cena, enquanto instância ficcional, à realidade da vida dos artistas. Saison também pensou na materialidade da cena, na realização das ações, nos objetos reais, nos corpos concretos e na inclusão de documentos que se referem àquilo que não era ficcional. A autora identificou uma tendência na cena contemporânea de voltar-se para fatos da vida real: documentos, depoimentos e cartas, incluindo ainda elementos da própria história de vida das pessoas envolvidas na criação. Essa inclusão do real se aproxima da estrutura do cinema documentário, que organiza o seu modo de fazer para apresentar situações reais e não inventadas: revelando locações onde os fatos se desenrolam, ao invés de locações cenográficas, mostrando pessoas reais ao invés de personagens e disponibilizando para os espectadores documentos e registros que validem a veracidade dos fatos.

\footnotetext{
${ }_{38}$ Pero Hsieh iba un poco más allá. En su performance, por alguno de esos misteriosos mecanismos del arte, la radicalización de lo individual le permitió alcanzar lo social, a fin de examinar, más en términos foucaultianos que de "democracia radical", las versiones más extremas de los fenómenos de exclusión experimentados en la sociedad. (...). Su obra entrañaba una crítica feroz a la América de la desproporción creada por la administración del presidente Reagan. Outdoor Piece hablaba de una desproporcionada exclusión social, económica, psicológica... la misma que había generado la crisis de los sin techo en Nueva York. Tehching Hsieh fue uno de los primeros artistas en detectar, a principios de la década de 1980, quién iba a ser el gran otro en la ciudad en los años que siguieron (tradução minha).
} 
No entanto, no campo cinematográfico a distinção entre documentário e cinema de ficção também gera dúvidas e controvérsias, pois os gêneros e os estilos se mesclam cada vez mais, tornando-se híbridos. O professor de cinema Ismail Xavier costuma afirmar em suas aulas que a diferença entre o cinema de ficção e o documentário não está na forma do filme ou no seu modo de fazer, mas no espectador. Para ele, é o espectador que se coloca diante da tela com o conhecimento de que se trata de uma história real ou de uma história inventada, de um filme que se propõe a documentar um fato, ou de uma história que pretende emocionar, comover ou entreter o público. Este saber, por parte do espectador, altera substancialmente a experiência.

O exemplo do cinema pode ser bastante elucidativo para se pensar sobre os teatros do real, mesmo que o correspondente direto do cinema documentário seja o teatro documentário. Diante desses teatros nos quais o real é anexado à cena, o espectador é mergulhado na realidade concreta. Mesmo quando a criação ocorre no espaço teatral, nota-se a presença de elementos reais na composição cênica. Trata-se de uma rua de sua cidade, de um não-ator, de um morador de uma casa vizinha. No entanto, o real e o ficcional se mesclam, promovendo alterações no fazer teatral. Esse movimento de anexação do real pode tanto enfraquecer algumas tentativas de construção teatral - fazendo parecer falsa a interpretação de um morador de rua realizada por um ator, por exemplo - quanto pode levar o espectador a incluir os pedestres, o fluxo da cidade e os acontecimentos cotidianos em sua leitura da construção artística. Nos casos analisados aqui, há a incorporação do espaço público como espaço cênico.

\footnotetext{
No teatro brasileiro contemporâneo, ainda que não constituam um campo uniforme, essas manifestações aparecem como tentativas de escapar do território específico da reprodução da realidade para, nos casos mais radicais, tentar sua anexação, ou melhor, ensaiar sua presentação sem mediações. Nessas experiências, o impulso de captura do real leva os criadores a confrontar o espectador com as coisas em estado bruto, seja por colocá-lo em espaços concretos, contaminados de imaginário próprio, seja por misturar atores a não atores nas apresentações [...] (FERNANDES, 2013, p. 9).
}

A cena em si também aparece impregnada de real, pois frequentemente ela se apresenta com um caráter de experimento, de inacabamento e de work in progress, revelando sua efemeridade e os demais dispositivos que articulam sua materialidade. Não há uma intenção de representação do mundo ou de causar impressão de realidade, não se trata de cópia de algo existente, mas sim de ocupar-se com a realização de uma ação concreta. $A$ corporalidade e a atenção ao fazer concreto da ação é um traço performativo recorrente nessas manifestações cênicas. Silvia Fernandes categoriza os teatros do real como teatros performativos, utilizando a terminologia desenvolvida por Josette Féral para discutir a cena brasileira contemporânea. 
No Brasil, dentre suas principais características, a cena performativa tem ocupado o espaço público, realizando intervenções como forma de anexação do real. Silvia Fernandes fala de "espaços públicos contaminados de alta carga política e simbólica" ao referir-se aos trabaIhos de grupos como o Teatro da Vertigem ${ }^{39}$ e a Cia. São Jorge de Variedades ${ }^{40}$. É sabido que tal característica não se restringe apenas ao território brasileiro. Tadeusz Kantor já se utilizava dos espaços carregados de memória da guerra e realizou o Happening Panorâmico do Mar no qual ele regia o oceano, como se fosse um maestro, em 1967. As experimentações cênicas de Klaus-Michael Grüber, em uma capela dentro de um hospital em Paris e em um estádio na Alemanha como espaço cênico também são exemplos desse tipo de anexação. No caso de Kantor, o mar foi anexado como elemento do real, sem substitutos simbólicos. Qualquer representação, por mais fidedigna que seja, usando tecidos, pinturas ou projeções, não seria tão contundente quanto o mar ele mesmo.

De acordo com Iria Candela, as práticas site specific iniciadas pela Land Art aparecem com força nos Estados Unidos na década de 1970, assinalando uma tendência da arte contemporânea de voltar-se para o espaço. Em contraponto à ideia de ocupação dos terrenos descampados e rurais, uma geração de artistas optou por incorporar em suas criações a paisagem urbana. Em larga medida, essas modalidades artísticas que dialogam com o espaço da cidade promovem um rompimento com instituições como teatros, museus e galerias de arte. Porém, tal investimento vai além dessa contestação, ele reconfigura os estatutos dessas criações artísticas, fundando outras relações sociais e simbólicas com e na cidade. Em alguns casos, a inscrição da obra no espaço é tão determinante, que a obra não poderia existir fora dele, ou seja, seria impossível realizar sua transposição para outro lugar. Por isso, pode-se afirmar que a experiência da obra é inseparável do espaço que a acolhe. Muitas vezes, o lugar é considerado específico por interferir diretamente na criação, inspirando sua composição e, ao mesmo tempo, transformando-se temporária ou permanentemente.

Como assinalou Miwon Kwon em seu estudo retrospectivo dessa tendência, as práticas site specific entenderam inicialmente site (lugar) como uma localização física, como uma realidade tangível cuja identidade se compunha de uma combinação singular de elementos físicos constitutivos: extensão, profundidade, altura, textura e forma de paredes e salas; escala e proporção de praças, edifícios ou parques; condições de luz, ventilação, tráfico e características topográficas. Porém desde então e ao longo dos últimos trinta anos, a definição operativa de site foi se desvinculando de uma localização física (posicionada, fixa e concreta), para envolver-se em um vetor discursivo (deslocado, fluido e virtual). (CANDELA,

\footnotetext{
${ }^{39}$ A partir da década de 1990, em São Paulo, o Teatro da Vertigem explora com verticalidade a criação em site specific, desde a realização de sua trilogia bíblica, que compreende uma peça em uma igreja ( $O$ Paraíso Perdido), outra em um hospital (O Livro de Jó) e uma última em um presídio (Apocalipse, 1,11), até o uso do Rio Tietê (BR-3) e de um bairro (Bom Retiro $958 m$ ) como locação para suas inscrições teatrais.

${ }^{40}$ A companhia explorou a partir dos anos 2000 os espaços não teatrais, como um abrigo de moradores de rua (As Bastianas) e outro bairro da cidade de São Paulo (Barrafonda).
} 
O uso de espaços não convencionais foi radicalizado por artistas como Gordon Matta-Clarck, que promoveu cortes em edifícios abandonados, e Trisha Brown, que compôs coreografias para serem dançadas nos telhados dos edifícios e em deslocamentos verticais pelas paredes dos prédios. Neste último caso, a artista usava cabos de aço para descer do alto dos prédios até a altura da calçada, simulando um caminhar impossível tendo em vista a lei da gravidade. $O$ que tais artistas propõem com a exploração fenomenológica desses lugares é a inscrição de visões inimagináveis e descontextualizadas no corpo da cidade. Ambos ressaltaram a materialidade de espaços concretos, provocando poeticamente a percepção dos passantes, como se caminhando pelas paredes acionassem dispositivos adormecidos de seus imaginários.

No território nacional, é a persistência desse movimento para além da década de 1970 o que chama a atenção, por motivações diferentes, principalmente econômicas, muitos grupos e coletivos optaram pelos espaços públicos inclusive como alternativa à escassez de incentivos na área da cultura e educação. Desse modo, o espaço público passa a ser incorporado não apenas como localização geográfica, mas como elemento do real. E essa atribuição é tão exata, que o simples fato de desenvolver uma ação na rua, já a modifica a contextualiza. Devido a sua localização, a criação já fica impregnada do contexto, o que gera leituras e reações que não seriam possíveis caso a ação fosse desenvolvida em outro lugar. No espaço público, a diferenciação entre real e ficcional torna-se complexa, de modo que tais ações permanecem em constante diálogo com a rua, passando por embates e atritos.

\footnotetext{
_A última palavra é a penúltima, Teatro da Vertigem (2008/2014): um lugar de passagem, onde se instauram jogos do caminhar

Do mesmo modo pelo qual a pesquisadora francesa nos alerta sobre a teatralidade do cotidiano, presente na vida real, a intervenção cênico-urbana $A$ última palavra é a penúltima
}

\footnotetext{
${ }^{41}$ Como he señalado Miwon Kwon en su estudo retrospectivo de esta tendencia, las prácticas site-specific entendieron inicialmente site (lugar) como un emplazamiento físico, como una realidad tangible cuya identidad se componía de una combinación singular de elementos físicos constitutivos: extensión, profundidad, altura, textura y forma de paredes y salas; escala y proporción de plazas, edificios o parques; condiciones de luz, ventilación, tráfico y características topográficas. Pero desde entonces y a largo de estos últimos treinta años, la definición operativa de site se fue desvinculando de una localización física (emplazada, fija y concreta), para involucrarse en un vector discursivo (desubicado, fluido y virtual). (tradução minha).
} 
também cumpre esse papel ao deslocar a vida cotidiana para sua passarela cênica ${ }^{42}$. Trata-se de uma intervenção simultânea que acontece tanto em uma passagem subterrânea desativada quanto na faixa de pedestres localizada exatamente sobre ela. Essa passagem pertencia à antiga loja do Mappin (uma das primeiras lojas de departamento inauguradas em São Paulo ${ }^{43}$, onde hoje há uma loja das Casas Bahia), situada entre a loja e o Prédio da Light (que se tornou em 1999 o Shopping da Light). Alguns espectadores podem assistir a intervenção do Teatro da Vertigem de dentro da passagem, em um número limitado de assentos e os demais assistem às ações que são replicadas e/ou desenvolvidas na faixa de pedestres, criando um moto contínuo entre os dois espaços de travessia. Àqueles que não conseguem um assento dentro das vitrines que margeiam a passagem subterrânea é dada a oportunidade de assistir do lado de fora as ações que ocorrem na faixa de pedestre e de atravessar o espaço cênico em certos momentos integrando eles também as cenas.

O dispositivo de jogo destinado aos espectadores é simples: duas luzes foram posicionadas nas entradas dos túneis que dão acesso à passagem. Quando a luz vermelha está acesa a entrada não é permitida, ao passo que quando ela está verde, o espectador pode atravessar a passagem, assumindo a função de performer. Sim, de performer e não de ator, pois não lhe é dada nenhuma instrução, nenhuma recomendação sobre o modo segundo o qual ele deve agir. Sua ação se restringe ao ato de caminhar como ocorre quando ele se desloca pela cidade. Há apenas uma exceção, em um movimento anunciado por todos os que estão nos bastidores da cena: o momento da "balada". Nessa hora, a maioria das pessoas entra dançando impulsionada pela música e pela ação dos atores, que se comportam como se estivessem numa festa de música eletrônica. Dessa forma, o jogo é facilmente apreendido e dispensa maiores explicações. Há um deslocamento da teatralidade do cotidiano para o espaço cênico, como se o encenador colocasse janelas diante dos olhos dos espectadores, convidando-os a observar e a fabular sobre as pessoas comuns, os pedestres da cidade, destacando a teatralidade que pode ser percebida apenas com o consentimento de quem olha.

Trata-se de um ótimo exemplo para refletir sobre o potencial pedagógico presente nessas encenações, que explicitam na própria configuração da cena, seu "modo de usar". Tal potencial pode ser identificado pela ausência de instruções destinadas aos espectadores: nem àqueles que se sentam dentro das vitrines - cujo modo de usar coincide com aquele

\footnotetext{
${ }^{42}$ Essa intervenção foi realizada primeiramente em 2008, numa parceria do Teatro da Vertigem com mais dois coletivos, o Zikzira, de Belo Horizonte e o LOT, do Peru. E em 2014 o Teatro da Vertigem, sob a batuta de Antônio Araújo remontou o experimento, aprimorando sua construção. Tive a oportunidade de assistir às duas versões, sendo que a última assisti tanto na condição de espectadora sentada, quanto na condição de espectadora em trânsito, pedestre e participante da experiência.

${ }^{43}$ O Mappin estabeleceu-se em São Paulo em 1913 a partir da iniciativa de duas famílias de comerciantes ingleses, vendendo produtos importados e oferecendo espaços de convivência, como barbearia e salão de chá. A loja entrou em falência antes de completar um século na cidade, em 1999.
} 
das salas tradicionais, pela relação sentada e frontal que se estabelece, nem àqueles que integram a ação performática junto com os atores. Desse modo, os espectadores percebem suas possibilidades de participação ao "fazer", a cada passagem pelo túnel de pedestres, por meio do acordo tácito instaurado em cada fluxo. Como esses espectadores passantes estão posicionados ao lado dos atores, atentos aos sinais verde e vermelho, eles entendem e incorporam o dispositivo de jogo implícito na encenação.

A última palavra é a penúltima é fruto de uma criação colaborativa que teve como ponto de partida as discussões presentes no texto L'Epuisé (O Esgotado), de Gilles Deleuze. Embalada pela noção de esgotamento, usada pelo autor para discutir algumas obras de Beckett, a intervenção está centrada sobre a ação de caminhar. Mesmo quando algumas situações são apresentadas, elas se dão em deslocamento, com breves pausas e textos esparsos ou ditos em trânsito, o que faz com que o espectador apreenda apenas parcialmente as palavras emitidas. Muitas dessas ações são decorrentes do deslocamento da figura representada pelo ator, seja um entregador de água, que rola galões azuis ao longo do percurso, seja ao colecionar anúncios de compra e venda de imóveis. O esgotamento de que fala Deleuze é diferente do cansaço, o autor se refere às palavras e aos fluxos, representados na intervenção pelas séries de deslocamentos ocupando a passagem. Com alto grau de performatividade, a intensidade e a profusão das imagens expostas dissipa a potência dessas imagens. No mesmo movimento do autor de referência, investe-se em uma política que nada quer significar ou comunicar. Esse impulso encontra ressonância na estética do performativo, centrada na materialidade das ações, nas imagens que nada representam, além de uma exposição delas mesmas. Há uma recusa do espetacular e uma produção de interferências

Figura 13: Teatro da Vertigem - A última palavra é a penúltima
Foto: Disponível em: <https://www.teatrodavertigem. com.br/a-ultima-palavra1 ?lightbox=dataltem-im1a8key>. Acesso em: 30 mar. 2017.

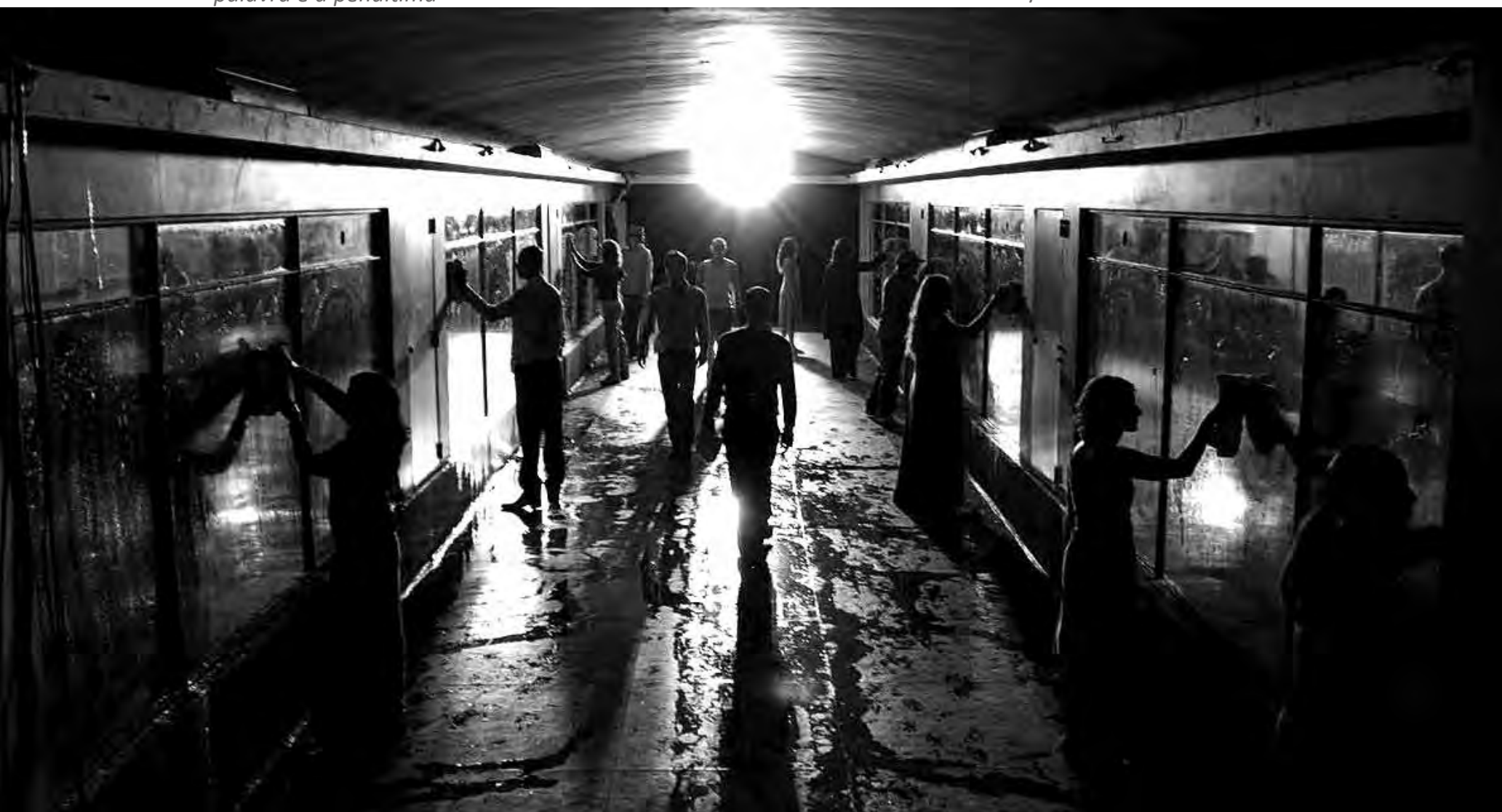


sutis no cotidiano, como acontece na faixa de pedestres com as ações que duram o tempo exato em que o sinal permanece aberto para a circulação das pessoas.

Dentro da passagem subterrânea há antigas vitrines cujos espaços internos foram adaptados para receber os espectadores, com bancos e luzes usadas como dispositivos para delimitar as margens do jogo. No documentário em vídeo realizado por Evaldo Mocarzel a partir do processo de criação da peça, nota-se que ele pretendia não apenas registrar o experimento cênico, mas também desmontá-lo, revelando os impasses vividos. 0 cineasta articulou, desse modo, cenas da primeira versão da intervenção, tomadas dos ensaios e discussões entre os artistas envolvidos. $O$ documentário apresenta quatro ações que definem alguns momentos da interação com os espectadores que estão dentro das vitrines. São elas: olhar o espaço, olhar para si mesmo, olhar através da vitrine e ser olhado pelos outros.

Os espectadores que ficam sentados lançam um primeiro olhar para o espaço quando o percorrem em direção às vitrines. Assim que se sentam, as luzes da passarela se apagam e as de dentro das vitrines se acendem, fazendo com que os vidros espelhem o coletivo de espectadores. No movimento seguinte, numa demonstração dos efeitos do dispositivo, uma vitrine acende e a outra apaga, fazendo com que os integrantes de uma vitrine vejam os da outra. De dentro das vitrines ouve-se a canção "Bicho de Sete Cabeças", de Itamar Assumpção, uma oração à cidade de São Paulo: "Eis aqui o bicho de sete cabeças (...). Eis aqui São Paulo metrópole intensa. Eis aqui minha cabeça e o meu coração".

Quando a vitrine se apaga, o público assiste as ações que se sucedem ao longo da passagem. Concomitantemente, pequenas telas, associadas a câmeras de vigilância, exibem as ações que são postas em cena na faixa de pedestres. Transitando entre os campos do real e do ficcional, os atores dividem com os espectadores passantes a figuração de tipos urbanos. Foi curioso notar que alguns atores incorporam apenas uma figura que passa por diferentes situações, enquanto outros exploram mutações que os confundem com os passantes ocasionais. Um último movimento de exposição do público inverte a posição de quem detém o olhar. As luzes das vitrines se acendem, a passarela se apaga e, finalmente, os espectadores são observados pelos atores como evento cênico. Desse modo, o dispositivo da luz acaba por dimensionar o espaço do jogo.

Uma ressalva poderia ser feita a respeito do modo pelo qual os atores-performers realizam suas ações. $O$ fato de se tratar de um agrupamento muito variado, de atores profissionais a passantes ocasionais, pode ser considerado, em parte, a razão para o aparecimento de teatralidades e performatividades tão distintas. Os participantes podem ser divididos entre os atores profissionais, que integra(ra)m o Teatro da Vertigem, os atores convidados, os usuários recorrentes da peça e os passantes fortuitos. Há entre eles muitas camadas de experimentação reveladas pelos seus modos de agir, produzindo uma convivência de corpos 
dissonantes. Há quem crie uma situação dramática para justificar cada passagem pela passarela e quem passe com o foco em executar uma ação. Há quem componha uma coreografia a cada travessia e quem estabeleça relações com outras figuras. Há quem experimente ações arriscadas, pelo simples prazer de colocar-se à prova e quem componha programas para realizar a cada noite. Há muita gente interessada em participar mais de uma vez, para testar o dispositivo e quem passe inadvertidamente pela primeira vez, a cada sessão.

A multiplicidade de corpos, ações e situações resultantes das explorações dessa estrutura performática inventada pelo Teatro da Vertigem possibilitou a visão de uma população plural, bastante representativa da cidade. Se não fosse a abertura da passarela cênica para as performatividades presentes em São Paulo, os atores sozinhos não chegariam a essa qualidade. É à convivência desses corpos e à abertura para o fluxo de pedestres e performers experimentais, juntamente com o acaso, que se deve o agenciamento desses comportamentos e escolhas poéticas. A instauração desse jogo (mise en jeu) é que torna essa equação possível; não se trata da criação de visões, mas da apreensão casual de amostras de fluxos cotidianos. $O$ ato de caminhar, sintetizado aqui como prática estética, não poderia ser fixado por mera visão. Caminhar é antes de mais nada uma ação. Como desenvolverei mais tarde (no capítulo quatro), tratam-se de fragmentos de percursos de passantes diversos, revelando o quanto a materialidade cotidiana do caminhar pode se configurar como materialidade artística, dependendo da mediação feita pela intervenção, capaz de dotar o cotidiano de qualidade estética. Dessa forma, o papel do real nessa criação é garantir que não se defina uma visão estática da cidade, mas de tornar visíveis as teatralidades presentes no cotidiano. Nenhuma imagem que não fosse transitória, movediça ou fluida, não serviria de amostragem da população paulistana, nem representaria o esgotamento presente no texto de Deleuze.

$$
<<<>>
$$

Quando se nota a presença do real na construção das cenas, seja por sua anexação, seja pela observação da teatralidade presente no real, percebe-se uma aproximação dos eventos cênicos da noção de acontecimento. Se considerarmos um acontecimento como um conjunto de ações imprevisível, inesperado e não programado, dificilmente uma ação artística poderia ser considerada um acontecimento. No entanto, tanto em um caso como no outro, os processos estão centrados no corpo e nos encontros fortuitos; são igualmente efêmeros, transitórios e impossíveis de serem repetidos. Desse modo, não é estranho afirmar que a estrutura de certas modalidades cênicas se assemelhem a um acontecimento ou mesmo que o tomem como inspiração. Ainda que um acontecimento não resulte da iniciativa de ninguém, nem possa ser controlado, ao serem inscritas na cidade, as criações artísticas podem ser vistas ou experimentadas como acontecimentos, pois muitas vezes quem as identifica no meio do fluxo do cotidiano não as difere do real. 
Ao apresentar a noção de teatralidade, em um dos primeiros textos em que se debruçou sobre o tema, Josette Féral ("A Teatralidade: Em Busca da Especificidade da Linguagem Teatral") apoia-se sobre a ideia de clivagem, uma separação tênue que seria percebida entre aquele que observa e aquilo ou aquele que é observado. Em sua consideração, a autora utiliza quatro exemplos para explicar a teatralidade. No último deles, parte de uma experiência pessoal, na qual ela se encontra sentada no terraço de um café, observando através de uma janela as pessoas que passam na rua. Mesmo que não tenham nenhuma intenção de serem vistas, pois não se exibem, nem performam, afinal agem cotidianamente como usuárias da cidade, essa observadora apreende no fluxo dessas pessoas através de um recorte da janela, a teatralidade do cotidiano.

Desse exemplo final (...) pode-se depreender uma importante conclusão: a teatralidade não parece relacionar-se à natureza do objeto que investe - o ator, o espaço, o objeto, o evento; também não se restringe ao simulacro, à ilusão, às aparências, à ficção, já que pudemos apreendê-la em situações cotidianas. Mais que uma propriedade, cujas características seria possível analisar, é um processo, uma produção relacionada sobretudo ao olhar que postula e cria outro espaço, tornado espaço do outro - espaço virtual, é claro - e dá lugar à alteridade dos sujeitos e à emergência da ficção. (FÉRAL, 2015, p.86, grifos da autora).

Nos casos analisados aqui, não há separação (clivagem) entre o espaço cênico e o espaço da vida ou da cidade. Não há preparação do espaço, não se faz silêncio para que a ação comece, não há espaços preparatórios para a acomodação do público (hall, bilheteria, sala de espetáculo), assim como não há espaço destinado ao público. Um acontecimento é uma intromissão no real, uma turbulência, e necessariamente, uma sobreposição de acontecimentos. Sempre que algo acontece, as outras coisas ao seu redor não são interrompidas para que o algo programado aconteça. Por esse motivo, um acontecimento sempre se configura pela sobreposição e simultaneidade. Seguindo esse modelo, tais criações artísticas também são sobreposições, pois a cidade não para de acontecer para que essas ações aconteçam.

Eleonora Fabião se refere ao espectador de performance como alguém que participa de uma festa, "sua presença é parte do show. Se você está lá, faz parte dela"44. Ela ressalta ainda o fato de existir para o espectador um antes e um depois da performance, o que evidenciaria seu caráter de transformação. Um acontecimento também envolve a todos os presentes, independente dos motivos que o levaram até o local, naquele momento exato. Depende de presenças e propõe transformações, ainda que transitórias. Desse modo, basta estar presente para viver/participar de uma experiência. Assim como um acontecimento é da ordem da experiência, essas modalidades cênicas também são, e embora elas possam ser programadas e planejadas, elas não podem ser controladas.

${ }^{44}$ Disponível em <http://www.nyu.edu/classes/bkg/issues/Fabiao.htm>. Acesso em: 04 jun. 2016. 
Erika Fischer-Lichte, em sua Estética de lo performativo, discute a realização cênica como acontecimento. Para tanto, ela evoca dois autores (Peter Behrens e Georg Fuchs), que na passagem do século XIX para o XX, "proclamaram que o teatro devia converter-se de novo em uma festa" (FISCHER-LICHTE, 2011, p.321) ${ }^{45}$. Tal afirmação a conduz ao sentido original do teatro, que reuniria atores e espectadores em uma festa-teatro, onde "todos tinham em mente a condição de acontecimento da realização cênica" (Ibid.). Entender uma manifestação cênica como festa a aproxima da noção de acontecimento e também de ritual, e, ao mesmo tempo, a afasta da noção de obra. Se fizermos o exercício de observar as manifestações cênicas do teatro à performance, como festa e não como obra, notaremos a oscilação presente nos elementos cênicos que tenho evocado até agora, com maior clareza. Se uma obra é encenada, uma festa é "programada", depende da "iniciativa" de uma ou mais pessoas que não participarão dessa festa sozinhas. Se uma obra tem uma autoria precisa, uma festa pode ter sido produzida por alguém ou por um grupo, mas sua autoria cabe a todos os participantes do evento, pois sozinhos eles não teriam realizado a festa vivida por todos. Se uma obra tem atores ou artistas que estão no centro de sua estrutura, em uma festa há corpos que desfrutam de um espaço-tempo coletivo; há um sentido de comunhão e de comunidade. Se há espectadores para uma obra, numa festa todos são participantes, retomando as palavras de Eleonora Fabião, citada acima. Vale ainda destacar a impossibilidade de separar a festa da esfera da vida, por isso analisar os 'modos de fazer' e os 'modos de usar' dessas modalidades cênicas engendra também discussões sobre os modos de organizar e agir (n)a vida.

A oposição entre arte e realidade tem gerado uma grande quantidade de novas oposições dicotômicas como as do estético x o social, o estético x o político, o estético $\mathrm{x}$ o ético. Como se tem mostrado, as realizações cênicas desde os anos sessenta têm conduzido ao desmantelamento de todas as oposições de maneira ostensiva. A mudança de papéis e a formação de comunidades revelam com particular clareza que as realizações cênicas são sempre uma situação social, uma forma de sociabilidade.(...) Sempre que um indivíduo, ou um grupo, intenciona impor a outros determinadas posições, modos de comportamento, ações ou ideias, estamos diante de processos de natureza política (Ibid., 2011, p.339) ${ }^{46}$.

Ao propor esses deslizamentos de função, mudanças de relações e outras definições de posições, tais modalidades cênicas exploram outras possibilidades de organização não somente na cena, mas também na esfera social e, portanto, política. Desde a escolha do espaço

${ }^{45}$ O livro de Erika Fischer-Lichte foi consultado na sua versão espanhola, publicada em Madri em 2011, sendo que o texto original foi escrito em alemão e sua primeira edição data de 2004.

${ }^{46}$ La oposición entre arte y realidad ha generado gran cantidad de nuevas oposiciones dicotómicas como las de lo estético vs. lo social, lo estético vs. lo político y lo estético vs. lo ético. Como se ha mostrado, las realizaciones escénicas desde los años sesenta han conducido al desmantelamiento de todas esas oposiciones de manera ostensible. El cambio de roles y la formación de comunidades revelan con particular claridad que las realizaciones escénicas son siempre una situación social, una forma de sociabilidad. (...) Siempre que un individuo, o un grupo, intenta imponer a otros determinadas posiciones, modos de comportamiento, acciones o ideas, estamos ante procesos de naturaleza política. (tradução minha). 
para a realização de determinada ação, até o tipo de proposição que se faz ao espectador, todas essas experimentações jogam com a desorganização do status quo, de algo que já está posto e estabelecido. A seguir, apresentarei algumas análises que apontam para o que Féral define como um ato de transgressão do cotidiano através da criação, ou seja, a teatralidade como transformação do real. No próximo exemplo, uma série de acontecimentos trágicos se sucedem, sem que a intervenção aconteça no espaço público. Entretanto, ela se configura como uma síntese de muitos acontecimentos justapostos, simulando com exatidão a ambiência urbana pós tragédia.

_Le Metope del Partenone, Romeo Castellucci (2015): quando a arte replica acontecimentos

Trata-se de uma intervenção ${ }^{47}$ no grande hall do La Villette, um espaço amplo e vazio, iluminado com luzes frias e sem nenhum aparato cenográfico que o modifique antes de as cenas serem instaladas. Há apenas um projetor posicionado em uma das paredes, onde serão insFigura 14:

Romeo Castellucci - Le Metope del Partenone

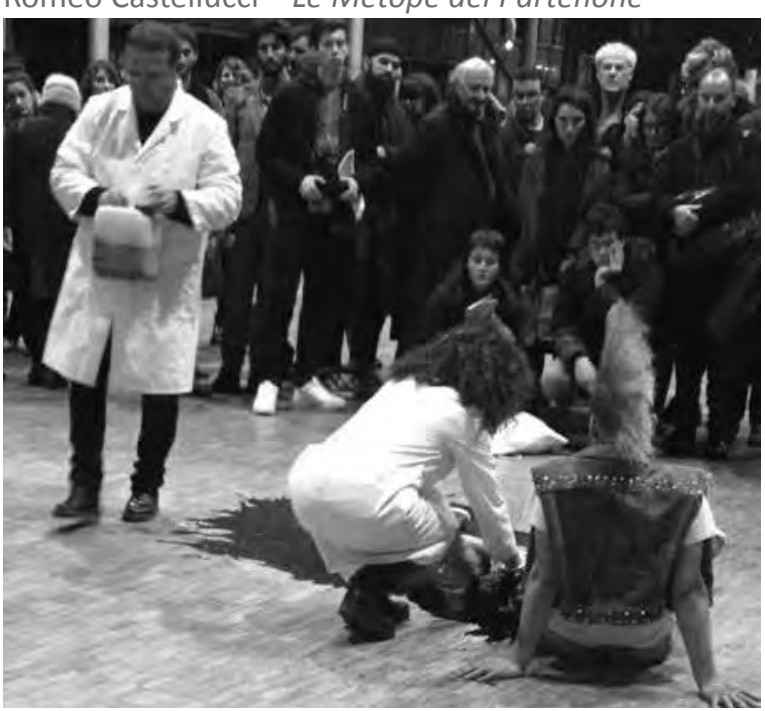

Foto: Verônica Veloso
Figura 15:

Romeo Castellucci - Le Metope del Partenone

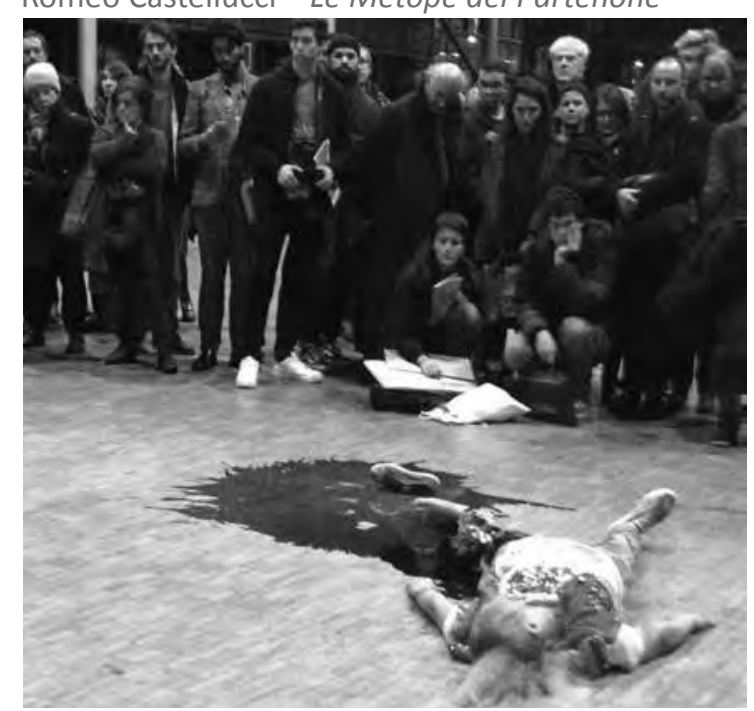

Foto: Verônica Veloso

critos jogos de adivinhação: perguntas em forma de charada, cujas respostas serão sempre surpreendentes. Os espectadores permanecem de pé, podendo se deslocar e se posicionar onde quiserem. Seis acidentes são apresentados em sequência seguindo a mesma estrutura. Um grupo de pessoas entra no espaço, caracteriza um performer com sangue, bile, vômito, toda sorte de fluidos corporais, dependendo do acidente a ser representado. A situação é construída diante dos olhos do público, como se acompanhássemos uma equipe de um filme ao criar efeitos especiais para representar um corpo agonizante. Assim que a

\footnotetext{
${ }^{47}$ Apresentada no quadro do Festival de Outono, em novembro de 2015, duas semanas depois dos atentados que ocorreram em Paris em 13 de novembro, do mesmo ano.
} 
equipe deixa o local da cena, o performer inicia sua encenação da dor: uma mulher sangra em decorrência de um acidente; a outra tem uma reação alérgica que provoca o inchaço do seu rosto e de suas mãos; um homem tem os órgãos expostos, depois de um grave ferimento abdominal; o outro queima boa parte do corpo com uma substância altamente inflamável; um senhor tem um ataque cardíaco e uma jovem punk tem a perna explodida em um show. As cenas se sucedem uma depois da outra e todos, inevitavelmente, morrerão.

A ordem se repete a cada acidente: equipe prepara o performer, encenação da dor, chegada de uma ambulância com paramédicos reais (que não são performers), cuidados para tentar reavivar o paciente e morte. Em seguida, a ambulância sai e uma charada é projetada na parede. Um exemplo desse jogo de adivinhação:

"A natureza, que decide cada coisa equitativamente, nos colocou, a mim e ao meu irmão, que somos gêmeos, nascidos de uma só mãe, de maneira simétrica. Eu estou separado dele por uma fronteira estreita formada de uma pequena colina, eu nunca o vi e ele nunca me viu." ${ }^{48}$

O performer se levanta e vai até a parede onde as frases são projetadas. Ele se apresenta de pé diante do público, enquanto a resposta ao enigma é revelada. No caso acima, a resposta revelada é: o olho. Todas as situações dispostas nesse espaço "vazio" poderiam acontecer no espaço público, no meio do fluxo da vida real. "Idealmente, é como estar na rua: estamos de pé, caminhamos, formamos círculos espontâneos em torno das ações", nas palavras do encenador ${ }^{49}$. Um elemento retirado da vida real merece destaque: a ambulância, cuja sonoridade sofre um processo de acumulação à medida em que as cenas progridem. Após os atentados de 13 de novembro de 2015, a ambiência sonora parisiense sofreu uma notável alteração. A presença de sirenes na paisagem sonora da cidade passou a ser frequente. Para um habitante de São Paulo a constância desse ruído já está incorporada no dia-a-dia da cidade. Entretanto, na capital francesa, esse som não é tão frequente e sua repetição evoca um estado de suspensão, a iminência da guerra e o estado de urgência.

Não é apenas a repetição desse som, mas a representação do sangue e a iminência da morte também ecoam como uma referência direta ao ocorrido. Tanto é que a ação começa com um registro da própria voz de Romeo Castellucci explicando que a criação foi realizada em junho de 2015 para a feira de arte contemporânea de Basel e que ela seria apresentada de maneira idêntica em Paris. O que Castellucci pretende com essa fala é revelar o irreparável que o teatro representa, quando ele tem a infelicidade de se apresentar como um espelho

${ }^{48}$ La nature, qui decide de chaque chose équitablement, nous a placés, mon frère et moi, qui sommes jumeaux, nés d'une seule mère, de façon symétrique. Je suis séparé de lui par une frontière étroite formée d'une petite colline, je ne l'ai jamais vu et il ne m'a jamais vu (tradução minha).

${ }^{49}$ Frase retirada do texto de Romeo Castellucci. Ao final das apresentações, cópias desse texto eram distribuídas ao público na saída do espaço cênico. A frase citada: Idéalement, c'est comme être dans la rue: on est debout, on marche, on forme de cercles spontanés autor des actions (tradução minha). 
atroz do que acaba de acontecer nas ruas dessa cidade. Ao se referir às "imagens difíceis de suportar, obscenas na sua exatidão inconsciente ${ }^{\prime 50}$, o artista pede desculpas aos espectadores e os deixa à vontade para tomar suas decisões: ficar ou partir.

Ao colocar em cena acidentes, fazendo uma referência direta ao contexto urbano, o encenador lança mão de uma estrutura recorrente na cidade. Nesse contexto, quando acontece um acidente, os passantes tendem a se organizar em roda, transformando uma fatalidade em espetáculo da vida real. Esse apelo voyerista acompanha a encenação, responsabilizando o espectador por suas escolhas. Como ele está livre para se deslocar, é ele quem decide o quanto observa ou se escolhe não ver. Há quem tenha se recusado a ver, mantendo-se o tempo todo distante dos focos do acontecimento, mas também há relatos de espectadores que se sentem mal e de outros que se entregam completamente à ação, vivendo junto com os atores as suas dores. Há ainda aqueles que não se deixam embalar pela interpretação duvidosa da dor e outros que analisam os procedimentos adotados pelos paramédicos, que segundo alguns, não se aplicam aos casos específicos tratados.

Dentre todos os mortos, uma delas chama a atenção (figuras 14 e 15). Tratava-se de uma jovem punk, com cabelo estilo moicano cor de rosa, que embora performe como os outros participantes da ação, não tem, de fato, uma das pernas. Seu ciclo é o último a ser apresentado, o que gera certo espanto em alguns espectadores, já habituados com o simulacro proposto. Ela chega de muletas com a equipe de maquiadores que deve prepará-la, deita-se no chão e, junto ao seu corpo real, uma meia perna mutilada é posicionada, nas mesmas dimensões daquela que um dia integrou o seu corpo. Essa moça, por algum motivo, resolveu reviver repetidamente o acidente que modificou sua vida de forma definitiva. Foi curioso observar que em sua "interpretação" houve um lapso temporal antes de ela se dar conta de que sua perna estava realmente descolada de seu corpo. Há quem diga que em situações de dor extrema, os acidentados quase não choram, não reclamam. Há uma espécie de anestesia inconsciente que ajuda o corpo a lidar com a dor. Todos os outros performers mostram imediatamente a dor. Apenas ela, que já possuía um corpo verdadeiramente mutilado, demorou alguns segundos para se dar conta da ausência da perna e só então, gritou. Independente do aspecto do jogo do "ator", o que é impactante é a presença desse corpo, sem mediação, sem truque, para além da representação. Há uma frase que foi repetida para todos os moribundos: "mantenha os olhos abertos, fique com a gente!". Essa mensagem coincide com o final da carta aberta de Castellucci para os espectadores: "nesse momento, me parece mais humano estar aqui. Estar aqui essa noite significa que é preciso estar presente e vivo, diante dos mortos" ${ }^{51}$.

\footnotetext{
${ }^{50}$ [...] images difficiles à suporter, obscènes dans leurs exactitude inconsciente (tradução minha).

${ }^{51}$ En ce moment, il me semble plus humain d'être là. Être ici ce soir signifie qu'il faut être présent et vivant, devant les morts (tradução minha).
} 
O exemplo mencionado acima apresenta uma série de acontecimentos que embora estejam posicionados dentro de um galpão e não na rua, não se distancia da realidade e do contexto urbano. Ao se apropriar de uma estrutura do real, o artista traz a rua para dentro do galpão. Ao repetir uma sequencia de acontecimentos dentro de uma sala cênica, ainda que branca e sem separação fixa entre a cena e a plateia, Castellucci instaura acontecimentos, como na performance. Performers, espectadores e todas as pessoas envolvidas na ação caminham, formando círculos em torno de acontecimentos, como se fossem passantes que reagem a um acidente real no espaço público.

Paralelamente à noção de acontecimento, parece coerente destacar a noção, proposta pelo jovem Guy Debord, de situação construída, que deu nome ao grupo dos Situacionistas. Partidários da superação das artes, a construção de situações correspondia para o grupo ao desejo de fundar uma nova civilização. Tais situações estão ligadas à necessidade de jogar com a arquitetura, com o tempo e com o espaço. De modo similar àquilo que Fischer-Lichte aponta sobre a noção de acontecimento, superar as artes significava para os situacionistas "aboli-las enquanto atividades separadas da vida cotidiana, para transformá-las em maneiras de fazer, em meios de ação ou em modos de vida"(THÉODOROPOULOU in GUY e LE BRAS, 2013, p.50). Na Internacional Situacionista n.5, ao se referir à arte das situações, os autores afirmam que "são esquemas, equações em que os participantes poderão escolher com quais incógnitas vão jogar, seriamente, sem espectadores, e sem outra finalidade além do jogo em si" (JACQUES, 2003, p. 131). Os situacionistas apresentam a noção de jogo como uma arma contra a alienação, sem, no entanto, apoiar "nenhuma forma desejável ou garantida de felicidade" (Ibid.). Voltarei aos situacionistas no capítulo três.

No espaço do real existem configurações já estabelecidas. A rua já está povoada antes da chegada de diferentes modalidades artísticas e nela existem representações, códigos, sinais, que não podem ser negligenciados. Quando o artista opta por instaurar uma ação no espaço público com a intenção de se fazer visível, como acontece no teatro de rua por exemplo, já existem convenções estabelecidas. Forma-se um círculo, integra-se os espectadores passantes, anunciando o evento que deverá acontecer. Os artistas do teatro de rua se valem de uma série de artifícios (re)conhecidos por todos. Há uma estética difundida, capaz de provocar nos passantes uma leitura imediata: trata-se de uma peça de teatro. No entanto, quando a ação não está claramente anunciada e, muitas vezes, se perde em meio aos acontecimentos cotidianos, ela se torna uma turbulência. Este é o caso das performances e intervenções urbanas que, como já mencionei, tomam a cidade de assalto. Desse modo, os performers têm que estabelecer outras convenções sociais, inventando outros regimes de atenção, cientes de que se trata da mesma cidade, que dispõem das mesmas relações de poder e das mesmas organizações sociais e legais. 

atuando na sombra, ele produz uma outra dimensão para o acontecimento, sobretudo se levarmos em consideração o objetivo final do artista. Não se sabe exatamente como, Francis Alÿs convence os policiais a figurarem na refilmagem de sua ação, como se estivessem realmente participando de uma vigorosa intervenção na vida real. Ele não propôs, no entanto, nenhuma alteração na performance dos policiais e nem alterou em nada a sua ação. Depois de sua primeira detenção, portanto, Francis Alÿs reperforma a própria performance, sendo novamente registrado pela câmera de Rafael Ortega e contando desta vez com a ajuda dos policiais.

Nesse caso, o potencial pedagógico da ação está na sua reperformance, acompanhada dessa refilmagem. Se ela não fosse filmada e refilmada não chegaria ao conhecimento do público. Uma performance praticamente invisível aos olhos da cidade ganha uma proporção mundial ao ser difundida pela internet, onde também se revela o dispositivo criado pelo artista: criar um remake da ação, usando os policiais que o abordaram como performers. Não se trata apenas de sua documentação por meio de outra materialidade artística, mas de uma crítica à fabricação explícita de documentação na arte da ação. $\mathrm{O}$ artista, dessa forma, joga com a máxima de Hegel na qual afirma que os grandes acontecimentos da história acontecem duas vezes. Não que se trate de um grande acontecimento, nem que da primeira vez ele tenha ocorrido como tragédia. Antes disso, trata-se de um ato de desobediência civil, de teste de limites. Entretanto, sua reperformance ocorre como farsa.

A performance em pauta se configura como uma caminhada provocativa que revela como a realização de uma ação relativamente simples, calcada no ato de caminhar pela cidade, pode provocar choque. Trata-se de um testemunho, que segundo Thierry Davila, pretende colocar em questão o sistema policial mexicano, demonstrando o quanto é fácil portar uma arma no México, em plena luz do dia e sem ser punido. É possível questionar como Alÿs conseguiu convencer os policiais a participarem dessa reconstituição e por que eles aceitaram atuar como se fossem atores. Seria um simples desejo de jogar, de se colocar em situação? Seria o fascínio exercido pela câmera? Francis Alÿs, por meio da caminhada armada, coloca em discussão o estado dos lugares, revelando a (des)ordem urbana e suas falhas. Segundo o performer: "A cidade é um espaço favorável a todos os tipos de encontros possíveis, ela é propícia ao acidente. Aquele que passeia pelas ruas é alguém que está fora de qualquer controle, alguém que pode, a qualquer momento, explodir". ${ }^{52}$

Desse modo, cabe ao artista decidir o seu nível de engajamento e de interferência na paisagem urbana, qual o tipo de experiência pretende ter e proporcionar, assim como, as ques-

\footnotetext{
${ }_{52}$ La ville est un espace favorable à toutes sortes de rencontres possibles, elle est propice à l'accident. Celui qui se promène dans la rue est quelqu'un hors de tout contrôle, quelqu'un qui peut, à n'importe quel moment, exploser (tradução minha). Entrevista realizada por David Torres: Francis Allÿs. Simple passant, Art Press, n. 263, dez. 2000, p.20.
} 
tões que deseja colocar em circulação. De modo paralelo, cabe também ao espectador reforçar o tipo de ação que ele alimenta, o que ele autoriza com seu olhar e o que ele se dispõe a viver como experiência. É notável nesse primeiro capítulo, o movimento da cena contemporânea em direção ao real, caminho que promove, em diferentes medidas e de maneira não definitiva, a dissolução de seus elementos constitutivos e a transformação de seus estatutos. Os efeitos, que tal dissolução promove, abrem um vasto campo de investigação sobre os novos paradigmas oferecidos ao espectador, que pode ser considerado o "outro" do artista. À medida que a arte pode ser observada como construção de situação, da qual se participa diretamente como experiência ou virtualmente pelo acesso aos seus vestígios, a arte se configura a partir de outros modos de operar e usar. As noções de aqui e agora são deslocadas, assim como as de presença e ausência, expandido a noção de jogo e borrando ainda mais as fronteiras entre arte e vida. 


\title{
> capítulo dois: o ato de flanar no contexto urbano
}

\author{
$O$ artista e o homem do mundo. \\ (para Baudelaire) \\ A multidão é meu universo. \\ Fixar residência no numeroso, no ondulante, no movimento, \\ no fugidio e no infinito. \\ Estar fora de casa e sentir-se em casa. \\ Estar no centro de São Paulo e permanecer oculto ao mundo. \\ Observar e estar incógnito.
}

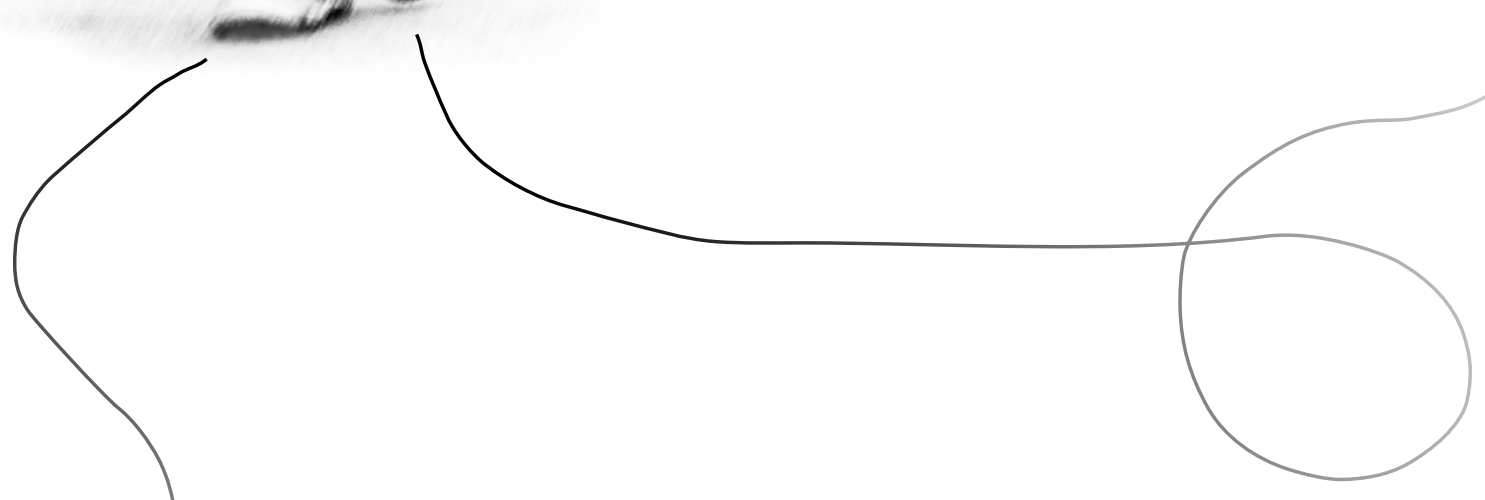

[nota sobre o capítulo: o presente capítulo apresentará a inserção do caminhar dentro da história da arte, a partir de estudo realizado pelo historiador Thierry Davila. Inicialmente, proponho uma diferenciação entre andar e caminhar e, em seguida, aproximo esta ação do pensamento e da criação. Por fim, a figura do flâneur será evocada como paradigmática da inserção do caminhar dentre as práticas estéticas. Tal estudo introduzirá a primeira modalidade que servirá de referência para a análise de ações artísticas fundadas sobre o caminhar: o passeio. Optei por este termo por considerá-lo similar ao flanar, porém mais usual na língua portuguesa.] 
"Caminhar é talvez - mitologicamenteo gesto mais trivial, portanto o mais humano" Roland Barthes

Caminhar é uma ação primária, embora não possa ser considerada uma ação simples, nem fácil. Caminhar envolve quase todos os músculos do corpo e só é possível caminhar quando conseguimos sustentar o peso da cabeça. Diz-se que o homo sapiens aprendeu a erguer a cabeça por necessidade de observar a paisagem. Do ponto de vista do olhar, os humanos se tornaram humanos na medida em que se permitiram enxergar mais longe. Entre os doze e dezoito meses de vida, os filhotes humanos aprendem a andar e essa ação é tão esperada quanto a aprendizagem da fala. Aprender a andar é uma conquista, uma forma de desvendar o mundo, de ir ao encontro, de explorar territórios, de ultrapassar obstáculos e de demonstrar interesse.

\begin{abstract}
A história corporal do caminhar é aquela da evolução do bípede humano e de sua anatomia. Caminha-se o mais frequentemente por razões puramente práticas, utilizando sem nem mesmo pensar nisso esse modo de locomoção para ir de um ponto a outro (SOLNIT, 2002, p.9) ${ }^{1}$.
\end{abstract}

A condição do homem como sujeito/corpo móvel é reconhecida desde sua aparição na Terra e acompanha toda a história da humanidade. Foi o desejo de deslocamento do homem que o levou a mover-se sobre rodas e alimentou sua aspiração por voar. Não se trata simplesmente de ir mais rápido, mas de percorrer territórios de outros modos, explorando outros pontos de vista. Marshall McLuhan, o teórico canadense que vislumbrou o que seria a internet trinta anos antes de sua invenção, considerava rodas, asas e máquinas como extensões do corpo humano. As rodas seriam extensões das pernas e as asas, extensões dos braços. As máquinas, as extensões do cérebro, da mente.

Nesse cenário de desejos de mobilidade, ao qual se acrescenta o impulso pela velocidade e a busca pelo aproveitamento do tempo, a espécie humana tornou-se gradativamente uma sociedade de homens sentados. Os modos de vida mais frequentes nas sociedades ocidentais contemporâneas convocam as pessoas a permanecerem sentadas. Sentados estudamos, escrevemos, trabalhamos, somos levados em diferentes meios de transporte; sentados nos divertimos, comemos, bebemos e nos comunicamos; se antes assistíamos televisão e ouvíamos rádio sentados, hoje navegamos na internet, respondemos e-mails, fazemos posts, vemos vídeos, fotos e consultamos todas as nossas dúvidas majoritariamente sentados. O celular tornou-se o objeto que concentra em si funções anteriormente atri-

\footnotetext{
${ }_{1}$ L'histoire corporelle de la marche est celle de l'évolution du bipède humain et de son anatomie. On marche le plus souvent pour des raisons purement pratiques, en utilisant sans même y penser ce mode de locomotion pour aller d'un point à un autre (tradução minha).
} 
buídas a outros aparelhos. Ele é telefone, internet, agenda, calendário, relógio, calculadora, máquina de fotografar e filmar, mapa de diferentes cidades do mundo, gravador de voz e aparelho de som. O mais curioso de tudo isso é que o celular é móvel e, com seu uso, nosso corpo torna-se cada vez mais sedentário. Algumas vezes nos arriscamos a nos deslocar junto com o celular e promovemos uma caminhada totalmente desconectada do corpo. A cabeça pende para frente, como um corpo que não consegue sustentar seu peso; os pés tateiam o chão e tropeçam com frequência; a coluna aprende a existir num eixo que já não pode mais ser considerado vertical.

Antes de associar o caminhar ao pensamento e à criação, gostaria de diferenciar o andar do caminhar. Trata-se de uma sutileza, de um apontamento para justificar o uso prioritário da palavra caminhar, mesmo sabendo que esta aparece como sinônima de andar no Dicionário Houaiss da Língua Portuguesa. Andar é uma atividade física, que permite que nos desloquemos de um ponto a outro. Esse verbo é utilizado quando pretende-se falar dessa ação de modo mais específico, do seu caráter fisiológico e anatômico. Andar é funcional: andar e parar, andar apressadamente, ir e voltar de algum lugar; caminhar inclui o caminho no ato de andar, devolve uma atenção ao corpo e considera o trajeto percorrido. Quando se refere à prática do andar como esporte ou dos seus benefícios, fala-se em caminhada. Tal prática é recomendada por promover bem estar, devolver a atenção e a vivacidade ao corpo e garantir o bom funcionamento das articulações, da circulação, da digestão e da respiração. Um exercício possível de ser realizado nos mais diversos espaços públicos, por pessoas de todas as idades. Trata-se de um ato não apenas cotidiano, mas ordinário.

As caminhadas diferem caso sejam realizadas sozinhas ou acompanhadas, em meio urbano ou rural, de acordo com as distâncias, o tipo de percurso, o tempo, o hábito, a repetição ou a exploração de diferentes rotas. Podem ser associadas ao autoconhecimento, ao turismo, à exploração de novos territórios e à arte. Caminhar é uma atividade ambígua e infinitamente fértil, da qual decorrem múltiplos fins e muitas vezes essas finalidades se entrecruzam e se contaminam. Esses múltiplos formatos do caminhar inspiram artistas e usuários das cidades, que se propõem a se deslocar pelas ruas a pé fazendo do ato de caminhar não apenas um ato, mas um objetivo, um desenho e uma experiência.

Caminhar é se dar a ocasião de estar na vertical de si mesmo [...]. A solidão da caminhada é inicialmente uma liberação do inferno dos outros. Tentar então se encontrar, pelo cuidado de si, como diziam os Antigos. Ao longo de todo o dia, ao contrário, estamos atarefados, ocupados, no sentido em que se diz que ocupamos um espaço: preenchidos, saturados, invadidos. São solicitações permanentes, atrasos que se acumulam, trabalhos que se encadeiam. Caminhamos então para encontrar nossa própria companhia, sentir-se viver um pouco, em vez de ser levado por uma torrente de tarefas. Não é, portanto, enfim só, mas 'enfim comigo 
mesmo'. (GROS, 2011, pp. 15 e 16) ${ }^{2}$.

A caminhada vista no sentido que Frédéric Gros Ihe atribui tem um caráter não apenas filosófico, mas também revela um posicionamento diante da vida. A opção pelo caminhar denota um cuidado consigo mesmo e uma espécie de meditação, pois ao adotar tal ação cotidianamente, o sujeito recusa a aceleração do tempo e coloca suas ideias no lugar. Seu texto aproxima o andar, comumente associado ao espaço, à esfera do tempo, assunto que será tratado quando abordarmos a figura do flâneur. Em suas pesquisas sobre os deslocamentos a pé pela cidade, Michel de Certeau opõe a figura do pedestre à visão panorâmica da cidade, dissecada por Foucault ao estudar as organizações espaciais e o olho do poder ${ }^{3}$. O homem em sua conjuntura mais baixa, mais próxima do chão, mais enlaçada e embaraçada com a cidade é o caminhante.

Mas "embaixo"(down), a partir dos limites onde cessa a visibilidade, vivem os praticantes ordinários da cidade. Forma elementar dessa experiência, eles são caminhantes, pedestres, Wandersmänner, cujo corpo obedece aos cheios e vazios de um "texto" urbano que escrevem sem poder lê-lo. Esses praticantes jogam com espaços que não se veem; têm dele um conhecimento tão cego como no corpo a corpo amoroso. Os caminhos que se respondem nesse entrelaçamento, poesias ignoradas de que cada corpo é um elemento assinado por muitos outros, escapam à legibilidade. Tudo se passa como se uma espécie de cegueira caracterizasse as práticas organizadoras da cidade habitada. As redes dessas escrituras avançando e entrecruzando-se compõem uma história múltipla, sem autor nem espectador, formada em fragmentos de trajetórias e em alterações de espaços: com relação às representações, ela permanece cotidianamente, indefinidamente outra (CERTEAU, 2014, p. 159).

O autor retoma em seus estudos a história da perspectiva nas pinturas medievais e renascentistas como uma utopia de um olho totalizador. Para ele, a invenção da visão do alto da cidade é contemporânea da ideia de panorama. Certeau inicia seu texto sobre as caminhadas pela cidade evocando a experiência de observar Nova York do alto do World Trade Center $^{4}$ e questionando-se de onde vem o prazer de observar a totalidade, de colocar o corpo fora das ruas e de assumir a posição de um voyeur. A posição privilegiada desse olho divino

2 Marcher, c'est se donner l'occasion d'être à la verticale de soi [...]. La solitude de la marche, c'est d'abord une libération de l'enfer des autres. Tenter alors de se retrouver, par 'souci de soi', comme disaient les Anciens. Toute la journée, autrement, nous sommes affairés, occupés, mais au sens où on dit qu'on 'occupe' un espace : remplis, saturés, envahis. Ce sont des sollicitations permanentes, des retards qui s'accumulent, des travaux qui s'enchaînent. On marche alors pour retrouver sa propre compagnie, se sentir vivre un peu, plutôt qu'emporté perpétuellement par un torrent de tâches. Non pas donc : enfin seul, mais plutôt 'enfin avec moi-même'. (tradução minha).

3 Foucault estudou o panóptico, um protótipo arquitetônico criado em 1791 como espaço de vigilância e gestão da produção industrial (e não penitenciária, no princípio), que se converte em modelo diafragmático do biopoder, pois permite ao pesquisador pensar a organização espacial e visual da relação entre corpo e poder na modernidade.

${ }^{4}$ É importante ressaltar que sua publicação na língua original data de 1990, onze anos antes da queda das torres gêmeas. 
permite uma leitura da cidade como se ela fosse um texto e assim, o autor associa a visão panorâmica da cidade à ficção do saber. Para ele, "a vontade de ver a cidade precedeu os meios de satisfazê-la" (Ibid., p.158).

Com base nos estudos de Certeau, pode-se constatar que as práticas artísticas fundadas no ato de caminhar pela cidade são profundamente vinculadas e muitas vezes confundidas com o cotidiano. Desse modo, elas se constituem muitas vezes como ações anônimas, que podem ser realizadas por qualquer pessoa, enquanto são observadas por uma coralidade espectadora. Ou seja, o conjunto de pessoas que as observa é tão vasto e múltiplo que pode ser considerado indefinível, inapreensível e quase inteiramente ocasional (esse assunto será desenvolvido no capítulo quatro). A partir do momento em que tais ações não são anunciadas como eventos artísticos, para muitos elas podem nem mesmo estar acontecendo, pois a maioria dos passantes nem chega a se dar conta de sua existência. Poucos notam que há algo fora do lugar, que há um comportamento fora do comum ou uma mudança brusca de fluxo.

Quando voltei a observar meu corpo, já cursando Artes Cênicas, reaprendi a andar ao estudar a técnica Klauss vianna. Fazíamos quatro dias de treinamento semanais, com o intuito de preparar os corpos para o exercício da atuação. Mais do que fazer de mim uma atriz, esse tempo de treinamento acordou meu corpo, me colocou em situação, revendo escolhas e situando-me no espaço-tempo: a cidade de São Paulo.

Não queria falar dos quilômetros que andei em todo esse tempo de treinamento. Não só andei, como desdobrei o andar. A prática da caminhada lentissima, na qual apoiávamos o calcanhar e ímos aos poucos transferindo o peso do corpo de um pé para o outro reconfigurou, para mim, o ato de andar. Aprendi a andar com todo o corpo depois de observar, tocar e experimentar os pés em todas as posições possiveis. Também entendi que não é a perna que dá o primeiro passo a que nos leva, mas a que permanece atrás impulsionando o peso de todo o corpo para frente.

Talvez eu não tenha percebido o quanto me aproximei do caminhar até que uma turma de alunos da Universidade de Sorocaba questionou o porquê de caminhar tanto nas aulas de corpo que eu ministrava. Por influência do namorado da época, passei a ir para a universidade caminhando. Percebemos que levávamos o mesmo tempo de ônibus, que levávamos a pé. Gastava por volta de 40 minutos para ir andando da minha casa até a USP. ESSa experiência mudou de finitivamente minha relação com a cidade. Eu entendi o posicionamento da minha casa em relação à Universidade, me senti potente e autônoma ao percorrer essa distância com minhas próprias pernas. Eram quatro quilômetros que me acordavam, que me deixavam atenta ao meu corpo e à minha cidade. Eu vi o rio de perto e mais de uma vez reparei no quanto São Paulo se constrói as margens e de costas para os seus rios. 


\section{> II. caminhar, pensar}

No século XIX, o poeta Arthur Rimbaud considerava os filósofos e intelectuais como animais de biblioteca e os chamava de "os sentados"5. Dentre esses autores sentados, no entanto, muitos fizeram do ato de caminhar seu objeto de estudo, associando essa prática ao pensamento, à solidão e ao cuidado de si, à ecologia e à mobilidade urbana, aos atos de fé e às intenções religiosas. Frédéric Gros busca com seus estudos aproximar a filosofia do caminhar a pé, tornando indissociável uma relação que não parece evidente. Em sua Petite Bibliothèque du marcheur [Pequena Biblioteca do caminhante], o autor discorre sobre três filósofos caminhantes - Jean-Jacques Rousseau, Henry David Thoreau e Friedrich Nietzsche. Para Rousseau, a experiência de longas caminhadas vem de sua infância, em viagens que realizou pela Itália e pela França, nas quais caminhava em regiões rurais e sentia a força da natureza o atravessando. Por esse motivo, apreciava as caminhadas solitárias e próximas da natureza, onde podia se liberar dos papéis e máscaras sociais. "Eu só posso meditar caminhando; assim que paro, não penso mais, e a minha cabeça só vai com os meus pés" (ROUSSEAU apud SOLNIT, 2002, p. 25) Caminhar para Thoreau era equivalente a realizar um rito, um exercício reflexivo e cotidiano, com o qual dispendia algumas horas diariamente. Ele caminhava em média 4 horas por dia, às vezes mais. Um programa de exercícios que se impunha como uma maneira de construir-se a si mesmo.

Caminhar consistia, portanto, em um exercício espiritual completo, equivalente ao ato de rezar para um religioso. Foi Thoreau quem escreveu o primeiro manifesto filosófico sobre a caminhada a pé (Walking - Andar a pé - de 1862), considerado por ele sua obra inaugural. Foi ele "também [quem] escreveu o primeiro livro sobre a desobediência civil. É verdade que a caminhada nos ensina a desobedecer. Porque andar nos obriga a ter uma distância que é também uma distância crítica"7. Nietzsche, por sua vez, também caminhava muitas horas por dia e anotava, em seus cadernos, os pensamentos que lhe ocorriam. Na caminhada, a relação entre o corpo e a paisagem não se limita à imagem composta, à representação. Não havia para ele uma contemplação da paisagem, Nietzsche se impregnava dela, estabelecendo uma relação mais imersiva com o ambiente.

Mas o andar de que falo eu, nada tem que ver com exercício, nem a isso se destina; não é como o remédio que os doentes tomam a determinadas horas, nem como os halteres para o desenvolvimento muscular. É antes o motivo e a aventu-

\footnotetext{
5 GROS, Frédéric. Petite bibliothèque du marcheur. Paris: Flammarion, 2011.

${ }^{6}$ Je ne puis méditer qu'en marchant; sitôt que je m'arrête, je ne pense plus, et ma tête ne va qu'avec mes pieds (tradução minha).

7 Em entrevista concedida pelo autor à imprensa brasileira, na ocasião do lançamento de seu livro "Caminhar, uma filosofia" (Ed. Realizações, 2010), no qual faz a seguinte provocação aos pensadores: "você não é o que você pensa, mas como você anda". Entrevista disponível em: http://saopaulosao.com.br/nossoscaminhos/670-andar-nos-ensina-a-desobedecer-diz-fil\%C3\%B3sofo-franc\%C3\%AAs.html, acesso: 20 Out. 2016.
} 
ra do dia. Se quiserdes exercícios, procurai as fontes da vida. Imaginai um homem levantando halteres para cultivar a saúde, quando as fontes dela estão borbuIhando nos prados longínquos desprezados por ele! Sobretudo, deveis caminhar como um camelo o qual, ao que sabemos, é o único animal capaz de ruminar em marcha. Quando um viajante pediu à criada de Wordsworth para mostrar-lhe os estudos do amo, ela retrucou: "Eis aqui sua biblioteca, mas os estudos, ele os faz na rua."(THOREAU, 2003, p. 9).

Há estudos na área da sociologia, da arquitetura e do urbanismo, da antropologia urbana, da literatura e da história da arte que investigam a prática da caminhada e os sentidos atribuídos a ela em diferentes contextos. É nesse sentido que Frédéric Gros apresenta diferentes categorias do caminhar relacionadas à produção literária de uma gama de poetas e escritores, para os quais o caminhar como um exercício físico e o relato sobre o caminhar se confundem. Em 1833, Honoré de Balzac escreve: "Mostre-me como você anda e eu te direi quem és", é esse o desafio que tenta revelar em sua "Teoria da caminhada"" (GROS, 2011, p.32) ${ }^{8}$. Enquanto isso, Jacques Lanzmann interroga ao caminhante o que ele carrega, pois assim será possível desvendar quem ele é - um reflexo fiel de nossas preocupações e nossas obsessões - e tece, a partir dessa premissa, um elogio à mochila, objeto que remonta ao início do século XX. Jacques Lacarrière, por sua vez, percorreu mil quilômetros a pé pelas estradas da França e coube a ele escrever um elogio aos pés, aos quais tudo acontece e sem os quais nada seria possível. David Le Breton, que também escreveu um elogio ao caminhar, afirma que "o caminhar reduz a imensidão do mundo às proporções do corpo" (Ibid., p. 281) ${ }^{9}$

O caminhar está sempre associado à reflexão; caminhar suscita pensamentos, é o que afirma Rebecca Solnit em seu ensaio sobre a caminhada a pé. Segundo ela, a história do caminhar em suas dimensões histórica, cultural e política traduziria a própria história do pensamento. Autora que também figura na pequena biblioteca do caminhante, escreveu " $A$ History of Walking" $(2000)^{10}$, um ensaio sobre o ato de caminhar a pé, a cinco quilômetros por hora, no qual ela revela como a caminhada está associada ao pensamento. Segundo ela, numa cultura orientada para a produção, pensar é visto como nada fazer. Então, o melhor meio de não fazer nada é disfarçando-o com o caminhar, que é a atividade mais próxima do nada fazer. Nesse sentido, a caminhada se apresenta como detonadora de pensamentos e, ao mesmo tempo, como um disfarce para não se fazer nada. Talvez por isso ela provoque e perturbe a ordem estabelecida.

Nesse sentido, o caminhar deve ser entendido como uma ação possível a todos, uma ação que se desenrola não só no espaço, como no tempo. Solnit discorre também sobre o ato de

\footnotetext{
8 Montre-moi comment tu marches et je te dirai qui tu es", c'est un peu ce défi que tente de relever Balzac dans $s a$ "Théorie de la démarche" (tradução minha).

9 La marche réduit l'immensité du monde aux proportions du corps (tradução minha).

${ }^{10}$ Tive acesso à versão francesa desse livro, intitulada L'art de marcher (Actes Sud, 2002).
} 
caminhar em conjunto e afirma que nesses casos, o caminhar se torna um meio de testemunhar. Essa pré-disposição para estar junto, em estado de fruição e de errância, ocupando o espaço público tem um caráter de provocação. Uma provocação da ordem estabelecida. Essa experiência perturba aquilo que Ardenne descreveu como o "que a ordem das coisas controla, por tradição, preguiça ou estratégia, para não mudar" (ARDENNE, 2009, p. 43) ${ }^{11}$.

\section{> III. caminhar, criar}

Todo leitor do ensaio de Thoreau, "Andar a pé", sabe que colocar um pé diante
do outro leva inevitavelmente a abordar os temas mais diversos. A caminhada é
um tema vagabundo por excelência.
Rebecca Solnit

Na História da Arte, a figura do homem em deslocamento pode ser considerada um tema. Para o historiador da arte Thierry Davila, a arte ocidental foi afetada pela representação do homem que caminha ${ }^{12}$. Segundo ele, a aparição de figuras humanas em deslocamento em um afresco de 1425 é contemporânea do nascimento da Renascença Florentina e, desde então, a história do caminhar passa a ser inscrita na história das imagens. Para Davila, a representação do deslocamento de Adão e Eva sendo expulsos do paraíso nessa pintura criou um efeito de realidade que faz com que não se veja a imagem da 'coisa', mas a 'coisa' em si. O corpo que caminha inaugura um novo estilo pictural, uma vez que o modo de se representar o corpo humano em deslocamento modificou-se. Os pés humanos, sobretudo, deixam de ser pintados em uma posição plantar e passam a ser representados com seus metatarsos empurrando o chão. Há uma busca por capturar a transferência do peso, de um pé para o outro. Esses corpos não estão fixos, estão de passagem; são capturados em movimento, o que revela certa vulnerabilidade. Tratam-se de corpos instáveis, móveis, em busca ou em trânsito.

O historiador da arte, ao mapear a aparição do homem que caminha, passa por inúmeras pinturas, esculturas e chega até a cronofotografia, no final do século XIX (uma sequência cronológica de fotografias, anterior ao cinema, que pode ser considerada como uma forma de inscrever o tempo nas imagens). Ele pontua que o tema do deslocamento levou peregrinos, judeus e artistas a serem representados - esses últimos na forma de autorretratos - como andarilhos, inserindo definitivamente a história da caminhada como um tema para a história da arte. Essas primeiras tentativas de representar o caminhar simbolizam os primeiros passos da arte em direção ao real. Do mesmo modo, Raymond Williams, especialista em história da literatura constata que: “Desde o início, a percepção das novas qualidades

\footnotetext{
${ }_{11}$ [...] ce que l'ordre des choses commande, par tradition, paresse ou stratégie, de ne pas bousculer (tradução minha).

${ }^{12} \mathrm{Na}$ conferência "Le flâneur est indestructible" [0 flâneur é indestrutível], realizada no Ciclo de estudos sobre a Caminhada, organizado pela École Spéciale d'Architecture, em Paris, no dia 24 out. 2013. <http://www. esa-paris.fr/Conference-Le-flaneur-est-2057.html?lang=fr>. Acesso em: 01 ago. 2016.
} 
Figura 1: Giacometti - L'homme qui marche

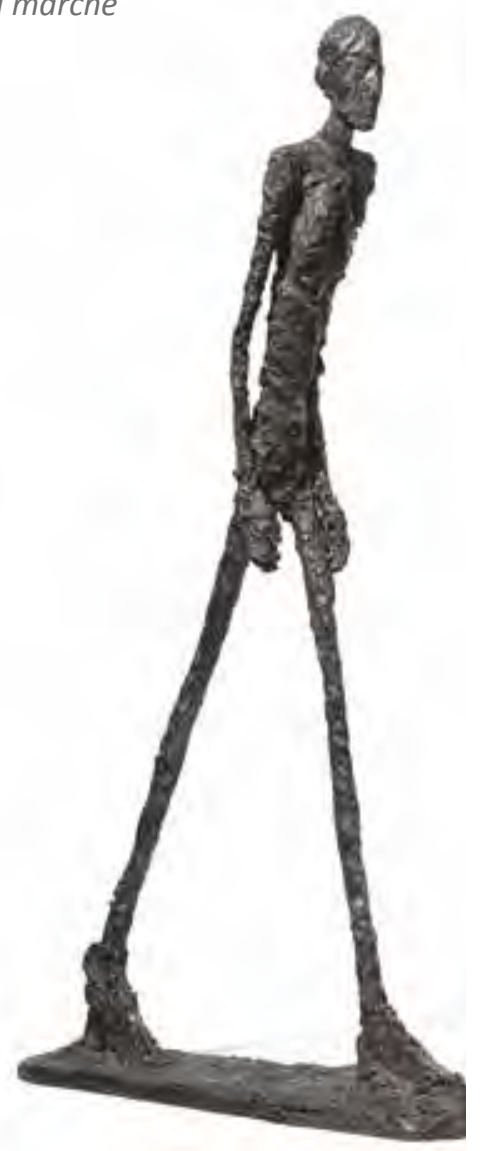

Foto: Disponível em: <http://artenarede. com.br/blog/index.php/tag/giacometti/>. Acesso em: 01 ago. 2016. da vida moderna foi associada a um homem que caminha nessas ruas como se estivesse só" (WILLIAMS apud SOLNIT, 2002, p. 244) $)^{13}$.

É igualmente importante destacar o momento no qual o ato de caminhar salta da representação na tela e passa a figurar como ação física, fenomenológica e processual. Thierry Davila elege, portanto, algumas obras marcantes para mostrar essa passagem da representação para a ação. Uma delas é L'homme qui marche [O homem que caminha] de Alberto Giacometti criada em 1947. Trata-se de uma figura desencarnada, frágil, longilínea e determinada no seu passo. Um homem que não foi destruído por um século terrível, que ainda guarda alguma esperança e caminha em direção ao seu destino. Embora não haja a intenção, da parte de Giacometti, de representar um homem real em deslocamento, suas dimensões se aproximam das reais dimensões de um homem. Apesar de ter a altura de um homem, a escultura apenas sugere um homem, criando uma presença supostamente humana. Há nela uma determinação desmedida, o que causa a impressão de que ela caminha sem olhar para os lados. Se ela de fato pudesse ver, poderia facilmente deixar de notar alguém que passasse ao seu lado. Os personagens de Giacometti habitam num espaço do não-encontro, o que diz muito sobre a solidão do homem do século XX. É interessante destacar que esse artista considerava todo homem de pé, antes de tudo, como um homem em deslocamento.

Jean Genet em seu livro sobre o atelier de Giacometti diz ao escultor: "uma de suas estátuas em um quarto, e o quarto é um templo" (GENET, 1995, s.p.) ${ }^{14}$. Para ele, essas esculturas criam ambiências. Busquei a foto do homem que caminha nesse livro sobre seu atelier, certa de que a encontraria em uma paisagem urbana, como muitos dos registros das esculturas de Giacometti. Ele as posicionava na rua para fotografá-las. Mas não, ela aparece apenas parcialmente em uma das fotos, capturada enquanto o escultor a realizava, dentro do atelier. Como seu corpo aparece cortado pelo enquadramento da foto, a impressão de movimento impregnada na escultura é tamanha, que tem-se a sensação de que ela está de

\footnotetext{
${ }^{13}$ Dès le départ, la perception des nouvelles qualités de la ville moderne fut associée à un homme qui marche dans ses rues comme s'il y était seul (tradução minha).

${ }^{14}$ [...] une de vos statues dans une chambre, et la chambre est un temple (tradução minha).
} 
partida. Mesmo estática, ela parece estar de passagem, ela encara o espaço fora e almeja ganhar a rua, para transformar o espaço transitório da rua em templo.

Thierry Davila também associa o universo da mitologia pessoal do alemão Joseph Beuys à passagem da representação para a ação de caminhar, pois o performer caminha pela cidade como um médico da civilização. Ativista convicto, o artista inscreve a frase "a revolução somos nós" em uma fotografia que o retrata caminhando em direção à câmera. A frase associada à imagem enfatiza o ato de caminhar como ato plural, coletivo, relacionado a

Figura 2: Alberto Giacometti em seu ateliê esculpindo L'homme qui marche

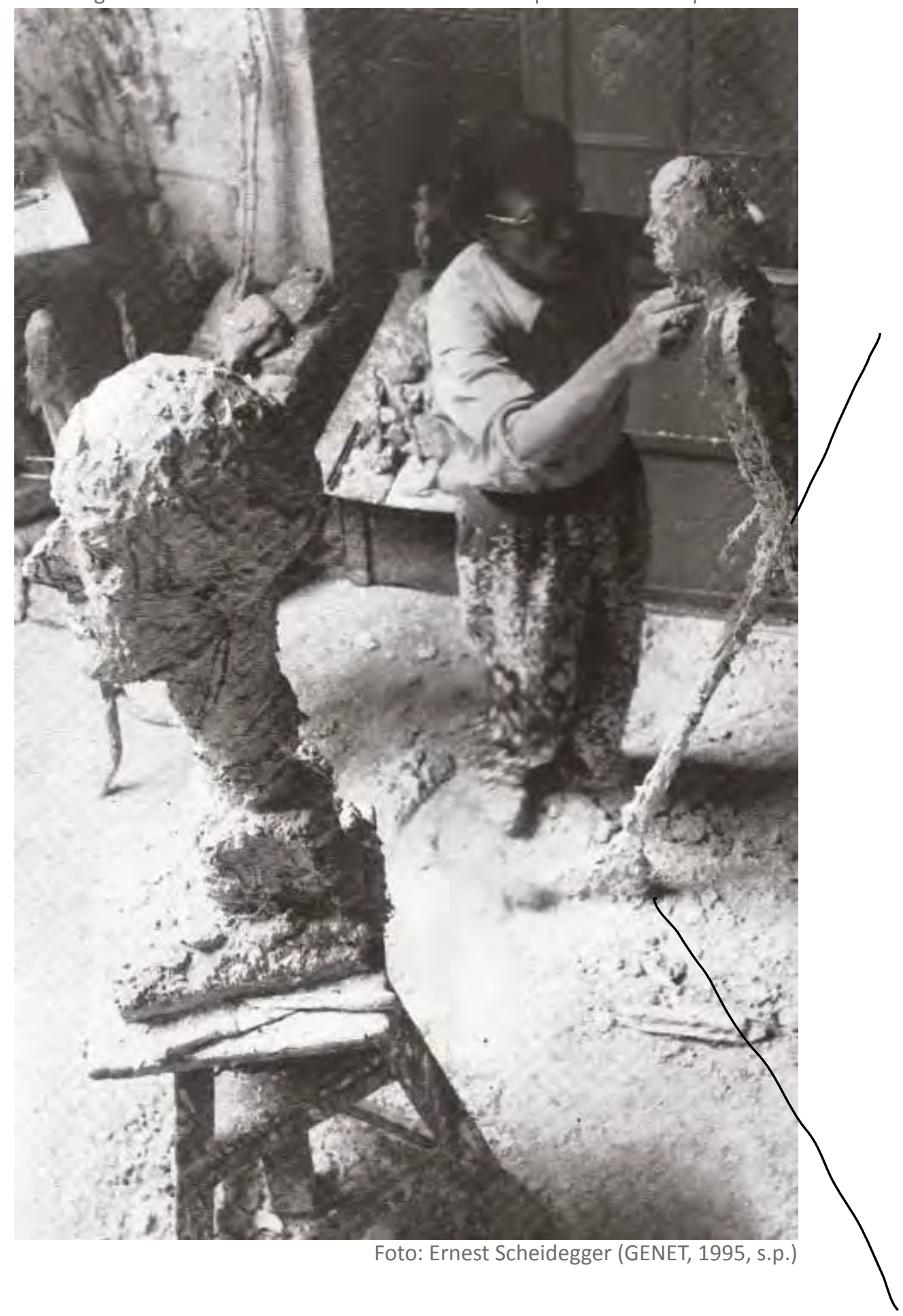


uma comunhão na sociedade. Ao afirmar, caminhando, que somos todos a revolução, ele convoca a todos para fazerem a revolução. Beuys afirma igualmente que "todo homem é um artista", não só democratizando a ação artística, mas depondo contra a ideia de talento e de que os artistas seriam seres especiais, escolhidos, detentores de um dom divino. Com essas atitudes, ele desloca o foco do sujeito para o coletivo e também enfatiza o quanto a "marcha" está intrinsecamente ligada à ideia de revolução.

Figura 3: Joseph Beuys - A revolução somos nós

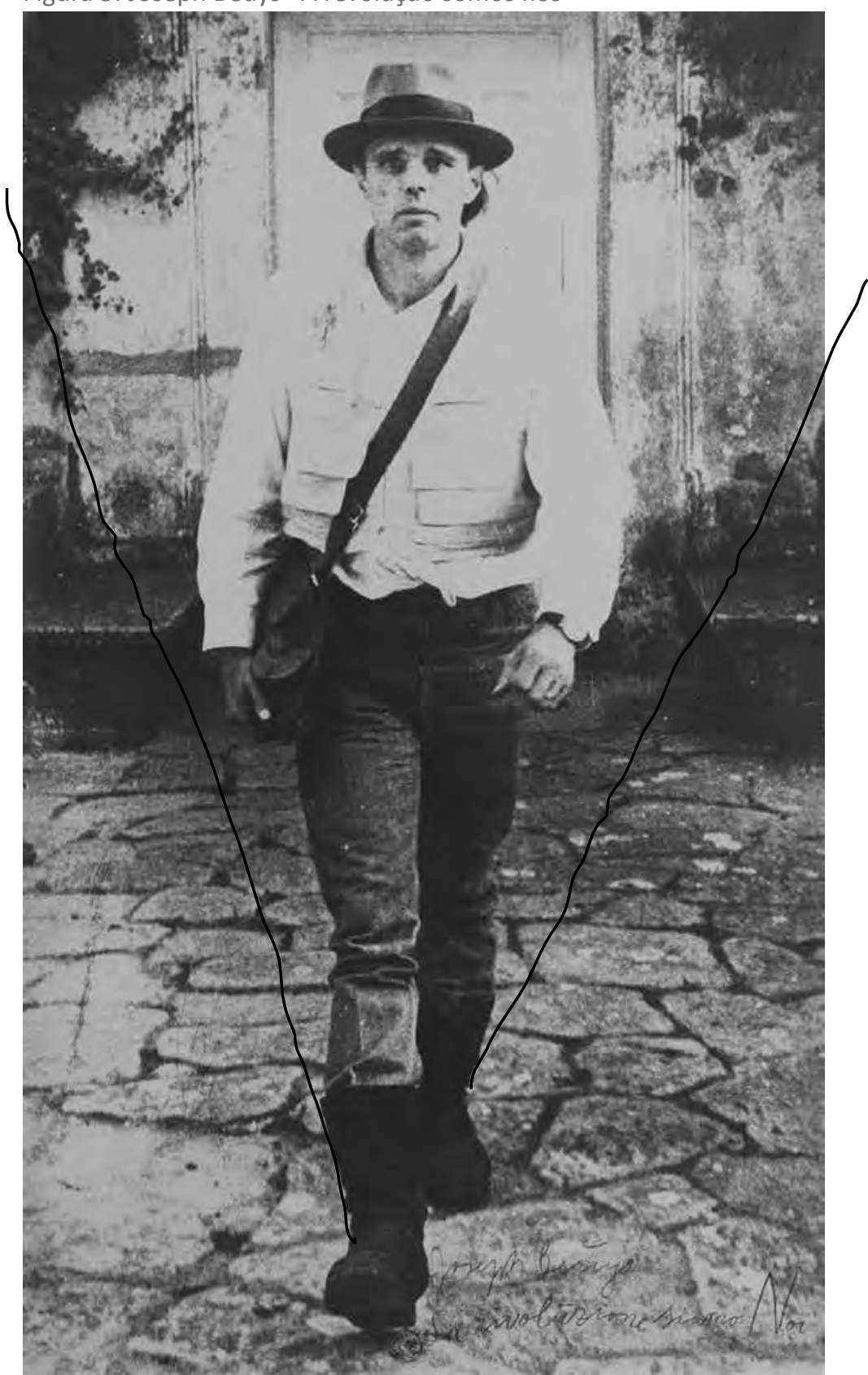

Foto: Disponível em: <http://www.tate.org.uk/art/images/work/AR/ AR01021_10.jpg>. Acesso em: 18 ago. 2016. 
[passeio]: caminhada despretensiosa, associada ao lazer. O trajeto de um passeio pode ser pré-definido ou não e pode ser realizado em território desconhecido, embora seja bastante recorrente nos espaços habitados, onde se vive cotidianamente. O tempo do passeio também é bastante variável, pode levar alguns minutos, um dia ou uma noite inteira. Associa-se ao flanar, à figura do flâneur ${ }^{15}$ e da flâneuse, bem como aos estudos de Charles Baudelaire e Walter Benjamin.

Passear é sair de casa, deslocar-se em espaço aberto, uma ruptura de ritmo, uma mudança de ambiente. É assim que Frédéric Gros aborda inicialmente o passeio, uma busca pelos espaços verdes da cidade, os jardins, os parques, a margem dos rios ou a praia (eu acrescentaria). Uma atividade que visa "tomar ar, escapar das paredes, sair de um quadro de trabalho, deixar a cadeira, sua condição sedentária, para esticar as pernas, sentir seu corpo, abrandar seu cansaço" (GROS, 2011, p. 9) ${ }^{16}$. No entanto, esse autor opõe ao passeio o flanar, que segundo ele, supõe prioritariamente a cidade, as ruas lotadas, as avenidas iluminadas e a observação das vitrines. Enquanto isso, aquele que passeia busca escapar dessa atmosfera cosmopolita em prol da tranquilidade da natureza, de modo que o passeio estaria associado a um tempo mais curto, a algumas horas de relaxamento, funcionando como um parêntese no meio do dia.

Experimentar o tempo também: caminhar é escolher a lentidão, é menosprezar a obsessão contemporânea pela velocidade e pelo desempenho. Faz-se um esforço para não estar mais apressado, para não ser mais escravo dos minutos. Querer caminhar é querer se dar tempo. A grande transformação está aqui: não se corre mais atrás do tempo, dá-se o tempo (GROS, 2011, p. 16) ${ }^{17}$.

Segundo Thierry Davila, a diferença entre um caminhante e um flâneur é que o primeiro simplesmente se desloca e o segundo leva o tempo consigo, se carrega de tempo. Desse modo, flanar se diferencia de passear e é comumente associado a uma ocupação aristocrata, que segundo Gros, não dependeria de possuir dinheiro, mas uma nobreza de espírito. "O luxo do flâneur é não fazer nada quando, em torno dele, todos se empenham, se aglomeram porque têm um compromisso importante, se apressam para não perder uma

${ }^{15}$ Optei por não traduzir essa palavra, por não encontrar um correlato em português. Trata-se de um andarilho do espaço urbano, cujas características serão devidamente esboçadas neste capítulo.

${ }^{16}$ [...] prendre d'air, échapper aux murs, s'extraire d'un cadre de travail, quitter sa chaise, sa condition de sédentaire, pour se dégourdir les jambes, sentir son corps, calmer sa lassitude (tradução minha).

17 [...] Goûter le temps aussi : marcher, c'est choisir la lenteur, c'est mépriser l'obsession contemporaine de la vitesse et de la performance. On met son point d'honneur à ne plus être pressé, à ne plus être l'esclave des minutes. Vouloir marcher, c'est vouloir se donner du temps. La grande transformation est là : on ne court plus après du temps, on se le donne (tradução minha). 
baldeação. A verdadeira nobreza do flâneur é seu tempo livre, tempo que não é portanto perdido" (GROS, 2011, p.11) ${ }^{18}$. Porém, o discurso em torno da nobreza do espírito recai insistentemente sobre a impossibilidade de um indivíduo comum sentir tal necessidade, como se para flanar fosse necessário dispor de certa condição social. Ao menos é o que pensa Karl Gottlob Schelle, um dos escritores apresentados na pequena biblioteca de Frédéric Gros, que escreveu um tratado sobre o passeio em 1802. Para ele, o passeio não é um simples movimento do corpo. Ele considera que para ser tocado pelo charme do passeio seria necessário ter um certo nível cultural, uma bagagem intelectual que não é dada a todos. E acrescenta que seria natural que um simples jornaleiro não sentisse o prazer agradável de um passeio, uma vez que ele figuraria na categoria de uma massa de indivíduos insensíveis, cujo espírito não foi tocado e por isso, executaria suas ações de maneira mecânica, enquanto as pessoas cultas engendrariam na mesma ação uma necessidade intelectual (Ibid., p. 70).

Obviamente, tanto um intelectual quanto um jornaleiro têm plenas condições de apreciar um passeio e é claro que a tarefa de entregar jornais não pode ser comparada à ação de passear. São qualidades distintas de caminhada, pois o esforço de carregar e de distribuir jornais, associados à obrigatoriedade do trabalho e à repetição do gesto e dos percursos não equivalem à um caminhar vinculado ao lazer. Independentemente de quem caminha, qualquer corpo pode apreciar o prazer de um passeio, bastaria, para tanto, inverter as atividades atribuídas a cada um desses personagens citados por Schelle para verificarmos que o passear não pode ser considerado uma categoria reservada apenas a pessoas de espírito elevado. Se um intelectual entregasse jornais ao longo de um dia inteiro, certamente ele também não encontraria disposição para sentir prazer em uma caminhada despretensiosa. Por esse motivo, optei por colocar o passeio e o flanar lado a lado no estudo dessa categoria, justamente para observar de modo crítico algumas abordagens que foram feitas a respeito desses modos de caminhar.

\section{_O flâneur e o Homem da Multidão}

De acordo com o historiador da arte Thierry Davila, se na Renascença a aparição dos corpos que caminham modificou o modo de representar a figura humana, na contemporaneidade - mais precisamente desde o final dos anos 80 - houve um retorno do flâneur na história da arte ocidental. A historiadora e socióloga Régine Robin considera alguns artistas caminhantes mais recentes como post-flâneurs. A ação diretamente relacionada ao flâneur, cujo

\footnotetext{
${ }_{18}$ Le luxe du flâneur, c'est de ne rien faire quand, autour de lui, tous s'affairent, se pressent parce qu'ils ont un rendez-vous important, se dépêchent pour ne pas rater une correspondance. La vraie richesse du flâneur, c'est son temps libre, temps qui n'est pas pour autant perdu (tradução minha).
} 
nome deriva do verbo correlato a ele, é flanar. Em português, flanar significa passear ociosamente, sem destino. Entendo, portanto, que nomear a presente categoria de passeios é um modo de expandir o sentido dessa categoria, não deixando-a restrita ao universo do flâneur, mesmo que essa figura seja a maior referência histórica para os artistas recentes que se utilizam da ideia de passeio para compor suas criações artísticas.

Desde o século XVIII, a cidade de Paris é percorrida e contada por diferentes autores que contribuíram para estreitar os laços entre a cidade e a literatura. Paola Berenstein Jacques elencou uma série de autores ${ }^{19}$ que escreveram sobre Paris e cuja literatura tem uma relação direta com o ato de percorrer essa cidade. De acordo com ela, a produção desses autores seria suficiente para não atribuir à Baudelaire a invenção da figura do flâneur e nem mesmo a originalidade do tema. A autora ainda afirma que a importância de Baudelaire entre os errantes urbanos reside na recriação dessa figura mítica (JACQUES, 2012, p. 41). Ela se refere também a uma publicação de 1941 intitulada Physiologie du flâneur [Fisiologia do flâneur], de Louis Huart, que atestaria a existência do flâneur como um tipo urbano duas décadas antes da obra de Baudelaire. Independente do ineditismo do tema, é Charles Baudelaire quem atrai a atenção para essa figura e faz o termo ganhar projeção na Paris do final do século XIX, com "O pintor da vida moderna" ${ }^{20}$. O autor o associa a uma mobilidade dupla: física e psíquica, alguém capaz de se deslocar e de observar, ao mesmo tempo, o que se passa ao seu redor. Ele pode ser caracterizado por uma imaginação ativa, impulsionada pelo ato de olhar. A fórmula foi desenvolvida por Baudelaire, a partir da observação de um ilustrador que admirava mas que não gostaria de perder seu anonimato. Por isso, Baudelaire se refere a ele usando apenas as iniciais do seu nome: M.G. Ele não gosta de ser chamado de artista.

M.G. inspirou a recriação da figura do flâneur. Ao mesmo tempo observador e filósofo, viajante e cosmopolita, não se trata de um artista, mas de um homem do mundo. $\mathrm{O}$ artista para Baudelaire é um especialista que se distingue do homem do mundo: "ele se interessa pelo mundo inteiro; ele quer saber, compreender, apreciar tudo o que acontece na superfície de nosso esferoide. $\mathrm{O}$ artista vive pouquíssimo - ou até não vive - no mundo moral e político" (BAUDELAIRE, 1997, p.17). O flâneur se caracteriza pela curiosidade aguçada, que

\footnotetext{
${ }_{19}$ São eles: Sébastien Mercier (Tableau de Paris, de 1781), Restif de Baronne (Les nuits de Paris ou le spectateur nocturne, de 1788), Honoré de Balzac (La fille aux yeux d'or ou La comédie humaine, de 1841), Victor Hugo (Notre Dame de Paris, de 1831 e Les Misérables, de 1862) e ainda Émile Zola (Le ventre de Paris de 1873) (JACQUES, 2012, p.41).

20 "Le peintre de la vie moderne", publicado em três partes distintas no jornal francês Le Figaro, entre os meses de novembro e dezembro de 1863. Texto original em francês disponível em: <http://disciplinas.stoa.usp.

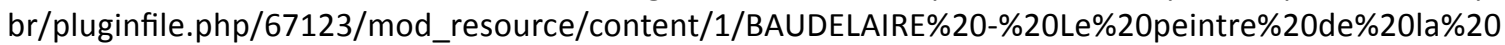
vie\%20moderne.pdf>. Acesso em: 9 ago. 2016. No Brasil, esse texto foi publicado na íntegra em uma edição de bolso da Coleção Leitura, da Ed. Paz e Terra, em 1997, com o título Sobre a Modernidade. Usaremos essa tradução em todas as citações.
} 
só poderia ser comparada com a curiosidade do narrador de $O$ homem da multidão ${ }^{21}$ ou das crianças. Esse narrador encontra-se em um café, observando os passantes através de uma vidraça. Trata-se de um homem convalescente que observa a multidão com prazer, deixando-se contaminar pelos pensamentos que se agitam em torno dele. Para Baudelaire, a convalescença desse homem funciona como um retorno à infância. O homem que se recupera de uma doença passa a se interessar vivamente pelas coisas, mesmo pelas mais triviais. "A curiosidade transformou-se numa paixão fatal, irreversível!" (Ibid. p. 17). Se por um lado, esse homem goza do mais alto grau dessa capacidade de se interessar pelas coisas, a criança está inebriada por tudo o que se encontra em sua volta, ela vê novidade em tudo. O flâneur de Baudelaire seria então um eterno convalescente, um homem-criança, um homem que não deixou de possuir esse atributo da infância, para quem nenhum aspecto da vida estaria neutralizado.

No auge de sua observação da multidão, o narrador do texto de Poe nota um homem que difere da massa, "uma fisionomia que inicialmente me paralisou e absorveu toda a minha atenção, por causa da absoluta idiossincrasia de sua expressão" (Poe, 2006, p. 104) ${ }^{22}$. Trata-se de um homem com seus 65 anos, que despertou no narrador imagens confusas e paradoxais de cautela e avareza, de triunfo e alegria, um terror excessivo, um desespero supremo. Era um andarilho pobre, um possível morador de rua, se por acaso essa figura fosse transposta para a atualidade. E é esse pobre demônio que o poeta inglês denomina como o homem da multidão, tamanho o interesse que sua atitude lhe provoca. O poeta surpreende-se, então, maravilhado, fascinado por esse corpo errante. Em um dado momento, o narrador se põe a seguir esse desconhecido, passando por diferentes ruas da cidade de Londres. Tal perseguição dura a madrugada toda e o dia seguinte até a chegada da segunda noite, quando ele finalmente decide parar de se esconder e encará-lo de frente. O desconhecido nem o nota e só então o narrador desiste de segui-lo. As palavras de Baudelaire a seguir tentam descrever o espírito do flâneur, o pintor da vida moderna, associando-o ao homem da multidão.

A multidão é seu universo, como o ar é o dos pássaros, como a água, o dos peixes. Sua paixão e profissão é desposar a multidão. Para o perfeito flâneur, para o observador apaixonado, é um imenso júbilo fixar residência no numeroso, no ondulante, no movimento, no fugidio e no infinito. Estar fora de casa, e contudo sentir-se em casa onde quer que se encontre; ver o mundo, estar no centro do mundo e permanecer oculto ao mundo, eis alguns dos pequenos prazeres desses espíritos independentes, apaixonados, imparciais, que a linguagem não pode definir senão toscamente. O observador é um príncipe que frui por toda parte do

\footnotetext{
${ }^{21}$ Conto de Edgar Allan Poe de 1840. Charles Baudelaire traduziu esse texto, juntamente com as outras histórias extraordinárias de Edgar Allan Poe, em 1857, para o francês. Usamos, contudo, essa versão para análise do texto, em edição mais recente, de 2006.

22 [...] une physionomie qui tout d'abord arrêta et absorba toute mon attention, en raison de l'absolue idiosyncrasie de son expression (tradução minha).
} 
Ele compara esse amante da vida universal a um espelho tão imenso quanto a própria multidão, capaz de refletir a multiplicidade da qual emerge, como um "caleidoscópio dotado de consciência". A mobilidade do flâneur reflete o mundo igualmente móvel, porém o que sua mobilidade pretende é dar à modernidade a espessura da antiguidade. Walter Benjamin, ao seguir os passos de Baudelaire, não considera o homem da multidão de Poe similar ao tipo do flâneur, pois seu comportamento não é tranquilo, estaria mais próximo de um maníaco. O alemão acrescenta ainda, em sua crítica, a diferença de ambientes quando se toma a Paris de Baudelaire e a Londres de Poe. Esta última já contava com mais de o dobro da população de Paris, de modo que o flâneur sentiria falta de espaço livre para não perder sua privacidade. Para Benjamin, portanto, o flâneur estaria entre o homem da multidão de Londres e o ocioso das esquinas de Berlim, figura popular no período da Restauração. O homem da multidão, no ponto de vista de Benjamin, seria o próprio narrador do conto, pois é ele quem se lança na multidão a buscar o outro, é ele quem se deixa levar, quem está verdadeiramente curioso e passeia ociosamente, sem destino. Do outro, sabemos apenas o que o narrador vê e nos conta; ainda que o outro também flane, quem o faz flanar é aquele que o observa.

\section{_Paris: do passeio ao bulevar, das passagens às lojas de departamento}

De acordo com Thierry Davila, essa figura aparece inscrita em uma cidade particularmente preparada para o exercício da caminhada: Paris. Na passagem do século XVII para o século XVIII, segundo o historiador Laurent Turcot, mudanças urbanísticas ocasionadas na capital francesa motivaram alterações no ato de andar. Passa-se da caminhada ao passeio, em decorrência da criação de bulevares amplamente arborizados e de grandes avenidas das quais a Avenue des Champs-Elysés seria sua melhor representante: uma fábrica do passeio urbano. O historiador afirma que foi no século XIX que essa cidade, deliberadamente reformada para o passeio, encontra o reinado da multidão e o fascínio da mercadoria. Nesse sentido, pode-se afirmar que a aparição do flâneur também estaria ligada ao triunfo da mercadoria.

Nesse contexto de grandes reformas urbanas na Paris do Segundo Império, é preciso destacar a operação do então prefeito: o Barão Haussmann. A pedido do imperador Luís Bonaparte, Haussmann empreendeu a mais espetacular de todas as reformas, aumentando a escala da cidade, reformando bairros inteiros, demolindo quarteirões de ruas estreitas e tortuosas em favor da construção de largas avenidas. Para se ter uma ideia, quando o arquiteto contratado pelo Barão apresentou seus projetos para um novo bulevar, ele os devolveu imediatamente alegando que 40 metros de largura não eram suficientes; ele queria 120 metros (HARVEY, 2014, p. 34-35). Com essa dita modernização, um projeto de "embeleza- 
mento estratégico", iniciou o que hoje conhecemos como "espetacularização das cidades" que caminha de braços dados com os processos de gentrificação das áreas mais antigas. Ou seja, as populações mais pobres são expulsas do centro, de modo que junto com o desaparecimento do Vieux Paris [a Velha Paris], desaparecem os antigos moradores, que passam a superpovoar os bairros ainda mais populares e periféricos. É nesse contexto que se criam as banlieues (geralmente traduzidas para português como "subúrbios"), sendo que a origem da palavra decorre de lieu du ban [lugar do banido].

Tais reformas foram impulsionadas por uma visão caótica da cidade, acometida por problemas com excedentes de capital e desemprego, que motivaram discursos sobre "a invasão ou a multidão de vagabundos" e "a turba de nômades", proferidos pelo Barão de Haussmann. Por detrás de suas intenções estéticas e sanitaristas, que previam também o controle de epidemias, diminuindo a densidade demográfica das áreas centrais, havia também uma intenção militar. Era importante conter as revoltas e manifestações populares, tornando impossível a construção de barricadas e permitindo o livre trânsito dos militares. Nessa mudança brusca, o prefeito criou novas instituições financeiras e absorveu imensas quantidades de mão de obra, transformando Paris na "Cidade Luz": "o maior centro de consumo, turismo e prazeres - os cafés, as grandes lojas de departamento, a indústria da moda, as grandes exposições transformaram o estilo urbano, permitindo a absorção de vastos excedentes mediante um consumo desmedido" (Ibid., p. 35). Benjamin relata em seu texto "Paris, capitale du XIXe siècle" [Paris, capital do século XIX], que Haussmann se auto intitulava um "artista demolidor", o responsável pela descaracterização da cidade. "Assim, ele torna Paris estranha aos seus próprios habitantes. Não se sentem mais em casa nela. Eles começam a tomar consciência do caráter desumano da cidade grande" (BENJAMIN, 2000, p.63) ${ }^{23}$. E foi justamente esse espírito destruidor um dos motivadores da Comuna de Paris, ocasião em que as barricadas ressurgem mais fortes do que nunca, numa tentativa de recuperação da cidade.

Com as reformas de Haussmann uma quantidade significativa de passagens também foram destruídas. As passagens são galerias cobertas construídas entre 1822 e 1837, dedicadas ao comércio de luxo, sobretudo relacionado à indústria têxtil. Algumas delas são conhecidas por seus telhados de vidro. Elas atravessavam quarteirões inteiros e eram destinadas exclusivamente aos pedestres. Paris contava com 150 passagens cobertas nos anos 1850 , sendo que esse modelo foi exportado para outras cidades e países. O projeto urbanístico de Haussmann destruiu uma quantidade significativas delas, como por exemplo, o Passage du Pont Neuf e o Passage de l'Opéra, para a qual Aragon dedicou boa parte de seu livro Le Paysan de Paris [O camponês de Paris]. Essas galerias foram as vitrines das primeiras ilumi-

\footnotetext{
${ }^{23}$ Cependant il rend Paris étranger à ses propres habitants. Ils ne s'y sentent plus chez eux. Ils commencent à prendre conscience du caractère inhumain de la grande ville (tradução minha).
} 
nações a gás da capital e representaram o início da arquitetura do ferro, um material que será utilizado a partir de então em construções relacionadas aos espaços de passagem : os trilhos e as estações de trem, as salas de exposição, além das galerias, que também se configuravam como espaços de trânsito. É o ferro que dará condições para um século mais tarde se aprimorar o que ficou conhecido como a "arquitetura do vidro". Ao longo do tempo, o uso das passagens foi sendo incorporado ao modo de vida parisiense e se tornando um lugar de convívio do luxo e de produtos artesanais de uma era pré-industrial, um espaço de resistência dos objetos que não tinham mais o direito de se mostrar à luz do dia. Siegfried Kracauer as considerava como as últimas ilhas de um passado que sobrevivia à marcha triunfal da racionalização.

Elas acolhiam todos os objetos obsoletos que não cabiam mais na sociedade burguesa e que, rejeitados pelo exterior, pela luz do dia, no mundo reificado da mercadoria, se refugiavam na sua penumbra. Lá floresciam as livrarias antiquários, os artigos usados, as velhas lojas de selos e os pequenos mercados de pulgas nos quais se empilhavam "todas as coisas que não serviam mais para decorar as fachadas" (TRAVERSO, 1994, p.101) ${ }^{24}$.

Conviviam igualmente pessoas de diferentes procedências e grupos sociais, tanto os consumidores das mercadorias como prostitutas, jogadores e vagabundos. Tratava-se de um microcosmo consagrado ao passeio, onde era possível ler sem necessariamente comprar a revista, onde havia espaços de leitura e de jogo, onde foram criados os primeiros banhos públicos de Paris, onde se concentravam várias salas de teatro e também as salas precursoras dos cinemas (George Méliès tinha uma sala em uma dessas passagens). Esses centros não eram apenas comerciais, mas também culturais e ditavam um modo de vida urbano bastante distinto da cidade moderna representada pelas avenidas retificadas e as grandes lojas de departamento ${ }^{25}$ da era Haussmann. As passagens mantinham uma ligação direta com a rua, configurando-se quase como uma extensão das calçadas, que não por acaso, em algumas regiões, também são chamadas de passeios. Essas construções se voltavam para um modo de vida fundado na caminhada, cortavam caminhos e encurtavam percursos para os pedestres. Tinham uma dimensão humana e podem ser consideradas como os últimos

\footnotetext{
${ }^{24}$ Ils accueillaient tous les objets obsolètes qui n'avaient plus de place dans la société bourgeoise et qui, rejetés de l'extérieur, à la lumière du jour, dans le monde réifié de la marchandise, se réfugiaient dans leur pénombre. Là fleurissaient les librairies antiquaires, les brocantes, les vieux magasins de timbres et les petits marchés aux puces dans lesquels s'entassaient "toutes les choses qui ne servaient plus au décor de la façade" (tradução minha).

${ }^{25} \mathrm{~A}$ fundação da primeira grande galeria da cidade, Le Bon Marché, coincide com o ano em que se iniciam as obras do Barão Haussmann, em 1852. A ideia do casal que a criou mantinha alguns traços daquilo que se encontrava dentro das passagens, como por exemplo uma biblioteca. A galeria disponibilizou pioneiramente entregas a domicílio e vendas por correspondência. Mais de 40 anos depois (em 1894), após o fim das obras, a Galerie Lafayette é inaugurada justamente na Avenue Haussmann, região onde grandes bulevares foram abertos e muitas passagens, destruídas. Em 1912 foi inaugurada a imensa cúpula de vidro Art Nouveau que se tornaria uma das marcas da galeria, que curiosamente mantém esse traço arquitetônico similar aos tetos de vidro das passagens.
} 
redutos do flâneur.

\begin{abstract}
Assim o apaixonado pela vida universal entra na multidão como se isso the aparecesse como um reservatório de eletricidade. Pode-se igualmente compará-lo a um espelho tão imenso quanto essa multidão; a um caleidoscópio dotado de consciência, que, a cada um dos seus movimentos, representa a vida múltipla e o encanto cambiante de todos os elementos da vida. É um eu insaciável do não-eu, que a cada instante o revela e o exprime em imagens mais vivas do que a própria vida, sempre instável e fugidia. "Todo homem", dizia G. um dia, numa dessas conversas que ele ilumina com um olhar intenso e um gesto evocativo, "todo homem que não é atormentado por uma dessas tristezas de natureza demasiado concreta que absorvem todas as faculdades, e que se entedia no seio da multidão, é um imbecil! Um imbecil! E despreze-o!". (BAUDELAIRE, 1997, p.21, grifo do autor) ${ }^{26}$.
\end{abstract}

Enquanto isso, as grandes galerias já se configuram como um esboço dos shoppings centers; são templos da mercadoria, voltados para o consumo hermético, sem contato com a rua, sem precisar por os pés nas calçadas. Os tetos envidraçados de algumas passagens chegaram a ser retomados nas grandes galerias, porém enquanto nas primeiras eles permitiam a entrada do sol, mantendo as pessoas protegias das intempéries, mas conectadas com a passagem do tempo; nas segundas, devido às grandes proporções dessas construções, eles serviam para exibir o luxo e o avanço tecnológico de uma arquitetura em vias de verticalização.

\title{
_O flâneur e a invenção da vida moderna: a cidade como literatura
}

A cidade tornou-se em minhas mãos um livro. Walter Benjamin (Rua de Mão Única)

Depois do estudo de Baudelaire sobre o flâneur, é Walter Benjamin quem chegará a sua descrição filosófica mais completa. Para o intelectual alemão, trata-se de um caminhante exclusivamente urbano, que passeia pelas ruas, vielas e passagens de Paris, cidade considerada por ele como a capital do século XIX. Segundo ele, o flâneur é aquele que colhe plantas no asfalto, que tem outra relação com o tempo; alguém com domínio do próprio tempo, que se preenche de tempo, assim como uma bateria é carregada de corrente elétrica. Ele distingue essa figura de duas outras igualmente relacionadas ao tempo: o jogador e

${ }^{26}$ Ainsi l'amoureux de la vie universelle entre dans la foule comme dans un immense réservoir d'électricité. On peut aussi le comparer, lui, à un miroir aussi immense que cette foule; à un kaléidoscope doué de conscience, qui, à chacun de ses mouvements, représente la vie multiple et la grâce mouvante de tous les éléments de la vie. C'est un moi insatiable du non-moi, qui, à chaque instant, le rend et l'exprime en images plus vivantes que la vie elle-même, toujours instable et fugitive. "Tout homme», disait un jour M. G. dans une de ces conversations qu'il illumine d'un regard intense et d'un geste évocateur, "tout homme qui n'est pas accablé par un de ces chagrins d'une nature trop positive pour ne pas absorber toutes les facultés, et qui s'ennuie au sein de la multitude, est un sot ! un sot ! et je le méprise ! (tradução minha). 
daquele que espera. $\mathrm{O}$ jogador seria alguém que simplesmente faz passar o tempo, que o expulsa, que o deixa escapar ou que torna o tempo fugidio. Alguém que passa seu tempo jogando, divertindo-se, ou seja, que não se preocupa que o tempo lhe escape. Aquele que espera, por sua vez, experimenta a inércia do e no tempo. Ocupar-se de caminhar significa para Benjamin encarnar uma dinâmica do tempo.

Desde 1920, Walter Benjamin produziu uma série de textos curtos sobre grandes cidades. Para ele, caminhar é um modo de desvelar delicadamente os segredos de uma cidade. Ao falar de Paris em "Declarações de amor dos poetas e artistas à capital do mundo", Benjamin afirma que "nenhuma cidade está tão intimamente ligada ao livro como Paris (...). Paris é a grande sala de leitura de uma biblioteca que atravessa o Sena" (GROS, 2011, p.101) $)^{27}$. Assim como os poetas criam correspondências entre decifrar uma cidade e estudar um livro, o caminhar torna-se um ato de leitura e ganha outras acepções: o objeto arquitetônico e a narrativa do trajeto. Assim a leitura, a atividade por excelência dos sentados, é usada como metáfora da apreensão da cidade. Em revanche, a experiência de percorrê-la gera uma vasta produção textual que encerra um ciclo muito fértil entre literatura e deslocamentos urbanos.

É Michel de Certeau, no entanto, quem apresenta a ideia de que "o ato de caminhar está para o sistema urbano como a enunciação está para a língua ou para os enunciados proferidos" (2014, p. 164). Para esse autor, o ato de caminhar "é um processo de apropriação do sistema topográfico pelo pedestre" e, ao mesmo tempo, "uma realização espacial do lugar" (ibid.). $O$ ato de caminhar seria portanto um espaço de enunciação. Dito de modo elementar, cada passo dado pelo caminhante se constitui como uma palavra que compõe as frases que seus pés inscrevem sobre o terreno percorrido.

De modo complementar ao espaço de enunciação de Certeau, para Franz Hessel (que escreveu sobre o flâneur em Berlim), flanar é uma espécie de leitura da cidade, na qual cada elemento observado (os rostos, as bancas, as vitrines, os terraços dos cafés, os bondes, os carros e as árvores) poderia ser considerado como as letras, que em conjunto, formam palavras e páginas de um livro sempre novo. Segundo esse autor, para verdadeiramente flanar, não é necessário ter nada de preciso para fazer, basta arriscar-se num passeio sem objetivo e buscar a aventura imprevisível do olho. O flanar, para Hessel, é uma arte, um deciframento da cidade, na qual as ruas, os passantes e as lojas formam as letras de um livro escrito pelo próprio flâneur. Nesse sentido, essa figura se aproxima daquela do vagabundo (desenvolvida por Kracauer), que utiliza a cidade como um depósito de objetos surrealistas, rompendo com os códigos da racionalização e recusando a eficácia e a produtividade.

\footnotetext{
${ }^{27}$ Aucune ville n'est liée aussi intimement au livre que Paris. [...] Paris est la grande salle de lecture d'une bibliothèque que traverse la Seine (tradução minha).
} 
Hessel e Kracauer prefiguram aqui as reflexões de Benjamin nos Livros das Passagens, no qual o flâneur possuía todos os traços de um revoltado contra a lógica do capitalismo. Por um lado, ele era atraído pela fantasmagoria dos objetos e não ia em busca de mercadorias para consumir, ele olhava sem comprar subtraindo-se às leis do mercado; de outro lado, ele escapava do mesmo modo à organização capitalista do tempo. Para Benjamin, a flanância era uma arte que não aceitava as restrições de uma decupagem produtiva da jornada de trabalho. A liberdade do flâneur se opunha à racionalidade instrumental do tempo capitalista, cronológico e calculável. (...) o vagabundo de Kracauer correspondia ao flâneur de Hessel e Benjamin, estranho às leis da racionalização do tempo e da vida e entregue à uma guerrilha estética secreta contra a ordem da sociedade burguesa (TRAVERSO, 1994, pp.102-103) $)^{28}$.

Paola B. Jacques, por sua vez, ressalta a ambiguidade presente na figura recriada por Baudelaire, que embora faça uma crítica contundente às reformas urbanas empreendidas na Paris do século XIX, é fruto dessa modernização, faz parte dela e talvez não existisse sem ela (JACQUES, 2012, p. 47). A figura do flâneur se desenvolve ao mesmo tempo em que a cidade se moderniza, é contemporânea do surgimento da ideia de multidão, onde o flâneur se perde voluntariamente, sem perder seu anonimato. Para Baudelaire, multidão e solidão não se opõem, ele amava a solidão e a buscava incessantemente no numeroso, no espaço público, na multidão. Pode-se dizer que o flâneur se constrói em reação à ideia de modernização, caracterizada pela aceleração da velocidade, pela circulação rápida e pela divisão taylorista do trabalho. Dessa forma, Baudelaire adota a lentidão e o ócio (que considera mais precioso que o trabalho), chegando durante algum tempo a levar tartarugas para passear nas passagens parisienses, deixando com que elas prescrevessem seu andamento e também ilustrassem sua relação com o tempo. Por mais que haja nessa figura uma crítica à sociedade burguesa e à lógica do capital, ela está longe de assumir um papel contestatório. Para Benjamin, os surrealistas se detinham no componente anarquista da revolução, sem no entanto se engajarem verdadeiramente nela. Kracauer acreditava, do mesmo modo, que eles se escondiam na marginalidade, abdicando da revolta e caindo em uma doce resignação.

O passeio é uma prática comumente associada aos surrealistas, com mais frequência do que a prática da deriva. Embora o passeio se confunda com a deriva pelo aspecto desnorteado dessa deambulação, ele pode ser considerado mais despretensioso, engendrando uma

\footnotetext{
${ }^{28}$ Hessel et Kracauer préfiguraient ici les réflexions de Benjamin dans Les Livres des passages, où le flâneur possédait tous les traits d'un révolté contre la logique du capitalisme. D'une part, il était attiré par la fantasmagorie des objets et n'allait pas à la recherche de marchandises à consommer, il regardait sans acheter en se soustrayant aux lois du marché; d'autre part, il échappait aussi à l'organisation capitaliste du temps. Pour Benjamin, la flânerie était un art qui n'acceptait pas les contraintes d'un découpage productif de la journée de travail. La liberté du flâneur s'opposait à la rationalité instrumentale du temps capitaliste, chronologique et calculable. [...] le vagabond de Kracauer correspondait au flâneur de Hessel et Benjamin, étranger aux lois de la rationalisation du temps et de la vie et livré à une guérilla esthétique secrète contre l'ordre de la société bourgeoise (tradução minha).
} 
caminhada na qual o errante não se perderá necessariamente. Há nos passeios uma recorrência, eles podem ser repetidos todos os dias ou ocasionalmente, explorando os mesmos percursos com pequenas variações, o que não ocorreria no caso de uma deriva. Desse modo, o aspecto cotidiano do passeio é algo próprio a essa categoria. A deriva se constitui, portanto, como outra categoria, que será apresentada no próximo capítulo.

O passeio estava presente na vida cotidiana de André Breton, de modo que ele conta peripécias vividas em deambulação no espaço público, ao mesmo tempo em que se utiliza dessas experiências ao narrar suas histórias. Ele conta, por exemplo, que realizou um passeio na companhia de Giacometti e o quanto essa caminhada a dois permitiu a cada um deles particularmente encontrar soluções para certos problemas pessoais que ambos passavam naquele momento. Em uma de suas obras mais célebres, Breton narra seu encontro com Nadja, em um fim de tarde totalmente despretensioso. Era uma moça pobremente vestida que vinha no sentido inverso ao dele, de cabeça erguida, contrariamente a todos os passantes, com um sorriso imperceptível e com olhos como ele jamais havia visto. O encontro se dá no dia 4 de outubro de 1926 e ele fica igualmente encantado pelo nome da moça: Nadja, que acaba intitulando o referido livro. Segundo a moça, em russo seu nome é o começo da palavra esperança. No momento de se separarem, quando Breton pergunta quem ela é, Nadja responde: "Eu sou a alma errante".

Ainda sobre o componente ambíguo do passeio - como ressalta Paola Berenstein Jacques, ao dizer que o flanar traz nele a crítica moderna da própria modernidade - é importante lembrar que o flâneur está profundamente vinculado à multidão, estabelecendo com ela uma relação complexa, de amor e ódio, de exaltação e de crítica. Como prova dessa ambiguidade, gostaria de evocar dois exemplos capazes de revelar o quanto a atividade do flâneur pode tanto aproximá-lo, quanto distanciá-lo dos discursos dominantes, dos vencedores, dos abastados e dos intelectuais. O primeiro exemplo é o cronista e jornalista João do Rio, considerado pela mesma autora citada acima como um flâneur carioca. De modo similar àquele adotado por Baudelaire ao referir-se às mudanças ocasionadas na Paris da era Haussmann, João do Rio compôs crônicas sobre as reformas empreendidas no Rio do Janeiro do início do século XX. Com a ressalva de que se tratava de um cronista negro, que levava a cidade no seu próprio codinome, uma testemunha ocular dos avanços da modernidade e do desaparecimento do Rio antigo. Em suas crônicas, o poeta flâneur falava das pessoas que realmente habitavam as ruas, tais como: ciganos, carroceiros, vendedores ambulantes, selistas, meretrizes, carregadores, marinheiros, mercadores de livros, entre outros.

Em contraposição ao flanar de João do Rio, que resultava no encontro com outros porta-vozes para a história, vemos a figura do flâneur totalmente apropriada pela cultura dominante na exposição Dans l'oeil du flâneur [No olho do flâneur], organizada entre setembro e outubro de 2015 em Paris. Trata-se de uma luxuosa produção, instalada às margens do 
dor modelo da Hermès. Vemos nesse último exemplo, a figura crítica à modernidade sendo completamente associada à lógica da mercadoria e sendo usada para o único e restrito fim de implantar desejos nos consumidores.

Para Paola Berenstein Jacques, o flanar ocorre em um momento muito específico de transformações urbanas, coincidente com o surgimento da experiência de multidão, do turbilhão humano no século XIX, da experiência física de estar excessivamente próximo de outros corpos, que eventualmente se tocam e formam uma só massa humana (JACQUES, 2012, p. 56). Eu acrescentaria a essa descrição a sensação de perda dos próprios limites corporais, nas situações em que a multidão nos leva, quando já não é mais possível determinar nosso próprio andamento ou direção, ou ainda quando qualquer movimento do corpo implica na delicada invasão do espaço do outro. A autora fala em uma coexistência não pacificada no espaço público. "A multidão proporciona uma relação entre anonimato e alteridade que é exatamente o que constitui a própria noção do espaço público metropolitano"(Ibid.). Segundo Benjamin, a multidão foi o tema que mais mobilizou a literatura do século XIX, além de ser um conceito muito caro ao estudo da modernidade.

\section{_quando os artistas levam tartarugas para passear}

Mais recentemente, já no século XX, muitos artistas lançaram seus corpos em deslocamento pela cidade, propondo visões dessa multidão sem rosto ou da solidão ocasionada pela

Figura 7: Lebel - Happening

Foto: DELPEUX, 2010, p. 69

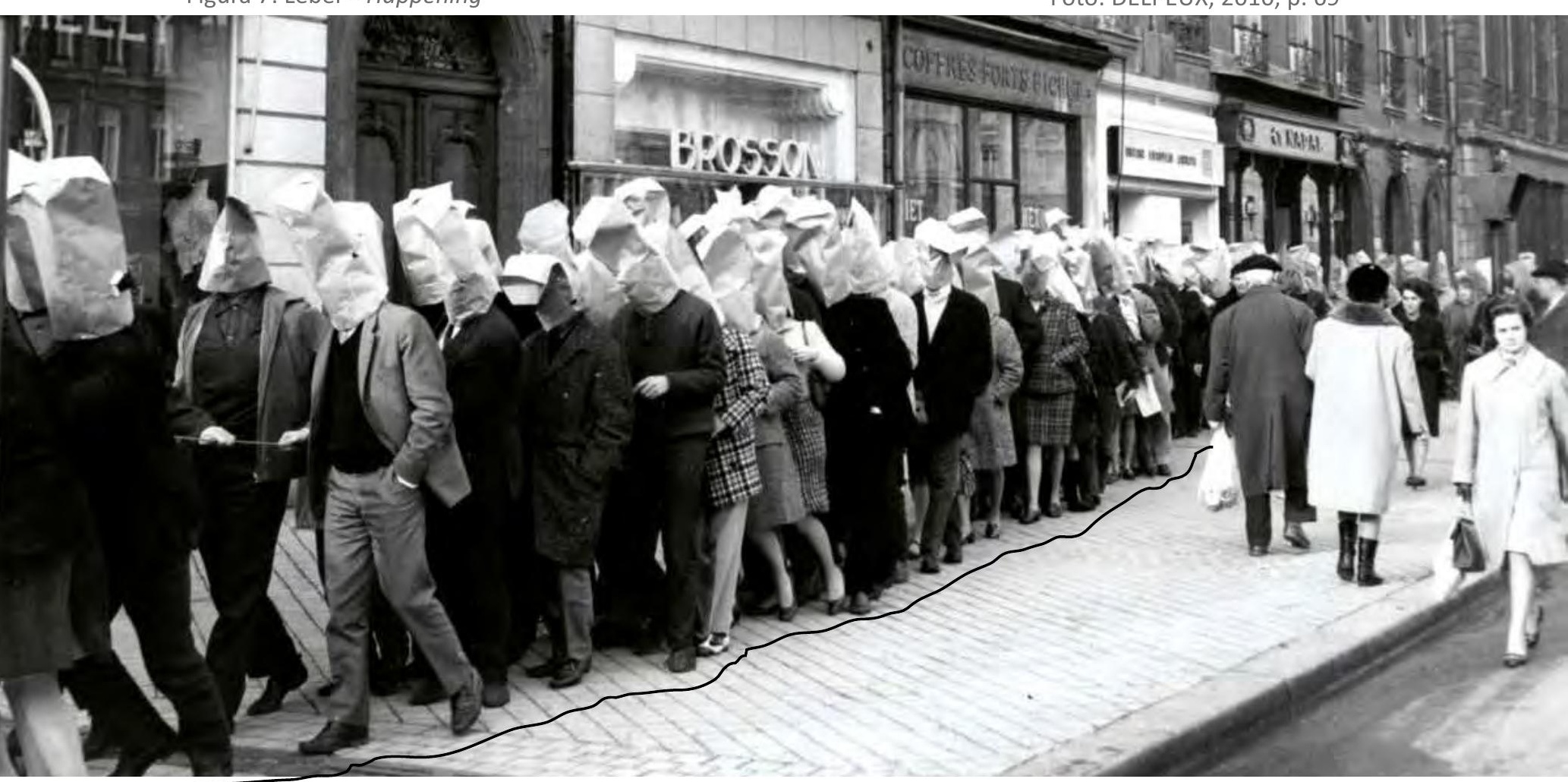


vida nas grandes metrópoles. Dois exemplos de performances da década de 1960 retratam com precisão esses temas ainda atuais nos dias de hoje, podendo se referir à modalidade passeio.

O primeiro deles é um Happening realizado por Jean-Jacques Lebel em Bordeaux, no dia 19 de novembro de 1966, no quadro do festival Sigma das artes e tendências contemporâneas, para o qual o artista foi convidado para fazer uma conferência-demonstração. Tal conferência consiste em um apelo à revolta. Lebel distribui uma "declaração de princípio" na entrada da sala e convida os participantes a colocarem sacos de papel na cabeça. Segurando todos em uma única corda, realizam juntos uma visita noturna da cidade, com as cabeças cobertas com sacos de papel. A ideia é revisitar o ambiente cotidiano em um passeio às cegas que dura por volta de uma hora e meia. No texto distribuído na entrada, o artista expõe sua visão sobre a noção de happening, refletindo sobre a posição do observador e as convenções com as quais está acostumado.

\begin{abstract}
O happening não é nem uma teoria nem um sistema infalível: seus únicos critérios são subjetivos. (...). O observador, condicionado por décadas de pintura de cavalete ou de teatro literário, adere à sua poltrona e se condena a si próprio a permanecer de fora. Há uma deformação profissional do observador que o impede talvez de sair de si mesmo, de seu condicionamento visual, psicológico ou moral. Colocado diante de uma obra inacabada, em processo de criação e aberta à ele, o espectador nem sempre está à altura de sua tarefa. A carência está na captação e a confusão na miopia. O happening nunca quis ser como uma cerimônia invariável mas, sobretudo, um enxerto, um movimento ou uma paralisia, uma pulsão exprimida ou reprimida, uma sensação de festa ou de desespero. Logo, o happening estabelece uma relação de sujeito com sujeito. Não somos mais (exclusivamente) observadores, mas observados, considerados, examinados. Não há mais monólogo, mas diálogo, troca, circulação (LEBEL, 2009, pp. 214-215). ${ }^{29}$
\end{abstract}

É interessante como Lebel apresenta sua noção de happening em relação à figura do espectador, que habitualmente se encontra do lado de fora mas nesse caso é peça chave da realização da ação. Na verdade, o passeio coletivo pelas ruas de Bordeaux pode ser tomado como uma sensibilização do corpo e da percepção da cidade para o happening que seria realizado posteriormente. A reação das pessoas que participam, ao retornarem à sala, foi de liberação absoluta, cada um fazendo sua performance ou expurgando sua raiva. Em decor-

\footnotetext{
${ }^{29}$ Le happening n'est ni une théorie ni un système infaillible: ses seuls critères sont subjectifs. [...]. Le regardeur, surdéterminé par des décades de peinture de chevalet ou de théâtre littéraire, adhère à son fauteuil et se condamne lui-même à rester dehors. Il y a une déformation professionnelle du regardeur qui l'empêche parfois de sortir de lui-même, de son conditionnement visuel, psychologique ou moral. Placé devant une cuuvre inachevée, en train de se faire et ouverte à lui, le spectateur n'est pas toujours a la hauteur de sa tâche. La carence est dans le captage et la confusion dans la myopie. Le happening n'a jamais voulu être comme une cérémonie invariable mais, plutôt, une greffe, un mouvement ou une paralysie, une pulsion exprimée ou réprimée, une sensation de fête ou de désespoir. [...]. Donc le happening établit une relation de sujet à sujet. On n'est plus (exclusivement) regardeurs, mais regardés, considérés, scrutés. II n'y a plus monologue, mais dialogue, échange, circulation (tradução minha).
} 
rência dessa ação, ocorreu um protesto contra as condições reais impostas pela indústria cultural e os limites institucionais atribuídos tanto às práticas artísticas quanto às políticas. De acordo com Lebel, essa manifestação teria "preparado o terreno" para o desencadeamento de Maio de 68.

O segundo exemplo Wiener Spaziergang [passeio vienense] foi realizado por Günter Brus, um dos acionistas vienenses, em 1965. Nessa ocasião, o artista realizou um passeio pela cidade de Viena todo vestido de branco e tendo todas as partes aparentes de seu corpo igualmente pintadas de branco, inclusive seu rosto, suas mãos e seus cabelos. Brus caminha portando sua característica marca negra cortando seu corpo em dois. Trata-se de um risco longitudinal que divide sua cabeça passando pelo rosto, pescoço, tronco e descendo por sua perna direita até atingir o pé. É interessante observar que o risco percorre também suas costas, fraccionando inteiramente o seu corpo, de modo que tem-se a impressão de que uma marca de sangue o divide ao meio. Ele caminha pela rua, cabisbaixo, seguido por uma dezena de pedestres que parecem seguir sua deambulação. $O$ artista incorpora assim a presença de um homem solitário, fissurado, partido ao meio, porém aparentemente sorridente. Ele transforma seu corpo em obra, em objeto para a apreciação, uma pintura viva. Depois de alguns metros caminhando tranquilamente pela rua, sendo atentamente observado pelos demais passantes, Brus é parado pela polícia ao passar em frente ao palácio

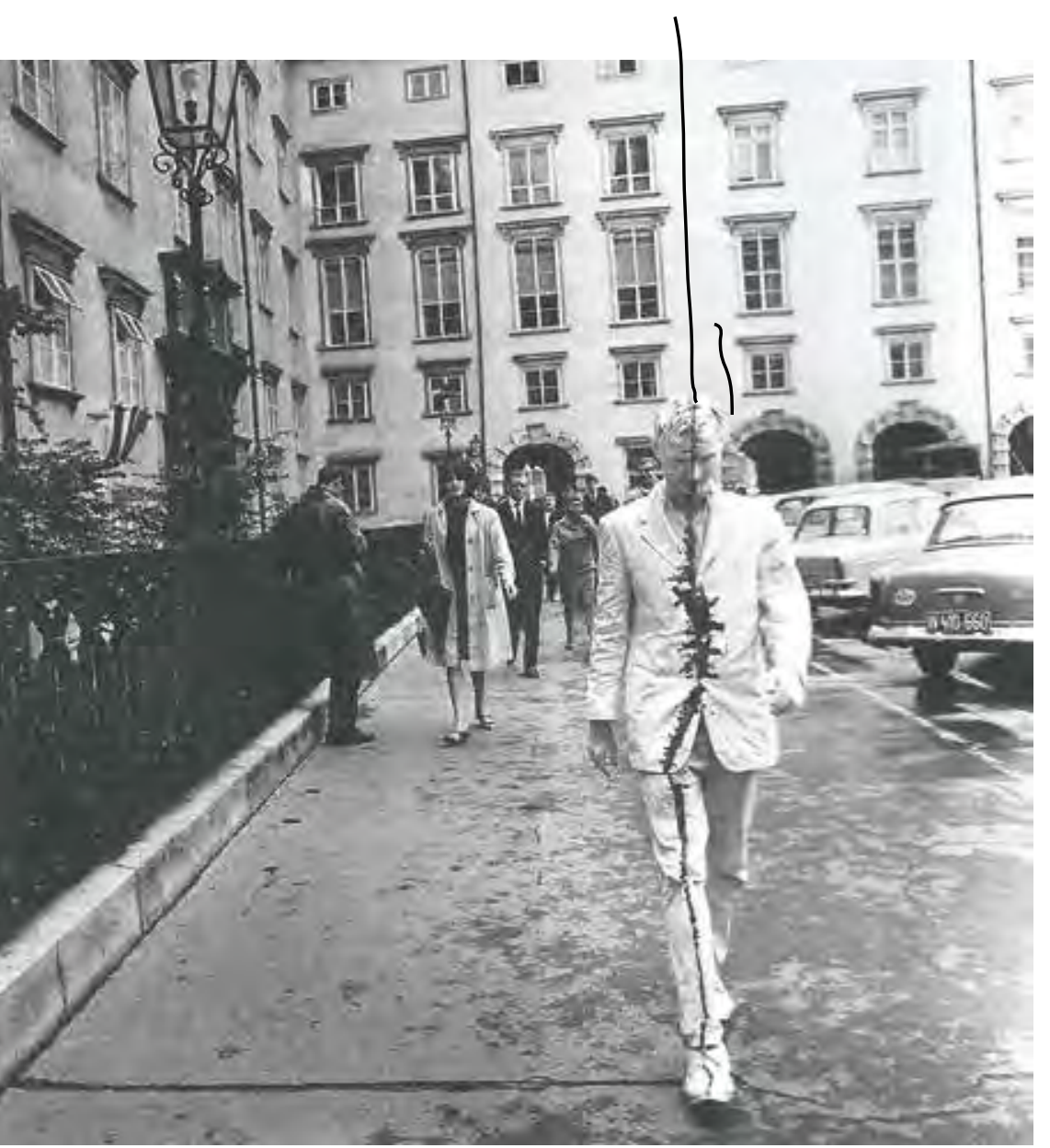

Figura 8: Günter Brus - Wiener Spaziergang imperial de Viena. O performer para, mostra seus documentos e é levado a uma delegacia próxima dali, onde paga uma multa

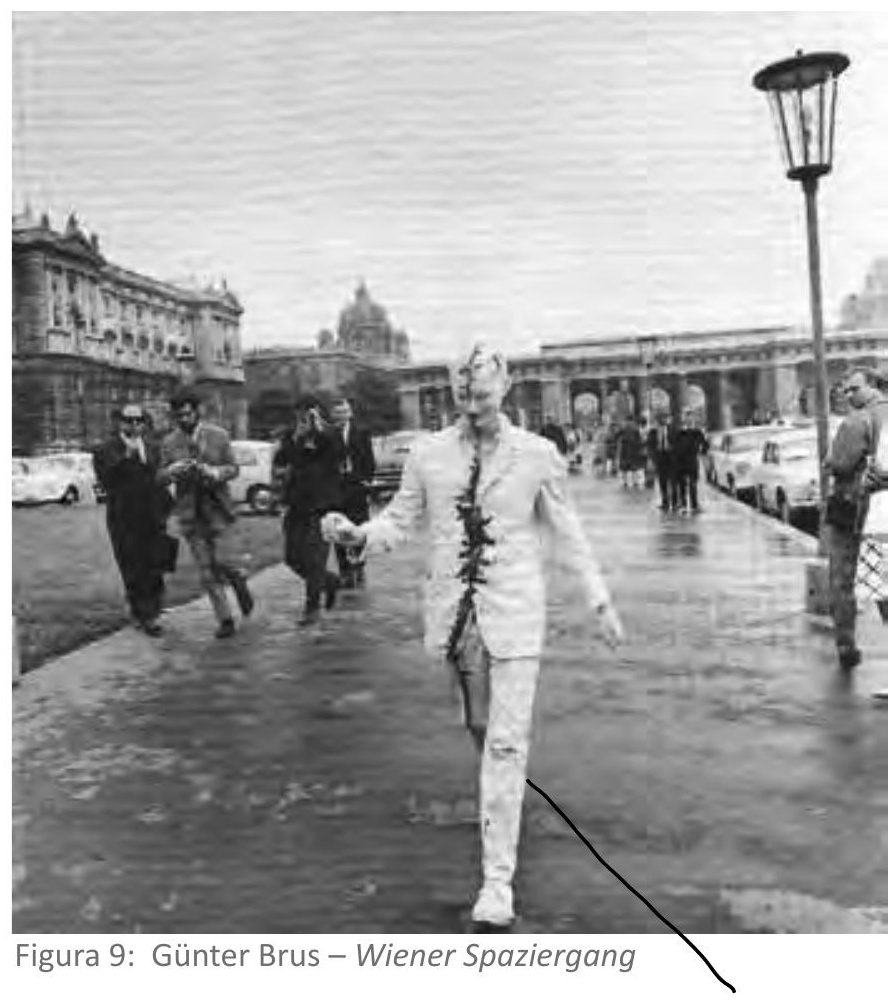


pela ação realizada. Günter Brus, em excerto de seu diário dos anos 1960-1961, discorre sobre a perda de referências na pintura e a sua propensão a fluir no espaço do real, tornando a representação parte do real, convidando-a a conviver com seres e objetos do mundo, sem diferenciação.

\footnotetext{
Deve-se viver na pintura. Rodeado pela pintura. É justamente por isso que o quadro é uma parte do mundo e não está jamais isolado. Uma incompreensibilidade espacial - ao menos incompreensível para a tradição - é isso o que eu espero de meus quadros. A apropriação radical do centro do quadro. Mas não no sentido de Pollock. Pollock falava de um quadro infinito - ele queria (é assim que eu o compreendo) que o quadro fosse um pedaço do universo, no lugar de ser [um universo]. Eu acho que essa arte está ultrapassada. Eu quero tentar pensar o quadro da mesma maneira (e assim ultrapassar o próprio quadro, para fazer dele um pedaço do mundo) - mas, como dizer, o mundo deve incluir o signo codificado, a rítmica, o grito, o sono, a sopa de ervilhas, o cachorro bassê de pelos longos, o tufão, a melodia infinita...etc...etc...etc... (FRANZISKA e MEIFERT apud DELPEUX, 2010, p. 67) $)^{30}$
}

Embora caminhe de maneira leve e despretensiosa, a visão desse homem cindido ao meio só parece possível num mundo posterior à modernidade. Vale lembrar que a representação de seu corpo todo pintado de branco com inscrições de marcas negras é um distintivo para esse artista. Prova disso é que nesse mesmo ano (1965), ele realiza mais duas ações nessas condições. Uma delas se intitula Selbstverstümmelung II [Automutilação] e nela, o artista simula mutilar partes do seu corpo. Nas fotos decorrentes do passeio vienense (único meio de se ter acesso às ações) pode-se observar que essas marcas presentes no seu corpo dialogam com as marcas da cidade. Sophie Delpeux afirma que como em um espelho, o corpo de Brus faz de Viena e de suas opressões um quadro, como se sua ação contaminasse o mundo real da sua mais apurada expressão.

Thierry Davila afirma que o flâneur explora a horizontalidade da cidade. Ele explora o mundo baixo, na altura dos pés e não na altura do corpo. O belga Francis Alÿs é considerado por esse autor como um flâneur por excelência. Esse célebre artista, radicado na cidade do México, tornou-se bastante conhecido por suas ações deambulatórias. Para ele, "caminhar em particular errar ou flanar já é - em relação à cultura da velocidade de nossa época -

\footnotetext{
${ }^{30}$ On doit vivre dans la peinture. Toute autour de la peinture. N'est-ce pas justement pour ça que le tableau est une partie de ce monde et n'en est jamais isolé. Une incompréhensibilité spatiale-du moins incompréhensible pour la tradition - voilà ce que j'attends de mes tableaux. Le détournement radical du centre du tableau. Mais pas dans le sens de Pollock. Pollock parlait du tableau infini - il voulait (c'est ainsi que je le comprends) que le tableau soit un morceau d'univers, à la place d'être. Je trouve que cet art est dépassé. Je veux essayer de penser le tableau de la même manière (et ainsi dépasser le tableau même, pour en faire un morceau du monde) - mais, comment dire, ce monde doit inclure le signe codé, la rythmique, le cri, le sommeil, la soupe aux haricots, le teckel à poils longs, le typhon, la mélodie infinie...etc...etc...etc... (tradução minha) - trecho de seu diário retirado de "Günter Brus: Je suis, donc j'essaie de me faire".
} 
um tipo de resistência" (ALYS in BIESENBACH e STARKE, 2010, p. 37) ${ }^{31}$. Seu trabalho é tão vasto e tão emblemático da presente pesquisa, que várias de suas performances servirão de exemplo para abordar diferentes categorias do caminhar presentes na esfera artística. Ao menos duas ações desse artista serão evocadas aqui para se discutir o ato de caminhar como um passeio. Para exemplificar a horizontalidade da cidade, The collector e Magnetic Shoes serão destacadas. Ambas se caracterizam pelo uso do ímã como elemento capaz de atrair e colecionar objetos de ferro. $\mathrm{O}$ ato de colecionar e a atração pelo ferro já são duas características suficientemente adequadas para aproximá-lo da figura do flâneur.

Ciência visível: (ímã) um corpo que atrai metal devido a um campo de força produzido pelo deslocamento de elétrons do polo positivo em direção ao polo negativo (sul e norte).

Contexto: Político no sentido grego de polis, a cidade como lugar de sensações e de conflitos de onde são extraídos materiais de criação de ficções, de arte e de

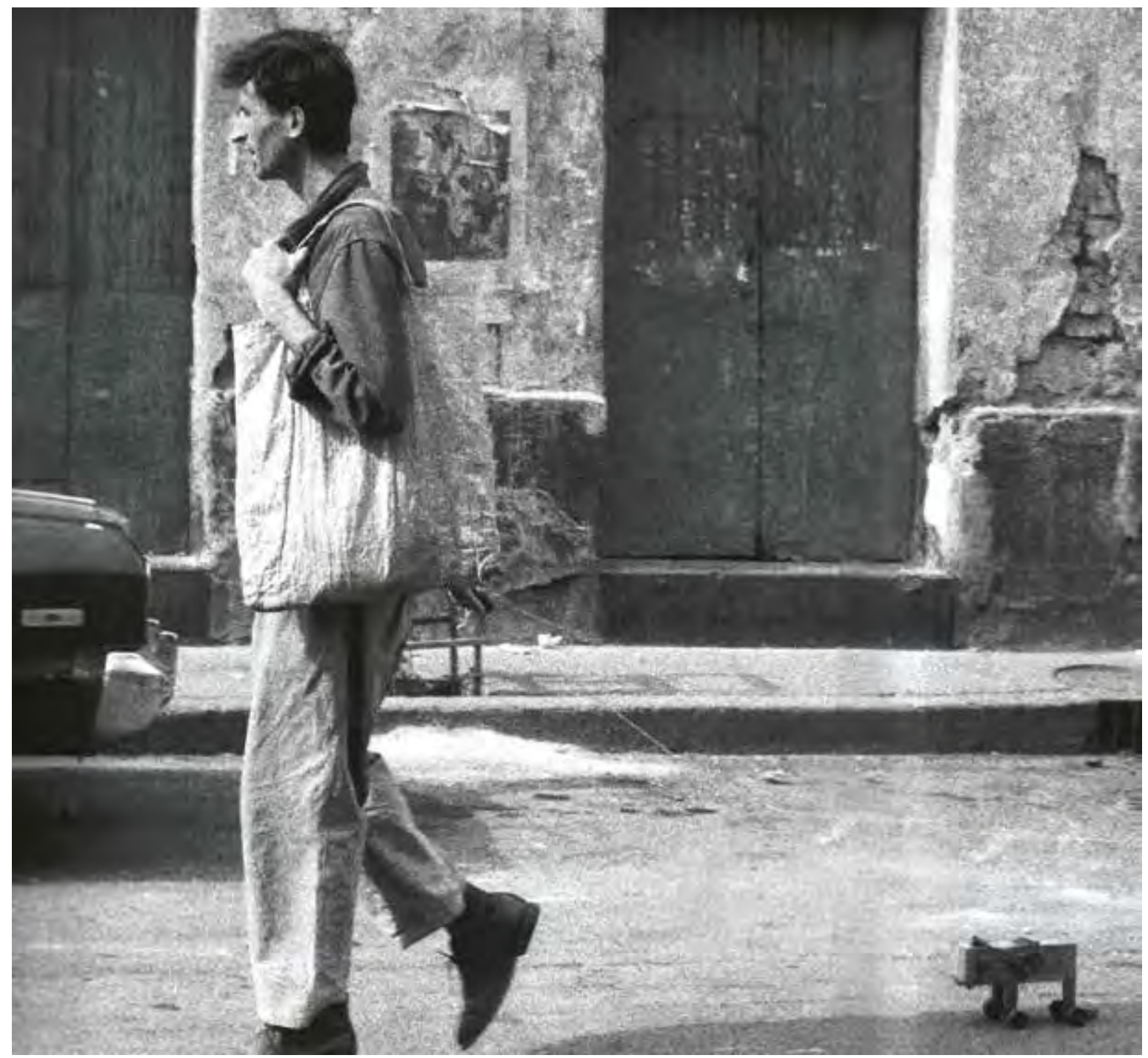

Figura 10: Francis Alÿs - The Collector

Foto: Ian Dryden (GODFREY et al., 2010, p. 50)

\footnotetext{
${ }^{31}$ Marcher, en particulier errer ou flâner, c'est déjà-en rapport à la culture de la vitesse de notre époque -une sorte de résistance (tradução minha).
} 
mitos urbanos.

Procedimento: Ao longo de uma duração indeterminada, o coletor magnético realiza um passeio cotidiano através das ruas e se constrói pouco a pouco uma manta de resíduos metálicos até que ele esteja completamente recoberto por seus troféus. (ALYS in BIESENBACH e STARKE, 2010, p. 51)

A primeira delas, The collector, realizada na cidade do México entre 1990-1992, em parceria com um mecânico, teve seu programa transcrito acima. Consiste em uma pequena e singela escultura de madeira, com rodas de borracha, com ímãs acoplados: uma espécie de cachorro magnético. Alÿs caminha lentamente puxando o objeto por um cordão, como se fosse um brinquedo, enquanto todos os objetos metálicos encontrados no caminho vão sendo sucessivamente acoplados. O contexto explicitado no programa da ação remete ao político, no sentido grego. O uso da rua se justifica como lugar da tessitura de significados, da elaboração artística e da construção de narrativas ou mitos urbanos, agindo diretamente no imaginário de quem vive na cidade. É a rua que aproxima o artista do real, das questões concretas, do debate sobre os modos de vida e os posicionamentos de cada um. The collector é uma ação determinante na carreira de Alÿs, inspirada por sua pesquisa de doutorado que versava sobre a expulsão dos animais da cidade na Idade Média como um fato coincidente com a chegada da modernidade. Esse movimento marca a emergência da racionalidade moderna, fundada na ciência para controlar a vida urbana. Essa performance foi criada como uma homenagem aos cães de rua e a outros animais selvagens da cidade, uma metáfora à resistência contra a modernização.

Com The collector, o performer revela a rua como um simples espaço de circulação e comércio e reivindica um retorno à noção grega de polis, como espaço de conflitos, de narrativas e de desejos envolvendo a vida da comunidade. A noção de caminhada-fábula (marche-fable) surgiu com essa ação e se tornou central para a obra do artista.

\footnotetext{
Para além das analogias entre as caminhadas de Alÿs e o flâneur baudelairiano ou a deriva situacionista, o artista empreendeu sistematicamente suas ações como narrativas destinadas a tocar o imaginário social, obras que disseminam uma força poética e alegórica por meio de imagens e objetos (ibid.) ${ }^{33}$.
}

Na segunda performance, Magnetic Shoes, realizada em Havana em 1994, o artista calça sapatos com ímãs que fazem as vezes do cachorro. Desse modo, Alÿs passa a recolher com

${ }^{32}$ Science visible: (Aimant) Un corps qui attire le métal grâce à un champ de force produit par le déplacement d'électrons du pôle positif vers le pôle négatif (sud et nord) Contexte: Politique au sens grec de polis, la cité comme site de sensations et de conflits d'où sont extraits les matériaux de création des fictions, de l'art et des mythes urbains. Procédé: Sur une durée indéterminée, le collecteur magnétique fait une promenade quotidienne à travers les rues et se construit petit à petit un manteau de résidus métalliques jusqu'à ce qu'il soit complétement recouvert par ses trophées (tradução minha).

${ }^{33}$ [...] Au-delà des analogies entre les marches d'Alÿs et le "flâneur" baudelairien ou la "dérive" situationniste, l'artiste a systématiquement entrepris ses actions comme des récits destines à toucher l'imaginaire social, des oeuvres qui diffusent une force poétique et allégorique au moyen d'images et d'objets (tradução minha). 


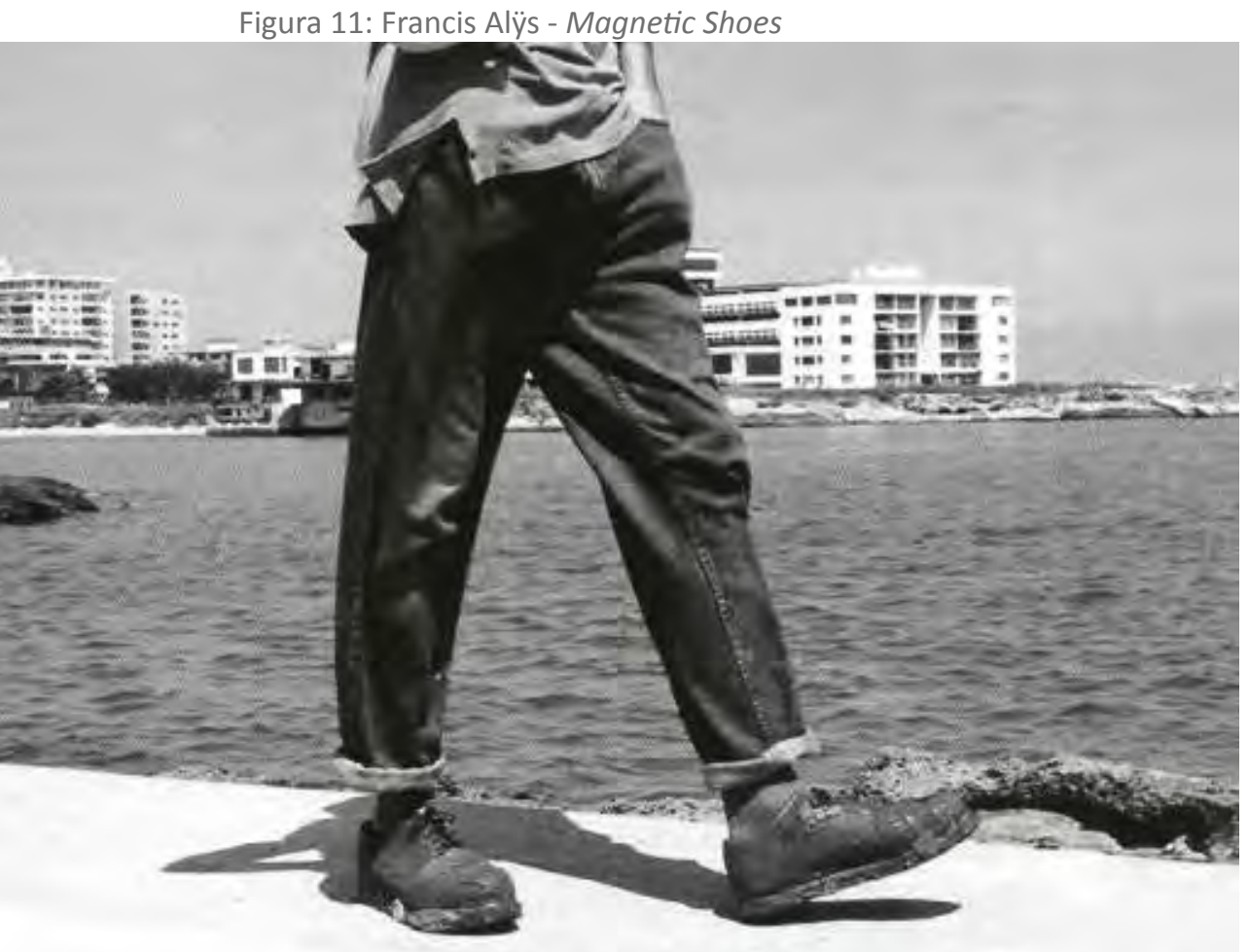

Foto: DAVILA, 2002, p. 93

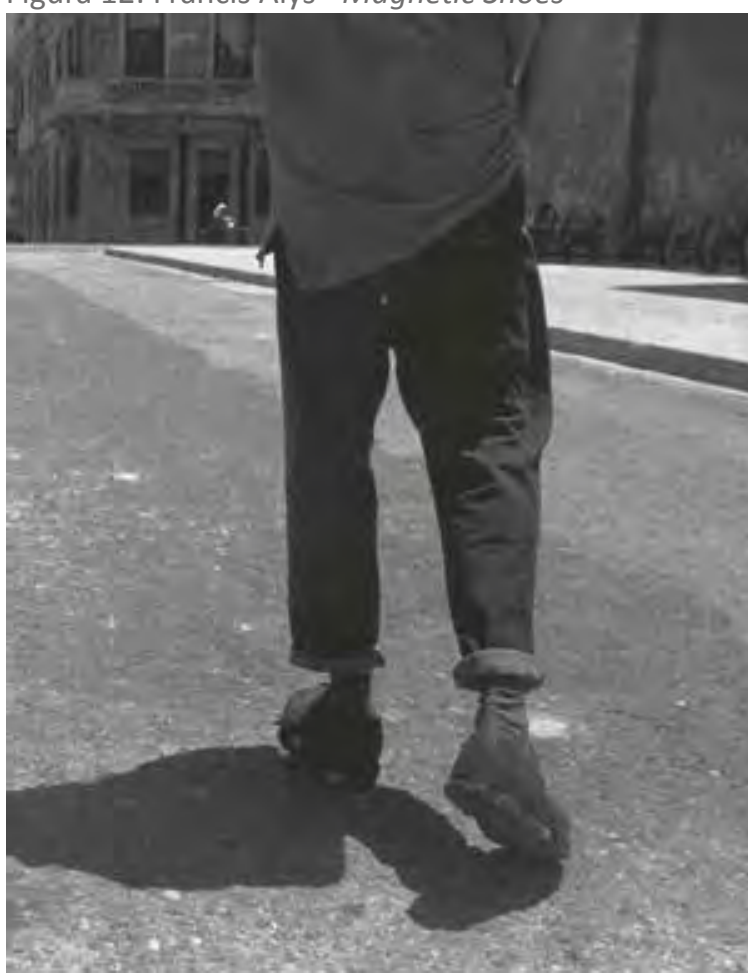

Foto: Jorge Golem (GODFREY et al., 2010, p. 64)

os próprios pés os elementos metálicos encontrados ocasionalmente. Com seus sapatos magnéticos, o performer passeia pela cidade em todos os dias que correspondem à quinta Bienal de Havana, para a qual ele não estava oficialmente convidado. A ideia dessa performance surge de uma anedota encontrada na imprensa popular mexicana sobre uma tribo de homens que tem o dom do magnetismo. Ao seu modo, Alÿs tornou-se um homem magnético, que recolhe objetos metálicos pelas ruas de uma Havana mergulhada na crise econômica do início dos anos 1990. Nesse contexto de declínio da economia socialista, essa ação ganha duplo sentido, pois ela mostra a atração exercida pelos bens de consumo estrategicamente posicionadas no mais baixo do chão. Magnetic Shoes revela dois aspectos interessantes da criação desse artista. Por um lado, revela sua intenção de inventar uma nova fábula urbana; por outro, "propõe também um comentário sobre a mentalidade consumista que ganha terreno mesmo nos últimos territórios das revoluções do século XX" (Ibid. p. 65) $)^{34}$.

Com essas ações, o artista compõe um retrato da cidade baixa, sobretudo se considerarmos o modo de difusão dessas ações, adotado por Alÿs. Ele cria cartas postais representando momentos significativos de cada uma de suas performances. Assim, enquanto o artista é móvel, os meios de difusão de seu trabalho são nômades. Alÿs estaria, segundo Thierry Davila, ao lado daqueles que passeiam com tartarugas: ele constrói uma espécie de resistência em meio ao tumulto da circulação urbana. Sua caminhada tem outra qualidade: a lentidão e o interesse pelo que está no espaço obscuro do chão, pelo resíduo. Assim, Alÿs compartilha de características similares àquelas do flâneur que fazia botânica no asfalto.

\footnotetext{
${ }_{34}[. .$.$] propose aussi un commentaire sur la mentalité consommatrice qui gagne du terrain même dans les$ derniers territoires des révolutions du XX siècle (tradução minha).
} 


\section{_quando se passeia no nível baixo}

Outro performer bastante conhecido pelas ações que desenvolve bem próximo do chão é William Pope L. Em Tompkins Square Crawl (1991), o artista rasteja-se pela rua, percorrendo a sarjeta da Tompkins Square Park, em Nova York. Pope é negro e encontra-se vestido com um terno, carregando um vasinho de flor com uma das mãos. $O$ detalhe que faz toda a diferença é que contratou um videografista branco para registrar sua ação. A condição de seu corpo, em contato direto com o asfalto, é a mesma de uma vasta população que habita a rua e vive em condições de vida extremamente precárias. De origem pobre, o performer optou por explorar a horizontalidade da rua, como forma de denúncia; um modo radical de atrair olhares para as pessoas que (sobre)vivem em condições desumanas. $O$ gesto de contratar um viodegrafista branco para acompanhar seu périplo propõe uma mudança de ponto de vista. Nesse caso, o homem branco dá o foco ao homem negro, que realiza a ação e deve ser contemplado, detendo assim algum privilégio dentro da situação construída. $O$ que parece ambíguo é o gesto, é a ação efetuada por Pope: ele rasteja-se no chão, abdicando da condição de bípede. O performer rasteja-se na rua, efetivamente ocupado em realizar tal rastejamento; ele não representa, não adota uma postura desesperada, nem humilhante. O modo como Pope articula a ação propõe uma outra ordem social para as coisas, rearticulando relações e valores.

Nesse ponto, vale a pena retomar duas noções apresentadas por André Lepecki em seu texto "Coreopolítica e coreopolícia" de 2012. A primeira delas é a noção de coreografia como algo profundamente materialista e antimetafórico. Ele cita Andrew Hewitt para defender a coreografia como um ato performativo, que não pode ser identificada como algo estético, em oposição à categoria do político. Nesse sentido, a "coreografia não deve ser entendida como imagem, alegoria ou metáfora da política e do social" (LEPECKI, 2012, p.46), uma vez que para Hewitt a função política se define como "a disposição e manipulação de corpos uns em relação aos outros" (HEWITT apud LEPECKI, 2012, p.46). Assim, Lepecki reconhece uma formação múltipla para o coreográfico, o que expande essa noção para além do campo restrito da dança, passando a defini-la como coreopolítica. A segunda noção é a ideia de política do chão, defendida por Paul Carter em seu livro "The Lie of the Land" (1996), e utilizada por Lepecki para atentar às particularidades físicas de todos os elementos de uma situação, que "se conformam num plano de composição entre corpo e chão chamado história. Ou seja, no nosso caso, uma política coreográfica do chão atentaria à maneira como coreografias determinam os modos como danças fincam seus pés nos chãos que as sustentam" (LEPECKI, 2012, p. 47). Desse modo, o que essa política do chão atesta é que cada coreografia está intimamente vinculada ao chão que a produz; a coreografia é fruto do lugar onde a dança nasce, que por sua vez, também produz ressonância no lugar. Assim, não seria certo afirmar que o espaço da cidade é neutro, um espaço vazio onde signos são 



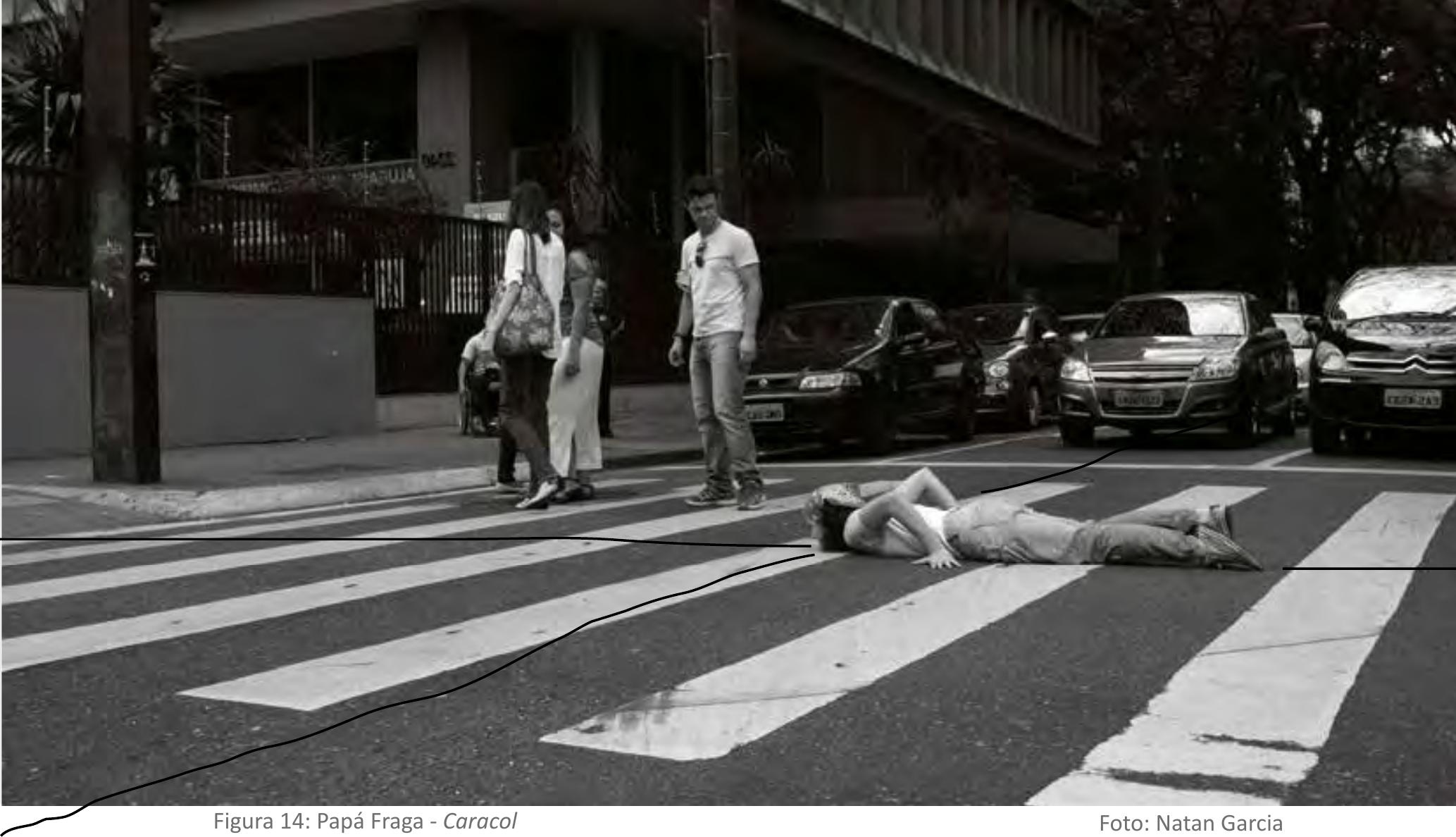

Figura 14: Papá Fraga - Caracol

Foto: Natan Garcia

pernas estendidas e movendo precisamente apenas os metatarsos para impulsionar o corpo todo para frente, numa troca de pés sutil e eficiente. A cada impulso detonado por um dos metatarsos, os braços (única parte de seu corpo que sobressai à sua referência inicial) se reacomodam, revelando cada pedaço de chão alcançado com muito esforço. Pelo apoio do queixo no chão e, provavelmente pela proximidade de seu rosto com todos os resíduos e dejetos que encontra pelas ruas que percorre (em São Paulo, Bragança Paulista, Juazeiro do Norte, Sorocaba e Fortaleza) suas sobrancelhas apresentam-se levemente arqueadas, de modo que sua testa anuncia antenas ausentes, mas facilmente imagináveis sob o lenço azul que se tornou marca do seu molusco.

Manoel de Barros afirma que há um comportamento de eternidade nos caramujos e que eles carregam com paciência o início do mundo. Esse referencial poético parece presente quando a performer anuncia que "se arrasta na insistência em se deslocar o pensamento e as formas de existência" ${ }^{\prime 35}$. Mesmo sabendo de sua tarefa vã, consciente de que nenhum caracol poderá deslocar formas de existência, a visão desse corpo vulnerável inverte pontos de vista e convida à reformulação de pensamentos. Mais uma vez, a expressão de um corpo nasce no trânsito de grandes cidades, nos espaços de circulação de pessoas e carros, numa versão atualizada da tartaruga de Baudelaire. Ela atravessa ruas pelas faixas de pedestres, propondo convívio com o acelerado, em oposição à sensação tão recorrente na vida cotidiana de correr atrás do tempo. Esse corpo não nasceria na cidade livre do trânsito, da pressa, dos compromissos inadiáveis, ele é fruto desse contexto, assim como o flâneur depende da modernidade, à qual se opõe.

35 Material fornecido pela performer sobre sua ação Caracol. 
Segundo a artista, "cabe ao público fabular a respeito do que vê, sugerindo definições sobre o corpo que rasteja no chão e nas horas" ${ }^{36}$. Assim, a cada vez que o evento se repete, ele produz novidades. Contrariando o poeta dos caracóis - Manoel de Barros, que diz que o caracol é uma solidão que anda na parede - a performer promoveu em 2015 encontros de caracóis em duas ocasiões distintas, em Fortaleza e em São Paulo (com algumas artistas do Coletivo Teatro Dodecafônico). Nesses encontros, bandos de caracóis humanos foram vistos arrastando-se pelo asfalto dessas duas cidades.

Entre o corpo que rasteja e o corpo bípede não há apenas uma diferença de velocidade, esse corpo lento ressalta a incapacidade humana de permanecer. Ao referir-se à coreopolícia, André Lepecki lembra que a palavra de ordem da polícia é "circular, circular", evitando a permanência, a concentração e promovendo a dispersão, o movimento contínuo e desprovido de pensamento. Desse modo é possível para o autor afirmar que a polícia coreografa, eliminando acontecimentos e diminuindo as oportunidades para que as pessoas se encontrem. Evitando acidentes e conflitos, ela configura o espaço, dispondo e manipulando corpos. O grau de permanência do caracol ressalta o andamento de todos que passam velozes, cria um dissenso, propõe uma ação ao mesmo tempo estética e política, como recomenda Rancière (RANCIÈRE apud LEPECKI, 2012, p.43). É essa a política do chão criada por Papá Fraga, que toma emprestado a qualidade do corpo do molusco para questionar contextos urbanos carregados de aceleração e intensidade. Quando perguntaram a ela se o caracol dançava, ela não respondeu de imediato, mas disse que sim com seu corpo. E concluiu: "cada um oferece ao mundo o que pode". Nesse exemplo, o flanar ocorre pela transmutação do corpo da performer em caracol; Papá busca um devir caracol, incorporando a lentidão que o poeta encontrou na tartaruga.

\section{_quando flanar acontece no feminino}

Recorrentes no contexto urbano, tanto o flâneur de Baudelaire quanto o de Benjamin são quase sempre retratados no masculino. Somente no final do século $X X$ algumas autoras começam a reivindicar o posto da flâneuse, ao lado do homem que caminha sem pressa. Em texto no qual relaciona as flanâncias femininas à etnografia ${ }^{37}$, Nadja Monnet faz um levantamento das autoras que colaboram para autorizar a mulher a flanar, discutindo historicamente o uso do espaço público pela mulher e elaborando discursos que incluem a mulher nesse espaço que não é apenas público, mas político e social. Régine Robin é uma flâneuse das megalópoles contemporâneas. Ela escreveu sobre sua experiência em Nova

\footnotetext{
36 Idem.

${ }^{37}$ Disponível em: <http://www.redobra.ufba.br/wp-content/uploads/2013/06/redobra11_23.pdf>. Acesso em: 09 mai. 2016.
} 
York, Los Angeles, Tokyo, Londres e Buenos Aires, cinco cidades que percorreu "em todas as direções e através de diferentes meios de locomoção, para apreendê-la(s) plenamente" (MONNET, 2013, p. 218). Robin optou por escrever sobre cidades imensas que não estivessem próximas dela, ou seja, não escreveu sobre a cidade onde nasceu, nem sobre a cidade onde mora. Desmitificando a vida nas megalópoles, por meio de uma escrita auto-ficcional, a historiadora e socióloga defende que a cidade que habitamos também nos habita. Regine Robin, no entanto, intitula seu livro Megalopolis: les derniers pas du flâneur (Ed. Stock, 2009) [Megalópole: os últimos passos do flâneur] e não os últimos passos da flâneuse.

Em seu livro sobre a arte de caminhar, Rebecca Solnit apresenta dados concretos que revelam o quanto a rua pertence ao homem (e aos seus prazeres), quando observa os fluxos de mulheres pelas ruas das cidades até o século XX. Além das prostitutas, poucas mulheres podiam sair livremente pelas ruas, sobretudo à noite. Apenas as prostitutas se aventuravam pelas ruas por prazer, tornando-se elas as únicas testemunhas desse contexto urbano, curiosamente explorado por autores homens em alguns romances do século XVIII. E elas não eram poucas, estima-se que em 1793 havia cerca de 50 mil prostitutas numa época em que Londres contava com apenas um milhão de habitantes. A rua representava para esse grupo social um espaço democrático, aberto a todos e cheio de possibilidades que não encontravam dentro dos bordéis, onde eram submetidas a regras e restrições (SOLNIT, 2002, pp. 242-244). É interessante observar que a função do caminhar para essas mulheres, não visava somente a sedução de seus clientes ou um modo de aquecer-se, mas uma tática para se livrar do aborrecimento e para tornar-se menos susceptíveis à polícia. Esse assunto é bastante significativo quando o corpo que se desloca na rua é feminino, pois a mulher no espaço público é frequentemente assediada e tratada como "coisa" pública.

A diferença de gênero percebida no contexto das deambulações urbanas deriva das desigualdades existentes no uso do espaço público, que não é um espaço acessível a todos. Distante de uma neutralidade, o espaço público revela conflitos e reflete organizações sociais estabelecidas fora do contexto da rua. Nadja Monnet afirma que a divisão entre público e privado, progressivamente imposta desde o final de século XVII contribuiu para a separação das funções e dos espaços reservados aos homens e às mulheres. Desse modo, a mulher foi relegada à esfera doméstica, teve sua liberdade de circulação restrita, transformando-se em "dona de casa". Por outro lado, crescia a ideia de superioridade e de dominação masculina. Embora essa ideologia burguesa tenha associado as mulheres ao espaço da casa, segundo Monnet isso não significou que elas não saíssem. Porém, seus percursos urbanos se restringiam às tarefas domésticas relacionadas à alimentação da família e aos cuidados com os filhos. Teresa Del Valle, em estudo sobre a mulher ocidental do século XXI, analisou itinerários femininos de diferentes épocas, revelando que eles se perpetuam e se parecem terrivelmente. Assim, ela constatou que por mais que na contemporaneidade as tarefas 
desvelamento não da cidade visível, mas daquela que não vemos, à qual dificilmente nos entregamos para conhecer. $O$ gesto de Eleonora, ao deslocar a experiência para o outro, tira o protagonismo da artista e o coloca na própria ação, cujo programa poderá ser vivido por qualquer pessoa ao qual tenha acesso.

Pensando nas desigualdades de gênero discutidas acima, vemos em Eleonora uma amostra de mulher completamente à vontade no espaço público. Não somente em Passeio na praça, mas em outras ações realizadas por ela, como Converso sobre qualquer assunto, Troco tudo ou Manchas, vemos uma mulher construindo com simplicidade seu espaço, seus círculos e suas interferências no contexto urbano. Não que tais desigualdades de gênero desapareçam, mas ela convive com elas e as enfrenta quando essas questões são trazidas por algum interlocutor. Quando o dispositivo se ancora na palavra, é na discussão aberta, falando sobre qualquer assunto, que ela apresenta uma presença feminina possível, sentada na cadeira da sua cozinha, trazendo o íntimo para habitar o público. Quando o dispositivo é o seu próprio corpo (em Toco Tudo ou em Manchas), ela assume o risco do encontro do seu corpo com o do outro e quando o dispositivo é outro material, como por exemplo o plástico, no caso de Manchas, ela inventa lugares distintos daqueles autorizados para uma mulher. Ela impõe sua presença, ocupando-se de afazeres pouco recorrentes para uma muIher no espaço público, tais como: não fazer nada, ficar de prosa batendo papo ou trocando suas roupas e pertences pessoais com quem passa por ela. Ou ainda, descansa, deitada no chão, quando o dispositivo é um livro de imagens de Claude Lévi-Strauss, retratando os índios nambikwaras do estado do Mato Grosso, na ação denominada Saudades do Brasil.

Outra performer que transita livremente pelo espaço público é a canadense Sylvie Cotton, que promoveu tipos diferentes de passeios ${ }^{39}$, resultando em encontros com desconhecidos e produções de desenhos e narrativas (que serão apresentadas no sexto capítulo). Em Promenades SETNJU (2004), a performer caminhou durante oito dias, por pelo menos três horas, de mãos dadas com desconhecidos na cidade de Pancevo na Sérvia. Ela caminhou ao lado de pessoas de 12 a 65 anos, em sua maioria mulheres, pedindo que a levassem a lugares com os quais tenham laços afetivos. Em seus relatos, Cotton revela que algumas dessas pessoas tendiam a levá-la a locais turísticos da cidade, entendendo que era isso que a interessaria. Porém, sua intenção era aproximar-se do universo pessoal desses desconhecidos, como uma forma de experimentar essa alteridade, através de seus espaços de afeto. Uma das jovens que caminhou ao seu lado, levou-a na casa de sua avó, na zona rural da cidade, um território que dificilmente acessaria como estrangeira. Essa moça decidiu lhe mostrar o refúgio onde seus pais a deixavam durante a guerra, como medida de segurança. Conforme relato da artista, todas as pessoas com quem caminhou acabaram fazendo confidências sobre suas experiências na guerra. Essa iniciativa gerou um material extremamente como-

${ }^{39}$ Mais informações sobre a performer no site: <http://www.sylviecotton.ca>. 
temos muita intimidade, as mãos carregam todos os vestígios da vida da pessoa, todos os lugares que ela tocou, tudo o que ela comeu e todos os seus processos de higiene íntima. As mãos têm temperaturas, umidades e texturas completamente diferentes. Há quem toque firmemente, quem escape ao toque e quem sue. Desse modo, passear de mãos dados é mais do que explorar o itinerário do outro, é ver o mundo ao lado de alguém, é um movimento de partilha de pontos de vista, de escolha de caminhos e de exploração de temporalidades.

De modo mais direto em relação às desigualdades de gênero, Natália Coehl propõe uma ação que poderia facilmente ter sido inspirada pela performance Portfolio of Doggedness, realizada por VALIE EXPORT em 1969, mas que na realidade não se inspirou em EXPORT. Nessa ação, já analisada no primeiro capítulo desta tese, EXPORT leva seu parceiro para passear, preso a uma coleira, fazendo as vezes de um cachorro. Em PET, de Natália Coehl, é ela mesma quem se propõe a usar a coleira, buscando transeuntes interessados em levá-la para passear, fazendo ela mesma as vezes do pet (uma alusão ao bichinho de estimação; ao filhote de um cachorro, no caso). A performer se apresenta elegantemente vestida, com um traje social preto, batom vermelho e cabelo bem composto. Ela adota poses elegantes em suas pausas, acomodando o seu corpo em posições de descanso, próximas ao corpo de quem a conduz. Natália, em sua incorporação pet, olha apaixonadamente para as pessoas que a conduzem, fiel e obediente como um pequeno cachorro deve ser. Nos momentos de deslocamento, ela caminha languidamente de quatro, deixando-se passivamente ser conduzida, pela coleira de pérolas presa ao seu pescoço. Nada disso aparece demasiado, em

Figura 17: Natalia Coehl - PET e Mário Filho - Cabeça de embalagem.

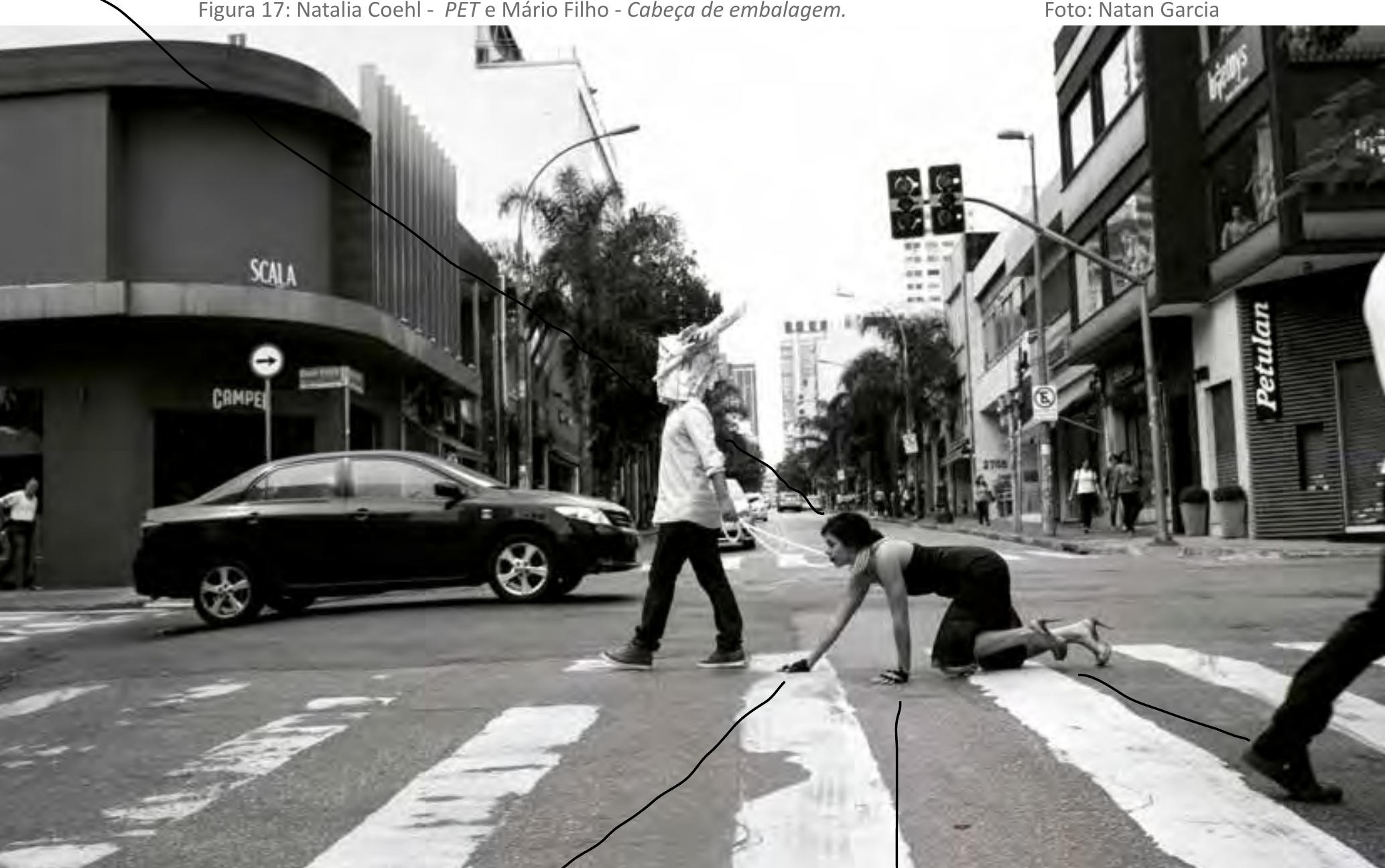


termos de teatralidade, pois a performer incorpora essa figura dentro dos limites possíveis ao seu corpo, dando sinais, por exemplo, quando não quer mais andar, quando se cansou ou quando gostaria de receber um cafuné.

Tal intervenção urbana coloca em questão valores enraizados na sociedade, mobilizando diferentemente homens e mulheres que se deparam com a figura de Natália em sua forma pet. Ao se sujeitar a essa ação, a performer evoca impulsos machistas e até mesmo fantasias sexuais, criticando um olhar de mercadoria endereçado às mulheres e causando revolta em outras, que não compactuam com tamanha reificação da figura feminina. Apoiada na ideia de que "compramos, padronizamos e vendemos nossos valores", a artista reproduz o ritual do passeio diário ao lado de seu dono, relacionado ao reduto do consumismo pet ${ }^{40}$. No release que apresenta a ação, a performer cita Richard Sennet, para quem "o desejo de neutralizar toda diferença, de domesticá-la, decorre de uma angústia em relação à diferença (...) um dos resultados é o enfraquecimento do impulso de cooperar com aqueles que se mantêm teimosamente Outros". Nesse sentido, ao se objetificar, a performer propõe justamente o contrário e, travestida de uma "cultura global de consumo", ela questiona a todos que cruzam com ela sobre o seu lugar de outro, o quanto se deixa levar, o quanto se padroniza repetindo valores com os quais não se identifica necessariamente. É como se cochichasse a cada mulher que passasse por ela: você é realmente livre?

Para concluir essa primeira categoria do caminhar, evoco a primeira parte de uma encenação teatral, realizada em São Paulo em 2009. Se muitos artistas (re)inventam a rua como o lugar onde o nada, o ócio ou a repetição de ações mecanizadas são cotidianamente exploradas, Heiner Müller atribui ao passeio uma perspectiva oposta, um movimento de transformação, de revolução, de profunda reivindicação de direitos populares. Há uma frase de Heiner Müller em Hamlet-máquina, na qual o intérprete de Hamlet diz que "a rebelião começa como um passeio". De uma parte, vê-se o dramaturgo evocando a caminhada aparentemente tranquila empregada em um passeio, como o ponto de partida para a revolta. Se não ocuparmos a cidade, sem a presença e a instauração de um acontecimento que nos coloque no corpo-a-corpo com a cidade, nenhuma mudança será efetivada. A frase em alemão é "Der Aufstand beginnt als Spaziergang", que indica que a insurreição, a rebelião, o tumulto ou a revolta começa como um passeio ${ }^{41}$.

O meu drama, se ainda tivesse lugar, realizar-se-ia na época da revolta. A rebelião começa como um passeio. Contra as normas do trânsito no horário de trabalho. A rua pertence aos pedestres. Aqui e ali um carro é virado. Pesadelo de um atirador de facas: lenta travessia através de uma rua de mão única na direção de um parque de estacionamento irrevogável no acostamento da rua. Quando o cortejo se aproxima da sede do governo, é barrado por um cordão de policiais. Formam-

\footnotetext{
${ }^{40}$ Material fornecido pela performer sobre sua ação.

${ }^{41}$ Tradução da frase em alemão realizada por Samir Signeu.
} 


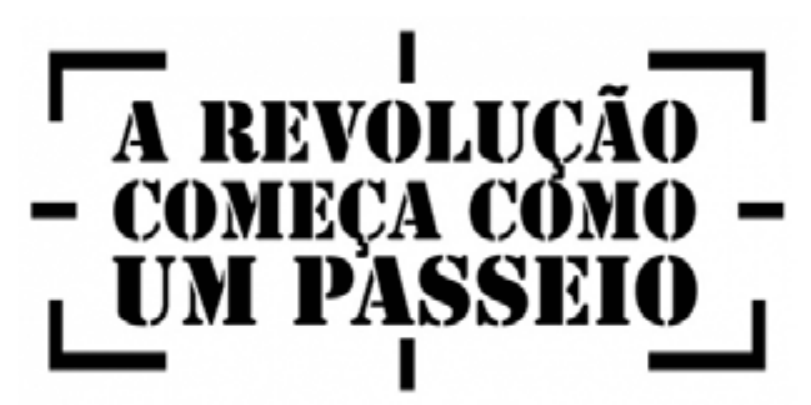

Imagem: Fernando Sato/Casadalapa

-se grupos de onde emergem oradores. Na sacada de um edifício governamental, aparece um homem com um fraque mal talhado e começa igualmente a discursar. Mal a primeira pedra o acerta, também ele se esconde atrás da porta de dois batentes de vidro blindado. $O$ apelo por mais liberdade transforma-se em grito pela derrubada do governo. Começa-se a desarmar os policiais, toma-se de assalto dois ou três edifícios, uma prisão, uma delegacia de polícia, uma agência da polícia secreta, penduram-se pelos pés uma dúzia de homens fortes do poder, o governo põe tropas na rua, tanques. O meu lugar, caso o meu drama se tivesse realizado, seria dos dois lados da frente, entre as frentes, acima delas. Encontro-me no cheiro de suor da multidão e jogo pedras em policiais, soldados, tanques, vidros à prova de bala (MÜLLER, 1987, p.29, grifo meu).

De outra parte, é possível constatar que a opção por andar a pé, ou seja, o mero uso das ruas pelas pessoas na vida cotidiana, como recusa a deslocar-se de transporte público ou carro, pode ser considerada uma ação política. É um modo de trazer a metrópole para uma dimensão mais humana. Ao caminhar, o sujeito recorta uma zona restrita da cidade para circular, para atuar, para cuidar e não se ilude com a falsa sensação de apropriação da cidade como um todo. Nossos domínios vão até onde nossas pernas nos levam, pois só quem olha de perto, olha junto e, de um campo de visão comum, apropria-se de algo. Quem conheceu de carro ou outro tipo de condução não viu, não impregnou-se da paisagem e portanto, não poderia dizer que conheceu um território. Isso não significa que as pessoas não devam ser conduzidas por algum meio de transporte, mas essa sociedade que se produz dia após dia que não coloca jamais os pés nas calçadas vive em bolhas cosmopolitas: de casa para o carro, do carro para o trabalho, entre estacionamentos e elevadores - estabelecendo uma relação quase virtual com a cidade concreta.

Tal frase (figura 18) foi usada como chamamento para uma montagem da Cia. São Jorge de Variedades, reunindo fragmentos de textos de Heiner Müller e que começa como um passeio pelo bairro da Barra Funda. A peça se intitula Quem não sabe mais quem é, o que é e onde está, precisa se mexer (2009) e se divide em duas partes. A primeira delas acontece em deambulação por alguns quarteirões ao lado da sede da companhia, onde acontece a segunda parte da encenação. Restringindo-me à primeira parte, alguns elementos merecem destaque. Quando o público, um grupo de umas 20 pessoas, chega à sede da São Jorge, recebe uma chave amarrada em uma fita vermelha. Essa é a marca de que integramos o conjunto de espectadores e podemos entrar no espaço cênico, depois de acompanhar as cenas de rua da peça. A caminhada começa com um chamamento discreto, pois dito em voz baixa, entre dentes - como se escondesse de alguém sua verdadeira intenção - realizado pela atriz Mariana Senne: "quem está comigo me acompanha". Ela chega sorrateiramente 

diferentes visualidades para suas identidades e totalmente vazio de discurso, de expectativa, de utopia, até o momento em que aparecem em cena as palavras de Rosa Luxembourg e o discurso revolucionário de Heiner Müller, que acaba por incitar a revolta iniciada literalmente com um passeio pela Barra Funda.

\section{$<<<>>>$}

Depois de apresentar essas análises, gostaria de destacar o fato de que um passeio é um modo de preencher o tempo, estabelecendo uma relação direta e não objetiva com a cidade. É a prática, por excelência, do flâneur, que poderá ser retomada por qualquer pessoa, a qualquer época, enquanto se mantiver a percepção de que a rua é um espaço público, de trânsito e de circulação de pessoas e mercadorias, mas não só. A rua é também um lugar de convívio e de definição das coreografias sociais e políticas, um espaço a ser reivindicado, um espaço aonde discursos podem ser redigidos, dependendo do modo como se permanece nela. É por isso que Thierry Davila afirma que o flâneur é indestrutível, justamente pelo fato de inventar experiências e (re)inventar formas de lidar com a cidade que contesta, mas que não deixa de habitar. É nesse sentido que diferentes artistas incorporam a estrutura do passeio em suas ações, convidando espectadores a caminhar prazerosamente pela cidade ou a observar e desfrutar de maneira mais efetiva de suas próprias caminhadas subjetivas. 


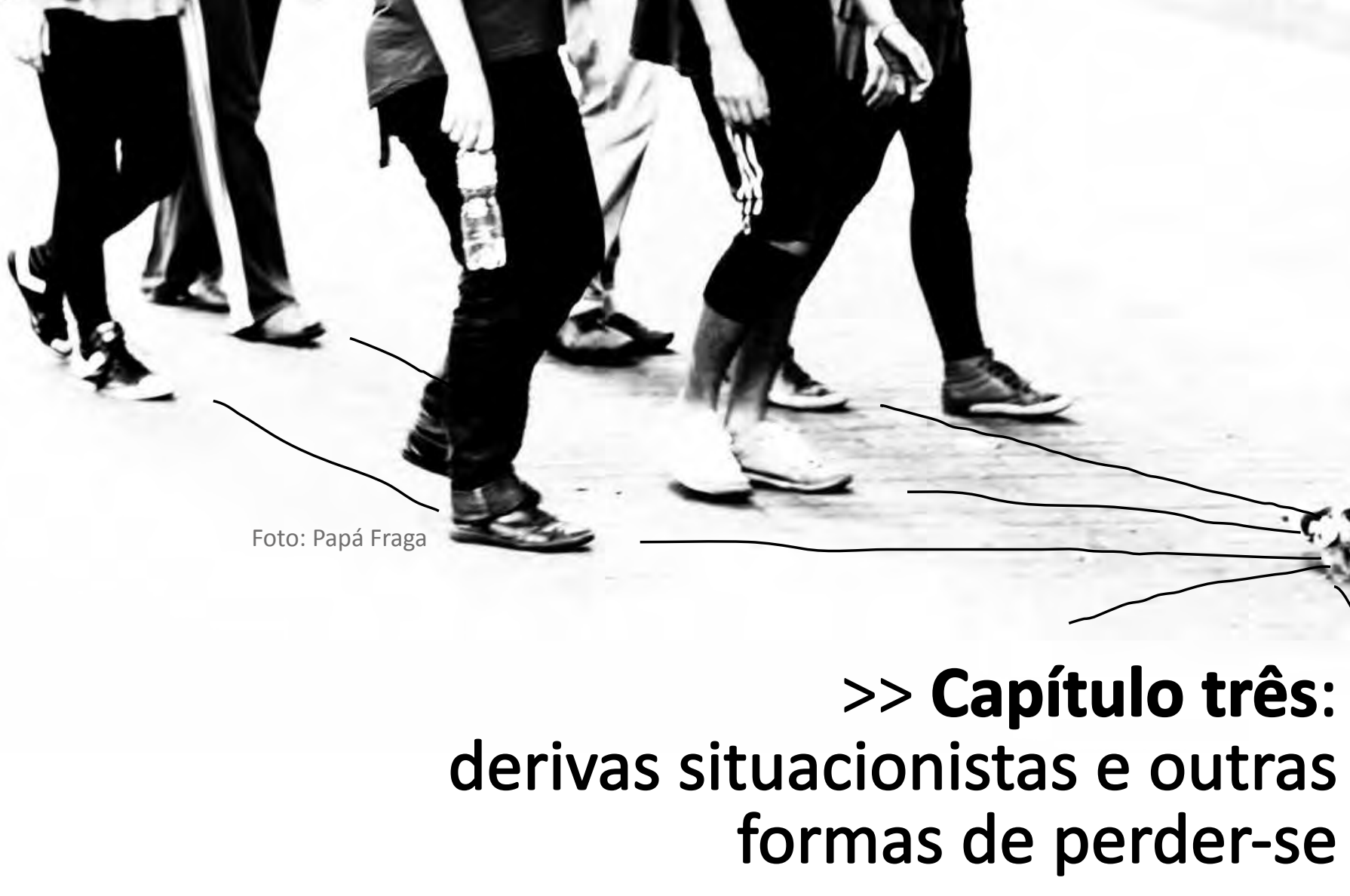

- Podia me dizer, por favor, qual é o caminho pra sair daqui? - Isso depende muito do lugar para onde você quer ir - disse o Gato.

- Não me importa muito onde... - disse Alice.

- Nesse caso não importa por onde você vá - disse o Gato.

- ...contanto que eu chegue em algum lugar - acrescentou Alice como

explicação.

- É claro que isso acontecerá - disse o Gato - desde que você ande durante algum tempo. Lewis Carroll

[nota sobre o capítulo: no presente capítulo, apresento mais uma modalidade do caminhar sedimentada na deriva, como forma de perder-se no contexto urbano. Parto da maior referência sobre o assunto: o movimento situacionista e o ideário do jovem Guy Debord. Em seguida, apresento a pesquisa do Coletivo Dodecafônico sobre esse tema, bem como algumas derivas realizadas durante meu período de estudos na França. Além disso, outras práticas teatrais e performativas também são evocadas, mostrando a inscrição desse tipo de exploração do território urbano no campo das artes. Ao final do capítulo, um conjunto de ações articuladas em torno de fugas e perseguições também são apresentadas, pois muitos artistas exploram os itinerários alheios como forma de se aproximarem diferentemente das cidades percorridas. Dentro da cartografia de ações reunidas aqui, a deriva se destaca como modalidade mais amplamente investigada. Por esse motivo, ela se estabelece como uma referência para as outras categorias estudadas nos capítulos dois, quatro e cinco.] 
[deriva]: caminhada aleatória realizada prioritariamente no contexto urbano. O percurso definido em uma deriva nunca coincide com uma linha reta, nem com a distância mais curta entre dois pontos. Trata-se de um caminhar sem rumo, deixando-se levar pelo sabor dos acontecimentos e pelas pessoas que eventualmente se encontra pelo caminho. Pode durar algumas horas e até mesmo dias. Em uma deriva, experimenta-se a sensação de perder-se, mesmo em um espaço conhecido. Porém, o que está em jogo é mais a perda de tempo do que o ato de perder-se. Pode ser associada à vagabundagem e à boemia. Pode ser realizada só ou na companhia de outras pessoas, raramente acontece em grupos muito grandes. Guy Debord e o movimento situacionista são referências quando o assunto é deriva.

\section{> I. Derivas situacionistas e a exploração do acaso}

Il faut systématiquement explorer le hasard
[É preciso explorar sistematicamente o acaso]
Slogan Maio de 1968

No primeiro capítulo desta tese, introduzi a discussão sobre deriva como um modo de apresentar a noção de encenação em deriva: uma abordagem sobre o estado atual da cena contemporânea, tida como impermanente, movediça e intimamente vinculada ao real. Antes de abordar a noção de deriva propriamente dita, apresento um panorama do contexto histórico no qual as práticas situacionistas apareceram. Tendo Guy Debord como figura central do movimento, a complexidade de sua teoria não permite que se discuta deriva sem abordar a ideia de situação construída, a psicogeografia e a prática do desvio ou apropriação, amplamente exploradas em suas criações textuais, plásticas e cinematográficas. Sem a intenção de restringir os estudos sobre deriva à prática situacionista - por isso apresento práticas de inúmeros artistas que exploraram táticas para perder-se em um momento pós-situacionista - não parece coerente recusar essa filiação. Afinal, dos artistas analisados aqui nenhum deles parece negar a deriva situacionista como fonte de inspiração, mesmo que para Debord e seus companheiros a deriva não se configure como uma prática artística.

Paola Berenstein Jacques, que estudou os situacionistas no já citado "Elogio aos errantes", reforça a ausência dessa intenção artística nas derivas e afirma que assim como os tropicalistas no Brasil, os "situacionistas acreditavam que a revolução precisaria passar pela vida cotidiana, e não poderia ser programada" (JACQUES, 2012, p. 209). Como prova dessa 
intenção de modificar os modos de agir e de operar nas esferas da vida, Debord realizou a conferência "Perspectivas de modificações conscientes na vida cotidiana", no grupo de pesquisa de Henri Lefebvre, no Centro Nacional de Pesquisa Científica da França (CNRS) em 17 de maio de 1961. É curioso notar na ótica de Debord, que a ação na esfera da vida impediria a consumação de uma atividade artística, como se a arte não fosse suficientemente potente para acionar dispositivos de vida. Ou antes, como se arte e vida não pudessem ser associadas ou como se o fato de se tratar de uma ação artística retirasse a discussão da esfera da vida. Trata-se de um assunto bastante discutido na contemporaneidade (para alguns, até mesmo exaustivamente retomado, mas não esgotado). A arte se constrói em relação e em contato direto com a vida, utilizando-se cada vez mais do real como material de composição.

\section{_a deriva como ato estético e político [primeiro estudo sobre a participação]}

A respeito das interações entre estética e política, Jacques Rancière elencou em seu livro "A partilha do sensível" algumas categorias centrais para se pensar a criação artística do século XX. São elas: a modernidade, a vanguarda e a pós-modernidade. Para isso, ele explica os diferentes regimes de identificação reconhecidos na tradição ocidental: o ético das imagens (grosso modo, a maneira pela qual as imagens artísticas promovem certa educação aos cidadãos), o poético (ou regime representativo, pois "é a noção de representação ou mimesis que organiza suas maneiras de fazer, ver e julgar") e o estético. É interessante destacar que o autor não entende a mimesis "como um procedimento artístico, mas um regime de visibilidade das artes" (RANCIÈRE, 2012, p. 31). Entretanto, é ao regime estético das artes que gostaria de me ater, pois ao meu ver ele responde à questão exposta anteriormente: por que o fato de uma ação ser considerada artística a torna menos revolucionária do que outras experiências da esfera coletiva?

\footnotetext{
O regime estético das artes é aquele que propriamente identifica a arte no singular e desobriga essa arte de toda e qualquer regra específica, de toda hierarquia de temas, gêneros e artes. Mas, ao fazê-lo, ele impede a barreira mimética que distinguia as maneiras de fazer arte das outras maneiras de fazer e separava suas regras da ordem das ocupações sociais. Ele afirma a absoluta singularidade da arte e destrói ao mesmo tempo todo critério pragmático dessa singularidade. Funda, a uma só vez, a autonomia da arte e a identidade de suas formas com as formas pelas quais a vida se forma a si mesma (Ibid.).
}

O autor associará esse regime ao que foi confusamente designado como modernidade. $E$ a respeito dessas confusões em torno do conceito de modernidade, ele destaca dois aspectos que contribuíram para a falência do modelo teleológico da modernidade. Segundo Rancière, ambos se apoiam em uma contradição dentro desse regime estético, que faz da 
arte uma forma autônoma da vida e que, além de afirmar a autonomia da arte, também afirma uma suposta auto formação da vida. Como se a vida estivesse realmente ao alcance das escolhas de cada um de nós ou, dito de outro modo, como se fossemos realmente autônomos na configuração de nossas próprias vidas. O primeiro aspecto, que se refere à autonomia da arte, uma "revolução antimimética", levaria a arte ao encontro de uma forma pura. Ou seja, o eterno retorno da arte àquilo que lhe é próprio, uma busca pela essência de cada linguagem separadamente, sem misturas, sem hibridismos. Desse primeiro aspecto decorre uma ideia de crise da arte, como derrota de um paradigma simplista, relativo à especificidade das artes, que, assim como afasta a mistura entre as artes, os gêneros e os suportes, afasta a arte da política. $\mathrm{O}$ segundo aspecto se refere ao que o autor chama de modernitarismo: "a identificação das formas do regime estético das artes às formas de execução de uma tarefa ou de um destino próprio da modernidade"(Ibid., p.39). A determinação da arte como forma e como auto formação da vida é a base dessa identificação, que remonta ao ideário de Schiller e à noção de educação estética do homem. Essa noção propõe um modo específico de habitação do mundo sensível, desenvolvido pela educação estética a fim de formar "homens capazes de viver numa comunidade política livre" (Ibid.). Desse modo, essa revolução estética teria produzido uma nova ideia de revolução política, sendo que a falência da revolução política resultou na falência desse modelo estético.

É nesse contexto histórico-estético que se encontram os situacionistas e o paradoxo identificado no cerne de suas propostas, ao mesmo tempo, vanguardistas e revolucionárias. Para Rancière, há na noção de vanguarda algo que convém à visão modernista: a intenção de conectar o estético e o político. Ele identifica duas ideias de vanguarda, uma topográfica e militar ("da força que marcha à frente, que detém a inteligência do movimento, concentra suas forças, determina o sentido da evolução histórica e escolhe as orientações políticas subjetivas") e outra "que se enraíza na antecipação estética do futuro, segundo o modelo schilleriano". Desse modo, o conceito de vanguarda teria um sentido dentro do regime estético das artes, não por apresentar novidades artísticas, mas pela "invenção de formas sensíveis e dos limites materiais de uma vida por vir. É isso que a vanguarda 'estética' trouxe à vanguarda 'política', ou que ela quis ou acreditou Ihe trazer, transformando a política em programa total de vida" (Ibid., p. 43).

Paola Berenstein Jacques chama a atenção ainda para o fato de que tanto os situacionistas quanto os tropicalistas defendem a participação como modo de se opor à espetacularização da vida. A autora afirma que Debord propunha a transformação dos espectadores em 'vivenciadores', enquanto Oiticica propunha a transformação dos espectadores em 'participadores'. Segundo ela, "o principal antídoto contra o espetáculo seria o seu oposto: a participação ativa dos indivíduos em todos os campos da vida social, principalmente no cultural" (JACQUES, 2012, p. 206). A luta contra o espetáculo é abrangente e se refere à cultura do 
espetacular, amplamente disseminada em muitas esferas da vida. Ela diz respeito à espetacularização em geral e não ao espetáculo restrito ao campo das artes. Desse ponto de vista, ir de encontro ao espetáculo significa contestar a alienação e a passividade da sociedade. Debord fala em ampliar a parte não medíocre da vida e negar-se a ocupar o tempo apenas de maneira produtiva.

A questão da participação foi e continua sendo revista, pelos próprios situacionistas e mais recentemente por pelo menos três autores que merecem ser estudados. São eles: Nicolas Bourriaud e Claire Bishop (cuja visão será desenvolvida no último capítulo), além de Jacques Rancière, cujo esforço em revelar a relação intrínseca entre estética e política já foi mencionado aqui. Inicialmente, os situacionistas pregavam a participação ativa dos cidadãos, que ao construírem situações, chegariam à transformação revolucionária da vida cotidiana. No entanto, eles tinham consciência de que a própria noção de participação poderia ser tomada apenas parcialmente como uma pseudoparticipação, ou ainda que ela poderia ser espetacularizada. Para Paola Berenstein Jacques, no campo das artes, essa discussão perdeu muito do seu potencial político. Nicolas Bourriaud, com sua estética relacional uma teoria que visa observar obras de arte em função das relações interhumanas que elas produzem ou suscitam - considera a prática artística contemporânea como um rico terreno de experimentações sociais, no qual se desenham utopias de proximidade.

Inspirado pelas ideias filosóficas e políticas de Louis Althusser, em particular no que se refere ao materialismo do encontro ou materialismo aleatório, Bourriaud edificou sua estética relacional. Ele também retoma a noção de situação construída, na qual Guy Debord e os situacionistas optam pela esfera do jogo, em detrimento da arte, para empreender uma revolução na vida cotidiana.

\footnotetext{
A essência da prática artística residiria assim na invenção de relações entre sujeitos; cada obra de arte particular seria a proposição de habitar um mundo em comum, e o trabalho de cada artista, um feixe de relações com o mundo, que geraria outras relações, e assim em seguida, ao infinito (BOURRIAUD, 1998, pp. $20-21)^{1}$.
}

A fim de investigar as proposições de relação com o mundo e entre as pessoas, Bourriaud retoma a teoria situacionista sobre o espetáculo que também investiga a relação entre pessoas, porém, mediada pelas imagens. Embora o autor considere o diagnóstico de Debord sobre o processo de produção espetacular implacável, Bourriaud observa que o situacionista teria negligenciado o fato de que o espetáculo só poderia ser combatido por meio da produção de novos modos de relação entre as pessoas. Nesse estudo, ele afirma que a

${ }_{1}$ L'essence de la pratique artistique résiderait ainsi dans l'invention de relations entre des sujets; chaque oeuvre d'art particulière serait la proposition d'habiter un monde en commun, et le travail de chaque artiste, un faisceau de rapports avec le monde, qui générerait d'autres rapports, et ainsi de suíte, à l'infini (tradução minha). 
participação do espectador, inicialmente estimulada pelos happenings, preconizados por Allan Kaprow, e pelas performances do grupo Fluxus, tornou-se uma constante na prática artística. Essa ideia de interação, contudo, ultrapassa o domínio artístico e se estende para o domínio das comunicações, com o suporte das novas tecnologias e da internet, como "um desejo coletivo de criar novos espaços de convívio e instaurar novos tipos de transação diante do objeto cultural"(Ibid., p. 26)². Bourriaud conclui seu pensamento afirmando que a sociedade do espetáculo se torna, a partir de então, uma sociedade de figurantes em busca de canais de comunicação, que de fato apenas auxiliam a criação nessa sociedade da ilusão de uma democracia interativa. Entretanto, esse autor acredita que as obras de arte relacionais colaboram para atualizar o situacionismo e reconciliá-lo com o mundo das artes.

Debord escreve em 1959, citando Constant e a via do Urbanismo Unitário, que uma arte popular não pode corresponder atualmente às concepções do povo, pois enquanto o povo não participar ativamente da criação artística, ele conceberá somente os formalismos socialmente impostos (2004, p. 449). Acrescenta, nesse mesmo texto, que não há liberdade no emprego do tempo sem a posse dos instrumentos modernos de construção da vida cotidiana e que o uso desses instrumentos marcaria um salto de uma arte revolucionária utópica a uma arte revolucionária experimental. Desse modo, a obra de Debord é concebida como teoria revolucionária e não por acaso acabará inspirando o movimento de maio de 1968 na França.

Para Paola Berenstein Jacques, há uma progressiva perda de força e potência crítica na prática artística que imprime no ato de caminhar sua marca criativa após 1980, o que a levaria inclusive a adotar características espetaculares. Ainda que a autora possa encontrar exemplos para justificar sua análise, o livro de Jacopo Crivelli Visconti "Novas Derivas" (Martins Fontes, 2014) prova o contrário, pois reúne um vasto material de artistas errantes que desenvolvem "derivas artísticas ontologicamente 'novas', ou outras, se comparadas com a matriz situacionista" (VISCONTI, 2014, p. X-introdução). É nesse sentido que o autor afirma que no final dos anos 1960, à medida em que os situacionistas migravam para práticas cada vez mais engajadas politicamente, a prática da deriva como ação de cunho artístico firmava-se mundialmente como tipologia autônoma e reconhecida.

Interessa no âmbito deste estudo ressaltar que a consideração do fim da arte pelos situacionistas levou Debord a produzir obras em deslocamento: seja por meio de derivas, filmes ou desvios [détournements]. Nas derivas, o deslocamento é físico e concreto. Nos filmes, é a câmera que se desloca, produzindo um traço visual da apreensão do cineasta da experiência de deslocar-se. Nos desvios, há um deslocamento de um fragmento de texto ou de uma

\footnotetext{
${ }^{2}$ Un désir collectif de créer de nouveaux espaces de convivialité et d'instaurer de nouveaux types de transaction face à l'objet culturel (tradução minha).
} 
imagem para uma composição derivada de outras. $\mathrm{O}$ ato de caminhar the permitiria agir diretamente na vida. Infelizmente, Debord não reconheceu na performance uma linguagem possível para o seu exercício, como uma prática artística para si, ou antes, não reconheceu o potencial performático de suas proposições. A performance pode não se configurar como um produto e pode não ser tomada como uma mercadoria. Ela pode ser suficientemente invisível e constituir-se como uma intervenção no cotidiano, uma interferência no real.

A deriva era tida pelo jovem Debord como uma prática comparável à experiência amorosa. Em carta endereçada à Ivan Chtcheglov", ele afirma: "estou calmo, mas passei um dia atroz ao invés de um dia de amor e derivas" ${ }^{4}$. Nessa mesma carta, ele considera que a vida nos dá motivos suficientes para vivermos dias atrozes, revelando seu olhar crítico e a sua insatisfação diante do mundo que presenciou. Não paro de pensar enquanto estudo as práticas situacionistas em paralelo à noção de performance, o quanto a adoção da performance como linguagem artística poderia ter sido uma solução para o paradoxo entre a arte e a revolução vivido por Debord.

\section{_Guy Debord e a superação da arte: do Movimento Letrista ao Movimento Situacionista}

O autor que inicialmente escreveu sobre deriva, o poeta e cineasta Guy Debord poderia ser considerado paradoxalmente como o último dos artistas de vanguarda e como o último dos revolucionários. Apesar de seu pioneirismo como detonador de dois movimentos de vanguarda - a Internacional Letrista (1952-1957) e a Internacional Situacionista (1957-1972), depois dele não pode-se dizer que tenha havido outro artista de vanguarda. Como último revolucionário, Debord influenciou enormemente os movimentos contestatórios e a cultura da segunda metade do século XX. Foi ele quem escreveu, em 1953, nos muros de Paris: "Ne travaillez jamais" [Não trabalhem nunca]. E segundo os organizadores da exposição Guy Debord - un art de la guerre [Guy Debord - uma arte da guerra] ${ }^{5}$, ele nunca trabalhou mesmo; ao invés disso andou bastante pelas ruas de Paris, também bebeu e leu com igual intensidade. No final de sua vida, interrompida por ele mesmo de forma abrupta em 1994, o autor condenava a sociedade do espetáculo, o uso do tempo exclusivamente a favor do capital e havia abandonado progressivamente suas atividades artísticas, recusando-se a

\footnotetext{
3 Ivan Chtcheglov ficaria conhecido pelo codinome Gilles Ivan. Em Formulaire pour un urbanisme nouveau [Formulário para um novo urbanismo], publicado na I.S. no.1, ele inicia o texto com a seguinte frase: "Sire, je suis de l'autre pays" [Senhor, sou de outro país]. Nascido na França, era filho de pai ucraniano e mãe francesa.

${ }^{4}$ Je suis calme, mais j'ai passé une journée atroce à la place d'une journée d'amour et de derive (tradução minha). Trecho retirado de Guy Debord - Ivan Chtcheglov: correspondance croisée [Guy Debord - Ivan Chtcheglov: correspondências cruzadas], documento pesquisado no Fond Guy Debord, na BNF.

${ }^{5}$ Exposição realizada na Bibliothèque Nationale de France - BNF, na Grande Galeria da unidade FrançoisMiterrand, entre 27 de março e 13 de julho de 2013.
} 
produzir mais mercadorias para o chamado mercado das artes.

Uma breve retrospectiva será suficiente para percebermos o quanto o movimento situacionista é indissociável do contexto intelectual e cultural no qual estava inserido. Ele surge a partir de uma divergência no âmbito de um movimento anterior, a Internacional Letrista (IL). No final da segunda Guerra Mundial, Isidore Isou decide dar continuidade à história das vanguardas, fundando um movimento chamado Letrismo. Isou propunha não a morte da arte, mas o desaparecimento das artes tal qual eram conhecidas naquele momento, para que elas pudessem dar espaço a novas formas de arte. Na ocasião do Festival de Cinema de Cannes, em 1951, ao assistir ao filme de Isidore Isou (Traité de bave et d'éternité), Guy Debord encontra os letristas e passa a integrar o movimento. No ano seguinte, Debord e Gil Worman, juntamente com Serge Berna, Jean-Louis Brau, Ivan Chtcheglov e Michèle Berstein (futura esposa de Debord), entre outros, fundam a Internacional Letrista, braço mais politizado e belicoso do Letrismo, que em pouco tempo se constituirá como uma oposição à autoridade de seu fundador: Isodore Isou. Em novembro desse mesmo ano, os letristas protestaram contra a recepção a Charles Chaplin, organizada pelo responsável pela polícia de Paris, provocando um escândalo que foi veementemente desaprovado por Isidore Isou. Desse modo, consumou-se sua ruptura com os letristas.

Desde o início a Internacional Letrista visava a superação da arte. Havia um interesse em tornar a vida uma forma de arte, ou seja, organizar circunstâncias da vida cotidiana de tal modo que experiências intensas fossem multiplicadas. Vêm desse momento, pré-situacionista, os fundamentos da ideia de situação construída, que anos mais tarde daria nome ao Movimento Situacionista. Em 1953, Ivan Chtcheglov6 apresenta com maior precisão as modalidades dessa superação da arte: experimentar formas de vida alternativas e intervir sobre o meio urbano. Nesse sentido, a ambiência de um bairro dependeria de sua composição social e da fisionomia de sua arquitetura, que por sua vez determinariam os encontros que se produziriam ali (MARCOLINI, 2013, p. 8). A partir de então, alguns fatos importantes se sucedem: a publicação do boletim Potlatch - a revista da IL (1954 - 1957); a colaboração com os surrealistas belgas, reunidos em torno da revista Les Lèvres Nues (1954 - 1959); a aproximação do pintor dinamarquês Asger Jorn, juntamente com seu Mouvement pour un Bauhaus imaginiste [Movimento por uma Bauhaus imaginista (MIBI)] ${ }^{7}$. Sendo assim, em julho de 1957 em uma Conferência realizada em Cosio d'Arroscia, na Itália, esses grupos - IL e MIBI - se uniram, integrando também Ralphy Rumney e seu Comité Psicogeográfico de

\footnotetext{
${ }^{6}$ O texto foi consultado no Fundo Guy Debord da BNF, em versão datilografada. Versão em português no livro: Apologia da deriva. Escritos Situacionistas sobre a cidade, de Paola Berenstein Jacques. Rio de Janeiro: Casa da Palavra, 2003, pp.67-73.

7 O MIBI pode ser considerado como uma tentativa de prolongar e aprofundar as pesquisas do movimento COBRA, um grupo constituído por uma corrente marginal do surrealismo na Europa do Norte. O nome evoca as cidades dos principais países onde o movimento existiu entre 1948 e 1951: COpenhague - BRuxelas Amsterdam (MARCOLINI, 2013, p. 21).
} 
Londres e formando assim uma nova organização, a Internacional Situacionista (IS).

Desde a revista Potlatch os assuntos do interesse desse grupo migraram da arte para a superação da arte e do surrealismo, das relações entre a arte e a vida, da vida cotidiana em geral, até chegar à questões relacionadas à arquitetura, ao urbanismo e à crítica ao funcionalismo moderno. Ou seja, a partir de 1954, os membros da IL lançaram as ideias centrais do pensamento urbano situacionista: a psicogeografia, a deriva e a construção de situações. A psicogeografia é tida como o estudo sobre os efeitos do meio geográfico agindo diretamente sobre o comportamento afetivo dos indivíduos e a deriva, como uma técnica de passagem rápida por diferentes ambiências (como já mencionado no primeiro capítulo). Vale ressaltar que no texto "Formulaire pour un urbanisme nouveau" [Formulário para um novo urbanismo], Gilles Ivan faz um relato no qual descreve um percurso realizado por Paris. Inicia dizendo o quanto se aborrece na cidade e o quanto se cansa ao tentar descobrir algum mistério por trás dos letreiros expostos na via pública. Cita uma sequência de nomes de estabelecimentos comerciais, cada um em uma linha, usando sempre letras maiúsculas, como se lesse letreiros ao longo de um percurso. Em seguida, descreve o que vê, transformando em texto tais visões da cidade.

\footnotetext{
E a piscina da rua das Meninas. E a delegacia de polícia da Rua do Encontro. A clínica médico-cirúrgica e a agência de empregos do cais dos Ourives. As flores artificiais da rua do Sol. O hotel dos Porões do Castelo, o Bar do Oceano e o Café Vai e Vem. O hotel da Época. E a estranha estátua do Doutor Philippe Pinel, benfeitor dos alienados, que agoniza nas últimas noites do verão. Explorar Paris. ${ }^{8}$
}

Optei por traduzir também os nomes das ruas para marcar o aspecto poético dessa escritura, que aparentemente não se refere a um percurso verdadeiro. Porém, os nomes das ruas não são falsos e elas poderiam ter feito parte de um único trajeto, ou de um conjunto de trajetos percorridos pelo autor nessa mesma região, pois todas elas se concentram na parte nordeste de Paris (entre os arrondissements 12, 18 e 20). Alguns dos locais citados por Gilles Ivan ainda existem: a piscina da rue des Fillettes (Piscine Municipale Hébert), o café Va et Vient (localizado na Place Félix Éboué) e a estátua do Doutor Pinel (localizada em frente à Gare d'Austerlitz). O autor finaliza esse excerto com um convite: explorar Paris. E é justamente isso que vemos aqui: um relato de uma experiência exploratória da cidade, que revela ao mesmo tempo a prática da deriva e os efeitos de diferentes ambiências nos afetos desse autor-errante. A escolha das ruas citadas é bastante significativa e há um jogo entre

\footnotetext{
${ }^{8}$ Et la piscine de la rue des Filletes. Et le commissariat de police de la rue du Rendez-vous. La clinique médicochirurgicale et le bureau de placement gratuit du quai des Orfèvres. Les fleurs artificielles de la rue du Soleil. L'hôtel des Caves du Château, le bar de l'Océan et le Café Va et Vient. L'hôtel de l'Époque. Et l'étrange statue au Docteur Philippe Pinel, bienfaiteur des aliénés, qui agonise dans les derniers soirs de l'été. Explorer Paris (tradução minha). CHTCHEGLOV, Ivan. Formulaire pour un urbanisme nouveau [Formulário para um novo urbanismo], publicado na I.S. no.1, em junho de 1958. O texto foi consultado no Fundo Guy Debord da BNF, em versão datilografada.
} 
esses nomes e o que se encontra em cada rua: uma piscina na rua das meninas, uma delegacia na rua do encontro, uma agência de empregos na rua dos ourives. Do mesmo modo, parece proposital o posicionamento do bar do oceano ao lado do café vai e vem. O relato não se constitui de maneira distanciada do ponto de vista do observador, uma vez que ele revela seus afetos ao apontar a estranheza da estátua que agoniza.

Outro aspecto possível de ser apreendido a partir da leitura desse texto é a passagem da análise da vida cotidiana, por meio da descrição da paisagem, a uma crítica da arquitetura e do urbanismo. Mais adiante no texto, o autor se refere a Le Corbusier, afirmando que seu estilo convém às usinas, aos hospitais e às prisões e que o uso do concreto armado em suas criações acaba por esmagar o homem. Critica ainda as salas climatizadas, que fazem com que as noites e o verão percam seu charme e que a alvorada desapareça. Ele adverte que o homem das cidades (modernas) se distancia da realidade e já não sonha. E a razão evidente para tal feito é que o sonho tem como ponto de partida e como espaço de realização a própria realidade, mas uma vez que esse homem se encontra distante da realidade, ele já não é mais capaz de sonhar.

\footnotetext{
A arquitetura é o meio mais simples de articular tempo e espaço, de modular a realidade, de fazer sonhar. Não se trata apenas de articulação e de modulação plásticas, expressão fugaz da beleza. Mas de uma modulação influencial, que se inscreve na curva eterna dos desejos humanos e dos progressos na realização dos desejos. A arquitetura de amanhã será portanto um meio de modificar as atuais concepções de tempo e de espaço. Será um meio de conhecimento e um meio de agir. ${ }^{9}$.
}

No texto supracitado, Chtcheglov refere-se a um novo urbanismo (1958). Tais ideias lançariam as bases do que viria a ser o conceito de urbanismo unitário, considerado no final da década de 50 como a primeira tarefa e o objetivo principal dos situacionistas. Ao vislumbrar uma nova arquitetura, os situacionistas almejavam a construção de uma nova civilização. O urbanismo unitário, como bem sintetizou Francesco Careri pode ser entendido como um experimentalismo, uma tendência a certa interdisciplinaridade unificante, como crítica aos princípios da arquitetura moderna. O maior representante dessa arquitetura é Le Corbusier, cujos conjuntos habitacionais monótonos e repetitivos pareciam tratar a vida cotidiana como embalagem, na visão de Lefebvre. Além disso, as ideias de separar as pessoas e a cidade em grupos de acordo com suas funções, encarcerava os cidadãos em suas máquinas de morar. "A casa como máquina de morar" é uma ideia defendida por Le Corbusier, igual-

\footnotetext{
${ }^{9}$ L'architecture est le plus simple moyen d'articuler le temps et l'espace, de moduler la réalité, de faire rêver. Il ne s'agit pas seulement d'articulation et de modulation plastiques, expression d'une beauté passagère. Mais d'une modulation influentielle, qui s'inscrit dans la courbe éternelle des désirs humains et des progrès dans la réalisation de ces désirs. L'architecture de demain sera donc un moyen de modifier les conceptions actuelles du temps et de l'espace. Elle sera un moyen de connaissance et un moyen d'agir (tradução minha). Excerto do mesmo texto de Ivan CHTCHEGLOV, citado na nota anterior.
} 
mente criticada pelos situacionistas e mundialmente difundida, chegando a influenciar a proposta urbanística de Lúcio Costa na invenção da nossa capital federal: Brasília.

O combate dos situacionistas à arquitetura moderna os leva a idealizar casas móveis que giram junto com o sol (por Gilles Ivan, no mesmo texto supracitado) e uma cidade nômade: a New Babylon (pelo holandês Constant), uma cidade imaginária do futuro, da qual apenas maquetes foram realizadas. Trata-se um projeto utópico e ao mesmo tempo tecno-futurista, calcado sobre a esperança de uma mecanização avançada que tornaria o trabalho humano obsoleto. Sendo liberados do trabalho, os habitantes dessa cidade poderiam se dedicar ao trabalho criativo e teriam a deriva como sua atividade principal.

No início dos anos 1960, entretanto, os situacionistas passaram a temer os aspectos formais dessa cidade visionária, cujos meios de produção continuariam dependendo de um trabalho alienado. Ou seja, o projeto da New Babylon não levava em consideração a crítica social aos modo de produção, nem inventava outras relações possíveis entre trabalhadores e arquitetura. Ele repetia o que os situacionistas criticavam na arquitetura moderna, uma produção centrada no trabalho alienado de quem a constrói. Desse modo, nota-se que o fascínio inicial pela tecnologia dá lugar a uma leitura crítica sobre a banalização da mercadoria e uma reflexão sobre os modos de produção presentes no sistema capitalista. Em $A$ Sociedade do Espetáculo, Debord desenvolverá a ideia de espetáculo como um modo de socialização no qual os homens são cada vez mais dominados pela economia e, nesse sentido, as técnicas e modos de organização adotados por essa sociedade contribuiriam para reforçar esse domínio. Assim, a partir da década de 1970, nota-se na obra de Debord uma crítica à ciência e à técnica alienada pelo capitalismo.

\section{_situação construída: a prática (performática) dos Situacionistas}

Muito cedo em sua trajetória, antes mesmo de sua adesão à Internacional Letrista, Debord já considera o fim da arte como um fato dado. "A poesia só sobreviverá com sua destruição. É preciso lançar-se em toda aventura intelectual suscetível de re-apaixonar a vida"(DEBORD, 2004, p.86) ${ }^{10}$. Segundo ele, a superação da arte só poderia acontecer na medida em que houvesse uma transformação qualitativa da vida cotidiana. Destruir a poesia e tornar a vida cada vez mais apaixonante. Patrick Marcolini cita um manifesto de Debord - Manifeste pour l'éternité de la violence [Manifesto pela eternidade da violência] - no qual ele defende a morte da ideia de criação artística e afirma que toda manifestação neo-artística se alinha a partir daquele momento com a categoria 'propaganda'. A propaganda, por sua vez, es-

\footnotetext{
${ }^{10}$ La poésie ne survivra que dans sa destruction. [...] II faut se lancer dans toute aventure intellectuelle susceptible de 'repassioner' la vie (tradução minha).
} 
taria associada ao escândalo e à provocação, como um subproduto da ação (MARCOLINI, 2013, p. 55). O autor cita a seguir o célebre escândalo da Notre-Dame, que monopolizou a imprensa francesa em 1950. Nessa ocasião, um pequeno grupo de agitadores infiltrou-se na catedral Notre-Dame de Paris e conseguiu fazer com que um deles, disfarçado de dominicano, realizasse um discurso proclamando a morte de Deus, diante de mais de dez mil fiéis. A blasfêmia foi descoberta e o grupo foi perseguido por um bando de cristãos em cólera e acabaram sendo salvos de um linchamento pela chegada da polícia que dissipou o acontecido. Embora a ação tenha ocorrido anteriormente à criação da I.L., seus membros a reivindicam como seu crime fundador.

O evento será retomado algumas vezes por Debord em versões distintas do roteiro de seu filme Hurlements en faveur de Sade [Gritos a favor de Sade], nos quais ele considera a possibilidade de que uma estátua em homenagem à Serge Berna - autor do texto blasfêmico - fosse construída ou que diversas catedrais fossem erguidas em sua memória. Tal ação, realizada no plano concreto, sem separação com a vida, poderia ser interpretada alguns anos mais tarde como uma performance ou um escrache ${ }^{11}$.

O exemplo do escândalo da Notre-Dame remete à questão central do movimento situacionista: a construção de situações. Embora ela dê nome ao Movimento, essa questão gerou uma produção insuficiente de reflexão da parte dos situacionistas. O próprio Debord reconhece que essa noção é a menos clara e a mais aberta dentre as questões discutidas pelo grupo. Há diversos estudos que buscam identificar a origem do termo situação como ponto de partida para a teoria de Debord, chegando-se a supor que o emprego dessa palavra seria um desvio, uma apropriação. Uma suposta origem do termo seria uma referência à Jean-Paul Sartre. No entanto, Patrick Marcolini não considera possível afirmar a influência de Sartre sobre Debord. Embora a noção de situação de Sartre tivesse pontos em comum com aquilo que defendiam os situacionistas, estes recusam qualquer tipo de parentesco com o filósofo. Há evidências de que Debord tenha lido os romances de Sartre - como bom representante de sua geração - prova disso é a apropriação que ele fez da seguinte frase de La Nausée [A Náusea] de 1938: "Você sabe, quando jogamos como o aventureiro e a aventureira: você era aquele a quem as aventuras aconteciam, eu era aquela que as fazia acontecer". A frase apropriada por Debord tornou-se assim: "O aventureiro é aquele que faz as aventuras acontecerem, mais do que aquele a quem as aventuras acontecem" (MARCOLINI, 2013, p. 68) ${ }^{12}$. Além disso, Debord afirma ter desviado tal frase de Lautréamont em carta à Ivan Chtcheglov - não se sabe se por esquecimento ou dissimulação de sua parte - o

${ }^{11}$ Prática desenvolvida por grupos militantes na América latina, em especial na Argentina, como denúncia do paradeiro dos militares associados à ditadura militar naquele país. Alguns exemplos dessa prática serão apresentados no capítulo cinco.

12 Tu sais, quand nous jouions à l'aventurier et à l'aventurière: toi tu étais celui à qui il arrive des aventures, moi j'étais celle qui les fait arriver (SARTRE) e L'aventurier est celui qui fait arriver des aventures, plus que celui à qui les aventures arrivent (DEBORD) - tradução minha das frases entre aspas. 
que leva Marcolini a concluir que os personagens de Sartre tem preocupações similares aos letristas da época e não que ele tenha inspirado o movimento que estava por vir. Entretanto, não há como provar que ele tenha tido acesso à teoria produzida por Sartre.

Outra suposta origem do termo 'situação' remete à leitura de L'amour fou [O amor louco] de 1937, do surrealista André Breton. Trata-se da última parte da trilogia iniciada por Nadja (1928), na qual Breton relata os acontecimentos cotidianos decorridos nos nove dias em que passou na companhia dessa moça, encontrada ao acaso perambulando pelas ruas de Paris. Do mesmo modo como ocorreu com Sartre, o situacionista apropriou-se de uma frase de Breton. Desta vez, a frase de Nadja "A beleza será convulsiva ou não será", de Breton, tornou-se "As artes futuras serão irrupções de situações, ou nada", nas palavras de Debord (Ibid., p. 69) ${ }^{13}$.

O mais importante não é exatamente desvendar a origem do termo dentro do léxico de Debord, mas, antes, observar o quanto a noção de situação colabora para a reflexão sobre a superação da arte. "A situação é então entendida como algo além da obra de arte, mas também como uma matéria a tratar, ou seja, uma coisa enormemente transformável"

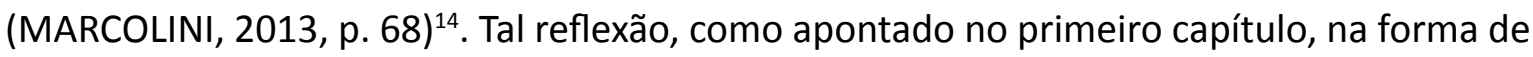
dissolução da obra de arte, aproxima-se do cenário das manifestações cênicas recentes que foram analisadas. Ou seja, se a situação construída não pode ser considerada uma ação performática, ela ao menos se constitui de elementos muito similares àqueles identificados nessa linguagem. As práticas performativas (e aqui me refiro às mais diversas manifestações cênicas, desde as mais teatrais até as mais performáticas, passando por inúmeras ações minimalistas), também se configuram como algo elaborado e não ocasional, que se inscreve na esfera do real e cujos materiais são extremamente maleáveis. Muitas vezes, elas não se enquadram tampouco na categoria obra, se considerarmos os padrões modernos vigentes no mercado da arte da década de 1960. São criações fugazes e precárias, que embora partam de uma elaboração prévia, estão sujeitas à adaptação, dependendo do ambiente no qual se inserem. E em ambos os casos - tanto nas situações quanto nas ações performativas atuais - é possível identificar níveis de visibilidade variados, indo do mais visível (no caso da Notre-Dame) ao mais sutil e invisível (no caso das derivas).

\footnotetext{
${ }^{13}$ La beauté sera CONVULSIVE ou ne sera pas (BRETON) e Les arts futurs seront des bouleversements de situations, ou rien (DEBORD) - tradução minha das frases entre aspas.

${ }^{14}$ [...] la situation est donc entendue comme un au-delà de l'œuvre d'art, mais aussi comme une "matière à traiter", c'est-à-dire une chose transformable à volonté (tradução minha).
} 
No dia 14 de abril de 1921, em Paris, os membros do movimento Dadá promoveram uma visita-excursão, saindo da Igreja Saint-Julien-le-Pauvre, localizada na Rive Gauche, a poucos metros do Sena. Essa deambulação marcaria a abertura da Grande Saison Dada - uma série de excursões urbanas a lugares banais da cidade que poderiam desaparecer em breve. A escolha dessa igreja e do jardim localizado atrás dela se deve ao fato desses lugares parecerem semiabandonados. $O$ jardim era considerado na época um terreno baldio e a igreja era pouco conhecida, embora a primeira etapa de sua construção fosse anterior à construção provavelmente por encontrar-se num canto desimportante do Quartier Latin, que não seria atravessado por nenhuma grande avenida. A escolha pela visita a um espaço banal, sem nenhum interesse particular, era uma forma concreta de realizar a dessacralização total da da catedral Notre-Dame. Após a grande reforma dos bulevares parisienses empreendida por Haussmann, o local escolhido para a ação dadaísta parece ter escapado ao seu projeto, arte. Esse conjunto arquitetônico foi considerado um ready-made urbano (uma referência ao conceito de Marcel Duchamp), configurando-se como "a primeira operação simbólica que atribuiu valor estético a um espaço vazio e não a um objeto"(CARERI, 2013, p. 75). Tratou-se de uma operação esteticamente consciente e amplamente difundida pela imprensa, com panfletos e registros fotográficos.

Aparentemente essa ação não se restringia à visita à igreja e ao jardim, uma vez que foi acompanhada por alguns discursos - considerados de uma terrível nulidade por Breton anos depois - pela leitura de trechos escolhidos ao acaso do dicionário Larousse, pela distribuição de souvenirs a quem passava por ali e pela tentativa de convencer os moradores das redondezas a descerem de suas casas e participarem do ato. A excursão propriamente dita não chegou a acontecer devido a uma forte chuva que caiu e dispersou cerca de cinquenta pessoas que se reuniram no local. Francesco Careri chama a atenção na foto que retrata o grupo dadá posando no jardim, para o terreno vago e não cultivado, que sintetizaria para ele o ato mais importante dessa operação. Um grupo consciente do que faz - nada - sendo que a ação consiste mais na elaboração do programa da visita do que na realização dos atos subsequentes.

[...] essa primeira visita continua a ser a mais importante operação dadá sobre a cidade. Com efeito, a passagem "das salas de espetáculo ao ar livre" foi o primeiro passo de uma longa série de excursões, deambulações e derivas que atravessaram todo o século como forma de antiarte.

O primeiro ready-made urbano do dadá marca a passagem da representação do mote à construção de uma ação estética a ser realizada na realidade da vida cotidiana. [...] após a experiência dadá, passou-se da representação do mote à 
Figura 1: Grand Saison Dada. Na foto: [Jean Crotti, Georges D’Esparbès, André Breton, Georges Rigaud, Paul Eluard, Georges Ribemont-Dessaignes, Benjamin Péret, Théodore Fraenkel, Louis Aragon, Tristan Tzara, Phillippe Soupault].
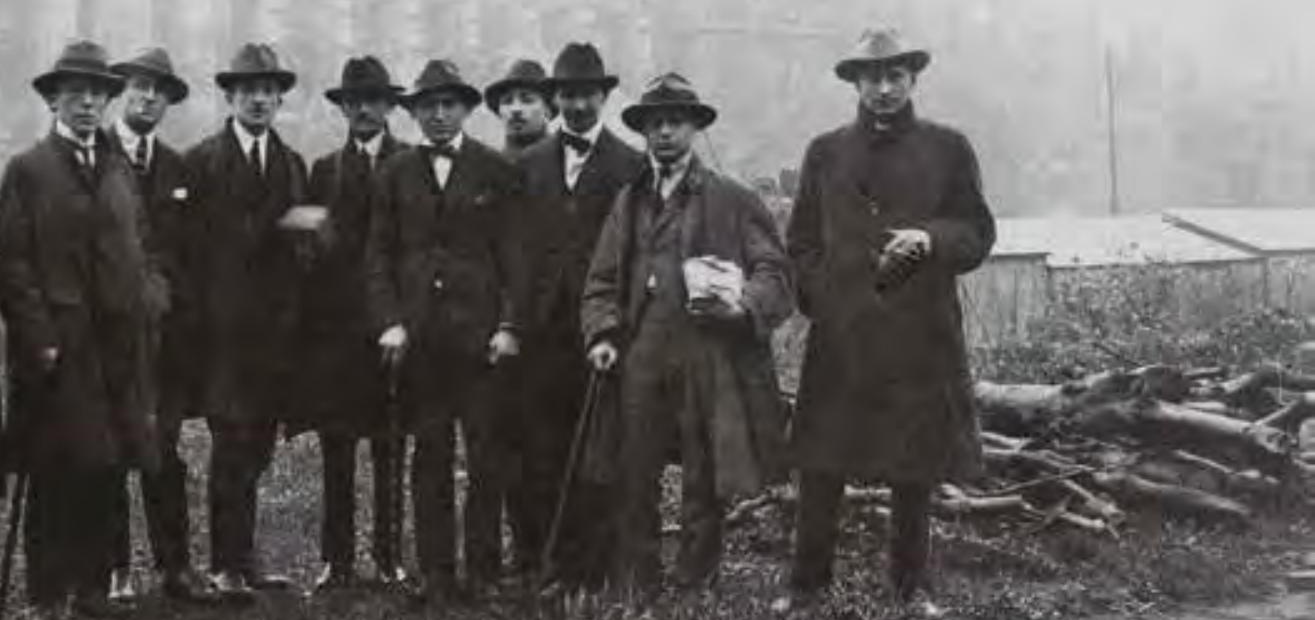

15

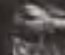

아요
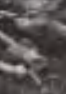

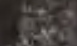

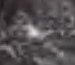

-

$-$

Foto: Irène Andréani. Disponível em $<$ http://www.metalocus.es/en/news/playgrounds-reinventing-square $>$ Acesso em:

15 mar. 2017.

prática do mote no espaço real. Com as visitas dadá e com as subsequentes deambulações surrealistas, a ação de percorrer o espaço será utilizada como forma estética capaz de substituir a representação e, por isso, de atacar frontalmente o sistema da arte (Ibid., p.71-74)

A intenção do grupo composto por André Breton, Paul Éluard, Louis Aragon, Tristan Tzara, Francis Picabia, dentre outros, era remediar a incompetência dos guias e cicerones suspeitos empreendendo uma série de visitas a lugares escolhidos, em particular àqueles que não têm qualquer razão real de existir (trechos retirados do panfleto dos dadaístas). As demais visitas programadas não ocorreram; elas aconteceriam em locais como o Museu do Louvre, o Parque Bouttes-Chaumont, a estação de trem Saint Lazare, o Canal de I'Ourcq. Para Careri, o projeto não continuou porque, de fato, já havia sido concluído. Ele acredita que ter realizado essa ação naquele lugar específico correspondia a tê-la realizado na cidade inteira. Esse projeto de deambulação dadaísta é considerado um marco na história do caminhar como prática artística. Paola Berenstein Jacques considera essa primeira visita dadá "um prenúncio das deambulações surrealistas, do estranhamento do que é banal e cotidiano, que vai ser um dos motes para a exploração de Paris por inúmeras experiências" (JACQUES, 2012, p. 95). A autora nos lembra que na mesma época, os artistas modernos brasileiros realizavam visitas e excursões nos mesmos moldes que os dadaístas faziam em Paris. Data de 1926 a foto de um grupo de artistas brasileiros, juntamente com o futurista italiano Marinetti, visitando o Morro da Favella no Rio de Janeiro. Depois disso, foi a vez do poeta Blaise 
Cendras e do arquiteto Le Corbusier.

Abro aqui um parêntese para relatar a primeira experiência de deriva realizada por mim no período que vivi em Paris, durante o Doutorado Sanduíche ${ }^{15}$. Em meio aos meus estudos sobre ações deambulatórias no contexto urbano, percebi que estaria na cidade na mesma data na qual os dadaístas realizaram essa ação na Saint-Julien-le-Pauvre, porém 94 anos depois. A partir desse marco banal, que nem se configura como uma data simbólica (50 ou 100 anos, por exemplo), propus-me uma visita à mesma igreja desimportante, seguida de uma deriva, no dia 14 de abril de 2015. Vale ressaltar que nem a igreja, nem o jardim, correspondem às descrições da época dos dadaístas. Embora infinitamente menos visitada que a Notre-Dame, a igreja está bem conservada e abriga diversos concertos de música noturnos durante a semana. Nessa ocasião, experimentei o registro de um áudio nas dependências da igreja, experimentando uma proposta de escrita automática sonora. Observando os cartazes e as informações sobre a igreja, percebi que apesar de não haver nenhum vestígio do que acontecera ali há exatos 94 anos, a história da igreja era marcada por sucessivas reconstruções, pelo abrigo de andarilhos e pela defesa das pessoas necessitadas. De

14 de abril de 2015 : Deriva da SaintJulien-les-Pauvres

Caminhei em torno do Quartier Latin, sem antes ver passar um grupo de japoneses, bem agrupados andando atrás de uma guia que portava um guarda-chuva preto fechado, como um estandarte, anti-clichê. Se portar guarda-chuvas, favor mantê-los fechados! A visão de uma guia ou cicerone suspeita do panfleto dadá.

Entre ciaos e buonas seras, passei repetidas vezes pelas ruas abarrotadas do Quartier Latin. Pelo visto, minha imagem para aqueles que me observavam remetia a algum lugar remoto da Itália.

E minha deriva se mantém incógnita e invisível.

Qual é o objetivo de tudo isso? Ainda não sei responder, mas percebi que quando estava em Paris em 2000, pensei que era a primeira vez na vida em que me encontrava completamente só e responsável pelas consequências de virar à esquerda ou à direita [minha primeira verdadeira sensação de liberdade]. Talvez não fosse a primeira vez, mas foi quando eu me dei conta disso e achei significativo perceber que depois de 15 anos, eu atribuía à uma moeda de 1 centavo esta responsabilidade. A escolha da moeda foi uma homenagem à Saint-JulienLe-Pauvre: a moeda mais insignificante, inválida, indesejável. Vejo escrito na rua: Por que dormir se podemos sonhar? [POURQUOI DORMIR SI ON PEUT REVER?]

Continuo caminhando e na vitrine da livraria: Éditions IVREA, diante do número 22 da Rue du Sommerard, vejo os seguintes títulos: "Dada", "Les situationnistes et mai 68 - théorie et pratique de la révolution (19661972)", "Histoire de L'Internationale Situationniste", "Le dit d'amour et de mort", "Vies imaginaires". Entendi essa coincidência como uma mensagem dos dadaístas, que me conduziram 94 anos depois a essas referências bibliográficas. Foi quando li sobre a calçada: Perder a vida a ganhá-la [PERDRE LA VIE À LA GAGNER] - o que poderia perfeitamente ser uma inscrição situacionista. Senti naquele momento que estava no caminho certo e que tudo fazia sentido!

\footnotetext{
${ }^{15}$ Período de 10 meses de estudo, ao longo do terceiro ano da pesquisa, na Paris 3 - Université Sorbonne Nouvelle,sob a orientação de Josette Féral, com o apoio da Capes.
} 


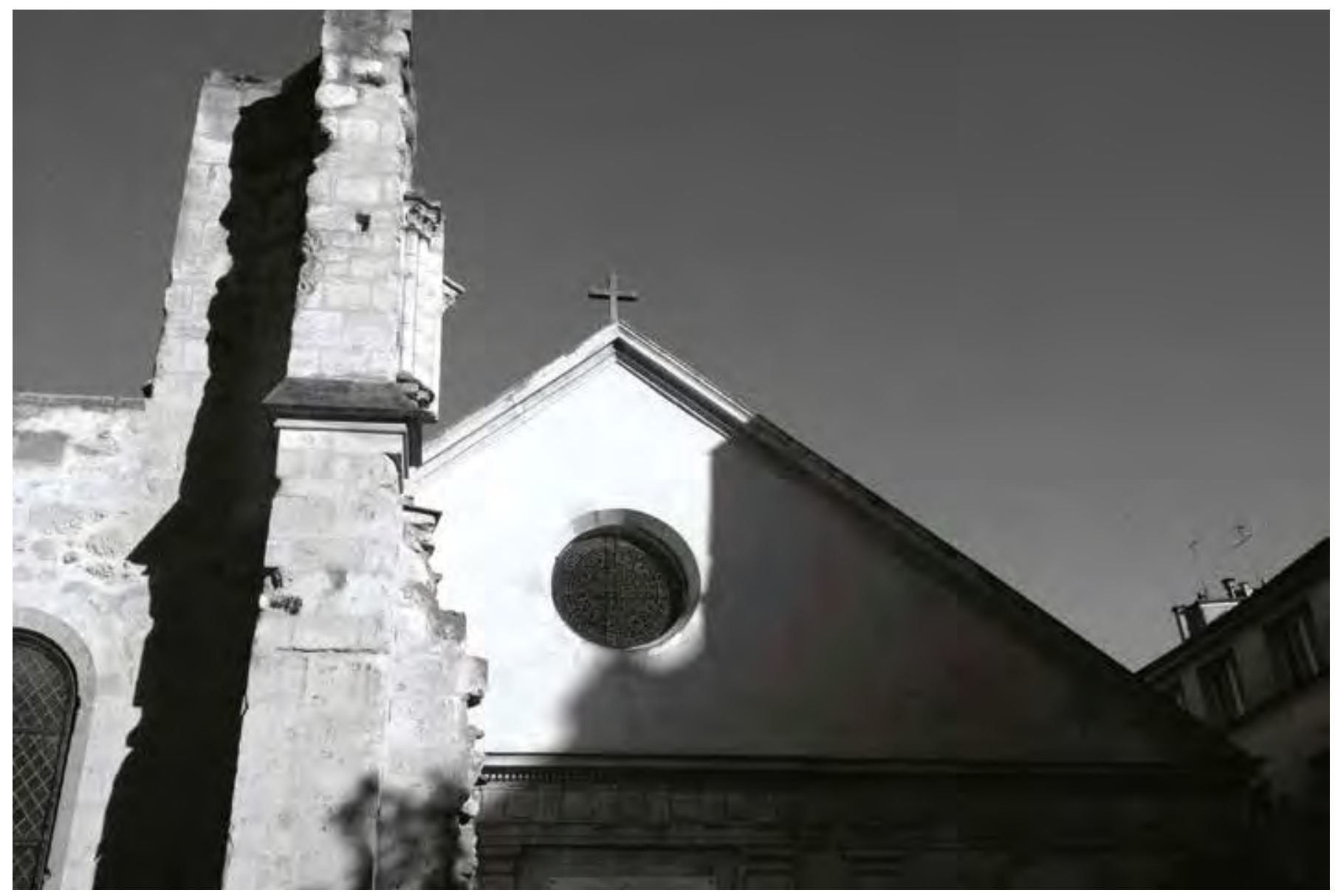

Figura 2: Saint-Julien-les-Pauvres

Foto: Verônica Veloso

algum modo, essa informação fez sentido, criando alguma conexão entre a deambulação dadaísta e a história daquele lugar.

Partindo do ponto de encontro dos dadaístas, segui meu fluxo de deriva pelo pequeno labirinto de lojas de souvenirs do Quartier Latin, usando como dispositivo de jogo uma moeda de 1 centavo. A cada esquina com que eu me deparava, posicionava meu corpo diante de sua quina, jogava a moeda para cima e ela decidia se me permaneceria à esquerda ou à direita daquele vértice. Para isso, escrevi 'cara' na minha mão direita e 'coroa', na esquerda.

Vale ressaltar que como todas as vanguardas, o Dadaísmo negava qualquer parentesco com o movimento anterior: o Futurismo. Diferente dos futuristas, que não intervinham no ambiente urbano, o Dadá se posiciona contra o futuro e nega todas as utopias hipertecnológicas do futurismo. Enquanto a vanguarda anterior busca representar a cidade do futuro, - Dadaísmo busca habitar a cidade do banal. Três anos após a dissolução do Movimento Dadaísta, alguns de seus membros, dentre eles André Breton (que escreveria o primeiro Manifesto Surrealista, em 1924), empreendem uma viagem a pé no centro da França, partindo de Blois (para onde seguiram de trem) e chegando até Romorantin. A pequena cidade tomada por ponto de partida foi escolhida ao acaso sobre um mapa. Perambularam por quatro dias ininterruptos, conversando e explorando os limites entre o consciente e o so- 

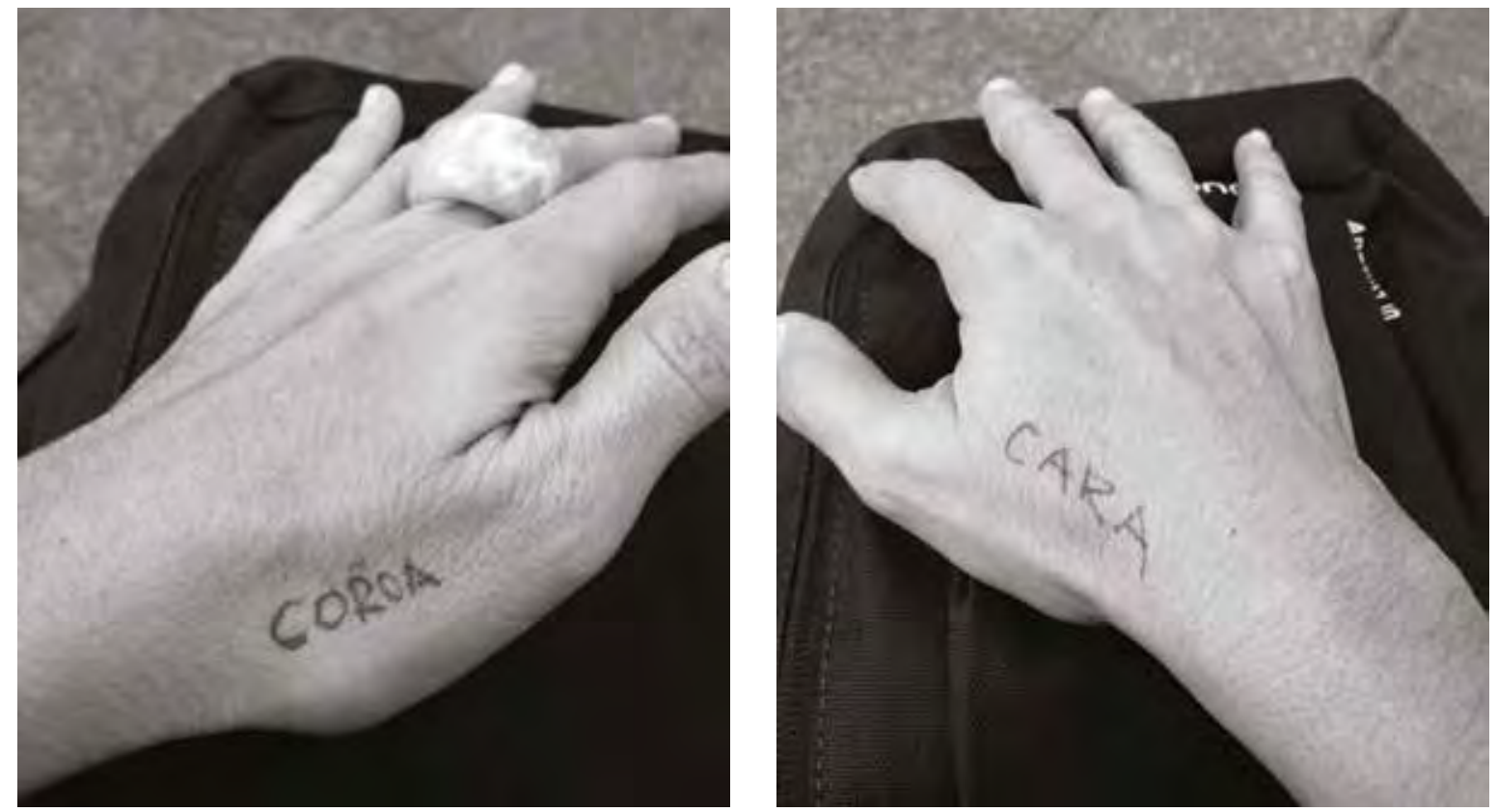

Figura 3 e 4: Verônica Veloso - Deriva da Saint-Julien-les-Pauvres

Fotos: Verônica Velloso

nho. Na volta dessa viagem, Breton transformou essa experiência em escrita automática no espaço real, "uma errância literário-campestre impressa diretamente no mapa de um território mental" (CARERI, 2013, p. 78). A escrita automática é uma exploração do inconsciente que se encontra entre o literário e o científico, entre a arte e o conhecimento. Ela torna-se assim uma prática surrealista por experimentar traduzir na forma de texto, o funcionamento real do pensamento.

André Breton teria, desse modo, se apropriado da psicanálise freudiana por um via literária, como escritor, uma vez que a escrita automática propunha uma exploração sistemática da parte inconsciente da subjetividade. Como representante do Movimento Surrealista, situado exatamente entre as duas grandes guerras mundiais, Breton seria o responsável por apresentar a Debord a teoria psicanalítica, a filosofia hegeliana e o marxismo. Ainda sobre a relação entre Debord e Breton, Gabriel Zacarias afirma que do mesmo modo pelo qual os situacionistas recusaram o acaso e o irracional, eles negaram a escrita automática - o procedimento surrealista por excelência. Debord reprova, portanto, o fato de os surrealistas se satisfazerem com a inconstância do acaso e os condena por cair no misticismo e no ocultismo. De sua parte, o situacionista buscará algo mais científico: a psicogeografia.

_ os jogos situacionistas como práticas cotidianas: escândalo, festa e encontro amoroso

O continente escolhido como brinquedo. Gilles Ivan ${ }^{16}$

${ }_{16}$ Le continent choisi comme jouet (Gilles Ivan in DEBORD, 2006, p. 112) (tradução minha). 
Na revista Potlatch no. 1, de 22 de junho de 1954, publicou-se Le jeu psychogéographique de la semaine [O Jogo psicogeográfico da semana], uma situação construída bem sucedida. Esse exemplo é apresentado como uma receita ou uma regra do jogo, o que poderia ser interpretado hoje como um programa de intervenção extremamente atual e factível. Alguns exemplos de intervenção urbana recentes, onde situações muito similares acontecem, podem ser citados ${ }^{17}$.

Em função do que você procura, escolha uma região, uma cidade de povoamento mais ou menos denso, uma rua mais ou menos animada. Construa uma casa. Coloque móveis. Tire o melhor partido de sua decoração e de seus entornos. EscoIha a estação e a hora. Reúna as pessoas mais adequadas, os discos e as bebidas que convém. A iluminação e a conversa deverão ser evidentemente adequadas à circunstância, assim como as condições climáticas e suas lembranças. Se não houve erro nos seus cálculos, a resposta será satisfatória (MARCOLINI, 2013, p.63) $)^{18}$.

A noção de situação, de acordo com sua definição no Dicionário Houaiss da Língua Portuguesa, implica em uma unidade de espaço e de tempo: "ato ou efeito de situar(-se), localizar(-se). Localização de um corpo no espaço em relação a um ou vários pontos de referência fora dele; posição (...). Combinação ou concorrência de acontecimentos ou circunstâncias num dado momento; conjuntura" (HOUAISS, 2001, p. 2587). A teoria situacionista agrega à noção de situação "uma tentativa de estruturar determinada conjuntura". Em resposta à teoria dos momentos, defendida por Henri Lefebvre em sua crítica à vida cotidiana, Debord considera a construção de situações como a criação de "momentos de ruptura, de aceleração", ou ainda, "revoluções na vida cotidiana individual". Na análise marxista das condições de existência no capitalismo avançado, Lefebvre reconhecia que as civilizações antigas souberam encontrar uma forma de vida coletiva que fazia de cada momento uma obra de arte. Ao passo que o Ocidente moderno não definiu uma estilização coerente da vida, tornando a existência uma sequência de momentos descosturados, sem estrutura, nem ordem. Momentos separados, estanques, e ao mesmo tempo, misturados. Na contracorrente, Debord recusa tal intenção ordenadora de Lefebvre e coloca sua noção de situação como um ele-

\footnotetext{
17 Em 2009, o Coletivo PIU (Pequenas Intervenções Urbanas) realizou no bairro do Bom Retiro uma intervenção urbana chamada Sala de estar na rua, uma forma de refletir sobre o espaço da cidade e o espaço da casa. Segundo os membros do coletivo, "ocupada a cidade fica melhor". Em 2015, o Coletivo Teatro Dodecafônico organizou uma Sala de Estar no Coreto do Parque da Luz, como parte da Ocupação Mulheres, Performance e Gênero. O espaço foi armado com o objetivo de compartilhar materiais de performers mulheres e de discutir as diversas formas de feminismo presente nas artes hoje. Foi nessa ocasião que se deu, por exemplo, a leitura e discussão do texto "O Feminismo não é um humanismo", de Paul Beatriz Preciado, trazido por uma das participantes, que se tornou uma referência para a pesquisa do coletivo, sem que, no entanto, tivesse havido nenhum planejamento prévio.

${ }^{18}$ En fonction de ce que vous cherchez, choisissez une contrée, une ville de peuplement plus ou moins dense, une rue plus ou moins animée. Construisez une maison. Meublez-la. Tirez le meilleur parti de sa décoration et de ses alentours. Choisissez la saison et l'heure. Réunissez les personnes les plus aptes, les disques et les alcools qui conviennent. L'éclairage et la conversation devront être évidemment de circonstance, comme le climat extérieur ou vos souvenir. S'il n'y a pas eu d'erreur dans vos calculs, la réponse doit vous satisfaire (tradução minha).
} 
mento de transição, uma vez que defende a construção de situação como ruptura, como revolução (MARCOLINI, 2013, p. 72-74).

$\mathrm{Na}$ internacional Situacionista n.5, ao se referir à arte das situações, os autores afirmam que "são esquemas, equações em que os participantes poderão escolher com quais incógnitas vão jogar, seriamente, sem espectadores, e sem outra finalidade além do jogo em si" (JACQUES, 2003, p. 131). A situação é feita para ser vivida pelos seus construtores. Assim como Debord não atribuiu aos participantes do jogo o papel de público, mas de 'vivenciadores', ele também não considera as situações construídas como encenações, mas como uma experiência vivida. Embora o autor recomende que a situação não devia ser encarada como uma nova forma de teatro, ele admite que seria interessante alguém assumir, temporariamente, o papel de diretor da ação. Debord afirma que a construção de situações substituirá o teatro somente no sentido no qual a construção real da vida substituiu a religião. Os situacionistas apresentam a noção de jogo como uma arma contra a alienação, sem, no entanto, apoiar "nenhuma forma desejável ou garantida de felicidade" (Ibid.). Além de não constituir-se como espetáculo, pois o jogo situacionista não se apresenta para um suposto espectador, mas o inclui como participante da experiência. Tal proposição de jogo também se distingue da propaganda de consumo, pois não associa a felicidade à posse de certos objetos ou à experimentação de certas ações.

Os programas situacionistas se propõem a dar à vida uma textura poética, o que alteraria diretamente a vida cotidiana. Marcolini defende que três modelos guiam as investigações da I.L. e depois da I.S. na busca por uma construção consciente de situações: o escândalo (e aqui ele se refere ao ocorrido da Notre-Dame de Paris), a festa e o encontro amoroso. A construção de situações é para ele uma maneira de organizar a ambiência e de criar condições favoráveis para o desenvolvimento de formas de sociabilidade comunitárias, centradas não no trabalho, mas no lazer. Os membros do grupo Spur, que compuseram a sessão alemã da I.S. entre 1959 e 1962 e que foram os que mais experimentaram a proposição de festa como jogo situacionista, afirmavam: "Assim como Marx deduziu uma revolução da ciência, nós deduzimos uma revolução da festa. [...] Uma revolução sem festa não é uma revolução" (MERCIER, 1997, p.42) ${ }^{19}$. Os encontros amorosos, por sua vez, transparecem de maneira subterrânea nas produções mais poéticas de alguns membros da I.S. No entanto, a ideia de amor dos situacionistas não coincide com as características de um amor romântico, esse amor passa pelo viés do desejo. Segundo Marcolini, o encontro amoroso é um modelo difícil de integrar nessa teoria, pois ele deixa um espaço maior para o aleatório, o incontrolável, o inexplicável. Um encontro amoroso é uma desordem provisória e sem retorno, pois abre espaço para uma nova ordem estabelecer-se. Ao meu ver, esse encontro amoroso

\footnotetext{
${ }^{19}$ Pareils à Marx qui a déduit une révolution de la science, nous déduisons une révolution de la fête. [...] Une révolution sans fête n'est pas une révolution. Excerto do Manifeste de janvier [Manifesto de janeiro], de 1961 (tradução minha).
} 
se refere ao encontro corporal com a cidade. O corpo que sai em deriva é desejante, ele percorre a cidade num corpo a corpo amoroso e imprevisível. A cidade é quem mostra os caminhos e inspira a cada encontro uma aventura única para o corpo afetado por ela.

Diante desses três modelos - o escândalo, a festa e o encontro amoroso - o autor supracitado conclui que, para os situacionistas, a construção de situações equivale a um jogo. Exemplo disso é o jogo do Rendez-vous possible [Encontro possível], proposto por Guy Debord no texto Théorie de la Dérive [Teoria da Deriva], de 1956. Aquele que deseja experimentar novas situações marca um encontro com uma pessoa totalmente desconhecida, em um local público, de modo que ele se veja forçado a iniciar uma conversa com qualquer passante. $O$ desenvolvimento dessa iniciativa poderia resultar em outros encontros imprevisíveis. Mesmo que o encontro marcado não seja bem sucedido, no caso das pessoas envolvidas não se reconhecerem, outros encontros possíveis poderão ocorrer, de acordo com a conjuntura. Debord sugere ainda que uma série de encontros se sucedam, seja com alguém que conheceu nesta noite, seja com alguém sugerido pela primeira pessoa encontrada. Ele conclui a descrição do jogo, enaltecendo os recursos quase infinitos desse passatempo (DEBORD, 2006, p. 255).

Vale destacar que essa proposição de situação construída poderia ser tomada nos dias de hoje como um programa de performance. Em termos de estrutura, ela obedece a mesma lógica de uma performance de Eleonora Fabião, chamada Linha Nova lorque (2010/2011), na qual ela visita uma pessoa desconhecida para conversar e combinar um ação a ser realizada em conjunto na cidade de Nova lorque. A performer leva café e chá para tomarem juntos e pede que essa pessoa indique a próxima a recebê-la em sua casa. Desse modo, tece-se uma série de performances que colocam em questão o privado e o público, o individual e o coletivo, a lógica dos encontros e as linhas de comunicação tecidas em redes de convivência.

Para Debord, fazer teoria (atividade que ele reconhece tardiamente em sua trajetória, somente em 1985) é antes de tudo um jogo, um passatempo. Ele adota em relação à criação teórica a mesma atitude que tem diante de sua criação artística, insistindo que a criação não pode se distinguir da vida: é um jogo, um conflito, uma aventura. Em 1958, os situacionistas publicam em sua revista um diagrama intitulado Nouveau Théâtre d'Opérations dans la Culture ${ }^{20}$ [Novo Teatro de Operações na Cultura], no qual estabelecem seus modos de operar no campo cultural. Segundo leitura do diagrama realizada por Emmanuel Guy e Laurence Le Bras ${ }^{21}$, o jogo permanente seria o ponto de entrada a partir do qual o dispositivo deveria ser ativado. $O$ jogo estaria presente no desvio ou apropriação de elementos estéticos pré-fabricados, na psicogeografia, como fundamento do urbanismo unitário e nas

\footnotetext{
${ }^{20}$ DEBORD, Oeuvres, 2006, p. 354.

${ }^{21}$ Catálogo da exposição: GUY DEBORD: Un art de la guerre (2013, p. 92).
} 
propostas arquitetônicas dos situacionistas, bem como no comportamento experimental no espaço urbano, do qual decorre a deriva. A articulação entre psicogeografia e deriva contribui para a construção de situações, o ponto de chegada de uma estratégia pautada na ideia de jogo permanente.

O estudo do jogo para os situacionistas é marcado pela leitura do ensaio sobre a função social do jogo, realizado pelo holandês Johan Huizinga. Nesse sentido, o situacionista seria também um homem lúdico, em oposição ao homo faber e ao homo oeconomicus, pois cria suas relações a partir do prazer do jogo e de sua potencialidade subversiva. $\mathrm{O}$ jogo funcionaria como uma resposta e uma revanche ao espetáculo. $O$ jogo pode ser encontrado na base do espetáculo, mas ele é constantemente deformado e enrijecido pela estrutura onipresente do espetáculo. Dessa forma, o jogo seria um modo de tomar a sociedade do

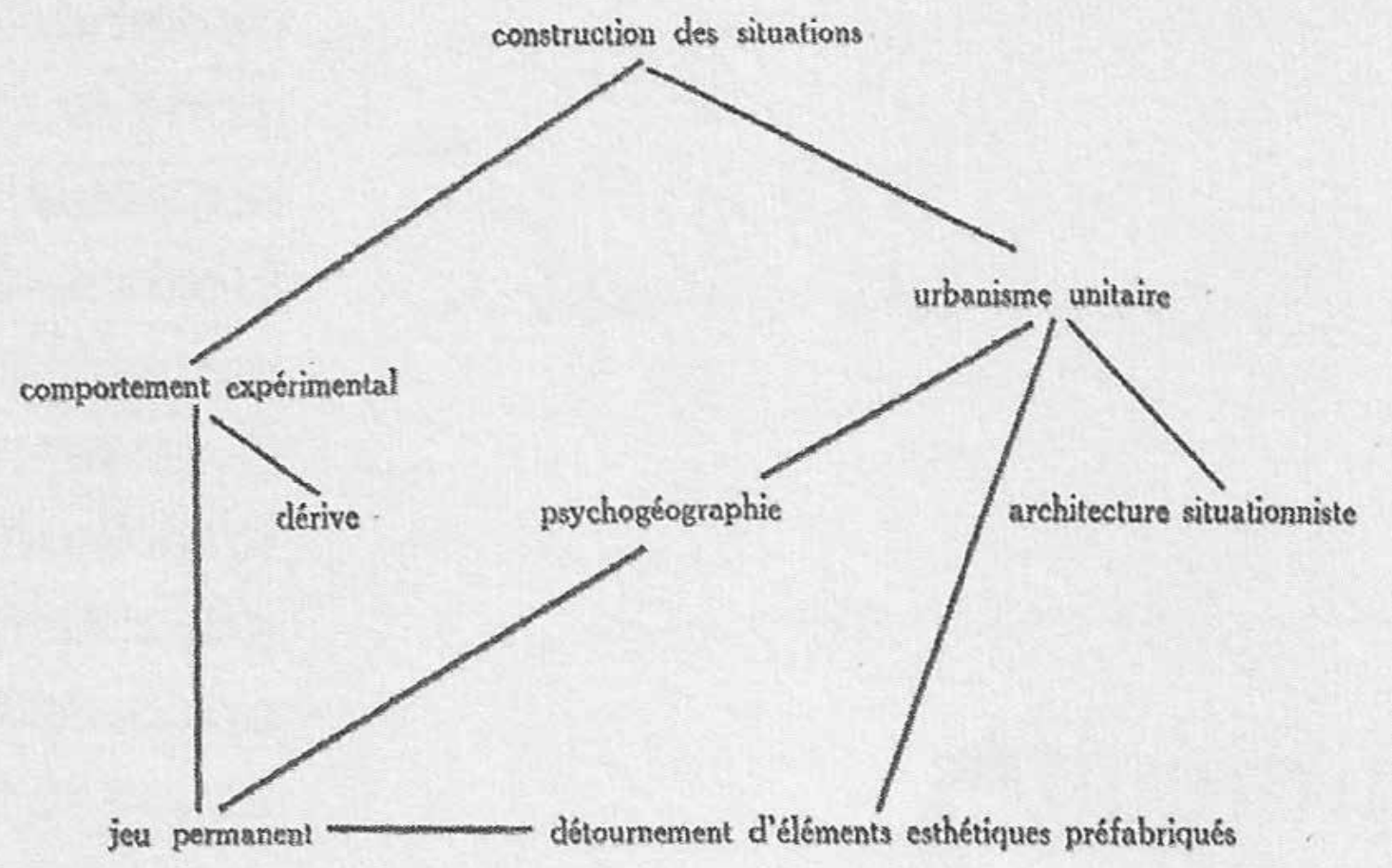

Figura 5: IS - Noveau Théâtre d'Opérations dans la Culture

Diagrama: material do Fond Guy Debord da BNF (GUY; LE BRAS, 2013, p. 93).

espetáculo de assalto, instaurando em sua estrutura previsível, uma atmosfera de acontecimento. O jogo constitui-se como um acontecimento da ordem do imprevisível, do imponderável, do incontrolável.

Voltando ao diagrama, há uma frase que o encerra, onde podemos ler: "A dissolução de antigas ideias acompanha a par e passo a dissolução de antigas formas de existência" (DEBORD, 2006, p. 354 ${ }^{22}$. A frase evidencia a proximidade das ideias e das formas de existência

\footnotetext{
${ }^{22}$ La dissolution des idées anciennes va de pair avec la dissolution des anciennes conditions d'existence (tradução minha).
} 
no ponto de vista dos situacionistas. De tal modo, uma seria o reflexo da outra, pois na medida em que antigas ideias se dissolvem, antigas formas de existência também seriam dissolvidas. Nesse sentido, fica clara a intenção desse grupo de operar no campo da realidade, da vida, das estruturas sociais e políticas vigentes. O campo da arte não parecia suficiente para a atuação almejada por eles. Os situacionistas não se interessavam pela representação ou pela transformação simbólica do cotidiano, atuavam em prol de uma modificação mais estrutural dos sistemas de vida. Por esse motivo, esses intelectuais se interessam pela arquitetura, em especial pelo urbanismo, pois é ele que mostra como a forma das cidades autoriza ou impede os encontros entre as pessoas, define os seus deslocamentos e estabelece os espaços destinados às mais diversas atividades, modos de vida e classes sociais.

Debord dizia que uma arquitetura adaptada ao uso situacionista, juntamente com um alto nível de pensamento e liberdade entre os habitantes de uma cidade permitiriam a instauração de pequenas situações sem futuro e só assim o futuro seria agradavelmente modificado. Mesmo que essa não fosse sua pretensão, suas ideias o mantinham na esfera da criação artística ou ao menos da criação de acontecimentos, de situações performáticas, que são como ele mesmo diz, "sem futuro". Compreendo essa ausência de futuro como uma ausência de produto, de resultado mercadológico. Bourriaud afirma que uma exposição de arte contemporânea não simboliza mais o encerramento de um processo de criação, seu happy end, mas um lugar de produção, no qual o artista coloca à disposição do público elementos para interagirem (BOURRIAUD, 2009, p.67). Essa transformação do espaço de exibição em espaço de (co)habitação tem um de seus vetores de origem no movimento situacionista.

A deriva, por sua vez, poderia ser considerada como o exercício prático da psicogeografia, que se configura como uma crítica ao urbanismo. Ela anuncia uma vontade de criar um novo urbanismo; por esse motivo, os situacionistas consideravam "a psicogeografia como a ficção científica do urbanismo" ${ }^{23}$. "A psicogeografia seria então uma geografia afetiva, subjetiva, que buscava narrar, através do uso de cartografias e mapas, as diferentes ambiências psíquicas provocadas pelas errâncias urbanas que eram as derivas situacionistas" (JACQUES, 2012, p. 215).

A construção de situações, a deriva, o desvio ou apropriação e a psicogeografia podem ser considerados meios adotados pelos situacionistas para transpor para o real as experimentações de ruptura efetuadas no terreno da literatura e das artes plásticas. É sabido que ao longo de toda sua vida, Debord passeou por diferentes modalidades artísticas, sem,

${ }^{23}$ La psychogéographie, c'est la Science fiction de l'urbanisme. Excerto presente no conjunto de datilografias para a maquete do catálogo inédito sobre a "Première Exposition de Psychogéographie" (tradução minha). Esse material foi apresentado em nome do Mouvement Internationale pour un Bauhaus Imaginiste, pela Internationale Lettriste e pelo Comité Psychogéographique de Londres, como uma maquete de uma exposição que aconteceria na Galeria Taptoe, em Bruxelas, entre 2 e 26 de fevereiro de 1957, mas não chegou a acontecer. O documento foi consultado no Fond Guy Debord, da BNF. 
contudo, considerar a deriva uma delas. Apesar de seu desejo por abolir a arte, realizou produções artísticas relevantes no campo das artes gráficas e do cinema. No final da década de 1950, a influência de Asger Jorn em sua trajetória se faz presente na obra Mémoires (1959), realizada pela dupla em Copenhague. Em texto de1956, Debord desenvolveu sua teoria do desvio ou da apropriação [détournement] que consiste em recortar e colar frases e imagens de jornais e revistas, retirando-as de seu contexto original. Essa prática propõe a reutilização, em um novo contexto, de elementos pré-existentes na cultura: textos, filmes, publicidades, atualidades, quadrinhos. Ou seja, na apropriação de conteúdo, sem menção da fonte, como crítica à propriedade e à originalidade artística. Trata-se de um jogo consciente de reapropriação, inicialmente, da tradição literária: um plágio. Esse jogo aparece, portanto, como uma necessidade histórica na tese de número 207 da Sociedade do Espetáculo: "As ideias melhoram. O sentido das palavras entra em jogo. 0 plágio é necessário. 0 progresso supõe o plágio" (DEBORD, 1997, p.134). Ele continua com essa mesma reflexão na tese seguinte:

O uso desviado é o contrário da citação, da autoridade teórica sempre falsificada pelo simples fato de se ter tornado citação; fragmento arrancado do seu contexto, do seu movimento, da sua época como referência global e da opção exata que representava dentro dessa referência, exatamente reconhecida ou falseada. 0 desvio é a linguagem fluida da antiideologia (Ibid.).

A opção por essa modalidade de escrita configura-se para Debord como um afastamento da escrita automática, representante da estética surrealista. Mesmo que a apropriação possa ser considerada como um jogo de associações livres e, portanto, com traços surrealistas, o fato de se tratar de uma atividade consciente de escrita já a posiciona no sentido inverso da escrita automática. O desvio ou a apropriação foi o princípio de composição adotado para a escrita de $A$ Sociedade do Espetáculo.

Essa prática inicia-se na criação gráfica de colagens, articulando frases e fotografias com jatos de tintas do pintor Asger Jorn. Em seguida, ela aparece nas composições de Debord com recortes de mapas de Paris e inspira a montagem disjuntiva que aparece em sua criação cinematográfica. Desde 1953, Debord insistia sobre a necessidade de se inventar uma nova forma de representação da cidade. Essa intenção o levou a compor ao menos cinco mapas psicogeográficos, nos quais encontrou maneiras de exprimir a dimensão passional estabelecida pela deriva. Nesse sentido, a deriva e a psicogeografia também podem ser consideradas desvios ou apropriações do espaço da cidade. Pode-se dizer que o desvio ou a apropriação é um elogio ao plágio, uma desmitificação da obra como unidade sujeita a um criador. O desvio seria capaz de dotar cada elemento artístico de duplo sentido, um passado e outro presente. Marcolini afirma em artigo escrito para o catálogo da exposição supracitada que "Debord passa a ter o hábito de ler cada texto como um conjunto potencial de fórmulas a transformar, a tal ponto que pode-se ver o desvio tornar-se em sua obra quase 
um método de pensamento, e não somente uma técnica de escrita" (MARCOLINI in GUY; LE BRAS, 2013, p.33) ${ }^{24}$.

Assim, as ideias do jovem Debord o posicionavam à frente do seu tempo. A discussão sobre a apropriação de conteúdos e a reivindicação de autoria se mantém polêmica até hoje, quando a internet colabora de maneira muito eficiente para reinventar os modos de acesso à informação, constituindo-se como um meio propenso à prática do desvio [détournement].

_deriva como ação improdutiva: uma interface com o tempo

O mundo já possui o sonho de um tempo. Para vivê-lo de fato, deve agora possuir consciência dele. Guy Debord (tese 164 de A Sociedade do Espetáculo)

A partir dos pontos apresentados no primeiro capítulo, formulo uma síntese: a deriva é um deslocamento sem rumo, que não prevê um local de chegada, apenas um ponto de partida. É uma técnica de deslocamento praticada por uma ou mais pessoas, que caminham ao sabor dos acontecimentos, definindo percursos a partir das solicitações do terreno e das pessoas que encontrarem pelo caminho. Trata-se, portanto, de um deslocamento subjetivo, o oposto de uma caminhada funcional que levaria do ponto $A$ ao ponto $B$. Ela é frequentemente associada à perda de tempo, à vagabundagem, ao zanzar irresponsável pelas ruas. Inúmeras vezes ela leva o sujeito a se perder, mesmo em locais conhecidos. É antifuncional e improdutiva, como o jogo.

Debord usa a palavra passatempo ao apresentar sua proposta de jogo para uma situação construída e usa também a palavra distração, ao se referir à importância do uso do taxi na deriva. Ele diz: "a importância do taxi na distração que chamamos deriva". A escolha dessas palavras é bastante significativa para ilustrar o teor das práticas situacionistas. Há um apelo à uma vida em deriva: "um modo de comportamento experimental ligado às condições da sociedade urbana: técnica de passagem apressada por ambiências variadas" (DEBORD, 2006 , p. 358). Essa prática poderia se confundir com os passeios surrealistas ou o flanar de Baudelaire e Benjamin, no entanto, a deriva não se integra nessa divisão do tempo social entre trabalho e lazer. Ela reivindica para si um outro emprego do tempo: contrária ao trabalho, ela não se configura como um deslocamento objetivo, utilitário ou funcional pelo espaço urbano, nem como um passeio. A deriva, para os situacionistas, se configura como um modo de vida, um modo poético de viver intensamente as situações que se apresentam ao longo de um percurso.

\footnotetext{
${ }^{24}$ Debord prend ainsi l'habitude de lire chaque texte comme un gisement potentiel de formules à transformer, au point qu'on peut voir le détournement devenir chez lui quasiment une méthode de pensée, et non seulement une technique d'écriture (tradução minha).
} 
[...] algumas brincadeiras de gosto dito duvidoso, que sempre apreciei profundamente nas minhas imediações, como por exemplo entrar tarde da noite nos andares das casas em demolição, percorrer Paris sem parar de carona durante uma greve dos transportes, com o pretexto de agravar a confusão sendo levado a qualquer lugar, errar pelos subterrâneos das catacumbas interditadas ao público fariam parte de um sentimento mais geral que coincidiria com o sentimento da deriva (Ibid., p. 255) 25 .

Debord não era o único a relatar as experiências de deriva com o mesmo tom deliberadamente irresponsável e juvenil. Eram caminhadas aleatórias praticadas por grupos de jovens não somente em Paris, como em outras cidades europeias. Perambulações entre um café e outro, regadas a bebidas alcoólicas e marcadas por certa vagabundagem. Não se tratava de eventos planejados, combinados ou agendados previamente. As derivas aconteciam em suas vidas, como uma forma de diversão, praticada por pessoas que saíam de casa em busca de algo novo, de uma aventura. Jean-Michel Mension e Ralph Rumney falam em errâncias de um café a um bar, ou um restaurante, praticadas noite adentro e mesmo, nas madrugadas, ao voltar para suas casas. Segundo Mension, suas primeiras derivas aconteceram na companhia de Debord, a partir de um procedimento muito simples: depois de pegar carona em cinco carros diferentes, parar em um bar, comprar várias garrafas de vinho e partir completamente bêbados. A dupla revela que em 1953, em decorrência da greve geral dos serviços públicos em Paris, as pessoas passaram a pedir carona como uma forma de passear pela cidade. O grupo achava Paris muito agradável nessa ocasião, pois foi justamente nesse momento que a prática da deriva foi mais intensa.

A partir desse modo de deslocamento, sem rumo e sem objetivo preciso, os letristas (pois trata-se de um momento anterior à I.S.) se apropriam da cidade, conhecendo caminhos e desvios que não teriam jamais percorrido, caso não tivessem se proposto a caminhar à deriva. Não há uma escolha racional de trajetos, mas um deixar-se levar pelas solicitações do terreno e pelos encontros casuais. Não há economia de tempo, nem de esforços, o jogo consiste numa ocupação irreverente e deambulatória do espaço público. O cansaço, o efeito do álcool, o desejo de explorar a cidade em sua inteireza e o jogo estão presentes nas ações relatadas pelos participantes dessas primeiras derivas.

"É particularmente significativo que uma greve de transportes tenha permitido aos letristas tomarem consciência de que a deriva era um objeto de estudo em si" (MARCOLINI, 2013, p. $90)^{26}$. De acordo com esse autor, a deriva começa quando os trajetos escolhidos para ir de

${ }^{25}[. .$.$] quelques plaisanteries d'un goût dit douteux, que j'ai toujours vivement appréciées dans mon entourage,$ comme par exemple s'introduire nuitamment dans les étages des maisons en démolition, parcourir sans arrêt Paris en auto-stop pendant une grève des transports, sous le prétexte d'aggraver la confusion en se faisant conduire n'importe où, errer dans ceux des souterrains des catacombes qui sont interdits au public, relèveraient d'un sentiment plus général qui ne serait autre que le sentiment de la dérive (tradução minha).

${ }^{26}$ II est particulièrement significatif que ce soit une grève des transports qui ait permis aux lettristes internationalistes de prendre conscience que la dérive était un objet d'étude à part entière (tradução minha). 
um ponto a outro não são os mais curtos, quando as pessoas se perdem ou quando não se deslocam com precisão, mas aleatoriamente. Ele também afirma que "no fluxo laminar dos deslocamentos urbanos, a deriva começa sempre como um clinamen introduzido por um comportamento desviante" (Ibid., p. 92-93) ${ }^{27}$. Tal afirmação refere-se aos trajetos descritos pelos praticantes de uma deriva, que não se configuram nunca como uma linha reta conectando dois pontos. A noção de clinamen é complexa, vem dos estudos da física - de uma tese de Epicuro desenvolvida posteriormente por Lucrécio - e consiste em uma leve inclinação realizada por um átomo a partir de si próprio. Assim como o átomo, o sujeito desviante modifica a linha do seu movimento, criando pequenas inclinações que impossibilitam que esse deslocamento ocorra em linha reta.

Como se não bastasse percorrer horizontalmente a cidade, expandindo os territórios habituais frequentados por um habitante ordinário, há um desejo nesses primeiros derivantes de explorá-la de alto a baixo, incluindo o seu eixo vertical. Tal interesse os levou a explorar os caminhos subterrâneos de Paris, passando pelos esgotos e pelas galerias das catacumbas $^{28}$. Na época, eles ainda propuseram a abertura dos túneis do metrô para que fossem percorridos durante a noite e também dos telhados de Paris para passeios destinados à observação da paisagem urbana. Para tanto, sugeriam a criação de passarelas e a mudança de algumas escadas de segurança. Esses últimos projetos permaneceram no plano das ideias, mas são emblemáticos desse movimento que visava a transformação de todos os cantos da cidade em um complexo tabuleiro de jogo.

A deriva é, como você diz, um negócio perigoso, por razões complexas que fazem com que a exploração geográfica, a militância política, talvez até certas pesquisas em psicanálise (ver Wilhelm Reich) tenham sido ou sejam ainda atividades perigosas. ${ }^{29}$

Contrário à circulação das pessoas apenas por partes restritas da cidade, Debord afirmava que a extensão máxima do campo espacial de uma deriva não ultrapassava o conjunto formado por uma grande cidade e suas periferias. Entretanto, há relatos de derivas extremas nas quais os errantes mudam de cidade ou têm a intenção de atravessar o deserto do Saara de carona. Na primeira delas, chamada por Ralph Rumney de deriva em escala planetária, ele revela já ter bebido bastante com um amigo sueco e cansado de tudo o que encontrou pelo caminho, sugere ao outro de continuarem a deriva de maneira solitária, até que se

${ }_{27}$ Dans le flux laminaire des déplacements urbains, la dérive commence toujours comme un clinamen introduit par un comportement déviant (tradução minha).

${ }^{28}$ As catacumbas de Paris até hoje atraem a atenção dos jovens, que não se contentam em visitar sua restrita parte histórica. Há relatos de exploradores que abrem as tampas dos bueiros e se aventuram por esse mundo subterrâneo, convocando passeios e festas clandestinas.

${ }^{29}$ La dérive est, comme tu dis, un métier dangereux, pour les raisons complexes qui font que l'exploration géographique, le militantisme politique, peut-être aussi certaines recherches en psychanalyse (voir Wilhelm Reich) ont été ou sont encore des activités dangereuses (tradução minha). Trecho de carta citada acima de Debord à Gilles Ivan, datada de 30 de abril de 1963, consultada no Fundo Guy Debord. 
encontrassem novamente em Nova Deli. Cada um partiu para um lado e, pegando algumas caronas, Rumney acabou chegando a uma pequena ilha na Sicília. Mais tarde recebeu uma carta do amigo reclamando que tinha ido até a Índia e não o tinha encontrado (MARCOLI$\mathrm{NI}, 2013$, p. 94). Na direção oposta a essa, há o relato de Debord no qual ele conta de uma deriva de um dia inteiro dentro da Gare de Saint Lazare. Isto comprova que o que está em jogo quando o assunto é deriva não é o espaço, nem a extensão percorrida, mas o emprego do tempo de modo não produtivo.

Ao se referir às narrativas errantes - flanar, deambular e derivar - Paola Berenstein Jacques identifica três dinâmicas processuais distintas que perpassam esses três tipos de experiências erráticas. Segundo ela, são características da própria ideia de errância nas cidades: a desorientação, a lentidão e a incorporação. Enquanto os urbanistas modernos buscam a orientação por meio de mapas, o errante está ocupado com a desorientação, pois ao perder-se, deixa certos condicionamentos urbanos, se aproxima da alteridade urbana e encontra os vários outros da cidade. Essa autora nota uma lentidão nos errantes e a essa lentidão atribui um valor qualitativo "desses outros urbanos, dos homens lentos, que negam, ou Ihes é negado, o ritmo veloz imposto pela modernidade" (JACQUES, 2012, p. 264). Tal constatação remete aos homens lentos de Milton Santos, para quem a força dos fracos é o seu tempo lento. De acordo com ele, "quem, na cidade, tem mobilidade - e pode percorrê-la e esquadrinhá-la - acaba por ver pouco, da cidade e do mundo" (SANTOS apud JACQUES, 2012, p. 279). Ele opõe sua visão do homem lento às ideias acerca da velocidade de Virilio; ele afirma a sobrevivência do tempo lento na cidade, apesar da hegemonia do tempo e dos homens rápidos, reforçando a co-presença de tempos diversos no contexto urbano.

Numa época em que ser eficaz condiciona os praticantes da cidade a considerar a "velocidade uma necessidade e a pressa uma virtude", Milton Santos realiza um "elogio à lentidão". Ao associar a lentidão a uma virtude e identificar essa qualidade principalmente nos mais pobres, nos que não têm acesso à velocidade, Santos inverte valores e coloca a lentidão como uma possibilidade de resistência, uma ação política. Segundo ele, os homens lentos vivem nas zonas opacas da cidade e estabelecem uma relação mais selvagem com o lugar, o que os levaria a adquirir uma sabedoria pelo exercício de diferentes modos de sobrevivência. Os espaços opacos e luminosos descritos pelo geógrafo versam sobre diferentes visibilidades no contexto urbano. Os espaços luminosos, onde vivem os mais ricos e os mais rápidos, são os reinados das mercadorias, enquanto o espaço opaco exige um corpo a corpo com o ambiente, um conhecimento tático e astuto da parte de seus usuários. E no trânsito entre esses espaços, os homens lentos resistem nos espaços opacos e sobrevivem nos luminosos.

Paola Berenstein Jacques afirma que o errante urbano é um homem voluntariamente lento, consciente de sua lentidão e que se nega a acelerar. Por esse motivo, é possível associar a 
lentidão a um estado de atenção e à qualidade de um movimento, que não se confunde com a velocidade lenta. Deleuze e Guattari diferenciam movimento de velocidade, alertando que um movimento pode ser muito rápido e nem por isso ser velocidade, enquanto uma velocidade pode ser muito lenta e ainda assim é velocidade (Ibid., p. 314). Os praticantes ordinários do espaço urbano conhecem a cidade com seus pés, passo a passo, e assim eles definem um estado para seus corpos errantes. É nesse sentido que se insere a terceira característica da experiência errática: uma contaminação corporal que levaria à incorporação do espaço pelo corpo, a partir do próprio ato de errar, em contraposição à suposta busca contemporânea pelo virtual e imaterial.

Ele é inicialmente um tempo outro que o tempo abstrato da sociedade capitalista, pois ele é necessariamente destacado do uso utilitário e portanto do ciclo de produção - consumo de mercadorias. Além disso, sua duração não é dada pela sucessão das horas, segundo uma representação especializada, mas pela intensidade das experiências que preenchem a passagem do tempo" (ZACARIAS, 2014, p.121) $)^{30}$.

O tempo da deriva é portanto um tempo qualitativo, um tempo outro, destacado da vida corrente. Quando Debord fala em "passagem rápida por ambiências diversas" podemos apreender dessa prática um certo gosto pela velocidade. É certo que, ao observar a cidade em deslocamento, propõe-se um tipo de observação distinta de quem a observa de um mirante, por exemplo. Esse observador permanece estático enquanto aquele, que observa a cidade caminhando, a enxerga em movimento. O caminhar imprime um ritmo e uma temporalidade à visão.

\section{_a deriva como tática para perder-se ou um modo cinematográfico de olhar a cidade}

Thierry Davila acentua em seus estudos o aspecto plástico presente na deriva. Para isso, ele recorre ao termo cineplástica ${ }^{31}$ - empregado pela primeira vez por Élie Faure em um artigo consagrado ao cinema de 1920 - para assinalar o aspecto fenomenológico presente no deslocamento. Davila considera plástico o nomadismo das ações de Francis Alÿs, Gabriel Orozco e o coletivo Stalker, pois "tem o poder de dar forma" e também sentido à significação, além de ter "o poder de criar", estando suscetível à mudar a forma (DAVILA, 2002, p. 22). Ele explica: "o caminhante é simultaneamente aquele que dá um perfil ao seu caminho,

${ }_{30}$ Il est d'emblée un temps autre que le temps abstrait de la société capitaliste, car il est forcement détaché de l'usage utilitaire et donc du cycle de production-consommation de marchandises. De plus, sa durée n'est pas donné par la succession des heures, selon une représentation spatialisée, mais par l'intensité des expériences qui remplissent le passage du temps (tradução minha).

${ }^{31} \mathrm{O}$ autor sublinha o quanto o qualitativo plástico é comumente atribuído à configurações fixas, sendo que ele pode perfeitamente caracterizar formas móveis, em deslocamento (DAVILA, 2002, p. 21). 
abre ou traça um caminho e aquele que adapta o trajeto a um contexto" (Ibid.) $)^{32}$.

Thierry Davila nos alerta igualmente sobre a importância de considerar a cineplástica como uma tentativa de não reduzir o movimento do caminhar à mera mobilidade física; ao contrário, à tomada desse movimento de maneira mais ampla: espacial, plástica, material e processual. Os artistas que se colocam em deslocamento, em diferentes geografias, implementam ao mesmo tempo a transposição de um espaço, de dispositivos plásticos produtores de formas diversas e de processos que não se contentam em ilustrar certas leis do trabalho psíquico, mas em verificá-las e experimentá-las. Davila associa essa produção derivada do ato de caminhar à plasticidade do sonho.

Dessa interpretação, voltamos à psicogeografia como metodologia da deriva, a interferência direta do meio geográfico nos afetos de quem percorre a cidade. Tal metodologia revela o quanto a deriva é um movimento tanto físico quanto psíquico. A natureza circunstancial do caminhar colocado em jogo na deriva, de acordo com Thierry Davila, a inscreve numa dialética entre o acidental e o estrutural, permitindo sublinhar o aspecto plástico ou cineplástico dessa prática. A partir dessa constatação, o autor afirma que os meios de elaboração e de representação aproximam a deriva dos procedimentos cinematográficos. Nesse sentido, a deriva aparece como uma construção, ou seja, "uma montagem de ambiências singulares ligadas à diversidade dos cenários urbanos atravessados, uma montagem produtora de momentos de aceleração e ruptura"(DAVILA, 2002, p. 31) ${ }^{33}$. Ele chama a atenção ainda para o termo hâtif [apressado] empregado por Debord na definição de deriva - "uma técnica de passagem apressada através de ambiências variadas" (grifo meu) - pois ele traduziria o ritmo dessa deambulação. Esse ritmo se parece mais com "uma sucessão de cenários próximos de uma colagem urbana realizada pelo próprio caminhante com a energia do seu corpo e a acuidade de seu olhar" (Ibid.) ${ }^{34}$, do que com o desenvolvimento fluido de um encadeamento de visões e ambiências.

Davila conclui, portanto, que os agenciamentos resultantes da deriva são essencialmente cinematográficos. Trata-se de um jogo entre situações e circunstâncias urbanas que produzem um percurso e uma série de trajetos que são descritos a partir de desvios efetuados nas arquiteturas atravessadas. Tais agenciamentos são compostos por intervalos; são movimentos capazes de produzir um entre dois, um entre imagens, tal qual o mapa psicogeográfico concebido por Guy Debord em 1957: The Naked City (figura 6).

\footnotetext{
32 [...] le marcheur est simultanément celui qui donne un profil à son chemin, ouvre ou trace une voie, et celui qui adapte ce trajet à un contexte (tradução minha).

${ }^{33}$ [...] un montage d'ambiances singulières liées à la diversité des décors urbains traversés, un montage producteur de moments d'accélération et de rupture (tradução minha).

${ }^{34}$ [...] une succession de décors proche d'un collage urbain réalisé par le marcheur lui-même avec l'énergie de son corps et l'acuité de son regard (tradução minha).
} 
Trata-se de uma composição que articula por meio de flechas vermelhas várias regiões recortadas de um mapa de Paris, possibilitando a visualização das mudanças de ambiência resultantes de deslocamentos urbanos. Ela evidencia a velocidade e a descontinuidade dessa deambulação, igualmente característica da montagem cinematográfica. Um filme expõe seu movimento por meio dos intervalos entre as imagens que o compõem, seja materialmente (pelos fotogramas), seja formalmente (pelo efeito da montagem). À propósito da produção cinematográfica de Debord, Giorgio Agamben refere-se à repetição e à pausa como dois procedimentos presentes tanto na construção de situações e na realização das

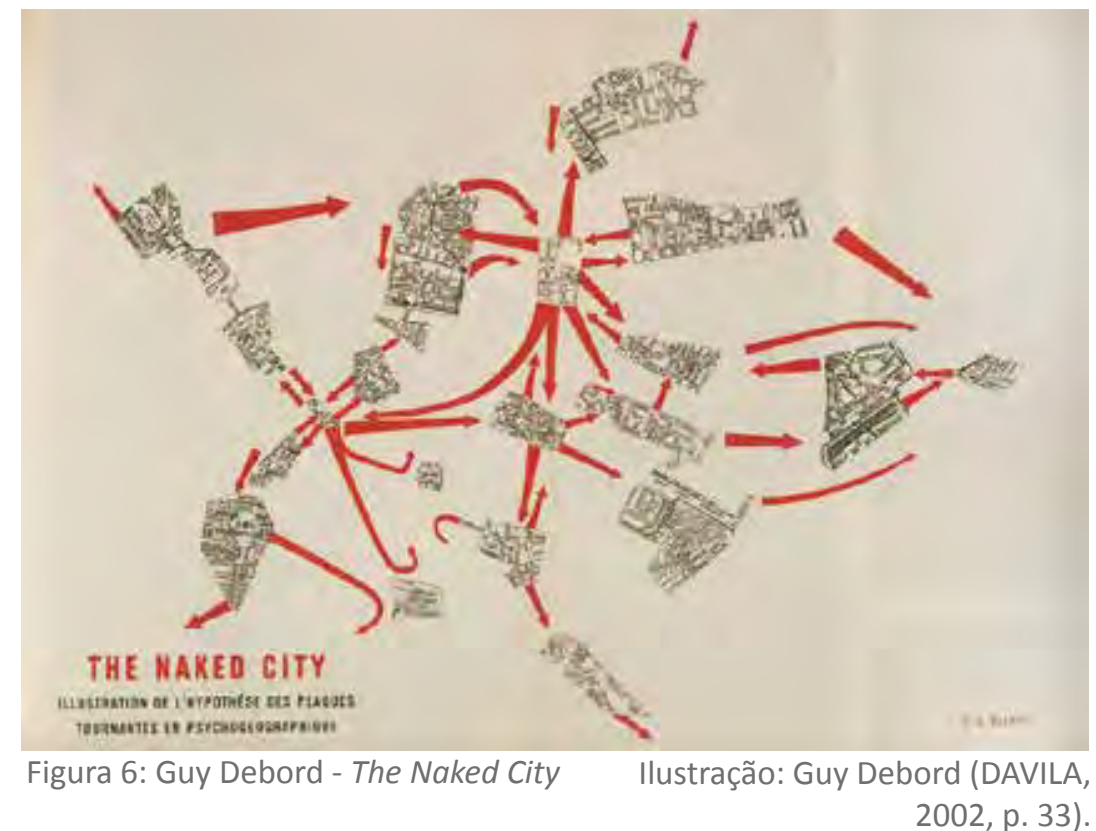

derivas, quanto na composição fílmica de Debord (DAVILA, 2002, p. 32). Ao aproximar deslocamento e cinema, o caminhar e a composição de uma sequência de imagens, Davila afirma que a "deriva é um desvio ou uma apropriação cinematográfica da cidade e de sua arquitetura". Assim, a deriva seria um modo paralelo de apropriação da cidade, suas imagens e ambiências, uma vez que ela traduz com exatidão o modo pelo qual Debord compunha seus filmes e suas colagens, a partir da prática do desvio ou da apropriação [détournement].

Nesse mesmo sentido, Patrick Marcolini relembra que os efeitos de montagem produzidos pela deriva estão em consonância com o interesse dos situacionistas pelo cinema e pela história em quadrinhos. Seguindo essa linha de raciocínio, poderíamos afirmar que a deriva é um modo cinematográfico de observar a cidade, pois a sensação da caminhada sem rumo é a mesma de uma câmera em movimento, realizando um travelling e no caso dos percursos de taxi, uma cena de cinema on the road.

Em seu estudo sobre a experiência e a representação do sujeito na genealogia da arte e do pensamento de Guy Debord, Gabriel Zacarias afirma que "a deriva se propõe como um mé- 
todo de conhecimento objetivo da cidade, que deve produzir uma nova experiência para os

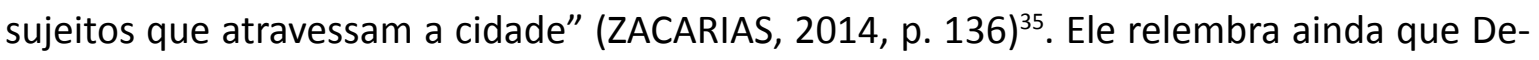
bord designa o sujeito da deriva como um "observador-observado", tentando resolver essa contradição fazendo apelo à figura literária do passante. De acordo com esse pesquisador, o sujeito se configura como resultado da experiência. "O sujeito da deriva é o produto temporário dessa experiência"(Ibid.) ${ }^{36}$. Assim como Debord afirma que as dificuldades da deriva são as mesmas da liberdade, o jogo não se constitui a partir de uma postura artificial. Ou seja, a deriva não existe a priori, ela depende de um ato de entrega, de um deixar-se levar, correndo riscos e entregando-se para o que nela acontecer. Desse modo, a deriva é sempre um devir e pode ser traduzida como uma reconquista dos territórios ocupados da vida.

\footnotetext{
Certamente a questão do andar é significativa e está relacionada com a errância, mas o errante urbano busca ir além da questão do andar, o que lhes interessa é a experiência do percurso, do percorrer, que pode também se dar por outros meios. O foco dos errantes não é exatamente o andar em si, mas o estado em que eles se colocam ao andar sem rumo, pelos percursos indeterminados, um estado de corpo errante (JACQUES, 2012, p. 271, grifo meu).
}

Em seu livro sobre os errantes, Paola Berenstein Jacques associa as errâncias de Helio Oiticica à prática da deriva, tomando como referência as práticas que o artista brasileiro definiu como Delirium Ambulatorium. Trata-se de uma espécie de movimento criativo desenvolvido por Oiticica em suas andanças pelo Rio de Janeiro, nas quais sempre levava consigo um bloco de anotações (Index cards), onde tomava notas sobre seus projetos. Oiticica falava em caminhar sem linearidade, em ambulatoriar e em "inventar coisas para fazer durante a caminhada".

Ele se pergunta se o campo urbano se transformaria pelo Delirium Ambulatorim naquilo que Lygia Clark chamaria de objeto relacional, em todo caso, a cidade, em particular o Rio de Janeiro, aparece aí como um grande jogo, uma cidade playground a ser pensada pelo corpo-pé (Ibid., p. 227).

Por esse motivo, Paola B. Jacques aproxima Oiticica dos surrealistas Aragon e Breton, que agiam como etnógrafos do espaço urbano. $\mathrm{O}$ artista relaciona-se com a cidade como quem explora um labirinto, descobrindo trajetos, perdendo-se e "reconstruindo o mundo como um grande quebra-cabeça", segundo Cesar Oiticica Filho, curador e sobrinho do artista (Ibid., p. 166). Ele tinha o hábito de pegar o ônibus e ir até o ponto final para ver onde chegava, uma prática que levou Helio Oiticica a conhecer todo o subúrbio carioca. No início dos anos 60, Oiticica percorria com frequência as áreas mais marginalizadas da cidade, inclusive em passeios noturnos. "Helio Oiticica nunca separou seu trabalho artístico da sua vida

\footnotetext{
${ }^{35}$ La dérive se propose comme une méthode de connaissance objective de la ville, qui doit produire une nouvelle expérience pour les sujets qui traversent la ville (tradução minha).

${ }^{36}$ Le sujet de la dérive est le produit temporaire de cette expérience (tradução minha).
} 
cotidiana, nem as questões corporais das questões urbanas, nem a experiência sensorial do corpo da própria experiência corporal da cidade, principalmente através da prática das errâncias" (Ibid., p. 168).

O corpo tem um papel definitivo em sua criação, não apenas o seu próprio, mas o corpo de quem entra em contato com suas invenções, enfatizando um deslocamento do corpo como sujeito (como eu) para um corpo social, coletivo, outro. Não se trata de algo particular ou próprio a esse artista, que teria uma apreensão especial da obra, mas de uma ideia de corpo, em estado de entrega, de exploração. Quando apresenta a ideia de parangolé, Hélio explica que a obra requer a participação direta do corpo, ele fala em incorporação. Não se trata de algo que reveste o corpo, nem do seu uso como suporte da obra, é a incorporação mútua: do corpo na obra e da obra no corpo. O parangolé é um programa. O parangolé é um criador de situação, é um dispositivo de movimento, um detonador de um clímax corporal. Oiticica pensa o parangolé como uma extensão do corpo e ao mesmo tempo, o modo de descobrir, de (re)conhecer o próprio corpo. Para o artista, o corpo é a medida, é a constatação máxima que ele aciona seja pelo movimento, no sentido de uma dança (no caso dos parangolés), seja pelo deslocamento em diferentes propostas nas quais convoca os espectadores-participadores a caminharem.

Nesse sentido, o que Hélio Oiticica defende é a exploração da obra pelo corpo. Não se trata de um contato visual, mas de um mergulho, uma imersão, na instalação ou na cidade. As proposições desse artista nos ajudam a refletir sobre esse estado do corpo errante, um corpo que perscruta a cidade, apreciando não apenas suas visões, mas seus sons, seus cheiros, suas texturas. $\mathrm{O}$ corpo errante é impregnado e imantado pela experiência imersiva na atmosfera urbana. Walter Benjamin refere-se a essa sensação do corpo errante em sua Rua de mão única:

\footnotetext{
Saber orientar-se numa cidade não significa muito. No entanto, perder-se numa cidade, como alguém se perde numa floresta, requer instrução. Nesse caso, o nome das ruas deve soar para aquele que se perde como o estalar do graveto seco ao ser pisado, e as vielas do centro da cidade devem refletir as horas do dia tão nitidamente quanto um desfiladeiro. Essa arte aprendi tardiamente; ela tornou real o sonho cujos labirintos nos mata-borrões de meus cadernos foram os primeiros vestígios (BENJAMIN, 1987, p. 73)
}

A experiência de perder-se, que Benjamin associa à figura do labirinto, é recorrente nas narrativas sobre errâncias na cidade. $O$ estado corporal de quem percorre um labirinto tem menos a ver com o espaço concreto e mais com a experiência de perder-se, ao longo da qual percursos são descritos. O resultado desse desorientar-se é o traçado de um itinerário não funcional, não habitual e, muito provavelmente, impossível de ser retomado. Acontece que a sobreposição de muitas ações recorrentes de errância no mesmo território vincula 
definitivamente o errante àquele espaço. Quando Benjamin fala em instrução para perder-se, ele afirma a necessidade de uma abertura para o novo, para o inesperado, para o sem controle. Há uma entrega, um deixar-se levar, um vagar sem rumo e uma coragem embutida no uso inoportuno e não programado do espaço público. Tendo em vista os projetos urbanísticos modernos aos quais os situacionistas se opunham, uma deriva é em si mesma um desvio, uma apropriação de um espaço projetado para ser sumariamente utilizado (apenas para deslocamentos rápidos e funcionais) para fins subversivos.

Guy Debord afirma na tese de número 172 de $A$ Sociedade do Espetáculo que desde a Revolução Francesa, há um esforço dos poderes estabelecidos para ampliar a ordem da rua, o que teria culminado na sua supressão. Os meios de comunicação de massa à longa distância, assim como o isolamento da população em pseudocoletividades (fábricas, centros culturais, clubes de férias e condomínios residenciais), seriam medidas bastante eficazes para a desaparição da rua. Todos os desenvolvimentos tecnológicos que contribuem para a aceleração dos tempos - como os meios de transporte, os meios de comunicação e as estradas - se retrocedermos ainda mais historicamente, servem para encurtar as distâncias geográficas e reduzir os tempos de experiência. Todo o tempo de sobra, resultante da economia proveniente dessas tecnologias, passa a ser tempo dedicado ao trabalho e, apenas teoricamente, ao lazer. Junto com a supressão da rua e da experiência de percorrer geograficamente o espaço, suprime-se também o tempo do ócio, que consiste em permitir-se o tempo do pensamento, do decantar, do vagar pela casa e pela cidade sem a intenção de produzir algo.

Para concluir, é relevante distinguir o deslocamento empregado nas derivas daqueles realizados em situações de turismo. É provável que muitas pessoas tenham se permitido algum tipo de errância apenas em situações de viagem, ao fazer turismo, ainda que muitos viajantes considerem essa prática perda de tempo e desperdício de dinheiro. Contudo, essa circulação humana associada ao turismo é considerada por Debord como um subproduto da circulação de mercadorias. Segundo ele, o turismo "resume-se fundamentalmente no lazer de ir ver o que se tornou banal.(...) A mesma modernização que retirou da viagem o tempo, lhe retirou também a realidade do espaço" (DEBORD, 1997, p. 112).

\section{> II. derivas dodecafônicas e outras derivas artísticas}

A partir de agora apresento duas ações de grande escala realizadas pelo Coletivo Teatro Dodecafônico: a Deriva 24 horas e a Deriva do Elástico, uma deriva estendida no tempo. Integrei tais derivas apenas de maneira parcial, mais como observadora-pesquisadora, do que como vivenciadora dessas experiências. Em seguida, apresento algumas experimenta- 
ções que realizei sozinha ou com parceiros ocasionais durante meu período de estudos na França. Por fim, um exemplo de performance e outro de encenação no contexto urbano serão igualmente analisadas.

Depois de experimentar derivas de algumas horas, o Coletivo Teatro Dodecafônico realizou a Deriva $\mathbf{2 4}$ horas, segundo proposta realizada por Bia Cruz: uma deriva que iniciou no dia 6 de dezembro de 2014 às 19 horas e durou até às $19 \mathrm{~h}$ do dia seguinte, tendo a Praça Roosevelt como ponto de partida ${ }^{37}$. Ao final de um dia inteiro de deslocamento, com pausas a cada quatro horas para descansar, comer, realizar escritas automáticas e recarregar as baterias, o grupo chegou ao Cemitério do Araçá. Ou seja, entre o ponto de partida e o ponto de chegada há uma distância relativamente curta, que poderia ser realizada em menos de uma hora, no entanto o percurso resultante de uma deriva nunca tem a forma de uma linha reta ${ }^{38}$. A finalização aconteceu na frente do Estádio do Pacaembu, onde os participantes que resistiram até o final da experiência desenharam mapas psicogeográficos da deriva, pontos de vista pessoais e poéticos dessa jornada em deslocamento. A partir de um chamamento pela internet, cerca de 10 performers resolveram acompanhar o coletivo nessa empreitada. Nem todos permaneceram todo o tempo, mas a experiência gerou um "atravessamento de seu corpo pela rua", nas palavras de Hideo Kushiyama. Ele sentia "a rua entrando pelas veias abertas do [seu] corpo EXPOSTO"; para ele, "errar nunca foi tão motivador".

Nas práticas do Coletivo Teatro Dodecafônico, mantemos o procedimento surrealista da escrita automática. Em algumas experimentações que realizei individualmente, esse tipo de escrita também ocorre antes de caminhar pelo espaço público, no que nomeei como prévia da deriva. Os textos decorrentes desse processo, além de documentar as derivas, que são práticas invisíveis no corpo da cidade, tornam-se materiais de trabalho, que podem ser manipulados por todos os integrantes do Coletivo e transpostos para publicações e performances, geralmente sem identificação do autor inicial. Para isso, o Coletivo mantém um blog e um arquivo virtual conjunto, este último é acessível apenas aos integrantes do Dodecafônico. Algumas frases produzidas pós derivas voltam para as ruas na forma de inscrições com giz e carvão em muros e calçadas, outras se inscrevem na cidade por meio de estênceis. Sandra Ximenez, uma das integrantes do coletivo, faz composições musicais a partir dessas escritas, algumas delas figuram em seu mais recente álbum Turbulência.

\footnotetext{
${ }^{37}$ Participaram da deriva, com tempos diferentes de permanência: Ana Paula Augusto, Beatriz Cruz, Cacá Bernardes, Hideo Kushiyama, Juliana Rodrigues, Karen Santos, Monica Lopes, Nathalia Imbrizi, Paulina Caon, Papá Fraga, Pedro Galiza, Sandra Ximenez, Tatiana Ribeiro e Verônica Veloso. Algumas escritas automáticas e imagens fotográficas produzidas nessas 24 horas podem ser vistas no blog do coletivo: <http://teatrododecafonico.blogspot.com.br/search/label/Deriva\%2024h>.

${ }^{38} \mathrm{O}$ percurso realizado pelo grupo levou da Praça Roosevelt ao Cemitério do Araçá, passando pelo Bixiga, Avenida Paulista, imediações do Parque do Ibirapuera, Jardins até o Cemitério do Araçá.
} 
Para Sandra Ximenez, que permaneceu a madrugada com o grupo, a relação com a cidade foi retratada assim:

"lugar estado situação nômade provisória

quando estar e ser se (con)fundem 24hs de deriva urbana

radicalidade

não peregrinação não modo de vida sim engajar namoro com a urbe”

Monica Lopes, conta nessa escrita au-

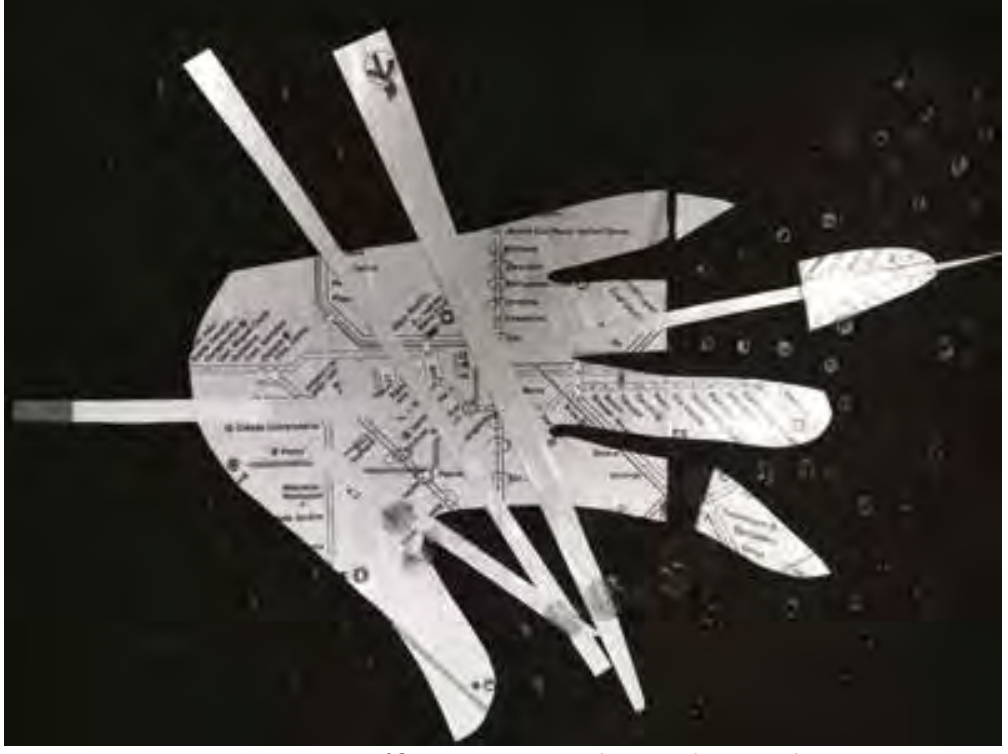

Figura 9: Mapa psicogeográfico

Desenho: Hideo Kushiyama

Deriva $24 h$

tomática, realizada na pausa do café da manhã, da sensação do corpo depois de 12 horas de deriva. Ela foi uma das performers que permaneceu 24 horas em errância.

"Amanheceu, estamos na Ana Rosa, em uma Ilha de carros, hora de tomar café da manhã para seguir viagem. Estamos na metade de nossa jornada de $24 \mathrm{~h}$, os pés doem. Preciso de um café, o corpo pesa mais ao perceber que amanheceu e não dormiu. A quantidade de carros na rua aumenta o som dos motores, permanecemos parados na Ilha, ninguém se move, os comércios abrindo as portas. Na madrugada só se ouvia os passos, uns dos outros, silêncio absoluto no bairro, ocupar a rua. A noite não fez frio e a lua cheia nos acompanhou a noite inteira."

Beatriz Cruz, que também caminhou as 24 horas, escreveu: "Durante: Morri várias vezes". Tal experiência funcionou como um teste dos próprios limites, um reconhecimento das energias vitais. Trata-se de uma microprática política, uma vez que a ação persiste durante as 24 horas de um dia, sem ser vista por ninguém. Ela também funciona como uma discreta turbulência no cotidiano. Apesar de ter sido divulgada pela internet e algumas pessoas saberem do que estava acontecendo, as pessoas eram convocadas para integrar a ação, participando efetivamente dela e não para assisti-la De duas em duas horas, uma pessoa diferente assumia a função de cuidadora do grupo, portando um celular, cujo número havia sido divulgado como referência pra encontrar o grupo. Além disso, um aplicativo do tipo GPS foi instalado no celular da performer proponente, possibilitando que o grupo fosse encontrado ou seguido virtualmente. Esse dispositivo mostrava o traçado do percurso, caso alguém quisesse se juntar aos errantes ao longo das 24 horas, pois só havia ponto de partida e não era possível prever aonde as pessoas se encontrariam às 4 da manhã, por exemplo.

Nessa exploração, as dimensões política e artística se viam de tal modo integradas que dificilmente um passante poderia identificar que se tratava de uma performance, tamanha a simbiose da ação com o corpo da cidade. Também era possível afirmar que houve uma dissolução do espectador. Nesse ponto, voltamos à radicalidade do jogo situacionista, uma deriva que não se pretendia artística, mas um "jogo antifuncionalista" (Debord), "uma forma de (des)orientar-se, na contra-mão da proposição urbanista"(Jacques) e "um exercício experimental da liberdade" (Oiticica). A revolução molecular nesse caso é infrapessoal. É 
importante permitir-se, ir além dos próprios limites, para descobrir outra relação com a cidade, "outro tipo de produção de subjetividade e de desejo na cidade" (Jacques, 2012, p. 265).

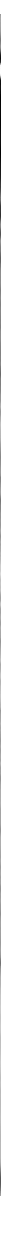

A 6 horas do fim da deriva, Monica Lopes escreveu:

"Eu me aquietei também em um ponto de táxi, um banco de madeira na sombra. 0 Sol estava bem quente, Sol a pino. Neste momento eu me sentia uma velha de 100 anos ou mais, 200 anos talvez, que pausa na soleira da porta e permanece sem nada fazer, apenas refletindo sobre a vida, que passou, sobre as experiências vividas até então. 0 corpo responde pouco neste momento. Apenas contempla, vê a cidade de outra forma. Não dá para correr ou fazer movimentos abruptos, um corpo em falência. Viadutos, carros, escada, uma casa com janelas, parede branca. Exaustão, faltam mais 6 horas. Caminho lentamente e apenas permaneço nos lugares, como uma coisa, um objeto jogado no chão. [...] cachorros, muitos cachorros presos a coleiras levam seus donos para passear. 0 cachorro que seguimos, não tinha coleira, ele finalizou nossa trajetória esta manhã. Abriu para a próxima jornada, o período da tarde, com o que nos resta de corpo".

Um dos procedimentos para a deriva de 24 horas é seguir alguém. No final da experiência esse procedimento foi desviado e o grupo seguiu um cachorro. A seguir reproduzo a lista dos procedimentos pelos quais o errante condutor pode transitar. Ele anuncia o procedimento escrevendo no chão com giz. Cada errante permanece 2 horas nessa função, que é 
alternada entre todos os participantes.

_TOCAR: Em cada encruzilhada, defina que caminho tomar a partir daquilo que você quer tocar: texturas, mobiliário, objetos e etc. Encoste-se, sente-se, deite-se, esfregue-se.

_OUVIR: Sempre que tiver que optar por um caminho, atente para os sons que consegue ouvir. Escolha a partir do som que mais

te interessa.

_DADO: Jogue um dado sempre que tiver que definir o caminho. Na primeira jogada, você define o lado (par = esquerda ou ímpar = direita). Na segunda jogada, você determina o número de quarteirões para andar.

_AR: Sempre que tiver que optar por um caminho, escolha aquele em que o ar pareça mais agradável.

Em uma das notas de fim de capítulo do livro de Paola Berenstein sobre os Errantes, ela cita Deleuze e a disputa no campo do simbólico principalmente quando se trata do contexto urbano. Quando publicitários e marqueteiros passam a criar conceitos, a produzir e vender experiências, as esferas da arte e da educação devem entrar em estado de alerta. Essa questão é apresentada por Jean-Gabriel Carasso no seu livro "Nos enfants ont-ils droit à l'art et à la culture? " [Nossas crianças têm direito à arte e à cultura?], (Éditions de l'Attribut, 2011), um manifesto para uma política da educação e da cultura. De acordo com ele, a mercantilização geral desenha a paisagem, transformando tudo em mercadoria. "Do objeto à imagem, do material à força de trabalho, as ideias, as formas, os corpos, os pensamentos... tudo se compra, tudo se vende. Até o tempo de 'cérebro' disponível" (CARASSO, 2011, p.20) ${ }^{39}$.

O autor se enraivece diante dos jovens cérebros disponíveis a serviço de anúncios de refrigerante. Em resposta aos territórios sem fronteiras, incertos em seu espaço e em sua identidade, ele confia à educação, à arte e à cultura o papel de adaptação ao mundo em movimento. A função das ações artísticas seria, portanto, a de antecipação do mundo em mutação. Carasso aposta em um desenvolvimento durável, promovido pela reconquista dos espaços públicos, o que permitiria uma nova representação da cidade e da arte. "A educação artística e cultural deveria ser para a política cultural o que as energias renováveis são para as opções energéticas: uma política de desenvolvimento cultural durável!" (Ibid., p. 115$)^{40}$.

\footnotetext{
${ }^{39}$ De l'objet à l'image, du matériau à la force de travail, les idées, les formes, les corps, les pensées... tout s'achète, tout se vend. Jusqu'au temps de cerveau disponible (tradução minha).

${ }^{40}$ L'éducation artistique et culturelle devrait être à la politique culturelle ce que les énergies renouvelables sont aux choix énergétiques : une politique de développement culturel durable ! (tradução minha).
} 
Passar 24 horas em deriva, nessa ação que se propõe como uso livre dos espaços e tempos da vida, é um modo de ocupar conscientemente esses tempos de cérebro. A ideia de passar 24 horas zanzando pela cidade, sem objetivo definido pode parecer para muitos uma perda de tempo, ou vagabundagem. Na vida cotidiana urbana não nos permitimos perder tempo, a regra geral é que o tempo seja útil e produtivo. Não nos damos tempo e raramente respeitamos nossos tempos de fazer as coisas. O que uma deriva promove é um uso poético do tempo, como "namorar a urbe", uma negação a deixar tempos de cérebro disponíveis.

Uma série de hábitos, comportamentos e usos do espaço e do tempo são repetidos, sem percebermos que vivemos sob um forte sistema de controle, que vem da máquina do mundo, do dinheiro, do trabalho, da família e de cada um. A ousadia dessa ação vem, portanto, do fato de um grupo de pessoas decidir junto romper com a regra dada, como quem faz uma greve, como quem interrompe um fluxo, como quem se recusa a continuar. Caminhar 24 horas ao léu significa menos o traçado de um percurso, do que a proposição de uma pausa, à medida em que um grupo de pessoas interrompe temporariamente a máquina do mundo. Trata-se de um gesto simbólico: a interrupção do espaço/tempo disponível de cérebro para as influências e estímulos vigentes. Essa deriva é uma escolha deliberada, capaz de modificar o corpo pós 24 horas, um intervalo para (re)pensar como viver a soma de todos os dias, um movimento de revisão.

Tríade que se configura em estado de lentidão Não somos lentas,

esse é nosso tipo de movimento

Lentas, atentas

A trinca trava a rua

a escada

sem espada, mas em escudo

trios

ângulos se

observam se

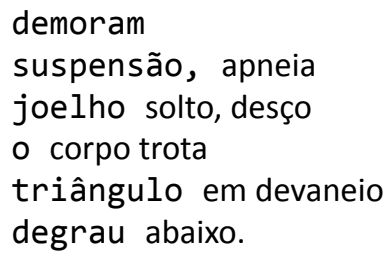

[escita automática de Verônica Veloso, de 11 de agosto de 2014] ${ }^{41}$

A Deriva do Elástico começou a ser desenvolvida pelo Coletivo Teatro Dodecafônico em fevereiro de 2015 nas imediações da Praça Roosevelt e ela segue seu fluxo até os dias de hoje (início de 2017). Trata-se de uma experiência de deslocamento em deriva pelo contexto urbano, na qual o grupo de participantes age como se um elástico invisível os envolvesse. A ideia original dessa deriva surgiu da experimentação do programa de performance "Aqui enquanto caminhamos", de Gustavo Ciríaco e Andrea Sonnberger (2006), proposta por Antônio Araújo aos estudantes da disciplina Práticas Performativas II. Depois de tal experimentação, iniciamos uma exploração semelhante, subtraindo a materialidade do elástico,

\footnotetext{
${ }^{41}$ Período anterior à exploração da Deriva do Elástico propriamente dita, mas no qual já experimentávamos os estados de atenção.
} 
pela percepção conjunta do corpo do bando. Inspiradas também na prática dos Viewpoints, disseminada por Anne Bogart, sobretudo no que se refere à expansão da visão periférica e à noção de campo de visão, a ação dodecafônica consiste em deslocar-se conjuntamente perguntando-se: o que te faz parar e o que te faz andar. Cada participante responde íntima e silenciosamente por meio de suas ações, ao mesmo tempo em que coloca os próprios desejos em negociação com os desejos dos outros. Desse modo, cada participante deverá manter ao menos um outro jogador em seu campo de visão. Ou seja, por mais que o elástico se expanda, ele não permitirá que um de seus participantes se disperse completamente na complexa rede de itinerários e atrações da metrópole.

pouco movimento que distancia e muito daquele que aproxima a gente da gente e dos lugares dos passantes do ar da cidade suja tocando cores e pedaços. tem hora pra aquietar e tempo pra correr estamos sempre incansáveis em movimento deslocamentos por momentos em conjunto. querer pertencer fazer daquilo que vê algo que fica da deriva, deriva sendo sempre passagem mas fica no corpo, fica no corpo de bando. sigo com os pensamentos em fluxo pé com pé sensação de ter observado a rua de um lugar pouco frequentado, frequento estados relembro o tempo - esquecimento - que hoje trouxe lembrança, escrita e deriva têm fim? o fim me lembra o começo o fim me deixa do avesso para para anda para anda para anda anda anda para anda para para o que atrai nem sempre alcanço. o coletivo é pulso, não resta resto de nada restamos parados em reverberação de lugares passados futuros possíveis. [escrita automática de Luisa Hokema, de 7 de março de 2016]

Diferente da Deriva 24h, na Deriva do elástico não há um errante condutor. Todos os envolvidos agem simultaneamente fazendo escolhas e negociando com os próprios desejos e interesses despertados pelos passantes, pelos fluxos de gente e de automóveis, pelos mobiliários urbanos, pela paisagem e pelos acontecimentos revelados pela cidade. Tendo partido algumas vezes da Praça das Artes (em março de 2015), essa ação começou a ser repetida mais ou menos semanalmente na região do centro de São Paulo, até o momento em que se percebeu que não fazia sentido errar sempre pela mesma região. Foi quando o Coletivo decidiu retomar o elástico, a cada novo encontro, a partir do ponto em que se havia chegado no último elástico experimentado. Desse modo, tem-se uma impressão de continuidade da experiência, de modo que a deriva que se iniciou na Praça das Artes há mais de dois anos, encontra-se agora em Santana, Zona Norte de São Paulo (março de 2017).

\footnotetext{
Uma deriva costurada em meio a outras tantas experiências da vida, em meio a intervalos potentes. Uma deriva linha que conecta as distâncias entre os pontos, construindo um tecido duplo, triplo, múltiplo. Um percurso único que se percorre em camadas ou dimensões no espaço-tempo. Um eterno recomeço, uma eterna possibilidade. Afinal, quando recomeçamos o próximo trecho, já não somos os mesmos, assim como aquele espaço de início já se reconfigurou. Corpo e cidade em constante transformação, regeneração. Deriva leito de rio (CRUZ, 2016, p.9596).
}

Ao longo dessa exploração sempre há uma ou duas pessoas que se encarregam de docu- 
mentar a ação em tempo real. Essa documentação pode ocorrer por meio de fotografias ou vídeos e ainda pela prática de escrita ou narração sonora. Nesse último caso, o observador pode descrever o que vê, tanto a respeito dos jogadores quanto dos passantes, narrar situações ou desenvolver pensamentos que lhe ocorrem. Do mesmo modo como ocorreu na Deriva $24 \mathrm{~h}$, ao final de cada dia de deriva os participantes realizam escritas automáticas, que podem ser reformuladas posteriormente. Na escrita abaixo, Olívia Niculitcheff descreve suas impressões em um dia que se colocou como observadora da deriva, na tarefa de registro fotográfico dos passos do Coletivo:

sou o outro, criadora das imagens, mas me sinto em jogo. eu> primeiro estado de atenção, muitas linhas são formadas pelos braços, queremos sentir o ar? queremos espaço? outro> antes de espaço, pessoas nos cruzam, nos olham, carros buzinam quando alguém está no lado do rio em qualquer posição pouco comum, espaço>nos atravessa, o movimento do fluxo contínuo dos carros, sempre na mesma direção nos atravessando a todo e todo momento, é agressivo, é risco, atravessar a rua exige um outro corpo, estado de atenção, prontidão, esperar, correr. seguimos a linha reta da avenida, o espaço estreito da calçada entre o rio e a avenida fazem com que andemos em linha, pontos que formam linhas, aprendemos a convivência na avenida com os comerciantes que vendem pequenas coisas aos carros, porta GPS e etc. eu me sinto em jogo, em linhas, em risco, quero captar a imagem dessas linhas infinitas de um trajeto reto. fluxo de pessoas, posto de gasolina, detran, metrô, espaço de passagem, corpos corpos corpos, estamos praticamente invisíveis, cidadãos comuns, mas eu não posso me sentir invisível pois tenho uma câmera pendurada no pescoço, isso impossibilita a invisibilidade e traz um risco, uma faísca de medo, que ao mesmo tempo me deixa em estado de alerta de criação, de movimentação, captadora de ângulos e enquadramentos. [escrita automática de Olívia Niculitcheff, de 20 de junho de 2016]

O jogo do elástico invisível configura-se como uma deriva cujo percurso é estendido no tempo. Beatriz Cruz usa a fórmula "jogo de partículas que se movem no espaço" para referir-se de maneira poética tanto aos integrantes da deriva, quanto a tudo o que se move na cidade. Corpos errantes, passantes, carros, o vento ou a chuva, a bicicleta ou um ruído, uma música ou um passarinho, todos são partículas móveis que integram e constituem o território urbano.

Um observador atento ouve o motor tremilica as mãos a todo vapor quer morder feito vibrador, quer ouvir o cimento se mexer por dentro, quer ver as cores se moverem na parede da cidade. Tudo se move em um tempo imprevisto, lento ou rápido. Os tempos não morrem. A lentidão não morre, apenas vai ficando mais invisível dentro da cidade estriada. As milhares de informações extremamente estimulantes desviam a atenção do grande. O grande vazio que há em mim há na parede branca. A velocidade do trem me leva pro centro da terra. Me puxa para a realidade visível. Mas volto para os pontos de luz amarelos que encobrem 0 chão velho, cheio de memória. o agora sobreposto ao passado. Transversalidade dos tempos. Uma flor pinta o chão que o homem pinta. Esquecida todos os dias. Sua morte é a alegria de quem passa. 0 corpo quer cheirá-la. Quanto tempo dura o cheiro de uma flor após a sua queda? 0 encontro com o invisível prepara a minha carne para o próximo instante. Não quero saber, mas sei, sei o suficiente que não sei. Esse saber não perdura, passa e volta. Eu vôo com as costelas. $\mathrm{Eu}$ ando com as minhas costelas flutuantes, ando com os cílios tocando o céu, ando com o osso alcançando o ar. E canto a vibração dos homens. Ele nos observa 
com toda a sua voz embriagada de vibração. Ele nos olha com sua voz.

Vai embora e deixa o tom aqui. Canta. Mas não é como os passarinhos. É como aquela árvore presa. Até as árvores foram presas, porque estavam cantando por dentro. Foi possível ouvi-las. o canto preso na matéria dura, nos espaços curtos. Seria limitante outra rua? [escrita automática de Papá Fraga, de 19 de outubro de 2015]

JOGO PARA UM PERCURSO - Elástico invisível

(Regras e procedimentos) ${ }^{42}$

Jogo para um percurso ou elástico invisível ou jogo de partículas que se movem no espaço

\section{0 que é o jogo?}

Uma experiência de deslocamento em deriva num percurso urbano.

\section{Regras:}

Pode-se andar e pausar.

Na dúvida, siga as perguntas: 0 que te faz andar? 0 que te faz parar?

o andar e a pausa acontecem pelo estímulo dos elementos do espaço, dos outros jogadores, das pessoas que passam e de tudo o que se move na cidade.

Jogadores se mantêm como se tivessem conectados por um elástico invisível que pode esticar ou aproximar. Por isso, mantém-se pelo menos um jogador no campo de visão.

Jogadores são partículas em movimento conectadas e afetadas por outras partículas.

Traçam linhas e desenhos no espaço.

Palavras-chave: Sutil, simples, impulso.

\section{Procedimentos :}

_Seguir o fluxo daquilo que se move (pessoas, carros, caminhões, bicicletas, pombas etc).

- Traçar linhas imaginárias que dialogam com as linhas do espaço (verticais, horizontais, diagonais, circulares).

_Seguir o andamento de alguém que passa (jogador ou transeuntes), no mesmo sentido ou em sentido oposto.

_Formar figuras geométricas imaginárias (retas, triângulos e quadrados) com os outros jogadores. Cada participante é um vértice.

${ }_{42}$ Programa organizado por Beatriz Cruz, disponível no blog do Coletivo Teatro Dodecafônico: <http:// teatrododecafonico.blogspot.com.br/2015/03/jogo-para-um-percurso-elastico.html>. 
A cada saída do Coletivo para a Deriva do Elástico há uma sequência que se repete. Inicialmente, escolhe-se um recorte do espaço para espreguiçar-se e soltar o corpo, apoiando-se em muros, mobiliários urbanos, usando grades e postes como apoio. Em seguida, passa-se à exploração das articulações em uma proposta derivada da Balada Silenciosa, chamada de articula-som. Nesse caso, não se usa fones de ouvido e toda a exploração das articulações passa a ser estimulada pelos ruídos da própria cidade. A partir de um certo momento, notou-se que a Balada Silenciosa ${ }^{43}$ podia afastar os corpos de sua relação concreta com a cidade, além de isolar os participantes na relação com as músicas de sua preferência. Com o articula-som, os performers despertam o sentido da audição e se aproximam do contexto urbano a partir dessa percepção sonora.

Antes de sair em deriva, o grupo ainda passa pela ativação de três estados de atenção. Proveniente do estudo da técnica Klauss Vianna, esse procedimento desperta as relações de cada participante com o espaço, o outro e o próprio corpo. Sendo abordado em qualquer ordem, os estados de atenção colaboram para a construção de um estado do corpo errante. Há uma percepção direta do espaço em sua materialidade, da arquitetura do entorno, das condições climáticas, das luminosidades, das dimensões e das distâncias. Nesse momento compreende-se corporalmente o território ocupado, estabelece-se uma relação mais concreta com o espaço da rua e das calçadas ou praças e também com os fluxos de pedestres e automóveis. Ao observar os demais corpos, um vínculo entre os integrantes da deriva se constituiu, é nesse momento que o elástico invisível se constrói, no acordo entre os diferentes tempos e os diferentes corpos. O elástico se configura nesse espaço entre, na tensão e nos vazios entre os corpos envolvidos. Ao observar o próprio corpo, dedica-se um tempo de observação a si mesmo, à relação com o chão, à medida dos passos, ao andamento que se pratica na vida e às variações mais ou menos perceptíveis a cada dia.

O corpo de bando se esgueira pela Rua do Bosque. Mas o bosque aqui nasceu foi dentro de um grande galpão feito só de paredes, ao lado do trilho do trem. Foi o tempo que cavou essas reentrâncias bem no meio do edifício. Esse galpão costumava guardar o bosque embaixo dos assoalhos. Veio o tempo, passaram os homens, correu o trem, o teto desabou. As árvores ganharam ganas de crescer e exibiram-se. De baixo, ninguém suspeita que tem um bosque guardado. Mas de cima da ponte, vê-se tudo. É uma cidade esquecida, ao lado de uma cidade habitada e de outra percorrida em alta velocidade, em corpos metálicos. Um entroncamento de velocidades. No máximo 50 quilômetros para os carros, 20 quilômetros para as bikes e 10 quilômetros pros meninos que passam a pé. Nós, pausados, extasiados, boquiabertos diante do bosque dentro do galpão, os prédios, o skyline, o trilho do trem e a escola de samba que puxa o compasso pra trás. O tempo em decomposição. E o mato crescendo logo ali a mil por hora.[...]. o corpo é tão íntimo ao lado da pista de alta velocidade. Se eles pudessem

\footnotetext{
${ }_{3}$ Proposta realizada pelo Coletivo Teatro Dodecafônico que consiste em colocar fones de ouvido, sendo que cada participante coloca sua playlist de preferência e começa a dançar, partindo dos pés, joelhos, pernas, quadris, coluna, cabeça, ombros, braços e mãos, sucessivamente. Ao final, explora-se todas as articulações aleatoriamente.
} 
ouvir o barulhão daqui de dentro do meu peito. Mas a pista é para os carros. São eles que, agora, operam o vento. São eles que mobilizam nossos corpos, nossas roupas e agitam nossos cabelos.
Enquanto uma escola de samba se desmaterializa, logo ali, embaixo das avenidas. Esse é o lugar dos silêncios trocados.

[escrita automática de Verônica Veloso, 7 de março de 2016]

No dia 07 de abril de 2015, iniciei as Derivas parisienses [Dérives parisiennes] inspirada por uma frase de Guy Debord, publicada em sua Teoria da Deriva: "pode-se derivar sozinho". Contudo, o autor afirma que as derivas mais interessantes são realizadas em pequenos grupos, ao que Jacopo Crivelli Visconti reage afirmando em seus estudos sobre as novas derivas - aquelas assumidamente desenvolvidas no âmbito artístico - justamente o contrário: "é possível derivar em grupo, mas as ações mais memoráveis são levadas a cabo na solidão" (VISCONTI, 2014, p. 150). Encorajada por esses estudos, cheguei à conclusão de que as derivas poderiam ser encaixadas nos intervalos das minhas atividades cotidianas. Procurei então inserir a deriva na minha semana, como uma prática de desvio, de apropriação da minha vida praticada, ciente de que o uso dos tempos da vida de uma mulher, uma esposa, uma mãe não são integralmente definidos por ela. De início, algumas regiões foram mais exploradas que outras, aproximando-se mais do que passei a considerar como exploração de "percursos" (que serão tratados no próximo capítulo).

\section{DERIVA COMO ATO COTIDIANO E ELEMENTAR}

07 de abril de 2015: Hoje descobri que as derivas são assuntos cotidianos, que não podem ser inscritos no cotidiano, mas descobertos; permite-se que a deriva encontre o seu lugar. Não poderia fixar minhas derivas na agenda. É preciso percebê-las escondidas nas idas e vindas de todos os dias. Procuro passear e também me perder em torno do lugar onde moro. É uma maneira de compreender a cidade, de reconhecê-la através de meus próprios caminhos. Quando experimentamos outros itinerários, começamos a conhecer verdadeiramente a cidade.
Figura 11: Coletivo Teatro Dodecafônico - Elástico Invisível 
Paralelamente a isso, organizei uma série de derivas partindo dos quatro quadrantes de Paris, sempre tomando como ponto de partida um parque, onde eu pudesse, sozinha ou acompanhada, preparar meu corpo para a deriva. Selecionei os seguintes parques como ponto de partida: Parc Buttes-Chaumont (de onde parti em deriva com mais duas pessoas), Parc Montsouris (de onde parti em solitária; essa ação será detalhada na categoria fugas e perseguições), Parc Monceau (de onde parti em deriva com mais um pessoa) e o Parc Georges Brassens (de onde acabei não realizando nenhuma deriva). Esse plano foi traçado estrategicamente, estudando o mapa de Paris e com o intuito de percorrer minimamente os quatros cantos da cidade.

Nessa série, mantive as escritas prévias às derivas e as escritas automáticas posteriores às derivas sempre realizadas a lápis, parte para retratar a efemeridade dessas ações, parte para registrar sua invisibilidade. São ações que podem facilmente ser apagadas. Nos cadernos de registro, esses relatos poéticos destacam-se das notas das aulas, seguidamente realizadas com caneta azul ou preta. Assim começam as prévias das derivas parisienses de uma narrativa imaginária das derivas realizadas entre abril e dezembro de 2015, nessa cidade. Inicio assim, sentada, derivando sozinha com o corpo na biblioteca e o pensamento em deslocamento pela cidade dos situacionistas.

A deriva a partir do Parc Bouttes Chaumont ${ }^{44}$, tendo como referência os procedimentos desenvolvidos em São Paulo com o Coletivo Teatro Dodecafônico. Nessa ocasião, a Balada Silenciosa ainda integrava o programa dessa deriva como recurso para aquecer o corpo no seu primeiro encontro com a cidade. Usamos o momento da balada para sair do parque e encontrar a rua, uma forma de quebrar o gelo entre o comportamento inapropriado no espaço público e a observação deambulatória da cidade.

Chegamos ao Buttes-Chaumont às 18 horas. Ao lado do coreto, no ponto mais alto do parque, Paris nos avista. Nos bancos ao lado do coreto, apresento a proposta, as regras e os procedimentos do jogo. Elegemos o coreto como local de preparação - acordar a pele e soltar o peso. O espaço é erguido por colunas greco-romanas, barras de ferro são parapeitos e o teto é redondo e alto. $O$ topo está a mais de 3 metros das nossas cabeças. No centro do espaço há uma espécie de aparador, uma mesa rodeada de assentos, um abatedor ancestral (destinado a sacrifícios?). O espaço circular nos acolhe, assim como os materiais frios - pedra e metal - acolhem nossos corpos. Acionamos concavidades e espaços recônditos do corpo, que passam a ser tocados pelo espaço.

Fazemos a exploração dos níveis de atenção no próprio coreto. O meu corpo, a relação do meu pé com o chão, joelhos, eixo, cabeça leve, balanço dos braços. Ombros e peitos aber-

${ }^{44}$ Deriva realizada no dia 29 de maio de 2015, na companhia de André Mourão e Rodrigo Scalari. 
Ao olhar as fotos - que estavam ordenadamente de acordo com o trajeto da deriva - me dei conta de que nosso percurso foi em caracol. Em muitos sentidos:

Físico: Expansão e ocupação de um espaço a partir de um centro e arquiteturas caracolares.

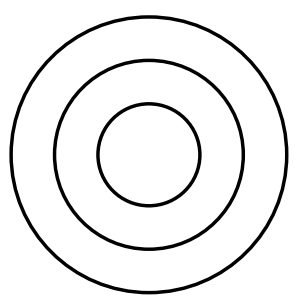

Essa outra imagem (abaixo) ilustra melhor, a meu ver, nosso trajeto. Onde os círculos se tangem estaria um empecilho físico que, num acordo silencioso, nosso grupo evitou: a subida. Assim, quando começamos o percurso fomos do ponto de partida - ponto mais alto do trajeto
Metáfora: Analogia das "instruções" para a deriva - "EU - O ESPAÇO - 0 OUTRO” - com o traçado do trajeto. Essa ordem pode ser pensada como um possível crescente, um "de dentro para fora". A linha espiral característica do caracol pode ser imaginada partindo do centro da imagem (à esquerda) e passando pelos três círculos.

Círculos correspondem, do menor ao maior, respectivamente, a: EU - ESPAÇO - OUTRO

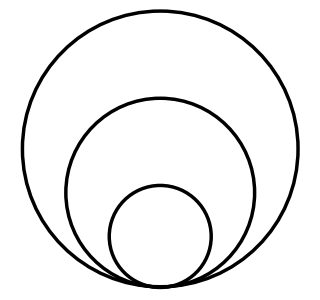

Vista do coreto. Outra analogia possível seria:

EU - ESPAÇO - OUTRO correspondente a CORETO - PARQUE - RUA

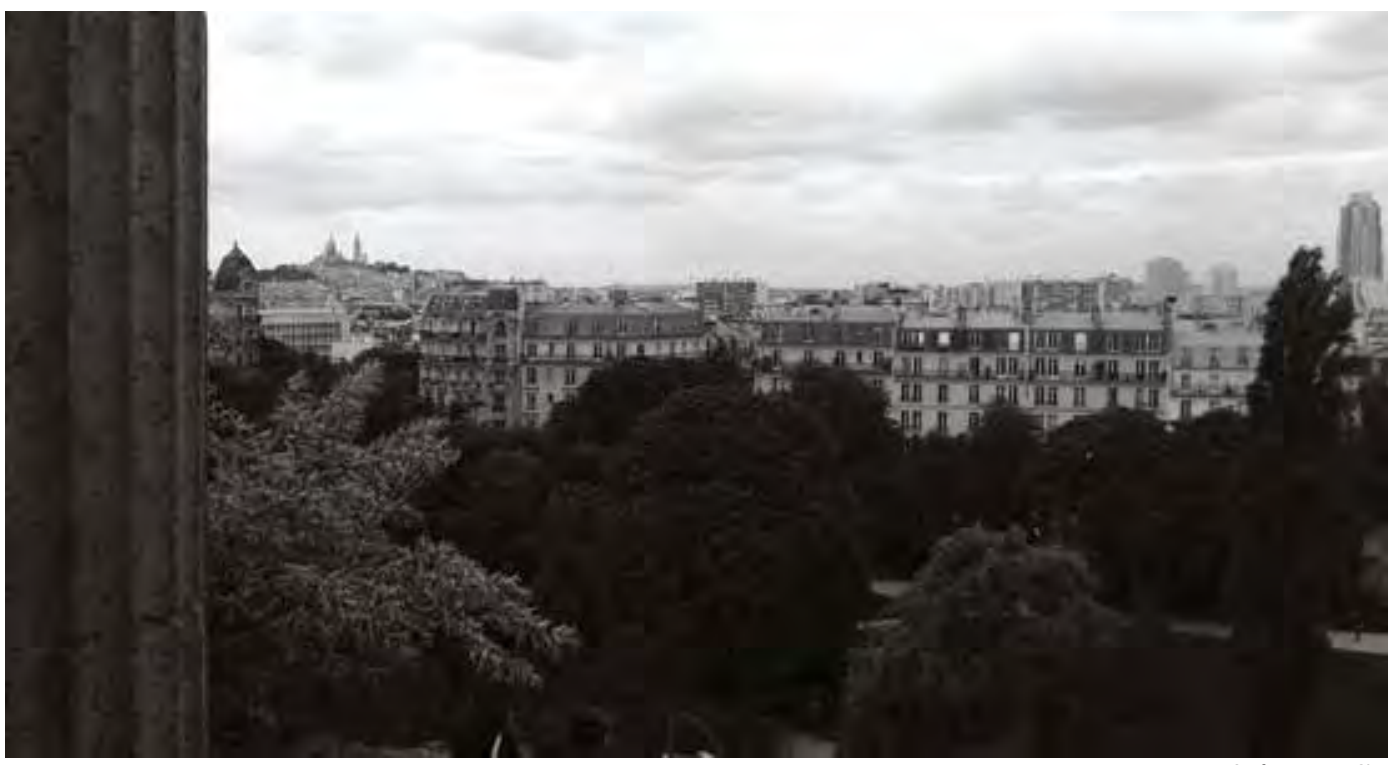


Após nossa primeira transgressão, que consistiu em atravessar as barreiras que bloqueavam o acesso ao coreto, percorremos os caminhos do parque ouvindo trilhas sonoras familiares. Para mim, a balada silenciosa é um movimento libertador, uma prova de que outros corpos são possíveis no espaço público, corpos menos rígidos, menos sisudos, menos formatados na ordem estabelecida. Primeiros olhares: esse é o ponto mais visível da deriva. O trio ritmado atravessou o parque em passeata. Nossas músicas são silenciosas aos olhos dos outros, mas nossos corpos são vistosos e cheios de gingas. Os usuários do parque que usam o mesmo dispositivo que nós para correr logo se identificam. Os fones de ouvidos nos une, um modo de isolamento compartilhado, que curiosamente conecta pessoas que não se ouvem. Usamos o mesmo dispositivo, mas não corremos, dançamos. Alguns sorriem, outros olham curiosos.

Alguns até ensaiam um balanço, deixando escapar a sensação da música que também percorre seus corpos.

$\mathrm{Na}$ calçada, novos olhares. As reações mais alegres e animadoras vêm das pessoas de dentro dos carros. Talvez a lataria das máquinas e as 4 rodas os protejam. Rodrigo corre e atravessa a rua. Indica uma longa escadaria por onde subimos, dançando e entoando sons que são amplificados pelas arcadas sobre as escadas. No topo da subida, tiramos os fones e um novo percurso se inicia. Somos levados por nossos desejos de deslocar-se ou parar. Da primeira pausa, uma Kombi nos leva. É seu movimento que promove o primeiro rompante. Em corrida, seguimos seu fluxo por uma rua estreita. Tijolos grandes, portão que nos reflete, alguma saída para os bombeiros. Rodrigo toca as paredes da casa da esquina e nem percebe uma aranha grafitada ao seu lado. 0 seu movimento não a revela, convive apenas com ela. Esquinas são lugares de perguntas. Em uma delas, pergunto ao André: cara ou coroa? E sigo em disparada. [escrita automática de Verônica Veloso].

Figura 17 e 18: Derivas Parisienses - Bouttes Chaumont

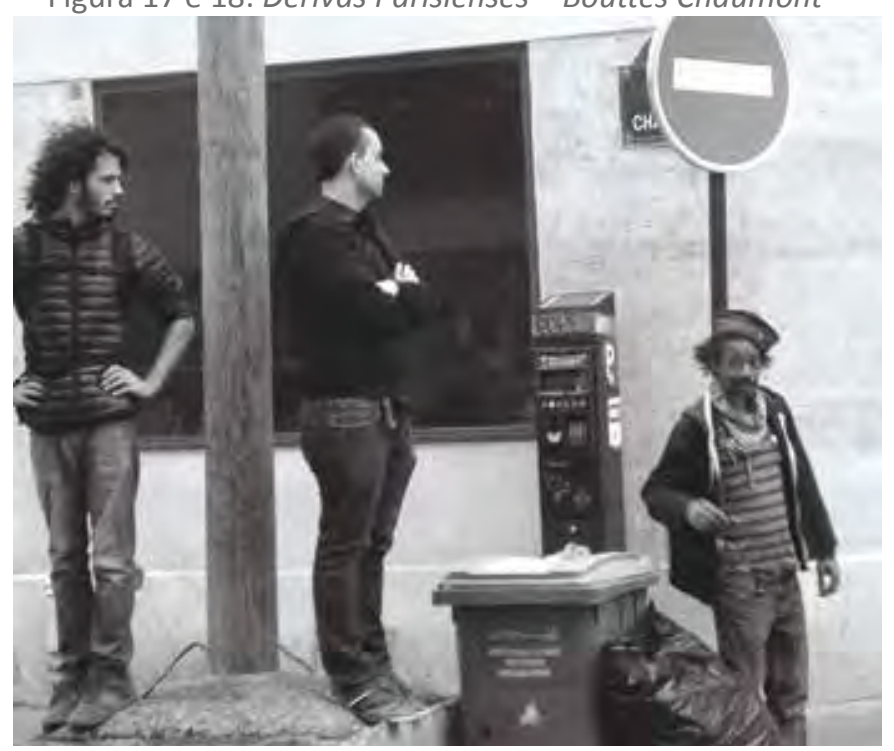

Foto: Verônica Veloso

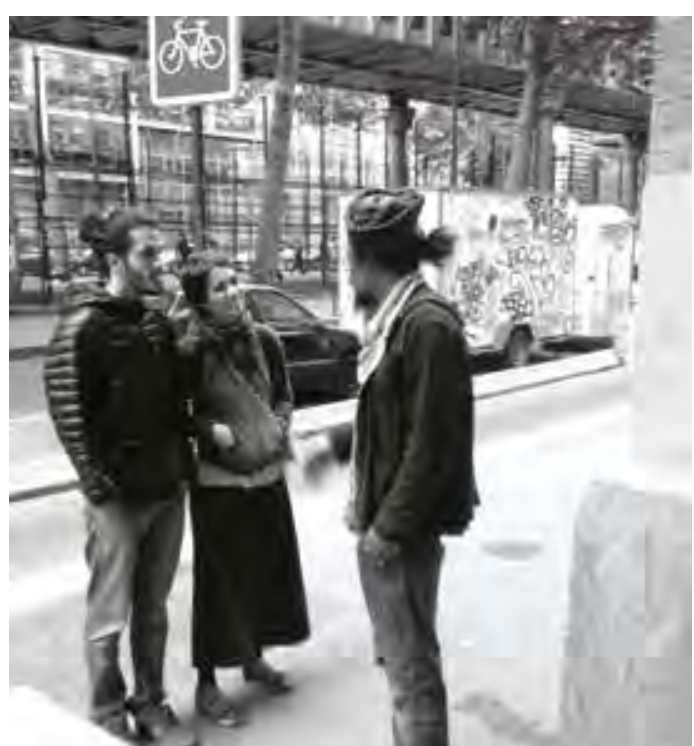

Foto: Rodrigo Scalari
Personagens e objetos: Pois se a RUA seria análoga ao OUTRO, o fim da deriva foi de fato a chegada ao círculo externo (maior) de um caracol: o encontro e conversa com Ludwig. 0 extremo do OUTRO - dentro da nossa perspectiva de começo-meio-fim, onde o começo foi o EU/Nós total (inclusive, justamente um momento de "aquecimento") - seria precisamente terminar o trajeto espiral 
dialogando com alguém que encontramos na rua. Ou, melhor ainda, alguém que nos abordou._Ainda mais tendo em vista que a parte do percurso relativa à ESPAÇO/PARQUE aconteceu sob a proposta da Balada Silenciosa. Ou seja, num estado no qual seria difícil alcançar um extremo do OUTRO. Estaria mais para uma transição entre EU e o ESPAÇO - um "abrir os olhos" [escrita automática de André Mourão].

Nesse último movimento em direção ao outro, encontramos Ludwig: o outro, o outro imigrante, o outro negro, o outro que a cidade nos apresenta. Do deslocamento do eu para o outro, entramos em contato com uma alteridade representante de toda uma coletividade. Em pouco tempo de conversa, Ludwig fez questão de nos mostrar que tinha uma chave. A chave de sua casa tinha para ele o peso de quem dispõe de documentos: era a prova de uma conquista de território. Diferente de outros imigrantes das antigas colônias francesas que encontrei nesses meses na França, Ludwig não se considerava francês. Apesar de ter nascido na França, ele se reconhecia como da Martinica, como sua mãe. Era uma alma errante, um corpo acostumado à livre circulação na rua, que nos surpreendeu, justamente quando André e Rodrigo subiram em uma espécie de pedestal que encontraram numa esquina. Ele os abordou perguntando o que faziam ali e com que direito se colocavam acima de todos na cidade. Para ele, o posicionamento daqueles corpos de maneira elevada era significativo. Não demorou para seus olhos astutos também me localizassem, como quem encontra a peça que faltava de um jogo, cuja lógica não conseguia desvendar. Conversamos sobre ocupar o território urbano, criar outros usos para os espaços públicos e o direito das pessoas sobre a cidade. Ludwig abriu os vértices de nosso triângulo e nos mostrou uma Paris para além dos contornos geográficos, nos ensinou sobre os usos da topografia da cidade e nos fez refletir sobre os territórios expandidos do corpo e do pensamento.

Mais tarde descobri que nesse mesmo parque, André Breton e Marcel Noll realizaram em 1925 uma deambulação noturna, que foi imortalizada na forma do texto "Le sentiment de la nature aux Buttes-Chaumont" [O sentimento da natureza no Buttes-Chaumont], publicado como um dos capítulos do livro Le paysan de Paris [O camponês de Paris], de Aragon (1926). O parque foi construído durante a reforma de Haussmann, em um local onde havia uma pedreira e foi considerado como um jardim cenográfico ou um "pulmão verde" instalado em uma área populosa e operária, perto das usinas de La Villette. De acordo com Paola B. Jacques tratava-se de um projeto higienista e sanitarista da cidade, inaugurado para a Exposição Universal de 1867. Ela afirma ainda que Paris é a protagonista do livro de Aragon, que se constitui como uma narrativa-mapa, um "livro-cidade" (e aqui ela toma emprestado o termo empregado por Jeanne Marie Gagnebin no posfácio da edição brasileira desse livro). 
te afetados. Toda a escuridão se dissipava, sob uma esperança imensa e ingênua. Enfim, nós destruiremos o tédio, diante de nós se abria uma caça miraculosa, um terreno de experiências, onde era possível que tivéssemos mil surpresas, e quem sabe? uma grande revelação que transformaria a vida e o destino. (...) Esse grande oásis em um bairro popular, uma zona obscura onde reina um célebre dia de assassinatos, essa área louca nascida da cabeça de um arquiteto, resultante do conflito de Jean-Jacques Rousseau e as condições econômicas da existência parisiense, para os três caminhantes é uma pequena prova da química humana, na qual os precipitados têm a palavra e os olhos de uma cor estranha (ARAGON, 1953, pp. 164-165). ${ }^{45}$

Assim Aragon propõe sua construção subjetiva da cidade, por meio da descrição dessa aventura também realizada a três por esse parque, cuja paisagem resulta de uma construção artificial. Trata-se de um espaço semifechado, que reforça o comentário de Walter Benjamin sobre a Paris dos surrealistas: um pequeno mundo (BENJAMIN, 1994, p. 27). "Benjamin afirma várias vezes que Paris se transforma, pelas errâncias, ao mesmo tempo em quarto e em paisagem, ou seja, um interior, uma passagem e um exterior, um parque" (JACQUES, 2012, p. 128). Nesse sentido, a metáfora utilizada por André da deriva caracol é eficiente para descrever também a deambulação dos surrealistas, que também observam a cidade como quem a examina através de um microscópio, recortando-a como um microcosmo, uma microcidade.

A deriva seguinte realizada no contexto parisiense se deu a partir do Parc Monceau, na companhia de Juliana Jonson, para a qual eu propus um programa similar à deriva do elástico, com algumas alterações. Por exemplo, a finalização da deriva se daria por meio de uma condução cega, realizada por telefone. O vértice ausente do triângulo era Rodrigo Scalari (que também participou da deriva anterior), que não se encontrava conosco presencialmente, mas participaria de maneira virtual. Ele receberia um telefonema e nos conduziria sem saber exatamente aonde nos encontrávamos.

\footnotetext{
${ }_{45}$ Les Buttes-Chaumont levaient en nous un mirage, avec le tangible de ces phénomènes, un mirage commun sur lequel nous nous sentions tous trois la même prise. Toute noirceur se dissipait, sous un espoir immense et naï. Enfin nous allions détruire l'ennui, devant nous s'ouvrait une chasse miraculeuse, un terrain d'expériences, où il n'était pas possible que nous n'eussions mille surprises, et qui sait? une grande révélation qui transformerait la vie et le destin.(...) Cette grande oasis dans un quartier populaire, une zone louche où régne un fameux jour d'assassinats, cette aire folle née dans la tête d'un architecte du conflit de Jean-Jacques Rousseau et des conditions économiques de l'existence parisienne, pour les trois promeneurs c'est une éprouvette de la chimie humaine où les précipités ont la parole, et des yeux d'une étrange couleur (tradução minha).
} 
- entrar no parque e apresentar o programa de deriva

- procurar o fresco, o vento e entregar peso, relaxar ao ven-

to, baixar a adrenalina.

- espreguiçar, acordar a pele

- balada silenciosa: dos pés à cabeça, dos ombros às mãos, saindo do parque.

Parar e repetir:

- Parar: pausa do movimento e do fluxo

- Repetir: seguir fluxo, alterar direção, seguir alguém, repetir movimento de alguém ou alguma coisa.

- Ligar para alguém e pedir que a pessoa nos conduza.

À distância e às cegas, Rodrigo cria procedimentos para nos conduzir, como "andem dois quarteirões", "atravessem a rua" ou "sigam em frente por aproximadamente 200 metros". Ele também se utiliza dos sons da rua que consegue identificar pelo telefone, para propor seu percurso. Desse modo, ele nos conduz até uma rua movimentada, onde passam muitos carros e nos faz aproximar de um cachorro cujo latido ele ouve, e descobrir o nome dele. Além disso, nosso condutor pede que a gente se abrace no meio da rua e que a gente permaneça assim durante um tempo e, em seguida, que eu conduza Juliana de olhos fechados. O mais curioso desse último procedimento foi perceber (principalmente para Juliana que estava de olhos fechados) que Rodrigo, sem saber onde estamos e por onde nos conduz, nos leva exatamente de volta para o portão do Parc Monceau, de onde saímos em deriva cerca de duas horas antes.

\section{9 de agosto de 2015: Deriva Parc Monceau}

\section{A deriva circular}

Com os olhos fechados, ela chegou ao Parc Monceau. Ela não sabia onde estava e simplesmente aceita ser levada. Ela decide dizer sim. A palma da minha mão está suada. Mesmo assim, eu a conduzo pela mão. Ela treme, algumas vezes, ela para. Ela se torna rígida. A voz ao telefone dita nosso caminho em um percurso cego. A voz não sabia onde estávamos, ela pergunta se víamos um cachorro. Respondemos sim, três. Um deles se chama Houf. Não sei brincar com cachorros.

No final do ano, na época em que aconteceram os atentados em Paris, organizava uma última deriva antes de voltar ao Brasil, que deveria sair do Parc George Brassens. Diante dos atentados de 13 de novembro, conversei longamente com o grupo com o qual preparava a deriva, questionando se deveríamos realizá-la mesmo com a cidade em estado de urgência. Por um lado, isso significava que a polícia tinha o direito de deter qualquer pessoa com atitude suspeita e que estrangeiros podiam ser deportados sem grandes explicações. Por ou- 
tro, havia o desejo de combater o medo, de voltar ocupar a cidade, de circular como um ato de resistência. Decidimos realizar a deriva um pouco mais de um mês depois do acontecido.

Prévia da deriva em estado de urgência, por Verônica Veloso

\section{5 de Dezembro de 2015}

De dentro do metrô, vejo o sul da cidade se distanciando. 0 ponto de encontro: République. Morgan não poderá vir. Mais uma vez, estaremos só mulheres. Quatro ou cinco.

É estranho esse espaço entre o meu corpo e o corpo do outro. o espaço é estreito, mas a distância é gigantesca. Vejo orientais e me lembro de ontem na Gare du Nord, um oriental gritava: "I'm robbed!". Dois caras grandes arrancaram a mochila das costas dele, na escada rolante. Uma moça ainda gritou, tentou ajudar. Só homens no meu campo de visão. Alguns deles me olham: uma mulher que observa pessoas, escreve e volta a olhar. Fones de ouvidos desligados, sem música. Ouço a voz do trem. Eles parecem dispostos em cena: Dois taiwaneses [um deles é prognata], um francês de alguma origem qualquer, outro oriental com foulard branco. Um negro se levanta do meu lado. Diante de mim, um indiano. Ao lado dele, um moço com traços árabes. Ouço a música dos fones de ouvido dele. Este com os olhos fechados, deitado e com a boca aberta. Mais ao fundo, um moço toma coca-cola. Ele está de óculos escuros e tem as bochechas rosadas. Entram algumas moças e colorem o vagão de vermelho. Hoje a deriva será feminina, de batom vermelho e em estado de urgência. Vou acordar meu corpo numa balada não apenas silenciosa, mas invisível, preciso de um corpo quente.

Partimos da Place de la République ${ }^{46}$, que tinha sido transformada naquele momento num grande santuário em memória aos mortos de 13 de novembro. Muitas fotografias, cartas e velas estavam dispostas no monumento central da praça e em configurações concêntricas realizadas por jovens que na véspera tinham prestado alguma homenagem aos seus amigos assassinados. Em toda aquela região pairava uma atmosfera de perda e de dor. Havia um silêncio desconfortável convivendo com uma tentativa de transformar essa atmosfera com a instalação de bandeirolas coloridas na esquina onde se encontravam o Petit Cambodge e Le Carillon, os dois bares onde ocorreu o pior massacre de pessoas no espaço público. 0 grupo terrorista passou atirando cegamente em quem se encontrava nos terraços desses restaurantes.

A deriva em estado de urgência devia acontecer da maneira mais invisível possível, sem balada silenciosa, sem atitudes suspeitas, sem chamar a atenção. Decidimos ir para o foco do problema, ao encontro da ferida, para reconhecer os vestígios desse acontecimento atroz no corpo da cidade. Como estaríamos em deriva não era possível supor por onde passaríamos. Eu não conhecia os locais que tinham sido atingidos, embora frequentasse a região. Por um motivo ou por outro, acabamos passando por essa esquina que um mês depois dos atentados ainda exalava o cheiro da pólvora. Os bares estavam fechados para reforma e tinham suas fachadas transformadas em espaço de homenagem às vítimas. Por

${ }^{46}$ Participaram dessa deriva: Anna Ten, Anne-Sarah Faget, Maria Clara Ferrer e Verônica Veloso. 
mais que a cidade não pudesse parar, as pessoas ao passar por ali abaixavam as cabeças, o ar parecia escasso e os curiosos buscavam vestígios da tragédia. Apesar das bandeirolas coloridas, tentando revitalizar a atmosfera do local, um rastro de tristeza, desconfiança e revolta pairava no ar.

\section{5 de dezembro de 2015}

Foi difícil sair da Place de la République. 0 exército estava lá, juntamente com as homenagens às vítimas do atentado. Andamos as quatro, sem saber exatamente onde estávamos. No final da Rua Deus [Rue Dieu], vi escadas e pensei que se tratava de uma igreja. Não, era uma ponte sobre o Canal Saint Martin. Havia uma distância entre nós, mas não nos perdíamos de vista. Gostava de olhar o que atraía olhares das meninas. Anna, em especial, reparava nos pequenos detalhes: os cartazes, os grafites, os escritos e as narrativas da rua. Quando paramos diante do Petit Cambodge, notamos uma mudança de ambiência e o rosto de Anne-Sarah crispou- se. Andamos cabisbaixas até a entrada de um hospital, onde enfim respiramos um pouco. Em seguida, novamente sobre o canal, um grande espelho verde reflete o céu em plena cidade, a água está sempre calma. Dois casais, sentados em bancos distintos, choram. As pombas se observam no espelho d’água. Em uma pequena rua, um grupo de estudantes de uma escola. Anne-Sarah e eu tentamos integrar o grupo, mas não nos confundimos facilmente com eles. Quando percebemos que girávamos em círculo e sentíamos muito frio, decidimos nos aquecer. Café, chocolate e suco de tomate. Quatro cabeças de mulheres escrevendo no café dos vizinhos (nome do bar onde paramos). $\mathrm{Na}$ vizinhança da região dos atentados, um mês após o acontecido, notamos que a vida corre. A vida continua e tenta se pintar de colorido. O canal continua no mesmo lugar, testemunhando e ecoando ainda: os gritos, o sangue, as lágrimas.

[Escrita automática de Verônica Veloso]

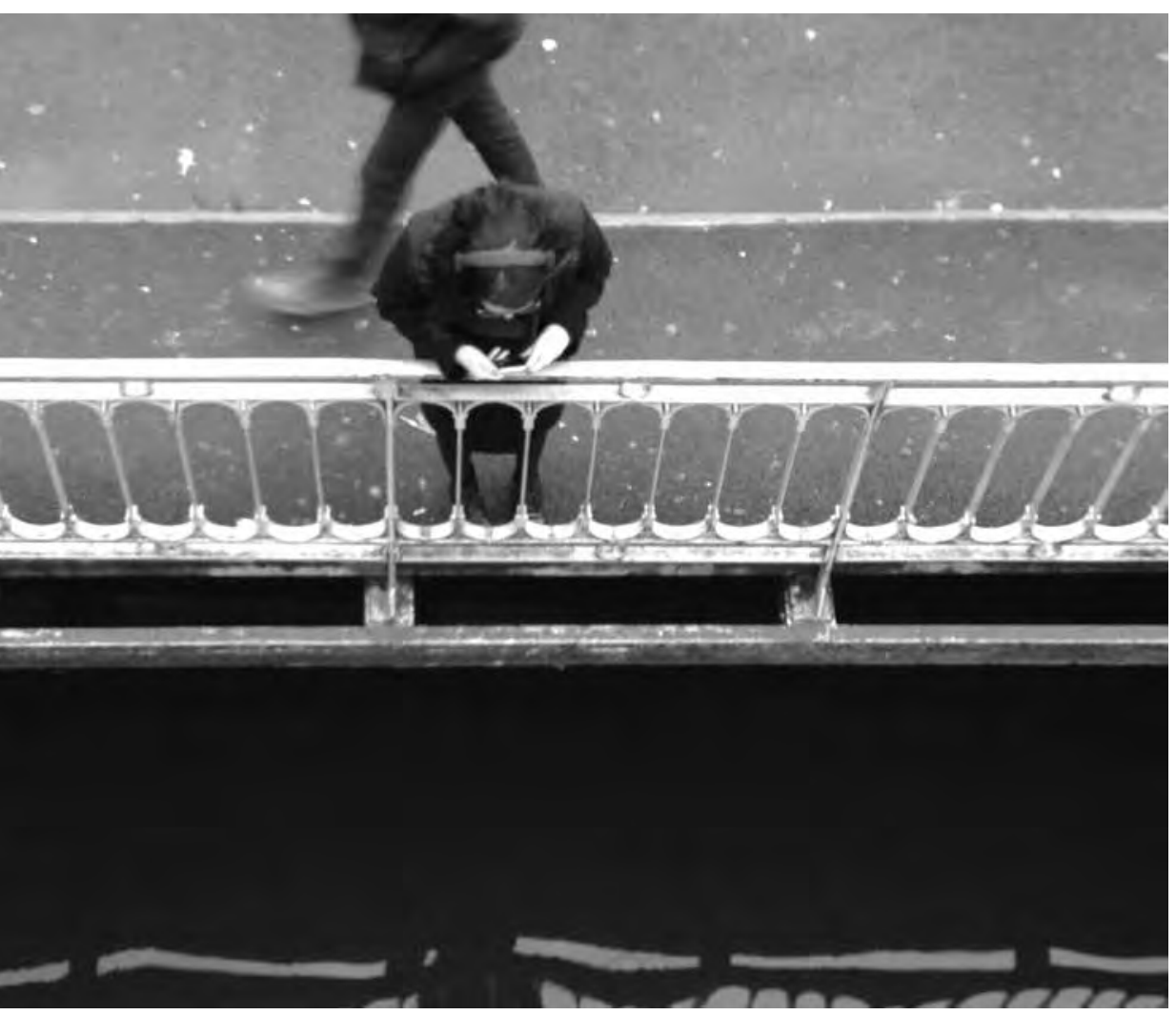

Figura 19 e 20: Deriva em estado de urgência

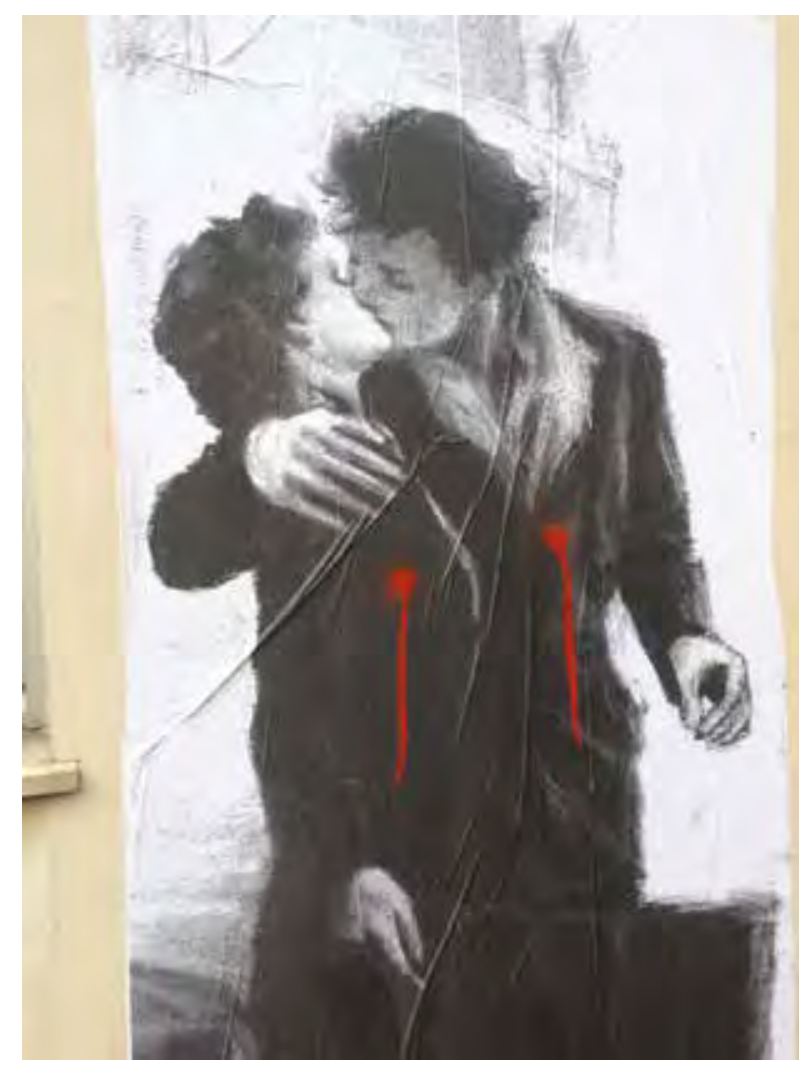

Fotos: Verônica Veloso 
A fim de concluir essa longa parte dedicada ao estudo da deriva, encerro com a análise de uma performance e uma encenação em deriva. A deriva é comumente associada a um ato mental, tanto é que em diferentes contextos fala-se em derivas do pensamento. Todo tipo de devaneio ou situação em que o pensamento vaga livremente de uma ideia a outra pode ser considerado uma deriva mental. As derivas que têm como matriz as práticas situacionistas não visam a exploração das zonas inconscientes da cidade, como faziam os surrealistas. A associação da deriva com a mente passa por outro lugar, pelo deixar-se levar, pelo perder-se, pelo descontrole do corpo-mente. É nesse sentido que os situacionistas visam uma criação sem obra, sem artistas e também sem espectadores, "o rechaço da representação e do talento pessoal, a busca de uma arte anônima coletiva e revolucionária", fundada no ato de caminhar (CARERI, 2013, p. 83).

Paola B. Jacques, contudo, afirma que "as errâncias são práticas labirínticas da cidade". Esse estado labiríntico se aproxima da experiência da deriva e também da embriaguez proveniente do uso de diferentes drogas, do álcool ao haxixe, além do ópio, droga bastante difundida no início do século XX.

\footnotetext{
O perder-se muitas vezes se confunde com perder o controle de si próprio; várias narrativas errantes fazem alusões ao uso de drogas ou álcool, os "paraísos artificiais", como os chamou Baudelaire em 1860. São os estados de exaltação, de êxtase, saída de si, especialmente pelo uso de drogas daquela época: o ópio e o haxixe. Em "Um comedor de ópio", Baudelaire comenta e analisa o livro de Thomas de Quincey, de 1921, Confissões de um comedor de ópio, de quem foi tradutor e grande admirador. De Quincey erra pelo imenso labirinto de Londres, cidade que na época já atingia mais de um milhão de habitantes (JACQUES, 2012, p 275).
}

Tanto Baudelaire quanto Benjamin escrevem sobre a influência de drogas em suas experiências deambulatórias. O primeiro escreveu sobre os efeitos do vinho e do haxixe em seus Paraísos artificiais, embora considere que o embaralhamento dos sentidos também pode ser provocado pela multidão. Benjamin, por sua vez, relata suas peripécias pela cidade de Marselha, passando por bares e restaurantes sob os efeitos do haxixe. Ele afirma nesse texto que "a rua que tenho visto tantas vezes é como um corte feito por uma faca" (BENJAMIN, 1987, p. 249). Descreve em diferentes situações sua fome de leão e fala de sua intenção de jantar naquela noite em dois restaurantes distintos. Discorre sobre os efeitos provocados em seu corpo, para quem todas as distâncias parecem curtas: "essa maravilhosa leveza e decisão do passo que transformava o chão pedregoso e inarticulado da grande praça, que estava atravessando, na superfície de uma estrada de rodagem que eu, robusto andarilho, percorria à noite" (Ibid., p. 250). Nesse trecho fica nítida a associação do efeito provocado pela droga no ato de seu caminhar, os passos parecem leves e seu corpo, robusto. Ele ainda afirma numa associação do percurso com a prosa, que "no haxixe somos, em alto grau, prosadores alegres" (Ibid., p. 253). 
Obviamente o perder-se não depende desses aditivos, cujos efeitos negativos também são destacados por esses autores. Benjamin menciona uma certa inapetência sexual em decorrência do uso do haxixe e Baudelaire fala em degradação e morte intelectual.

\footnotetext{
O vinho exalta a vontade; o haxixe a aniquila. O vinho é um suporte físico, o haxixe é uma arma para o suicídio. O vinho nos torna bons e sociáveis; o haxixe nos isola. Um é laborioso, por assim dizer, o outro essencialmente preguiçoso. $\mathrm{Na}$ verdade, para trabalhar, laborar, escrever, fabricar o que quer que seja, quando podemos tomar o paraíso de um só golpe? Enfim, o vinho é para o povo que trabalha e que merece bebê-lo. O haxixe pertence à classe dos prazeres solitários, é feito para os miseráveis ociosos. O vinho é útil, produz resultados proveitosos. $\mathrm{O}$ haxixe é inútil e perigoso (BAUDELAIRE, 1998, p. 243-244).
}

Uma performance mais recente que coloca justamente essa questão em debate foi realizada por Francis Alÿs, na cidade de Copenhague, sob o título de Narcoturism. Ao longo de uma semana, o artista perambulou pela cidade sob os efeitos de uma droga diferente a cada dia. Essa viagem foi documentada por fotografias e por meio de notas diárias, batidas à máquina, onde registrava suas impressões e sensações a cada droga experimentada. Consta nessas notas o título da obra, datada de maio de 1996, o protocolo ou programa definido pelo artista, a droga utilizada a cada dia (álcool, haxixe, anfetamina, heroína, cocaína, valium, ecstasy), assim como a experiência vivida.

Com o álcool, Alÿs identificou dificuldades para se conectar com seu estado físico, desconfiou de seus reflexos e caminhou de um modo desajeitado. $O$ haxixe foi associado à câmera lenta e à percepção de um aquecimento da musculatura corporal. Tudo parecia demasiadamente engraçado, ele falava alto, caminhou de olhos fechados e comeu o melhor sanduíche de pastrami da vida. Com a anfetamina, experimentou uma deambulação paranoica, sentiu os pés frios e temia os sinais de sua própria presença, evitando encontros na rua. Percebeu também uma mancha no seu campo visual. Com a heroína, sentiu-se muito entusiasmado, o que o ajudou a quebrar o gelo e a se sentir em grande sintonia com o lugar. Visualizou uma sequência de imagens congeladas ao caminhar ao longo do rio. Os efeitos passaram rápido, mas retornaram no fim do dia. Teve dificuldade de respirar à noite. A cocaína provocou uma consciência de sua mudança de estado, sem alterações visuais, mas com uma melhora da acuidade auditiva. Ficou completamente sem apetite e com pouca vontade de fumar. À noite, sentiu náuseas e sede. O valium o deixou cansado, desanimado e indiferente ao contexto. Sentiu uma vontade regular de fumar, assim como de urinar e, eventualmente, vomitou. Enquanto andava, memórias agridoces vieram à tona em intervalos regulares. Com o ecstasy, teve visões luminosas e impulsos eróticos. Seus sapatos moviam e ele sentia uma urgência em sair andando. Tudo parecia se mover, não fisicamente, mas conceitualmente. Ele se sentiu o epicentro do mundo. No oitavo dia, Alÿs passou por um período de depressão e apesar de conhecer os motivos que o levaram a se sentir assim, ele 
não soube evitar esse sentimento ${ }^{47}$.

O documento no qual o performer toma suas notas é "certificado" (se fosse no Brasil, seria autenticado em cartório), o que lhe atribui um certo valor de autenticidade. Essa produção é considerada pelo artista como um documento gráfico da ação, assim como os desenhos de cada percurso registrados sistematicamente sobre um mapa da cidade. Tal experiência foi concebida como uma crítica à melancolia e à sensação de sufocamento provocada em Alÿs pelo estilo de vida da burguesia europeia. Esse foi o primeiro convite recebido por ele depois de adotar o México como país de residência. Com o pretexto de estar apenas fisicamente presente, Alÿs propôs essa ação na qual consumia um coquetel de autointoxicação como um meio de escapar da realidade desse retorno para o qual não se sentia preparado. Ao submeter seu próprio corpo a esse abuso cotidiano de drogas, sem contar o acúmulo desses efeitos ao longo dos sete dias de entorpecentes, o performer experimentou um alto grau de radicalidade e levou a fundo a exploração da conexão entre deriva do corpo e do pensamento. É interessante notar como ele descreve com precisão suas reações físicas e também sua relação com o espaço e com o ato de caminhar. No entanto, o próprio artista reconhece que essa semana de errância em Copenhague não resultou em uma documentação de real valor artístico, o que vale aqui é a experiência em si mesma. Há outro valor, quase científico, do estudo dos efeitos das drogas em um corpo que as experimenta ao longo de um único dia.

Por fim, apresento uma encenação em deriva, dirigida por Roberto Rezende ${ }^{48}$, do Cambar Coletivo, em parceria com os atores Ricardo Henrique e Sidney Santiago Kuanza, intitulada Cartografia do afeto: Manifesto Leonilson. Trata-se de uma reação à obra de Leonilson, sem pretensões de se configurar como um retrospecto biográfico do artista. Usando a deriva como uma escolha formal para a composição desse evento cênico, os artistas investigaram modos de tornar Leonilson presente, sem necessariamente contar sua história. Há diversas referências à obra do artista que podem ou não ser percebidas pelos espectadores. Por exemplo, quando se chega ao ponto de encontro, os receptores do público pedem que cada espectador escolha um botão, sendo que na bandeja onde eles estão acomodados, os botões estão em pares. Ou seja, duas pessoas necessariamente escolhem botões iguais, formando um suposto par. Numa certa medida, esse par pode representar o amor que se busca na cidade e que, depois do desenrolar dos fatos, não será encontrado. O botão é uma

\footnotetext{
${ }^{47}$ Todos os dados foram encontrados no catálogo Francis Alÿs. A Story of Deception. Bruxelas: Lannoo e Wiels Centre d'Art Contemporain, 2010, p. 80.

${ }^{48}$ Esse mesmo artista realizou, como performer, uma deriva de aniversário chamada Instante Presente na qual permaneceu 24 horas em deslocamento pela cidade (2015). Nessa ocasião, recebe "presentes", ou antes, pedidos de amigos e pessoas que tomam conhecimento de seu programa pela internet. $\mathrm{O}$ artista seleciona e realiza algumas dessas ações encomendadas ao longo de sua jornada de aniversário. Além disso, Roberto registra suas peripécias em áudio utilizando-se sempre da terceira pessoa do singular para falar sobre si mesmo.
} 
dessas referências à obra de Leonilson. Do mesmo modo, os títulos de suas obras, que são usados tanto como material de criação quanto como elemento poético instalado em uma das casas visitadas, são percebidos como tal apenas pelos espectadores que já conhecem a obra desse artista.

No texto do programa, Roberto fala sobre tentativas, pois Cartografia do Afeto se configura, antes de tudo, como uma série de "tentativas de se comunicar com o outro, com o mundo e consigo mesmo". Já fazendo uma alusão à deriva a que o espectador será lançado, o diretor afirma que não se trata de caminhar sobre territórios fixos, mas de caminhar sobre placas tectônicas ou sobre placas de gelo que se desfazem e se refazem em deslocamento pelo oceano, numa referência clara à ideia da deriva continental (uma das teorias à respeito da formação dos continentes). Leonilson se auto intitula andarilho em seus diários sonoros e Roberto escolhe a deriva, não por acaso, como "tentativa-manifesto de acionar uma cartografia afetiva".

Tudo começa para o espectador antes mesmo de sair de casa. Como é preciso agendar a participação previamente por email e informar um número de celular, algumas horas antes da peça, os espectadores passam a receber mensagens por whastapp. São provocações, frases que já convocam o espectador para entrar no universo da peça. Em dado momento, perguntam sobre onde estamos e o que fazemos. O grupo de espectadores que eu integrei trocou fotos que relatavam onde cada um estava e com quem. Primeira tentativa de comunicação bem sucedida! Ao chegar no ponto de encontro, a escolha do botão é o primeiro movimento, que vem seguido do anúncio de que a outra pessoa que escolher o botão igual ao seu, será seu par. Isso cria uma expectativa do momento desse encontro, que nunca acontece, mas o gesto que importa é o lançamento desse outro na complexo mapa da cidade de São Paulo. Só o fato de saber que esse par existe em algum lugar da cidade, já coloca o espectador na ação de buscar esse outro. No fundo, os botões servem apenas de subterfúgio para colocar as pessoas lado a lado, divididas em duas filas.

Cada fila será guiada por uma pessoa que conduzirá metade do público até a casa de um dos atores/performers ou homens-peixe, para usar uma designação de Leonilson. Sigo a linha que conduz para a casa de Sidney (os atores usam seus próprios nomes, sem atribuição de personagem). A outra linha conduz até a casa de Roberto, que o homem-peixe Ricardo apresenta como sendo a casa de um amigo e, a partir dela, ele apresenta aos espectadores a própria casa. Quando chegamos na casa de Sidney, ele está sentado numa cadeira, imóvel, com um nariz de palhaço ${ }^{49}$ e a casa toda etiquetada com post-its, com frases como "gostava sempre das noites de amor". As frases instaladas na casa são todas citações das obras de Leonilson. Há uma indicação para ficarmos à vontade e circularmos pela casa.

\footnotetext{
${ }^{49}$ Em conversa com o diretor, soube que essa imagem foi substituída ao longo da temporada pela imagem do performer com post-its sobre os dois olhos, segurando um espelho.
} 
Há também livros espalhados pelo chão e o convite para folheá-los. São livros de fotografia, de cinema e de arte erótica, em sua maioria. Depois de passar um tempo percorrendo aquela casa e lendo as mensagens espalhadas aqui e ali, Sidney começa a tocar uma música em uma clarineta; o público se aproxima dele. Assim que ele se apresenta, notamos que ele fala sobre ele mesmo na terceira pessoa. Trata-se de um procedimento para colocar-se em estado de narrativa em fluxo, uma estratégia de fabulação. Depois de se apresentar, ele tenta adivinhar o nome de cada espectador de uma maneira muito envolvente, tomando o tempo necessário para a instauração do jogo e para o risco do erro. Às vezes o erro pode se configurar como um acerto. Comigo, por exemplo, o primeiro nome que ele arriscou foi o nome de minha mãe (Lúcia) e depois o da minha sogra (Helena). Como dificilmente ele acertaria o meu nome, os erros dele passaram muito perto da mulher que eu sou. De um modo geral, Sidney conseguiu construir um ambiente acolhedor entre nós.

Ainda dentro de seu apartamento, dois momentos merecem ser lembrados. O primeiro deles é o preparo do chá, pois há ali uma experiência compartilhada, um traço nítido de sua biografia pessoal, do aprendizado proveniente das mulheres que o criaram. Situações assim se configuram como encontros reais, o modo de Sidney preparar o chá fica marcado como algo que eu aprendi e tomei para mim. A partir de então, passei a misturar ervas e frutas na composição dos meus chás, que invariavelmente levam canela. Outro momento bastante significativo, ocorre quando o homem-peixe divide os espectadores em dois grupos e os convida a desenhar a cidade que imaginam ou onde gostariam de viver, em uma placa de madeira. Em um pedaço de tecido branco, cada grupo desenha um homem. Uma dessas criaturas desenhadas (digo criaturas pois os dois grupos desenharam seres que não podiam ser associados a uma relação binária de gênero) foi lançada pela janela, enquanto o ator diz um texto sobre o homem que está presente no dia da criação do mundo, de autoria de um amigo de José Leonilson.

A partir desse ponto, saímos em grupo e em deriva explorando um conjunto de programas performativos acionados na rua. Sidney vai aos poucos apresentando seu leque de ofertas para a deriva; ele também não sabe onde vamos parar, nem por onde vamos passar. Ele oferece programas e nós realizamos e nos lançamos nesse deslocamento sem rumo. Alguns exemplos de suas propostas: o performer pede que uma pessoa guie os demais, até que paramos num ponto para observar a cidade. Em um dado momento, diz que assim que cruzarmos com uma mulher de cabelos longos e pretos, todos devem parar e olhar para o céu. Em outro, pergunta para algum passante: você pode me dizer onde é o coração da cidade? O performer, ao chegar em uma esquina, abre sua mochila, pega um pacote de maçãs, entrega uma para cada espectador e diz: "esse é o seu coração, entregue para alguém que encontrar no caminho, espero vocês a duas quadras daqui". E assim, partimos cada um segurando a maçã-coração e pensando em como se dará o encontro com a pessoa 

pessoas na rua onde havia uma festa junina nas redondezas. Ouvimos duas indicações (uma na Roosevelt e outra numa igreja da Frei Caneca). Optamos pela Frei Caneca, mas não temos tempo de chegar até lá. Na altura do shopping, deixamos a segunda criatura amarrada em uma árvore e nos despedimos. Ele diz: siga sem olhar para trás. Assim nos despedimos, com uma ponta de melancolia dos amores desencontrados e com certa esperança de que encontraremos, ao virar a próxima esquina, uma pessoa que despertará mais do que nossos desejos imediatos.

\section{III. fugas e perseguições}

Seria preciso opor dois tipos de ciências, ou de procedimentos científicos: um que consiste em "reproduzir", o outro que consiste em "seguir". Um seria de reprodução, de iteração e reiteração; o outro, de itineração, seria o conjunto de ciências itinerantes, ambulantes.

Gilles Deleuze \& Felix Guattari

[fugas e perseguições]: deslocamento pela cidade do qual participam no mínimo duas pessoas. Tanto a fuga quanto a perseguição contêm qualidades específicas no modo de executar a caminhada. A fuga é rápida, atenta, desesperada e não se confunde com um passeio; a pessoa que foge busca distanciar-se de alguém que pode estar ausente. Na perseguição há uma variação de andamento, pode ser rápida e violenta ou sorrateira e invisível; neste caso há uma diferença de comportamento entre as duas pessoas envolvidas. Em ambos os casos poderia tratar-se de uma deriva, pois frequentemente as pessoas em fuga ou em perseguição se perdem. Podem ser consideradas como estilos, comum na literatura e no cinema.

Diferentes das modalidades apresentadas anteriormente, a fuga e a perseguição não se configuram como práticas amplamente discutidas na história da arte. No entanto, ao estudar passeio e deriva, identifiquei inúmeros artistas que erraram pelas ruas seguindo pessoas desconhecidas. Essas ações podem ser consideradas como derivas, uma vez que o ato de seguir alguém possibilita uma variação dos percursos cotidianos e uma desorientação das direções, o que levaria o sujeito a se perder. Em alguns casos, confundem-se com o flanar, por isso optei por definir uma modalidade à parte que contemplasse a ação da fuga e da perseguição, distinguindo-as ainda que parcialmente da deriva e do passeio. Tanto na fuga 
quanto na perseguição, identifico características particulares que não estão presentes em quem passeia, nem em quem deriva. Há um estado de tensão em quem foge, persegue ou simplesmente segue. Ao reunir a fuga e a perseguição numa mesma categoria, busquei demarcar o fato de que em ambas impera uma função dupla: enquanto alguém segue, outro é seguido; enquanto alguém persegue, outro foge. Isso ocorre mesmo quando a pessoa seguida não percebe que alguém a segue. Ela se torna inconscientemente o outro de alguém.

Na fuga a ação principal está em quem foge, ainda que essa figura seja o objeto da perseguição. Quem foge desloca-se aceleradamente e nem sempre percorre um trajeto conhecido; seu objetivo está em afastar-se de algo que o coloca em perigo. Quando a fuga é tomada como inspiração para modalidades artísticas, geralmente, o performer se coloca no papel de quem está em fuga. Algumas vezes, ele procura se afastar do público, em outras, ele se afasta de algo que não está presente mas o incomoda e o leva a mover-se, a deslocar-se em busca de outra ambiência, de outras possibilidades de vida.

Na perseguição o foco da ação encontra-se sobre quem persegue, sendo que a pessoa seguida pode nem se dar conta de que alguém a perscruta. A ação de seguir é cautelosa, coloca o corpo todo em estado de alerta e de prontidão máximas. A pessoa que segue alguém esconde-se de quem ela segue e também dos demais passantes. Por esse motivo, a perseguição como modalidade performativa acontece com baixíssimo grau de visibilidade. Em muitos casos, a ação de seguir alguém resulta em outras materialidades, como fotografias e relatos associados à ação. Por ora, tratarei aqui de alguns exemplos de (per)seguição, sem me ater demoradamente aos vestígios dessa ação, pois eles serão estudados com maior atenção no último capítulo.

A literatura e o cinema exploram de forma bastante recorrente a fuga e a perseguição. No conto de Edgar Allan Poe $\mathrm{O}$ Homem da Multidão, citado anteriormente na categoria passeio como modo de se aproximar da figura do flâneur, constitui-se como a narrativa de uma perseguição. Como o autor afirma que mesmo tendo sido seguido por uma noite inteira, o pobre diabo que atraiu a atenção do narrador não percebeu que alguém o seguia. Sem conseguir identificar o mistério desse cidadão, nem apreender sua personalidade, que "não se deixava ler", esse sujeito foi batizado de "homem da multidão", justamente para preservar firmemente seu anonimato. No cinema, a persistência no registro de situações de fuga e perseguição levou à elaboração de um tipo específico de montagem: a montagem paralela. Nela, mostra-se consecutiva e repetidamente imagens de quem foge e de quem persegue, em planos rápidos e curtos, a fim de aproximar a situação retratada da realidade.

Nas modalidades artísticas tratadas aqui nem sempre a fuga e a perseguição estão presentes no mesmo exemplo e os casos de fuga são mais raros, sobressaindo-se os exemplos de perseguições, como se os performers optassem por explorar o papel de detetives. Walter 
Benjamin chegou a afirmar que o trabalho do detetive seria um devir social possível para o flâneur, buscando encontrar um emprego no qual pudesse converter sua ociosidade em uma ocupação profissional. Ao experimentar a tarefa do detetive na cidade, o espaço do real por excelência, diferentes performers criaram situações fictícias inspirados em passantes que nem sequer se deram conta do que acontecia. A ação do seguir engendra no contexto urbano um jogo invisível, que tem na multidão e nos fluxos da cidade um terreno fértil. Trata-se de um dispositivo amplamente explorado nas situações de espionagem, sendo que no contexto da performance o foco do interesse pode ser colocado sobre qualquer pessoa, fazendo do real um espaço de criação de muitas ficções possíveis.

\section{_seguir pessoas para explorar outros itinerários}

O primeiro artista do campo da performance a perseguir pessoas na rua foi Vito Acconci. Em 1969, ele criou uma performance duracional intitulada Following Piece, na qual ele seguiu diversas pessoas desconhecidas pelas ruas de Nova York ao longo de 23 dias (de 03 a 25 de outubro de 1969), até que elas entrassem em um lugar privado no qual ele não pudesse entrar. $\mathrm{O}$ artista seguiu homens e mulheres invariavelmente nessas três semanas, colocando o próprio corpo como objeto da arte ao invés de explorar alguma ideia específica. Esse comportamento é típico de sua época, momento no qual os artistas plásticos passaram a explorar efetivamente o corpo em suas criações. Não se trata da manipulação do corpo na esfera íntima, mas da maneira mais pública possível, uma vez que ele submete seus movimentos aos dos passantes incógnitos. Ao invés de expor mais um objeto em uma galeria, nesse momento determinante da história da arte os artistas buscam sair das galerias e ocupar as ruas, explorando os espaços públicos, expandindo o tempo das ações e usando seus corpos como meio de expressão.

Ao dispor-se diretamente no corpo-a-corpo com a cidade, percorrendo o caminho de um desconhecido, o artista mostra como estamos todos sujeitos a forças e impulsos externos que não podemos controlar. Se cada pessoa seguida compusesse simbolicamente um fio pelas ruas, poderíamos dizer que Acconci fia os passos de cada uma delas. O tempo de composição de cada um desses fios é extremamente variável, podendo durar de 5 minutos (se a pessoa entra em um prédio ou em um taxi) até cinco, seis, sete horas, por exemplo (se a pessoa entra em um restaurante ou em um cinema). A cada dia, Acconci escreveu relatórios sobre suas perseguições, além de ser fotografado seguindo todas as pessoas e enviar tais fotografias posteriormente para pessoas do mundo da arte.

A geração de Acconci estava interessada em engajar-se com as questões sociais que emergem das ruas ao invés de permanecer nos problemas específicos da arte, representados pela produção associada ao cubo branco das galerias. Seguir pessoas na rua não se configura meramente como um passatempo, mas uma maneira de observar as relações entre 


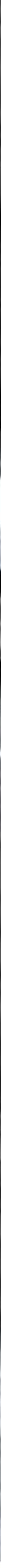

Figura 22: Vito Acconti - Following Piece

Foto: Disponível em: <http://www.medienkunstnetz.de/works/following-piece/>. Acesso em: 27

mar. 2017

os indivíduos e a esfera social, investigando os modos de agir e viver cotidianamente. Essas propostas traduzem, em certa medida, códigos complexos de sobrevivência que são continuamente tecidos no contexto urbano. Cada cidade, cada país, cada grupo social tece seus códigos dependendo da conjuntura social e do contexto político definido por cada época. Esse artista não opera de modo subjetivo, mas esquemático. Ele elabora diagramas nos quais explora os campos privados e públicos apreendidos em todos os espaços sociais. Em suas palavras: "Eu não sou mais um 'eu'; eu me coloco a serviço desse esquema" ${ }^{50}$. Para o artista essa era uma maneira de sair de si mesmo, experimentando o itinerário de outras pessoas.

\footnotetext{
${ }^{5}$ I am almost not an 'I' anymore; I put myself in the service of this scheme (tradução minha). Disponivel em: <http://www.metmuseum.org/art/collection/search/283737>. Acesso em: 20 set. 2016.
} 
No mesmo ano (1969), Yoko Ono, acompanhada de seu assistente John Lennon, seguiu com uma câmera uma mulher imigrante ilegal durante 10 dias pelas ruas de Londres, registrando todos os seus itinerários urbanos. Essa ação resultou em um filme intitulado Rape (em inglês violação ou estupro), que resultou em opiniões favoráveis e contrárias à sua produção. Certamente se a ação tivesse sido produzida nos dias de hoje, a polêmica seria infinitamente maior, tendo em vista a obrigatoriedade dos direitos de imagem e a vigilância proveniente das leis de imigração. As questões que o filme levanta giram em torno da atitude de quem a persegue sem seu consentimento, do fato de se tratar de uma mulher estrangeira, que mal conseguia se comunicar com seus seguidores em inglês e de certo abuso de poder da parte de Yoko Ono. Os críticos da artista ressaltam o fato de Ono se apoiar sobre a popularidade de seu companheiro e, munida de um equipamento caro e raro à época, ter intimidado a moça com a câmera direcionada insistentemente para ela. Os que reconhecem o gesto de Yoko Ono como legítimo, alegam que em nenhum momento a moça tenha se revelado verdadeiramente incomodada com a presença da câmera. Além disso, o fato de se tratar de uma mulher seguindo outra não se configura como um gesto invasivo, o que certamente ocorreria caso se tratasse de uma ação proposta por um homem.

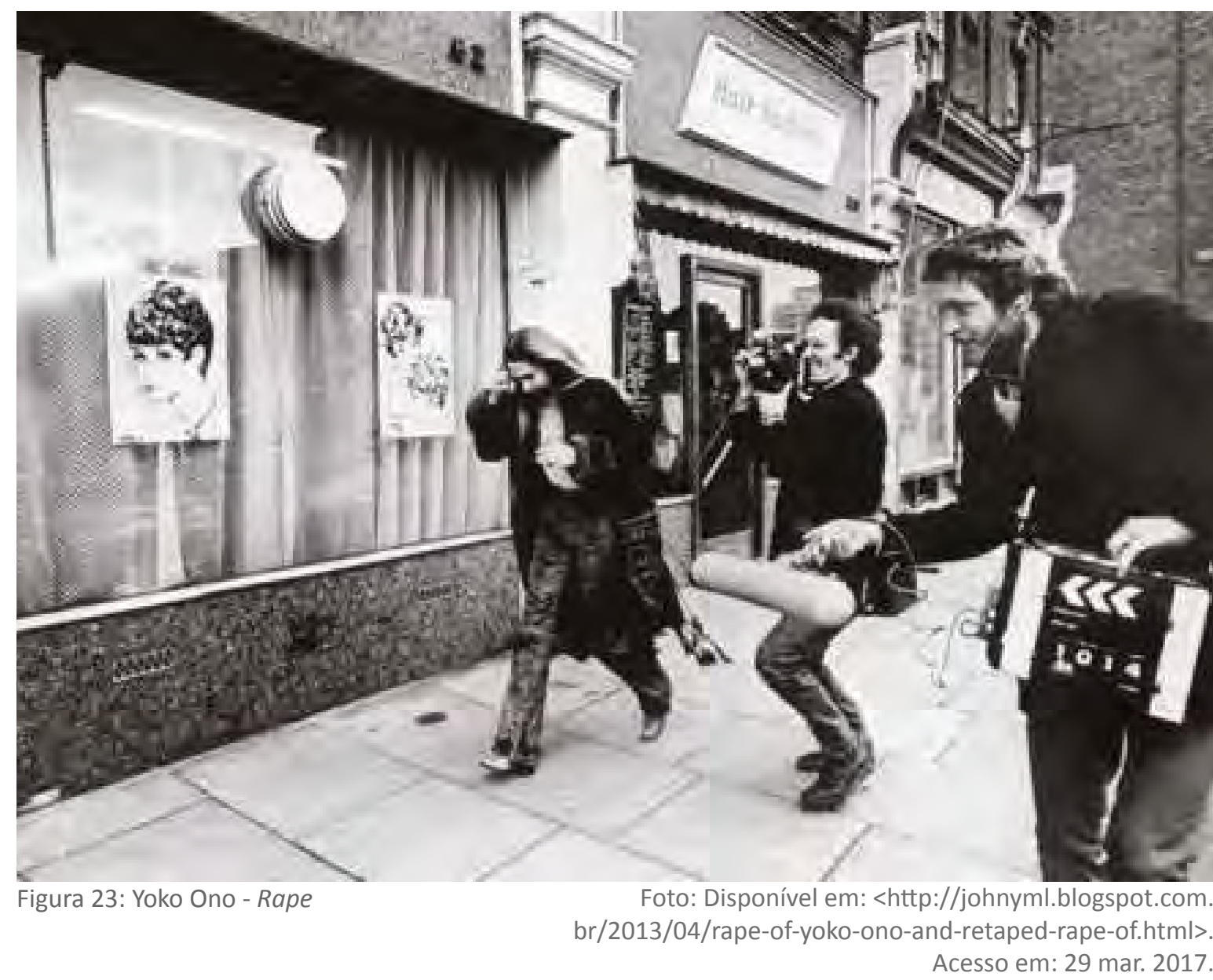

Um ano antes de realizar o filme, Yoko Ono publicou o roteiro correspondente, considerado por parte da crítica da época como uma obra de arte em si. É interessante ressaltar 
que os trabalhos de arte [artworks], segundo definição da própria artista, são capazes de incorporar diversas formas: um roteiro, uma performance, um objeto e um filme. Se Rape fosse simplesmente uma performance, seu roteiro seria um programa de ação, no qual o cinegrafista deveria perseguir uma moça jovem persistentemente até que ela entrasse em um beco e caísse no chão. Mesmo sem contato carnal, a ideia é que o filme resultasse em uma ação violenta, inclusive sexualmente. O filme se configura como uma dramatização de uma descoberta recente na época, de que a presença da câmera altera o comportamento de quem é observado. Ele também se configura como uma metáfora gráfica da vigilância que domina todos os cidadãos do mundo moderno. Mal compreendida, Yoko Ono realizou há 35 anos um trabalho de arte que coloca em foco questões que são muito debatidas na contemporaneidade. O modelo da perseguição foi usado por ela pra discutir o quanto a mulher é considerada um alvo fácil, usando a câmera como dispositivo do ato abusivo. Além disso, esse modelo convida à reflexão sobre a vida excessivamente monitorada por câmeras, os mesmos dispositivos de controle estudados por Michel Foucault.

Com a mesma intenção de ficcionalizar o real e de injetar fiç̧ões na vida da metrópole, Francis Alÿs realiza a ação The Doppelgänger [O sósia], uma deambulação organizada inicialmente na cidade do México, depois em Istambul e Londres (1998-1999) e que continua sendo experimentada a cada nova cidade que o artista conhece. 0 programa se restringe a caminhar por uma cidade desconhecida procurando alguém que se pareça com ele. Assim que identifica esse pedestre anônimo, Alÿs o segue e o fotografa de costas, até que seu passo corresponda ao passo do desconhecido. $O$ artista se coloca não somente como um detetive, mas como "o outro do passante anônimo, seu suplemento de alma silenciosa e discreta, seu fantasma ou seu anjo guardião, o tempo de alguns passos esboçados de um mesmo seguimento, no curso de um encontro no qual um dos protagonistas não saberá jamais o que terá acontecido" (DAVILA, 2002, p.109) ${ }^{51}$.

Com suas próprias palavras, Francis Alÿs afirma: "porque eu nunca pertenço verdadeiramente às cidades que eu atravesso, invento um papel para mim mesmo a fim de me fundir com o novo ambiente na pele de um outro personagem local" (ALŸS in BIESENBACH e STARKE, 2010, p.105) ${ }^{52}$. Diferente do que acontece com as ações de Acconci, o que Alÿs propõe ao buscar mimetizar o passo de seu "sósia", é incorporar o andamento do outro no seu próprio corpo. Esse gesto modifica o seu corpo a tal ponto que seu comportamento não pode ser associado à corporalidade típica de um "perseguidor". Isto é, alguém que se esconde enquanto espreita o outro, alguém que age com cautela e atenção. $O$ que esse

\footnotetext{
${ }^{51}[. .$.$] l'autre du marcheur anonyme, son supplément d'âme silencieux et discret, son fantôme ou son ange$ gardien, le temps de quelques pas esquissés d'une même foulée, au cours d'une reencontre dont l'un des protagonistes ne saura jamais qu'elle a eu lieu (tradução minha).

${ }^{52}$ [...] parce que je n'appartiens jamais vraiment aux villes que je traverse, je m'invente un rôle afin de me fondre dans le nouvel environnement dans la peau d'un autre personnage local (tradução minha).
} 
performer promove está mais próximo de um mimetismo, uma incorporação ou uma apropriação da cadência do outro.

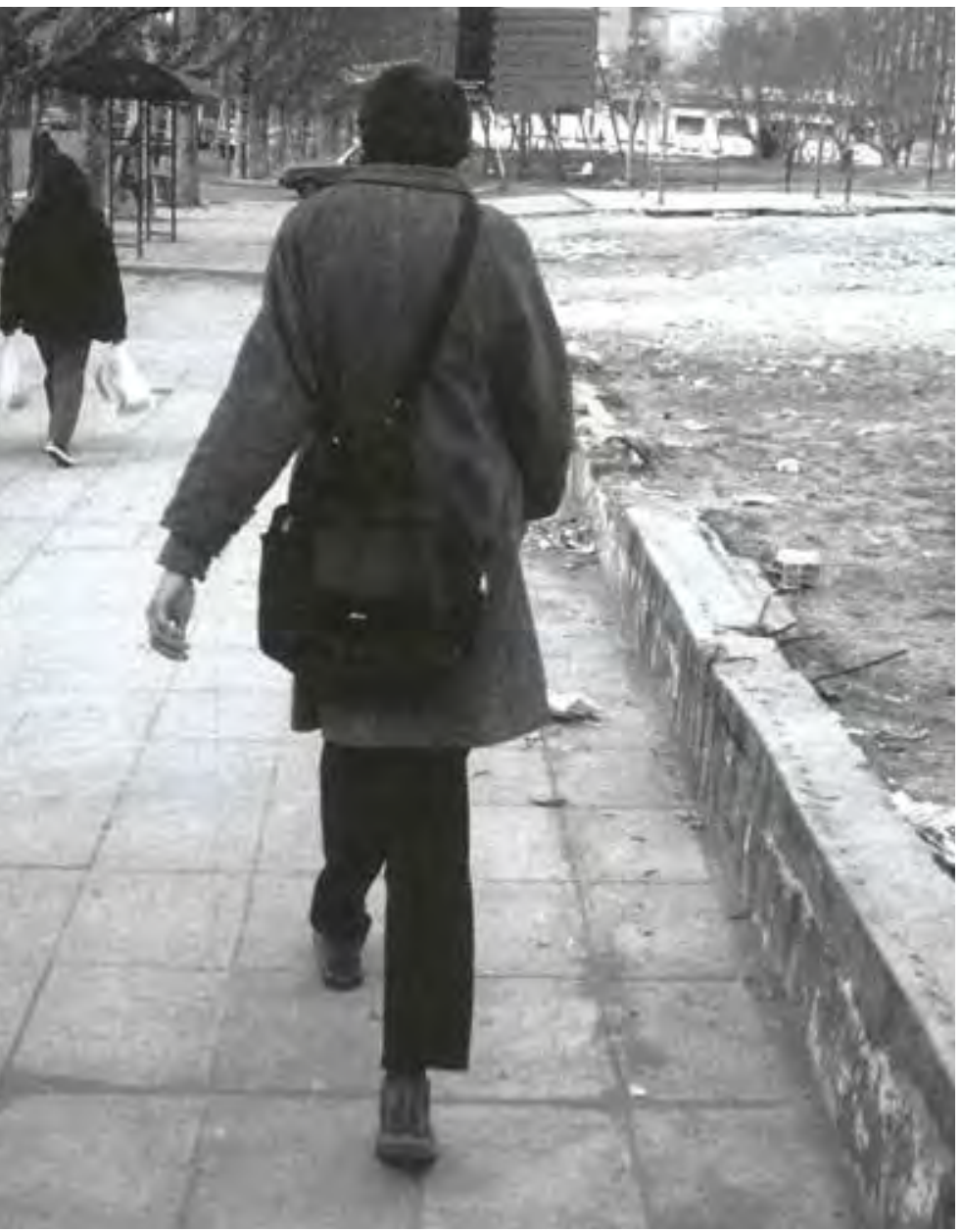

Figura 24 e 25: Francis Alÿs - The Doppelgänger

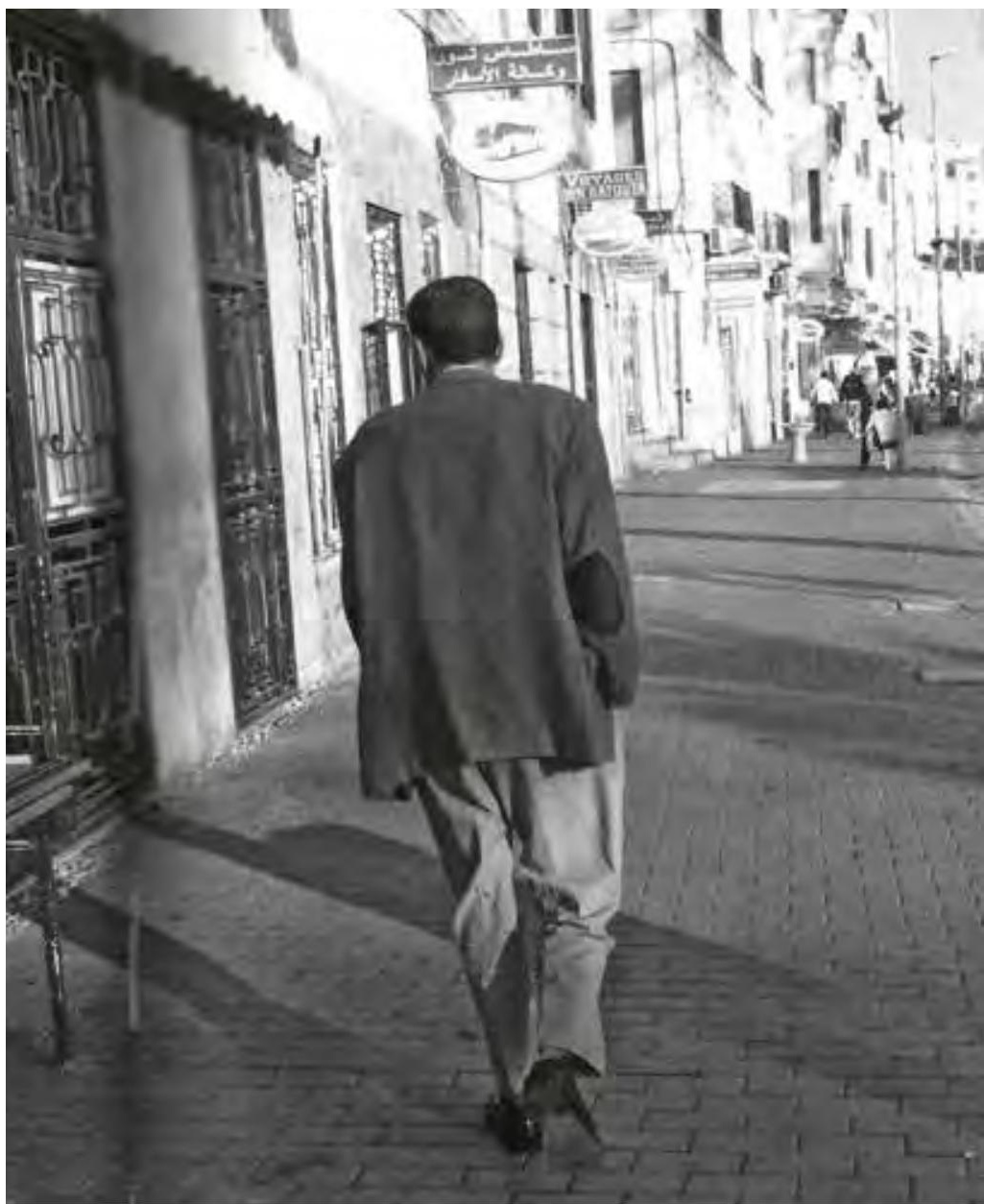

Fotos: Francis Alÿs (GODFREY et al., 2010, p. 104-105)

_entre a fuga e perseguição: um jogo duplo

Outra mulher artista que empreendeu perseguições assumindo os dois papéis possíveis dentro dessa ação foi Sophie Calle. Entre os dias 11 e 24 de fevereiro de 1980, a artista segue pessoas desconhecidas pelas ruas - "uma maneira de reencontrar Paris através dos trajetos dos outros"53 - depois de sete anos viajando pelo mundo. Nessa ocasião, a artista encontra-se sem referências topográficas, desterritorializada, aborrecida com seus rumos profissionais e carente de amigos, daí a opção por flanar pelas ruas, percorrendo trilhas desconhecidas. Um dia Sophie decide adicionar outra dimensão a essa experiência: fica sabendo que um homem que acaba de conhecer está de viagem marcada para Veneza no dia seguinte e decide segui-lo até lá, lançando-se a uma experiência radical. Ao chegar na cidade, ela telefona para uma centena de hotéis até localizar onde ele está hospedado. Ela

\footnotetext{
${ }^{53}$ une manière de retrouver Paris à travers les trajets des autres (tradução minha). Disponível em: $<\mathrm{http}: / /$ mediation.centrepompidou.fr/education/ressources/ENS-CALLE/ENS-calle.html>. Acesso em: 20 set. 2016.
} 
convence o proprietário de uma casa em frente ao hotel a usar uma janela para observá-lo e fotografá-lo. A artista também registra os locais onde ele frequenta durante as duas semanas, incluindo o carnaval, nas quais permanece nesse jogo. Informa-se sobre os seus planos questionando pessoas das lojas onde ele passa e usa uma peruca loira para não correr o risco de ser reconhecida por ele. É interessante ressaltar que a artista não espera nada do homem em questão e não quer conhecê-lo. O jogo consiste em manter o segredo, sob o risco dessa história cair na banalidade. Essa perseguição resulta no livro "Suite vénitienne" [Suíte vienense], em cujo posfácio - Please follow me [Por favor siga-me] - Jean Baudrillard afirma que "nada devia acontecer, nem sequer um evento que levasse ao estabelecimento de algum contato ou relação entre eles. Esse é o preço da sedução" ${ }^{54}$ (BAUDRILLARD in CALLE, 1983, p.84).

Mas a sedução à qual Baudrillard se refere não coincide com o desejo sexual; é uma sedução relacionada ao jogo, ao interesse da artista em transformar a observação da vida alheia em ficção. Henri B. foi escolhido casualmente como o protagonista de um história secretamente composta. Sophie Calle tem consciência de seus passos e usa os rastros desse personagem meio real, meio inventado pela fantasia dela, como dispositivo de criação para sua escrita.

\footnotetext{
Tenho medo de me encontrar com ele. Tenho medo que o encontro seja um lugar comum. Eu não quero me decepcionar. Há um lapso entre os seus pensamentos e os meus. Eu sou a única sonhando. Os sentimentos de Henri B. não pertencem à minha história (CALLE, 1983, p.30 $)^{55}$.
}

Cécile Camart, em artigo sobre a artista, comenta o quanto "é insólito apreender que na primavera de 1957, um jovem situacionista inglês e membro do Comitê de Londres, Ralph Rumney, teve também a intenção de realizar uma longa deriva até Veneza" (2005) ${ }^{56}$. Segundo ela, o projeto de realização dessa deriva, juntamente com o mapa do percurso que seria seguido, estavam profundamente marcados pelos efeitos da psicogeografia dos espaços atravessados, do mesmo modo como ocorre com Sophie Calle. Esse plano foi anunciado na revista Potlach, mas não saiu do papel. Diante das informações recolhidas sobre esse projeto, acredito que seria mais correto posicioná-lo dentro da categoria travessia, devido ao planejamento do trajeto e à intenção declarada de se atravessar um território chegando-se até um destino preciso.

\footnotetext{
${ }^{54}$ Nothing was to happen, not one event that might establish any contact or relationship between them. This is the price of seduction (tradução minha).

${ }_{55}$ I'm afraid of meeting up with him. I'm afraid that the encounter might be commonplace. I don't want to be disappointed. There is such a gap between his thoughts and mine. I'm the only one dreaming. Henri B.'s feelings do not belong in my story (tradução minha).

${ }^{56}$ Il est aujourd'hui insolite d'apprendre qu'au printemps 1957, un jeune situationniste anglais et membre du Comité de Londres, Ralph Rumney, avait tenté lui aussi une longue dérive à Venise (tradução minha). Texto na íntegra disponível em http://esse.ca/fr/dossier-sophie-calle-de-derives-en-filatures-un-erotisme-de-laseparation acesso em: 20 Set. 2016.
} 
A relação singular com o acaso é talvez o lugar onde se aproximam e se distanciam as práticas situacionistas e as perseguições calleanas. A deriva era antes de tudo um estudo sobre o terreno; ela implicava uma forma de deixar-se levar e também sua contradição, ou seja, um certo conhecimento topográfico e o cálculo de seus efeitos. Em Calle, identificamos uma vontade de controle na introdução progressiva de regras e de restrições que delimitam a liberdade postulada (CAMART, 2005, s.p. $)^{57}$
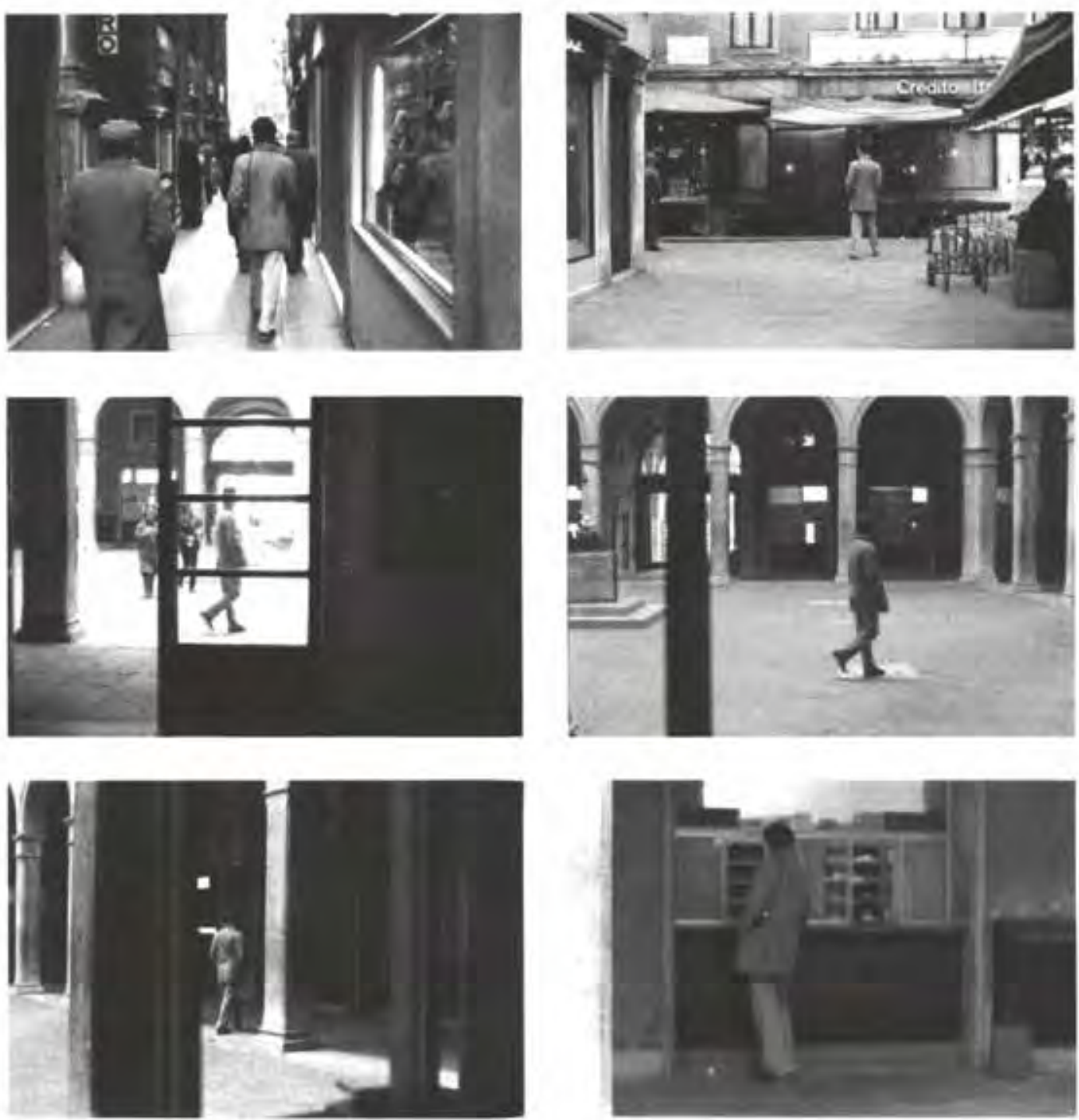

Fotos: Sophie Calle. Disponível em: Figura 26 a 31: Sophie Calle - Suite vénitienne $<$ http://jacindarussellart.blogspot.com. br/2011/07/sophie-calles-suite-venitienne.html>. Acesso em: 20 set. 2016.

Sem entrar nos pormenores a respeito da categoria na qual eu classificaria essa ação prevista por Rumney, vale observar de que modo a prática de Calle se relaciona com as derivas situacionistas. Enquanto os situacionistas desdobram sua atenção entre as ambiências

57 Le rapport singulier au hasard est peut-être celieu où se rejoignent et se séparent les pratiques situationnistes et les filatures calliennes. La dérive était avant tout l'étude d'un terrain; elle impliquait une forme de laisseraller et sa contradiction elle-même, c'est-à-dire une certaine connaissance topographique et le calcul de ses effets. Chez Calle, nous devinons une volonté de contrôle dans l'introduction progressive de règles et de contraintes qui donnent un cadre à la liberté postulée" (tradução minha). 
atravessadas e os encontros decorridos pelo caminho, as deambulações de Calle estão centradas nos desconhecidos e na exploração dos hábitos do outro, como se ao percorrer os itinerários alheios, ela pudesse acessar a identidade do outro. No entanto, pode-se dizer que se trata de um falso postulado, pois no fundo a artista espera que as pessoas seguidas por ela se mantenham desconhecidas. Nas palavras dela: "Eu sigo pessoas sem nenhum outro motivo que aquele de segui-las. Eu sigo por seguir. De mim, eles não sabem e nem saberão nada. E eles serão somente pessoas seguidas" (CALLE apud CAMART, 2005, s.p.] ${ }^{58}$. Na verdade, sua intenção era explorar os itinerários de cada um como uma forma de imaginar a vida daquelas pessoas a partir das quais escrevia, em seguida, biografias imaginárias.

Tanto para Calle quanto para os situacionistas as deambulações são encaradas como um divertimento. Porém, os situacionistas não consideravam a deriva como uma atividade artística, enquanto Sophie Calle se insere, pela própria produção literária que acompanha suas deambulações, dentro da arte conceitual. Suas explorações discutem a autobiografia e as relações estreitas entre arte e vida. Ao deixar-se conduzir por desconhecidos, Sophie Calle entra totalmente na perseguição, de maneira obsessiva, como alguém que se abandona completamente na experimentação de um ritual. Cécile Camart observa em sua análise que há inclusive uma dificuldade por parte da artista de separar-se do desconhecido. E como prova dessa ligação afetiva entre seguidor e seguido, a pesquisadora relembra que Benjamin ao comentar o soneto "A une passante" [A uma passante] - do livro "Fleurs du Mal" [Flores do Mal] - de Baudelaire, afirma que o arrebatamento desse sujeito que observa a mulher passante está menos associado a uma paixão à primeira vista e mais próximo de um erotismo da separação.

Depois de ter passado muito tempo seguindo pessoas na rua, Sophie Calle realiza o que Baudrillard sintetiza de maneira tão precisa no título do posfácio de seu livro: por favor siga-me. Ela inverte os papéis e passa a ser ela agora o objeto do interesse de alguém. Em 1981, Sophie Calle realizou La Filature, ação na qual pediu a sua mãe para contratar um detetive para segui-la pelas ruas de Paris. Ele deveria tomar notas e fotografar todos os lugares que a artista frequenta, as pessoas que encontra e o que faz a cada dia. Durante todo o mês de abril, em suas andanças pela cidade, a performer visita lugares que evocam suas memórias pessoais. $O$ detetive contratado, por sua vez, ignora o fato de que a mulher espionada teria encomendado deliberadamente uma investigação sobre si mesma.

No início, ele a segue religiosamente ao longo de todo o dia; com o passar do tempo, passa a abandonar seu posto no final da tarde. Sophie Calle mantém um caderno de bordo e recebe os relatórios e as fotografias do detetive. Quando um dia, ela percebe sua presença,

\footnotetext{
${ }^{58}$ Je suis les gens sans aucun autre motif que celui de les suivre. Je suis pour suivre. De moi ils ne savent et ne sauront rien. Et eux ne sauraient être autre chose que des suivis (tradução minha).
} 
pede que um amigo o fotografe em ação. Nesse momento, houve um retorno da artista ao seu papel original: o detetive que a segue é observado e fotografado no ato de fotografá-la. Ao final da performance, Calle realiza uma publicação na qual justapõe as fotografias e os relatórios do detetive com notas redigidas por ela sobre as experiências dessas deambulações. Ela demonstra com esse livro a impossibilidade de descrever objetivamente ações simples como caminhar na rua.

Esse desafio literário, no entanto, parece ter sido aceito por Paul Auster, romancista igualmente afeito à interdisciplinaridade entre as linguagens artísticas e à identificação com seus próprios personagens. Em A Trilogia de Nova York (de 1985), Auster reúne três romances de suspense em série. No primeiro deles, "The city of Glass" [A cidade de vidro], o escritor retoma a mesma lógica deambulatória de uma perseguição. Há uma relação intertextual com Cervantes, sendo que seu personagem principal tem as mesmas iniciais que Dom Quixote: Daniel Quinn, que improvisa o papel de detetive seguindo Peter Stillman e anota em um caderno todos os trajetos realizados por ele. O personagem Quinn constata que, ao perseguir Peter Stillman, ele teria vivido sua vida, caminhado no seu ritmo e visto as mesmas coisas que ele. No segundo romance dessa trilogia, há detetives que são contratados ao mesmo tempo para seguirem um ao outro. No entanto, é em Leviatã, seu romance de 1992, que não integra essa trilogia, que Auster cria uma personagem inspirada em Sophie Calle: Maria, uma mulher fascinante que também segue desconhecidos na rua e realiza os mesmos rituais que a artista. Maria não por acaso é uma artista difícil de ser classificada, cuja criação se baseia em aventuras que ela inventa para si mesma. No romance, ele narra diversas ações que foram verdadeiramente concebidas e levadas a cabo por Calle e inventa outras, que mais tarde seriam de fato vividas pela artista em questão.

Sophie Calle, por sua vez, também utiliza a escrita de Auster em suas publicações. Na série de livretos intitulada "Double Jeu" [Jogo duplo], trechos de Leviatã são citados, riscados pela artista e seguidos de anotações sobre o que não era verdade a respeito dela na interface com a personagem Maria. Dando continuidade às trocas nada óbvias promovidas pelos dois artistas, Sophie Calle colocou em prática as ações inventadas por ele e atribuídas à sua personagem (o que resultou no primeiro volume dessa série). O sétimo e último volume de livretos foi escrito por Paul Auster, a pedido da performer, transformando Sophie Calle em sua personagem. Trata-se de um guia com instruções sobre como ela deveria se comportar quando estivesse em Nova York. Esses artistas usam experiências pessoais próprias ou alheias como matéria-prima para a composição de suas ficções, colocando uma lupa em detalhes e rotinas banais. Ambos se encontram no campo de batalha do cotidiano, tendo no acaso suas marcas registradas.

Um exemplo bastante contundente em que a ação parece fundamentada sobre a ideia de fuga é No visa for this country (2014), uma criação da Cie. Sous X, sediada em Marseille. 
Trata-se de um audiotour ficcional, nomeado pela companhia de travelling ficcional na paisagem urbana, a partir do seguinte disparador: "seguir um chapéu". O grupo de espectadores, reunido em um ponto de encontro nas imediações de um trilho de trem, espera a aparição desse chapéu, munido de fones de ouvidos e rádio transmissor da trilha sonora ${ }^{59}$. Para tanto, o público recebe uma foto do chapéu que deve seguir, um chapéu estilo cowboy. Inicialmente, ouve-se os recados da secretária eletrônica de uma moça e percebe-se pelos fragmentos revelados de suas relações pessoais, que ela está ausente há algum tempo. Nesse momento, chega ao local onde o público se encontra uma moça loira, vestindo um casaco preto, carregando uma mala e usando o tal chapéu da foto. Os espectadores iniciam, então, uma perseguição dessa figura enigmática. No ponto de vista de Anne Gonon, que também analisa essa criação em seu livro, é como se os espectadores seguissem uma silhueta encarnada na performer, uma presença spectral da personagem Jeanne, que desapareceu. A autora considera o som um meio conveniente para trabalhar as problemáticas da memória e da presença.

O registro, tanto de vozes quanto de sons, faz aparecer o que não está lá. A noção
de ilusão se confirma como capital. Ilusões sonoras, imagens mentais geradas
pelo próprio espectador escapando do controle do autor, descontextualizações
sonoras, importação de temporalidades passadas no tempo presente... Possibili-
dades muito ricas de um ponto de vista narrativo e dramatúrgico. (GONON, 2016,
p. 106) ${ }^{60}$.

O texto veiculado nos fones sussurra pensamentos nos ouvidos, complementando de maneira surpreendente a visão dessa mulher em fuga. Se ela se configura como o espectro da personagem desaparecida, é como se ela fugisse dos espectadores, que em muitos trechos correm para não perdê-la de vista. Enquanto os espectadores a perseguem, essa figura espectral parece buscar a si mesma. Nesse sentido, o fato de se tratar de uma deambulação pela cidade é bastante oportuno, pois caminhar ativa o pensamento, colaborando para a resolução de problemas e o encontro consigo mesmo.

Enquanto erra-se pela cidade atravessando ruas, parques, entrando em estacionamentos e condomínios, o grupo se depara com outra moça loira, vestida de preto, carregando uma mala e um chapéu como o da foto. O mais curioso é perceber que ela também é seguida por um grupo de espectadores, que a persegue desde outro ponto de encontro. A situação de espelhamento ultrapassa uma possível relação entre personagens. Ela não está sozinha e nós também não. Seus conflitos internos não acontecem somente com ela, assim como

\footnotetext{
59 A peça integrou a mostra Play Mobile do Théâtre Châtillon, voltada para percursos urbanos e experiências atípicas, em setembro de 2015.

${ }^{60}$ L'enregistrement, des voix comme des sons, fait apparaître ce qui n'est pas là. La notion d'illusion se confirme comme capitale. Illusions sonores, images mentales générées par le spectateur lui-même échappant au contrôle de l'auter, décontextualisations sonores, importation de temporalités passées dans le temps présent... Autant de possibilites très riches d'un point de vue narratif et dramaturgique (tradução minha).
} 
nós, que buscamos, seguimos, somos espectadores das pessoas e das coisas do mundo, não somos únicos. Ao final da peça, dentro de um supermercado, essa figura se multiplica mais uma vez e muitas pessoas, de diferentes características físicas aparecem misturadas aos produtos à venda na loja, todas usando o mesmo tipo de chapéu.

Trata-se de um longo travelling, uma brecha poética nos espaços do cotidiano, na qual o espectador acompanha alguém que desistiu, que fracassou e que poderia ser tantos outros ou ele próprio. A influência do cinema nessa composição é evidente. O travelling que o espectador constrói com o próprio corpo vem acompanhado de uma trilha sonora que o situa no contexto da personagem, funcionando como um filtro para a observação do mundo. A visão da moça em fuga, dos espectadores e dela mesma, evoca uma experiência cinematográfica e ao mesmo tempo, física, carnal, em contato direto com o espaço urbano. Esse exemplo será retomado no próximo capítulo ao examinarmos mais de perto a modalidade cênica audiotour ou percurso sonoro.

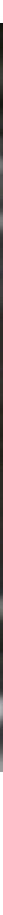

_seguir pessoas com o Coletivo Teatro Dodecafônico: uma questão de gênero

Passo agora à apresentação de algumas ações que envolvem o ato de seguir, realizadas por mim em diferentes derivas, seja em Paris ou em São Paulo, sozinha ou acompanhada pelo Coletivo Teatro Dodecafônico. Quando percebi que convinha derivar sozinha, seguir foi uma ação recorrente, um modo prático de me perder, de me engajar rapidamente em uma deriva. Todas essas ações de perseguição remetem a um tema que tem me interessado muito: o estudo de gênero. Não só a mim particularmente, mas ao Coletivo Teatro Dodecafônico como um todo e a muitas mulheres e coletivos de artistas atuais. 
Logo cedo, no metrô, sentei diante de uma mulher bastante altiva. Ela vestia um casaco de couro verde limão. Há que se ter personalidade para vestir algo do tipo. Mas a cor só desviava a atenção dos seus dedos e punhos. Entre o casaco e seus dedos secos, com unhas de artesã, de quem lida com materiais, havia braceletes grossos e metálicos. Nos dedos, anéis de formas tortuosas, elípticas, do mesmo metal. Os adereços frios e escuros enrijeciam suas mãos que se tornavam praticamente invisíveis. Ela era dedos e punhos que conduziam a um casaco fluorescente, argolas, óculos quadrados e certo efeito de presença. Ela estava ali, mas era [também] imagem, carregava nela um écran potencial. Ao levantar-se, foi rápida. Corria como uma esportista, calçando tênis de corrida. Ela carregava uma câmera fotográfica.

Dentro da Série Derivas Parisienses, tomando como ponto de partida um dos quatro cantos da cidade, propus um programa para discutir gênero, saindo do Parc Montsouris, localizado na região sudeste de Paris. Estava sozinha e depois de aquecer meu olhar e meu corpo no parque, saí em deriva pela cidade com o objetivo de seguir mulheres. Tinha acabado de assistir uma conferência de Alain Badiou sobre a feminilidade e estava cheia de perguntas na cabeça. Eu me questionava sobre o sentido de aquele homem, branco, intelectual, europeu, discutir sobre o que era ser mulher hoje. Aos poucos, entendi seu ponto de vista: ele se atém a dados históricos, a algumas referências literárias - as visões de mulher produzidas nessa sociedade - e propõe uma análise do seu papel social. Ele não dá respostas, nem dita como tem que ser, apenas (e isso é muito) apresenta um cenário, um contexto político, social e econômico e pergunta: o que é uma mulher hoje? O que pode uma mulher hoje? Ele organiza questões e convida a refletir, a questionar e (ao menos para mim) a experimentar, a explorar mulheres possíveis que cabem no meu corpo, no meu modo de ser e de agir. Nesse dia, saí para ver, observar, seguir mulheres, percorrer seus itinerários e refletir sobre a mulher que eu me torno e me permito ser a cada dia.

20 de agosto de 2015 - Deriva Parc Montsouris

0 que é uma mulher hoje ?

0 que pode uma mulher hoje ?

[a partir da conferência de Alain Badiou sobre a feminilidade]

\section{Programa:}

- Seguir uma mulher que se pareça comigo até que ela entre em

um espaço privado.

- Seguir uma mulher que não se pareça comigo e adotar uma ação ou comportamento dela.

- Escolher um espaço público para repousar meu corpo, como se ele fizesse parte da arquitetura. 


\section{Prévia da deriva:}

Subo a rua comendo uma grande nectarina. Tento fazê-la durar todo o tempo do meu percurso. Gosto de enfiar minha boca na fruta inteira e sugar um pouco do suco antes de mordê-la. Guardo o caroço no pé de uma árvore e penso nas tradições e no contemporâneo. Badiou ainda ocupa os meus pensamentos.

0 que é uma mulher hoje? 0 que ela pode? Qual o seu estatuto depois de distanciar-se dos papéis tradicionalmente associados a ela? Não é doméstica, nem sedutora, nem amorosa e muito menos santa! Somos tudo isso, nada disso, um pouco disso, outras configurações disso. Badiou fala nos espaços entre, entre esses papéis, de modo que parece que ocupamos temporariamente esses papéis. Passamos por eles algumas vezes a cada dia. E às vezes, nos esquecemos de alguns deles, ou fugimos, negamos nos aproximarmos deles. Há ainda os dias em que heroicamente pretendemos inventar outros papéis, outros interstícios.
Somos corpo, objeto, mercadoria, recipiente sem ideias?

Não é isso que vejo no metrô.

Vejo uma jovenzinha negra de óculos vermelhos comendo chips. Vejo uma moça de cabelos curtos e bagunçados, olhos estrábicos e boca de quem falou francês a vida inteira. Nada de maquiagem. Vejo outra que lê e analisa um dossiê ou algo do tipo. Esta tem ares da mulher número 1 , a superwoman, multifuncional, não só cheia de ideias, mas excessivamente ocupada e eficiente. Aparentemente infeliz, mas funcional e útil. Seria a mulher um resultado do desejo do unitário depositado nela pelo capitalismo contemporâneo? A mulher tomada como reserva do exército capitalista?

Não quero julgá-las, mas meus olhos insistem em materializar, em exemplificar as teorias que acabei de acessar, como se fosse possível encontrá-las assim,

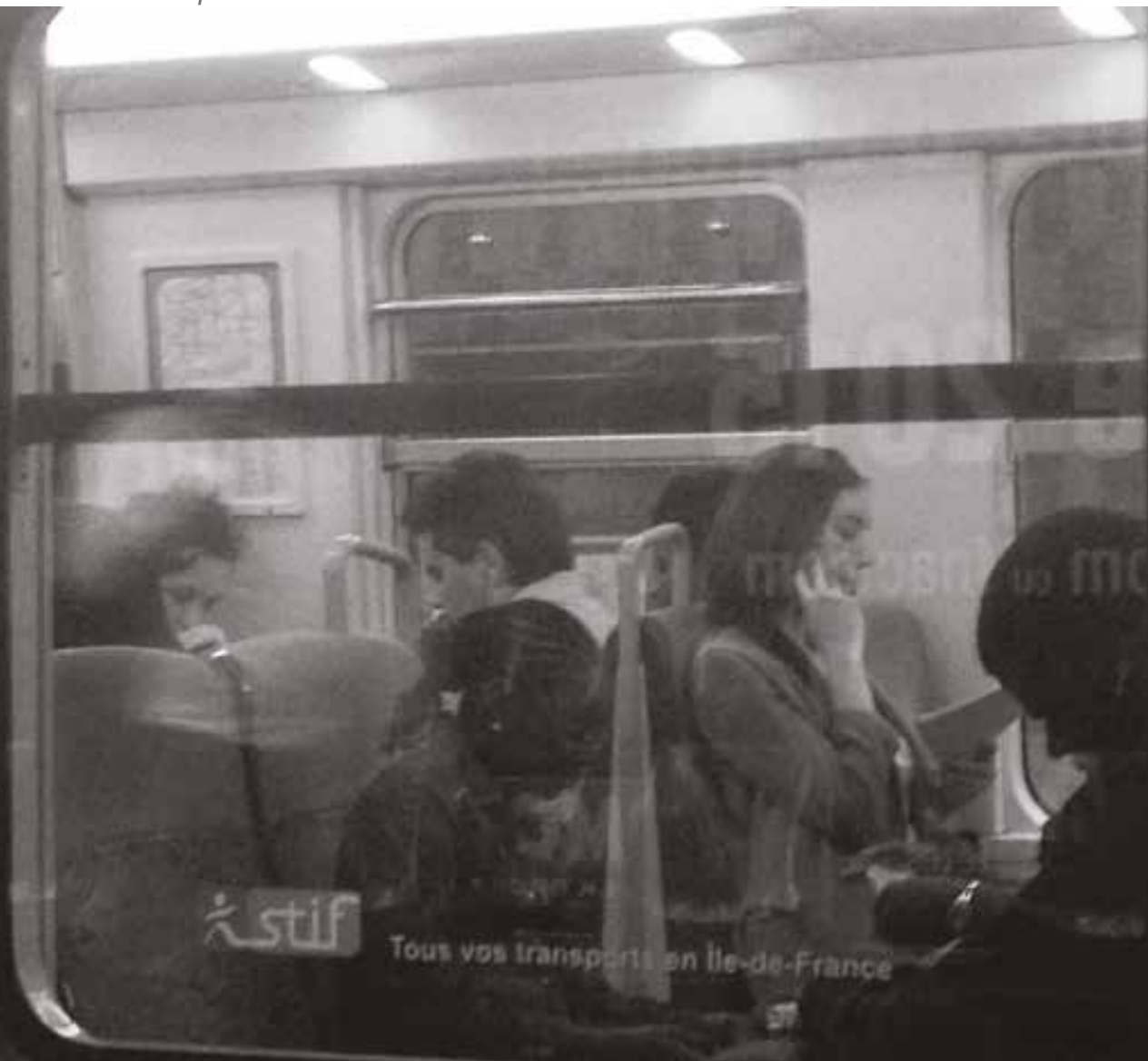


andando pela rua ou sentadas num banco do metrô.

É como li agora há pouco: por trás de toda mulher bem-sucedida, tem ela mesma.

Desço do trem na Cité Universitaire, a estação mais próxima do ponto de partida: o Parc Montsouris. Resolvo terminar meu relato prévio sentada nas cadeiras azuis da plataforma. Ocupo meu tempo, permito-me, desprendo-me. Declaro: Uma mulher hoje pode descer do trem às 19 h04 e sentar-se nos bancos da estação que almeja chegar só para terminar seu relato.

\section{Chegada ao parque:}

Na entrada do parque, vejo um pai segurando uma criança de menos de dois anos pelo braço, como se ela fosse o patinete que ele carrega no outro braço. A criança encontra-se no ar, depois de levar uma palmada na bunda. Ela esperneia e é levada como coisa, objeto, corpo-criança, suspensão. A primeira visão é amenizada ao ver outro pai levando uma criança pela mão e uma bicicleta com cadeirinha, na outra. Mais adiante, ouço: "tchau, tchau, salut, salut". Mais um pai que tenta convencer a filha a voltar pra casa. Desta vez, também há doçura no tom desse adeus. Sim, eu vejo homens carregando e ocupando-se de seus filhos. Mais ou menos desajeitados, eles se responsabilizam pelos seus filhos, assumindo um pouco mais que tradicionalmente o papel doméstico tão comumente delegado às mães. Aqui, não se trata de ajuda, de um cuidado em forma de favor, destinado às crianças sob o olhar agradecido e, muitas vezes, vigilante das mães sobrecarregadas. Digo isso, pois nesse parque, as mães estavam quase ausentes.

Mulheres exercitam os glúteos, fazem agachamentos, como se sentassem em um banco invisível. Mercadorias na linha de produção? Outro papel? Treinamento para femme fatale? Como olhar e não julgar ou categorizar? Desculpe, estou fazendo uma pesquisa científica e busco/colho exemplos, estudos de caso. Necessito de categorias apenas para justificar minhas hipóteses, são rótulos passageiros utilizados apenas para conversar com um Badiou ausente, mas pontiagudo como um martelo em meus pensamentos.

Os homens são mesmo adolescentes crescidos puxados pelas mãos de jovens mulheres amadurecidas antes do tempo? Trata-se de um efeito Badiou?

Desço escadas. Sigo meu fluxo dançante. Uma dança íntima. As vozes, eu ouço ao longe. Hoje eu penso em português, mesmo quando a Ave Maria das crianças é cantada em francês. Sigo o fluxo de uma bike e viro na esquina. Uma moça de vermelho conversa com dois rapazes. Chego na Tolbiac. Uma moça parecida comigo passa rápido sobre rodas. Não dá para seguir seu fluxo com essas pernas que me levam. Percorro a Tolbiac e descubro um jardim. Mais uma visão das filles et fils de Badiou. Parecem tão iguais em sua juventude. Mas é a fille que disfarça mais perfeitamente o cigarro que fumam. o jardim é habitado por vozes e cercado de prédios. Eu me sento num banco e me permito. Declaro: Pode uma mulher sentar-se num banco enquanto a vida corre lá fora! Pessoas voltam do trabalho, correm, cuidam das crianças. Ai ai ai as crianças! Como preparar essas moças? Sem escondê-las. Sem concorrê-las. Sem amadurecê-las antes do tempo? Sem torná-las úteis, dispostas, trabalhadeiras, a(1)tivas? Criativas, pensativas, sem vida, sem ideias! Declaro: Pode uma mulher ter esses pensamentos. Rir assim alto. Descobrir-se. Permitir-se. Habitar a cidade sem ficar pesarosa. Sem culpas. Sem neuras. Sem apegos. Sem sofrer pelos filhos.

\section{Seguir mulheres:}

Eu procurava uma moça de cabelos curtos, como os meus, com quem, de certa maneira, eu me identificasse. Escolhi uma de cabelos longos mesmo, porém presos, com a certeza de que ela me levaria até uma de cabelos curtos. Ela se vestia em tons de cinza e calçava sapatos vermelhos. Dito e feito, achei a moça de cabelos curtos e bolsa verde bandeira. Eu a achei e a perdi. Depois de esperá-la impacientemente, ela foi engolida pelo Tabac.

Optei por seguir outra mulher muito diferente, de outro tempo. Tradicional, de certa forma. Ela usava um vestido de mangas fofas rosa envelhecido, saltos altos e um laçarote preto nos 
fico e o Núcleo Tríade. Dentro do projeto LIMINARIDADE / 5 movimentos, o Dodecafônico participa de algumas ações conjuntas, como grupos de estudo sobre gênero (lendo Beatriz Preciado e Judith Butler), e propõe práticas. Como eu estava distante, os coletivos propuseram que eu enviasse um programa de deriva para ser explorado em São Paulo. Organizei um programa a partir dessa deriva mencionada anteriormente, inspirada em Badiou, nas propostas de perseguição estudadas nas ações de Vito Acconci e de Francis Alÿs e o enviei para o Brasil. Acrescentei também uma proposta de deixar-se guiar por alguém que estivesse ausente, por telefone, numa espécie de condução às cegas. Uma tentativa de testar a capacidade da mulher contemporânea de se deixar levar, de ser conduzida, de perder o controle sobre os próprios passos. Por razões mais operacionais, o tempo e a falta de um combinado prévio, a maioria das participantes da deriva não conseguiram cumprir essa parte do programa ${ }^{61}$.

Na América do Sul, caminhar significa enfrentar muitos medos : medo da cidade, medo do espaço público, medo de infringir as regras, medo de apropriar-se do espaço, medo de ultrapassar barreiras muitas vezes inexistentes e o medo dos outros cidadãos, quase sempre percebidos como inimigos potenciais. Simplesmente, o caminhar dá medo e, por isso, não se caminha mais ; quem caminha é um sem-teto, um mendigo, um marginal (CARERI, 2012, p.170).

Ao discurso de Careri, a todos esses medos (no plural), parece importante acrescentar o medo de ser mulher. O modo de uma mulher caminhar na rua não é o mesmo de um homem. À mulher não é dado o benefício da lentidão, nem da distração e, muito menos, da dúvida. Pelo simples fato de caminhar sozinha na rua, uma mulher coloca-se em risco. Os relatos das derivas de gêneros revelam isso: senti-me insegura ao buscar um lugar para repousar meu corpo na cidade e do mesmo modo, nenhuma das mulheres que realizaram a deriva em São Paulo se deixaram ser guiadas às cegas por telefone. Será que essas duas interrupções de roteiro são uma simples coincidência? As ações realizadas por mulheres aparecem, em maior ou menor medida, marcadas pela discussão de gênero, sobretudo quando são posicionadas no espaço público. É como se a rua colocasse em relevo qualquer ação realizada por uma mulher, por mais simples que seja, como por exemplo, andar. Nesse contexto, as ações realizadas por mulheres tem um papel político bastante importante, pois expõem no espaço urbano outras mulheres possíveis, outras configurações sociais, assim como outros papéis a serem vividos e inventados.

\footnotetext{
${ }^{61}$ Esse programa está disponível na publicação organizada pelos coletivos supracitados. "Programa performativo em deambulação" in Liminaridade/ 5 movimentos, Coletivo Cartográfico e Núcleo Tríade, contemplado pela 17ạ. Edição do Fomento à Dança da Cidade de São Paulo, p. 134.
} 


\section{> capítulo quatro: percursos cotidianos - flanar com fones de ouvido}

- Devo começar por onde? - Comece pelo começo - disse o Rei com ar muito grave - e continue até chegar ao fim: então pare. Lewis Carroll

[nota sobre o capítulo: neste capítulo apresentarei algumas análises de ações performativas fundadas em percursos traçados no contexto urbano. Na maioria dos casos, as ações decorrem de trajetos percorridos cotidianamente, visando deslocamentos objetivos e funcionais. As ações se configuram de maneiras variadas, podendo resultar em fotografias, desenhos ou intervenções no espaço público. Reconheço nesses percursos uma característica comum: tratam-se de criações focadas em práticas cotidianas. Incluo nesse capítulo os audiotours ou percursos sonoros como modalidades artísticas que inevitavelmente propõem que o espectador percorra uma trajetória pré-definida pelo artista, ainda que para quem se desloca com fones de ouvido, a experiência possa ser associada a um passeio ou uma deriva.] 
[percursos]: deslocamentos objetivos realizados sobretudo no contexto urbano. Em um percurso, tanto o ponto de partida quanto o ponto de chegada são conhecidos. Nem sempre trata-se da distância mais curta, mas será sempre um caminho escolhido. Alguns são percorridos todos os dias, repetidamente, constituindo-se como parte de uma rotina. Os percursos são individuais ou compartilhados. Dificilmente alguém experimenta todos os dias os mesmos percursos que uma outra pessoa, embora alguns percursos sejam sempre realizados na companhia de alguém. É uma modalidade que se confunde com o real.

\section{I. quando os artistas se valem de percursos para compor ações}

Ao definir essa tipologia do caminhar, deparei-me com inúmeros artistas caminhantes que sintetizam suas criações na invenção de um percurso. Ou seja, são artistas que fundam suas ações no ato de caminhar, definindo previamente os trajetos a serem percorridos, resultando num percurso como construção artística. Como já apresentado anteriormente, é Francesco Careri quem associa o termo "percurso" a três acepções distintas: a ação do caminhar, "a linha que atravessa o espaço" (que ele considera como objeto arquitetônico) e "o relato do espaço atravessado (o percurso como estrutura narrativa)" (CARERI, 2013, p.31). Alguns dos artistas mencionados aqui criam representações gráficas desses percursos, um material que nos ajuda a enxergar essa construção realizada ao andar. O desenho do percurso é um rastro, um vestígio do ato performático, que será observado como repetição e como ação inserida no cotidiano. Neste capítulo, portanto, analiso essas ações enquanto percurso: o ato de atravessar um espaço dado, tendo em vista seu ponto de partida e seu ponto de chegada e apenas no sexto capítulo, analiso as outras materialidades resultantes dessas ações.

No Fundo Guy Debord da BNF [Bibliothèque nationale de France - Richelieu], encontrei as notas de leitura de Debord sobre o texto "Paris et l'agglomération parisienne" [Paris e a aglomeração parisiense, sem tradução para o português], de Paul-Henri Chombart de Lauwe, de 1952. Nesse livro, o sociólogo urbano propõe um método de pesquisa para o estudo de uma grande cidade, observando processos ancorados na vida cotidiana dos habitantes da capital francesa. Na nota de número 3, Debord discorre sobre o comovente mapa dos trajetos coletados durante um ano por uma jovem moradora do 16ème arron- 
dissement $^{1}$. A garota era aluna de Chombart de Lauwe e teve o cuidado de registrar em um mapa os percursos entre a École de Science Politique, seu domicílio e o de seu professor de piano. Trata-se de uma região nobre de Paris e é curioso observar como ao longo de um ano, o território frequentado por essa moradora ficou restrito às imediações de seu bairro. Debord retoma esse exemplo na "Teoria da Deriva" para discutir um possível confinamento no qual vivem a maioria dos habitantes das grandes cidades, ou seja, habitar uma metrópole não significa percorrê-la em sua inteireza, nem tampouco conhecê-la em sua amplidão. $A$ tendência dos moradores de uma cidade grande é criar pequenos nichos nos quais circulam e estabelecem suas relações de trabalho, de convívio e de afeto. Os percursos dessa moça

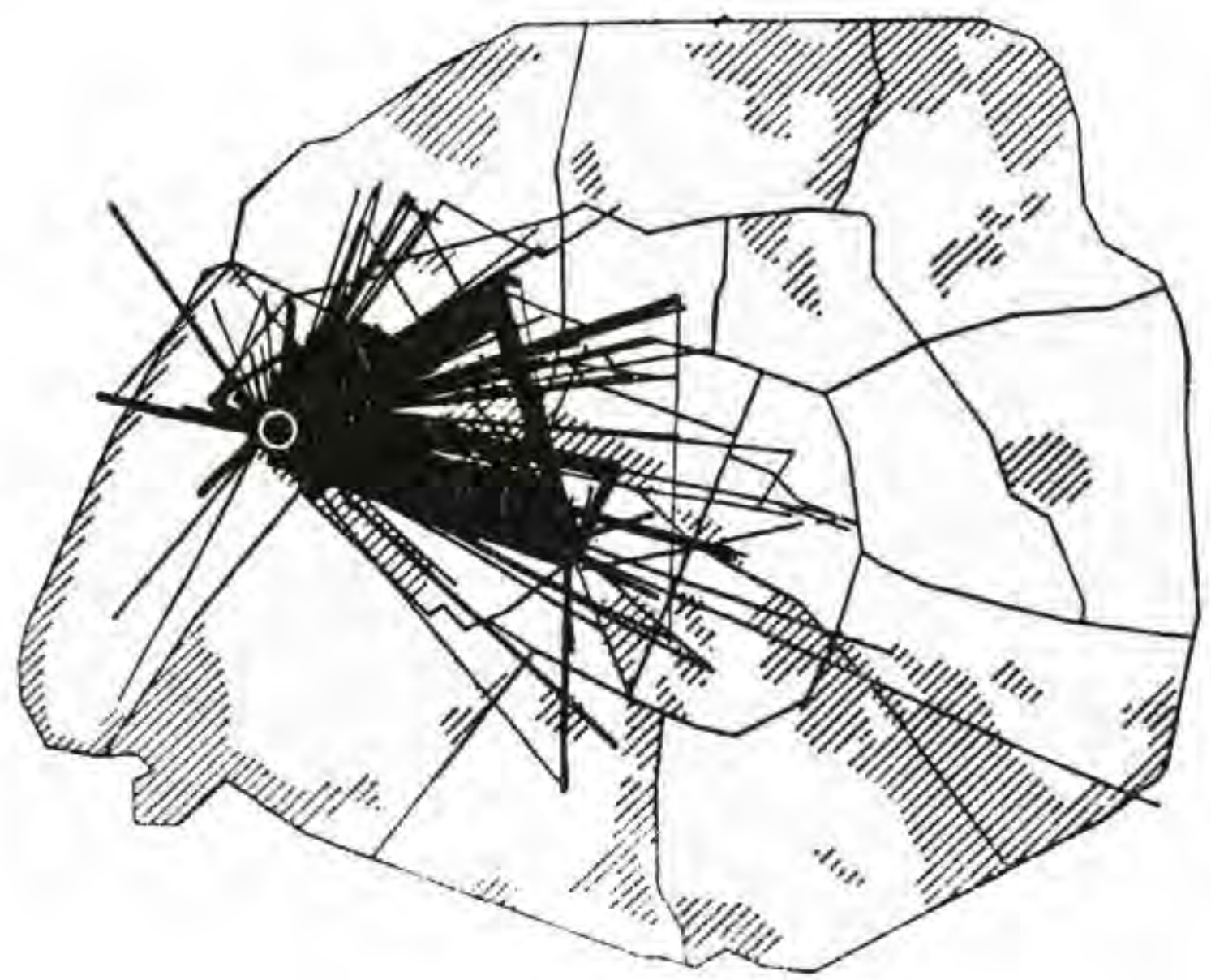

Figura 1: mapa dos percursos da aluna de Chombart de Lauwe pin/260294053435807111/>. Acesso em: 15 out. 2016.

também se restringem a um triângulo de dimensões reduzidas, como revela o mapa acima.

Nesse mapa, vemos não somente os percursos objetivos realizados por essa moça, mas também a organização de um conjunto de afetos. Em São Paulo ou em qualquer outra capital faz todo o sentido a opção por restringir-se a um recorte da cidade, criando micro-

1 Correspondente a um bairro da cidade de Paris. 
cidades dentro de um grande organismo inapreensível em sua totalidade. No entanto, o que parece interessante destacar é o quanto os itinerários de alguém podem ser o ponto de partida para a criação artística, configurando-se menos como um retrato de seus deslocamentos e mais como um mapa de seus afetos. Gilles Deleuze, em seus estudos sobre territórios e trajetos percorridos, cita uma observação de Fromentin na qual ele afirma analisar mapas não como geógrafo, mas como pintor. As ações sedimentadas em percursos, se opõem ao monumental, ao espetacular, e se aproximam do cotidiano e do real. Além disso, é relevante notar como tais ações ampliam a perspectiva do fazer artístico, pois toda e qualquer pessoa poderia compor a partir dos próprios itinerários.

O trajeto se confunde não só com a subjetividade dos que percorrem um meio mas com a subjetividade do próprio meio, uma vez que este se reflete naqueles que o percorrem. O mapa exprime a identidade entre o percurso e o percorrido. Confunde-se com seu objeto quando o próprio objeto é movimento. (DELEUZE, 2011, p. 73).

Nesse texto, intitulado "O que as crianças dizem", Deleuze discorre sobre as narrativas que as crianças constroem a partir de suas ações; elas descrevem tudo o que fazem, o tempo todo. Rapidamente, em sua reflexão, o autor associa a narrativa ao trajeto, de modo que o trajeto pode ser entendido com um fio narrativo, o relato do percurso. Um mapa é um objeto que não comporta o corpo; seu caráter bidimensional o afasta, coloca-o em posição de ser observado e não vivido. Por outro lado, a linha de um trajeto inscrita sobre um mapa reintroduz o corpo nesse espaço. $O$ desenho da trajetória é um resquício do corpo deixado no mapa, ainda que o corpo tenha percorrido a cidade e não o mapa propriamente dito.

Paul Zumthor em seu livro sobre performance, recepção e leitura me fez lembrar o quanto a vida estudantil pode ser demarcadora dos itinerários recorrentes ao longo da vida. Aos 10 anos, fui com minha família morar em Goiânia e me lembro bem do quanto as idas e vindas da escola foram importantes para me localizar naquele espaço/tempo. Isso aconteceu novamente comigo, em todas as cidades onde morei, os primeiros itinerários foram definidores de uma inscrição pessoal em cada um desses contextos. A partir desses fluxos constantes, outros caminhos e desvios se abrem, fazendo desses itinerários os primeiros passos para a exploração de um novo território.

o caminho até a escola também representava para mim um território a ser conquistado. A escola primária era longe de casa, do lado de lá do Córrego do Sapo, então, eu e meus irmãos éramos levados de carro até lá, de carona na ida e pela minha mãe na volta. Meus pais viveram num tempo e se fizeram num contexto em que o carro os definia, era parte da representação de quem eles eram socialmente. Minha mãe, por exemplo, foi a primeira moça a ter un carro na cidade. Sempre gostei disso, de ter uma mãe pioneira, que colaborava para mudar os valores locais. Raramente, talvez por esse motivo ou por comodismo mesmo, ela ia a pé até a escola onde lecionava e onde eu almejava estudar: o colégio do 
Sol. Quando entrei na quinta série, pude ir a pé pra escola: minha primeira conquista de território. Andar em bando, aprender a andar em bicicleta grande, deslocar-se com as próprias pernas, percorrer ruas e quarteirões, conhecer a cidade com os próprios pés. Depois de seis meses nesse colégio, mudamos para longe, porque a antiga casa foi vendida. Desta vez, a familia estava de mudança para Goiânia. Fomos morar em um apartamento longe do colégio. A vida em quatro rodas parecia sempre confortável. Tudo se resolvia tendo um carro. Vivi assim três anos, indo de carona e voltando com minha mãe. Na cidade grande, onde tudo é mais perigoso, as pessoas estranhas, as distâncias maiores, também há mais ofertas de estudo e entretenimento. Resultado: minha mãe se tornou uma espécie de motorista dos três filhos. Quando ela deu um basta nessa situação, e eu já era adolescente. Com ânsias de me deslocar sozinha, o transporte público entrou na minha vida. No ensino médio, passei a estudar numa escola perto de casa e hoje me lembro que esse foi o critério que eu secretamente usei para escolher onde estudar.

\section{_percursos como linhas que atravessam o espaço}

Em 1960, Stanley Brouwn recolheu uma série de desenhos pedindo aos passantes para lhe indicarem o caminho de um ponto a outro desenhando em um papel o percurso, do modo como preferissem representar, segundo o que tinham guardado na memória (figura 2). A ação - This way Brouwn - aconteceu em Amsterdã e se configura como uma obra anônima, composta por esses desenhos que são voluntariamente apropriados pelo artista. Aos croquis realizados pelos passantes enquanto explicavam uma determinada rota, o artista acrescenta um carimbo com a seguinte frase: "This Way Brouwn" [Nesta direção, Brouwn], o título da obra. O gesto de carimbar os papéis desenhados com essa frase passa pela adição de uma singularidade na formulação de uma obra coletiva, fruto da coleta de desenhos realizados pelas pessoas mais diversas. Trata-se de um tipo de apropriação ou desvio, no sentido situacionista, pois nenhum dos desenhos foi realizados pelo artista; foram apenas recolhidos e reunidos por ele sob a mesma marca. Esse movimento reforça a centralidade do caminhar, em especial da configuração de um percurso dentro de sua criação. Ou seja, sua tarefa como artista não é desenhar, é observar a plasticidade dos deslocamentos, dos fluxos, dos percursos urbanos. A partir dessa ação, ele passa a desenvolver propostas que convocam os visitantes de suas exposições a caminhar, bem como desenvolve sistemas de representação de medidas e distâncias pedestres correspondentes à medida do passo de cada pessoa.

Entre 01 de junho de 1968 e 17 de setembro de 1979, o artista japonês On Kawara marcou sobre mapas geográficos de diferentes cidades onde morou todos os seus itinerários urbanos. Trata-se de uma série composta por 12 volumes intitulada I went [Eu fui]. $\mathrm{O}$ artista utilizou-se de fotocópias de mapas em branco e preto de Nova York, Tokyo, Berlim, Düsseldorf, Cidade do México e Bruxelas sobre as quais marcou com lápis vermelho seus 


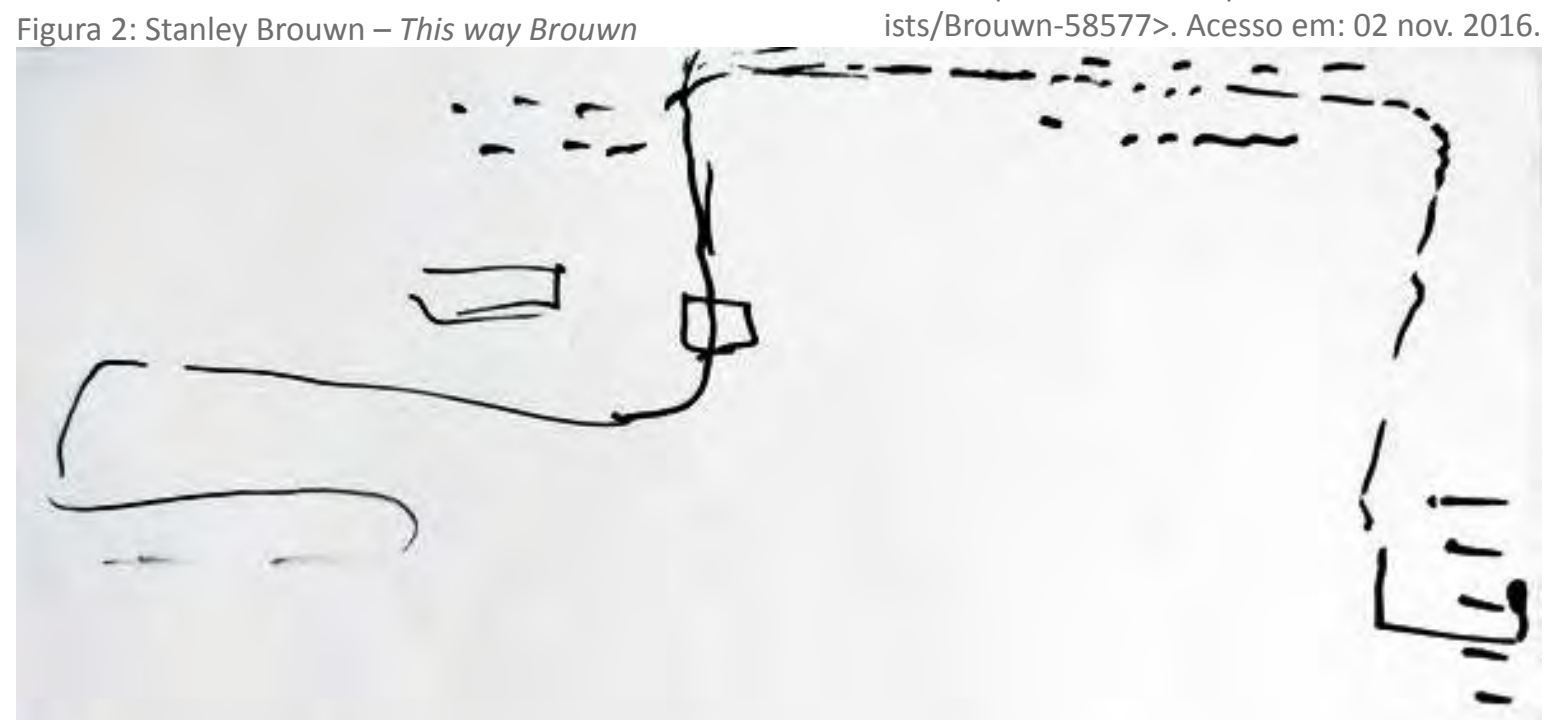

THIS WAY BROUWN

deslocamentos. Nos dias em que permaneceu em casa, marcou um ponto vermelho sobre sua localização no mapa. A sistematização empreendida por On Kawara é fora do comum, devido a sua amplidão: são 27.881 dias e 4.740 páginas no seu conjunto. A mesma radicalidade aparece em outros dois trabalhos de registro obsessivo de seu cotidiano: I got e I met. O primeiro consistia no envio de cartões postais a um mesmo endereço, como forma

Figuras 3, 4 e 5: On Kawara - I went

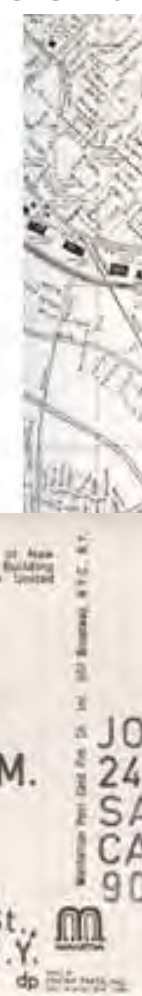

\section{$\checkmark$ GOT UP AT} 9.17 A.M.

On Kawara 24 E. 22nd St. New York, N.Y. on-and-on-kawara.html>. Acesso em: 25 out. 2016. 
de testemunhar suas errâncias por diversos continentes e o segundo, no registro do nome de todas as pessoas que ele encontrou durante esses 12 anos. On Kawara desenvolve em sua obra uma profunda relação com a vida cotidiana e empreende um trabalho colossal de notação sobre aspectos de sua vida íntima, como se compusesse um diário gráfico.

Nas ruas de Florênça entre 1973 e 1975, Maurizio Nannucci realizou a ação Star / scrivendo camminando. Da creare l'artista creativo [Estrela / escrevendo caminhando]. Por meio do traçado do percurso impresso na cidade por seus passos, o artista italiano escreveu a palavra "estrela" no chão. Trata-se de uma obra completamente invisível. Segundo Thierry Davila, ele investe na invisibilidade a tal ponto que ninguém percebe sua ação, até mesmo a existência de sua obra, a não ser que se tenha contato com o protocolo ou o programa da performance. Esse historiador da arte atribui à figura do flâneur (e ele tem uma visão bastante ampla a respeito dessa figura) a invenção do infra-mince ${ }^{2}$, fazendo uma referência direta ao conceito criado por Marcel Duchamp para referir-se à exploração de fenômenos extremamente sutis, das pequenas percepções ou das sensações ínfimas. Tal conceito, enunciado por Duchamp em suas "Notas" para se referir a alguns exemplos de criações artísticas, é operativo à medida em que coloca em jogo dualidades recorrentes na arte contemporânea, tais como o visível e o invisível, o material e o
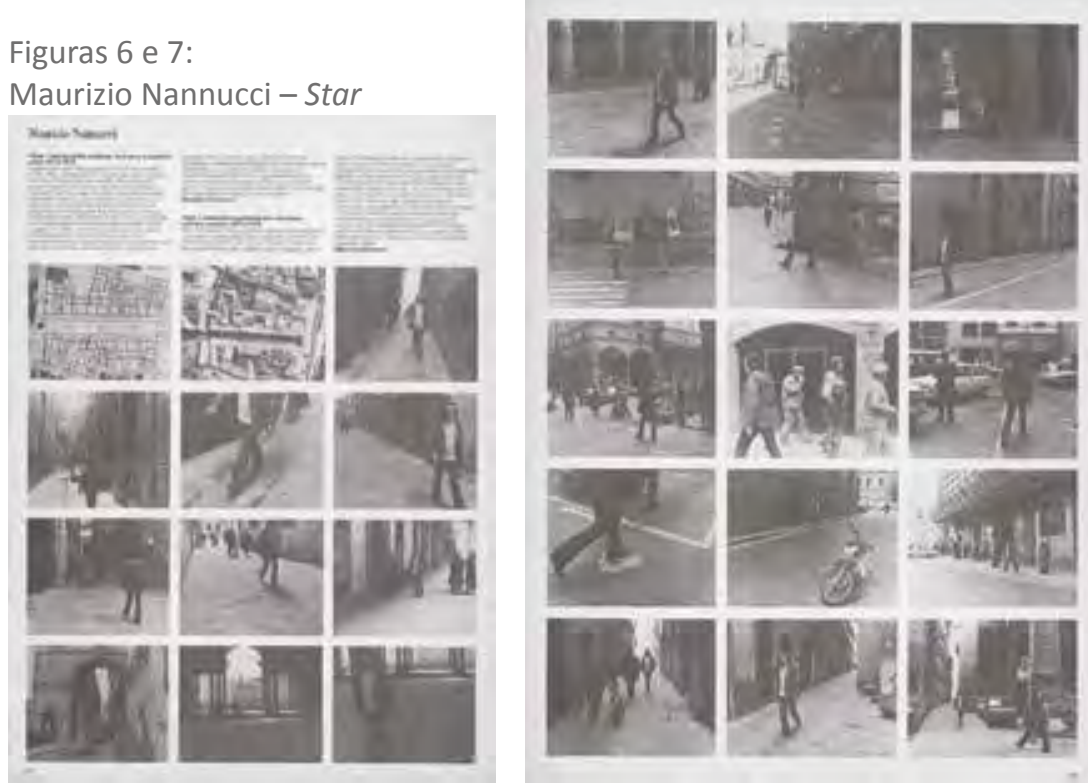

Fotos: Disponíveis em: <https://lecdla.wordpress.com/2016/02/24/maurizio-nannucci-3/>. Acesso em: 27 out. 2016. imaterial, a presença e a ausência, o verbal e o visual. De fato, Nannucci trabalha na esfera do imperceptível - abaixo do sutil, abaixo do transparente.

Ao chamar a atenção a respeito do infra-mince, Duchamp revela outras possibilidades no campo da recepção estética. Ações altamente implicadas ou confundidas com as práticas cotidianas operam na esfera do não-espetacular, criando até certo ponto algo próximo a um não-acontecimento. Tais ações propõem uma diferença igualmente ínfima no mundo

2 Trata-se de um neologismo, pois a palavra também não existe na língua francesa e aparece grafada de diferentes maneiras ao longo da obra de Duchamp: inframince, infra-mince e infra mince. Infra tem o mesmo sentido que em português, "abaixo de" enquanto mince significa fino. Desse modo, o inframince pode ser considerado algo muito fino, finíssimo, delgado, magro, enxuto, tênue, insignificante ou leve. 
e é assim que constituem suas identidades, entre o invisível e o silencioso. Nesse mesmo sentido, Thierry Davila apresenta as ações do esloveno Roman Ondák, que, segundo ele, se posicionam na lógica do desaparecimento. Em 2008, ele instaurou uma situação na qual diversas pessoas andam pela rua com suas roupas do lado do avesso, na ação intitulada Insiders. O autor chama a atenção também para ações nas quais considera os passantes como flâneurs, ou seja, só perceberão o que se passa aqueles que estiverem especialmente atentos aos sinais que se revelam no contexto urbano.

Outra artista que utiliza percursos em suas criações, demarcando a composição de linhas no espaço, é a canadense Sylvie Cotton. Na ação intitulada Dessins marchés [Desenhos caminhados], a artista decide passar cada dia com uma pessoa desconhecida. Seis pessoas responderam ao anúncio da internet e da rádio lançado pelo produtor que a convidou para participar do evento na cidade de Toronto (2003). A ideia é passar no mínimo três horas com a artista, sendo que a pessoa convidada decide se passarão esse tempo em silêncio ou

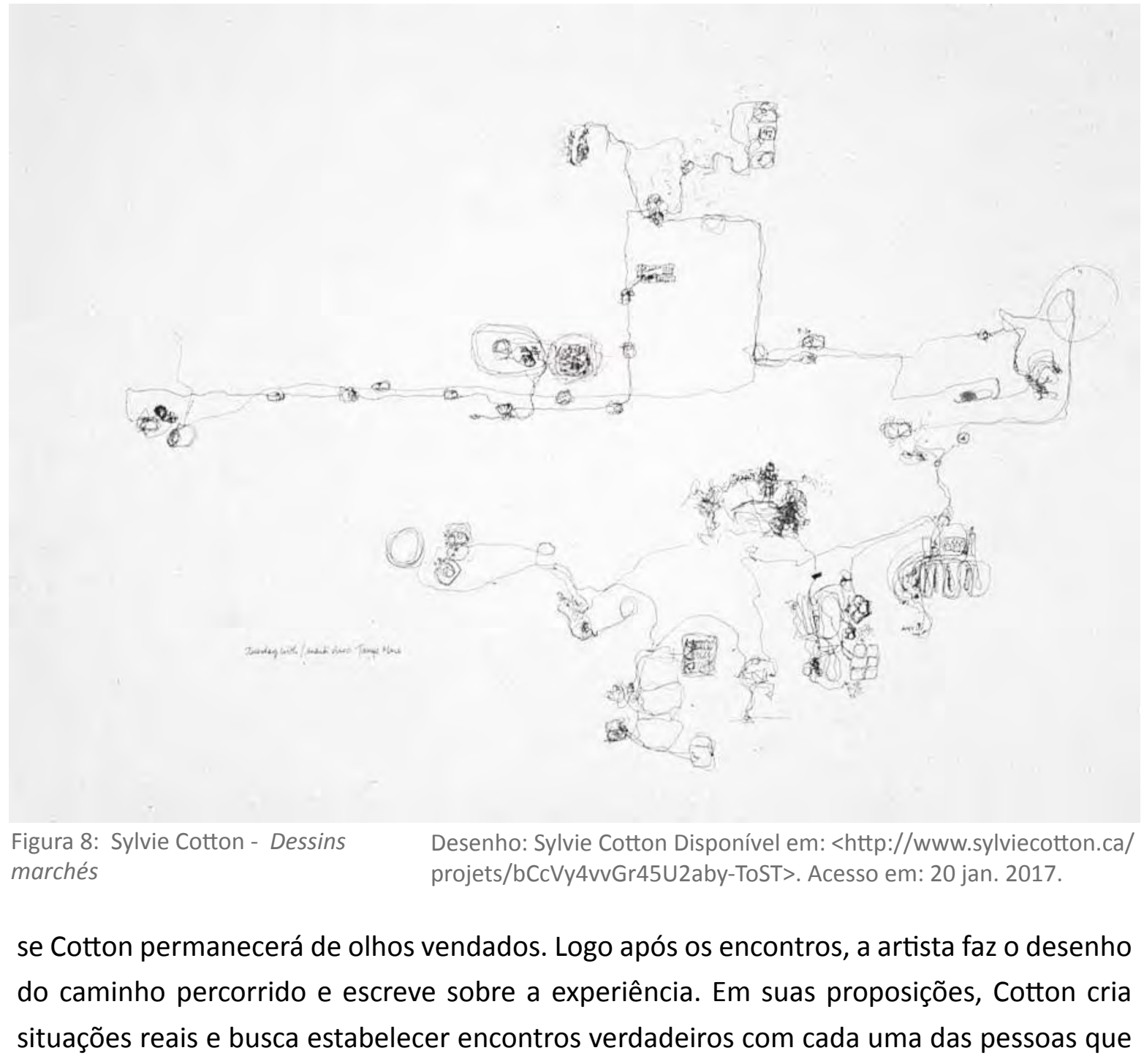


caminha ao seu lado. O desenho do percurso funciona como a síntese desse encontro, que pode ser entendido como uma proposta de arte relacional. No final dessa semana em Toronto, foi proposto um encontro com todos os participantes para a partilha de impressões e a exposição dos materiais formulados a partir de cada uma dessas aventuras.

\section{inscrições artísticas como interferências no percurso}

Muitos artistas, ao invés de se valerem dos percursos como materialidade para suas criações, optam por interferir no espaço público criando marcas ou sinais para serem percebidos por quem caminha pela cidade. Esses artistas colocam em evidência a teatralidade do cotidiano e revertem o olhar cotidiano em estético, num processo de des-automatização, de revelação de um estado anestésico cotidiano. Em outros casos, é a observação diária do

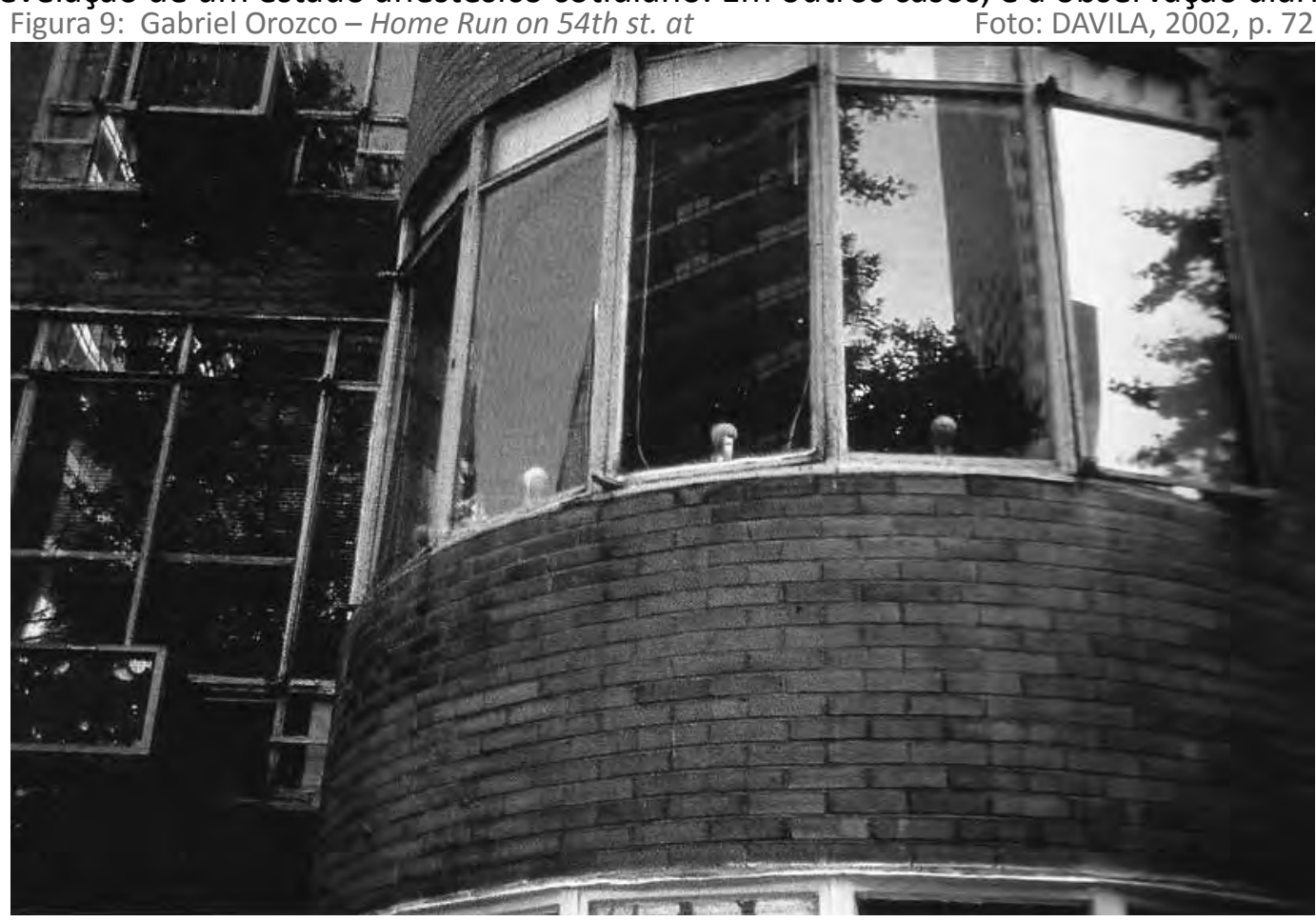

artista de itinerários alheios que gera a composição artística. Em todos eles, no entanto, há um jogo entre o acaso e a composição, o visível e o invisível, os caminhos e seus efeitos sobre o corpo. Gabriel Orozco, em uma ação exemplar do tipo de trabalho que realiza, compõe Home Run on 54th.st. at Moma (1993), que consiste em uma série de laranjas posicionadas atrás das vidraças de diferentes andares de um edifício vizinho ao Museu de Arte Moderna de Nova York. A instalação pode ser observada unicamente pelos passantes e segundo Thierry Davila, uma obra que somente o flâneur, e nenhum outro personagem urbano, poderia imaginar (2002, p. 71). E de fato o que essas ações inspiram ou provocam no espectador fortuito é uma atitude diferente, é o exercício do olhar atento, de quem realmente desfruta dos percursos cotidianos. 
Para montar esse dispositivo, o artista escreveu para os moradores do edifício, propondo colocar as frutas em suas janelas, segundo suas indicações e garantindo que receberiam laranjas frescas do MOMA semanalmente. Essa intervenção conjuga deslocamento e percepção, movimento e atenção, ao mesmo tempo que compõe na dimensão do inframince de Duchamp. Trata-se de uma interferência sutil e discreta, como um ato de presença destinado a passantes observadores que poderão se surpreender com a composição, como testemunhas de um gesto artístico. Davila considera Home Run on 54th.st. at Moma uma escultura efêmera capaz de ativar uma relação com o espectador contrária à monumentalidade e ao espetacular (Ibid., p.74).

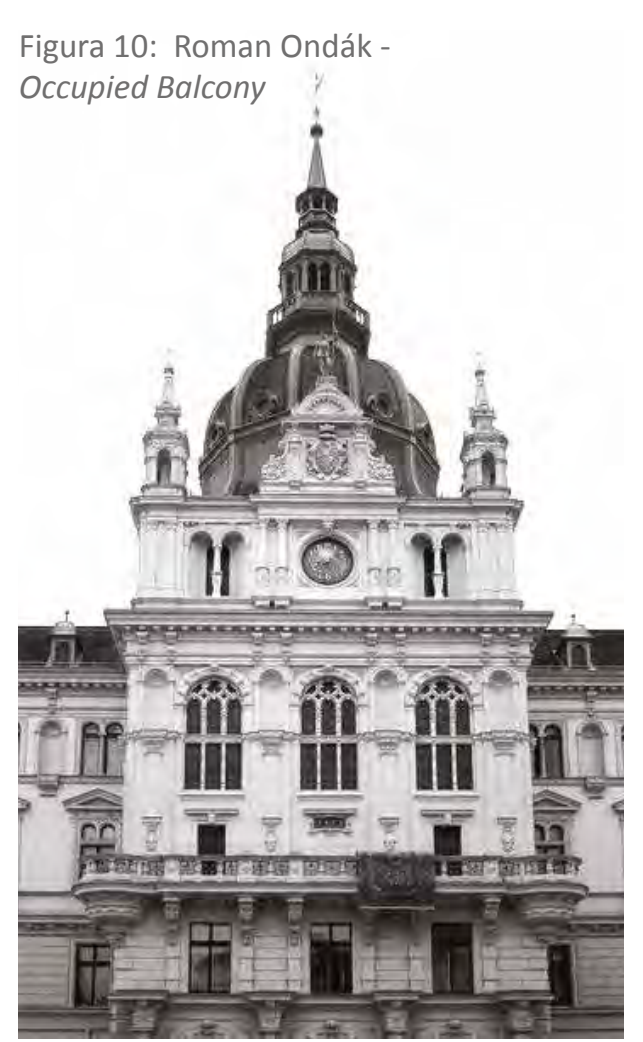

Foto: Disponível em: <http://www.kurimanzutto.com/en/artists/roman-ondak>. Acesso em: 20 jan. 2017.
Para evidenciar o modo de operar do infra-mince, a ação Occupied Balcony [Balcão ocupado], do já mencionado Roman Ondák, pode ser evocada. Realizada em Graz, na Áustria, em 2002, o protocolo da ação consiste em colocar um tapete persa na sacada do prédio-símbolo do poder administrativo da região. O tapete é posicionado de modo a ser visto de qualquer ponto da praça onde esse prédio se encontra. Cuidadosamente colocado no guarda-corpo do balcão, ele poderia ter sido esquecido pela pessoa que realiza a limpeza do local e poderia estar ali por simples obra do acaso. Como não há nenhuma indicação de que se trata de uma criação artística, só percebe a presença desse objeto o pedestre atento e, ao mesmo tempo envolvido com as questões relacionadas às políticas de imigração adotadas pelo país. Não por acaso, naquele momento, a extrema direita ocupa o poder e o tapete posicionado no edifício representa um gesto político: um ato contrário às medidas adotadas pelo governo. É como se toda a população de imigrantes árabes estivesse presente naquele balcão, reivindicando um lugar ao sol. Como sempre, o impacto causado pelo trabalho de Ondák é inversamente proporcional à sutileza de suas ações. Se por um lado, Roman Ondak não é tido como um agitador, um provocador invicto da esfera política, por outro, ele pode ser tomado como conspirador, um inventor de táticas de ataque às macroestruturas.

Diferente das estratégias de desterritorialização e reterritorialização adotadas por ativistas da década de 60 e 70, Ondák cria táticas, age por dentro da estrutura, utilizando-se de recursos avessos ao espetacular. Ele se vale de princípios provenientes da arte conceitual, explorando programas de performance no espaço público que colocam em pauta questões 
relacionadas à imigração. O tapete se constitui como um mapa, um retrato da condição desterritorializada em que vivem os trabalhadores imigrantes dentro de um país que se recusa a investir em políticas de integração de comunidades árabes. A ação de Ondák cria inquietação e sublinha os conflitos territoriais, na forma de uma fina conspiração contra o governo austríaco no poder. Nesse estudo de caso, a ação está posicionada em algum ponto do percurso cotidiano de cada um dos transeuntes que perceberam que o tapete era fruto de uma construção simbólica e não do mero acaso.

Um exemplo de utilização do cotidiano como matéria para a criação provém de Didier Bay, que ao invés de percorrer trajetos ou de interferir nos trajetos alheios, observou à distância, e discretamente, tais itinerários e os reverteu em dispositivos para sua composição artística. Entre 1971 e 1972 realizou um projeto autobiográfico que resultou em Mon quartier (vu de ma fenêtre) [Meu bairro (visto de minha janela)]. Após o suicídio de sua mãe, o jovem artista com apenas 20 anos de idade se deu conta de que não sabia nada sobre ela,

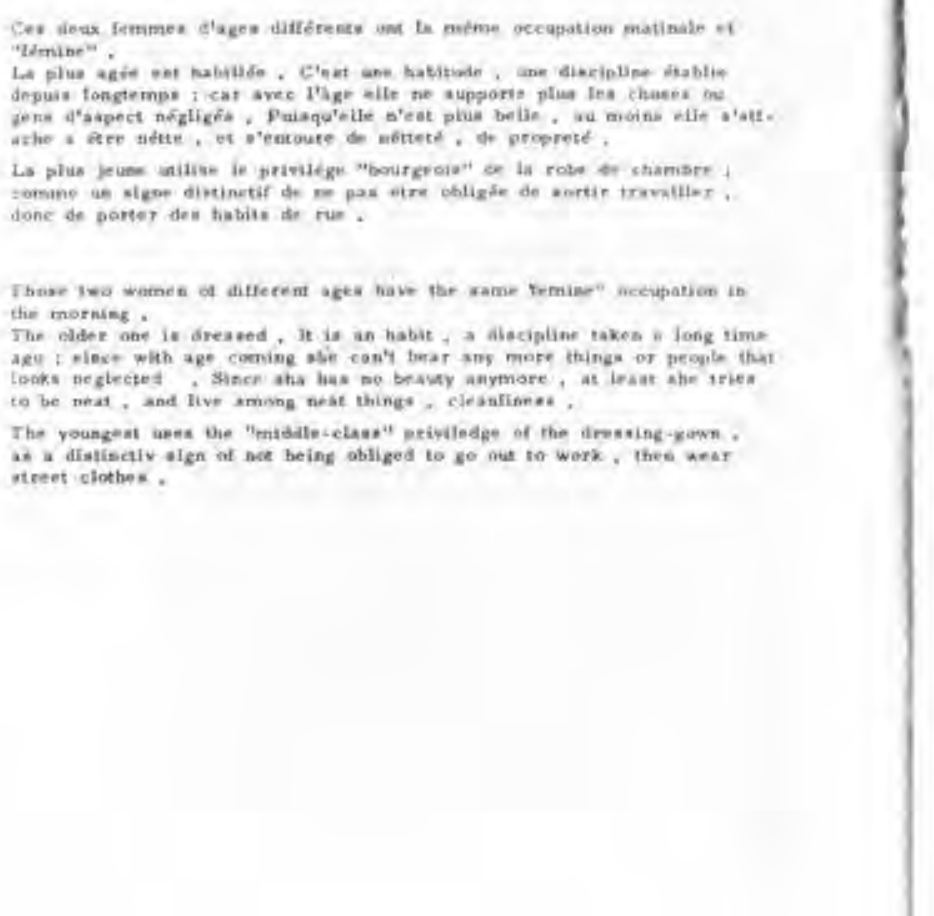

Figura 11: Didier Bay - Mon quartier (vu de ma fenêtre)
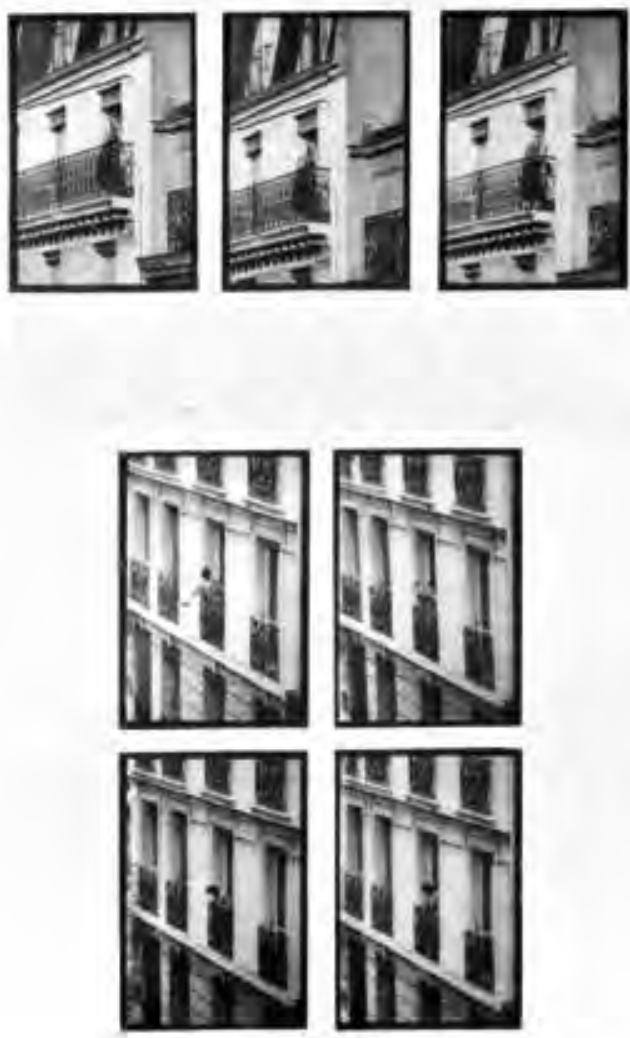

Foto: Disponível em: <http://nonsite. org/article/didier-bays-photographic-sociology-of-post-1968-paris>. Acesso em: 21 jan. 2017. 
à parte o fato de que aquela mulher era sua mãe. Ele então passa a investigar quem ela era e também quem eram outros membros de sua família, vasculhando as gavetas e caixas de sapato em busca de fotografias que não revelavam com profundidade quem eram aquelas pessoas. Diante da enorme dificuldade de ler aquelas imagens e dar um sentido a elas, Bay decidiu partir em busca de si mesmo, investigando quem ele era naquele momento. Ele acreditava que o estudo do seu cotidiano e de seu bairro elucidaria sua própria identidade.

Desse modo, abandona suas memórias e todos os rastros deixados pelas pessoas que se foram, para mergulhar na obscura matéria do presente, que de tão imediata e explícita seria capaz de confundir a visão, como alguém que olha em direção ao sol do meio dia. Para ele, o presente se caracteriza por uma ausência de relevo, um aspecto informal. Sua produção, entretanto, pode ser interpretada como uma fabricação de vestígios para o futuro. Desse modo, ele se posiciona com uma mínima distância de seu cotidiano, para poder fixá-lo em sua escritura artística. A partir da observação da vida corrente através de sua janela, o artista realiza uma coletânea de fotografias e textos que se desdobram em dez álbuns. Esse modo de associar fotografias e textos ficou conhecido na década de 1970 como arte narrativa. Além de fotografar a vida do alto de sua janela, ele também descreve o que vê, não desenvolvendo apenas o registro das coisas, mas colocando-se como sujeito ao revelar sua experiência sensível. Não se trata somente do que ocorre ao acaso sob sua janela, mas do que esse artista escolhe enxergar e enquadrar com sua câmera.

Vale ressaltar que ao mesmo tempo em que o estudo de Didier Bay analisa a vida de sua vizinhança, ele analisa também o poder do estado por meio da observação do quartel da guarda republicana da Place Monge, assim como o local onde supostamente mora um agente secreto da polícia com sua família. A posição estratégica do apartamento de Bay, localizado no Quartier Latin, região onde ocorrem os principais conflitos com os estudantes em Maio de 1968, permite que a obra ganhe um caráter político e contextual. Essa observação aparentemente pessoal do próprio entorno fornece dados cotidianos sobre a reorganização das atividades dos cidadãos e da vida pós Maio de 1968. Assim, o artista não se torna somente um produtor de vestígios sobre a própria história, mas um auto arqueólogo que produz rastros para uma investigação histórica futura.

\section{_performances que descrevem percursos}

Após essa mostra de trabalhos mais conceituais (com exceção de Didier Bay), apresento uma performance concebida recentemente por William Pope L. para 32a. Bienal de Arte de São Paulo (2016), na qual ele não performa com seu corpo. Em $\boldsymbol{O}$ Baile, uma dupla de performers vestidos com trajes que sugerem um baile de debutantes, e com máscaras de 
Foto: Disponível em: <https://turkagram.com/en/in-baile-2016-william-pope-Is-contri-

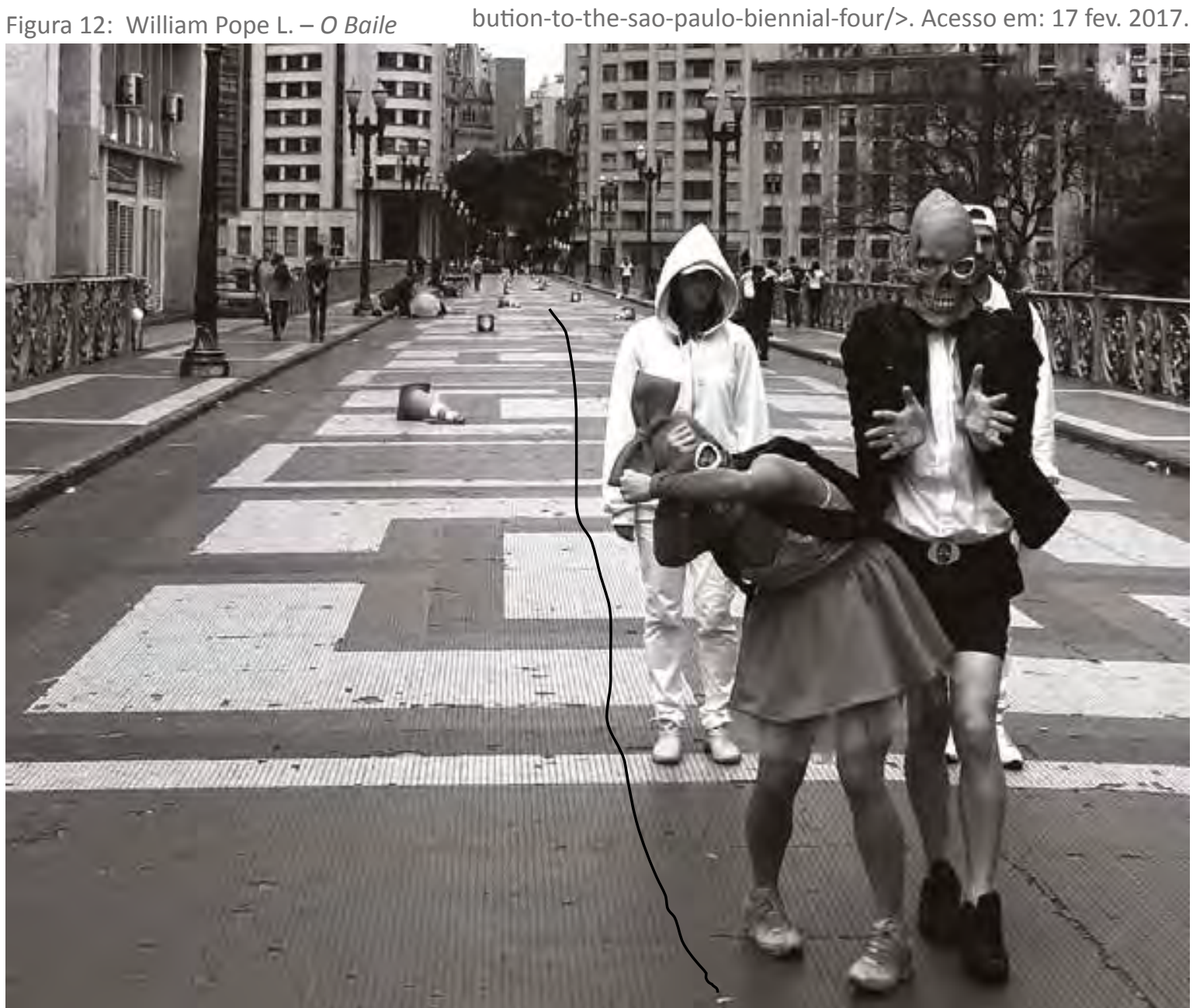

caveira cobrindo seus rostos, realiza um percurso pré-definido que evidencia as diferenças socioeconômicas da cidade. As máscaras de caveira remetem a rituais de morte e Pope entende a política igualmente como um ritual de morte. Essa primeira dupla é seguida por outra dupla - vestida com moletons brancos com inscrições de caveiras - que, por sua vez, dá as coordenadas para a dupla mascarada. $O$ trajeto é dividido em duas partes: do Largo São Bento, subindo a Avenida Brigadeiro Luiz Antônio até a Avenida Paulista e da Avenida Paulista, descendo a Avenida Consolação até o Largo do São Bento. O percurso é realizado ao longo de quatro dias, havendo um revezamento de performers para que a ação aconteça ininterruptamente. Cada dupla, no entanto, permanece em ação durante 8 horas.

Tendo como ponto de partida o conto infantil "João e Maria", Pope pretende refletir sobre a figura paterna e questionar o patriarcado. Nesse conto, os pais querem se livrar dos filhos e, no entanto, as crianças sempre voltam. É uma história de abuso, que repete a mesma estrutura de todas essas histórias: o abusado volta repetidamente ao abusador. $\mathrm{O}$ artista uniu essas referências ao universo das festas de debutante e à agressividade percebida nos recentes protestos ocasionados no país. Tais festas são representativas de uma forte herança patriarcal, momento em que as filhas das classes dominantes são apresentadas para a sociedade com o objetivo de iniciar a busca por um casamento adequado às posses 
do pai da noiva. Mesmo que há tempos a prática do dote não seja mais difundida, as festas de debutante são um resquício dessa troca comercial associada à vida afetiva das filhas. Esse mesmo grupo social que tem poder aquisitivo para realizar essas festas, representa um posicionamento mais elitista em oposição aos grupos sociais menos favorecidos. Não que essas práticas se restrinjam aos grupos sociais mais abastados; elas também aparecem em grupos menos favorecidos, que anseiam por reproduzir determinadas formalidades na esperança de ascender socialmente. A atual conjuntura política brasileira coloca todas essas classificações em desequilíbrio, sendo que os grupos sociais não são determinantes do ponto de vista político adotado, eles indicam apenas uma tendência.

Tal cenário político aparece como pano de fundo para a apresentação da dupla que caminha como se marchasse, realizando vez ou outra movimentos coreografados: andam em câmera lenta como se atravessassem uma multidão, dançam uma valsa como se estivessem bêbados e distribuem falsos panfletos, onde não se pode ler nenhuma mensagem em particular. A movimentação acontece em reação a uma trilha sonora difundida por alto-falantes escondidos na mochila carregada pela figura masculina. Sua duração é de 1 hora, exatamente o tempo da coreografia realizada por Ramiro Murillo, coreógrafo brasileiro que trabalhou diretamente com Pope. Ao longo dos quatro dias de percurso, essa partitura se repete de hora em hora, sendo que a cada hora cheia, uma das performers vestida de moletom branco realiza uma ação. Desse modo, a performance se estrutura em torno de três eixos: o percurso, a coreografia e o tempo, um elemento mais complexo de apreender a não ser se acompanhamos muitas horas do percurso. O extraordinário está justamente na relação dos performers com o tempo, pois eles repetem a mesma estrutura infinitamente e à exaustão.

A trilha é composta de músicas, incluindo uma valsa e um texto redigido pelo próprio Pope L. como se fosse o atual presidente do Brasil, Michel Temer. Esse texto foi gravado por um ator incumbido de imitar o presidente. Provavelmente por falta de referências, sua interpretação do atual presidente aproximou-se mais da expressividade vocal de Paulo Maluf. 0 texto, sem nenhuma mesóclise (traço estilístico associado aos discursos de Temer), contém frases como: "Dizem que eu sou um traidor", "É tudo culpa da Dilma", "Um golpe? Um golpe? O que foi que eu fiz? Azar de vocês, seus bananas!", "O Brasil está em chamas", "Eu não temo, eu não temo" (frase dita repetidas vezes até urrar), "Meu nome é Senhor [Aécio] Neves, Senhor Cunha, Senhora Dilma, Senhor Maluf, Senhora Salada", "Escrevo cartas ao Papai Noel". Se para Pope L. a política é um ritual de morte, a opção por mascarar os performers também simboliza o mascaramento político e a fabricação de mentiras. Apesar do contato restrito que o artista tem com o Brasil, ele observou a política como um assunto velado, quase proibido, uma vez que muitas pessoas foram evasivas quando Pope L. tentou entender a situação política do país. 
Intimidado diante do desafio de escrever sobre essa realidade desconhecida, o artista adotou um tom abstrato para o seu discurso, composto de lampejos de visões políticas, fazendo ecoar opiniões e bordões proferidos por políticos corruptos aqui e ali pelas ruas de São Paulo. Ele não constrói um discurso coerente com começo, meio e fim, apenas repete uma série de jargões e jogos de palavras, como se citasse frases ditas por políticos. Quando o narrador do texto assume uma identidade múltipla, fica clara sua referência ao conto infantil como uma história de abuso. Todos os senhores e senhoras citados são submetidos ao mesmo papel de abusadores, enquanto o povo, constantemente envolvido em mentiras, segue cego repetindo os mesmos erros e perpetuando o mesmo ritual de morte. $\mathrm{O}$ que Pope L. consegue com esse Baile é revelar de maneira atroz a imensa crise de representatividade que o Brasil atravessa, crise esta que não se restringe apenas ao campo da política, ela atinge também o campo da estética.

Em encontro promovido com William Pope $L .^{3}$ na ocasião de sua passagem pelo Brasil, o performer afirmou que percebeu com o tempo que não era mais fundamental ocupar o centro de suas performances, justificando sua opção por criar programas para serem performados por outras pessoas. A ausência do corpo negro de Pope nas performances altera uma condição-chave na concepção de suas performances - um negro rastejando no chão, um Super Homem negro, um negro carregando um vasinho de flores enquanto é filmado por um videografista branco, um negro amarrado a um caixa eletrônico por um cordão de salsichas - explorando assuntos que não se relacionam diretamente com a questão racial ou ampliando essa discussão pela configuração de coletivos. Ao ausentar-se fisicamente, em alguns casos, Pope consegue um efeito multiplicador, convocando outros corpos para integrarem suas ações. Nascido de família muito pobre, cresceu ouvindo que não podia controlar as coisas. Ao longo de sua vida, experimentou muitas ações perigosas, fora da lei, colocando sua vida em risco, até compreender os efeitos de ser "pequeno" (ser um) e "bravo" (revoltar-se). Foi assim que entendeu que precisava do teatro, para colocar as pessoas juntas. Quando se faz algo perigoso sozinho, a pessoa se arrisca e talvez nada aconteça; quando muitas coisas pequenas acontecem juntas, algo está acontecendo. Pope passou a reunir pessoas para realizar ações em conjunto, mesmo que a única coisa a ser feita seja andar junto por quatro dias.

Diana Taylor afirma, ao analisar inúmeras ações artísticas e igualmente políticas, que "não acredita que haja uma resposta meramente política para uma situação política, todos respondemos de alguma maneira social, ainda que seja fechando os olhos para o que nos rodeia" (2012, p. 139)4. Uma das ações analisadas por ela é Quién puede borrar las huellas?

\footnotetext{
3 Encontro realizado pelo Coletivo Teatro Dodecafônico, em conjunto com o evento Conversa (A)fiada do La Plataformance, no dia 10 de setembro de 2016, na Oficina Cultural Oswald Andrade.

${ }^{4}$ No creo que exista una respuesta meramente política a una situación política, todos respondemos de alguna manera social, aunque sea por cerrar los ojos a lo que nos rodea (tradução minha).
} 


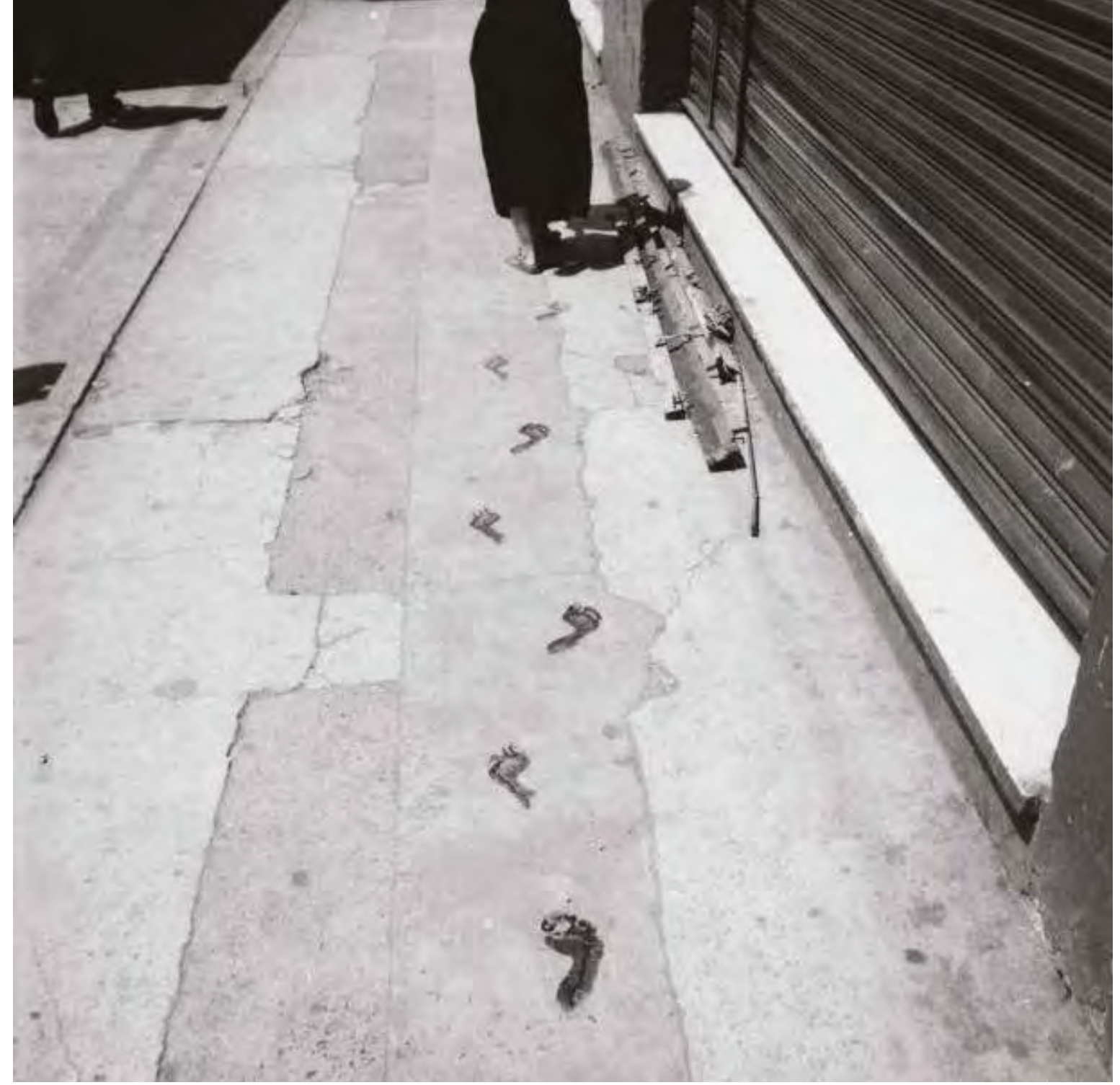

Figura 13: Regina Galindo - Quién puede borrar las huellas?

Foto: Disponível em: <http://www.arte-sur.org/home/ regina-jose-galindo-estoy-viva-i\%E2\%80\%99m-alive-2/>. Acesso em: 28 mar. 2017.

[Quem pode apagar pegadas?], da guatemalteca Regina José Galindo (2003), para quem a raiva é animadora e suas criações são reações à vida vivida, ao que tem visto e ouvido no país de onde vem. Regina Galindo deixa pegadas de sangue humano da Corte Constitucional até o Palácio Nacional na Cidade da Guatemala, para protestar contra a candidatura de Efraín Ríos Montt à presidência. Esse candidato chegou ao poder em 1982 por meio de um golpe militar e seu governo foi responsável pela morte de mais de 200 mil pessoas, em sua grande maioria indígenas. Galindo reconhece que seu trabalho não transforma efetivamente a realidade na qual se encontra, ainda assim a performer continua a fazê-lo. Mesmo que alguns espectadores não saibam como lidar com suas ações, o simples fato de ter evocado determinados temas lhe basta, pois de certo modo ela os convida a refletir sobre eles. Ao performar temas indigestos, a performer torna visível o que o poder público se esforça em esconder, como quem refaz pegadas apagadas pela história oficial. 
O tempo gasto nos transportes, como bem observou Le Corbusier, é um sobretrabalho que reduz a jornada de vida chamada livre.

Guy Debord

Como artista e pesquisadora que investiga o caminhar, comecei a observar os meus trajetos na cidade, sobretudo aqueles realizados a pé e veio daí o interesse de lidar com a ideia de percurso, no sentido funcional do deslocamento, como um dispositivo de criação. O percurso é a modalidade do caminhar mais próxima do real, pois está inserida no cotidiano, de modo que não poderia ser tomada diretamente como uma ação artística. Somente nesse contexto de dissolução da obra de arte e de questionamento de seus estatutos, é que os itinerários cotidianos de alguém poderiam ser vistos como experiências poéticas. Retomo aqui minha cartografia pessoal, reforçando o quanto ela está intimamente vinculada aos meus percursos urbanos.

Desde que adotei São Paulo e aqui me fixei, foi o interesse e o desejo de teatro que fez meu corpo se deslocar e mais tarde se misturar a esta cidade. Na declaração de amor de Itamar Assumpção à cidade de São Paulo, seu mais perfeito poeta maldito - negro, suburbano, de timbre inclassificável, diz: "Eis aqui, São Paulo, metrópole intensa, minha cabeça e meu coração". E nessa metrópole intensa, lugar árido, de ar alérgico e encontros passageiros, aconteceu do asfalto parecer fértil para fixar residência, plantar sementes, adubar com os anos, tecer convivios, ter filhos, descobrir permanências.

Comecei a redação dessa cartografia em abril de 2014, mais de quinze anos depois de ter chegado aqui. Preparava uma performance para um lugar onde nunca tinha estado: Santana é um pouco depois da estação que limitava uma das extremidades de minha cartografia pessoal. A chegada a São Paulo pela Rodoviária Tietê marcou meus primeiros anos na cidade. Pelo mapa do metrô, meu corpo reconhece a sensação desse percurso, geralmente feito de pé, equilibrando-se entre malas e mochilas, sob o efeito de 12 horas de viagem. Cansaço, sono, transportando peso acima das capacidades do meu porte físico, ruído, velocidade $e$ pluralidades de existências - eram as sensações recorrentes ao entrar na cidade.

Curioso que eu me lembre menos das partidas, como se deixar São Paulo fosse um movimento natural, de volta pra casa. Estava sempre correndo, atrasada, com medo de perder o ônibus. Com o passar do tempo, minhas voltas pra capital passaram a me oferecer uma estranha sensação de familiaridade. como se eu tivesse não só me acostumado, mas também desaprendido a viver sem tudo aquilo: o trânsito, a confusão, o excesso de ofertas, a polvição, a possibilidade de anonimato. No sentido inverso da linha azul, depois do Paraíso, em direção ao Tucuruvi, é possivel sentar-se, assim que boa parte das pessoas salta na Sé. Da Armênia em diante, consigo avistar a cidade, o metropolitano tem vias elevadas.

Em 2014, comecei a produzir pequenas narrativas ao longo das minhas trajetórias pela cidade, sobretudo quando me deslocava ao encontro do Coletivo Teatro Dodecafônico. Tais 
narrativas consistem em relatos produzidos durante o tempo que permaneço dentro do transporte público, uma espécie de escrita automática, na qual tento dar vazão ao meu fluxo de pensamentos, concretizando em palavras minhas sensações urbanas. São narrativas curtas, escritas a lápis, fragmentadas, com aspecto poético, sintetizadas pela marca do tempo e constantemente observadas pelos passageiros que, por acaso, sentam-se ao meu lado. Elas se restringem, entretanto, às viagens que consigo realizar sentada.

doze de fevereiro de 2014

(para ser lido em voz alta)

Uma puta passa batom

rosa pink

um garoto ruivo

vestindo camiseta

vermelho salsicha

toma fanta laranja

a máquina que vende tickets

me confunde e meu

joelho range um pouco

ventos surpreendentes dos

subterrâneos

Sensação estranha de estar sendo

lida enquanto escrevo.

Efeitos de uma escrita entre

Butantã-República.

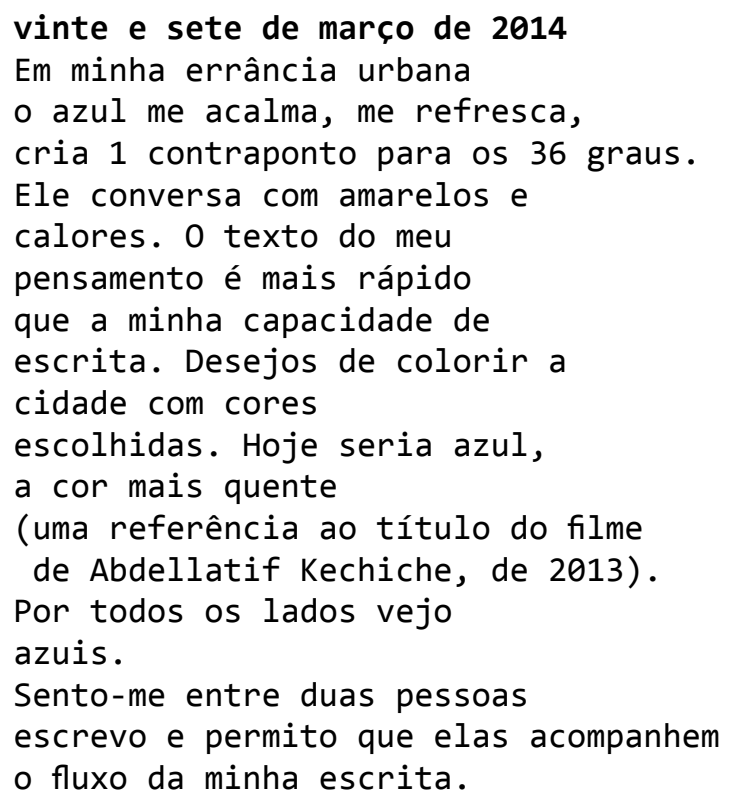

Considerei a prévia da deriva um procedimento complementar, um desdobramento da deriva, uma ação similar à escrita automática em espaço público, mas que nesse caso é feita antes - e não durante ou depois - de andar sem rumo pela cidade. O trecho acima corresponde a uma dessas escritas. Em outra ocasião, nesse mesmo estado prévio ao meu encontro com a rua, notei que o sentido de todas aquelas deambulações pela cidade de São Paulo podia se resumir à seguinte sentença: "atos íntimos contra o embrutecimento". E esse se tornou o título de uma intervenção que o Coletivo Teatro Dodecafônico realizou sob diversos formatos, reunindo diferentes performers e procedimentos, articulados sempre na forma de um percurso ${ }^{5}$.

A intervenção foi organizada como um agrupamento de procedimentos que experimentamos inicialmente em uma residência artística realizada na SP Escola de Teatro. Assumindo um formato de grupo de estudos, o Coletivo propôs a investigação de intervenções e performances urbanas, a partir de programas definidos a cada dia, coletivamente. Nessa ocasião, de março a junho de 2014, outros artistas se aproximaram do Dodecafônico e

\footnotetext{
Atos íntimos contra o embrutecimento foi realizada em 2014 na Virada Cultural, no SESC Santana (maio), no centro da cidade de São Paulo (junho), no projeto Poéticas Urbanas, do SESC Bauru (setembro) e na cidade de La Plata, na Argentina, como convidada do Festival DanzaFuera (novembro). Em 2015, ela integrou novamente a Virada Cultural, sendo apresentada também no centro de São Paulo. Em maio de 2016, fizemos Atos íntimos contra o embrutecimento no SESC Interlagos.
} 


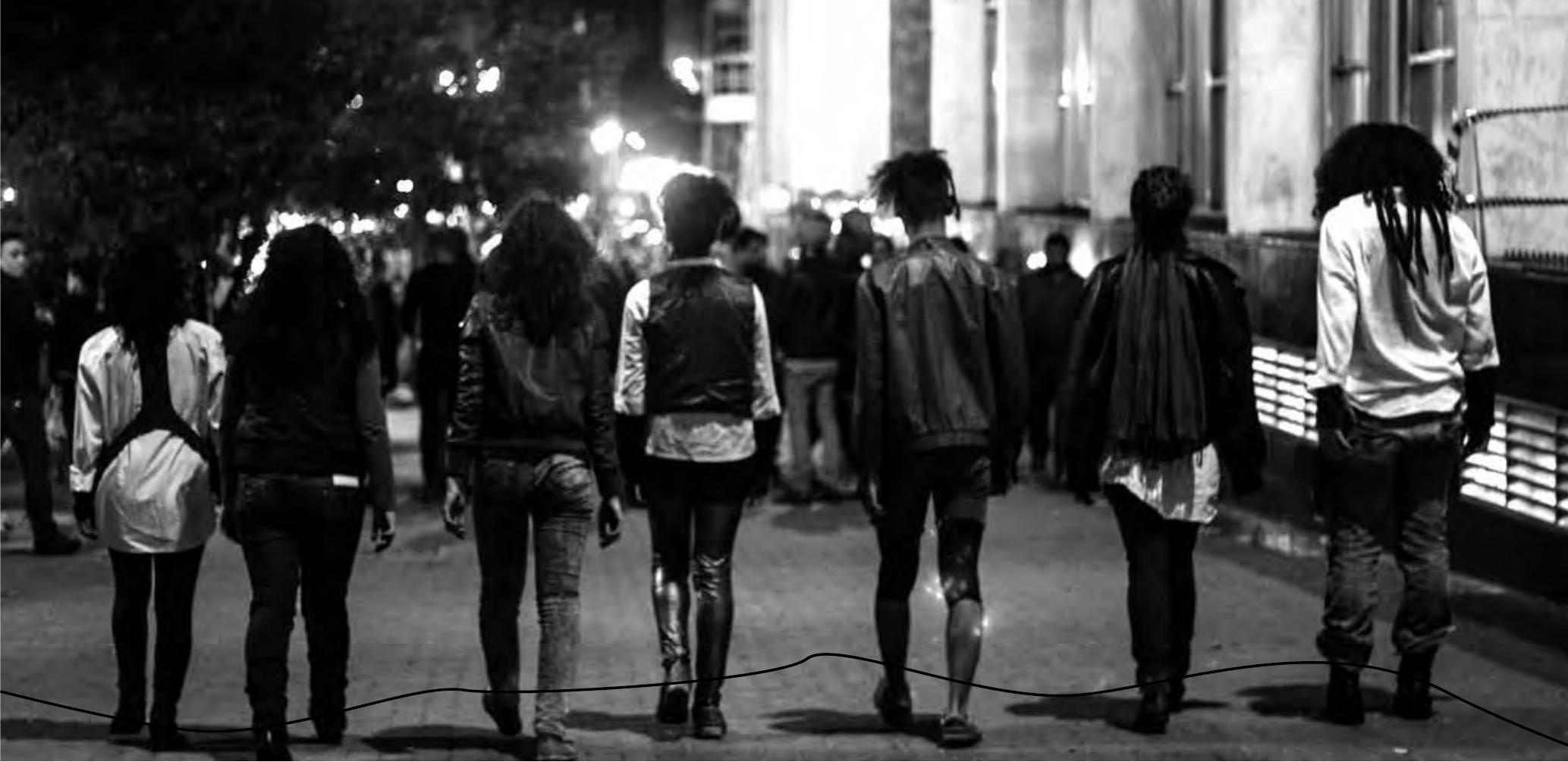

Figura 14: Coletivo Teatro Dodecafônico - Atos íntimos Contra o embrutecimento

Foto: Papá Fraga

passaram, aos poucos, a integrar o Coletivo. Para compor Atos íntimos contra o embrutecimento posicionávamos algumas ações em sequência, definindo os pontos de início e final, de modo que tanto espectadores convidados quanto passantes pudessem presenciar e eventualmente integrar cada uma das ações. Dentre outras propostas, realizávamos a balada silenciosa (percurso no qual cada integrante ouve sua playlist de preferência, enquanto dança tendo como ponto de partida as mesmas articulações), a linha em câmera lenta (o grupo posicionado em linha desloca-se o mais lentamente possível), caminhada seguida de desmaios $^{6}$. A intervenção já foi realizada por três, por cinco e por sete performers ${ }^{7}$.

Em 2015, morando em Antony, ao sul de Paris, deslocava-me diariamente de trem, bicicleta pública e cada vez mais realizava trajetos a pé. Na medida em que meus percursos se tornaram repetitivos, passei a percorrê-los a pé, a fotografar e escrever sobre eles, sobretudo quando voltava para casa. Tratou-se inicialmente de uma prática psicogeográfica, uma busca por perceber e registrar as ambiências dessas regiões, ora percorridas sozinha, ora acompanhada de um ou outro amigo. Esses percursos não se configuram como ações artísticas, mas como explorações poéticas do cotidiano.

Tendo em vista a prática da psicogeografia, é interessante compartilhar os relatos sobre os percursos realizados após os atentados de 13 de novembro de 2015. Há uma diferença

6 Cada integrante do grupo caminha para frente, saindo de uma formatação comum em linha reta, e para em um ponto diferente, alguns metros depois. Aquele que para mais longe 'desmaia', ao que todos respondem 'desmaiando' também. O jogador que para mais perto de onde estava a linha, levanta-se do chão e corre, passando por todos os jogadores e sugerindo onde uma nova linha deverá ser formada. Todos se levantam, à medida em que esse jogador passa correndo e o acompanham para formar novamente a linha. 0 jogo recomeça da nova linha formada e assim o grupo se desloca sequencialmente.

7 O Coletivo Teatro Dodecafônico foi contemplado pelo Prêmio FUNARTE Artes de Rua e circulou por cinco bairros de São Paulo em 2015, enquanto eu me encontrava na França: Vila Anglo, Centro, Jardim Damasceno, Bixiga e região da Avenida Paulista, realizando uma deriva aberta com os moradores das redondezas e a intervenção Atos íntimos contra o embrutecimento em cada um desses locais. 


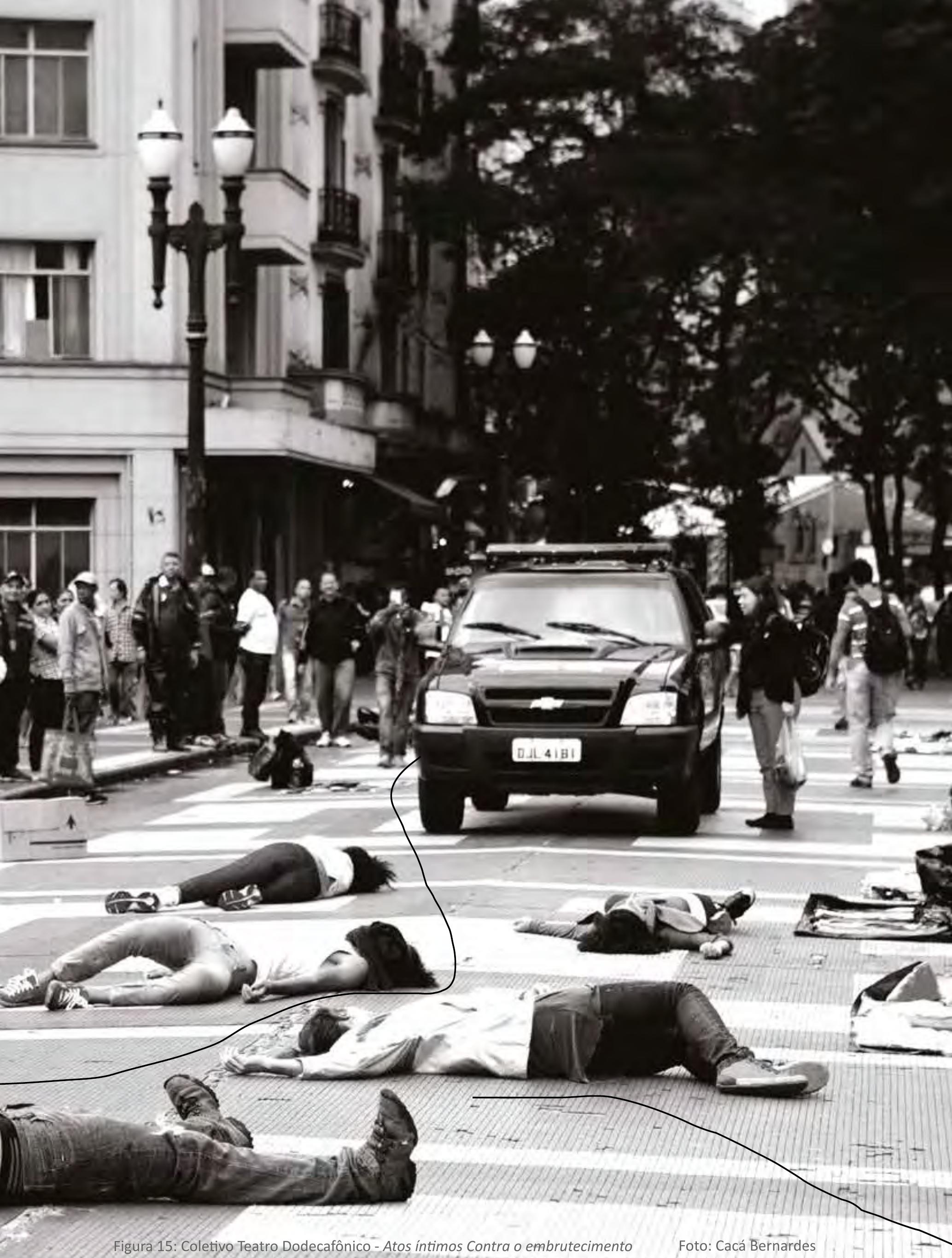


Percuso Tolbiac (para Regis Mikail Abud Filho): A partir da BNF caminhamos, tomando a Rua Tolbiac. Comemos em um asiático, falamos, fumamos. Algumas vezes, pegamos uma bicicleta pública. Aquele que conduz, escolhe o ritmo; aquele que segue, escolhe também seu tempo. Chegamos ao Parque Montsouris e damos uma volta, andamos com os pés descalços sobre a grama. Escutamos outras línguas e de longe um grupo fala português. Não é um grupo e sim um casal. Escuto "supermercado". Vozes em português atravessam minha narrativa. Chegamos à estação e nos separamos, cada um toma o seu caminho. Ainda guardo seu retrato do outro lado da linha. Ele se vai e eu continuo esperando o trem. Escrevo enquanto espero. Há outras pessoas ao meu redor, eles percebem que eu escrevo, mas eles não olham. Sou eu que os observo. 0 trem chega.

sensível entre o texto "Percurso Tolbiac", sobre os caminhos de volta da biblioteca, acompanhada de um amigo e os que se seguem. Nessa ocasião, houve uma mudança brusca nas ambiências percebidas na cidade e os itinerários cotidianos se tornaram percursos em estado de urgência. Apresento a seguir uma narrativa inspirada em minhas escritas automáticas e, depois, uma escrita automática realizada em casa, num momento em que recomendação era sair de casa somente em casos de extrema necessidade. Essa subversão dos procedimentos denota o momento de suspensão vivido nos meus dois últimos meses na França.

Só voltei à Paris no dia 17 de novembro. No metrô a manchete do jornal ao lado: le 'nouve$a u^{\prime}$ vivre ensemble [o novo viver junto], uma página do Le Monde. Quatro dias depois dos atentados, atravesso a cidade em direção ao Norte de Paris, para participar de um colóquio realizado em Saint Denis. Os trens estavam relativamente vazios. Em Denfert Rochereau encontro homens do exército. Eles andam tranquilamente portando metralhadoras, nada parecido com as imagens divulgadas na televisão brasileira. $\mathrm{O}$ ar parece mais pesado, há um estado de tensão, anterior ao estado da guerra. Nesse contexto, o inimigo é impreciso, quase invisível; mas a sensação era de que ele estava presente, escondido em qualquer corpo, tendo qualquer aspecto.

Mesmo indo a um colóquio, resolvo assumir minha prática de escrita: a prévia da deriva. Olho ao meu redor no vagão do metrô e constato: tratam-se de pessoas e não de homens-bomba. Então, onde esses homens se encontram? Impossível rastreá-los, talvez até para o exército. Procuro entender o espaço que eles ocupam em nossos imaginários. Os monstros fabricados por cada indivíduo tornam-se pouco a pouco uma versão terrorista e suicida de um homem-bomba. Uma prova de que a batalha que se trava contemporaneamente é uma batalha pelos imaginários. Eu me pergunto: como são ocupados os espaços livres do pensamento de quem se dispõe a um ato de tamanha atrocidade? Quem é capaz de explodir-se? Como combater alguém que não tem amor à própria vida? Como se produz o imaginário do garoto sentado na minha frente? Enquanto ele chama "mamãe, mamãe" a cada parada do trem, pergunto-me ainda: que homem ele se tornará? 


\section{HOJE UMA MULHER SE FEZ EXPLODIR}

Na manhã do dia seguinte, abro o noticiário pela internet e vejo: uma mulher se faz explodir em Saint-Denis. Ela ativou seu colete explosivo. Ouço sirenes como nunca antes em Paris. 0 sol que brilhava na França acaba de ser encoberto. Depois de visitar/estar em Saint-Denis ontem, onde falávamos que não podíamos nos calar diante do terrorismo, hoje, o terrorismo nos calou. Colóquio cancelado! Na noite de sexta-feira, um gato preto pulou do segundo andar do apartamento onde estávamos e minha amiga gritou. Susto. Hoje, as bexigas que estavam no armário - remanescentes de festa de criança, explodiram. Abro a janela. Recupero o ar do meu corpo enrubescido, enrijecido. As bexigas caem lentamente no chão, pousam, leves, reagindo aos explosivos e aos tiroteios que chegam em nossa casa, por intermédio da transmissão ao vivo da internet. As bexigas, somos nós?

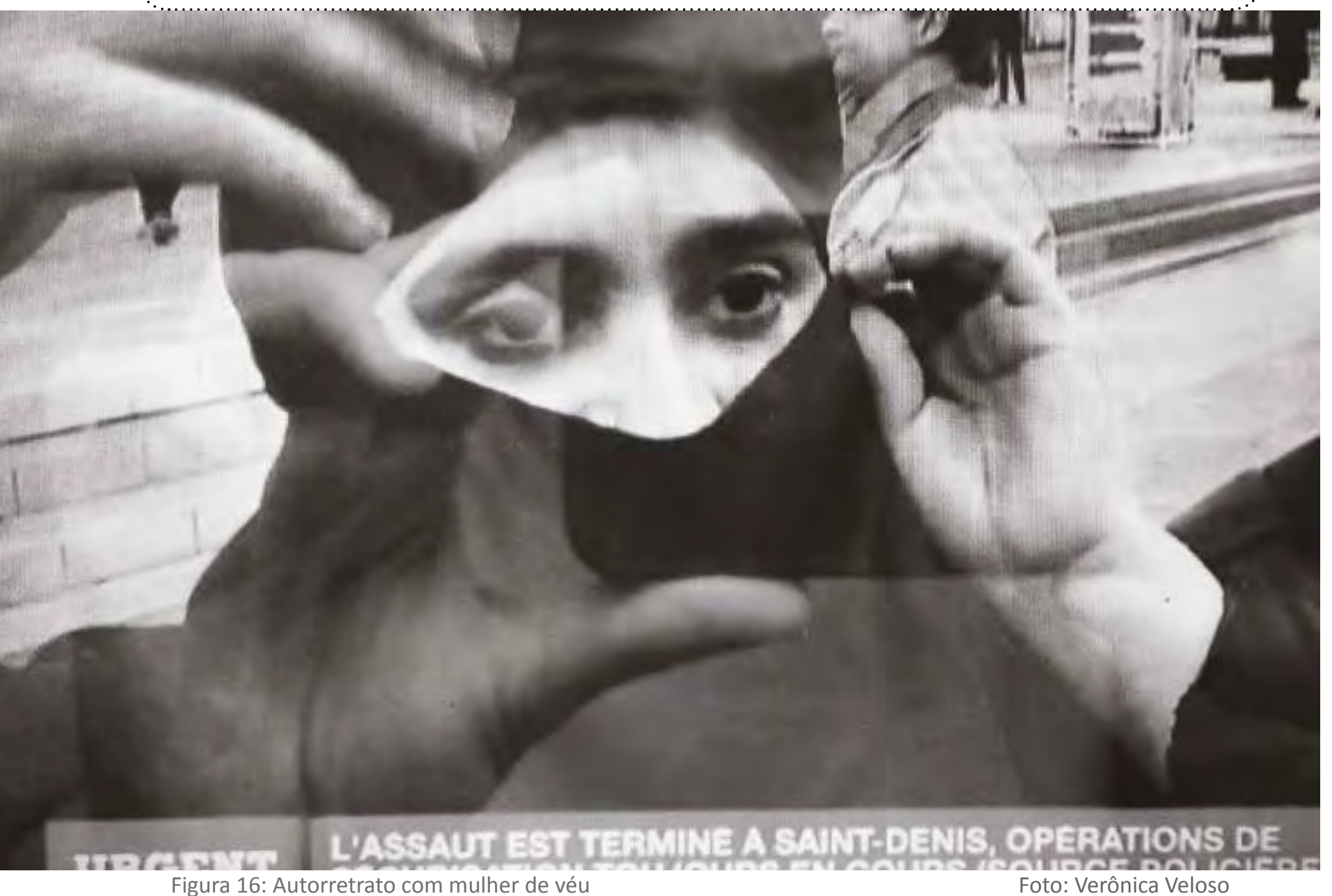

Era assustador pensar que uma mulher se fez explodir. Aparentemente era a primeira muIher-bomba de que se tinha notícia. Há casos de homens que se disfarçam de mulheres para portar explosivos sob vestimentas mais volumosas. Especulou-se que tal revelação poderia resultar na interdição do uso do véu na França. Mais tarde, chegou-se à conclusão de que não havia sido a mulher a explodir-se, mas o homem que estava com ela. Independente disso, as mulheres entraram no campo de batalha, conquistaram o lugar de suspeitas. Todos são suspeitos. O guarda da Universidade estava agora acompanhado de mais dois, olhou nos meus olhos e pediu que eu abrisse o meu casaco para verificar se não escondia nada embaixo da roupa. Ele me conhecia. As ruas estão fechadas. Há um cerceamento das 
liberdades. Uma ressalva no circular. Os fluxos são pesados, densos, carregados de desconfiança.

Há menos gente na rua e a tensão atmosférica propõe uma outra organização do sistema. O que se espera é o tic tac de uma bomba. Uma mala, uma mochila pesada, um pacote suspeito. O trem para, as estações são cotidianamente esvaziadas e os espaços isolados. Uma burca, um véu, uma mulher também podem ser uma bomba. Tento preparar meu corpo, alongo a coluna. Estou rígida. Penso na zona contaminada de Caio Fernando Abreu. Preparo o meu corpo para a caminhada. A rua está interditada. O que significa isso? A proibição de circular paralisa. A cidade continua em funcionamento, mas todos os gestos, todos os deslocamentos são pensados, são minuciosamente refletidos. Os itinerários se tornam pesados.

II. audiotour: quando passear acontece com fones de ouvido ou quando o artista programa o percurso sonoro

É verdade que mal conceberíamos que, lendo no seu quarto, você se ponha a dançar, e, no entanto, a dança é o resultado normal da audição poética.

Paul Zumthor

Às vezes, é como se o mundo inteiro fosse uma cena para a qual eu comprei um ingresso. Garry Winogrand, fotógrafo

Um audiotour é um percurso sonoro que pode ser analisado segundo dois pontos de vista distintos. Do ponto de vista do espectador, trata-se de um passeio, pois quem experimenta um audiotour se relaciona com o espaço a partir de um estímulo sonoro e, geralmente, desconhece o caminho a ser percorrido. Um audiotour embala os ouvintes ao longo de um trajeto como quem convida alguém para um passeio ou o conduz numa exploração aleatória de um recorte da cidade. Do ponto de vista do artista, portanto, trata-se de um percurso sonoro, cabendo a ele a definição do caminho e a proposição de um tipo de contemplação da cidade. Os exemplos de audiotour são variados, pois eles se configuram a partir da junção de um percurso - a visão e exploração de um espaço em movimento - com uma composição sonora, que articula sons, ruídos, textos e silêncios. Ao compor um audiotour, do mesmo modo como ocorre no cinema, o artista cria a faixa de som separadamente daquilo que seria a faixa de imagem.

A caminhada era um exercício de confiança entre a artista e os participantes, que nunca souberam para onde estavam sendo conduzidos, ou mesmo porque, e engendrou uma atitude ativa e engajada no público e em sua relação com a arte. Eu também me lembro como eu sorria ao longo de todo o caminho, porque a 
narrativa me deu um grande prazer (Bruce Ferguson) ${ }^{8}$.

A faixa de imagem será definida por cada espectador de maneira particular, tendo como referência comum o percurso definido pelo artista. Enquanto isso, a faixa de som, que corre paralelamente à experiência de atravessamento de um território, não pode ser considerada simplesmente como um acompanhamento; ela é similar à faixa ou trilha sonora de um filme. Em um audiotour, a faixa sonora visa ocupar o espaço de escuta do espectador, compreendendo além de textos, músicas, ruídos e sons ambientes. Em alguns casos, o artista deixa brechas - pela escolha do tipo de fone de ouvido, por exemplo - para que o espectador continue ouvindo o som do ambiente aonde se encontra. Mas na maioria dos casos, a faixa sonora se constitui como um espaço imersivo, descolado do espaço do real. Mesmo quando há o registro prévio dos sons ambientes e o aproveitamento desses sons na composição da faixa de áudio, o artista cria um ambiente sonoro diferente do que se ouve no espaço real.

Ao se referir à criação sonora da dupla Célia Houdart e Sébastien Roux - Car j'étais avec eux tout le temps [Uma vez que eu estava com eles todo o tempo], de 2010 - Anne Gonon ressalta o cruzamento entre a atenção destinada às paisagens, uma abordagem contextual e a arte radiofônica. Criando algo entre o real e o ficcional, a dupla se refere à própria produção como uma land art sonora, que neste caso acontece entre as cidades de Avignon e Villeneuve-lez-Avignon. A definição do percurso, que envolve a escolha de pontos de parada para observação da paisagem, traduz um tipo de escritura que se aproxima da ideia de montagem. Por esse motivo, Célia Houdart, em entrevista à Anne Gonon, destaca a influência do cinema nessa modalidade artística, que assim como a linguagem do rádio, interfere no modo de criação daquilo que nomeio aqui, de modo genérico, de audiotour ou percursos sonoros. Em alguns momentos, eu me refiro a essas ações também como peças.

Nós fizemos longas marcações, conta ela sobre o percurso escrito para Villeneuve-lez-Avignon. Era como se fizéssemos a faixa sonora de um filme, cuja imagem não seria jamais filmada, mas confiada ao espectador. O desafio é inscrever-se em uma realidade sem modificá-la, mas tentando perturbá-la, fazendo-a estremecer, às vezes, distorcendo-a (GONON, 2016, p.102) ${ }^{9}$.

\footnotetext{
8 The walk was an exercise of trust between the artist and the participants, who never knew where they were being led, or really even why, and it engendered an active and engaged attitude in the audience and their relationship to art. I also remember how I was smiling all along the way, because the narrative gave me such great pleasure (tradução minha). Comentário de Bruce Ferguson, curador da exposição Walking and Thinking and Walking [Caminhando e Pensando e Caminhando], a respeito de Lousiana Walk (de 1996), uma criação de Janet Cardiff para o Museu Lousiana, na Dinamarca. Texto disponível em: <http://www. cardiffmiller.com/artworks/walks/louisiana.html>. Acesso em: 29 dez. 2016.

${ }_{9}$ Nous avons fait des longs repérages, raconte-elle à propos du parcours écrit pour Villeneuve-lez-Avignon. C'était comme si nous faisions la bande-son d'un film dont l'image ne serait jamais tournée, mais confiée au spectateur. L'enjeu est de s'inscrire dans une réalité sans la modifier, mais d'essayer de la troubler, la faire trembler, parfois la distordre (tradução minha).
} 
Ao definir o trajeto é como se o artista escolhesse apenas a locação, da qual o espectador recorta seus próprios enquadramentos. Dependendo do teor da composição sonora veiculada pelo audiotour, o espectador poderá aproximar-se ou distanciar-se do espaço onde ele se encontra. Em alguns casos, a experiência convida o espectador a olhar o seu entorno de outro modo, ressignificando os espaços por onde passa, sendo esse território conhecido ou não. Em outros casos, a faixa sonora posicionada "dentro" das orelhas do espectador, substitui a suposta voz do pensamento do sujeito e pode convidá-lo, de maneira bastante diretiva, a imaginar situações ficcionais que não se referem ao que de fato acontece ao seu redor. Embora não seja possível definir características homogêneas que englobem todas as experiências decorrentes de audiotours, é possível afirmar que elas sempre remetem à experiência cinematográfica. Porém, nesses casos, o espectador penetra o espaço da locação com seu próprio corpo, vive as situações e é conduzido pela faixa de som organizada pelo artista.

\begin{abstract}
Enquanto o visual se apreende à distância, o sonoro se difunde de maneira ambiental e imersiva. Essa impressão de estar "no centro dos ruídos", que Michel Chion associa ao caráter "egocêntrico e centrípeto" de nossa relação com a audição, é reforçada pelo uso do fone de ouvido que espacializa o som no nível da cabeça. Nesse sentido, o projetista (ou designer) sonoro Thierry Balasse evoca uma propriedade "intracraniana" da escuta no fone de ouvido, lembrando que os fones estereofônicos colados ao pavilhão de cada orelha não permitem dissociar a fonte sonora do crânio. O ouvinte tem assim a ilusão de que a faixa sonora provém do interior da sua cabeça, um fenômeno de escuta interna e íntima que engendra um fechamento sobre si mesmo (KAPELUSZ, 2013, p. 126) ${ }^{10}$.
\end{abstract}

Anne Gonon, pesquisadora citada acima que acaba de lançar um livro sobre a criação musical e sonora no espaço público ${ }^{11}$, afirma que essa voz que fala ao ouvido do espectador gera uma forte impressão de presença, ainda que ela seja imaterial. Vale destacar que o dispositivo fone de ouvido pode ser considerado um signo da vida urbana contemporânea, sendo que muitos habitantes da cidade realizam seus percursos cotidianos ocupando suas percepções com trilhas sonoras que não coincidem com os sons ambientes das ruas. Isso gera um tipo específico de experiência urbana, de dissociação do contexto no qual o sujeito se encontra. Gera também uma presença corporal diferente, pois na medida em que o corpo está presente fisicamente, mas não ouve o som do ambiente no qual se encontra, ele apreende apenas parcialmente o seu entorno. Voltaremos a essa discussão mais adiante.

\footnotetext{
${ }_{10}$ Tandis que le visuel s'appréhende à distance, le sonore se diffuse de manière environnementale et immersive. Cette impression d'être " au centre des bruits", que Michel Chion associe au caractère "égocentrique et centripète " de notre rapport à l'audition, est renforcé par l'usage du casque qui spatialise le son au niveau de la tête. À ce propos, le concepteur sonore Thierry Balasse évoque une propriété "intra crânienne » de l'écoute au casque, rappelant que les écouteurs stéréophoniques collés au pavillon de chaque oreille ne permettent pas de dissocier la source sonore du crâne. L'auditeur a ainsi l'illusion que la bande-son provient de l'intérieur de sa tête, un phénomène d'écoute interne et intime qui engendre un recentrement sur soi (tradução minha).

11 Tout ouïe: La création musicale et sonore en espace public. Lavérune: Éditions l'Entretemps, 2016.
} 


\section{Janet Cardiff e o efeito de presença}

No início da presente pesquisa, explorei o conceito de presença a partir da noção de efeito de presença discutida no texto De la présence aux effets de présence. Écarts et enjeux [Da presença aos efeitos de presença. Variações e desafios], de Josette Féral e Edwige Perrot (2012, p. 11-40), pela criação de um audiotour (ou audiopaper) apresentado em uma disciplina da pós-graduação ${ }^{12}$. Usarei essa experiência como fio condutor para apresentar a noção de efeito de presença e introduzir algumas referências à pioneira dessa modalidade de criação: Janet Cardiff. Nesse audiotour, propus um percurso que levava meus colegas e professora do palco do Teatro Laboratório, passando pelos fundos do teatro (onde os cenários das produções universitárias são produzidos), pelo pátio e algumas salas do Departamento de Artes Cênicas. Tomei minhas memórias desse espaço como referência para reconstruir os efeitos de presença propostos por Janet Cardiff ${ }^{13}$ nos exemplos analisados pelas autoras do texto de referência. Tratava-se de um percurso ativo, combinando reconhecimento do espaço, reflexão e memória.

Nesse texto, as autoras apresentam os diferentes sentidos da noção de efeito de presença a partir da análise de duas criações de Janet Cardiff: Motet pour quarente voix [Moteto para quarenta vozes] e The Paradise Institute [Instituto Paraíso], ambas de 2001. Para tanto, Féral e Perrot lançam mão de estudos sobre a fenomenologia e os diferentes modos de presença: à distância, virtual e digital. Partem do conceito de presença que, de acordo com elas, pode ser entendido, inicialmente, como presença física. Por isso, a voz gravada no audiopaper ${ }^{14}$ convida os participantes a observar quem está presente na aula naquele dia, a verificar se há pessoas ausentes ou pessoas desconhecidas para o grupo. Assim, constata-se que a presença também se define em relação à ausência. Esses corpos podem não estar ali e o reconhecimento dessa possibilidade de ausência é a primeira constatação de uma presença - um conceito vasto, de natureza existencial.

Para destacar as diferentes modalidades de presença expostas pelas autoras, o áudio con-

${ }^{12} \mathrm{O}$ audiotour foi apresentado na forma de paper performativo sobre o referido texto para a disciplina "Performance : Teoria e Prática", ministrada pela Profa. Dra. Beth Lopes, no dia 31 de outubro de 2013.

${ }^{13}$ Janet Cardiff é uma artista canadense, conhecida pela série de percursos sonoros desenvolvidos entre 1991 e 2010, aos quais acrescentou pouco a pouco elementos visuais, como fotografias e filmes. Algumas de suas criações foram desenvolvidas em parceria com George Bures Miller, sobretudo as instalações ou caminhadas que se utilizam de vídeos, como nos casos mais recentes nos quais, além de dispositivos de áudio, câmeras ou ipod touchs são associados aos fones de ouvido. Duas obras da dupla podem ser apreciadas no Instituto Inhotim, na cidade de Brumadinho - MG. Tratam-se de duas instalações sonoras: "Forty Part Motet" (2001) e "The murder of Crows" (2008), esta última ocupa integralmente o galpão Cardiff \& Miller, dedicado à dupla.

${ }^{14}$ Convidei Sandra Ximenez para gravar a voz do paper produzido por mim. Mais tarde percebi, com a ajuda de Sandra e pelos retornos recebidos na disciplina, que faria mais sentido se eu mesma tivesse gravado o texto com minha própria voz, pois tratava-se de um estudo que envolvia as minhas memórias daquele espaço. Contei também com a colaboração de Felipe Julian que mixou o áudio com sonoridades e músicas. Ambos são parceiros artísticos do Coletivo Teatro Dodecafônico. 
vida os participantes a pensar no primeiro assunto que lhes ocorresse. Desse modo, percebemos que o ser humano tem a capacidade de estar presente apenas fisicamente e ausente mentalmente. Em seguida, a voz propõe procedimentos para ativar a percepção do corpo, sua relação com o chão e com seus apoios, visando a reconexão dos participantes com aquele espaço-tempo. Tomando a ação The Paradise Institute de Janet Cardiff como referência, os participantes são convidados a ocupar a boca de cena, de modo que todos avistassem a plateia. As cadeiras estão vazias, ninguém observa esse palco. Todos se viram de costas para a plateia e fecham os olhos. Nesse instante, os participantes ouvem ruídos de pessoas entrando e se acomodando, como se esperassem o início de uma peça.

Em Paradise Institute, uma complexa instalação que ganhou a 49a. edição do Festival de Veneza (figura 17), Cardiff cria a miniatura de uma caixa cênica cinematográfica - composta por uma tela ao fundo e alguns assentos - dentro de uma estrutura completamente hermética, na qual os espectadores entram usando fones de ouvido. Embora constatem que a plateia está vazia, os espectadores escutam simultaneamente os diálogos da ficção apresentada na tela e os comentários de pessoas também fictícias, do qual se escutam os cochichos e os ruídos ambientes. Tratam-se de ruídos parasita, como o som de um bombom sendo descascado, pessoas se ajeitando nas cadeiras e fazendo comentários entre dentes. Ao transpor tal situação para o palco do Teatro Laboratório, onde a turma se encontra, busquei criar uma impressão de presença, pois todos sabem que tais ruídos são enganosos, pois sua fonte não corresponde a pessoas efetivamente presentes no local, mas ao registro sonoro de uma situação similar. Mesmo sabendo que não havia ninguém nas cadeiras, temos a impressão de que alguém entra, senta e ocupa a plateia. Ao criar essa impressão de que há alguém vivo, real, sentado ali, instaura-se um jogo de ilusão, um modo de enganar os sentidos dos participantes. Há uma dissociação entre o olhar e o ouvir, entre a visão e a escuta. É nessa dissociação que se baseia o efeito de presença, noção estreitamente ligada à ideia de presença.

Conforme as autoras, efeitos de presença são estruturados a partir de instalações inteiramente técnicas, das quais o humano está quase sempre ausente. Seguindo esse pressuposto, em um dos pontos desse audiotour posicionei uma televisão dentro do banheiro feminino do Departamento de Artes Cênicas, mostrando cenas de A Mulher que Matou os Peixes, uma peça encenada por mim nesse banheiro há quase 20 anos. Antes dos participantes entrarem, a voz gravada os alerta de que verão pelo ouvido, fazendo uma alusão à afirmação de Cardiff segundo a qual não escutamos apenas pelo ouvido, mas com a totalidade do corpo. Ela afirma com suas práticas que o ouvir pode ativar um mundo invisível que se torna mais real que o real. Ao instalar a TV dentro de uma das cabines do banheiro, com os sons da peça realizada há tanto tempo, propus a reconstituição de uma presença sonora. De maneira rudimentar, escondendo a fonte sonora, criei a ilusão da presença de três atrizes. 
De certo modo, esse audiotour mostrou como os espaços contém muitos tempos sobrepostos e a memória é um modo de ativar tempos diferentes do presente. Para Janet Cardiff, um espaço nunca está estático, enquanto uma imagem (uma pintura, uma fotografia, um desenho) é totalmente estática. Artista plástica de formação, quando começou a usar o som como meio para sua criação, Cardiff percebeu seu caráter contínuo, que toca diretamente na memória, pois não podemos nos desligar de algo que acabamos de ouvir. Do mesmo modo, o som nos toca fisicamente e nos afeta diferentemente da visão ${ }^{15}$. Não há pálpebras para impedir que se ouça determinado som. Por esse motivo, quando ouvimos o som é como se mergulhássemos num outro ambiente, do qual não conseguimos facilmente emergir. A escuta está igualmente relacionada com o pensamento, por isso, essa modalida-

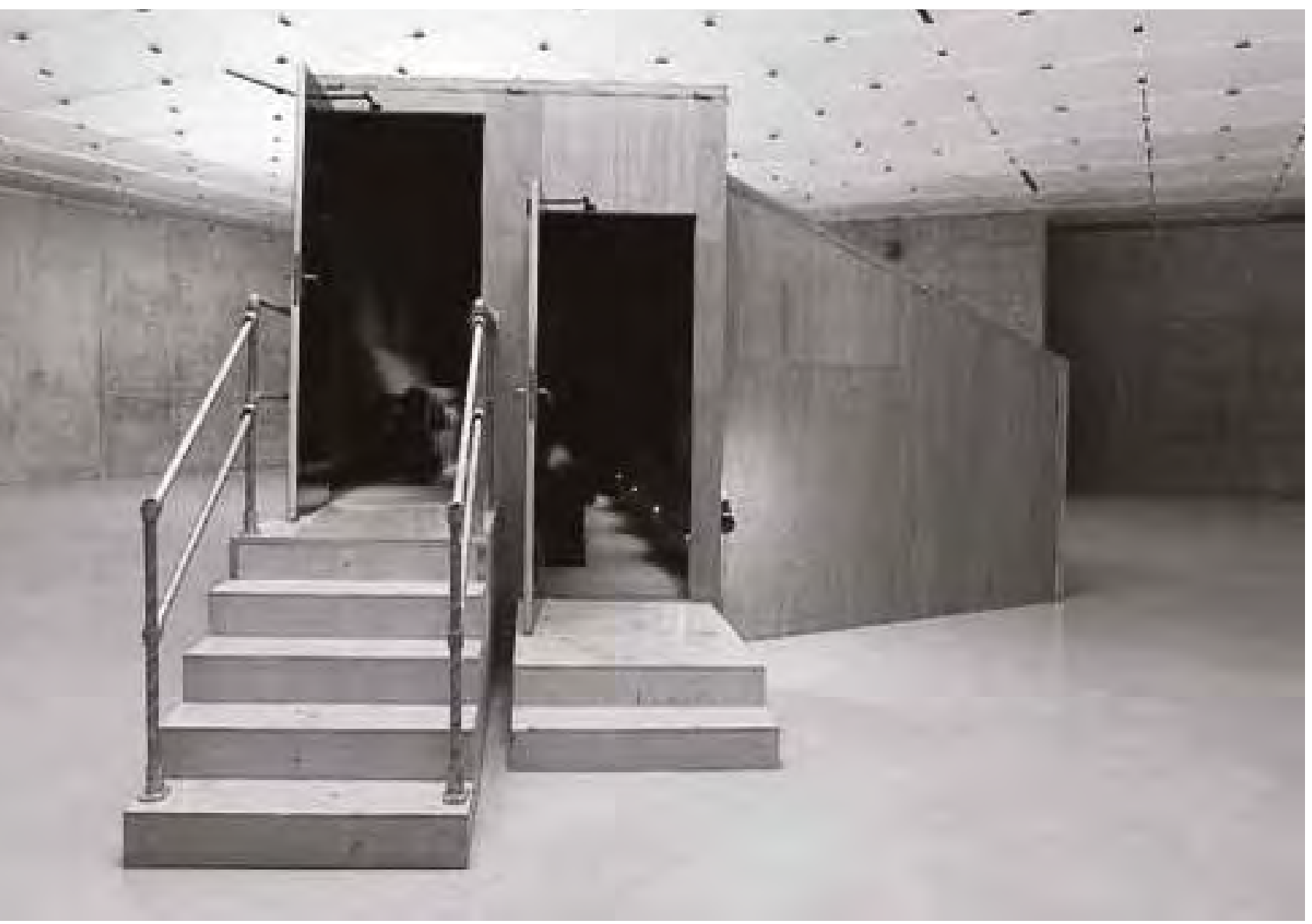

Figura 17: Janet Cardiff - Paradise Institute
Foto: Disponível em: <http://www.cardiffmiller.com/artworks/inst/ paradise_institute.html>. Acesso em: 17 fev. 2017.

de de percurso sonoro aciona uma rede de referências e de relações múltiplas que se situa entre o espaço interior do caminhante e o ambiente externo. Assim, nas criações de Cardiff o espectador se desloca pelo espaço sem ser guiado pelo controle do olhar, aquele que comumente nos guia na experiência da vida cotidiana.

\footnotetext{
${ }_{15}$ Informações disponíveis em entrevista concedida por Janet Cardiff e George Bures Miller à Anne-Lou Vicente, disponível no livro "Tout ouïe", de Anne Gonon (2016), p. 128-133.
} 
A artista promove uma perturbação do modo de funcionamento da percepção do público, desorganizando as informações e embaralhando os sentidos. Féral e Perrot afirmam que, de acordo com a fenomenologia, a percepção está calcada na ligação entre a sensação e a representação. Para perceber, é preciso buscar na memória uma concordância entre os sons ouvidos e uma imagem, uma representação. Essa representação passa pelo pensamento. Em Cardiff, há uma dissociação que opera entre a percepção e o pensamento, como se ela produzisse um desdobramento do pensamento, inscrevendo uma ruptura ou uma friç̧ão entre a percepção e a representação. O resultado disso é que a visão e a audição se tornam autônomas, sublinhando esse processo de dissociação, que confunde o espectador e ao mesmo tempo promove um prazer lúdico.

Segundo George Miller, parceiro de vida e obra de Cardiff, a partir de certo ponto de sua vida ele passou a se interessar por criar peças imersivas nas quais o visitante pudesse se deslocar. Por esse motivo, ele começou a realizar instalações com vídeos, que embora tivessem temporalidade e som, constituíam-se ainda em um formato estável, incapaz de envolver o outro como um filme ou um romance.

\begin{abstract}
Um romance, são simplesmente palavras sobre o papel, mas elas criam um mundo na sua mente. $O$ que eu queria fazer não tinha nada a ver com o som em si, mas ele permite desempenhar com êxito esse tipo de ideias, de criar mundos que contornam o intelecto e penetram diretamente nas pessoas (GONON, 2016, p.129 $)^{16}$.
\end{abstract}

\title{
_os percursos sonoros de Janet Cardiff: escrever em três dimensões
}

Andar é muito calmante. Um passo depois do outro, um pé movendo-se para o futuro e outro no passado. Você já pensou sobre isso? Nossos corpos ficam no meio, capturados entre um passo e outro. A parte mais difícil é permanecer no presente. Realmente estando aqui, realmente sentindo-se vivo... Pare. Janet Cardiff ${ }^{17}$

Os áudio walks desenvolvidos por Janet Cardiff ficaram conhecidos no meio artístico na década de 1990. Em seu livro "Janet Cardiff: The Walk Book", escrito com a colaboração de Mirjam Schaub, a artista afirma que os walking tours realizados por Linda Montano foram sua fonte de inspiração. Em 1974, Montano realiza passeios a pé em São Francisco como

${ }^{16}$ Un roman, ce sont simplement des mots sur du papier, mais ils créent tout un monde dans votre esprit. Ce que je voulais faire n'avait rien à voir avec le son en soi, mais il permet de mener à bien ce type d'idées, de créer des mondes qui contournent l'intellect et pénètrent directement les gens (tradução minha).

${ }^{17}$ Walking is very calming. One step after another, one foot moving into the future and one in the past. Did you ever think about that? Our bodies are caught in the middle. The hard part is staying in the present. Really been here, really feeling alive... Stop (tradução minha). Trecho transcrito de áudio disponível em: <http:// www.cardiffmiller.com/artworks/walks/longhair.html>. Acesso em: 3 jan. 2017. 
trabalhos artísticos, sem no entanto, utilizar fones de ouvidos ou quaisquer faixa sonora como nos percursos de Cardiff. Mesmo que esta última não se considere precursora desse tipo de arte, ela criou cerca de 24 percursos sonoros, inaugurando de maneira original essa modalidade artística. Caminhar usando fones de ouvido é uma ação bastante recorrente no cotidiano urbano contemporâneo e Janet Cardiff ficcionaliza essa ação, tornando-a mais complexa do que poderia parecer à primeira vista.

Conforme Karen O'Rourke, autora de "Walking and Mapping: Artists as Cartographers" [Caminhando e Mapeando: Artistas como Cartógrafos], estudar os áudio walks de Cardiff tendo acesso apenas a excertos de seus áudios pela internet, é o mesmo que estudar pintura a partir de suas reproduções fotográficas. Embora eu esteja de acordo com tal abordagem e concorde que tal estudo não substitui a experimentação do percurso sonoro em si, tive acesso a tais criações por intermédio da internet. Para tanto, recorri ao site de Cardiff e Miller, ao livro da artista mencionado acima e a outros autores que analisaram suas obras, como por exemplo Walter Moser, Olivier Asselin e Marie Fraser, cujos artigos integram o dossiê organizado por Josette Féral sobre a artista, publicado em "Le réel à l'épreuve des technologies: Les arts de la scène et les arts médiatiques" [O real à prova das tecnologias: As artes da cena e as artes midiáticas]. Foram consultados também o livro de O'Rourke supracitado e um artigo de Laura Dowart, publicado na revista Liminalities: A Journal of Performance Studies [Liminaridades: um diário sobre os Estudos da Performance].

Walter Moser descreve os percursos sonoros (walk, walking piece ou promenade) de Janet Cardiff como passeios nos quais "o receptor-executante da obra recebe fones de ouvidos conectados a um programa de áudio pré-gravado que se desenrola enquanto ele passeia, seguindo um percurso pré-programado pela artista, em um espaço real" (MOSER in FÉRAL e PERROT, 2012, p.101). No caso dos percursos videográficos (áudio-videowalks), uma pequena câmera de vídeo é acrescentada ao aparato técnico, de modo que a faixa de som e o vídeo se combinam ao guiar e acompanhar o visitante em seu passeio. Para esse autor, trata-se de um novo gênero dentro da categoria artmotion, que segundo sua abordagem é "uma experiência de mobilidade vivida pela pessoa que entra em contato com um obra ou com uma prática artística" (Ibid., p. 96) ${ }^{18}$.

Moser retoma os estudos de Arjun Appadurai sobre a globalização para distinguir três tipos de mobilidade no campo da cultura: locomotion, médiamotion e artmotion. A primeira delas, a locomoção, é o deslocamento físico de seres humanos, individual ou coletivamente, voluntário ou não, a pé ou usando algum meio de transporte. Há um sensível aumento da locomoção na esfera global no último século, inicialmente, pelo desenvolvimento dos sistemas de transporte e pela democratização do acesso econômico a esses serviços, mas

\footnotetext{
${ }^{18}$ [...] une expérience de mobilité que fait la personne qui entre en contact avec une cuvre ou avec une pratique artistique (tradução minha).
} 
também pelas desigualdades de todo tipo, que geram fluxos migratórios. A segunda, a "mídiamoção" é o conjunto de movimentos que tem como motor diferentes mídias, que embora mantenham o corpo humano imóvel, apresentam um mundo midiático em movimento. Ao se referir à mídiamoção, o autor afirma que tais experiências estéticas sempre acompanharam a arte, embora tenham sido reforçadas e exacerbadas recentemente. Elas já ocorrem na literatura, por exemplo. Ao ler um livro, uma mídia anterior à era digital, o sujeito se movimenta mentalmente pelo efeito de sua imaginação. Moser considera as caminhadas de Cardiff o que há de mais original dentro da tipologia artmotion, integrando igualmente elementos das mobilidades não artísticas (locomotion e médiamotion).

É que essas obras-passeios, nós não as "recebemos" mais, nós as fazemos, de acordo com o conceito estético elaborado pela artista. Nesse sentido, não são obras que "recebemos" em sua completude material, mas que nós performamos de maneira ativa. E por isso, participamos, pela nossa própria deambulação, da realização da obra de arte. Nesse sentido, nosso corpo em deambulação torna-se um material constitutivo da obra. Esse elemento representa a locomoção mais fundamental: nós nos deslocamos fisicamente em um espaço-tempo concreto e dado. (Ibid., p.102) ${ }^{19}$

Para o autor, as noções de receptor e recepção, e mesmo a distinção entre obra e recepção são problemáticas, disfuncionais, por isso, ele se recusa a usá-las quando analisa tais percursos sonoros. Os espectadores se engajam fisicamente, podendo ser considerados como o princípio ativo do jogo programado pela artista. Abordo essa noção no primeiro capítulo dessa tese quando afirmo que algumas ações implicam o espectador a tal ponto, que ele deixa de ser somente observador e passa a ser também "fazedor". Nesse caso, é a mobilidade do espectador que aciona o dispositivo criado por Cardiff, como se caminhar se igualasse à ação de pressionar o play e dar início ao áudio. Nesse sentido, o caminho é construção arquitetônica (no sentido atribuído por Careri), assim como o áudio é composição de faixa sonora. A junção dessas duas instâncias altera as ambiências percorridas, enquanto cada espectador vive sua experiência particular: "para cada caminhante, seu caminho/passeio" [à chaque promeneur sa promenade] (Ibid., p. 107).

Há um engajamento corporal do espectador em uma situação construída no espaço real, no tempo real, sem que nada se passe visivelmente e possa ser observado. Ou seja, não há o que ser assistido, os dispositivos colocados em jogo - a mobilidade e a faixa sonora intracraniana - operam na atitude e no olhar de quem experimenta tais percursos sonoros. Moser chama atenção para o fato de que tais criações artísticas se inscrevem em um mundo

${ }^{19}$ C'est que ces cuuves-promenades nous ne les "recevons" plus, nous les faisons, mais selon le concept esthétique élaboré par l'artiste. Dans ce sens, ce ne sont plus des ouvres que nous "recevons" dans leur complétude matérielle, mais nous les "performons" de manière active. Et par là, nous participons, par notre propre déambulation, à la réalisation de l'œuvre d'art. Dans ce sens, notre corps en déambulation devient un matériau constitutif de l'œuvre. Cet élément représente la locomotion la plus fondamentale : nous nous déplaçons physiquement dans un espace-temps concret et donné (tradução minha). 
igualmente móvel. Elas adotam a mobilidade de seu entorno, sem no entanto constituir-se como simples reproduções miméticas do mundo. Segundo o autor, Janet Cardiff articula a linguagem de tal modo que ela propõe um recuo em relação ao mundo real, o que a permite inscrever em suas criações uma dimensão não apenas cognitiva, mas também crítica. Por esse motivo, Moser não considera os walks de Cardiff propostas imersivas, pois essas experiências propiciam um vai-e-vem entre o espaço-tempo diegético e o mundo real que nos cerca. $O$ autor nos alerta, entretanto, para o perigo dessas ações serem interpretadas como solipsistas, ou seja, o risco de que se configurem como negação de tudo aquilo que esteja fora da experiência do indivíduo. "Essa particularidade dos passeios pode ser vista como um retorno a uma experiência estética muito pessoal, mesmo íntima, no contexto no qual dominam as mídias de massa, a arte produzida em série e a indústria cultural" (Ibid., p. 107$)^{20}$.

As ações apresentadas a seguir integram uma estética da lentidão, como uma forma de resistência à velocidade do mundo contemporâneo e uma crítica à cultura de massa. Ao recorrer à deambulação humana, a artista leva o espectador a reduzir a velocidade do mundo que o cerca. Renunciar à velocidade acelerada oferecida pelos meios técnicos de locomoção significa colocar o próprio corpo como matéria artística capaz de demarcar um ritmo de experiência propício à descoberta e à reflexão. Tais ações contribuem para a alteração da percepção sensorial do espectador, promovendo situações opostas àquelas nas quais ele se encontra em um estado anestésico, como por exemplo quando é exposto a muitas horas diante da televisão ou, mais recentemente, da internet. Não pretendo com essa afirmação condenar o uso dessas mídias, apenas ilustrar dispositivos que podem, quando utilizados sem distanciamento crítico, produzir certa anestesia social.

A primeira experimentação de Cardiff nesse campo, Forest Walk [Caminhada na Floresta], aconteceu em 1991 numa residência artística no Banff Centre of Art na província de Alberta, no Canadá. Nessa ocasião, a artista já dispunha de um sistema de áudio digital e portátil e um dispositivo de gravação binaural (uma maneira de gravar o som de modo que se perceba sua tridimensionalidade, pois os sons podem ser percebidos diferentemente em cada ouvido). Desse modo, era possível escutar nos fones de ouvido determinado som no local onde ele havia sido registrado. Isso possibilita a escuta de duas pistas sonoras, uma registrada e outra do mundo físico real. Ao associar as duas pistas tem-se a impressão de ouvir uma terceira, o que nas palavras de Cardiff, corresponde à criação de um terceiro mundo. Essa modalidade de criação descentraliza a visão dentro do processo de percepção do espaço-tempo e leva cada espectador a um exercício de semiotização, colocando em ação um manancial particular de referências.

\footnotetext{
${ }^{20}$ Cette particularité des promenades peut être vue comme le retour à une expérience esthétique très personnelle, voire intime, dans un contexte où dominent les médias de masse, l'art produit en série et l'industrie culturelle (tradução minha).
} 
O processo de escritura das caminhadas sonoras e videográficas é estreitamente ligado aos espaços. A escritura deve fazer eco direto à textura, à sensação desses espaços onde se realiza a experiência. Em certa medida, é como escrever em três dimensões. Certos elementos que são usados no som são respostas diretas à maneira pela qual a arquitetura nos afeta. (GONON, 2016, p. 131) $)^{21}$

Pode-se afirmar contudo que se tratam de ações site specific, pois a artista se desloca, explorando diferentes espaços e formulando interações específicas com cada território percorrido. Seguindo os mesmos princípios estéticos e conceituais, Janet Cardiff estabelece relações particulares com cada espaço, do mesmo modo pelo qual cada espectador terá uma relação particular com o percurso vivido. Desse modo, os percursos sonoros de Cardiff estão intimamente vinculados aos espaços para os quais foram criados, não podendo ser apresentados em outros locais: " [...] foram todos concebidos em função de um lugar real [...] que é por sua vez a origem e o destino da obra. Assim, por mais que elas sejam móveis, essas obras não são nômades" (ASSELIN in FÉRAL e PERROT, 2013, p. 111)22.

Em 1997, trabalhando sobre o mesmo princípio - uma associação de fones de ouvidos e caminhada - Cardiff chegou à Münster ${ }^{23}$ como uma visitante e após perceber a atmosfera da cidade, criou uma caminhada de 17 minutos: Münster Walk [Caminhada em Münster]. Esse percurso sonoro integrava um projeto, dirigido por Ulrike Groos, que visava reconhecer o ato de caminhar como uma escultura. Nessa ocasião, Cardiff trabalhou com um senhor idoso como personagem principal de sua história, pois notou que a maioria das pessoas sentadas nos bancos da cidade eram homens idosos, desempregados ou aposentados, sobre os quais pairava a memória da guerra. Refletindo sobre a relação desses homens com a guerra, todos os amigos e familiares que eles perderam nessa ocasião, Cardiff compôs uma história de um homem que traçava os caminhos da filha que havia perdido ${ }^{24}$.

A artista inspirou-se também na história de uma amiga cujo filho havia morrido num acidente de carro. Essa amiga lidou com a morte do filho reproduzindo seus percursos e refotografando paisagens por onde ele havia passado. Ela esperava recapturar algumas de suas memórias, ao olhar através da câmera fotográfica, o que ele havia visto (CARDIFF, 2005, p. 260). Como geralmente acontece em seus áudio walks, trata-se de uma narrativa contada pela voz de Cardiff, em conjunção com a voz de um homem idoso e outras vozes, bem como de ruídos e sons registrados na própria cidade, como por exemplo do sino da igreja e dos

\footnotetext{
${ }^{21}$ Le processus d'écriture des marches sonores et vidéo est étroitement lié aux espaces. L'écriture doit faire directement écho à la texture, à la sensation de ces espaces où vous en faites l'expérience. D'une certaine façon, c'est comme écrire en trois dimensions. Certains éléments que l'on utilise dans le son sont des réponses directes à la manière dont l'architecture nous affecte (tradução minha).

22 [...] elles sont toutes été conçues en fonction d'un lieu réel [...] qui est à la fois l'origine et la destination de l'œuvre. Ainsi, bien qu'elles soient mobiles, ces œuvres ne sont pas nomades (tradução minha).

${ }^{23}$ Cidade localizada ao norte da Alemanha.

${ }^{24}$ No site: <http://www.cardiffmiller.com/artworks/walks/>, a dupla disponibiliza além de descrições e fotografias, excertos dos áudios de todos os percursos sonoros realizados por eles.
} 
cascos dos cavalos. O personagem dessa ficção percorre as trajetórias da filha, para em locais onde ela esteve e escreve suas próprias reflexões sobre essa perda.

Em seus passeios, Janet Cardiff nos conta histórias. Entretanto, suas narrativas não são clássicas: não estão encerradas, por um início e um fim preciso, não têm uma grande unidade, nem de ação, nem de tempo. São fragmentadas, mesmo descosturadas, polifônicas, laminadas, elas agregam materiais heterogêneos: ideias, pensamentos, alguns autobiográficos, outros históricos, alguns factuais, outros ficcionais, além de instruções (ASSELIN in FÉRAL e PERROT, 2013, p. 109). ${ }^{25}$

As instruções para o deslocamento dos participantes são introduzidas na narrativa de maneira sutil, sem perder a atmosfera criada pela narrativa. Elas aparecem misturadas com as sensações dos narradores e as memórias que os espaços lhes evocam. Prova disso são as seguintes instruções: "I'm tired, let's seat in a bench for a minute" [Estou cansada, vamos sentar em um banco por um minuto], "Let's walk again. We have someone to meet..." [Vamos caminhar novamente. Temos alguém para encontrar...] ou "I think this is a Jesuit church. Keep walking straight ahead, across the street. There's a red car parked here" [Acho que essa é uma igreja jesuíta. Continue andando em frente, do outro lado da rua. Há um carro vermelho estacionado aqui]. São instruções simples e precisas, que algumas vezes brincam com o excesso de informação sobre o espaço real, propondo um jogo como: "From

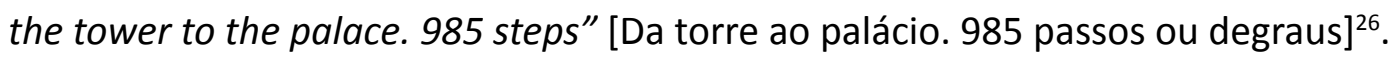

É interessante notar como a artista se mantém distanciada da narrativa que apresenta, ainda que toda a construção sonora conduza o participante para um estado diferente, poético, ligeiramente alterado ao observar o mundo que o cerca. Ela afirma, em dado momento, que segue os passos desse personagem, do mesmo modo pelo qual ele persegue os rastros deixados por sua filha. Em outro momento, diz que a casa à esquerda deve ser a casa dos Bishop, mas infelizmente não pode contar a história de todos aqueles prédios, nem fornecer um audiotour real, pois não passa de uma visitante daquela cidade (CARDIFF, 2005 , p. 260). Mesmo se reconhecendo como estrangeira e revelando o medo que tinha da Alemanha (por conhecê-la por intermédio dos filmes de guerra norte-americanos), sua pesquisa histórica sobre o país e a acuidade com a qual observou e escutou Münster, fez seus habitantes enxergarem a cidade de outra maneira. Pelo que se ouve nos excertos desse audiotour no site da dupla, tem-se a impressão de que o percurso passa por algumas ruas e uma praça ao lado do museu no qual o projeto está sediado. Entretanto, pela narrativa, o participante é convidado a visitar a casa da família Bishop, entrando na cozinha e no quarto

\footnotetext{
${ }^{25}$ Dans ses promenades, Janet Cardiff nous raconte des histoires. Cependant, ses récits ne sont pas classiques: ils ne sont pas clos, par un début et une fin précise, ils n'ont pas une grande unité, ni d'action, ni de temps. Ils sont fragmentés, décousus même, polyphoniques, feuilletés, ils rassemblent des matériaux hétérogènes: des idées, des pensées, certaines autobiographiques, d'autres historiques, certaines factuelles, d'autres fictionnelles, des instructions aussi (tradução minha).

${ }^{26}$ Os trechos citados foram transcritos por mim dos excertos de áudios disponíveis no site citado anteriormente.
} 


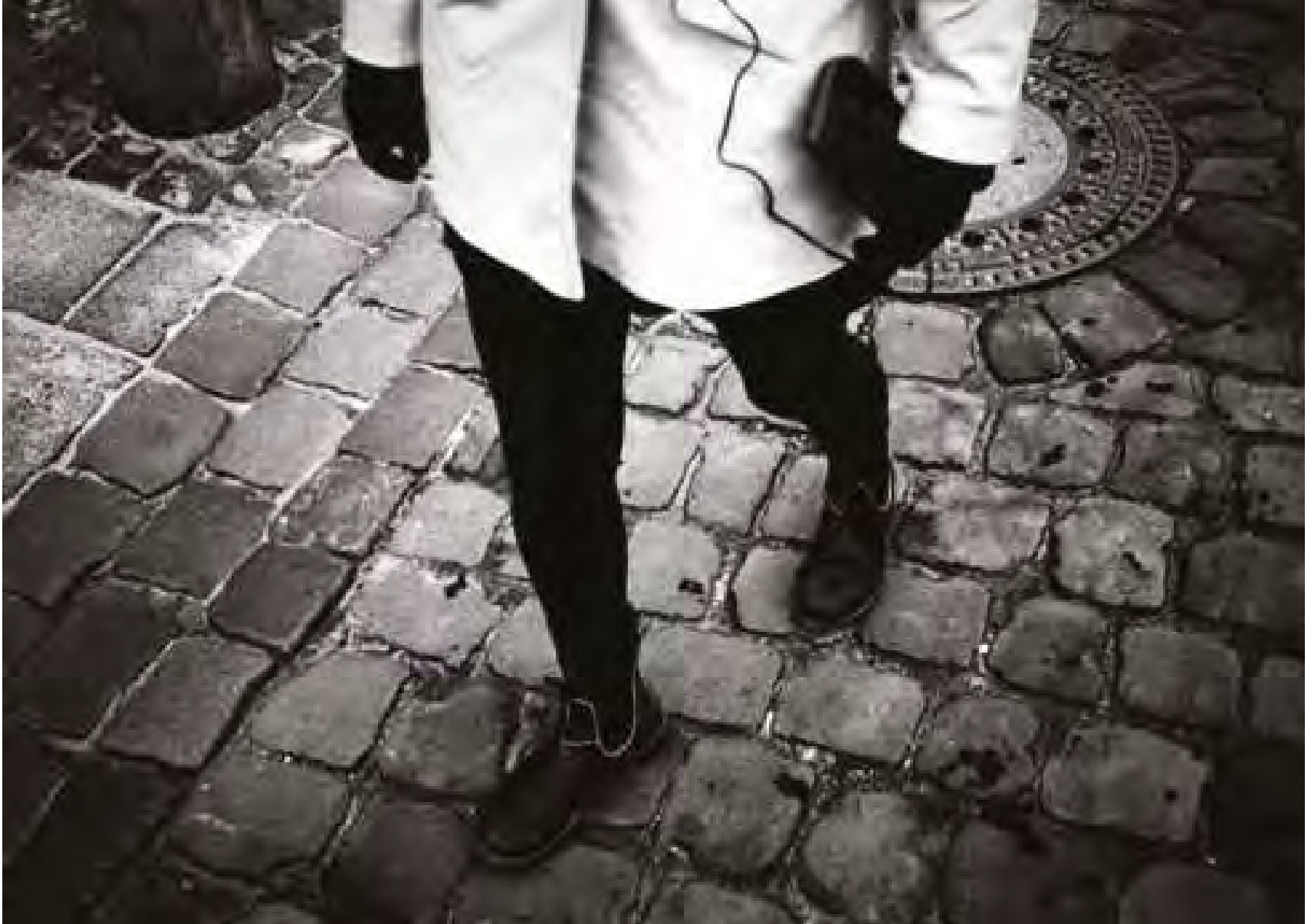

Figura 18: Janet Cardiff - Münster Walk

Foto: Disponível em: <http://www.cardiffmiller.com/artworks/walks/muenster.html\#>. Acesso em: 03 jan. 2017.

da filha. Ou seja, à medida em que se caminha pela cidade, percorre-se paralelamente os espaços da memória desse homem, como se fosse possível percorrer o imaginário de outra pessoa.

Vale ressaltar que em 1997 o áudio de Münster Walk foi disponibilizado para os participantes em fita cassete e walkman, um dos primeiros dispositivos portáteis de áudio (como notamos na foto da figura 18). Quando as pessoas realizavam o percurso com as pilhas de seus aparelhos fracas, acontecia da voz de Cardiff ficar parecida com uma voz masculina e do seu passo e, por conseguinte, o dos participantes desacelerarem. Na entrevista concedida à Anne-Lou Vicente, a artista constata, a partir desse exemplo, o quanto sua criação está intimamente relacionada à tecnologia empregada em cada época (GONON, 2016, p. 130).

Em The Missing Voice [A voz perdida], de 1999, Cardiff convida seu ouvinte a um percurso pela cidade de Londres, onde viveu por um tempo. Embora reconheça que algumas vezes desconhece os assuntos sobre os quais suas criações versam, a artista afirma que, sem dúvida, elas se configuram como respostas aos lugares aos quais se referem. Conforme James Lingwood, The Missing Voice é o primeiro trabalho de Cardiff para uma grande metrópole moderna. Várias vozes compõem uma cidade, tida pela narradora desse audiotour como infinita. Trata-se de uma criação para uma cidade onde todos são estranhos - uma cidade onde as pessoas vão para perder-se; um lugar onde as pessoas desaparecem todos os dias. Lingwood cita Georg Simmel, que escreveu no início do século XX em Berlim sobre a cidade como um lugar onde você está na companhia de estranhos (CARDIFF, 2005, p. 286). 
Acostumada a viver em uma pequena cidade no Canadá, Cardiff criou The Missing Voice como uma reação à vida na capital inglesa, às horas que passava nas bibliotecas, sendo uma pessoa solitária no meio da massa e lendo as manchetes dos jornais alheios. Ela identifica em muitas pessoas, sobretudo mulheres, uma paranoia ao chegarem em cidades desconhecidas (ibid, p. 286).

Tendo isso em mente, ela reuniu nesse trabalho alguns roteiros compostos a partir de fluxos de consciência que inventa quando passa por becos ou ruas escuras. Leitora de romances policiais e espectadora de filmes de suspense, a artista encontrou um modo de lidar com as visões e vozes assustadoras e violentas que seu inconsciente cria diante da mais simples realidade. Para compor essa peça, Cardiff anda pela cidade tomando notas em um mini gravador de voz. Ao ouvir essas gravações, de volta ao seu apartamento, ela nota que sua voz se parece com a de uma outra mulher, uma personagem diferente dela. Sua voz representa um conjunto de tipos e sintetiza metaforicamente a multiplicidade de vozes que nos habitam. O percurso inicia-se na sessão de crimes da Whitechapel Library, passa pelas ruas de Spitalfields e pelos lugares mais movimentados de Londres, até acabar no corredor principal da estação Liverpool Street. Ali, o ouvinte é deixado no meio da multidão, onde um grande número de pessoas passam e esperam (Ibid., p. 284-285). Em dado momento do audiotour, o som da cidade se torna ensurdecedor, ouve-se sons de tiros, correria, buzinas, helicóptero. Estamos diante de um acontecimento trágico, o pânico se instala na cidade e uma atmosfera de filme de ação toma conta do ambiente. Aos poucos, os passos da narradora vão se distanciando do local do acontecido.

Com o som de seus passos sempre marcando seus percursos sonoros, ditando ritmicamente um andamento para o ouvinte, a artista conta sobre uma mulher em busca de si mesma. "Sometimes when you read things it seems like you're remembering them" [Às vezes quando você lê algumas coisas, parece que está se lembrando delas]. Aqui a artista considera a possibilidade de confundir ficção e vida, embaralhando displicentemente narrativa e lembrança. Olivier Asselin ressalta o aspecto dramático presente nas criações de Cardiff, ainda que suas narrativas sejam fragmentadas, pois ele reconhece "uma intriga mínima que produz uma tensão dramática", igualmente reforçada pela música e pelos efeitos sonoros. O autor aponta para a presença simultânea da melancolia e do suspense decorrente da centralização no tempo real, no aqui-e-agora da percepção de seu ouvinte. Melancolia e suspense, no entanto, sugerem relações temporais antinômicas, pois a melancolia se volta para o passado e o suspense para o futuro.

Os passeios de Cardiff misturam o tempo da lembrança e o tempo da antecipação a ponto de torná-los indissociáveis, como o fazia aliás o romance policial, no qual o detetive chegava sempre depois do crime, mas devia pacientemente reconsti- 
Na peça, há relatos em primeira pessoa na voz de Janet Cardiff, gravados em fitas cassetes, atribuídos a uma mulher desaparecida. Tais fitas encontram-se, nesse momento, nos domínios de um detetive que procura desvendar os motivos do desaparecimento dessa mulher. Em um trecho, ouve-se a mulher dizer: "I've a long red haired wig on now. I look like the woman in the Picture. If he sees me now he'll recognize me" [Eu tenho uma longa peruca vermelha agora. Eu me pareço com a mulher da foto. Se ele me vir agora, ele me reconhecerá]. Em outro, o detetive diz: "Found in her bag, two cassette tape with a receipt and a tape recorder... As far as I can tell she's mapping different paths through the city. I can't seem to find a reason for the things she notices and records" [Encontradas em sua bolsa duas fitas cassete com um recibo e um gravador... Tanto quanto posso dizer, ela está mapeando diferentes trajetórias pela cidade. Não consigo encontrar uma razão para as coisas que ela percebe e registra em seu gravador]. Esse último trecho sugere que a mulher desaparecida é a própria artista, sobretudo ao revelar o conteúdo encontrado dentro de sua bolsa. Trata-se de metalinguagem, pois é Cardiff quem mapeia trajetórias na cidade, registrando falsos perigos e amores, como se dramatizasse ocorrências imaginárias de sua história pessoal. Dessa forma, a artista expõe o processo de composição desses percursos sonoros, usando a narrativa ficcional como meio de informar o público sobre seu processo de criação.

Há ainda relatos em terceira pessoa, nos quais Cardiff se coloca diferentemente, como voz over - alheia ao espaço-tempo ficcional, como um narrador de filme documentário. Ao excluir-se da história, ela olha os acontecimentos de fora, mantendo-se em uma distância segura, confortável. Assim, Cardiff guia o ouvinte no tempo presente, distinguindo-se da voz em primeira pessoa, que se refere a uma gravação anterior à experiência de caminhar pela capital inglesa. Uma voz masculina também integra o áudio, sugerindo o papel de um amante dessa mulher, que não se sabe se sumiu ou desapareceu deliberadamente. A peça termina de maneira abrupta com a seguinte fala, narrada em terceira pessoa e depois em primeira, como se aquela voz assumisse finalmente sua liberdade de circular entre dentro e fora da ficção.

Ela está entrando no trem. Ele corre ao longo da plataforma. Quando [o trem] está se afastando da estação, ela vê o rosto dele na janela e tenta se esconder. Quando o trem acelera, ela vira seu rosto para assisti-lo desaparecendo à distância. Tenho que sair agora. Eu queria te levar de volta à biblioteca, mas não há

\footnotetext{
${ }^{27}$ Les promenades de Cardiff mêlent le temps du souvenir et le temps de l'anticipation au point de les rendre indissociables, comme le faisait d'ailleurs le 'detective novel', où le détective arrivait toujours après le crime mais devait patiemment le reconstituer, ici et maintenant, devant le lecteur (tradução minha).
} 
tempo suficiente. Por favor, devolva o Discman o mais rápido possível. Adeus ${ }^{28}$.

Em seguida, o que se ouve são os passos de Janet Cardiff fugindo, o que remete às ações de fugas e perseguições apresentadas no capítulo três, em especial às ações promovidas por Sophie Calle. The Missing Voice foi o mais longo percurso sonoro proposto por Cardiff até aquele momento (50 minutos), ultrapassando as experiências do Louisiana Museum, de Münster e também de São Paulo ${ }^{29}$. Isso permitiu que muitas camadas narrativas se desenvolvessem e que a própria cidade tivesse seu protagonismo nessa ação. Parece relevante destacar o quanto os audiotours de Janet Cardiff promovem uma disjunção entre o que se ouve ou se descreve e o que se vê. Com o passar dos anos, essa disjunção vai aumentando, pois muitos elementos da cidade são modificados. Quando esse percurso foi criado, a cidade estava repleta de obras que já foram concluídas. Dessa forma, a experiência possibilita uma constatação do tempo que passa. A voz descreve uma cidade que já não há mais, embora permaneça cheia de estranhos, que cultivam sistematicamente o desejo de também desaparecerem.

\section{_cinema para os ouvidos ${ }^{30}$}

Em Her long black hair [Seus longos cabelos pretos], há um deslocamento temporal explícito. Os ouvintes são convidados a observarem fotografias realizadas em diferentes épocas no Central Park, enquanto seguem a trajetória de uma enigmática mulher pelas trilhas do parque, construídas no século XIX. As fotografias se tornam o ponto de contato entre 0 que é narrado e o que se percebe no espaço percorrido, promovendo um trânsito entre o presente, o passado recente e o passado mais distante. Pode-se dizer que o trajeto é definido a partir de percursos possíveis entre os locais onde as fotos foram capturadas. Pode-se afirmar que esse experimento preconizou o que anos mais tarde Cardiff desenvolveria em parceria com George Miller nos videowalks, pois a fotografia aqui tem a mesma função que terão posteriormente os vídeos pré-registrados e incorporados pelo espectador ao longo de sua trajetória.

Como sempre, nas composições de Cardiff, a percepção sensorial é exacerbada pelo viés da audição, efeito provocado pelo registro sonoro dos próprios locais que serão percorridos.

\footnotetext{
${ }^{28}$ She's getting on the train. He runs along the platform. Just as it's pulling out the station, she sees his face in the window and tries to hide. As the train picks up speed, she turns her head to watch him fade into the distance. I have to leave now. I wanted to walk you back to the library but there's not enough time. Please return the Discman as soon as possible. Goodbye (tradução minha). Disponivel em: <http://www. cardiffmiller.com/artworks/walks/missing_voice.html>. Acesso em: 2 jan. 2017.

${ }^{29}$ A artista esteve em São Paulo para a 24. Bienal de Arte, no ano de 1998, apresentando o audiotour Drogan's Nightmare.

${ }^{30}$ Expressão cunhada por Walter Ruttmann, em 1930.
} 


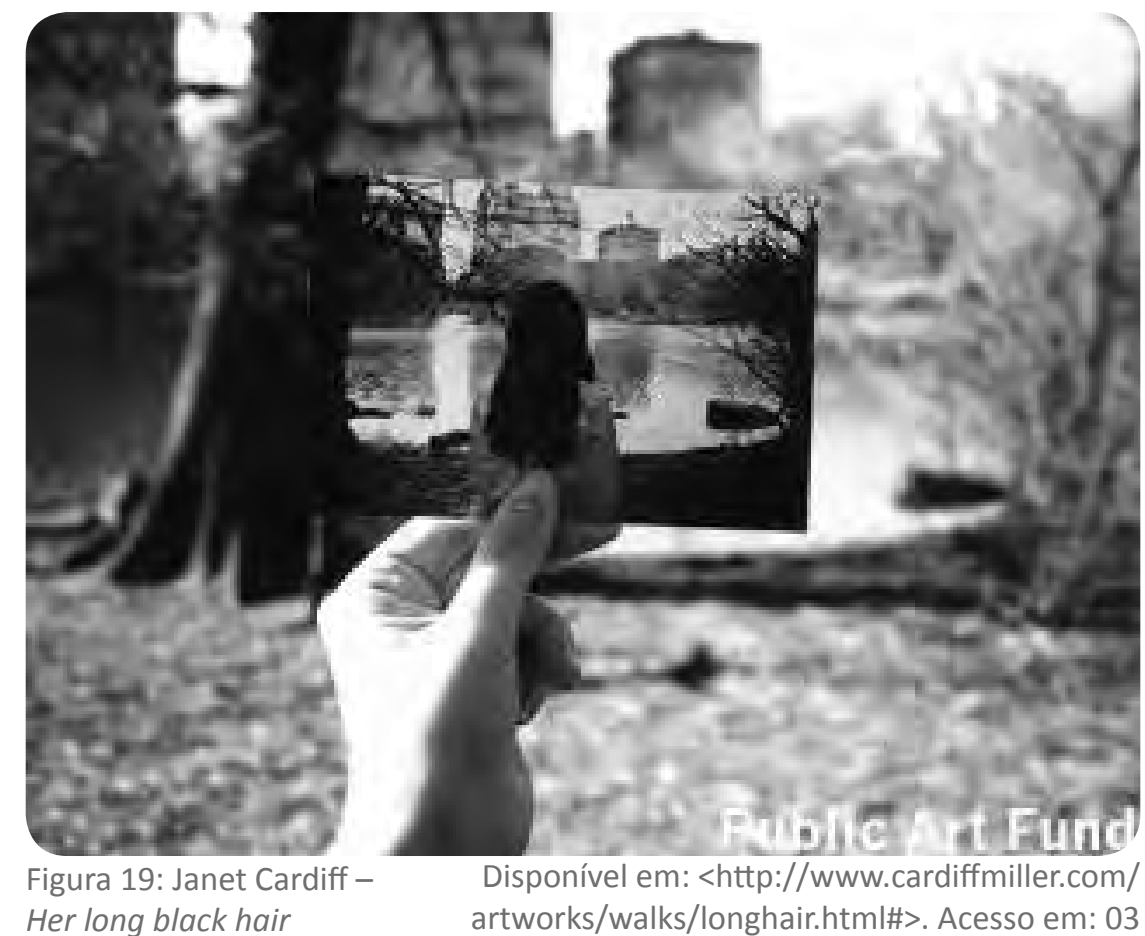

Her long black hair

jan. 2017.

É como se nos aproximássemos da cidade pela percepção sensível de seus sons. No caso de Nova York, a narrativa se inicia depois da chuva, com as ruas molhadas e com a artista comentando sobre o quanto as cidades grandes são barulhentas. Ela recomenda que se pense nos sons da cidade como uma sinfonia, como um subter-

fúgio para lidar com a quantidade de estímulos sonoros presentes nas grandes cidades. Ouve-se sons de ambulância, buzina, trânsito, um acordeão tocado por alguém na rua e os cascos dos cavalos que puxam as famosas charretes do Central Park.

Para acompanhar esse audiotour de 46 minutos, apresentado em duas temporadas distintas, uma em 2004 e outra em 2005, um stand foi montado perto de uma das entradas do Central Park. Nele, os participantes recebem um Cd player, um mapa do parque, no qual aparecem seis pontos marcados (correspondentes às seis faixas do áudio) e 5 fotografias. A primeira delas já revela um deslocamento temporal, pois retrata uma plateia acomodada em cadeiras posicionadas em uma das entradas do parque em 1965, quase 40 anos antes do audiotour ser realizado. A
Figura 20: Janet Cardiff - Her long black hair

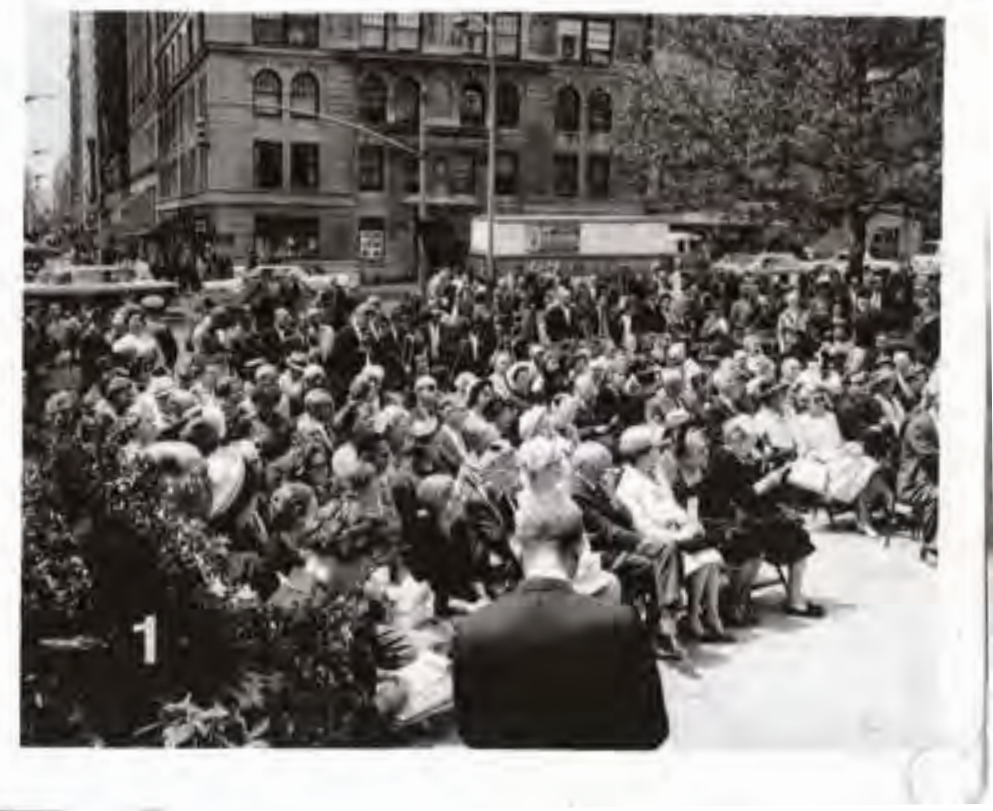

Disponível em: <http://www.cardiffmiller.com/artworks/ walks/longhair.html\#>. Acesso em: 03 jan. 2017. combinação da faixa sonora, que abre a percepção auditiva, com a fotografia - mais uma referência visual além do espaço percorrido - dá a exata medida daquilo que a artista define como uma escrita em três dimensões.

Desta vez, Cardiff é mais diretiva em seus comandos, recomendando que se tente andar no som de seus passos, pois assim os ouvintes permanecerão juntos com ela, que se encar- 


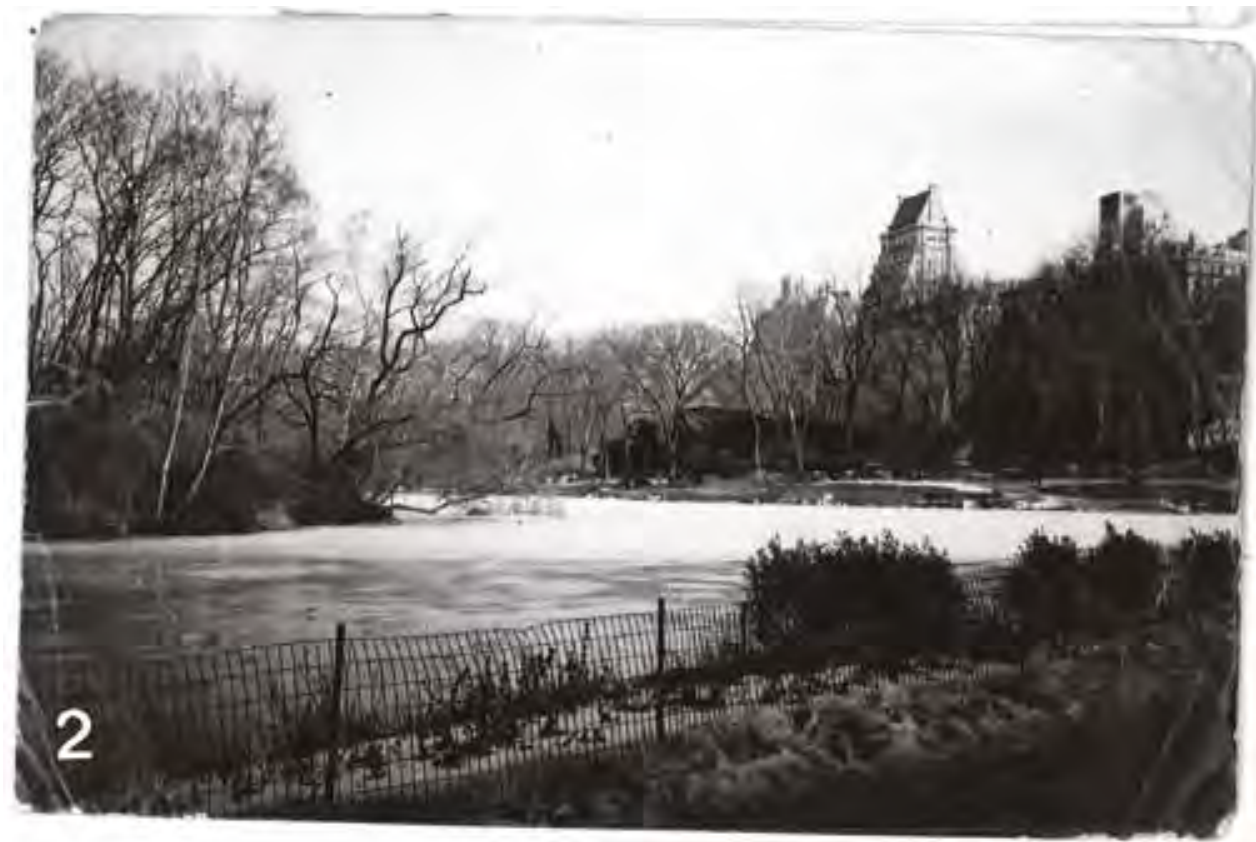

Foto: Disponível em: < https://phiffer.org/hlbh/>. Acesso em: 03 jan. 2017.

rega de fiar simultaneamente dois tempos: o da narração e o do trajeto. Entre esses dois tempos há um diálogo contínuo, pautado nas pausas do corpo para observação de recortes da paisagem, nos silêncios e nas mudanças de ambiências (percorridas ou ouvidas). Sendo assim, a artista descreve algumas situações que poderão ou não ser vistas na ocasião da experimentação do audiotour, como por exemplo, uma mulher falando ao celular, um homem sentando em um banco lendo jornal e uma mulher tirando uma foto. Percebe-se com isso que a artista joga com o acaso, pois se o ouvinte não encontrar essas pessoas ao longo das trilhas, poderá facilmente imaginá-las; porém, se o ouvinte reconhecer alguém que corresponde a tais descrições, terá a impressão de que se trata de uma narração em tempo real. A presença da chuva também se enquadra nessas apostas da artista no acaso, pois se ao realizar o percurso a chuva estiver mesmo caindo ou acabando, esta será uma coincidência muito feliz. Caso contrário, será um convite para visualizar a rua sob a chuva, lembrar do cheiro da terra molhada e um estímulo para apressar os passos.

No relato de Laura Dorwart sobre sua experiência de exploração desse audiotour, que ocorreu na primavera de 2009, portanto fora das temporadas oficiais, a autora revela que nevava levemente no dia em que percorreu os caminhos de Cardiff pelo Central Park. Ela foi convidada a fazer o audiotour pelo professor de um curso de performance do Barnard College ${ }^{31}$, como parte do programa da disciplina que ministrava. Dorwart faz duas considerações sobre as diferentes condições climáticas narradas por Cardiff e experimentadas por ela, como participante do audiotour. Primeiro, ela revela que não conseguiu acompanhar o andamento proposto pela artista, pois o chão estava escorregadio e, em seguida, afirma que a narração desestabiliza os sentidos do ouvinte, perturbando sua percepção.

\footnotetext{
${ }^{31}$ Faculdade privada de artes liberais para mulheres, localizada em Nova York.
} 
Eu sempre pretendi localizar os áudio walks de Cardiff dentro de um espectro de práticas contemplativas: uma espécie de 'caminhada em um labirinto escuro' que passa uma lanterna fosca nas sombras que povoam a paisagem binaural que ela suscita, permitindo a sua audiência um olhar íntimo, sussurrado, e calmamente urgente sobre elas, em vez de iluminá-las plenamente ou tentar afastá-las (DORWART, 2016, p.3) 32

Por meio do som, o corpo é envolvido nessa deambulação. É como se Janet Cardiff colocasse vozes dentro da cabeça do participante, cujo corpo se torna o veículo, o elemento móvel que conduz sua criação. Nesse exemplo, o paradoxo apresentado pelo título desta parte dedicada aos audiotours - de que para o artista trata-se de um percurso sonoro, enquanto para o participante trata-se de um passeio - fica explícito, sobretudo se levarmos em conta o fato de que se passeia, por 46 minutos, em um dos parques urbanos mais visitados do mundo. Há nessa proposição um apelo ao corpo nitidamente feminino, não apenas pela narração se dar por intermédio de uma voz feminina, mas também pela tentativa de localização de uma mulher de longos cabelos pretos, que um dia foi fotografava ali. Ainda que a narrativa aconteça de maneira fragmentada e resulte da combinação de diferentes gêneros textuais, a mulher de cabelos pretos está no foco dessa voz feminina, alter ego de Cardiff. Essa mulher só estará presente nas fotografias, ela não se materializará diante dos participantes; assim, essa presença fotográfica indica mais um deslocamento temporal.

As três fotos nas quais a mulher aparece foram compradas por Janet Cardiff em um mercado de pulgas e integraram o processo de criação desse audiotour, ao qual a artista dedicou 6 anos. Cardiff não conhece essa mulher, desconhece o autor dessas fotografias e, muito provavelmente, tal mulher também não tem conhecimento sobre o paradeiro dessas fotos. Ela não imagina que suas imagens tornaram-se um objet trouvé [objeto encontrado] - re-

Figura 22, 23 e 24: Janet Cardiff - Her long black hair
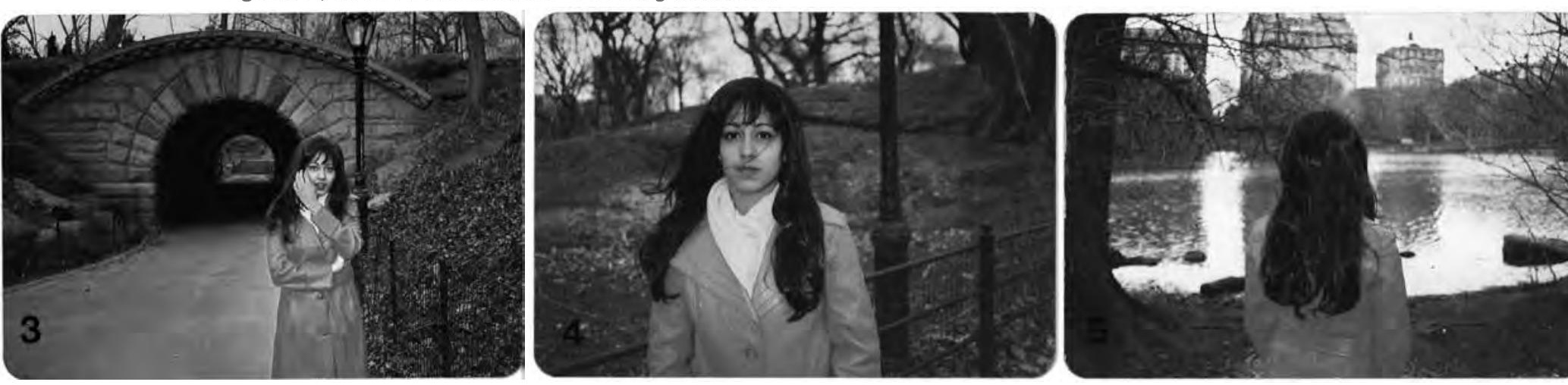

Fotos: Disponível em: < https://phiffer.org/hlbh/>. Acesso em: 03 jan. 2017.

32 I also intend to locate Cardiff's audio walks along the spectrum of contemplative practices: a kind of 'labyrinth walking noir' that passes a dim flashlight across the shadows that populate the binaural landscapes she conjures, allowing her audience of one an intimate, whispered, and always quietly urgent glimpse at them, rather than illuminating them fully or attempting to cast them out (tradução minha). Disponível em: <http:// liminalities.net/12-2/cardiff.pdf>. Acesso em: 4 jan. 2017. 
tomando a noção de Marcel Duchamp, nem tampouco que elas conduzem o fio narrativo de um percurso sonoro criado por Janet Cardiff na locação onde foi fotografada em uma data imprecisa. A artista, contudo, joga com tais informações, preenchendo a seu modo as lacunas deixadas pela falta de referências concretas sobre essa figura que, por obra do acaso, tornou-se a protagonista desse audiotour. Ela confabula não apenas sobre a identidade dessa mulher, como também sobre a identidade do fotógrafo, pois Cardiff nos leva a crer que se trata de seu amante. De maneira poética, a artista se pergunta sobre o destino dessas figuras depois desse instante congelado no tempo. Teriam voltado juntos para casa? De quem seriam essas fotos antes de serem vendidas em um mercado de pulgas? Qual o itinerário dessas fotografias, da tarde em que elas foram realizadas até o momento em que elas atraíram a atenção de Janet Cardiff?

É interessante como a artista, ao elucubrar a respeito dessa mulher, confunde-se com ela, criando camadas entre a ficção e a realidade. "She seems like a different person than me, but somehow I have her memories" [Ela parece uma pessoa diferente de mim, mas de algum modo eu detenho suas memórias]. Curiosamente, observando as fotografias utilizadas nessa ação, me surpreendo no mesmo exercício que a artista. Como o título ${ }^{33}$ do percurso sonoro se refere ao cabelo da mulher retratada, observo seus cabelos. Devaneio sobre o tema e crio minhas interpretações sobre essa cabeleira vista de frente e de costas, tão marcante e intencionalmente representativa que chega a ser artificial. E talvez seja, de fato, um mega hair ou uma peruca. Esse detalhe desmonta algumas leituras iniciais que o audiotour poderia suscitar: o cabelo como elemento representativo da identidade feminina, a associação do discurso a uma mulher no sentido biológico do termo, a identidade relacionada ao sexo de nascimento da pessoa, em detrimento da performatividade do gênero.

A despeito dessa leitura inicial que associa o cabelo ao feminino - enquanto o cabelo na esfera masculina reporta à força, se considerarmos o mito bíblico de Sansão - não pretendo reduzir a criação dessa artista à etiqueta "feminina". É chegado o momento de interromper esse impulso de restringir todos os temas tratados por mulheres a uma temática supostamente "feminina", como se esse adjetivo fosse suficiente para abarcar todos os assuntos igualmente tratados pelos homens, sem que suas obras sejam consideradas "masculinas". Desse modo, o que a voz narrativa de Janet Cardiff revela é uma pluralidade de vozes, típica do sujeito contemporâneo. Assim, a artista navega por várias histórias paralelas, justapondo histórias coletivas, ficção, mitologia e memórias pessoais. Em certo ponto do percurso, ela menciona as ossadas encontradas no Central Park, revelando algo factual, do conhecimento de alguns habitantes da cidade: corpos foram enterrados ali. Uma voz masculina recita um texto do lado direito do fone. É George B. Miller sussurrando um poema de Baudelaire. Em outro ponto, Cardiff revela que cortou os cabelos no hotel porque detestava o modo

${ }^{33} \mathrm{O}$ título faz uma referência ao poema de Charles Baudelaire: "La Chevelure" [O cabelo]. 
como eles estavam. Ela funde em sua narrativa os trajetos de três pedestres: Kierkegaard em Copenhague, Baudelaire em Paris e um escravo fugindo em território americano. Em seguida, outra voz masculina, mais grave e ofegante, incorpora o escravo de Harry Thomas em fuga. "Em 1850 enquanto Harry Thomas realizava seu tenebroso diário épico através da América, no qual narra três meses de caminhada, Baudelaire caminhava pelas ruas de Paris. Gosto de imaginar que às vezes seus passos se alinharam, como se eles caminhassem juntos" ${ }^{\prime 34}$.

Uma das fotografias, mostra a mulher de cabelos pretos diante de um túnel, justamente no ponto do percurso no qual os participantes se encontram. Ouve-se ao longe, um homem cantando "Sometimes I feel like a motherless child" à capela. A música carrega o momento de dramaticidade, mesmo que ao chegar no túnel, o público não encontre a figura registrada por Cardiff cantando. Desse modo, a artista joga com os elementos do real, criando pistas sonoras paralelas (a real e a ficcional) e faixas de imagens inéditas, pois cada caminhante monta a sua própria sequência de imagens.

Ao colocar-se no corpo a corpo com a cidade, Cardiff não apenas anexa o real, ela o toma como modelo para criar uma experiência, que por sua vez, não imita a realidade. Essa experiência quer criar outros mundos, compor diferentemente com os elementos retirados do real. Por isso, o espaço é tomado como site specific, o tempo é plural e percebido em camadas e as fronteiras entre a situação construída e a vida são cada vez menos visíveis. Até mesmo a ação na arte de Cardiff é compartilhada, não há discernimento entre quem faz e quem vê. Faz-se e vê-se simultaneamente. Assim, caminhar de fones de ouvido torna-se uma experiência disruptiva e subversiva.

Mais uma vez, uma mulher andando sozinha pode ser considerado um ato político; a ação de Cardiff explicita a desigualdade de gênero presente no espaço público. Ela afirma sentir medo, mesmo tendo consciência de que está segura, inserindo sons de tesoura entre o assunto do corte do cabelo e a impressão de que um homem a segue. "There're always so many layers in front of my eyes. I saw a man pushing a woman into a car. I saw a boy running down the street. I saw a woman fall to the ground. How can I really know what I've seen?" [Há sempre muitas camadas diante dos meus olhos. Vi um homem empurrando uma mulher para dentro de um carro. Vi um garoto correndo pela rua. Vi uma mulher cair no chão. Como posso realmente saber o que eu vi?].

Seu telefone toca e ela atende, sem interromper a gravação. Aparentemente, trata-se de

\footnotetext{
${ }^{34}$ In 1850 while Harry Thomas made his epic nighttime journey across America, three months of walking, Baudelaire walked the streets of Paris. I like to imagine that at times their footsteps, lined up as if they walked together (tradução minha). Transcrição do audio disponível no site supracitado.
} 
seu companheiro. A situação parece cotidiana, pois ele pergunta onde ela está. Ela responde que está no parque, ao que ele recomenda que ela tome cuidado. Ela afirma que tem bastante gente no parque, retomando o assunto do percurso analisado anteriormente, de que a cidade é um espaço cheio de estranhos. Quem está próximo é provavelmente o mais desconhecido, enquanto o mais conhecido está distante. No meio da conversa ela diz: "vire à esquerda" e ele não entende. Então, ela Ihe explica que está gravando. Nessa fricção com o real, Cardiff coloca em pauta a segurança da mulher na via pública, esse assunto que atravessa a esfera artística e nos envia de volta à vida real.

Conforme Olivier Asselin, os passeios de Cardiff transformam os espaços reais por meio das narrativas que se constroem, um dispositivo de realidade mista ativado pela artista. “(...) os lugares são narrados e ficcionalizados, tornam-se não somente romanescos, mas também cinematográficos. Os passeios de Cardiff são romance e cinema no espaço real. Produzem uma imersão ficcional na realidade" (ASSELIN in FÉRAL e PERROT, 2013, pp. 112$113)^{35}$. Como vimos anteriormente, retomando o ponto de vista de Walter Moser, há uma polêmica a respeito do caráter imersivo dessas experiências. Asselin atribui à voz over a responsabilidade de conduzir o espectador para um espaço outro, diferente daquele no qual ele de fato de encontra. Para ele, essa voz, sussurrada ao pé do ouvido, de maneira tão próxima e íntima, substituiria a voz da consciência. "O dispositivo tecnológico é aqui como um envelope corporal, uma pele que, ao mesmo tempo, nos protege e vem alterar nossa relação fundamental com o mundo" (Ibid. p. 111) ${ }^{36}$. Na esteira dessa reflexão, o autor associa os audiotours de Cardiff a um cinema-pele, tomando emprestado a expressão de Paul Schilder para se referir a essa experiência sensorial que envolve visão e audição como no cinema, sem deixar, no entanto, de incluir a percepção táctil proveniente do deslocamento do espectador por diferentes ambiências.

No sentido apresentado acima, os audiowalks de Cardiff seriam experiências imersivas. Contudo, o mesmo autor nos alerta sobre o caráter misto desses percursos, que muitas vezes, ao invés de nos distanciar dos espaços percorridos, nos aproximam deles. Ele afirma que esse mesmo dispositivo tecnológico que cria o cinema-pele, leva o espectador a ter uma consciência elevada dos espaços, como se o áudio assumisse a função tanto de filtro poético da realidade, quanto de lente de aumento de características imperceptíveis a olho nu. Ao ver de tão perto, com tanta precisão, o espectador passaria por um processo não de imersão, mas de emersão, distanciando-se da narrativa ficcional e sendo capaz de analisar a realidade de modo mais contundente.

\footnotetext{
${ }_{35}^{3}$ [...] les lieux sont narrativisés et fictionnalisés, ils deviennent eux-mêmes non seulement romanesques, mais aussi cinématographiques. Les promenades de Cardiff sont du roman et du cinéma dans l'espace réel. Elles produisent une immersion fictionnelle dans la réalité (tradução minha).

${ }^{36}$ Le dispositif technologique est ici comme une enveloppe corporelle, une peau qui, tout à la fois, nous protège et vient altérer notre rapport fondamental au monde (tradução minha).
} 
Os passeios de Cardiff participam dos dispositivos ditos de realidade aumentada ou mista que, contrariamente à realidade virtual, não visam a eclipse do mundo real e a imersão no mundo virtual, mas, ao contrário, a integração de dados virtuais no espaço real. (Ibid., p. 112) (17 $^{37}$

Apresentarei a seguir alguns exemplos de audiotours realizados por diferentes artistas. 0 nível de imersão proposto em cada uma dessas experiências é diferente. Alguns carregam mais no aspecto ficcional, outros contam realidades históricas; uns revelam a teatralidade do real, outros propõem ações inusitadas aos espectadores, radicalizando o corpo de quem porta fones de ouvido.

\section{_trajetórias guiadas pelo som}

No capítulo um apresentei o audiotour de Rimini Protokoll, Remote $\boldsymbol{X}$, para refletir sobre o espectador como princípio ativo da ação. Sem o corpo e sem o imaginário dos ouvintes, a mobilidade presente nessa modalidade artística não pode ser acionada. Trata-se de uma criação que coloca a cidade como protagonista (fator constatado nas três cidades onde experimentei o audiotour: Avignon, São Paulo e Paris), pois o texto se configura como uma dissertação sobre aspectos identificados nessas cidades em confronto com a mecanização da vida corrente, e não como uma narrativa ficcional. Em comparação a Cardiff, há uma perda literária ou romanesca. Não que Stephan Kaegi não se valha de elementos ficcionais, mas eles são menos impactantes do que nos walks de Cardiff. Pelo mesmo motivo, eles são mais abertos e socializáveis com os espectadores, que por sua vez são deliberadamente convidados a construir suas próprias narrativas. $O$ artista convoca cada participante a fabular a respeito desse ou daquele passante, ou imaginar algo a respeito de outro espectador. Em alguma medida, um se torna espectador do outro, assim como a cidade e o acontecimento cênico também se assistem mutuamente.

Com essa proposta, Kaegi subverte todos os estatutos da cena: o espectador detém a função de criador, experimentando o mesmo procedimento de Cardiff ao observar uma cidade para criar um audiotour; o passante e o espectador outro (que não sou eu) tornam-se as figuras sobre as quais se confabula; o espectador também se torna performer, pois é seu corpo que dá a partida ao evento, como se o corpo apertasse o play. Tratam-se ainda de acontecimentos imprevisíveis, mesmo que a faixa sonora não se altere. Cada apresentação é única, assim como a experiência de cada espectador. É claro que em alguma medida, esta afirmação será sempre verdadeira, inclusive nas peças teatrais mais convencionais. Porém,

\footnotetext{
${ }^{37}$ Les promenades de Cardiff participent des dispositifs dits de réalité augmentée ou mixte que, contrairement à la réalité virtuelle, ne visent pas l'éclipse du monde réel et l'immersion dans un monde virtuel, mais, au contraire, l'intégration de données virtuelles dans l'espace réel (tradução minha).
} 
no caso dos audiotours, há uma radicalização desse processo, pois em alguns momentos cada espectador imagina o seu roteiro, inventando histórias a partir da leitura dos deslocamentos dos passantes. Se a mulher que sobe a rua olha para o rapaz que desce correndo, o cruzamento dessas trajetórias, os diferentes andamentos dessas duas figuras e a tensão que se criou entre eles são componentes suficientes para que cada espectador imagine um enredo pessoal, íntimo.

Assim, o jogo se constrói na esfera do imaginário e o espectador o experimenta sem necessitar de nenhuma mediação extra. É o modo do artista entregar os dispositivos para o espectador que o transforma em jogador. Nesse caso, observo a presença de um potencial pedagógico intrínseco à ação, pois os próprios dispositivos que constituem a ação são suficientemente eficazes para localizar o espectador dentro dessa proposta. Ou seja, não é necessário que o artista explique o jogo para que o espectador se posicione dentro dele, realize ele mesmo as ações previstas, interaja com os demais envolvidos no audiotour e com os passantes e acione o seu imaginário para observar a cidade de outro modo. Ainda que seja a primeira vez que alguém realiza um audiotour, os dispositivos colocados em jogo são autoexplicativos. Desse modo, basta a pessoa se dispor a usar um fone de ouvido e seguir certas instruções para que ela experimente essa modalidade da arte contemporânea, que não poderá, de forma alguma, ser considerada hermética.

$\mathrm{O}$ ato de caminhar promove o mesmo efeito que se tem quando se desloca dentro de um museu; é pela ativação de certos músculos das costas e das pernas que se tem acesso ao próximo quadro. O espectador do audiotour está disponível para o movimento; ele não é sedentário, nem espera que as informações, as visões e as sensações cheguem até ele. Quem observa esse espectador de fora, na condição de passante sem fone de ouvido, percebe que ele não anda só. Trata-se de um grupo de pessoas caminhando simultaneamente, conectado a um "comando comum", que também faz pausas e realiza uma ou outra ação coletivamente. Em Remote $X$, do Rimini Protokoll, em alguns momentos as ações dos espectadores poderiam ser interpretadas como um flash mob, pois uma quantidade significativa de pessoas realiza algo inusitado ou simples, mas em conjunto e ao mesmo tempo.

Diferente de Cardiff, que propunha que seus espectadores saíssem em deslocamento em momentos diferentes, na experiência proposta pelo Rimini, as saídas são concomitantes. Essa escolha faz com que sempre haja espectadores com fones de ouvido no seu campo de visão, ou seja, o espectador não está só diante do espaço e dos demais transeuntes da cidade. Eles integram igualmente a realidade que se apresenta.

Se essa modalidade artística já lida com dispositivos da cultura urbana - como por exemplo fones de ouvidos e um cd player, depois um mp3 e mais recentemente transmissores de ondas radiofônicas - em Remote $X$, outros dispositivos contemporâneos são agregados: GPSs, 
aplicativos de corrida que marcam o trajeto percorrido e as coordenadas de alguém em um mapa. Somos todos facilmente localizáveis, nossos celulares funcionam como chips implantados em nossos bolsos e não raramente nos deixamos conduzir por uma voz artificial que decide nosso percurso. Desse modo, a ação proposta pelo coletivo alemão não é ingênua, nem casual, ela se utiliza dos mesmos dispositivos usados pelo espectador na vida corrente, posicionando-se na primeira camada auditiva do ouvinte. É como se essa voz dividisse o espaço com os pensamentos da pessoa, convidando cada um a refletir sobre seus modos de vida, suas escolhas e seus pontos de vista sobre situações distintas observadas na cidade. Alguns trechos do áudio são preenchidos com músicas que embalam a caminhada, assim o jogo adquire um pulso marcado e permite ao corpo se colocar em marcha e (re)visitar um terreno conhecido com outros olhos. As perguntas do artista são diretamente relacionadas aos espaços percorridos, fazendo com que os corpos sejam afetados pelo cemitério, pelo hospital ou pelo supermercado.

Nesse caso, não parece adequado falar em público como coletivo de espectadores, a não ser ao se referir ao grupo portador de fones de ouvido. Ainda assim, cada espectador individualmente estabelece uma relação particular com a experiência, dependendo do tipo de encontro que tem com a cidade. Como espectadora, conheci regiões de Avignon e de Paris por meio desse audiotour e revi São Paulo; reconheci a cidade onde moro há quase 20 anos a partir das proposições de Remote $X$. Em cada uma dessas ocasiões, estabeleci uma relação pessoal com os ambientes visitados e rapidamente me reconheci como pertencente a uma coletividade. "As tecnologias sonoras contribuem para a individualização dos espectadores e para a dissolução do coletivo teatral" (Kapelusz, 2013 p.128). Nesse sentido, o público passa a se constituir como espectador no singular, um agrupamento de particularidades. Tal característica reforça o pensamento de Rancière, contrário à ideia de teatro como assembleia. Para esse autor, a experiência do público de teatro hoje não se configura mais como uma assembleia, não se trata de uma coletividade, mesmo considerando que as origens do teatro remontam ao modelo ateniense. Parece mais adequado falar, no caso desses audiotours realizados em conjunto, em coralidade espectadora.

Quando a operação artística não acontece no imaginário do espectador, ela é deslocada para o seu próprio corpo. De fato, nada está acontecendo de excepcional, não há a configuração de cenas, nem a exploração de ações performáticas, a não ser aquelas realizadas pelos próprios espectadores. O bando de pessoas munidas de fones de ouvido deslocando-se pela cidade, a que nomeei coralidade espectadora, configura-se como o evento em si. Dito de outro modo, não há nada de extraordinário acontecendo que não seja a presença de um grupo portando fones de ouvidos.

A matéria sonora, as técnicas de gravação e de transmissão de áudio desempenham um papel pelo menos tão importante quanto o visual, mas levanta ques- 
tionamentos específicos. O porte do fone de ouvido engendra um paradoxo evidente: enquanto a escuta teatral é tradicionalmente coletiva - o público aparece como o "grande ressonador" no fenômeno de co-presença cena-sala -, os fones geram uma experiência privada, que fecha o ouvinte em si mesmo e o isola dos seus semelhantes, provocando de fato uma dissolução do coletivo formado pela sala (KAPELUSZ, 2013, p. 125) ${ }^{38}$.

O que se observa aqui não é apenas a dissolução do coletivo formado pela sala, mas a composição de uma outra coletividade, estabelecida pelo porte de um dispositivo comum. No caso do Rimini, o espectador é o sujeito da experiência e embora ele ouça a faixa sonora separadamente do outro que caminha ao seu lado, essa condição não o separa definitivamente desse outro. Isso ocorre, pois o tempo todo a voz condutora convida o espectador a refletir sobre uma cidade igualmente habitada e a explorar ações que não são individuais e, portanto, não excluem o coletivo. Como se trata de um ajuntamento casual de pessoas, aos olhos da cidade (ou seja, dos passantes) o que se vê é uma coralidade espectadora, um conjunto de pessoas das mais diversas procedências, reagindo aos mesmos estímulos, de maneira extremamente particular.

Contrariamente a isso, Klaas Tindemans discorre sobre a dificuldade do teatro documentário, em especial à dramaturgia do real operada pelo Rimini Protokoll, em se afirmar como uma força comunitária. Suas considerações sobre o assunto levantam outro aspecto da questão.

\begin{abstract}
A responsabilidade que esse tipo de teatro dá ao espectador é significativamente maior que em um teatro de ficção. O espectador é convidado, ou mesmo forçado, a relacionar dois quadros de referências: o da experiência teatral e estética, e o do cidadão bem informado. Os dois quadros não são sempre coincidentes e o acontecimento teatral não ajuda a reconciliar esses dois horizontes interpretativos. [...]. De fato, essa dramaturgia do real é apenas um caso exemplar das dificuldades do teatro contemporâneo de se afirmar como força comunitária. A mensagem subentendida de todos esses espetáculos é um grito político, sincero, mas mal orientado, seja expresso como partilha da ignorância, seja expresso como didatismo, seja expresso como apelo ingênuo à convivência. Esse grito político visa à indiferença dos cidadãos e, portanto, aos poderes. Mas a maturidade intelectual e o senso crítico da comunidade que poderiam ser resultantes dele
\end{abstract}

\footnotetext{
${ }^{38}$ La matière sonore, les techniques d'enregistrement et de diffusion audio jouent un rôle au moins aussi important que le visuel, mais soulève des questionnements spécifiques. Le port du casque audio engendre un paradoxe évident : alors que l'écoute théâtrale est traditionnellement collective - le public apparaît comme le 'grand résonateur' dans le phénomène de co-présence scène-salle - , les écouteurs génèrent une expérience privée, qui renferme l'auditeur sur lui-même et l'isole de ses semblables, provoquant de facto une dissolution du collectif formé par la salle (tradução minha).
} 
De fato, se os parâmetros usados para analisar tais modalidades cênicas contemporâneas forem o fortalecimento de uma força comunitária, engendrada por meio de uma maturidade intelectual e fundada no senso crítico de certa comunidade, as aquisições serão mesmo muito precárias. O que parece concreto dessas proposições contemporâneas é a articulação dos dispositivos cênicos em resposta ao modo de vida e aos efeitos criados pelas novas tecnologias no nosso cotidiano. Talvez seja apenas uma maneira de fazer com que os espaços de ficção conversem com os espaços de realidade, convidando os cidadãos a refletirem sobre suas escolhas. É provável que a função da arte não seja mobilizar politicamente cidadãos para gerar grandes revoluções ou mesmo alguma maturidade intelectual. Mas se tais ações artísticas desencadearem reflexões e alterações, ainda que temporárias, no senso crítico do espectador, tais experiências terão sido válidas o suficiente.

O mesmo ocorre em No visa for this country, da Cie. Sous $\boldsymbol{X}$, já analisada dentro da modalidade fuga no capítulo anterior, na qual a presença dessa coralidade é exacerbada, pois assim como a personagem principal é espelhada, o público também se vê espelhado em um momento crucial da encenação. $O$ encontro dessas duas coralidades espectadoras espelhadas em determinada rua poderia configurar-se de maneira espetacular, não fosse o aspecto pacato da periferia de Paris, onde a peça foi apresentada. Se se tratasse de um grande centro urbano, ou de uma rua com maior circulação, quando dois grupos de quase trinta pessoas se encontram, todos usando fones de ouvido, tal acontecimento não passaria despercebido.

Anne Gonon apresenta algumas limitações relacionadas a essas escrituras de teatro sonoro em deambulação. De acordo com a autora, a presença do dispositivo supera a exploração do espaço no qual o artista pretende mergulhar o espectador, impedindo que uma dinâmica imersiva se instaure. $O$ tempo cronometrado e a condução precisa do espectador o extrai da ficção, aproximando-o da experiência de ouvir um audioguia em um museu. Gonon considera a cronometragem arriscada, sobretudo nos casos onde há intervenções de atores - como acontece com essa criação de Alix Denambride, No visa for this country - pois ela delimita o tempo da recepção ao impor um ritmo ao espectador, definido por regras rigo-

\footnotetext{
${ }^{39}$ La responsabilité que ce type de théâtre donne au spectateur est nettement plus grande que dans un théâtre de fiction. Le spectateur est invité, voire forcé, à mettre en rapport deux cadres de référence : celui de l'expérience théâtrale et esthétique, et celui du citoyen bien informé. Ces deux cadres ne coïncident pas toujours et l'événement théâtral n'aide pas à réconcilier ces deux horizons interprétatifs. [...]. En effet, cette dramaturgie du réel n'est qu'un cas exemplaire des difficultés que le théâtre contemporain a à s'affirmer comme une force communautaire. Le message sous-entendu de tous ces spectacles est un cri politique, sincère mais mal ciblé, soit exprimé comme partage d'ignorance, soit exprimé comme didactisme, soit exprimé comme appel naï à la convivialité. Ce cri politique, il vise l'indifférence des citoyens et donc les pouvoirs. Mais la maturité intellectuelle et le sens critique de la communauté qui en résulteraient restent des acquis très précaires (tradução minha).
} 
rosas para a fruição do percurso sonoro (GONON, 2016, p. 106).

No seu ponto de vista, essa combinação de dispositivos (fone + percurso), marcada pelo peso da tecnologia e pela desmaterialização do espetáculo ao vivo, resulta para o público em uma experiência extremamente controlada pelo artista. De fato não se trata da exploração livre das ambiências de um percurso, como acontece numa deriva, onde o próprio trajeto se constitui como resposta às atrações ou repulsas percebidas ao longo do caminho. Além disso, estamos diante de uma modalidade artística que rompe com a ideia de recepção. De um lado, o que esse tipo de criação apresenta são faixas sonoras para acompanhar percursos a pé, de modo que este seja o único meio de interação entre o artista e o público. Em muitos casos, o artista nem mesmo se faz presente; ele não constrói visões, ele as revela, ele as recorta do espaço do real ou ele as narra, ele as inventa na forma de ondas sonoras. Por outro lado, não cabe ao espectador receber algo, mas acionar seus sentidos na medida em que se põe em deslocamento sob a forte influência de vozes, músicas e ruídos. Cabe a ele a formulação de uma experiência particular, resultante do cruzamento de recortes espaciais com uma faixa sonora, em confronto com a experiência que cada um consolida ao percorrer um determinado caminho. Por isso, ainda que o espectador complete a criação com a mobilidade do seu corpo, o tempo de fruição de um audiotour deve ser mesmo marcado, assim como o tempo de um filme é definido pela duração dos planos e pela montagem.

No visa for this country não se configura como uma composição site specific, pois a narrativa ficcional se vale de elementos comuns a diferentes contextos urbanos: um estacionamento de um edifício, um parque, um supermercado. Desse modo, a Cie. Sous $X$ pode itinerar por diferentes cidades, ajustando os tempos e a dramaturgia de seu roteiro e propondo um percurso sonoro colado à situação ficcional. A narrativa emerge tanto das palavras quanto do som. A esse respeito, Christophe Modica, criador da faixa sonora, afirma que há aspectos que não são evidenciados pelo texto. "A seus olhos, o som não tem vocação de 'acentuar ou indicar uma tensão dramática', o que o aproximaria bastante do uso clássico da música no cinema, mas de 'atribuir profundidade ao assunto'" (GONON, 2016, p. 106) ${ }^{40}$.

O mesmo não ocorre com La culpa la tiene Niemeyer: a última trilha de J.F., audiotour composto pelo coletivo argentino BiNeural MonoKultur, tendo como ponto de partida um recorte central da cidade de São Paulo. Trata-se, portanto, de um audiotour ficcional criado em site specific que não pode ser realizado em outra localidade. O percurso foi criado em 2007 para a Mostra de Artes do SESC, promovendo o encontro dos artistas do BiNeural com um dramaturgo e dois atores brasileiros. Saindo do SESC Consolação, cada espectador indi-

\footnotetext{
${ }_{40}$ À ses yeux, le son n'a pas vocation à "accentuer ou indiquer une tension dramatique", ce qui le rapprocherait trop d'un usage classique de la musique au cinéma, mais à "donner de la profondeur au propos" (tradução minha).
} 
vidualmente, à medida em que dá início ao percurso, passa a ser chamado de Gregório e a ser guiado pelo detetive Guedes. É ele quem dá, ao mesmo tempo, o percurso do passeio do espectador e as diretrizes de uma investigação, que visa encontrar uma moça desaparecida.

Você tem que fazer agora o que eu te peço. Desligue o celular, não troque ideia com ninguém e escute muito atentamente. Fique ligado nos carros, nos semáforos, porque um assistente ferido é a última coisa que eu preciso nesse momento. Está bem? Podemos começar? Posso contar com você? ${ }^{41}$

Guedes é um detetive sarcástico, com trejeitos de um personagem de Nelson Rodrigues, que coloca Gregório para perseguir os rastros dessa moça recém chegada à cidade de São Paulo, que "insiste em desaparecer". Porém, antes da perseguição começar, ele se dirige ao espectador localizando-o dentro do espaço-tempo diegético. O espaço coincide com o espaço real, pois a ação se passa na mesma cidade na qual se encontram os espectadores, embora o tempo seja outro. Na verdade, a dramaturgia nos posiciona na temporalidade da investigação empreendida pelo Detetive Guedes e por seu assistente, um momento intermediário entre o dia em que cada pessoa experimenta o audiotour e o último dia de que se teve notícias da moça. Ao dirigir-se a Gregório, seu assistente, o detetive Guedes introduz o espectador no jogo, alertando-o sobre certos riscos que ele corre no plano do real, sem interromper seu diálogo no plano da ficção.

Vez ou outra, o detetive-narrador convida seu ouvinte a observar alguns aspectos da cidade, como por exemplo a visão do trânsito no Minhocão (Elevado Presidente João Goulart), visto da Avenida Consolação. Tal visão o leva a refletir sobre o número de pessoas que morrem por dia em São Paulo. São irrupções do real dentro do contexto ficcional, fazendo ecoar pensamentos sobre as condições de vida nesta cidade, como um pano de fundo no qual aquela perseguição acontece. Elas não são suficientes para se considerar essa criação uma amostra de arte contextual; parecem lampejos de realidade, pistas para um reflexão futura, posterior ao mergulho no caso da moça desaparecida.

Na faixa de som, o que se ouve é uma costura de fatos reais e lendas urbanas, cuidadosamente posicionados nesse território, de modo a colocar em diálogo a arquitetura e as relações humanas. Pela Avenida Consolação, há uma pausa na Igreja, um desvio pela Praça Dom José Gaspar até o ponto final do percurso, o topo do Edifício Copan, de onde se tem uma vista espetacular da cidade. Em meio à narração do detetive, que apresenta o caso para Gregório, ouvem-se os relatos da moça desaparecida, que veio até São Paulo para encontrar seu namorado Paulo. Aparentemente, ela registrava em um mp3 suas tentativas de

\footnotetext{
${ }^{41}$ Transcrição do trecho inicial do audiotour, disponivel em: <http://www.bineuralmonokultur.com/web portugues/proyectos/audiotourficcional/audiotourFiccional_LaculpalatieneNiemeyer.html>. Acesso em: 27 jan. 2017.
} 
encontrá-lo no caos da cidade grande, na qual ela encontra um mendigo que fala consigo mesmo em espanhol. A moça tem a impressão de que ele conhece Paulo, mas na verdade

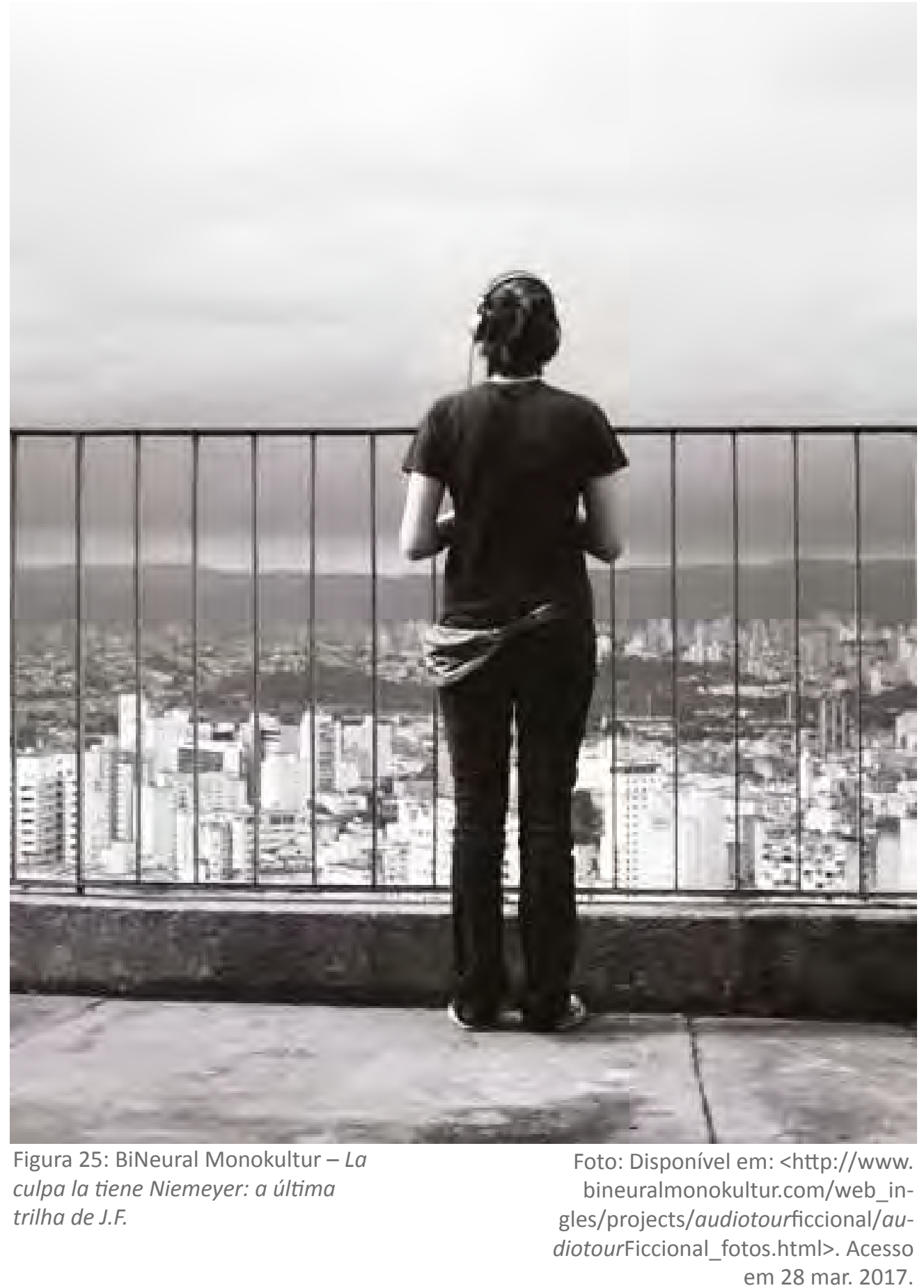

ele cita alguns arquitetos e afirma que a culpa é de Niemeyer, numa referência direta ao título do audiotour. Tanto a história quanto o percurso se configuram nos arredores do Copan, um projeto emblemático de Oscar Niemeyer, que será observado pelo espectador de longe, de dentro e de cima. É curioso que o narrador o aponte pela primeira vez como um prédio feio, arredondado, grandioso e cheio de quitinetes. E em outro momento, o mesmo narrador, ao observar esse que é um dos principais cartões postais de São Paulo, cita uma 
poesia de Niemeyer, na qual ele revela o princípio de seu traço: "Não é o ângulo reto que me atrai, nem a linha reta, dura, inflexível, criada pelo homem. O que me atrai é a curva livre e sensual".

Do alto do Copan acontece o desfecho da história, enquanto o narrador mantém o jogo entre a realidade e a ficção. "Eu já sei que é uma vista impressionante, mas não vá perder a atenção por conta disso. Cuidado com os canos no chão" ${ }^{42}$. E em seguida, convida o ouvinte a observar o relevo dos prédios e as montanhas ao longe, a visão mais próxima do que era o horizonte de São Paulo há 100 anos atrás. Se imaginarmos uma escala que leva do real ao ficcional dentre os percursos sonoros analisados aqui, No visa for this country e La culpa la tiene Niemeyer, seriam os exemplares mais próximos do campo da ficção. Em ambos os casos, a cidade é a locação para a experiência vivida pelo espectador e o pano de fundo para uma história que se desenrola nesse terreno, concomitantemente a tantas outras. É como se a arte nos desse a possibilidade de ver e experimentar por alguns minutos o fluxo de pensamento ou uma fatia da vida de outra pessoa, ambas mulheres: a primeira em fuga e a segunda desaparecida.

Outro exemplo que retrata uma situação menos particular e aborda o contexto explorado de um ponto de vista mais social é La porte du non-retour [A porta do não retorno], de Philippe Ducros, dramaturgo da companhia canadense Hôtel-Motel ${ }^{43}$. Embora não se trate de um percurso no espaço urbano, pois o espectador porta fones de ouvido dentro de uma galeria, esse percurso deambulatório teatral e fotográfico [parcours deambulatoire théâtral et photographique ${ }^{44}$ retrata a viagem do autor, um estrangeiro, à República Democrática do Congo. Trata-se, portanto, de uma exposição de fotografias para ser contemplada enquanto se ouve um áudio veiculado em fones de ouvidos. Ducros percorreu o oeste da África até chegar à Etiópia, percurso que os espectadores, de certo modo, revivem imergindo nesse contexto de conflito extremo. Menos do que ter a sensação de que passeia pelo país africano, o que é compartilhado com o espectador é a observação de fluxos migratórios. O olhar que capta as imagens é de alguém em deslocamento, não habituado ao que vê, que estranha os cheiros, os sons e a lógica do lugar. Nada lhe parece familiar. O texto murmurado em nossos ouvidos foi escrito pelo mesmo viajante solitário que produziu as fotografias. Nessa condição, o viajante se volta para si mesmo, tecendo um monólogo que inclui sua voz e a da mulher que o espera e de quem ele progressivamente se afasta.

O título da ação [La porte du non-retour] remete aos monumentos encontrados nessa região da África em memória aos milhares de escravos deportados para a América. Os afri-

\footnotetext{
42 Transcrição de trecho do audiotour, igualmente disponível no link citado na nota anterior.

${ }^{43}$ A companhia foi criada em 2000 e é sediada em Montréal, no Canadá. O nome Hôtel-Motel remete às múltiplas viagens empreendidas pelo diretor artístico e dramaturgo Philippe Ducros como forma de inspiração para suas criações. Maiores informações no site: <http://hotelmotel.qc.com/>.

${ }^{44}$ Modo pelo qual o artista nomeou sua criação, cujo texto foi inclusive publicado no formato dramaturgia.
} 
canos sabem que quem passa por essa porta nunca mais volta. Esse percurso pode ser considerado duplamente deambulatório. De um lado, há a perambulação do autor pela África dos campos de refugiados, dos êxodos urbanos, da violação dos direitos humanos, da guerra e da miséria, na qual boa parte da população também se encontra em estado erradio. Numa escala mais íntima, há ainda um desnorteamento vivido pelo autor, que diante dessa África passa a questionar suas escolhas, seu modo de vida, seus próprios caminhos. De outro lado, a deambulação do espectador pelo espaço da galeria, por intermédio do áudio e das fotografias, também o conduz a essa África dura e sofrida, um território outro ${ }^{45}$.

A deambulação dos espectadores é definida pela ordem dada às fotografias instaladas no espaço. Um conjunto de duas ou três fotos deve ser apreciado enquanto se ouve a faixa de número 1 do áudio que acompanha a exposição. E assim se repete durante todo o trajeto, com cada conjunto de fotos correspondendo a uma faixa sonora. Não se trata, portanto, de um audioguia convencional, como aqueles usados na maior parte das exposições, pois o texto veiculado não explica os detalhes de cada foto, como aconteceria com uma pintura ou escultura. Trata-se de um texto dramatúrgico, com relatos de viagem, diálogos e depoimentos das pessoas fotografadas. $O$ tom carregado da narração, associado à trilha sonora composta basicamente por músicas instrumentais, ilustra de maneira muito direta os climas propostos pela dramaturgia. Desse modo, o papel da música fica restrito à função de acompanhamento e reforço de certos climas já revelados pelo texto. A voz masculina fala sobre a viagem ao Congo, num movimento de idas e vindas entre o que o narrador vê e o que ele sente, o país no qual ele se encontra e o seu país de origem, as dificuldades enfrentadas ao longo de seu percurso e os dados estatísticos de que dispõe. Em alguns momentos, a narração é atravessada por diálogos do viajante com a pessoa amada, uma voz feminina a quem recorre nos momentos de maior aflição. Essa voz o questiona, o traz de volta ao lar e, em seguida, desaparece. Não há uma sequência linear de fatos, eles são expostos como os episódios embaralhados de uma viagem, em um movimento similar ao de alguém que mostra um álbum de fotografias.

A exposição é um bom exemplo de modalidade cênica que escapa da linguagem teatral, resultando em outra materialidade (assunto que será mais profundamente desenvolvido no capítulo 6). A combinação de um texto teatral - já publicado em formato de dramaturgia, ou seja, que se sustenta mesmo quando não apoiado nos dispositivos fones de ouvido e fotografias - com um percurso fotográfico, configura uma outra modalidade artística, que se vale da ação de caminhar como forma de sugerir a peregrinação do narrador viajante. Mesmo que caminhar seja uma ação já inserida no universo das exposições de arte, nas quais

\footnotetext{
${ }^{45} \mathrm{O}$ texto foi baseado no programa do percurso deambulatório teatral e fotográfico, na fortuna crítica sobre o trabalho e no vídeo da entrevista concedida pelo autor à imprensa, organizado pelo Festival de Avignon de 2013.
} 
caminha-se bastante, nesse caso essa ação vem acompanhada de uma peça dramatúrgica em áudio. Há um deslocamento da função dos atores presentes em um acontecimento cênico para as figuras retratadas nas fotografias, enquanto a voz posicionada nos ouvidos dos espectadores funciona como a mesma voz over, já mencionada aqui, oriunda da linguagem cinematográfica. Como vemos, nesse caso, as modalidades artísticas se misturam e cabe ao artista nomear o tipo de experiência que propõe.

É preciso destacar também a ausência de convívio (no sentido atribuído por Jorge Dubatti, no qual o acontecimento depende de um encontro de presenças ${ }^{46}$ ), tanto do artista com o público, quanto dos componentes do público entre si. Em La porte du non-retour, não há nenhuma convivência, já que cada espectador está isolado acusticamente pelos fones de ouvidos e tem controle sobre a duração e o tempo de fruição de sua experiência. Cada pessoa inicia seu trajeto pelas fotografias no seu tempo e não há nem mesmo concomitância temporal ao percorrer o espaço. Além disso, o espectador tem a liberdade de subtrair algum trecho do texto, editando-o de acordo com seu interesse, pois o aparato tecnológico Ihe dá esta possibilidade.

Philippe Ducros, autor de La porte du non-retour, afirma que gostaria de se infiltrar no espectador lentamente, por meio do áudioguia, para colocá-lo diante dessas realidades difíceis de imaginar, além de falar de uma migração mais íntima, vivenciada. Ele opta por uma estrutura de monólogo interior, revelando-se um viajante arrebatado pelo conflito que gerou mais números de mortos desde a II Guerra Mundial, cujo ponto alto se dá quando nos deparamos com fotos de mulheres congolesas vítimas de estupro. Como se sabe, na República Federativa do Congo a violação sexual se tornou epidêmica. Assim, é impactante a história de uma mulher, mãe de muitos filhos de pais desconhecidos, que se angustia com a possibilidade de um deles ser portador do HIV. Quando ela é questionada pelos médicos que deveriam acolhê-la, é possível compreender as sensações do autor frente às impunidades e aos maus tratos sofridos pelas pessoas retratadas. Nesse ponto da deambulação, o autor atinge verdadeiramente seu objetivo de não apenas expor cenas diante dos espectadores, mas de mergulhá-los no interior das cenas, por meio de audioguias. Ao dar voz a personagens invisíveis da História, revela-se a potência dessas estruturas como teatralidade, pois o espectador é convidado à experiência da solidão. Sozinho, sem o apoio do público como coletivo de espectadores, deve enfrentar essa África do abandono, do êxodo, da sobrevivência.

Os exemplos evocados nessa parte do texto evidenciam como o coeficiente imersivo pre-

\footnotetext{
${ }^{46}$ Jorge Dubatti partiu dos estudos de Florence Dupont sobre as práticas orais na cultura greco-latina, particularmente o symposion e o banquete. A oralidade é um fenômeno imerso nas situações de convívio, pois a transmissão ao vivo e in situ dos textos implica, no mínimo, a presença de outros ou de um grupo de ouvintes, estimulando vínculos sociais. No entanto, Dubatti não reduz o teatro ao objeto textual; ao contrário, ele o define como práxis, ação humana.
} 
sente em cada audiotour pode ser variável. Em La porte du non-retour, o artista se interessa por esse tipo de experiência, sendo que seu posicionamento dentro de uma galeria colabora para que o espectador tenha a impressão de imergir em um cenário africano. Nos casos mencionados anteriormente, No visa for this country e La culpa la tiene Niemeyer, há uma imersão no contexto da ficção que é constantemente friccionada com a visão da cidade real, revelada como uma camada da enunciação. Tanto a moça em fuga da Cie. Sous $X$, quanto a moça que desaparece do BiNeural, reagem ou respondem às opressões decorrentes da vida nessas cidades, às dificuldades identificadas nas relações humanas tecidas nesses contextos, aos desejos e às dificuldades de se comunicar tão presentes nesse modo de vida urbano e contemporâneo. Por esse motivo, o que o Rimini Protokoll consegue, ao manter apenas sutilmente uma estrutura ficcional, é trazer a cidade e a discussão sobre o real para o primeiro plano da experiência. Nesse sentido, à medida em que a ação artística nos aproxima da cidade vivida, mais ela se imbui de uma função questionadora, funcionando como detonadora de reflexões complexas sobre os nossos modos de agir e conviver na contemporaneidade. 


\section{> capítulo cinco: travessias de grandes territórios, maneiras poéticas de (con)viver}

A minha forma de arte é a viagem feita a pé na paisagem ... A única coisa que temos que tomar de uma paisagem são fotografias. A única coisa que temos de deixar nela é o rastro dos passos.

Hamish Fulton

A travessia vai costurando a cidade no meu imaginário, ligando pontos que antes ficavam boiando. Olívia Niculitcheff

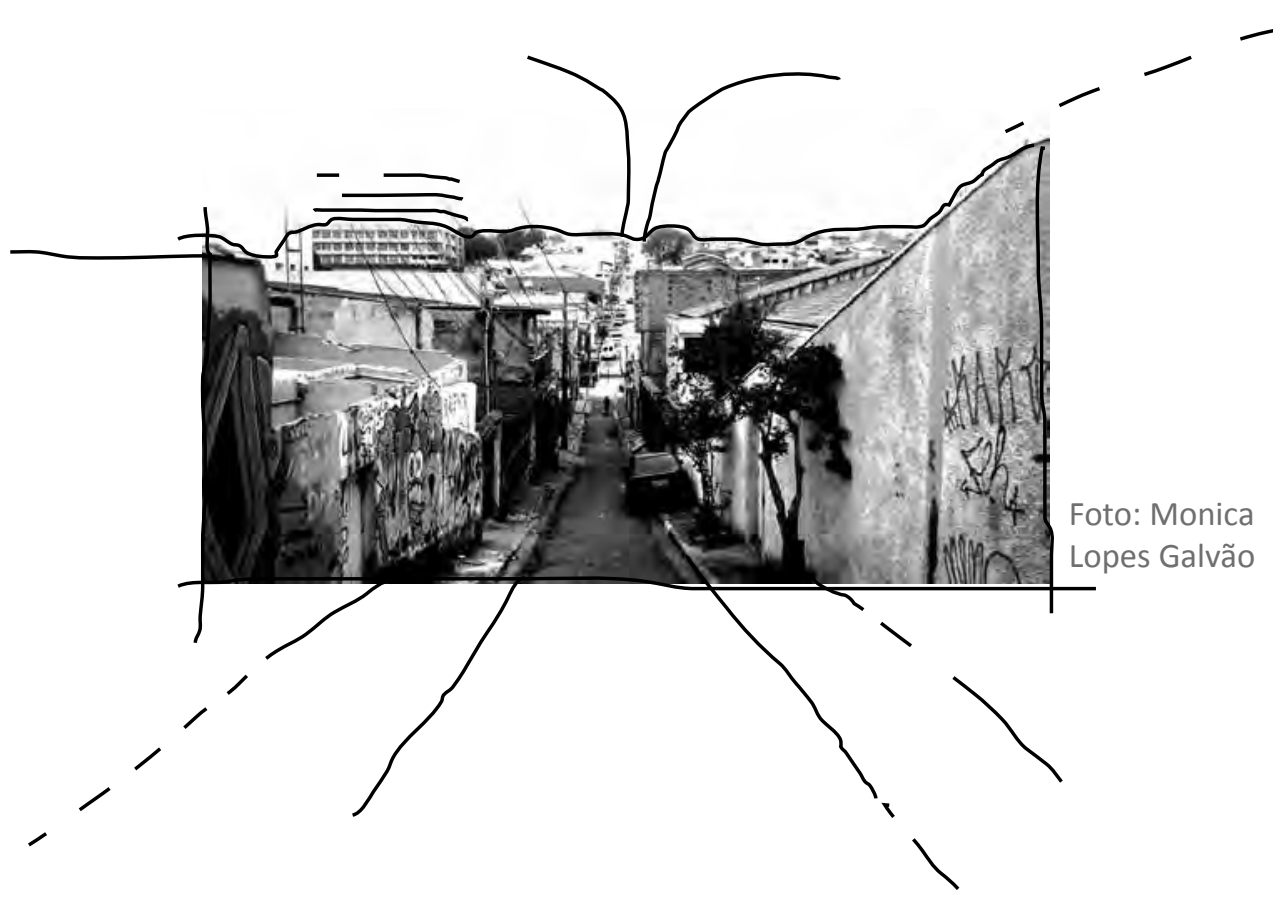

[nota sobre o capítulo: no presente capítulo apresento a noção de travessia, para evocar ações desde o início da land art nos anos 1960 até a atualidade na qual artistas ou grupos de pessoas quaisquer caminham longas distâncias atravessando vastos territórios a pé. As travessias se opõem diretamente às derivas, por se constituírem como um percurso objetivo. Não se trata apenas de uma transposição espacial, mas também do compartilhamento de um uso do tempo, seja como meditação para aqueles que caminham sozinhos, seja como exercício da convivência, para aqueles que caminham acompanhados. Apresento também algumas ações cidadãs nas quais territórios são atravessados de diferentes formas (como festa, cortejo ou manifestação), mas sempre evocando a força de ocupar o espaço público em conjunto.] 
[travessia]: deslocamento com o objetivo de percorrer um território pré-definido. $O$ percurso construído em uma travessia pode se configurar como uma linha reta ou um contorno de uma cidade ou de uma região. Embora o trajeto ou a ideia do trajeto seja preconcebido, há variações de tempo. $O$ espaço dessa prática ultrapassa os limites da cidade, podendo acontecer em zonas menos urbanizadas e no campo. Uma travessia pode ser realizada só ou na companhia de uma ou mais pessoas. Pode ser considerada também como uma figura de linguagem.

\section{> I. land art: caminhada que se inscreve na terra}

Um ponto de partida possível para se falar em travessia é a land art, pela abrangência dessa modalidade artística. Trata-se de uma arte da extensão, na qual se identifica travessias em larga escala, abrangendo terrenos habitados ou não. Na land art, usa-se a terra como suporte para uma inscrição artística, sendo que muitas vezes o foco dessa modalidade está na produção gráfica e não necessariamente no ato de caminhar. Essa 'arte da terra' está intimamente associada à noção de viagem, tanto que suas rotas são trajetos entre cidades ou em amplos terrenos baldios. Quando me refiro à travessia, penso em atravessamentos de territórios, sem a obrigatoriedade de se deixar algum rastro marcando esse percurso. A travessia é tomada aqui como uma modalidade que ultrapassa o território urbano, podendo utilizar-se de terrenos baldios ou escapar para além das fronteiras da cidade. Isso não quer dizer que os espaços atravessados tenham sempre as mesmas características. Há exemplos de travessias de grandes cidades, passando apenas pelos terrenos baldios, pelos espaços lisos desse território, assim como há outros que passam por espaços estriados, habitados e densos demograficamente.

Para Gilles Tiberghien - autor do prefácio do livro Walkcapes, de Francesco Careri - a origem da land art remonta ao relato de viagem de Tony Smith pela New Jersey Turnpike, uma estrada em construção na periferia de Nova York. É essa viagem on the road que teria inspirado uma série de caminhadas pelos desertos e periferias urbanas desde o final dos anos 1960. Esse autor aprofundou seus estudos sobre o caminhar na história da land art, passando pela investigação da arte minimalista, pela escultura e pelas relações entre natureza, arte e paisagem, até chegar ao estudo da conectividade dos neurônios (hodologia). Nessa viagem de Tony Smith, ele "decide entrar no canteiro de obras da autopista e percorrer de carro a faixa preta de asfalto que atravessa, qual uma cesura vazia, os espaços marginais da periferia estadunidense" (CARERI, 2013, p. 111). Ao experimentar essa contravenção, o artista sente uma espécie de "êxtase inefável", associado por ele ao fim da arte. Ele inau- 
gura assim uma longa discussão sobre a estrada como paisagem artificial, como construção humana, questionando a natureza estética do percurso. Afinal, a estrada poderia ou não ser considerada uma obra de arte em grande escala? Careri, nesse ponto, desdobra essa pergunta em múltiplos questionamentos: a estrada pode ser considerada como objeto, como ready made, como experiência, como espaço em si? E como ato do atravessamento?

Duas pistas se abrem. De um lado a estrada pode ser vista como o objeto atravessado, como construção arquitetônica. De outro, o ato de atravessar é tomado como experiência, como atitude que configura uma forma. Segundo Careri, essa experiência não representa o fim da arte, mas um momento de virada no pensamento sobre a arte, que teria acarretado a saída dos museus e galerias, a exploração dos espaços públicos, a retomada dos espaços vividos e a ocupação de grandes dimensões da paisagem. A partir desse momento, "a prática do caminhar começará a transformar-se em verdadeira e própria forma de arte autônoma" (Ibid., p. 112). O autor cita dois artistas que nos ajudam a compreender essa passagem do ato do caminhar como atividade primária e cotidiana para uma prática artística. Ele compara os trabalhos de Carl Andre, para quem a escultura ideal é um estrada, com as caminhadas de Richard Long. Os trabalhos mais bem sucedidos do primeiro são estradas criadas para o espectador percorrer, ou seja, esculturas planas que convidam a uma experiência, estradas que precisam ser percorridas.

Dentre as ações de Richard Long, uma das mais conhecidas $\boldsymbol{A}$ line made by walking (1967) constitui-se da imagem de uma linha desenhada pelo efeito de uma caminhada repetitiva sobre um terreno gramado. "A imagem da grama pisoteada contém em si a presença da ausência: ausência da ação, ausência do corpo, ausência do objeto" (Ibid., 2013, p. 125). A obra é o resultado da ação de um corpo sozinho, sem a ajuda de nenhum equipamento, de nenhuma tecnologia e que não foi documentado em ação. $O$ corpo está ausente e o objeto criado - o percurso - por mais que tenha sido registrado, também está em vias de desaparecer, pois essa marca só dura o tempo de uma poda. À medida em que a grama cresce, o percurso desaparece. A obra se apresenta como síntese e se restringe, quando entra em contato com o espectador, à alteração sutil e temporária de um terreno. Trata-se de uma experiência sem objeto, pois ela se configura pelo ato mesmo de caminhar. Sua arte se faz caminhando. Essa ação será retomada no próximo capítulo, quando discutirei as outras materialidades decorrentes das ações performativas.

É no sentido dessa arte sem objeto, que o mesmo Tiberghien, ao comentar o conhecido texto de Michael Fried "Art and Objecthood" [Arte e a sua condição de objeto], de 1967, afirma que a teatralidade estaria no fato dos artistas minimalistas se colocarem em relação aos espectadores, em detrimento de proporem obras com formas reconhecíveis. Desse 
Figura 1: Richard Long - A line made by waking
Foto: Disponível em: <http://www. tate.org.uk/art/artworks/long-a-linemade-by-walking-p07149>. Acesso em: 15 set. 2016 .

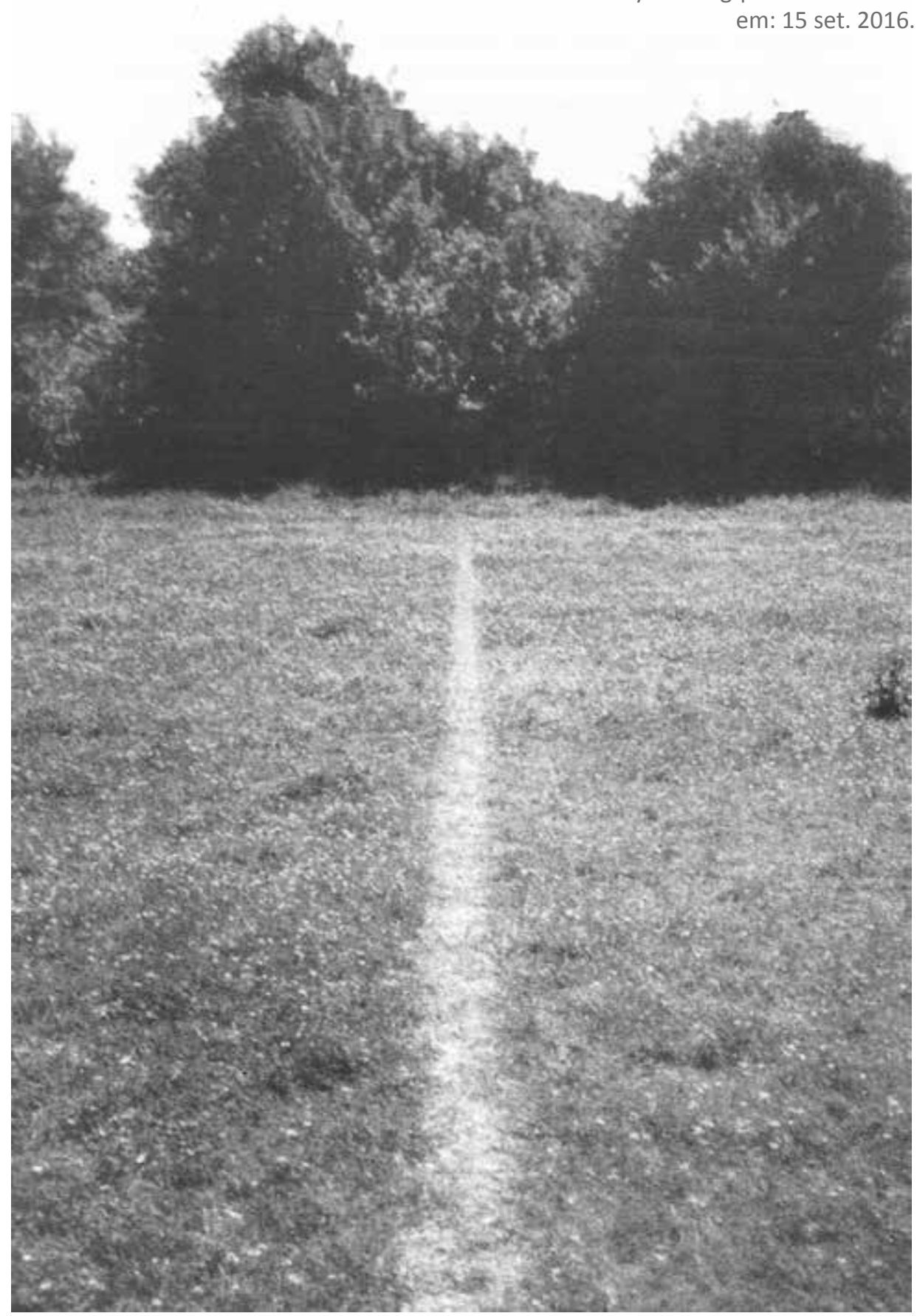

modo, essa arte minimalista ${ }^{1}$ (tida por Fried como literalista) - que configura percursos, ao mesmo tempo, como construção e como experiência - apresenta-se na forma de esculturas em grande escala, de ações sem objeto ou de objetos que apenas tangenciam a arte. A arte minimalista adota a objetidade, ou seja, a configuração de objetos que não são formas, que não representam, nem criam possibilidades de leituras e que, necessariamente, criam

\footnotetext{
1 A arte minimalista está vinculada à arte conceitual e à arte povera. Trata-se de um movimento que surgiu em Nova York, na década de 1960, tendo o legado de Marcel Duchamp como referência, bem como o construtivismo russo. Esses artistas exacerbam a condição de objeto da obra de arte, negando a tradição de suportes estáveis da pintura e da escultura modernistas e voltando-se para as relações entre observador e obra.
} 
presenças ou efeitos de presença. "Diz-se que uma coisa é dotada de presença quando ela exige do observador que a leve em consideração, que a leve a sério" (FRIED, 2002, p. 136)².

O autor também afirma que "a experiência da arte literalista [leia-se, minimalista] é a de um objeto em uma situação - que, virtualmente por definição, inclui o observador" (Idem, p.134). Nesse sentido, tais experiências estariam centradas no corpo, uma vez que é ele que vive as experiências; muitos exemplos de arte minimalistas têm o corpo como referência para a definição de suas dimensões. Tony Smith chegou a afirmar, sobre uma de suas esculturas, que não a realizou maior que o observador pois não queria fazer um monumento; também não a realizou menor que o observador, porque não se tratava de um objeto. Esse artista diz ainda que não pensa em suas obras como esculturas, mas como presenças. Nesse artigo, Michael Fried dá especial atenção ao relato de viagem de Tony Smith, associando-o ao conceito de teatralidade e afirmando que as artes se degeneram à medida em que se aproximam do teatro, uma linguagem que, segundo o autor, carece de especificidade. Fried considera o experimentalismo um risco para as artes, pois a interdisciplinaridade pode unificar todas as linguagens, tornando impossível a dissociação entre as disciplinas.

\footnotetext{
Esse trajeto de carro foi uma revelação para mim. A estrada constituía uma grande parte da paisagem artificial; mas não se podia qualificá-la como obra de arte. Por outro lado, essa viagem fez por mim algo que a arte jamais fizera. Aquilo que eu não sabia como chamar produziu, a seguir, o efeito de libertar-me de um grande número de opiniões que eu tinha acerca da arte. Parecia que havia lá uma realidade que a arte nunca expressara. A experiência que eu tinha vivido na estrada, por mais precisa que tivesse sido, não era reconhecida socialmente. Eu pensava comigo: claro que é o fim da arte. A maioria dos quadros pareciam petrificadamente pictóricos depois disso. Era impossível pôr aquilo num quadro, era preciso vivê-lo. (WAGSTAFF apud CARERI, 2013, p.115)
}

Para Fried é espantoso que Smith tenha compreendido essa experiência como a anunciação da morte da arte e não como um desnudamento de sua essência. Diferente das ações analisadas aqui, não se trata de uma caminhada, mas de uma rota percorrida de automóvel, cujo interesse para a presente pesquisa reforça a ideia de percurso como objeto arquitetônico. A estrada, ao ser percorrida, configura-se como um objeto distinto daquele inicial, mesmo que não haja espectadores presenciando o fato. O já citado Tiberghien situa essa ação num espaço aquém do simbólico, revelando o que está em jogo nesse exemplo: a oposição entre experiência e representação. A ação realizada na calada da noite transforma simbolicamente o território, sem deixar rastros nem criar nenhum objeto palpável. Segundo Fried, é como se a própria experiência fosse tomada como objeto. Este autor vê teatralidade nessa

\footnotetext{
2 Utilizei aqui a tradução de Milton Machado para o português do texto de Michael Fried, publicada na Revista do Programa de Pós-Graduação em Artes Visuais da Escola de Belas Artes da UFRJ, 2002.

3 Trecho de entrevista realizada por Samuel Wagstaff: "Talking with Tony Smith", Artforum, dezembro de 1966.
} 
ação efetiva, calcada no corpo e na experiência, na ausência de espectadores e na falta de representatividade. Sem pretender opor esses dois conceitos operatórios (a teatralidade e a performatividade), gostaria de chamar a atenção para a performatividade presente na estrada escura de Smith. $O$ enfoque na ação, na transformação de um território pela alteração de seu uso, a relação com o espaço real e o risco iminente sinalizam o rompimento com o modernismo, o hibridismo de linguagens, a recusa à representação e ao artifício. O que Smith experimenta e Fried condena, devido à teatralidade do ato, que abdica de objeto, é algo próprio ao que contemporaneamente entendemos por performance.

É justamente essa linguagem que começa a ser experimentada a partir da década de 60 como fruto de um grande experimentalismo e hibridismo entre as artes. Graças a essas características, recorrentes nas mais diversas experimentações, a performance permanece ainda hoje como uma linhagem múltipla. Há quem associe o seu surgimento aos movimentos das artes cênicas pós vanguardas históricas. Há quem o associe à retomada do corpo ou à inclusão do corpo nas artes plásticas pós segunda guerra mundial. Há quem reconheça a performance desde a origem do mundo até as ações mais banais e cotidianas. Por isso, a performance pode ser relacionada com todas essas linguagens, configurando-se como uma indisciplina, tamanha a abrangência do termo e das ações que cabem sob essa mesma definição. Entretanto, parece-me incoerente reivindicar a essência dessa linguagem, como se fosse possível distinguir uma performance pura, sem resquícios de teatro, de música ou de artes visuais. Quando o assunto é performance é preciso usar outras ferramentas teóricas, pois ela definitivamente não cabe como linguagem à parte, isolada e sem trocas com outras modalidades artísticas. A membrana da performance é tão permeável, que ela acaba se apresentando como uma linguagem expandida, movediça e solúvel.

De volta à viagem de Smith, não parece pertinente afirmar que não haja teatralidade ali, pois "a teatralidade tem a ver também com o corpo, as pulsões, os desejos e portanto com a performatividade" (FÉRAL, 2012, p. 11)4. Ao invés de sublinhar a incompatibilidade desses dois paradigmas, a pesquisadora enfatiza sua complementaridade. Ela continua: "a performatividade se inscreve realmente na teatralidade que, por sua vez, a determina" (Ibid. $)^{5}$. Nesse sentido, Michael Fried é considerado posteriormente como um guardião da essência da forma. Em oposição a ele, Robert Smithson compara a estrada com a estrutura de uma frase, como se o território fosse o meio onde a ação se inscreve: uma carta em três dimensões.

Ao estudar ações fundadas no ato de caminhar, busco reconhecer o terreno das artes como resultante da convivência e do intercâmbio entre linguagens. Tal intenção não impede que

\footnotetext{
4 Car la théâtralité a aussi à voir avec le corps, les pulsions, le désir et donc avec la performativité (tradução minha).

${ }^{5}$ La performativité s'inscrit réellement dans la théâtralité qui la détermine à son tour (tradução minha).
} 
categorias sejam definidas, desde que se revele o quanto elas são porosas e o quanto cada um dos exemplos analisados e citados nos últimos capítulos poderiam migrar entre uma categoria e outra. Reconhecer teatralidades e performatividades dentro dessas travessias é também uma maneira de assumir o campo expandido das artes cênicas, em constante diálogo com outras linguagens artísticas. É evidente, portanto, que podemos distinguir teatralidades em ações que poderiam constar dentro dessa categoria, como por exemplo a ação em que William Pope L. rasteja-se pela cidade de Nova York vestido de Super Man, que será analisada a seguir. E, ao mesmo tempo, podemos identificar performatividades diversas nos exemplos de travessia reunidos aqui.

\section{> II. travessias: recortar a cidade com os pés}

A cidade revela-se um espaço do estar inteiramente atravessado pelos territórios do ir. Francesco Careri

Apresento a seguir algumas ações identificadas como travessias, longos percursos que transformam o corpo em um instrumento de medida do espaço e do tempo. Diferente da deriva, a travessia parte de um planejamento estratégico, configurando-se inicialmente como um plano de atravessamento. Ela se define como um corte ou um recorte da cidade, de um bairro, de um território pré-definido, ou seja, o espaço em uma travessia é definido a priori. O tempo, em contrapartida, é definido a partir da ação do andar. Há travessias que duram horas e outras que duram dias. Em todos os exemplos analisados os deslocamentos são realizados a pé, como uma forma de confrontar ambientes e realidades sociais particulares. Tratam-se de formas variadas de conviver, de desviar, de subverter os usos, de se apropriar metaforicamente, de habitar uma cidade, de encontrar e conversar com as pessoas que cruzam o caminho e de recortar a cidade com os pés.

Um artista que realizou inúmeras ações deambulatórias no espaço público, e por esse motivo foi mencionado diversas vezes nesta tese, é o belga Francis Alÿs. Algumas de suas ações se caracterizam pelas marcas indicando o percurso por onde passou, chamando a atenção para a construção do trajeto como elaboração artística, sem enfatizar o ato do atravessamento do território. Em 1995, o artista esteve em São Paulo com The Leak, ação paradigmática de Alÿs, reproduzida em diferentes contextos. Ele sai da galeria e se perde pela cidade carregando uma lata de tinta furada, de onde sai um fio branco marcando seu trajeto. Quando a tinta acaba é a linha branca desenhada por ele mesmo no espaço público que o ajuda a reencontrar o caminho de volta à galeria. Nesse caso, trata-se de uma ação híbrida, uma deriva que ganha ares de travessia, pois é a errância do primeiro momento que define o percurso que será percorrido na volta. Ou seja, pode-se dizer que o artista agiu taticamente em todos os momentos dessa ação, abrindo mão de todo o pensamento estratégico. 
A partir da realização de sua proposta, o performer propõe uma reportagem na qual ele discorre sobre o vivido, de tal modo que é possível compreender suas intenções e conhecer os meios adotados por ele em suas deambulações. Alÿs trabalha sobre a noção de real, indispensável quando se fala em reportagem. As interrogações do artista sobre o real refletem seu questionamento a respeito da arte enquanto obra. Ele coloca em jogo elementos que não correspondem à lógica da arte, mas da realidade, como por exemplo: seu deslocamento, a perda das referências espaciais que o levam a se perder, a velocidade e os encontros ocasionais ocorridos ao longo do percurso.

Figura 2: Francis Alÿs - Green Line

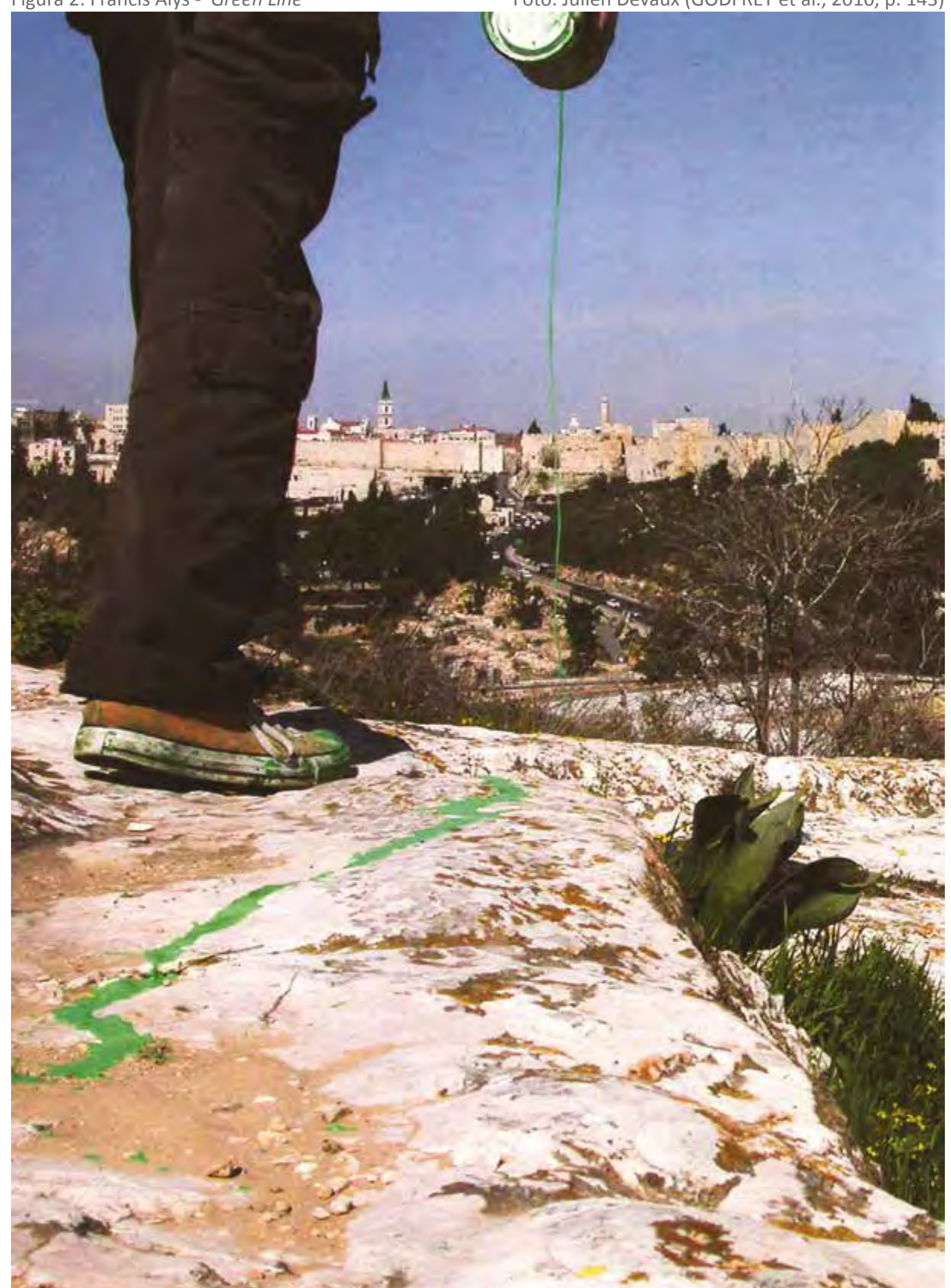


O caminhar, o deslocamento, intervêm na criação de Alÿs como ferramentas para reagenciar dispositivos urbanos, maneiras de fazer que produzem pontos de vista sobre a cidade e que, no final das contas, permitem elaborar, construir um olhar. O que ele chama de fábula é esse objeto fluido e impactante que descreve uma situação, um contexto, os faz ver, colocando uma distância entre o movimento realizado, consumado, e a megalópole (...). Se o real é um movimento, um processo, trata-se, enquanto pedestre, de produzir seu próprio deslocamento para integrar esse universo, e para poder igualmente e verdadeiramente tomá-lo para si (DAVILA, 2002, pp. 100-101). ${ }^{6}$

Ao se colocar em situação, deslocando-se de diferentes maneiras na cidade, Alÿs intervém no nosso olhar sobre esse contexto. Em São Paulo, com seu percurso de saída e de volta para a galeria, ele propôs uma conexão entre a cidade e os espaços da arte. Para o artista, caminhar é deixar o mundo da arte para reencontrar a vida, colocando em questão o objeto, que ele considera supérfluo, pois se dilui na cidade. A fábula que a interferência do caminhar desse artista constrói fica ainda mais evidente quando essa ação é reperformada em Jerusalém, no ano de 2004. Sob o título de Green line, Alÿs caminhou ao longo da antiga fronteira entre Israel e Cisjordânia, vertendo um fio de tinta verde onde há quarenta anos havia uma cerca, cujos vestígios foram cuidadosamente apagados com a ocupação dos territórios palestinos por Israel. $\mathrm{O}$ artista refresca a memória daquele povo sobre essa antiga demarcação territorial, proveniente de um armistício. Essa região ficou conhecida como "linha verde" após a Guerra Árabe-Israelense (entre Israel e seus vizinhos, em 1948). Tal fronteira foi mantida até 1967, ocasião da Guerra dos Seis Dias, que selou o fim desse acordo, quando Israel expandiu seus territórios, incluindo a anexação de Jerusalém Oriental. Nessas circunstâncias, o performer se pergunta: qual o papel de atos poéticos em situações políticas altamente carregadas?

Para esse artista, "Às vezes, fazer algo poético pode tornar-se político e, por vezes, fazer algo político pode se tornar poético." É justamente isso que ocorre quando traça sua linha de tinta em São Paulo: sua ação inicialmente poética acaba tornando-se política, por conectar dois mundos que frequentemente se mantêm separados. No nosso contexto sócio-econômico, o mundo da arte das galerias permanece restrito a grupos iniciados e, não por acaso, mais favorecidos economicamente. Age-se como se a arte fosse um artigo de luxo. Por outro lado, em um contexto onde a Guerra se faz presente há mais de 60 anos, por mais que sua ação tivesse intenção de denunciar um acordo político esquecido ou ultrapassado, ressoa como algo poético. $\mathrm{O}$ ato de caminhar ao longo de uma antiga fronteira carregando

${ }_{6}^{6}$ La marche, le déplacement, interviennent chez Alÿs comme des outils de réagencement des dispositifs urbains, des manières de faire qui produisent de points de vue sur la ville et qui, en fin de compte, permettent d'élaborer, de construire un regard. Ce qu'il appelle la fable est cet objet fluide et frappant qui décrit une situation, un contexte, les fait voir, en mettant de la distance entre le mouvement subi, consommé, de la mégalopole(...). Si le réel est un mouvement, un processus, il s'agit, en tant que piéton, de produire son propre déplacement pour être partie prenante de cet univers, et pour pouvoir également et véritablement le prendre à parti (tradução minha). 
-se no chão, em diversas ações realizadas ao longo de trinta anos, intituladas Crawl Pieces (uma delas já foi mencionada dentre as análises dos passeios). Na mais conhecida delas The Great White Way, ele atravessa as 22 milhas da Broadway (o equivalente a 35 quilômetros) rastejando, vestido de Super Man, com um skate amarrado às costas. Trata-se de uma ação não só de grande resistência, mas de persistência, que levou 9 anos para ser concluída. Nessa performance, realizada no final dos aos 1970, quando Pope tinha pouco mais de 20 anos, ele denuncia a condição dos moradores de rua nos Estados Unidos, em sua maioria negros.

Nessa ocasião, ele estudava artes na Universidade, mas tinha um irmão, uma tia e dois tios vivendo nas ruas. Essa performance tem um caráter de autopunição, tamanho o investimento físico que a ação exige. Porém, não se trata de um ato autobiográfico, no qual ele se coloca no lugar de seus parentes para experimentar em sua pele o que eles vivem; o que ele promove é uma inversão de valores, ele coloca um super herói negro no chão, rastejando-se e obriga a cidade a voltar seu olhar para o chão. Numa cidade eminentemente vertical, sua exploração da horizontalidade promove uma inversão do olhar. Estamos de volta aqui à política do chão, já mencionada anteriormente, de Paul Carter. The Great White Way desvia o ponto de vista direcionado para o alto, para os arranha-céus e luminosos da Broadway na direção do chão, da sarjeta; passa da altivez para a empatia, a humildade, a obrigatoriedade de se enxergar o outro, o invisível.

Um corpo negro rastejando no chão revela a vulnerabilidade dos moradores e moradoras de rua em oposição à agressividade da cidade vertical. As Crawl Pieces ocuparam o performer durante muitos anos, que explorou essa ação incessantemente, inclusive convocando voluntários para rastejarem pelas ruas de diversas cidades. Experimentar a travessia de uma rua nessas condições é uma experiência imersiva, de grande engajamento físico, que modifica definitivamente o modo como nos relacionamos com o outro e com a cidade. Somente quem se propõe a tal experiência, de substituição dos pés por joelhos e braços, conhece a sensação de (in)visibilidade que essa condição de horizontalidade nos coloca. Ao organizar essas travessias com grupos de pessoas rastejando-se, Pope atrai o olhar de cada uma das cidades por onde passou para a quantidade assustadora de pessoas vivendo em situação de rua.

\section{_atravessar ou circundar a cidade como um Stalker}

Quando o assunto é atravessar territórios, uma das práticas mais inspiradoras é sem dúvida a do Stalker: Laboratório de Arte Urbana, coletivo nascido em Roma e integrado pelo já citado Francesco Careri. Sem membros fixos, o Stalker era composto por arquitetos (Careri é um deles), artistas e pesquisadores em ciências humanas que interrogam a realidade ur- 
bana e a prática que se desenvolve sobretudo nas zonas suburbanas, espaços indefinidos e outros terrenos baldios. Stalker ocupa os espaços vazios e marginais da cidade. Em 1990, o movimento Pantera, organizado por estudantes de Roma, antecede a composição do laboratório, realizando bloqueios nas universidades italianas. Uma fábula urbana deu nome ao movimento e em seguida tornou-se um dos emblemas do Stalker: durante um mês, uma pantera que teria escapado do zoológico da cidade aparecia em locais diferentes e depois desaparecia. Pantera tornou-se, então, o primeiro movimento de agrimensores dos espaços entre a Roma monumental e seus arredores.

Careri opõe a presença do vazio à noção de 'cidade difusa', "um sistema de assentamento suburbano de baixa densidade que se estendia formando tecidos descontínuos e expandidos em grandes áreas territoriais" (CARERI, 2013, p. 156). Os moradores dessa cidade difusa viviam à parte, "habitavam unicamente os espaços privados da casa e do automóvel e concebiam como espaços públicos somente os centros comerciais, os restaurantes de estrada, os postos de gasolina, as estações ferroviárias, destruíam todo o espaço projetado para sua vida social" (Ibid.). No debate sobre a cidade contemporânea, as soluções para a desordem percebida sobre o caos urbano estabelecido ao redor das cidades se mantêm situadas no centro. Ou seja, o ponto de vista para se pensar a periferia continua posicionado no centro das cidades históricas. A partir do momento em que se propõe o reposicionamento desse ponto de vista, outras categorias interpretativas passam a ser solicitadas.

O problema dessa abordagem é que ela continuava a analisar o território a partir dos espaços cheios, habitados, ignorando a presença dos vazios. Dessa forma, notou-se que os difusos - os moradores da cidade difusa - não frequentam apenas os espaços privados e os supostos espaços públicos citados acima (centros comerciais, restaurantes, postos de gasolina...), mas frequentam também os espaços vazios. São espaços de práticas ilegais, de socialização e de liberdade, onde se cultivam hortas ilegais, onde se fazem piqueniques e por onde se buscam atalhos para se passar de uma estrutura urbana a outra. No contexto brasileiro, podemos identificar esses espaços vazios nos descampados, nos territórios onde há assentamentos ilegais e até nos campos de futebol de várzea, zonas com riscos de alagamento.

São diferentes dos espaços vazios tradicionalmente entendidos como espaços públicos - praças, bulevares, jardins, parques - e formam uma enorme porção de território não construído, utilizada e vivida de modos infinitos (...). os vazios são parte fundamental do sistema urbano e são espaços que habitam a cidade de modo nômade, deslocam-se sempre que o poder tenta impor uma nova ordem (Ibid., p. 157).

O autor chama a atenção para os muitos espaços vazios, resultantes tanto de um tipo de planejamento urbano moderno, quanto da especulação imobiliária e de outras interven- 
ções de ordem pública identificáveis no território urbano. Esses vazios não podem ser considerados como espaços privados de sentido, mas uma cidade paralela com dinâmicas e estruturas próprias, plural, dotada de redes de relações, de habitantes e de lugares (em oposição aos não-lugares, de Marc Augé). De acordo com Careri, a cidade pode ser descrita a partir de uma perspectiva estético-geométrica ou de uma perspectiva estético-experiencial. É no sentido de utilizar "a forma estética do percurso errático" que o pesquisador desenvolveu suas travessias com o Laboratório Stalker - e continua desenvolvendo com seus alunos do curso de Arquitetura da Università degli Studi Roma Tre - "para reconhecer uma geografia dentro do suposto caos das periferias" (Ibid., p.159). Neste contexto, o autor ministra um curso peripatético, no qual caminha de 80 a 100 quilômetros por semestre, prescindindo de sala de aula.

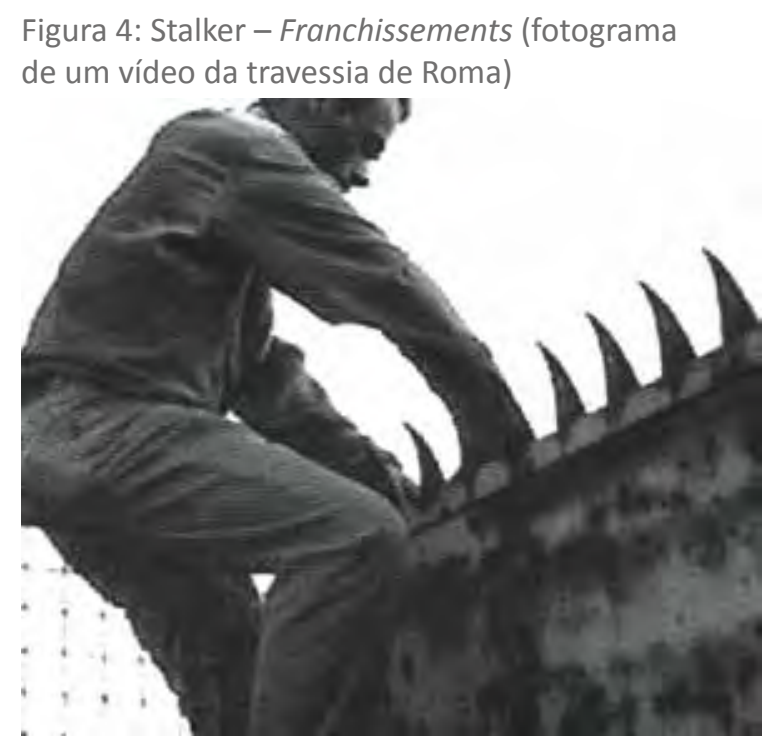

Foto: DAVILA, 2002, p. 141
O nome do coletivo é uma homenagem ao filme homônimo do cineasta russo Andrei Tarkovski, de 1979, no qual um stalker (um passador, um assediador, um perseguidor, um caçador, um traficante, pois a palavra engloba todos esses sentidos) conduz duas pessoas de um espaço habitado da cidade para um território abandonado e de acesso proibido. Nessa zona proibida há um quarto onde todos os desejos podem se realizar, destinado apenas àqueles que se entregam para a experiência de errância e dúvida ou se propõem a viver uma travessia. O filme busca revelar o inconsciente profundo das cidades. Para o Stalker: Laboratório de Arte Urbana, independente dessa metáfora do quarto, o deslocamento nesses terrenos baldios são ações coletivas realizadas por um sujeito múltiplo, que experimenta um evento também plural, capaz de abrir muitas perspectivas de futuros possíveis (DAVILA, 2002, p. 120).

Stalker através dos Territórios Atuais foi a caminhada iniciática do coletivo, na qual 15 pesquisadores realizam um percurso circular de cinco dias ao redor de Roma (cerca de 60km) inteiramente consumado a pé, em $1995^{\circ}$. Nesse contorno da capital italiana, os pesquisadores passam por terrenos abandonados, vazios e em transformação, seguindo um trajeto mais extenso do que a própria cidade. Os membros do Stalker acampam a céu aberto ao

8 Após essa primeira caminhada iniciática, duas derivas foram realizadas em Milão - Routes d'abandon à travers l'archipel milanais [Estradas do abandono através do arquipélago milanês], em 1994. Em Paris, percorreram 40 quilômetros em apenas 1 dia, na travessia intitulada Sortir de Paris [Sair de Paris], por um itinerário que seguia o antigo trilho do trem de ferro até a avenida periférica, passando por terrenos vagos de Montreuil e outros trilhos de trem, canais, estradas, até os confins do aeroporto Charles de Gaulle, em 1997 (DAVILA, 2002, p. 137). 
longo dessa travessia e seguem à risca a regra de jamais pisar no asfalto, nem dar meia volta ${ }^{9}$. Restringem-se a andar sobre canteiros e terrenos baldios. As imagens que documentam essas caminhadas mostram o grupo caminhando às margens do rio, por descampados, matagais, assim como saltando cercas e portões de zonas interditadas ao acesso. Dessa forma, os espaços são percorridos sem se levar em conta demarcações territoriais relacionadas à propriedade privada. A partir dessa experiência, concluem que podem fazer arquitetura sem construir 'coisas', pois caminhar pode ser uma arquitetura.

No Manifesto Stalker, redigido em 1995, o grupo coloca sua prática como uma alternativa, uma resistência e uma crítica à cristalização das cidades. Afirma-se que as grandes cidades do mundo se racionalizam cada vez mais e o turismo as faz morrer, tornando-se urgente (re)descobri-las. Consideram suas práticas derivas caóticas nos vazios urbanos altamente inspirados pelos situacionistas e pelas teorias de Guy Debord. Para Careri, é preciso andar pelas ruas sem medo de perder tempo, pois só assim se ganha espaço, isto é, percebe-se verdadeiramente os territórios atravessados. Na cartilha dos stalkers lê-se: não acrescentar nada ao território, nem depositar nele nenhum objeto pré-fabricado ou edificar monumento durável. Tendo em vista esses pressupostos, na travessia dos terrenos baldios de Roma os únicos elementos acrescentados ao território foram farinha e vinho. Em uma ação denominada Carnac, Careri espalhou farinha sobre uma dezena de cilindros de concreto de superfície modesta e aparentemente abandonados no local e, em seguida, verteu um pouco de vinho sobre as estruturas, visando uma celebração desse território.

No mapa da figura 5, a cidade de Milão foi retratada de maneira ampliada, como se ocupasse todo o globo terrestre (1996). Nele, os terrenos baldios aparecem em azul e os territórios construídos em bege ou marrom. Trata-se de um mapa fabuloso, que existe para transmitir a experiência e não para ajudar alguém a se localizar na cidade. Careri ressalta o quanto as cartografias produzidas pelos stalkers não são precisas, são mapas que visam identificar um fenômeno. Um mapa que convida a perder-se, um eco às derivas situacionistas, um modo não objetivo de cartografar uma cidade. Os Stalkers retomam, de certa forma, a prática da deriva e, ao mesmo tempo a modificam, propondo deslocamentos de dimensão bem mais ampla que aquelas dos situacionistas. Além disso, o "teatro de operações na cultura" (uma referência ao diagrama criado pelos situacionistas) citado pelo Stalker não é aquele da arquitetura ordenada. $O$ que esse Laboratório propõe são formas de pertencimento também transitórias e efêmeras e não construir uma arquitetura do futuro, nesses espaços supostamente vazios. Instaurando maneiras de ver e de fazer, eles acreditam numa opera-

9 Em deriva organizada por um dos curadores da Vila Itororó na companhia de Francesco Careri, apresentando ao pesquisador alguns espaços do bairro do Bixiga (uma escola que foi ocupada pelos estudantes secundaristas em 2015, o Teatro Oficina e a Vila Itororó) em São Paulo, no dia 5 de julho de 2016, o stalker chegou a propor que cumpríssemos uma parte do percurso caminhando de costas, para evitar passar duas vezes pelo mesmo local. 
ção mais imediata e inteira no devir desse território.

Há uma radicalidade nas práticas stalkers, justamente pela escala de suas ações; são práticas grandiosas, que duram vários dias, com grupos numerosos e passando pelos locais mais obscuros da cidade. Não por acaso, essas travessias os levaram a

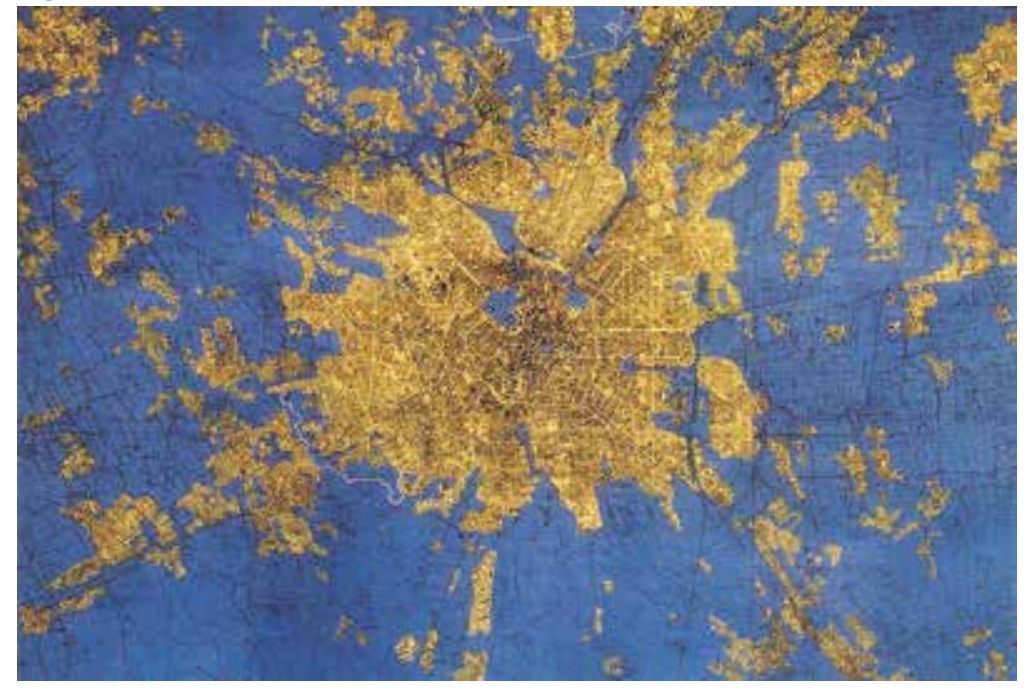

Foto: DAVILA, 2002, p. 140 conhecer uma população de moradores de rua e imigrantes ilegais que vivem às margens dos rios e sob as pontes de Roma. Estima-se que atualmente haja vinte mil pessoas vivendo nessas condições na capital italiana. Para Paul Ardenne, que também analisou as ações do Laboratório como exemplares de uma arte contextual, essas travessias diferem das derivas situacionistas também por visar uma retomada política desses territórios, em detrimento de um deslocamento ao acaso tendo em vista a subversão do uso da cidade (ARDENNE, 2002, p.97).

Uma travessia pressupõe um olhar crítico sobre o terreno e um igual engajamento com seu processo de modificação, pois caminhar permite experimentar o real. Prova disso é que "experimentar o real" era a fórmula de um dos membros do Stalker. Pelo mesmo motivo, Ardenne afirma que o primeiro impulso da arte contextual vem de um desejo social. Assim, caberia ao artista agir diretamente no campo da realidade, sem intermediários, enquanto sua ação se constitui como um comércio frontal com o campo da realidade. "Experimentar é acrescentar o novo (o que é atualizado), mas também o possível (o que ainda não aconteceu, que está por vir)" (Ibid., p. 62) ${ }^{10}$.

Em cada ação do Stalker, três momentos essenciais são repetidos e rejogados: primeiro acessar os territórios, para depois os atravessar e, em seguida, perceber seu devir. Para Thierry Davila, nenhum desses momentos existe por si mesmo, de maneira isolada e autônoma; cada um deles acontece no rastro do outro, numa série de encadeamentos, numa sucessão de atos que acabam por constituir o percurso. Desse modo, o atravessamento dos territórios funciona apenas porque ele desencadeia a produção de outras imagens (fotos e vídeos), outros dispositivos plásticos ligados ao ato de caminhar. Nesse sentido, a travessia é descoberta e também produção, por isso parece impossível refazer os passos do grupo, caso alguém quisesse refazer as caminhadas dos stalkers. O mapa da travessia é único como a performance, a experiência e as ações coletivas que o produziram.

\footnotetext{
${ }_{10}$ Expérimenter, c'est ajouter du neuf (ce qui est mise au jour), mais aussi du possible (le non-advenu, encore à naître) (tradução minha).
} 
Os territórios atuais são inventados: eles são exumados e criados, em um mesmo movimento, no seu rastro. É nesse sentido que atravessar espaços acaba também por produzi-los: não há olhar no estado selvagem que permita capturar sua essência, mas uma combinação entre o dado e o projetado, o dado e o compensado, do que já estava lá e do fabricado, da descoberta e da produção, e por consequência da travessia dos territórios atuais e de sua criação. A travessia é invenção (DAVILA, 2002, p. 138, grifos do autor). ${ }^{11}$

\section{_travessia como encontro e despedida}

Em 1997, uma dupla promoveu uma travessia da cidade de Nova York. Laurent Malone e Denis Adams, realizaram JFK no dia 5 de agosto, uma caminhada em linha reta saindo de um ponto de partida no Soho e indo até o aeroporto JFK. Eles caminharam durante 11 horas e 35 minutos, tomando como referência um protocolo bastante simples: quando um dos dois tira uma foto, o outro se posiciona de costas para o primeiro e também tira uma foto, sem contudo enquadrar o que fotografa. Ou seja, enquanto o primeiro compõe uma fotografia de algo que Ihe interessa, o segundo realiza uma fotografia da direção inversa, sem necessariamente atentar-se ao tema, ao objeto fotografado, ao enquadramento ou à regulagem da luz. Um detalhe: a dupla dispõe de apenas um aparelho de fotografia Reflex, que dividem ao longo de todo o percurso.

Ao todo, 486 negativos foram produzidos. A versão final da deambulação se apresenta na forma de um único livro impresso no qual as fotografias são apresentadas em pares, sem a inscrição de textos explicativos. Nas páginas à esquerda estão as fotos escolhidas e nas páginas à direita, as foto-respostas ou fotos cegas correspondentes, posicionadas uma de frente para a outra. Na ocasião de sua exibição, o livro é posicionado em uma mesa de madeira concebida especialmente para que dois espectadores possam consultá-lo ao mesmo tempo, um de frente para o outro. Somente o programa aparece inscrito na lateral da capa do livro; ele é apresentado como um "protocolo do passeio". O termo protocolo é usado por muitos artistas como sinônimo de programa e embora esses artistas afirmem que a ação seja um passeio, optei por posicioná-la no presente capítulo. Há nesse caso, um traço bastante característico do que compreendo por travessia: o trajeto foi definido de maneira estratégica, previamente à realização da ação. Mesmo que não tenham acordado com precisão a rota, definindo nomes de ruas, por exemplo, havia a intenção de caminhar em linha reta. À essa decisão prévia associada à observação de um mapa e à esse olhar panóptico

\footnotetext{
${ }_{11}$ Les territoires actuels sont inventés: ils sont exhumés et créés, dans un même mouvement, dans la foulée. C'est un ce sens que traverser ces espaces aboutit aussi à les produire: il n'y a pas de regard à l'état sauvage qui permette de les saisir à nu, mais une intrication du donné et du projeté, du donné et du plaqué, du déjà là et du fabriqué, de la découverte et de la production, et par conséquent de la traversée des territoires actuels et de leur création. La traversée est invention (tradução minha).
} 
direcionado ao percurso será confrontada a experiência tática do ato de atravessar um território.

É nesse nó que a travessia se situa: uma ação inicialmente estratégica, que ao ser realizada, migra para a esfera da tática. Trata-se de uma exploração do tecido urbano na qual um corte é realizado, possibilitando que esse tecido seja visto de outro modo. Além disso, o que essas experiências promovem é uma mudança de olhar sobre as metrópoles, pois a ação é afirmativa em relação à possibilidade de se deslocar a pé apesar das grandes dimensões da cidade, contrapondo-se à opção recorrente de percorrê-la sempre e inevitavelmente com meios de transporte mecanizados. Tais fotografias possibilitam ainda a elaboração de visões menos óbvias dos espaços visitados. Sobretudo quando se tratam de cidades turísticas, o resultado desse tipo de observação não será uma imagem de cartão postal. As imagens que captam a atenção desses artistas são inscrições nos muros, grafites, placas e siglas. Thierry Davila afirma que os geógrafos nomeiam esses percursos retilíneos de transects [trajetos] e os descrevem como registros de informações sobre um espaço. Em JFK o resultado desse trajeto é um longo travelling registrando o percurso de alguém que observa o desimportante, o banal, o cotidiano. Desse modo, a deambulação produz uma visão da cidade revelada a partir de um corte na paisagem, que será organizada posteriormente na forma de montagem (no sentido cinematográfi$\mathrm{co})$.

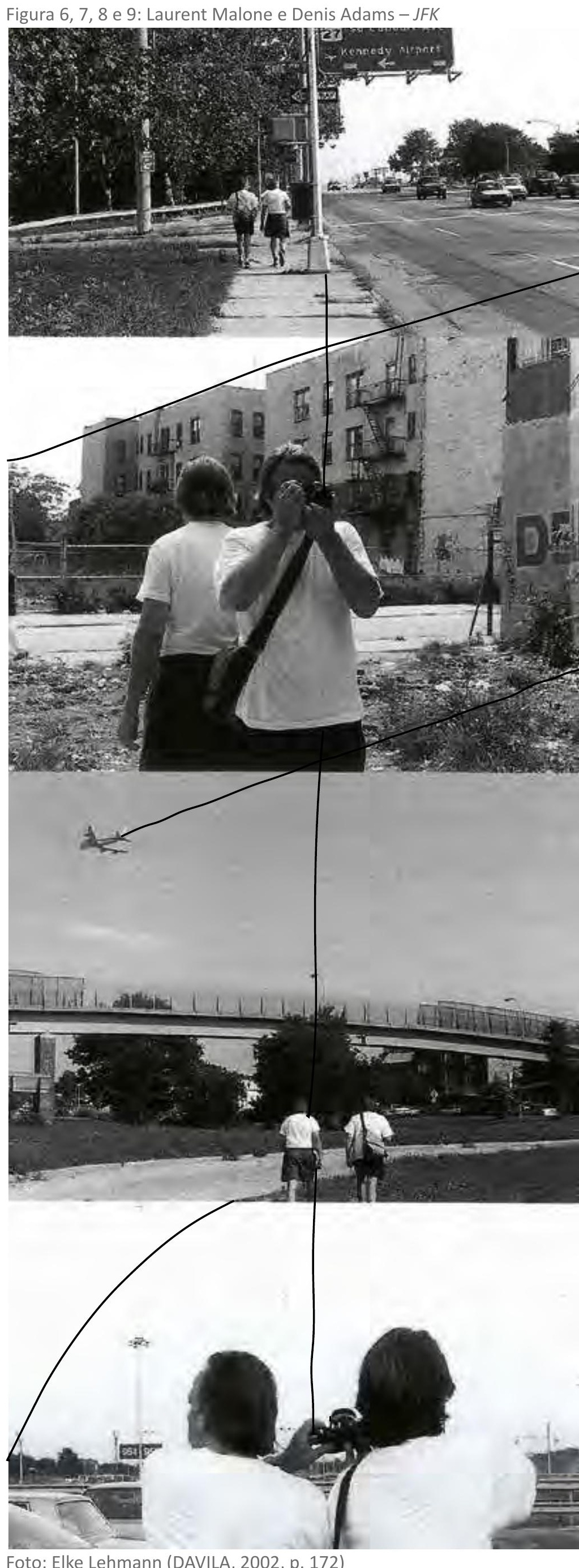


Outra travessia em dupla, de caráter mais íntimo, merece ser lembrada: é aquela efetuada por Marina Abramovic e seu então companheiro Ulay. Em 1988, o casal decide atravessar a muralha da China, sendo que cada um deles parte de uma das extremidades, até o momento em que os dois se encontram. A ação intitulada The Lovers (The Great Wall Walk) sela o fim da união do casal que, além de amorosa, representa uma cooperação artística muito rica, iniciada em 1976. Esse estudo de caso não se insere no contexto urbano, porém a travessia se deu no maior monumento construído pelo homem em todos os tempos. Trata-se de uma muralha cuja extensão chega a 21.196 quilômetros. A performance que marca o final dessa colaboração demandou anos de negociação com as autoridades chinesas, uma vez que foi amplamente documentada por uma equipe de vídeo. Marina Abramovic inicia sua travessia do lado leste da muralha e Ulay, do lado oeste. Após 90 dias caminhando, passando por diferentes províncias da China, os dois se encontram para dar o último adeus.

Juntos desenvolvem ações que se aproximam dos rituais, da mitologia e de um pensamento oriental, marcadas pela repetição, pela longa duração e pela intimidade evidente entre seus corpos. Certamente, esses doze anos simbolizam o período mais rico de experimentação da mais famosa performer do mundo. The Lovers (The Great Wall Walk) foi considerada o final perfeito dessa obra comum: uma ação que acontece num espaço não apenas real, mas monumental, no qual os performers radicalizam o ato de caminhar, mantendo a simbiose entre a arte e a vida. Embora não se trate de uma representação, há um aspecto espetacular na escolha desse espaço que traduz a grandiosidade da obra. Nesse sentido, há uma teatralidade no ato: Marina veste-se de vermelho e Ulay de azul; há uma referência clara ao universo mitológico, pois em diferentes culturas, usa-se o azul e o encarnado para sim-

Figura 10: Marina Abramovic e

Foto: Disponível em: <http://www.patricktreardon.com/wp-content/upUlay - The Lovers

loads/2013/04/Wall-1-without-caption.jpg>. Acesso em: 26 set. 2016.

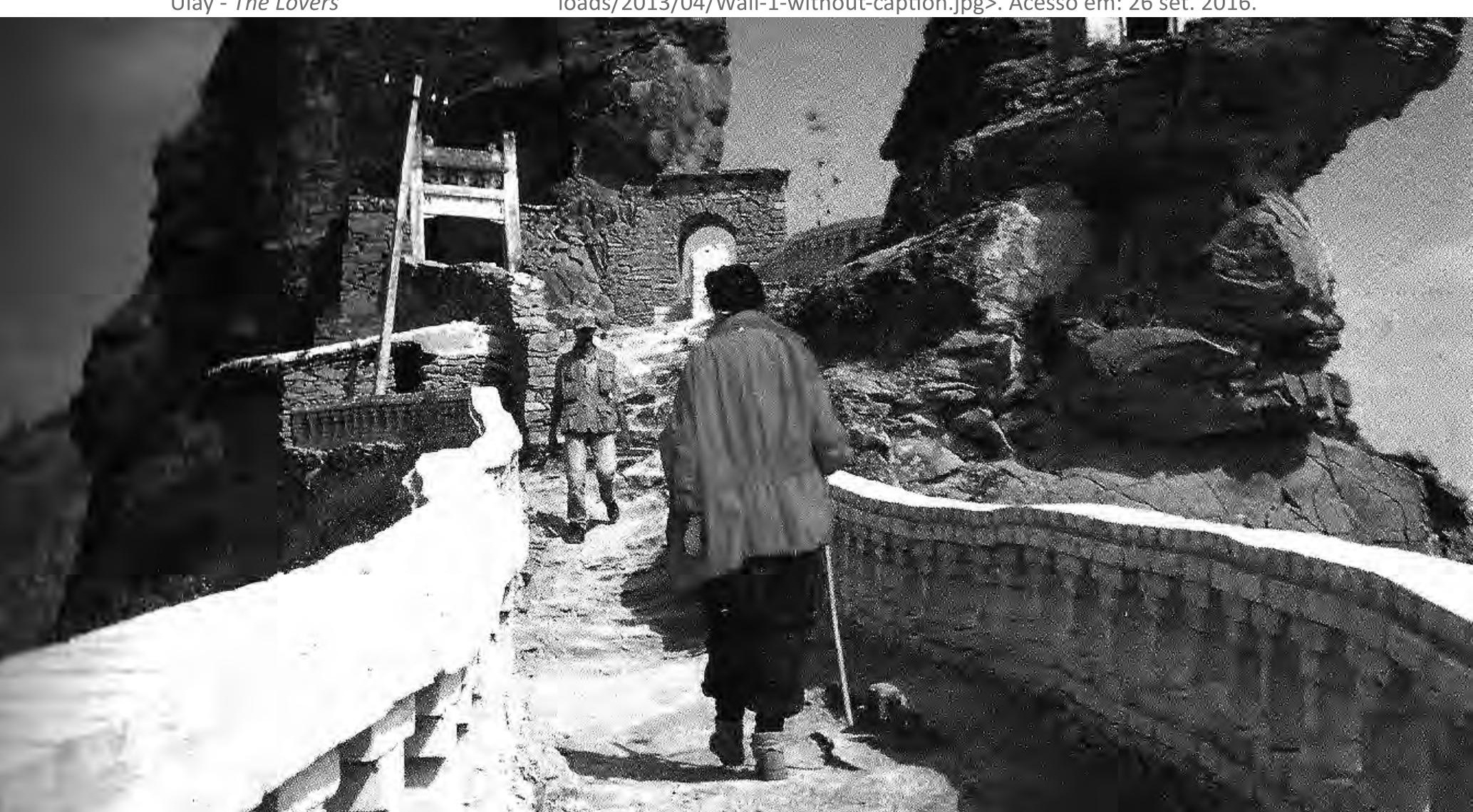


bolizar energias distintas e complementares. Mesmo que o modo de operar da dupla seja focado na ação que realizam, a documentação da performance foi grandiosa. Nos pontos de parada, onde cada um deles dorme, se alimenta, se troca, diferentes equipes se encarregava de seus pertences para que nenhum dos dois carregasse nada consigo. A performance foi registrada por Murray Grigor para a BBC, em um filme de $16 \mathrm{~mm}$, que resultou em um documentário intitulado The Great Wall: Lovers at the Brink ${ }^{12}$.

Tendo em vista o exercício reflexivo associado ao caminhar, vivenciar esse ritual por 90 dias para encontrar o parceiro com quem se compartilhou seus últimos 12 anos de vida é um modo de colocar-se à prova física e emocionalmente. A despeito do aspecto comercial envolvido na performance, há uma radicalidade na ação, que leva ao limite a representação da reflexão sobre o percurso vivido a dois e a encenação da separação. Dessa forma, a travessia foi escolhida como modo de experimentar esse desenlace, profundamente conectado com a biografia do casal. Fica evidente, portanto, a metáfora do caminho não apenas como transposição espacial, mas também como tempo de convivência.

\section{_uma travessia amorosa e outra coletiva com o Dodecafônico}

Em 2015, convidei meu companheiro - Rodrigo Mourão - para cortar a cidade de Paris comigo, em seus dois eixos axiais. Por motivos diferentes, que ao longo da experiência ficaram cada vez mais evidentes, empreendemos essa Travessia amorosa de Paris. Iniciamos pelo trajeto mais curto, o eixo sul-norte da cidade, partindo do ponto mais próximo de nossa casa. Uma série de combinados foram feitos para agenciar os desejos e as necessidades de cada um, além da obrigatoriedade de que a travessia se concluísse a tempo de resgatarmos nossa filha na escola. Inspirada na travessia de Dennis Adams e Laurent Malone, propus que a cada mudança de arrondissement, uma foto fosse tirada por cada um de nós, posicionados um de costas para o outro. Desse modo, intencionava realizar um registro da totalidade do trajeto, explicitando dois pontos de vista distintos, opostos e complementares. Nos primeiros pontos de onde fotografamos, percebemos que teríamos muita dificuldade de colocar as fotos em paralelo e que sentiríamos falta uma imagem que documentasse nossa posição no ato do registro fotográfico. Decidimos, então, nos posicionar um de frente pro outro para fotografar a paisagem que víamos, incluindo um ao outro na fotografia, de modo que ele estaria nas minhas fotos e eu nas dele.

Na primeira travessia o programa não estava preciso, o que me levou a redefini-lo ao longo da experiência. Eu havia proposto o sistema de registro e Rodrigo se encarregou de traçar nosso plano estratégico, definindo previamente o trajeto que seria cumprido. Já sabíamos

${ }^{12}$ Vídeo disponível em: <https://www.youtube.com/watch?v=zaso0j9x098>. Acesso em: 30 set. 2016. 


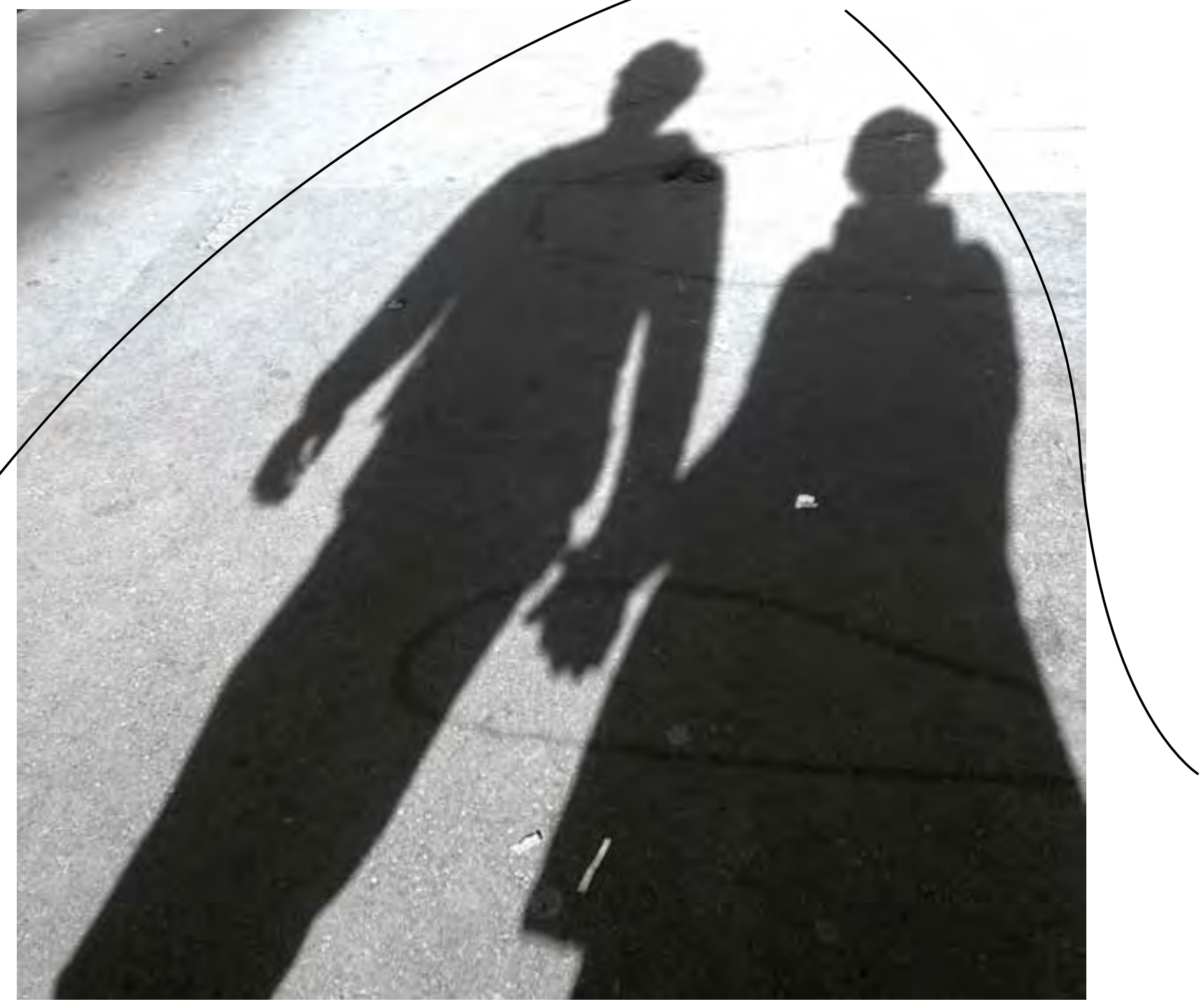

Figura 11: Verônica Veloso - Travessia amorosa de Paris

Foto: Verônica Veloso

das dimensões da cidade e que seria possível atravessá-la em poucas horas, principalmente no eixo sul-norte, de modo que propusemos uma pausa tranquila para o almoço, a parte mais assumidamente amorosa da ação. Alguns pontos foram acertados caminhando: conversar apenas sobre a percepção da cidade, não transformar a travessia numa prática consumista, nem turística. Sabendo das intenções do Rodrigo - conhecer Paris com os próprios pés, decorando o mapa da cidade, que ele estudou com afinco - propus que cada vez que uma vitrine chamasse nossa atenção, desviássemos o olhar para cima, mudando o campo de visão. Ao dissuadir meu companheiro de comprar uma luva, descobri um procedimento que acabou revelando uma parte da cidade que não observamos com frequência: a cidade que se esconde atrás da mercadoria. Nesse sentido, reparamos nas construções, nas características dos edifícios ao longo do caminho e nos comércios mais modernos, que escondem um pouco acima dos letreiros atuais os letreiros do que aquele estabelecimento tinha sido a décadas atrás. Por exemplo, um bar que já tinha sido uma sapataria ou uma livraria que em outros tempos foi uma loja de chapéus.

Apesar das diferenças evidentes, da dificuldade de afinar nossos passos e intenções ao cortar Paris com os pés, compreendi porque se tratava de travessias amorosas. Primeiro porque o mais intenso da experiência não é cumprir o trajeto físico, transpor um limite espacial, mas o tempo de convívio, de permanência lado a lado, de vida compartilhada. 


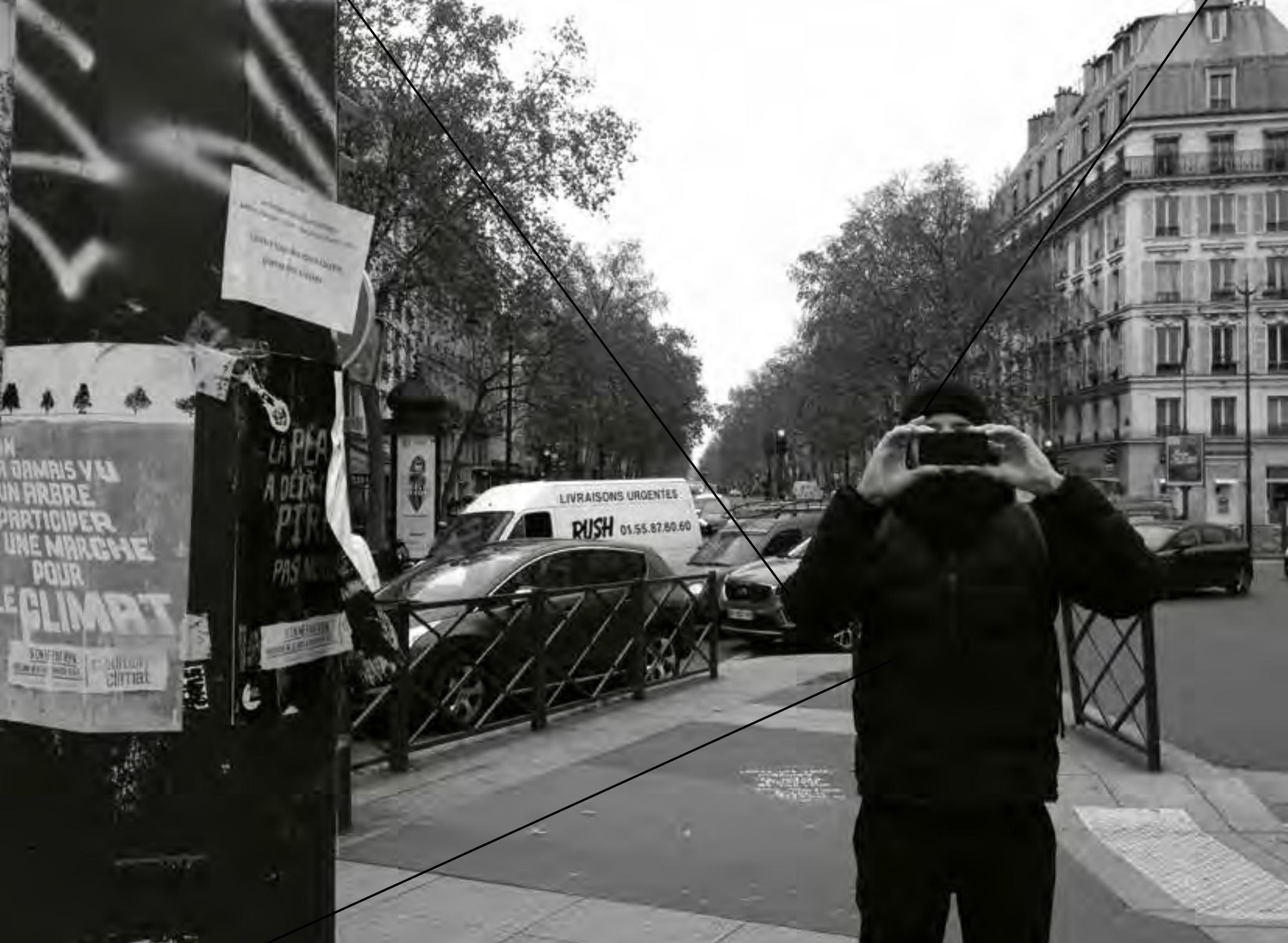

Figuver 12: Verônica Veloso - Travessia amorosa de Paris

Caminhar lado a lado com o Rodrigo é algo que eu já faço há mais de uma década, mas essa travessia é também um gesto simbólico de outra travessia, esta que não se configura como um deslocamento espacial. Só foi possível perceber isso porque vivíamos também, naquele momento, uma travessia transatlântica, pois havíamos juntos deixado o Brasil para viver dez intensos meses na França.

trinta de outubro de 2015: [travessia sul-norte de Paris] Corpo rígido, parceria estranha desvio

o que significa para um casal realizar uma travessia ?

Como percorreremos esse caminho tão simbólico juntos ?

Nessa prévia de travessia pergunto-me:
Foto: Verônica Veloso

Figura 13: Verônica Veloso - Travessia amorosa de Paris
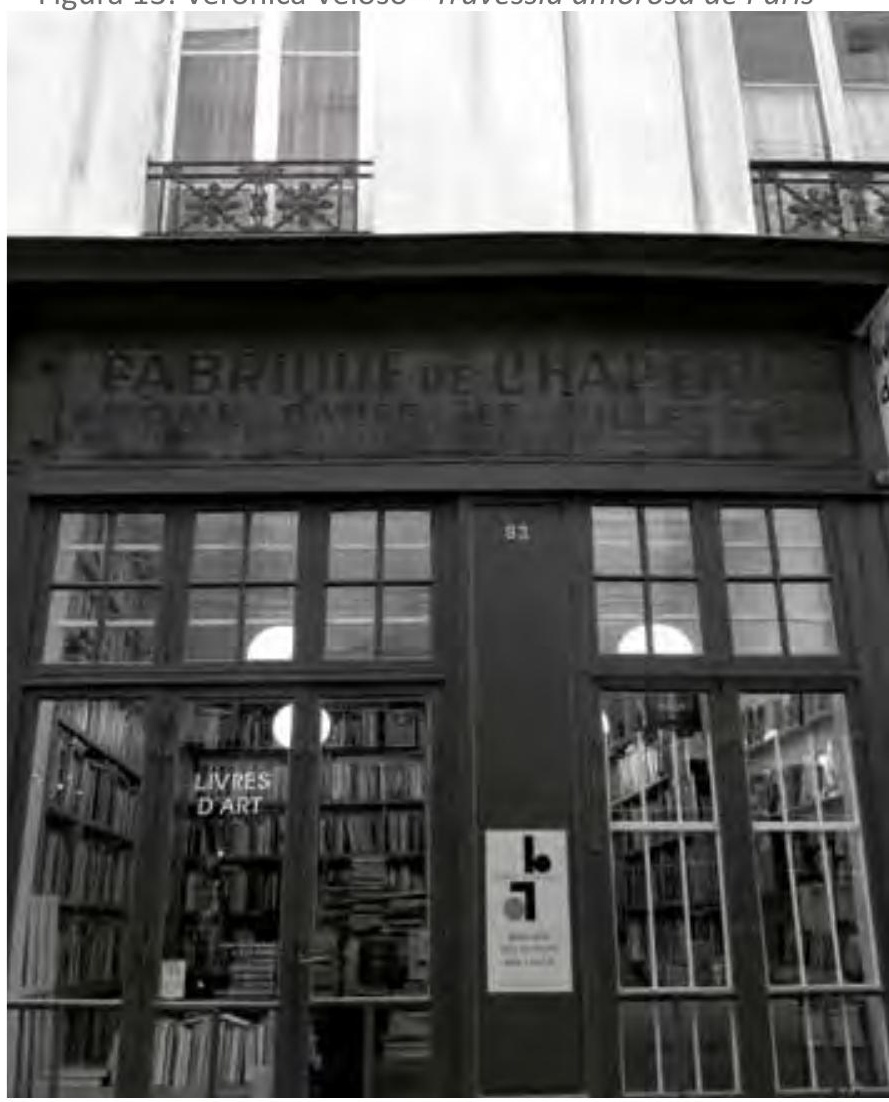

Foto: Verônica Veloso 
por que caminho para o norte ? Quando eu penso em descolonização, devíamos pensar em sempre voltar para o Sul.

Para o Sul seria um retorno para o Hemisfério Sul. A América Latina. A América do Sul.

Em Paris, caminhar para o norte significa

ir ao encontro dos imigrantes.

Saímos de uma banlieue privilegiada e caminhamos em direção à banlieue pobre, negra, imigrante.

Pegamos o 197 ao meio dia, em Antony, direção Port D’orleans. A porta por onde entramos para medir Paris com as pernas, como agrimensores da paisagem.

\section{Passagem/travessia:}

Sol quente nas costas

Silhuetas de nós dois desenhadas na calçada até às margens do rio.

Ali tornamo-nos andarilhos. A primeira imagem de nós dois Me fez ver o que estávamos realizando.

Depois do Les Halles, deu fome. Fizemos um desvio pela Saint Martin. Paramos em um café ao lado dos Arcos. Depois do almoço, os humores melhoram.

Buscamos o arco da Saint Denis e Caminhamos em direção ao Norte pela Faubourg Saint Denis.

Mais gente outros cheiros

calçadas cheias e sujas

Nossas aparências/imagens

atraem olhares.

0 nosso olhar, as nossas pausas, interrompem fluxos.

As pessoas buscam a direção do que olhamos.

0 que nos atrai?

É como se perguntassem :

0 que eles fotografam?

Parecemos turistas, estrangeiros como todos ali, desterritorializados, mas encantados pelo diverso, pelo outro que escapa do cartão postal.
Trata-se de uma Paris

desinteressante aos guias turísticos. Uma Paris pré-higienização

Solta, troca-se tudo

0 comércio corre

Solto. As relações são calcadas na

Troca. Trânsito, corpo a corpo.

Barulho, ruído, açougues,

culturas outras.

Ao fim da Saint Denis : uma pequena Índia.

Cores, tecidos, incensos.

Estamos ao lado do Bouffes du Nord, o teatro ocupado pela trupe de Peter Brook.

Avistar o Blvd Sainte Chapelle é vislumbrar nosso objetivo: La Porte Saint Chapelle.

É sujo, tem som de ambulância.

Os carros estão parados, engarrafados. Uma visão do terceiro mundo

Uma cidade satélite, à parte

onde moram os que servem a Paris dos sonhos

grande centro urbano marginal

descentralizado

A périphérique indica o fim do recorte da cidade por

$a r r o n d i s s e m e n t s$

Para além desse marco -

a Porte de Sainte Chapelle, são outras cidades.

Agora entendo nosso caminhar ao Norte. Uma simples busca por norte ? Uma volta para nossas desordens, multiplicidades, múltiplas cidades. Foram $10 \mathrm{~km}$ em 5 horas de travessia. Contando uma pausa de uma hora e meia para comer. Caminhamos três horas e meia. É um território tão restrito e descreve diferenças tão marcantes.

Fomos do rico para o pobre do zelo para a desordem do cinza para as cores

No caminho de volta para o Sul, na velocidade do trem, meus pensamentos se desterritorializam. Nossa filha nos espera. Concluímos nossa primeira travessia! 
vinte e sete de novembro de 2015: [travessia leste-oeste de Paris] Prévia da travessia: a caminho do leste, minha atitude incomodou. Das dificuldades de se estar junto. Lá fora faz frio e aqui dentro, as pessoas se apessoam.

Eu me sinto quente

tem música nos meus ouvidos.

Passamos por três portas de Paris:

Italie, Choisy, Charenton.

$\mathrm{Na}$ segunda porta, os letreiros estão escritos em japonês e na minha frente, uma senhora se transforma em urso de pelúcia.

Avenue de France.

0 tramway circunda a cidade

do sul para o leste.

Diante de mim, ela envelhece.

E é tão branca, de olhos tão azuis, que seus cabelos chegam a ser cor-de-rosa.

Suas luvas brancas não param de se mexeros olhos piscam, emoldurados por óculos de tartaruga.

Apenas seu manteau é vermelho.

Como eu poderia experimentar o mundo

a partir dos olhos dela?

Ela também está de tênis, só que sem meia.

[teço uma admiração enorme por essa elegante senhora, que desloca-se sentada, sendo levada pelo tramway. Ela respira o mundo diferentemente, tem saberes e tempo de crescimento.
Ela não envelhece, ela cresce.] A cidade está cinza.

Um grande estacionamento de trens sob a névoa branca em Porte de Charenton.

Chegamos em Porte de Vincennes: nosso ponto de partida.

Enquanto não andamos, somos levados pelo trem mas a travessia já começou.

Porte Dorée:

18h - Estou em Monceau, na linha 6 direção Nation.

Um pacote suspeito em Châtelet

E o tráfego é interrompido.

Do RER A de Auber à Nation

Eu e Rodrigo nos separamos

Em Charles de Gaule - Étoile.

Escrevo com o metrô

em deslocamento e tenho

quase certeza que alguém me lê

enquanto escrevo.

Meu corpo está cansado

Caminhamos mais ou menos

12 quilômetros

Nessa travessia, não chegamos

à extremidade oeste.

Foi preciso interrompê-la.

Eu disse ao Rodrigo que nosso

objetivo não era cumprir o percurso,

a todo custo.

o importante é viver a travessia.

De volta à São Paulo, relato minha experiência de travessia amorosa em Paris ao Coletivo Teatro Dodecafônico e falo do meu interesse em realizar a travessia da cidade de São Paulo. Para meu espanto, meus parceiros artísticos se animam com a ideia e organizamos juntos essa aventura. Desta vez, seríamos 11 pessoas caminhando por dois dias para atravessar São Paulo no seu eixo mais curto. Partimos do mesmo princípio usado na travessia parisiense: saímos da região mais conhecida (oeste) para a mais desconhecida (leste), traçamos o percurso previamente e aqui fica claro como o aspecto da invenção está intimamente relacionado a esta prática. Trata-se de uma construção que se reorganiza a partir da experiência. Não apenas pelo gesto estratégico de definir preliminarmente a rota e alterá-lo taticamente no ato de sua execução. Além disso, cada participante definiu um aspecto para observar ao longo do caminho, que orientaria a produção dos registros de cada um. Realizamos a Travessia oeste-leste de SP nos dias 18 e 19 de julho de 2016. 


\section{[escrita Olívia Niculitcheff]}

fazemos uma linha certeira na cidade que não diz sobre "leste-oeste" mas sobre esta linha específica. existem infinitas possibilidades "leste-oeste". andamos muito e eu poderia ficar muito tempo assim, exceto a mochila que começa a pesar, e sinto a sola dos meus pés, e a articulação coxo-femural direita. o corpo responde aos passos que não param.

A linha do percurso foi sendo moldada de acordo com alguns desejos, de passar em determinados lugares (como o meu, de incluir a cidade universitária dentro da travessia), até a passagem pela Oficina Cultural Alfredo Volpi, ponto de apoio para o final do percurso. Lá, poderíamos descansar um pouco, alongar, descansar, tomar um café quente e usar o ba-

Figura 14: Travessia Oeste-leste de SP

Arte: Papá Fraga

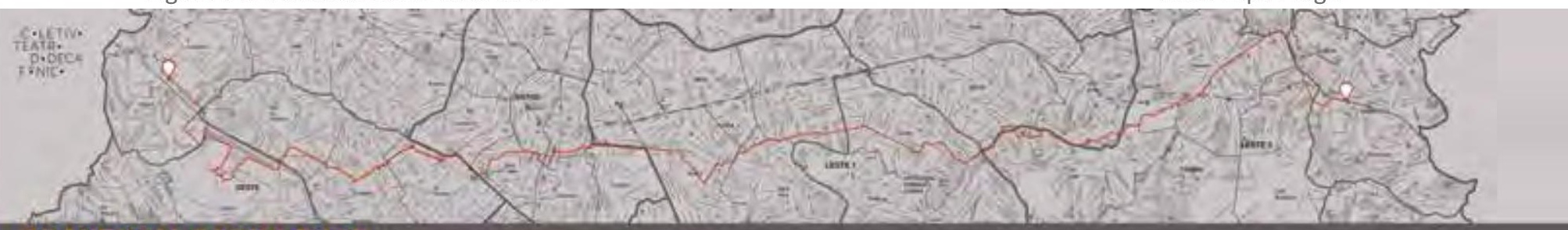

THAVESSM OSTE.LESTE

nheiro, próximos da reta final. O percurso foi dividido em prints do google maps e impresso, juntamente com sua descrição. Atravessar São Paulo é algo infinitamente mais complexo que atravessar Paris. Qualquer deslize de nossa parte, poderia desviar nossa rota, sem que tivéssemos parâmetros muito certos para nos apegar. Na travessia de Paris, o corpo percebia que andávamos em linha reta, com exceção de um ponto, bem ao norte, onde os caminhos se bifurcaram e tivemos que decidir se continuávamos à esquerda ou à direita. Em São

Figura 15: Travessia Oeste-leste de SP

Foto: Papá Fraga

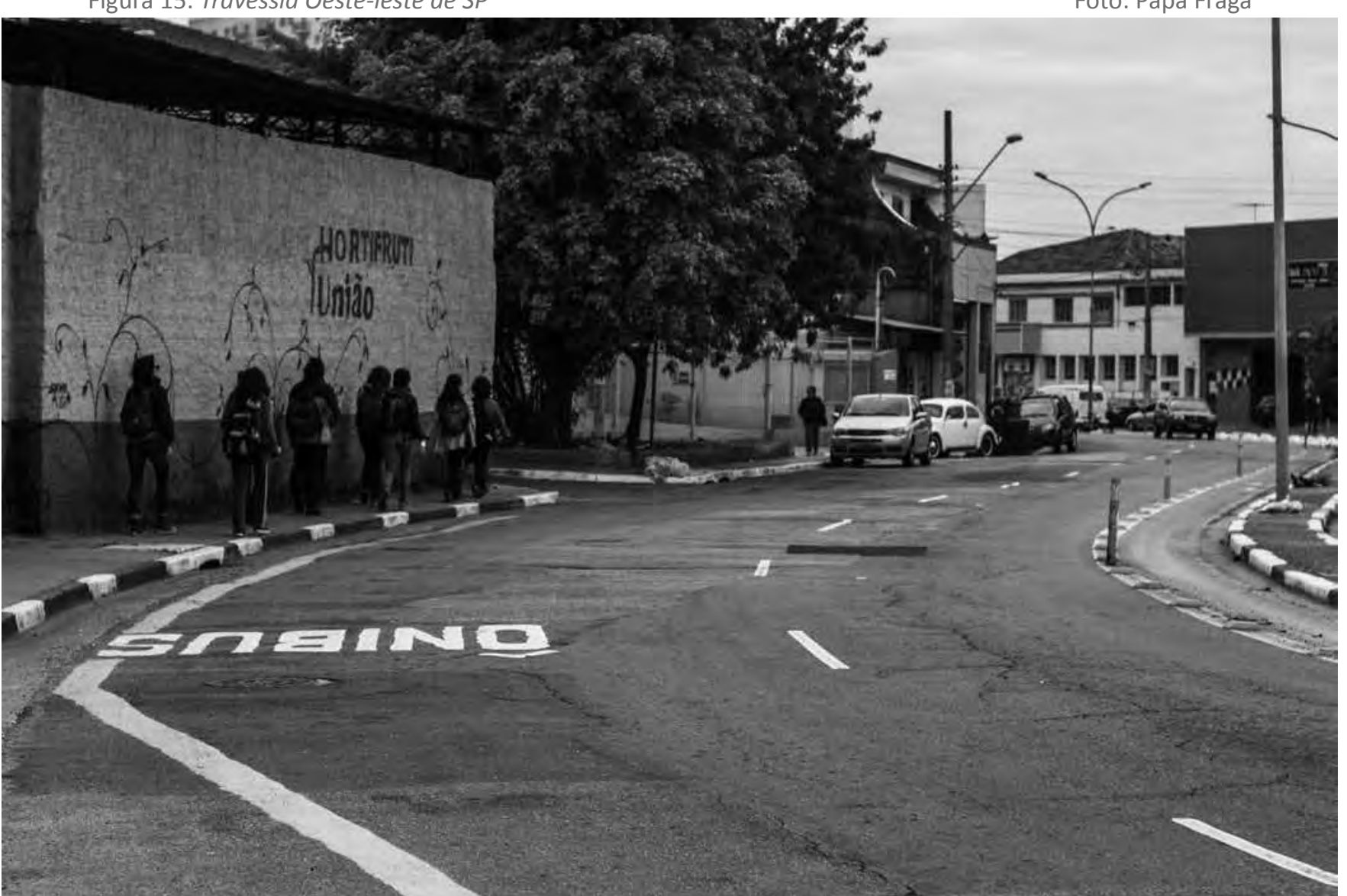


Paulo, a sensação física era curvilínea, com direito a muitas subidas e descidas, desvios, curvas, viadutos e pontes, além do tempo estendido que nos fez ver a cidade de dia e de noite.

\section{dezoito de julho de 2016}

Prévia da travessia: [Verônica Veloso] Primeiro fluxo - mar de gente saindo da estação Pinheiros de metrô (linha amarela) e indo em direção à linha da CPTM. No túnel vermelho, brechas de sol e o cheiro do rio. Ele nos acompanhará por todos o percurso.
Integrar a massa: posicionar meu corpo nas lacunas.

Configurar a multidão: preencher espaços vazios.

Na plataforma, encontro Luisa.

o anônimo ganha corpo e voz familiar. Ela se assusta comigo, com a minha presença inesperada no mar incógnito.

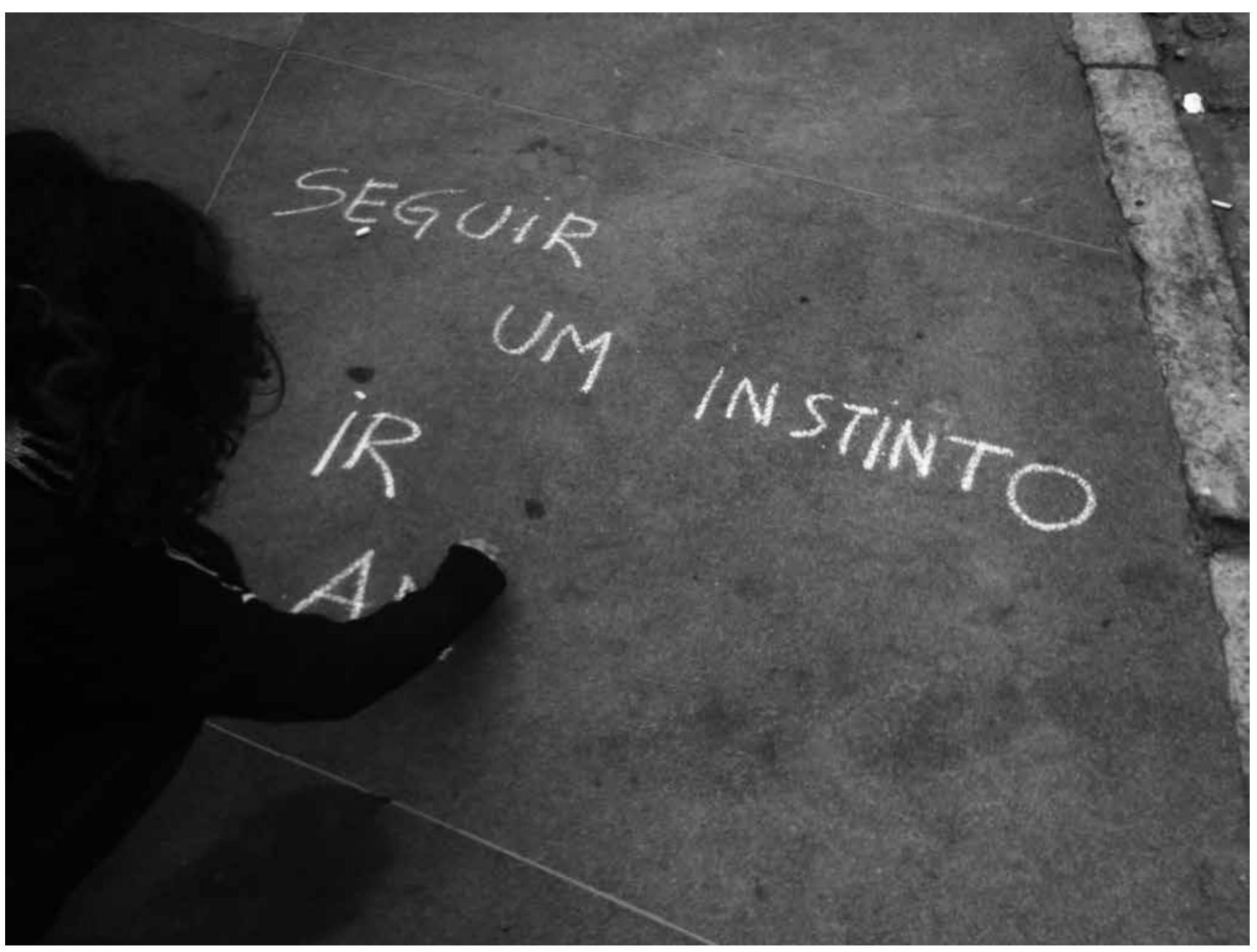

Figura 16: Travessia Oeste-leste de SP

Foto: Verônica Veloso

Propus alguns procedimentos previamente, uma vez que iria realizar essa experiência com parceiros que tinham intenções semelhantes: todos nós estávamos interessados em realizar uma ação performática, uma exploração artística. Porém, rapidamente percebemos que tais procedimentos não se aplicavam naquelas circunstâncias. 


\section{PROCEDIMENTOS PARA ATRAVESSAR A CIDADE}

[qualquer participante escreve com giz ou carvão no chão:]

> CAMINHAR _seguir o trajeto previsto, de acordo com condução da dupla que leva o mapa.

> DESCANSAR _repousar, sentar, deitar, espreguiçar, permanecer, usufruir da paisagem.

>> DESENHAR _olhar algo do entorno e desenhar sem julgamentos.

>> CONVERSAR _estabelecer diálogo com alguém ou grupo de pessoas encontrado no caminho.

> COMER _realizar refeição: almoço, jantar ou Lanches. Quem sentir fome primeiro, sinaliza.

>PAUSAR _interromper o percurso para discutir algo prático ou resolver algo rapidamente, por exemplo ir aobanheiro ou comprar água.

\section{instruções :}

travessia em modo avião (ou seja, com o celular em modo avião).

_silêncio, salvo nos momentos destinados a conversar com outras pessoas e

nas pausas para resolver questões práticas.

- a dupla que leva o mapa aponta o caminho.

_cada participante adota um aspecto pra observar no caminho e seu procedimento de registro do percurso.

_o programa do Careri servirá de material

poético para ser inscrito na cidade.

O primeiro procedimento a ser rompido foi o silêncio, era impossível não conversar com as pessoas vivendo uma experimentação tão impactante. Não falar, nem sobre a cidade, era um boicote à própria travessia. Sem silêncio, já não parecia necessário escrever as ações no chão; as decisões passaram a ser tomadas mais coletivamente, embora a dupla que detinha o mapa continuasse apontando a direção. Um dos procedimentos que se mantiveram ao longo dos dois dias de caminhada foi a inscrição de frases poéticas na rua a partir da composição de palavras do programa apresentado por Francesco Careri em Walkscapes (figura 15). 
Na primeira metade do caminho, observando nossa progressão no tempo, notamos que estávamos atrasados e não cumpriríamos nossa meta, chegar a Guaianazes no dia seguinte, caso mantivéssemos o mesmo tempo de deslocamento. Eu temia que transformássemos a travessia em uma caminhada funcional. Para mim, só fazia sentido cruzar a cidade, se ela fosse devidamente aproveitada. Sandra $X$. nos atentou sobre a diferença entre andamento, ritmo e fluxo. Para ela, era importante contemplar diferentes andamentos (para beneficiar as necessidades de todos os corpos), sendo que o grupo podia experimentar dois ou três fluxos semelhantes que identificamos entre nós e explorar ritmos diversos, como se a cada trecho do percurso ouvíssemos uma música diferente.

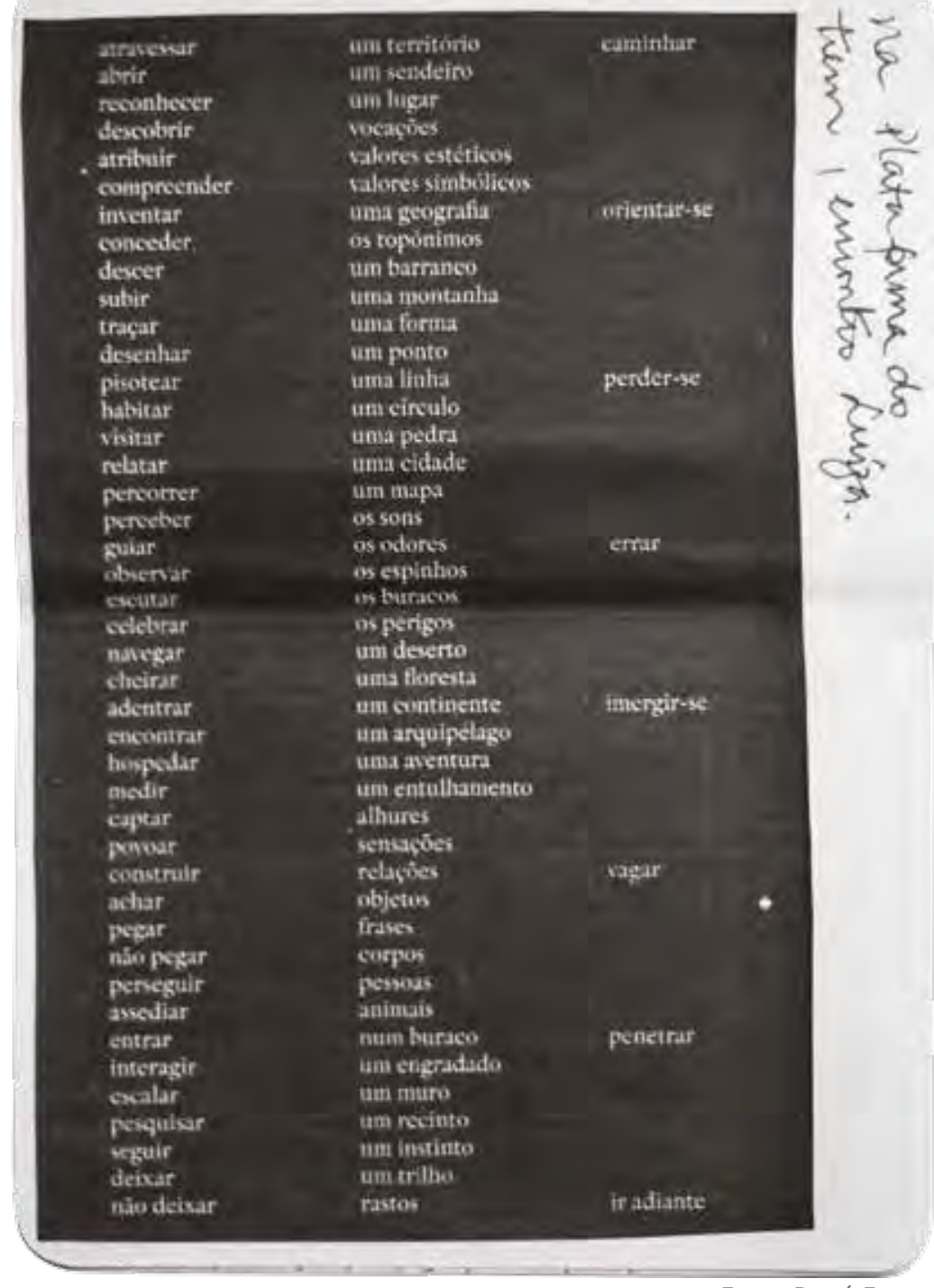

Foto: Papá Fraga Da Praça do Relógio à Pedroso de

Moraes nenhum procedimento foi proposto, coube apenas caminhar em fluxo dinâmico. Isso gerou muita reflexão sobre os sentidos da travessia. Bia Cruz apontou que talvez estivéssemos lidando com a travessia como se ela fosse uma deriva e que era importante entender essas aproximações e distanciamentos. Para Vânia, era fundamental que a travessia cumprisse seu objetivo. Chegar a Guaianazes era nossa meta, pois o percurso é uma construção arquitetônica.

[escrita Verônica Veloso: dia 1 - manhã]

Saindo da estação Ceasa somos conduzidos por cheiros.

0 cheiro do rio e o desejo do sol.

SP é essa cidade asfáltica.

Caminhar ao lado do rio e pela marginal, destinada aos carros, torna o corpo humano inconveniente. Nossos corpos não cabem ali.

Ao lado do Ceasa, o cheiro é adocicado e depois passado, podre.
Sinto vontade de atravessar fora das vias oficiais.

Criar fluxos, táticas de deslocamento. Meu corpo quer sol, mas não me arrisco. Eu não ando só. Sinto meu corpo ampliado.

Corpo coletivo - matilha - bando. Primeira ponte: o tempo dos cuspes tocarem a superfície rígida do rio. 0 rio está morto.

Nas suas margens, mais quebra de fluxo que corredeira. 
Um tropeço na primeira propriedade privada: um ferro velho.

Talvez não tão privado, me pergunto se aquela área não era estatal ou então da própria universidade, pois ali segredos são guardados.

A voz diz: "olhar pode! Entrar, não". Nossos olhos não respeitam a barreira física que se materializou com a chegada de um segurança.

Ele ameaçou deixar a Monica presa lá dentro.

PISOTEAR VALORES SIMBÓLICOS - inventar, construir, traçar, perseguir.

Entrando na USP, segui uma cartografia de afetos.

o banho de sol das capivaras transformam a raia olímpica em praia.

Elas se cuidam, tomam banho de rio e se alongam singelamente ao sol.

Foram os bichos mais bem cuidados, de pelos lustrosos, bem alimentados, que foram vistos de leste a oeste de Essepê.

[escrita Bia Cruz: dia 01 - manhã]

Grupo nômade em modo descoberta. Uma andança. Uma vasta extensão.

Um gato morto no pé de um poste, outro se lambendo num colchão.

A impossibilidade de entrar, sair ou circular nos leva a compreender valores simbólicos.

Cheiros e encontros. Brutalidades e joias.

Paramos nos locais que nos nutrem. Sinto a vontade do contrário.

tarde:

Pontes sobre grandes avenidas são rasgos no território. Rompem. Deixam a cidade em pedaços de zonas coladas. Zonas de conflito. Zonas indeterminadas. Alto-relevo que faz desaparecer a rua para abrir o céu. Faz desaparecer uma rua para abrir outras.

Nas pontes das zonas indeterminadas, onde não se habita o espaço a partir das regras que conheço, ainda circulam as mulheres com seus filhos. Cruzam e habitam a cisão.

[escrita Papá Fraga: dia 01 - manhã]

Olhar de Bando. Uma revoada de pássaros pode ameaçar?

FOTO DA FOTO

Observar as inclinações, pois elas vem antes do desvio. 0 que te faz parar? ATRAVESSAR! Verô grita. Nos inclinamos feito pássaros sobre o asfalto.

A inclinação é um desafio à gravidade. Ela é um desvio grav_intencional do tempo sobre o espaço.

$\mathrm{E}$ se o espaço influir no tempo?

\section{[Papá Fraga e a TRANSMUTAÇÃo DA CAPIVARA]}

Estávamos caminhando pela USP, quando quase todo mundo parou em frente a uma grade que dava para o rio. Havia umas pedras grandes e bonitas para observar. Mas indaguei tal admiração dos meus comparsas, e olhei com mais frisson. Me surpreendi ao ver leões charmosos nos jardins da USP. Não pude nem acreditar. Cheguei mais perto, e claro, eram macacos, uma pelugem digna de quem mora em São Paulo. Porém, sem que eu me desse conta, compreendi, eram as capivaras!!

Outro procedimento que se manteve e, de certo modo definiu as experiências particulares de cada um de nós, foi a escolha de um aspecto da cidade para ser observado. Algo que nos convidasse a olhar a cidade e a se relacionar com ela. Alguns exemplos dessas escolhas: Olívia observa o chão, quem habita o chão, o que ela encontra de marcas, objetos, corpos e moradias no chão. Luísa observa as cores e as texturas impregnadas em cada uma delas. Hideo repara nas pichações, nos grafites e outras inscrições presentes na cidade. Bia olha os recortes aparentes de céu, possíveis skylines que a arquitetura das casas e prédios compõem com o céu. Eu observo os fluxos das pessoas, das coisas, dos bichos, assim como as interrupções de fluxo. Papá, como podemos perceber na escrita acima, nota as inclinações, como prévias dos desvios. 
[escrita Verônica Veloso: dia 1 - tarde]

Subir a Cardeal, passando pelo cemitério até a Biblioteca Alceu Amoroso Lima é um trajeto que realizo quase que semanalmente. E justamente por se tratar de um pequeno trajeto familiar, comecei a imaginá-lo posicionado dentro do percurso da travessia. Esse exercício ampliou meu olhar e ressignificou minha experiência.

Há um fluxo de pessoas que vai à direita e outro fluxo que volta à esquerda de qualquer caminho.

Notei que em alguns momentos, o corpo do bando cria um antifluxo no meio da multidão e promove uma pequena turbulência nessa coreopolítica - uma coreografia política e social desenhada no cotidiano. O corpo matilha em deslocamento, criando antifluxos - nossa máquina da guerra.

Na Paulista, o movimento das pessoas sugere uma ficção. A coreografia é tão caoticamente harmonizada que seria muito difícil reconstruir esse fluxo. Ele só poderia ser casual, instável, nômade.

No Bixiga, escrevo no chão: PENETRAR OS BURACOS - uma combinação possível do programa de Careri. O Bixiga tem uma sexualidade latente. Desse ponto em diante ainda não tinha percorrido a cidade a pé.

No final da Rua dos Estudantes, chegamos ao Glicério. Um ponto cego da cidade. Região pobre, com muita gente na rua, imigrantes africanos. No letreiro se lê: envoyer de l'argent. Pela Radial Leste, vejo de perto as grandes igrejas evangélicas que só tinha visto da janela do carro, quando dava aulas no Brás.

Pela primeira vez, piso na Mooca, depois de atravessar um longo viaduto. $\mathrm{Na}$ passagem estreita, entre a avenida e a grade da ponte, andamos em fila indiana. Uma fila vai e a outra volta, na mesma direção que os carros. Está escuro, todos os celulares e câmeras devidamente guardados. 0 ambiente é de desconfiança e o bando está atento. À espera do lobo mau, só cruzamos com chapeuzinhos vermelhos, acompanhadas de suas vovozinhas.
Isso mesmo, mulheres carregando bebês e senhoras como acompanhantes estão no topo da densidade demográfica dessa passarela sobre a Radial Leste.

\section{[escritas 0lívia Niculitcheff: sobre o} chão]

- O chão é o lugar dos mortos, dos esquecidos e dos invisíveis. o chão é o lugar também das sombras e dos animais.

- Na passagem pela ponte, vejo a superfície do rio como chão, um chão de reflexos do céu.

- Descemos, Bela Vista. corpos no chão, os nômades são os moradores de rua. tudo que fica no chão é invisibilizado, por isso o lixo, por isso os nômades, os que vivem na rua. Barracas, cobertores. como registrá-los? talvez impossível naquele momento. uma câmera tem poder.

- Voltando às minhas reflexões sobre o chão, quantas irregularidades, quantas texturas! o chão dá um material estético muito rico, e me faz novamente pensar no descarte, na sujeira, no invisível, e talvez por isso em nosso jogo do urbano (elástico) eu sinto uma potência tão grande em deitar no chão. é uma subversão à ordem. Será culpa da gravidade? Que faz com que tudo que se abandona caia no chão e ali fique? Acho que a travessia vai fazer sentido depois que passar, enquanto história do corpo, da memória, da cidade.

[escrita Verônica Veloso: nota escrita no celular, na noite da travessia, enquanto todos dormem empilhados nos beliches do Hostel:]

o fluxo e a interrupção do fluxo.

o lixo, os escombros, a ruína, o mato e as pessoas podem interromper fluxos de pedestres na cidade.

Interrompo o fluxo da travessia, saindo do modo avião.

Caiu o primeiro dente da minha filha, eu andava com os dois joelhos doloridos negociando com subidas e descidas, organizando-me nas retas.

0 bando teve que se adequar ao meu passo lento nas descidas, vez ou outra, manco.

Meu corpo dava sinais em diferentes musculaturas 
e Alice perdeu seu primeiro dente.

Escombros e ruínas pela noite na Mooca.

Rua escura, grupo coeso.

Estavam atentos para não me deixar para trás,

Com Vânia, trocamos referências acadê-

micas e contei pra ela uma acepção da palavra pédestre, en français.

Comentei com Papá o quanto seria interessante gravar os sons que ouvíamos na rua, as conversas das pessoas e uma senhora que passou cantando.

Ela me disse: esta conversa está sendo gravada!

[escrita Olívia Niculitcheff : dia 2

\section{- manhã]}

Acordar juntos e continuar a caminhada, me sinto em uma viagem, o corpo em partida. Me sinto em um mesmo espaco mas em um outro tempo. Me sinto em São Paulo mas não em uma terça-feira, mas também não se parece a domingo e a nenhum dia existente. Sinto agora que não é necessário forçar um aprendizado ou apreender algo, a travessia se faz em mim, o corpo que caminha é afetado, se modifica, a vivência é inevitável. A verdade é que parece tão natural e normal andar tantas horas. Eu realmente tenho um amor por caminhar.

Saímos cedo do Hostel, por volta das 9 da manhã. Aos poucos o corpo foi se aquecendo e os alongamentos e as massagens com óleo tornaram possível continuar a travessia. A Mooca é um bairro agradável, de outro tempo. Conversamos com algumas pessoas no caminho e a imigração italiana começou a ser percebida. Uma senhora em frente de casa nos conta da vida, dos filhos e dos netos e diz que se pudesse caminhava com a gente. Pergunto pelas feiras do bairro, mas ela não ouve. Está absorta na própria conversa. Acabamos seguindo pela rua paralela à feira. Vejo muitos japoneses e um senhor com um simpático caminhão, vendendo cebolas. Muitas flores, ruas com jardins, casas. Nesse ponto da travessia, a sensação era de viajar. Essa não é a São Paulo que conhecemos e também não integra o imaginário que se tem sobre a cidade. A Mooca é a São Paulo do interior, de algumas décadas atrás.

[escrita Papá Fraga: dia 2 - manhã]

Nos tiramos do modo silencioso, o que foi bom, pois nos abrimos para conversas com os habitantes da Zona Leste.

Os anos 70 ainda está aqui. Fotografar aquilo que envelhece, que se deixa envelhecer, sem medo da morte.

Aqui as inclinações pareciam se configurar como atos simbólicos, como o menino Henrique que empina sua pipa na beira do córrego. Ainda sem tantos prédios, sua pipa pode voar arranhando o céu.

O Tatuapé é feito de vales. TATU A PÉ SE EMBRENHA NOS BURACOS DOS VALES.

Cemitério. Permitir envelhecer-se para não ter medo da morte. Durar até o fim.

TATU A PÉ PROCURA BURACOS, PORQUE EM TODOS ELES EXISTE UMA PASSAGEM QUE DÁ PARA O INFINITO.

Escrevo sobre a travessia dois dias depois de tê-la concluído. Quando não se enxerga o ponto de chegada, caminhar se torna o fazer. Chegamos à realização da ação em si. Caminhar é o que há para fazer. $O$ final do percurso se configurou por uma variação impressa no ato de andar. Meu corpo adapta-se ao terreno de maneira sistemática. Entendo os homens lentos, não os andarilhos do Milton Santos. Aqueles que realmente se deslocam lentamente, de andamento lento: os velhos, os deficientes, as crianças bem pequenas. Eu passei de desbravadora, daquela que portava o mapa para alguém alheia à direção. Passo de uma colonizadora que atravessou o rio Pinheiros, revelando a Cidade Universitária para 
o bando caminhante, à seguidora de um grupo altamente empenhado. David Le Breton foi quem afirmou que "caminhar dez dias com alguém é viver dez anos com essa pessoa" (LE BRETON, 2001, p.21).

No último quarto da travessia, eu me torno um homem lento, que se ocupa de caminhar, de manter-se caminhando, de manter-se em deslocamento. Meu estado de caminhante machucada me fez pensar nos andarilhos. Naqueles que meu pai apontava na estrada e dizia: "esse é o pior tipo de alma que existe: os andarilhos. São pessoas que andam sem rumo, eternamente. A alma deles não tem repouso". Sim, os errantes interplanetários. Penso também nos peregrinos que se propõem a chegar a determinado ponto, pagando uma promessa. Eles chegam de joelhos, estropiados, agradecidos e felizes, no ápice do prazer cumprido. Experimentei isso. Antes mesmo do almoço, logo depois do Cemitério da Vila Formosa, em frente ao Terminal de ônibus, enquanto esperávamos a Nathalia comprar um tênis, começo a dançar, pra soltar um pouco a musculatura endurecida pelo caminhar.

[escrita Olívia Niculitcheff : dia 2 tarde]

Andamos e andamos, chegamos em uma parte mais central e movimentada de Itaquera, mas extremamente árida e bruta, com muitos ônibus que andam como loucos. A
Papá por pouco não foi atropelada e um outro passou perto da Vaninha, no furor desse movimento, o sol! A maravilhosa cena da bola de fogo ardente no último segundo antes de se esconder atrás das montanhas.”

O caminho ao longo da Avenida Itaquera era árido, uma avenida rodovia, construção estranha, composta em diferentes tempos. Pura especulação imobiliária. Parece uma zona permeada de abandonos, fruto de uma urbanização artificial. A cidade quase desaparece, ou desmorona ou apodrece e depois se recompõe como arquipélagos cosmopolitas. Seguimos um longo trajeto em fila indiana. Numa das passagens há um muro entre a calçada e a rua, sendo que o espaço para o caminhar é um grande canteiro de lixo e entulho. É como se ninguém passasse ali. Caminhar nesse contexto é transgredir a regra do deslocamento obrigatório em quatro rodas. Muitas pessoas nos disseram: "a pé? Mas vocês têm que tomar um ônibus!". E então, explicávamos "saímos ontem do Ceasa, extremo da Zona Oeste e seguimos hoje até Guaianazes".

Outra parte do trajeto é uma sequência de morros, subidas e descidas sem pausa. A visão dos montes revela uma Zona Leste acidentada. O google não noticia topografia, porque ele também foi criado a partir de um ponto de vista colonizador, de quem desbrava territórios com automóveis ou a partir de uma visão panorâmica, panóptica. Esses dispositivos não são criados para quem percorre a cidade a pé, para quem perscruta, investiga com os próprios pés, pernas e corpo inteiro. Essa presença in loco não combina com a ideia que se tem da cidade de São Paulo. O google não considera o homem lento (o pedestre, de Milton Santos), o manco. 
[escrita Papá Fraga: dia 2 - tarde]

Tenho a sensação de que para caminhar à noite é preciso muito mais pele que olhos.

O trajeto final, pós Oficina Cultural Alfredo Volpi, estava previsto para ser realizado em 1 hora. Para conseguir essa eficiência na caminhada, só o homem máquina: masculino, racional, artificial e pós-humano. A velocidade do homem lento combina mais com as prosas no meio do caminho. Na barraca da frutas, a moça apontou a rota mais segura para tanta mulher reunida e anunciou: "40 minutos se vocês não pararem". Meu corpo de mulher lenta, cheia de desacelerações, pontos e vírgulas, busca um artifício para não sentir o tempo passar. É preciso pensar em outra coisa que não fosse o mínimo sinal de Guaianazes. Uma vez que já havia incorporado a velocidade para subir e a extrema lentidão nas descidas, resolvo colocar trilha sonora para seguir adiante. Despeço-me da travessia sambando. Meu corpo de mulher lenta chegou rindo em Guaianazes, com os joelhos, as pernas e os pés doloridos, mas felizes. Como os peregrinos que choram e riem, com todos os dentes, de pé e sem intenção de pagar promessa. Não é a fé que nos move, são pequenas metas, uma a uma alcançada, cumprida, no tempo da mulher lenta, descolonizada, revirada e entorpecida pela dimensão inapreensível da cidade.

Ao avaliarmos a travessia, Sandra propôs a seguinte questão: 0 que é o fluxo de uma travessia? Um fluxo criativo, saudável e derivante. Concluímos que o fluxo da travessia é diferente da deriva, embora eles tenham seus parentescos. $O$ andamento é uma permanência, uma insistência: a repetição do tempo dado pelos nossos passos. É similar àquilo que dá continuidade à música. Ele depende de uma intenção e da escuta fina daquilo que te faz parar e, principalmente, daquilo que cada um deixa passar. O ritmo, por sua vez, é definido pelas variações do andamento e pelas variações do corpo. A variação de procedimentos também define o ritmo. Mesmo que eles tenham sido parcialmente abandonados, passar por esses diferentes momentos ajuda a compor o fluxo da travessia.

Se o mapa define uma estratégia, o caminhar é uma tática. Uma travessia começa com uma linha no mapa e termina quando se chega fisicamente no ponto da cidade real onde termina a linha traçada no mapa. Ou melhor, ela termina quando o objeto arquitetônico se torna relato do percurso. Na travessia a linha traçada é circular ou retilínea. Isso significa que há uma delimitação espacial na travessia e que o tempo é flexível.

$$
<<>>>
$$

Atravessar um território não significa apropriar-se dele. Não se trata de possuir, de dominar, nem de conhecer definitivamente. Quando me pergunto qual o objetivo de uma travessia, respondo: promover um encontro com a cidade, conviver com ela, experimentando me ocupar apenas dela enquanto a percorro. Permanecer junto em travessia significa também 
ir ao encontro de pessoas e situações inesperadas. Quando nos dispomos a cortar uma cidade com os pés, nos abrimos para uma experiência coletiva no tempo. A travessia de um território é uma travessia no tempo.

[escrita Bia Cruz : dia 2 - tarde]

Na volta da travessia, abrir a porta de casa foi estranho, duvidei. Sentia-me pequena demais para habitar esse espaço.

Ser um ponto numa vasta extensão ou ser ponto e ser onda nesse acidentado, nesse acúmulo de superfícies. Volto para o sol. Percebo que não deitei no chão em nenhuma parte do trajeto.

o corpo incorpora o trajeto, o espaço, o tempo, as cores, os relances, os encontros furtivos. Está tudo marcado num raio interno. A extensão do caminho está em mim. Sou um balão que inflou. 0 peso de ontem se transformou em leveza. Levo no corpo as subidas e descidas, as superfícies recortadas, as contradições e desigualdades, levo as rachaduras, ranhuras e descascados da arquitetura, as linhas de comunicação e as de energia, o medo e seu oposto, uma casa na árvore habitada por meninas e um parque linear habitado por meninos. Levo as mulheres do caminho, na soleira da porta, empurrando carrinhos, trabalhando. Levo a longa caminhada feita todo o dia. Levo a distância.

Caminhar junto é se propor a conhecer a cidade fora do mapa. Trata-se de uma experiência imersiva, pois enquanto a cortamos com os pés nos envolvemos nela com todo o corpo. Uma travessia não tem o caráter religioso de uma peregrinação, embora seja uma caminhada realizada coletivamente. Não pode ser comparada a uma festa popular, nem a uma procissão ou a uma marcha, a um protesto; trata-se portanto, de uma ação íntima, que pode ser realizada em dupla ou em grupo, poética e ao mesmo tempo, política. Não pode ser considerada um levante, uma mobilização imediata que moverá as massas, mas uma pequena revolução, um gesto de reivindicação do uso de uma terra. A cidade é a terra do cidadão e todas as estratégias voltadas a ele que o enclausuram em espaços privados são alternativas discretas de usurpar do cidadão um espaço que é dele por direito.

Quando sou questionada sobre o aspecto visível, ou mesmo teatral, de uma travessia, respondo que se trata de uma ação performática, pois se trata de uma elaboração artificial, que difere da vida. De certo modo, uma travessia opera na lógica do não-acontecimento, ela se mantém no âmbito da situação. Ela pode ser considerada uma situação construída e não se configura como um acontecimento, uma vez que pode passar despercebida, sem se deixar notar pelos olhos dos outros. Quando pessoas atravessam um território, elas se colocam como espectadoras em tempo real da cidade; elas caminham com o objetivo de conhecer, de encontrar, de conversar e de refletir sobre a cidade. Trata-se , portanto, de um gesto político. Não interessa, pelo menos não de imediato, apresentar algo, formular uma proposta futura para a cidade. Uma travessia é uma experiência que visa um devir-cidade, explorado em tempo real e estabelecido posteriormente, na leitura dos rastros produzidos por ela. São nos relatos, nas fotos e na memória impregnada no corpo, que essa experiência se encerra. Por isso, ela precisa desse prolongamento no tempo. Afinal, não somos nós que atravessamos a cidade, é ela, e sempre ela, que nos atravessa. 


\title{
> III. caminhar junto: festa de rua, cortejo e manifestação
}

A física se reduz a duas ciências, uma teoria geral das vias e caminhos, uma teoria global dos fluxos.

Michel Serres

$\mathrm{O}$ ato de caminhar é frequentemente associado ao pensar, como se ao andar o sujeito ativasse pensamentos e pudesse mais facilmente investigá-los, passando dos mais imediatos aos mais profundos, esquecidos ou escondidos. Assim como os monges dervixes giram em torno do próprio eixo, muitas meditações são impulsionadas pelo caminhar.

\begin{abstract}
A estranha consonância assim criada entre percurso interior e exterior sugere que a mente, ela também, é uma paisagem para atravessar caminhando. Muitas vezes uma ideia nova aparece como um traço há muito tempo próprio à paisagem, e pensar se aproxima mais de viajar do que de fazer. Nesse sentido, a história do caminhar torna-se a história material do pensamento: diferente dos pés, a mente progride sem deixar rastros (SOLNIT, 2002,p. 13) ${ }^{13}$.
\end{abstract}

Conforme a autora citada acima, caminhar também pode ser considerada uma atividade visual, tanto para quem caminha e vê diante de si uma série de imagens em deslocamento, quanto para quem observa um corpo em plena mobilidade. Do mesmo modo como as imagens observadas ao longo de um percurso mobilizam pensamentos e suscitam ideias em quem caminha, o corpo móvel também traça um percurso (na acepção de Careri, esse corpo cria um objeto arquitetônico). Nesse sentido, um conjunto de corpos em deslocamento promove visões que representam ideias, bandeiras, pontos de vista. São muitas as causas que levam as pessoas a caminharem juntas, elas vão da dor à alegria, da insatisfação à comemoração, da reinvindicação de direitos à conclamação de heróis de guerra. O que acontece quando a multidão ocupa a rua vai além da travessia de um território; trata-se de manifestação pública, popular, de reivindicação de um espaço de visibilidade. A população também pode ser oficialmente solicitada para ocupar o espaço público, para assistir desfiles ou festividades organizadas para reiterar um espaço de poder. Nesse último caso, as estratégias são visíveis até nos projetos urbanísticos, desenvolvidos como passarelas para o desfile de autoridades.

O espaço arquitetônico e urbanístico, enquanto espaço, tem essa dupla característica: desarticulado e até estilhaçado sob a coerência fictícia do olhar, espaço de coações e normas disseminadas. Ele tem esse caráter paradoxal que se tenta definir aqui: junto e separado. É dessa maneira que ele é concomitantemente

\footnotetext{
${ }_{13}$ L'étrange consonance ainsi crée entre cheminement intérieur et extérieur suggère que l'esprit, lui aussi, est un paysage à traverser en marchant. Souvent une idée neuve apparaît comme un trait depuis longtemps propre au paysage, et penser ressemble alors plus à voyager qu'à faire. En ce sens, l'histoire de la marche devient l'histoire matérielle de la pensée: à la différence des pieds, l'esprit progresse sans laisser de traces (tradução minha).
} 
dominado (pela técnica) e não apropriado (para e pelo uso). Ele é imediato e mediato, ou seja, pertence a uma certa ordem próxima, a ordem da vizinhança, e a uma ordem distante, a sociedade, o Estado. A ordem próxima e a distante só tem uma coerência aparente que de modo algum impede a desarticulação (LEFEBVRE, 2016, p. 51).

Segundo Lefebvre, esse espaço depende de interesses e de grupos divergentes, que encontram uma unidade no Estado. Para que a lógica da produção, do trabalho e dos lucros seja mantida é interessante para a sociedade burguesa que tal separação seja mantida. "A ideologia [em questão] é aceitar a dissociação e considerá-la real" (ibid., p.50). Assim, a ideologia coincide, tem a forma da prática, e o espaço se torna um lugar de reprodução das relações de produção e consumo. Diante disso, é possível constatar o quanto as ruas se tornam também o lugar de encenação da estrutura social. Quando a cidade é tomada por grandes coletividades, ela se torna espetacular e o modo de ocupá-la e percorrê-la passa a ser legível, como um discurso inscrito coletivamente entre ruas e avenidas. Não podemos afirmar que o discurso dos corpos no carnaval, perambulando pelas ruas em blocos ou concentrando-se em pontos estratégicos da cidade, seja o mesmo dos desfiles oficiais e das passeatas ou protestos. Cada modo de deambulação pela cidade descreve teatralidades distintas.

Se por um lado é nítida a teatralidade dessas manifestações culturais que desfilam pela rua, sejam elas políticas ou festivas, por outro, elas também interferem e definem manifestações artísticas. À medida em que o real é incorporado, que o contexto determina a criação, que se cria em site specific e que a arte se desdobra em outras materialidades, o espectador é convidado a refletir sobre o seu modo de operar na vida. Diante de manifestações de grandes dimensões, integradas por um grande número de pessoas, o movimento da percepção é centrífugo, o que conduz o espectador de volta ao real, às problemáticas atuais e sociais. Há em certa medida um apelo ao espetacular, seja ao ovacionar um líder político, seja ao levantar uma bandeira e lutar por uma causa.

Penso nas imagens das mulheres polonesas vestidas de preto que tanto circularam na imprensa e na internet em outubro de 2016. Eram milhares de mulheres que tomaram as ruas de mais de sessenta cidades na Polônia em defesa ao direito de abortar. Contrárias a uma mudança na legislação que previa a restrição quase completa do aborto legal no país, mulheres das mais diversas procedências se organizaram em tempo recorde pela internet, manifestando seu repúdio às medidas de um governo de extrema direita. Como resposta aos massivos protestos, o governo recuou da decisão. Segundo o Ministro da Ciência e Educação, os protestos funcionaram como uma "lição de humildade" aos governantes.

Seriam inúmeros os exemplos de manifestações populares similares a essa, mas poucas tiveram resultados tão eficazes. O Brasil nos últimos anos teve novamente suas ruas tomadas 
por manifestantes, em uma estrutura bastante distinta dos comícios organizados no início da década de 1980 a favor das eleições diretas. Em junho de 2013, um movimento organizado inicialmente pelo Passe Livre (MPL) tomou proporções desmedidas ao levar para as ruas um conjunto heterogêneo de pessoas sem agendas claramente definidas, gerando interpretações variadas e desdobramentos em diferentes vozes. Essa Revolta de Junho, surgida de um impulso similar àqueles observados na Primavera Árabe e no Occupy Wall Street, teve os efeitos de um terremoto (usando a metáfora de Raquel Rolnik ao interpretar os fatos), tendo em vista a atmosfera de prosperidade e paz que pairava no país na última década. Em todos os casos citados acima, tratou-se de protestos compostos em sua grande maioria por jovens, convocados por meio das redes sociais e sem a presença de partidos, sindicatos ou quaisquer organizações de massa tradicionais. Para Paulo Arantes, essas semanas de rebelião urbana serviram para "desmanchar o consenso entre 'direita' e 'esquerda' acerca do modus operandi do capitalismo no Brasil"14.

Diante desse cenário, o que nos chama a atenção é o quanto essas novas maneiras de se fazer política tem reverberado em fenômenos localizados na estreita margem entre a vida e a arte, o real e o estético. Em resposta às estratégias do Estado, podemos dizer que as táticas políticas e artísticas se confundem? A partir da análise de ações realizadas na América Latina - tanto no Brasil quanto na Argentina, no México e na Colômbia - pretendo investigar em que medida a teatralidade presente em manifestações culturais, ações políticas e protestos cidadãos inspiram a produção artística nesses diferentes contextos. Em alguns casos, as táticas dos artistas provêm do universo do carnaval, dos blocos e dos desfiles, em outros, dos protestos, das marchas e manifestações e há ainda aqueles que se valem dos cortejos fúnebres e das vigílias.

Em seu Tratado de Nomadologia, Deleuze \& Guattari discorrem sobre o nomadismo no espaço público a partir da descrição de dois jogos de tabuleiro: o xadrez e o go. Os autores associam o espaço do xadrez à polis, uma vez que trata-se de um espaço fechado onde se trava uma guerra codificada, como ocorre com a estrutura do Estado. Há regras específicas para cada peça, que se deslocam de acordo com suas funções. Todos os movimentos visam ocupar o maior número possível de casas, com o menor número de peças. No go, o espaço é associado ao nomos, pois contrariamente ao xadrez, trata-se de um espaço aberto ao qual valores externos são atribuídos. Nessa guerra sem delimitações, a batalha é travada por peças com valores iguais, ordenadas aritmeticamente de acordo com as posições que ocupam.

\footnotetext{
${ }_{14} \mathrm{Na}$ apresentação do livro "Cidades Rebeldes: Passe Livre e as manifestações que tomaram as ruas do Brasil", editado pela Boi Tempo, no calor dos acontecimentos em 2013. Disponível em: <https://ujceara. files.wordpress.com/2014/01/cidadesrebeldes-passelivreeasmanifestac3a7c3b5esquetomaramasruasdob rasil.pdf>. Acesso em: 4 Fev. 2017.
} 
No primeiro caso, o jogo consiste na codificação e decodificação do espaço, que jamais será desconfigurado. A polis tem uma estrutura definida e define, ela mesma, os elementos que a habitam. Ela permite diferentes movimentos, embora não se reconstitua em função deles. No segundo, não há estrutura definida, nem definidora. O espaço é impreciso: cada lance das pedras implica em um processo de desterritorialização e territorialização. Assim, o xadrez é representativo do espaço sedentário, métrico ou estriado, instituído pelo aparelho do Estado, enquanto o go representa o espaço nômade, vetorial ou liso, onde evolui a máquina da guerra. Se no xadrez, mede-se o espaço a fim de ocupá-lo, no go ocupa-se o espaço sem medi-lo. "[...] os dois espaços só existem de fato graças às misturas entre si. 0 espaço liso não para de ser traduzido, transvertido num espaço estriado; o espaço estriado é constantemente revertido, devolvido a um espaço liso"(DELEUZE \& GUATTARI, 1997, pp. 157-158).

É nesse sentido que evoluem diferentes agrupamentos de pessoas no contexto urbano, configurando visões coletivas cuja potência se encontra no movimento e na capacidade de desterritorialização. A cidade é esse espaço estriado, que devido a sua constituição, revela de maneira tão nítida a circulação desses agrupamentos nômades. Sua natureza métrica e estriada ressalta os fluxos, identificados aqui em diferentes formas: manifestações, marchas, festas de rua e cortejos. "É nômade todo processo (político, coletivo, individual, psíquico, etc.) que traça uma linha de fuga aos aparelhos do Estado sedentário e de seus subprodutos" (Ibid.). A seguir, apresentarei algumas ações coletivas, igualmente deambulatórias, que recusam a lógica do confinamento, da mercadoria e do medo como sistema convencional e único para praticar e (con)viver (n)a cidade.

\section{_ no carnaval e no futebol, a festa é na rua}

Le bonheur est une idée neuve [A felicidade é uma ideia nova] Slogan maio de 68.

Em Barafonda da Cia. São Jorge de Variedades, o espectador em sua pluralidade é convidado a atravessar o Bairro da Barra Funda, das mediações do Metrô Marechal Deodoro às margens do trilho do trem. São 1.700 metros de caminhada entre algumas paradas em estabelecimentos comerciais e na própria sede do grupo, que permaneceu por quase uma década no bairro. Os atores da companhia responsabilizam-se coletivamente pela dramaturgia e a direção da peça, mesclando as histórias dos moradores locais com o surgimento do samba paulista e usando, como pano de fundo, duas tragédias gregas: Prometeu Acorrentado e As Bacantes. Elenco e público formam um grande coro que em deslocamento 


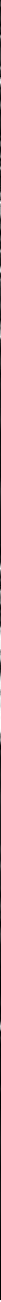

Figura 16: Cia. São Jorge de Variedades - Barafonda

Foto:Disponível em: <http://www.mainafantini.com.br/espetculos?lightbox=i18uw6>. Aacesso em: 29 mar. 2017

compõe um cortejo carnavalesco fora de época na capital paulistana. Moradores do bairro, que acompanham todo o processo de criação da peça ou que assistem a um grande número de apresentações se misturam e, de certo modo, recepcionam os espectadores convidados, atraídos pela divulgação na imprensa e pelo interesse pelo trabalho do grupo, bastante conhecido em São Paulo.

Ao longo das 4 horas de peça, nota-se em momentos distintos o corpo coletivo do público, configurando-se ora como brincantes de um bloco de carnaval, ora como torcedores de um time de futebol, ora como clientes de uma barbearia tradicional da Barra Funda, ora como convidados de uma festa. Influenciada pela música, essa pequena multidão dançante tem a mesma irreverência de um bloco de carnaval, onde as pessoas se encontram, conversam, bebem cerveja, comem e ocupam coletiva e festivamente a rua. Com a mesma liberdade com que atravessam esse bairro, espectadores são incorporados e abandonam a trajetória quando querem, pois o percurso pode ser vivido integral ou parcialmente, sem restrições, nem controle. É comum que espectadores dividam o trajeto da peça em dois, assistindo a segunda metade em um dia diferente daquele em que viu a primeira. Para alguns moradores, , a peça tornou-se um evento, um ritual incluído na rotina do bairro. Assim, é possível afirmar que os espectadores passantes ou fortuitos foram cooptados pelo evento, tornando-se espectadores convidados ou deliberados. Tive a oportunidade de conversar com uma espectadora que frequentava a peça todos os sábados; seguia o cortejo até certo ponto e 
vibrava diante das cenas de sua predileção. Como se não bastasse, ela convidava a cada final de semana amigos e vizinhos que ainda não tinham visto a peça para acompanhá-la. A peça funciona para ela como um ato de desobediência civil.

Nada disso impede a fluência da obra, que é fragmentada, livre e radical em seu modo de se inscrever no contexto urbano. Embora haja críticas bastante contundentes em relação à coesão dramatúrgica ou à composição das cenas da peça, decorrentes da ausência de um olhar de fora, ao meu ver Barafonda propõe uma experiência transgressora ao promover um uso festivo do espaço público, independente de uma data comemorativa. É como se a Cia. São Jorge de Variedades autorizasse a brincadeira e decretasse que o carnaval está permitido a qualquer época do ano.

As cenas iniciais são inteiramente musicadas. Na Praça Marechal Deodoro, ponto de partida dessa deambulação, há uma banda instalada, com caixas de som barulhentas, bem como um andaime da altura do Minhocão (Elevado Presidente João Goulart) ${ }^{15}$, que passa ao lado da praça. Do meio dos espectadores surge um dos personagens centrais da trama, vestido de homem comum; ele aos poucos se transforma a partir da manipulação de diversos tubos de tinta. Com alto índice de performatividade e de decibéis, inicia-se um cortejo do qual fazem parte os atores que abrem a peça, um coro de atores vestidos de macacões cinza e capas de chuva amarela, assim como o coletivo de espectadores. Esse coro invade a praça e dá início a um deslocamento do qual chegaram a participar mais de trezentas pessoas em uma única apresentação. Na maioria das vezes - o que era preferível do ponto de vista da companhia - participavam entre cem e cento e cinquenta pessoas.

Como não se trata de um desfile no qual diferentes frentes se apresentam sucessivamente, e sim de um cortejo, no qual todos caminham juntos (observadores e observados), os atores se dividem em grupos. Há um revezamento entre os atores que participam da primeira cena e aqueles que vestem macacões cinza, enquanto um triciclo acompanhado de uma cantora e um contador de histórias encabeça a comitiva. Os dois grupos, no entanto, compõem imagens estáticas ao longo do caminho, de modo que as longas distâncias percorridas estão sempre preenchidas pelas interferências dos atores, que se desdobram entre "fotografias" e corridas para avançar na direção do deslocamento do público. Desse modo, os atores são sempre os últimos a sair e os primeiros a chegar dentre os pontos que compõem esse percurso.

Os princípios operadores desse tipo de deslocamento são velhos conhecidos dos espectadores. Desse modo, a peça simula e faz reviver um antigo cordão carnavalesco, com a direito

\footnotetext{
15 O antigo Elevado Costa e Silva teve seu nome modificado no dia 22 de junho de 2016, a partir de um projeto de lei que previa deixar de homenagear um presidente da ditadura militar e passar a homenagear um presidente deposto por esse regime.
} 
a algumas histórias do berço do samba paulistano, enquanto a cantora entoa canções dessa mesma época. Mesmo quem nunca viveu tal experiência diretamente, consegue supor seu "modo de usar": basta caminhar pela cidade, embalado por boa música, seguindo o fluxo desse agrupamento de gente. Em pontos estratégicos, há pausas para ouvir as histórias, tal como a conversa que se estabelece com um barbeiro "real" do bairro, que poderá ser encontrado qualquer dia naquele mesmo endereço, realizando seu ofício, independente do acontecimento teatral.

Cada indivíduo que acompanha essa peça pelas ruas da Barra Funda nota rapidamente que cabe a ele escolher o nível de atenção que dedica ao evento. Como pedestre em atividade na cidade, ele pode optar por parar em um bar e comprar uma cerveja, pode fumar, conversar com os amigos que encontrar no meio da multidão e até atender seu telefone celular. Isso faz com que a encenação não seja apenas vista, mas vivida. As linhas da sua atenção estão cruzadas e o espectador segue seu caminho mais ou menos atravessado pelas teatralidades que se apresentam.

Na segunda parte da peça, outra estrutura bastante conhecida por parte do público brasileiro é usada como referência para a composição cênica: uma partida de futebol. Em um canto relativamente calmo do bairro, os espectadores são posicionados de um lado da rua, o narrador e o banco dos jogadores são dispostos do outro lado, enquanto a partida se instala no meio da rua. $O$ jogo instaurado recorre às mesmas conhecidas regras do futebol, com a diferença de que os atores prescindem da bola para jogar. Juiz, narrador e jogadores, como só acontece no teatro, veem e concordam com o posicionamento de uma bola ausente, embora entrem em disputa diante de alguns passes realizados pelos jogadores do time adversário. Os espectadores, por sua vez, também compactuam com o jogo da bola invisível, observando muito atentos a interação dessa partida com a passagem dos carros. Há um confronto entre ficção e realidade, magistralmente orquestrado pelo juiz da partida, que ganha ares de guarda de trânsito, parando os carros e autorizando o jogo, numa inversão explícita das convenções sociais. Como conhecedores das regras do trânsito e do futebol, os espectadores presenciam uma subversão dos valores e podem finalmente vislumbrar uma cidade utópica onde a pelada vale mais que o império dos automóveis.

Há na apropriação que a Cia. São Jorge realiza tanto das festividades do carnaval quanto da partida de futebol um potencial pedagógico, um modo de operar autoexplicativo para o uso do espectador. E esse "uso" tem como prerrogativa o desvio da atenção ao "consumo" o caráter oposto ao que seria o "consumo" (na acepção atribuída a esses termos por Michel de Certeau). É interessante destacar que não há hesitação por parte do público em relação a como agir; as pessoas incorporam rapidamente o deslocamento, integrando algo que poderia ser comparado a uma grande "ola" que atravessa a cidade. Não há maiores explicações, apenas o deslocamento dos atores, que vez ou outra se instalam nas lojas, nos muros e 
até nas lixeiras encontradas ao longo do percurso como se pousassem para fotografias que anunciam que as coisas estão fora do eixo. Os corpos se camuflam e interagem com as mais diversas mercadorias, como se eles também se tornassem objetos. Essa estranha interposição do corpo dos atores entre o olhar do espectador e a mercadoria interpela qualquer tipo de desejo que o primeiro possa nutrir em relação à segunda.

Dessa forma, a estrutura de Barafonda solicita uma atitude inteligente e ativa do espectador, responsabilizando-o por desvendar limites e possibilidades para a sua atividade. Até certo ponto, cabe ao próprio espectador definir sua operação; é dada a ele a oportunidade de reinventar a sua função. Por estar livre para ir e vir, o espectador transforma a prática da caminhada numa prática de liberdade, de fruição artística e de ocupação do espaço público. É ele quem inventa as regras, reagindo às provocações desses artistas, que por sua vez são obrigados a adequar sua criação às soluções que a multidão inventa a cada apresentação. No papel de foliões, por exemplo, os espectadores passam a ser "protegidos" pelo evento artístico. São os integrantes da companhia (atores e equipe técnica) que interrompem o fluxo dos carros e permitem que os espectadores atravessem displicentemente a rua. $\mathrm{O}$ que a São Jorge faz é alargar as faixas de pedestres, tornando os passantes mais importantes que os carros, mesmo que seja por apenas 4 horas e numa pequena extensão de 1700 metros.

\section{_ protestos, marchas e manifestações}

La barricade ferme la rue mais ouvre la voie

[A barricada fecha a rua, mas abre o caminho] slogan de Maio de 1968

Quando o modelo que se toma como referência para as manifestações artísticas são os protestos, as marchas e as passeatas, a cidade precisa ser analisada em uma escala mais ampla. Tratam-se de grandes trajetórias sendo percorridas por multidões, que muitas vezes utilizam dos espaços mais monumentais das cidades. Ao discutir site specific e política tendo a Inglaterra como território de referência, Sophie Nield nos alerta sobre a diferença entre a ocupação do espaço público pelo povo durante uma manifestação e a organização de espectadores nesse mesmo espaço com o objetivo de observar um desfile da Rainha, uma procissão real. No início de seu artigo, a autora distingue a teatralidade do protesto daquela associada ao poder no espaço público, descrevendo dois eventos específicos: o desfile da Rainha Victoria em 1887 e a Marcha contra os ataques ao Iraque, que mobilizou 60 países diferentes e levou milhares de pessoas às ruas de Londres, em 2003 (NIELD in BIRCH e TOMPKINS, 2012, p. 219). 
Os dois exemplos evocados por Nield tratam de deambulações coletivas como práticas cidadãs. Nos desfiles, entretanto, o espaço da representação está separado do espaço da observação, no qual o espectador permanece imóvel. Não são todos que desfilam, a mobilidade fica restrita a quem detém o poder. Raramente as pessoas que desfilam se deslocam a pé; esse deslocamento é necessariamente motorizado. Enquanto isso, em um protesto ou marcha, a estrutura se configura de modo mais participativo e horizontal, sem clivagem espacial e sem restrições ao ato de caminhar. Todos se deslocam e ninguém tem uma visão global do evento. Desse modo, não pode-se afirmar que o povo em marcha seja similar ao público que assiste a um desfile, pois o povo nos protestos detém a ação de caminhar e ocupa a centralidade do evento. Caminhar, nesse caso, é necessariamente um gesto político.

Existem muitas maneiras de avaliar a eficácia de um movimento de protesto. É
preciso levar em conta seu impacto sobre o grande público, diretamente ou pelo
intermédio das mídias, e seu impacto sobre o governo; esses dois parâmetros
dão uma ideia de sua audiência. Esquece-se com frequência, em contrapartida,
de falar sobre seu impacto sobre os protestantes, que a sua determinação em
agir publicamente os transforma em porta-voz da opinião pública, dito de outro
modo, em força atuante e não mais em "público passivo"(SOLNIT, 2002, p. 294). ${ }^{16}$

Rebecca Solnit reflete mais adiante em seu texto sobre os momentos de recaída do entusiasmo revolucionário, sobre os quais pode-se concluir precipitadamente que a revolução fracassou. Quando as revoltas resultam em pequenos, mas significativos ganhos, como por exemplo o direito ao voto, a deposição de um ditador ou a realização de eleições diretas, a população tem a sensação de que enfim pode desfrutar de algum benefício de sua luta. A autora descreve o momento no qual os revolucionários voltam a suas ocupações habituais, uma pausa entre uma luta e outra. Trata-se de um movimento incessante, pois mais cedo ou mais tarde, outros opressores surgirão para ameaçar os direitos comuns. Solnit então relembra o curioso fato de que no primeiro aniversário de comemoração da tomada da Bastilha em 1791, os parisienses foram convidados para um parada militar em homenagem à Voltaire: "o povo, que havia contribuído para a marcha feroz e feliz da história, deixava a cena para tornar-se espectador" (Ibid.,p. 298). ${ }^{17}$

A autora americana, assim como Sophie Nield citada anteriormente, analisa a posição das pessoas que participam desses eventos públicos nos quais o fato de permanecer sentado ou parado, aceitando a restrição ao deslocamento, representa uma pausa no momento re-

\footnotetext{
${ }_{16}$ II existe plusieurs manières de jauger l'efficacité d'un mouvement de protestation. II faut tenir compte de l'impact qu'il a sur le grand public, directement ou par l'intermédiaire des médias, et de celui qu'il a sur le gouvernement; ces deux paramètres donnent une idée de son audience. On oublie souvent, en revanche, de parler de son impact sur les protestataires, que leur détermination à agir publiquement transforme en porte-voix de l'opinion publique, autrement dit en force agissante et non plus en "public" passif (tradução minha).

${ }^{17}$ [...] le peuple qui avait contribué à la marche féroce et joyeuse de l'histoire quittait la scène pour redevenir spectateur (tradução minha).
} 
volucionário. Nesse sentido, quando o grupo de atores do Lume realiza sua Parada de Rua (uma criação de 1998, dirigida por Lai Bredholt) há uma subversão desse modelo militar. Essa parada é formada por um cortejo de palhaços que exploram o espaço público carnavalizando esse modelo e quase impedindo que os habitantes das cidades pelas quais eles passam fiquem parados. Trata-se de uma estrutura de desfile, que aos poucos começa a se dissolver e tomar as características de um bloco de carnaval. A atuação de Ricardo Puccetti merece ser destacada pela irreverência com a qual ele ocupa e se apropria dos espaços. Aproveitando seu corpo longilíneo, o ator desloca-se aos pulos, verdadeiros grands jetés, convidando o público a enxergar possibilidades inimagináveis na rua, transformando postes, árvores, lixeiras e monumentos em púlpitos para suas estripulias. Sua movimentação vigorosa mobiliza não apenas o olhar dos passantes e habitantes da cidade, mas também os incitam a caminhar e acompanhar o cortejo clownesco.

O exemplo citado acima pertence à esfera artística e borra as fronteiras entre o protesto e o carnavalesco, a luta e a festa, o político e o artístico, o real e o ficcional. Ele nos convida ao exercício de observar as deambulações coletivas urbanas sem distinguir suas motivações, como forma de avaliar o quanto o ato de caminhar determina o modo de relação, de participação e de interação que se tem com a cidade. No entanto, não basta estar em conjunto no espaço público, uma vez que as características urbanísticas desse espaço também contribuem para a configuração de um discurso. Ou seja, há espaços que tem uma longa tradição em ser palco de protestos e alguns deles são também considerados monumentais, mesmo sem disporem de monumentos. Isso acontece quando a arquitetura é concebida com o intuito de receber e mostrar as autoridades, revelando de maneira simbólica seus feitos e seu poder.

Dentro desse processo de representação instituído na cidade, percebe-se uma redução da figura humana, de modo que o indivíduo se sente minúsculo diante da grandiosidade da arquitetura. "E nesse sentido, [o espaço monumental] torna-se muito mais do que um texto cujos signos podem ser lidos, como a arquitetura. Espaços monumentais manifestam o po-

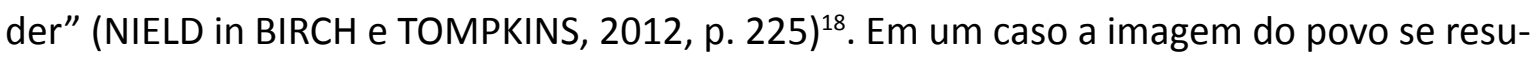
me à audiência que observa e cerca um indivíduo; e no outro, a imagem do povo é coletiva, um grande aglomerado humano, na maioria das vezes, polifônico. Esses exemplos servem para explicitar o quanto os espaços não são neutros, nem tampouco constituídos de formas desprovidas de conteúdo; os espaços urbanos têm história, uma história construída em camadas distintas de tempo.

Henri Lefebvre defende a ideia de que "o espaço não seria nem um ponto de partida [...], nem um ponto de chegada [...], mas um intermediário em todos os sentidos desse termo,

${ }_{18}$ And in this way, it becomes much more than a text whose signs can be read, like architecture. Monumental space makes power felt (tradução minha). 
ou seja, um meio e um instrumento, um ambiente e uma mediação"(2016, p. 44). É nesse mesmo sentido que Nield distancia-se da metáfora do palimpsesto ao se referir a tais espaços, quando usados como site specific. Um palimpsesto é um pergaminho cujo texto pode ser eliminado para o suporte ser reutilizado. O mesmo não acontece com o espaço público, pois nele sobrevivem camadas de performances simbólicas, desde sua configuração arquitetônica, passando pela história das intervenções que se inscreveram nele até chegar às ações mais temporárias e efêmeras. Sophie Nield menciona, no entanto, as trocas simbólicas, que operam frequentemente de modo desigual, pois muitas ações correm o risco de serem absorvidas pela narrativa dominante. Nessas circunstâncias, coloca-se em negociação e em questionamento o tipo de relação que se estabelece entre o povo, o estado, as leis e o governo. Quem tem o direito de tomar decisões? Quem decide como um espaço público pode ser usado? Quais manifestações culturais são tidas como legítimas ou ilegítimas?

Isso não é uma simples inscrição em um pergaminho raspado, mas uma narrativa maior: uma sequência variável de superimposições, inscrições, ocupações, e

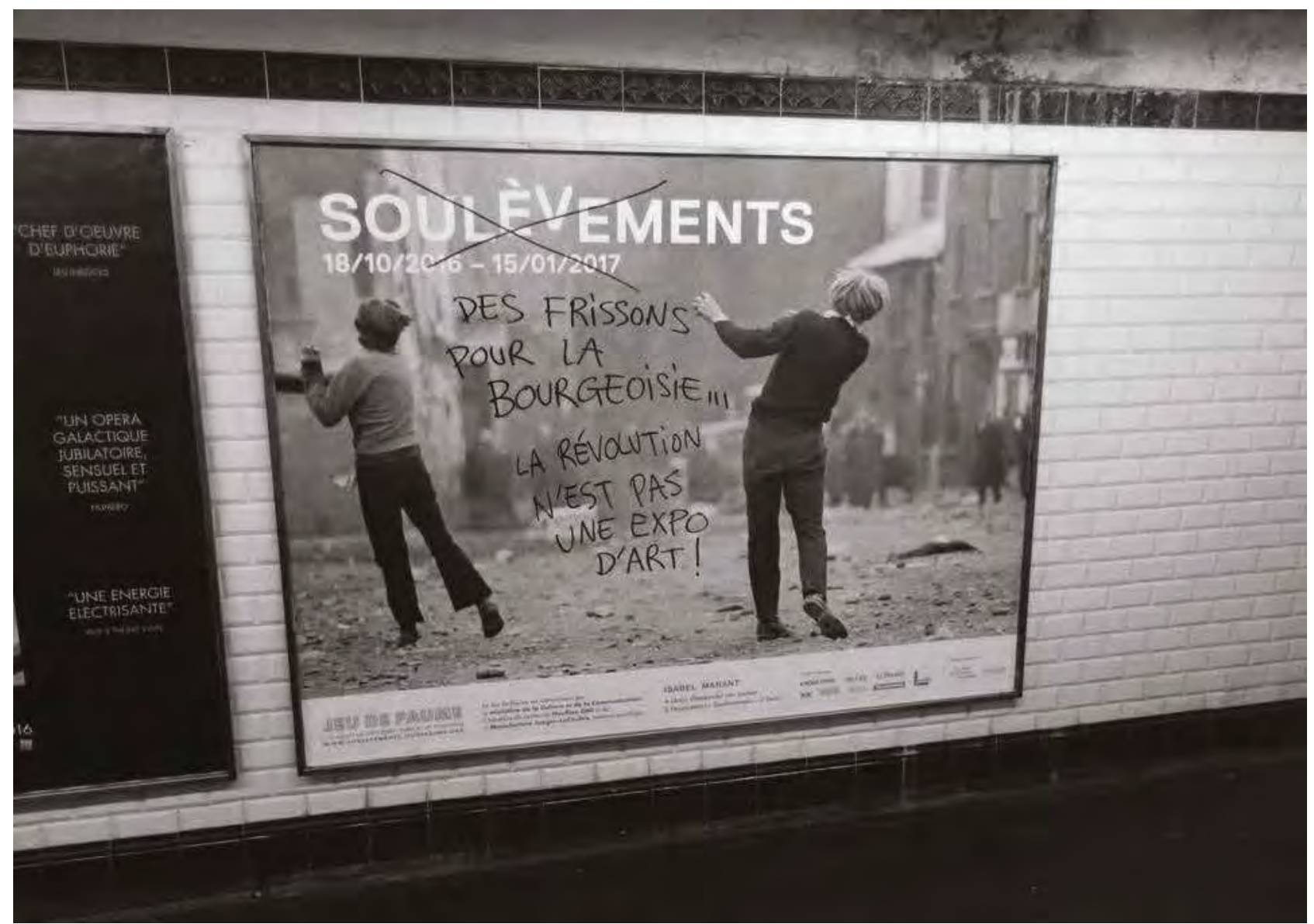

Figura 17: Cartaz da exposição Soulèvements no metrô de Paris
Foto: Disponível em: <https://paris-luttes.info/soulevementsla-revolte-n-est-pas-7276?lang=fr>. Acesso em: 10 fev. 2017.

autorizações; não uma simples performance site specific, mas uma dramaturgia do espaço. É aqui que a ideia de Lefebvre de 'horizonte de significado' torna-se 
Dessa forma, há uma multiplicidade de sentidos possíveis e as performances estão constantemente inscrevendo outras temporalidades no espaço, pois não existe espaço sem tempo. Isso significa que os espaços são constantemente definidos pelo uso que se dá a eles. Até mesmo uma imagem do espaço temporariamente modificado por uma performance, vista pela internet, é capaz de acrescentar camadas de significado sobre esse espaço. Entretanto, isso não quer dizer que a memória impregnada naquele lugar não se mantenha, que ela seja apagada ou substituída pela visão do presente; ela se mantém como uma ressonância. Entre um lugar específico e uma performance há uma troca constante de significados e mesmo que os aspectos fugazes da criação artística sejam apagados diante da memória impregnada no lugar, o trabalho da performance ultrapassa essa inscrição imediata e geralmente não tem a pretensão de uma inscrição definitiva. Sua função é justamente flexibilizar os limites impostos, ganhar espaços de expressão e visibilidade e reinventar modos de vida, o que em maior escala significa reinventar gradativamente esses espaços.

Em tempos de ampla despolitização da população, comprovada pela emergência de uma crise representativa, há urgência em observar os textos que as multidões inscrevem no espaço público. As legendas não são claras, as vozes não são uníssonas, de modo que ideias progressistas e de liberdade ocupam as mesmas avenidas que o conservadorismo e a brutalidade. Por um lado, há uma alienação e uma negação cada vez mais acirrada a tudo o que é político (como revela o discurso de candidatos que se dizem gestores ou empresários); por outro lado, o debate político emerge de contextos que anteriormente se mantinham à margem. Desse modo, torna-se urgente convocar a todos para pensar e debater $(\mathrm{n})$ a cidade - o verdadeiro sentido da palavra política - como acontece em uma exposição organizada recentemente (de outubro de 2016 a janeiro de 2017) a partir dos estudos de Georges Didi-Huberman sob o título Soulèvements [Revoltas ou Insurreições], exibida no museu Jeu de Paume em Paris.

\footnotetext{
"Soulèvements é uma exposição transdisciplinar sobre o tema das emoções coletivas, eventos políticos à medida em que assumem os movimentos de multidões em luta: serão abordados, portanto, desordens sociais, agitações políticas, insubmissões, insurreições, revoltas, revoluções, tumultos, motins, perturbações de todos os gêneros"20
}

${ }_{19}$ This is not a single inscription onto a scraped-out parchment, but a larger narrative: a changing sequence of superimpositions, inscriptions, occupations, and clearances; not a single site specific performance, but a dramaturgy of space. It is here that Lefebvre's idea of the 'horizon of meaning' becomes particularly useful (tradução minha).

20 Soulèvements est une exposition transdisciplinaire sur le thème des émotions collectives, des événements politiques en tant qu'ils supposent des mouvements de foules en lutte: il sera donc question de désordres sociaux, d'agitations politiques, d'insoumissions, d'insurrections, de révoltes, de révolutions, de vacarmes, d'émeutes, de bouleversements en tous genres (tradução minha). Excerto disponível em: <http://www. jeudepaume.org/?page=article\&idArt=2476> . Acesso em: 5 fev.2017. 


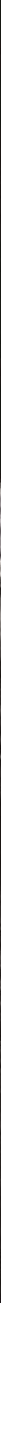

Trata-se de uma reunião de obras antigas e contemporâneas que se referem a diferentes agrupamentos e suas emoções coletivas, que "não devem ser excluídas de uma antropologia política". A exposição é dividida em cinco partes: elementos (desencadeados), gestos (intensos), palavras (exclamadas), conflitos (inflamados) e desejos (indestrutíveis). Uma revisão histórica necessária, ainda que concentrada dentro de uma instituição - motivo de críticas manifestas em frases escritas sobre cartazes do metrô que anunciavam a exposição, tais como: "Frisson da burguesia" ou "Recuperação", sempre seguido de "A revolução não é numa exposição de arte" - que propõe uma interrogação sobre a ideia de representação, ao mesmo tempo, estética e política.

Como exemplo dessas teatralidades que ocupam o espaço público, fortemente inspiradas e até mesmo confundidas com movimentos sociais reais, gostaria de evocar uma intervenção urbana realizada em São Paulo pelo grupo francês Générik Vapeur ${ }^{21}$, na Virada Cultural de 2008. A trupe composta por 15 atores, 3 músicos e 1 técnico, todos pintados de azul, invade o espaço público munida de grandes latões que, ao serem manipulados, produzem música,

\footnotetext{
${ }^{21}$ A companhia de teatro de rua, sediada em Marselha, foi fundada em 1984 por Caty Avram e Pierre Berthelot e tem como princípio a mescla de linguagens artísticas como teatro, dança, música e vídeo. Mais informações no site: <http://www.generikvapeur.com/accueilfr.html >. Acesso em: 5 fev. 2017.
} 
ruídos e certo terrorismo na abordagem radical que fazem do público. Na adaptação de Bivouac (criada originalmente em 1989, como uma alusão ao Muro de Berlim) para São Paulo, há um percurso pré-definido que sai da Galeria Olido na Avenida São João, percorre algumas ruas do centro da cidade e se encerra na Praça do Patriarca, diante de uma pirâmide de 102 latões coloridos. Em português, o título da intervenção seria "bivaque", que significa a área que acolhe a tropa. Desde a saída da trupe, o clima é de grande agitação; ao som de um rock muito barulhento produzido pelos músicos dispostos em um pequeno caminhão, os demais performers correm pelas ruas rolando latões (como aqueles que se usa para carregar gasolina) e gritando. Vez ou outra, fazem ações coreografadas, transformando os galões em instrumentos musicais e em seguida, partem novamente em retirada rolando os latões na direção do público.

A atmosfera produzida pelo Générik Vapeur é, em muitos momentos, aterrorizante, sendo que os espectadores se veem obrigados a correr, pois os cabeças azuis parecem ser capazes de atingir uma pessoa menos avisada com um de seus latões. A performance é enérgica e está longe de se configurar como um jogo de faz de conta; há revolta, sangue nos olhos, corpos e vozes preparados para a dimensão da rua, latões sendo erguidos e jogados no chão, fogos de artifício e gelo seco. Com esses artefatos, o grupo seria capaz de mobilizar uma revolta real, uma vez que a ação dentro de seu campo ficcional exercita a tirada do povo de um certo estado de inércia. Entrando no jogo proposto, como as antigas plateias do La Fura dels Bals (grupo catalão que ameaçava atingir os espectadores inclusive com serras elétricas, na década de 80 ), os espectadores não se intimidam e seguem o cortejo de Bivouac acompanhando suas ações truculentas e espetaculares pelas ruas do centro da cidade. Além do som, os performers manipulam feixes de luz e um caminhão que chega a simular um touro com ventas fumegantes, usado para carregar toda a parafernália de que precisam ao longo desse "percurso emocional" em grande escala.

Trata-se de um deslocamento coletivo turbulento, que no contexto dos protestos e manifestações reais estaria mais próximo de um motim, tamanho o tumulto provocado pela ação. Prova disso é o final apoteótico da intervenção, no qual um performer joga mais um latão sobre a pirâmide formada por latões similares, de cima do grande monumento da referida praça, e destrói um carro de polícia cuidadosamente posicionado embaixo dela. Como resultado dessa ação, a segunda apresentação que o grupo faria no evento foi cancelada pela polícia, segundo a qual o grupo não teria conseguido chegar a um acordo com as autoridades. No ponto de vista dos artistas, as exigências da polícia inviabilizam a performance. Dentre elas está a restrição da música ao ponto final, a diminuição significativa do cortejo e, obviamente, a retirada do adesivo "police" do carro que seria esmagado. O secretário de cultura de São Paulo à época declarou que a polícia se assustou com a ação e temeu que a performance suscitasse uma revolta real dentre os espectadores. Nesse exemplo, 
fica nítido o quanto a rua é o espaço do real por excelência, pois não existem parâmetros norteadores das fronteiras entre a ficção e a realidade, sobretudo quando está em jogo o deslocamento de centenas de pessoas.

Com uma criação na escala da cidade, o Générik Vapeur reinventa a rua como espaço de manifestação e visa mudar a percepção do centro da cidade. Suas ações encorajam os sujeitos a investirem na rua, em um corpo a corpo simbólico com sua época. Bivouac injeta no espaço cotidiano uma arte que não se encerra nela mesma, cujos sentidos e significados dependem de um exercício de leitura e imaginação por parte do público. É claro que, em certa medida, isso sempre acontece, mas nesse caso há uma radicalidade que solicita um esforço a mais do espectador. Primeiramente, ele escolhe não só acompanhar, mas também integrar esse manifesto, que se tivesse acontecido mais recentemente poderia ter sido confundido com um grupo de black (ou blue) blocks, devido ao caráter anárquico impresso na ação. Em seguida, o espectador precisa aderir à atitude corporal dos performers, propondo-se a correr e desviar de latões quando for necessário, se quiser acompanhar de perto a ação dos homens azuis. E por último, perceber que não havia nenhum discurso posto, nenhuma mensagem específica impregnada no ato, a não ser pela experimentação concreta de uma espécie de treinamento para uma luta em prol da desestabilização de um sistema capitalista excessivamente controlado por regras e autoridades (a polícia, no caso).

Embora não houvesse um discurso verbal articulado, a encenação da rebelião era notável nessa deambulação. Uso a palavra encenação para me referir à disposição dos corpos, à projeção das vozes, à organização das ações e ao tipo de energia empregada pelos atores, sem nenhuma menção pejorativa ao que pudesse haver de "teatral" nesse evento, pois nesse caso era importante parecer real. $O$ discurso que emerge de Bivouac era perfeitamente legível. Caso essa intervenção tivesse sido apresentada em São Paulo em 2013, ela poderia ter sido associada às ações experimentadas por alguns manifestantes nos primeiros protestos pelo passe livre. Nessa ocasião, os black blocks faziam barricadas nas ruas com sacos de lixo e ateavam fogo para barrar as tropas de choque que se utilizavam de tanques de guerra, bombas de efeito moral e gás lacrimogêneo para impedir as manifestações. Pode-se dizer, que o Générik Vapeur evoca um slogan de maio de 68: "A imaginação toma o poder"[L'imagination prend le pouvoir $]^{22}$ e não nos deixa esquecer que a rua é do povo ${ }^{23}$. A cidade pertence aos seus cidadãos, que dispõem de todas as condições de se impor e de promover, se não uma revolução, uma micro-resistência urbana.

\footnotetext{
${ }^{22}$ Há uma lista de slogans de maio de 1968 disponíveis no site: <http://users.skynet.be/ddz/mai68/slogans-68. html>. Acesso em: 9 fev. 2017.

${ }^{23}$ La rue est à nous... tous [A rua pertence a nós... todos], menção a um bordão que tem mobilizado muita discussão em torno dos modos de habitar as cidades contemporâneas. Em 2009, uma exposição com esse mesmo título aconteceu simultaneamente em diversos países do mundo, convocando um amplo debate sobre a rua e seus habitantes.
} 


\section{_ocupações, marchas cidadãs e rituais públicos}

On ne revendiquera rien, on ne demandera rien, on prendra, on occupera [Não reivindicaremos nada, não pediremos não, tomaremos, ocuparemos] Slogan de Maio de 1968

Ao se referir às intervenções que têm acontecido recentemente no espaços públicos, como manifestações não exclusivamente vinculadas à esfera artística, mas associadas principalmente à sociedade civil, lleana Diéguez Caballero afirma que essas ações são liminares. A pesquisadora cubana radicada no México usa o termo liminar ${ }^{24}$ para se referir às manifestações artísticas situadas numa zona complexa, na qual se entrecruzam a vida e a arte, a condição ética e a criação estética. Nessas teatralidades amplamente analisadas por ela há uma hibridação não apenas de linguagens artísticas, mas também de arquiteturas, filosofias, posicionamentos políticos e circunstâncias sociais. Dedicando-se prioritariamente a estudar ações criadas na América Latina, em muitos dos casos as próprias pessoas envolvidas nas ações se recusam a serem chamadas de artistas e não consideram o que fazem como arte. Na maioria das vezes, trata-se de acionismo, de artivismo (uma junção de arte e ativismo) ou de rituais públicos e participativos. Esses últimos são considerados como rituais dialógicos, dos quais os espectadores participam ativamente. Para reafirmar sua posição, a autora usa o enunciado de Olivier Poivre d'Arvor, diretor da Associação Francesa de Ação Artística à época, no qual ele considera que "se existe um lugar do mundo onde a arte teatral e a sua prática tem no dia a dia uma função política, social e cultural relevante, esse lugar é a América Latina" (POIVRE D’ARVOR in CABALLERO, 2011, p. 21).

Mujeres en la plaza, uma proposição de Patricia Ariza, durante o Encuentro Del Instituto Hemisférico realizado na cidade de Bogotá, na Colômbia (2009) é um exemplo do que Diana Taylor chamou de "performance massiva". Trata-se de um evento realizado por trezentas mulheres afetadas pela violência naquele país. A Plaza Bolivar de Bogotá recebeu milhares de espectadores, dentre eles familiares de pessoas desaparecidas, para tornar visível a violência no país. A esse exemplo, uma série de atos, marchas e paradas podem ser acrescentados, diluindo as fronteiras entre intervenção artística e movimento social, entre performance e acionismo. Nesse sentido, três ações cidadãs que borram as fronteiras entre arte e política, igualmente discutidas por lleana Diéguez Caballero e Diana Taylor podem ser citadas aqui: a Resistência Pacífica, na forma de ocupação pública da Avenida Reforma, como resposta ao resultado das eleições presidenciais de 2006 no México; as passeatas

24 Segundo a autora, "a questão liminar foi delineada pelo antropólogo Victor Turner ao estudar as características sociais da fase liminar" de alguns rituais de passagem, "associados a situações de margem ou limen (umbral)" (CABALLERO, 2011, p. 36). Ele analisa os ritos "em situações ambíguas, passageiras ou de transição, de limite ou fronteira entre dois campos, observando quatro condições: 1) a função purificadora e pedagógica"; "2) a experimentação de práticas de inversão"; "3) a realização de uma experiência, uma vivência nos interstícios dos dois mundos; 4) a criação de communitas", 'sociedades abertas' nas quais as hierarquias são suspensas e "relações igualitárias, espontâneas e não racionais" são estabelecidas (Ibid., p. 37). 
repetidas há 30 anos pelas Madres e Abuelas da Plaza de Maio em Buenos Aires e os escraches realizados pela organização H.I.J.O.S na Argentina pós ditadura militar.

A primeira delas são as ações do movimento de Resistência Pacífica desenvolvidas no México em 2006, como resposta a uma fraude eleitoral. Nessa ocasião, Jesusa Rodrigues colabora com o candidato da esquerda Andrés Manuel López Obrador, coreografando o evento para que todos pudessem vê-lo e escutá-lo.

Durante a segunda marcha ao Zócalo, Jesusa coreografou o evento. Enquanto AMLO [Andrés Manuel Lopéz Obrador] caminhava os quilômetros que separavam o Passeio da [Avenida] Reforma do Zócalo, atores e escritores conhecidos informavam e divertiam o público. Enormes monitores mostravam um vídeo da caminhada do candidato para que os que estavam em Zócalo pudessem vê-lo aproximar-se. A caminhada, visibilizada, ganhou sentido dramático, já que amplificou o efeito simbólico do líder que chegava para ocupar o centro do poder. Além disso, seus adeptos se viam refletidos nas telas, reconhecendo-se como parte de um movimento histórico. Ali se via claramente a todos os excluídos não somente das notícias televisionadas, mas de todo o processo eleitoral, os corpos de milhões de pessoas que queriam ser parte de um ato democrático (TAYLOR, 2012, pp.118-119) ${ }^{25}$.

Quando o candidato chega ao pedestal no centro da praça, ele é recebido pela performer Regina Orozco de braços abertos, personificando a Pátria. Nos dias que se seguem à terceira marcha, organiza-se um plantão no qual os cidadãos exigem a recontagem dos votos devido à suspeita de manipulação das eleições, que apontam uma diferença mínima para o candidato vencedor. Compõem esse movimento, que teve uma duração de aproximadamente dois meses, mais de 3400 performances realizadas de maneira espontânea por cidadãos que ocupam as ruas ou pela chamada Resistência Criativa, coletivo organizado por Jesusa Rodriguez. Em conjunto, cidadãos e artistas promovem um ato de desobediência civil, no qual explicitam sua insatisfação e seu desejo por um processo eleitoral democrático.

Por meio de intervenções simbólicas no espaço público, a Resistência Criativa promove boicotes a instituições e empresas associadas ao partido vencedor, propondo empacotamentos de edifícios, uma falsa conferência da imprensa internacional e o sepultamento de uma rede de televisão associada à manipulação das eleições. Enquanto isso, os cidadãos mexicanos se deslocam em passeatas em torno da Praça da Constituição portando carta-

\footnotetext{
${ }^{25}$ Durante la segunda marcha al Zócalo, Jesusa coreografió el evento. Mientras AMLO caminaba los kilómetros que separan el Paseo de la Reforma del Zócalo, actores y escritores conocidos informaban y divertían al público. Monitores enormes mostraban un video de la caminata del candidato para que los que estaban en el Zócalo pudieran verlo acercarse. La caminata, visibilizada, cobró sentido dramático ya que amplificó el efecto simbólico del líder que llegaba a ocupar el centro del poder. Además, sus adherentes se podían ver reflejados en las pantallas, reconociéndose como parte de un movimiento histórico. Allí se veía claramente a todos los excluidos no sólo de las noticias televisadas sino de todo el proceso electoral, los cuerpos de millones de personas que querían ser parte de un acto democrático (tradução minha).
} 


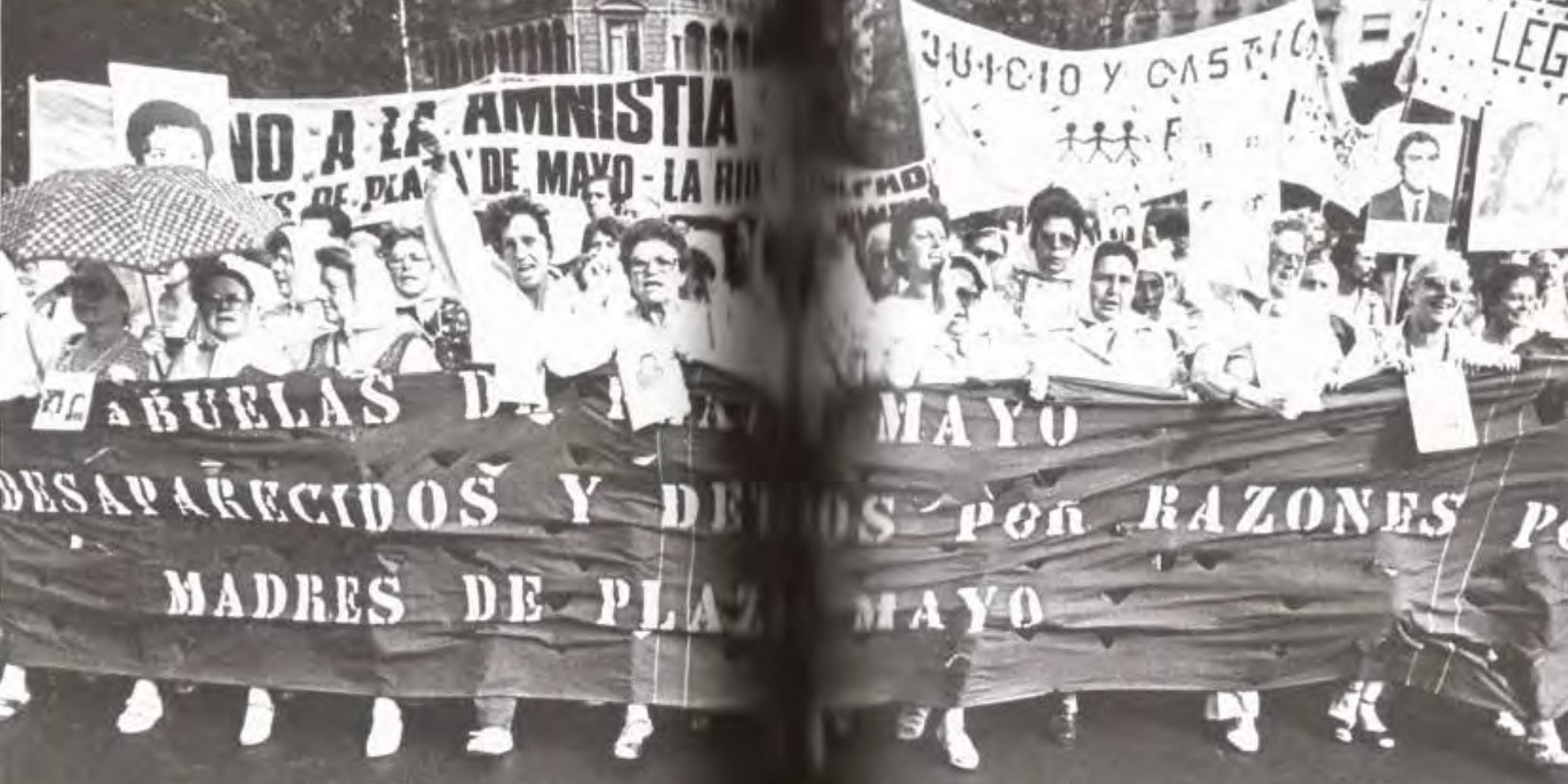

zes, fazendo paródias de políticos, improvisando performances e distribuindo flores amarelas ao longo do percurso. Embora o Plantão não tenha conseguido reverter o resultado das eleições de 2006, ele pode ser considerado como o início de um movimento a favor da democracia naquele país. Caballero aproxima essas ações cidadãs dos procedimentos situacionistas da teoria da deriva, elaborada por Guy Debord. Conforme a autora, os manifestantes caminham em deriva, passando ininterruptamente por diferentes ambiências e adotando comportamentos lúdicos que destoavam do andar comum. Sem se desconectar da indignação que os mobiliza, é nítido o prazer que sentem ao realizar a ação e o afeto presente nos encontros casuais promovidos por essa deambulação.

As ações seguintes são igualmente desenvolvidas em território argentino pelas mães que tiveram seus filhos desaparecidos e pelos filhos que foram separados de seus pais durante a Ditadura Militar que assolou aquele país entre 1976 e 1983. Trata-se respectivamente das Passeatas Circulares e ritualísticas realizadas pelas Madres de la Plaza de Mayo e dos escraches produzidos pelos filhos dos desaparecidos, por meio de uma organização intitulada H.I.J.O.S - Hijos por Ia Identidad y la Justicia contra EI Olvido y e El Silencio [Filhos em favor da identidade e justiça, contra o esquecimento e o silêncio]. São três gerações organizadas 


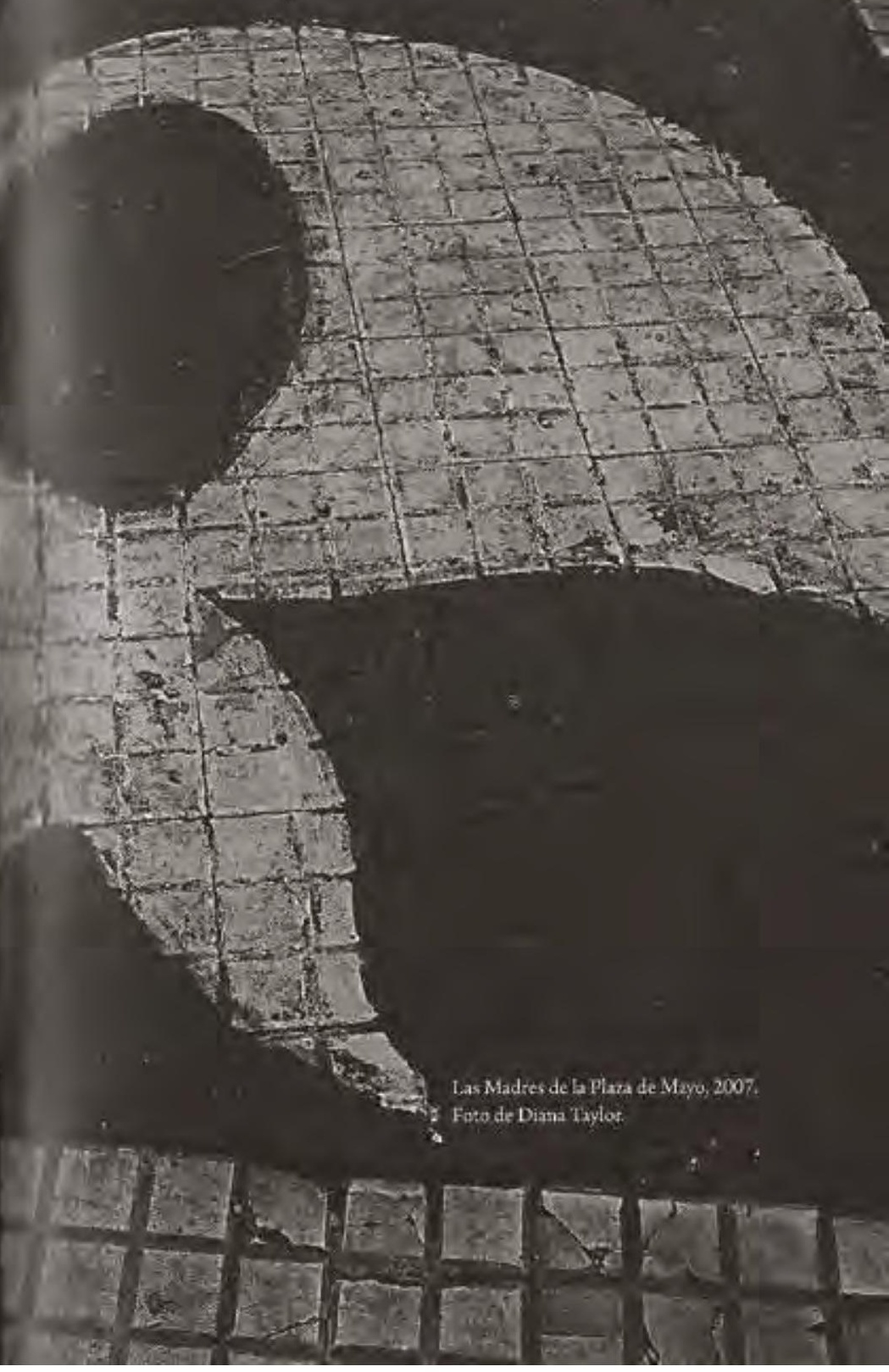

Foto: Diana Taylor (TAYLOR, 2012, p. 20-21).

em torno da perda dos esquerdistas perseguidos, torturados e desaparecidos durante a Ditadura Militar argentina. No primeiro caso, desde 1977 as mães e avós que tiveram seus filhos e netos desaparecidos realizam suas passeatas silenciosas em torno da praça, "inaugurando o protesto como forma de performance" (TAYLOR, 2013, p.240).

Depois de uma longa peregrinação por delegacias, quartéis e igrejas, essas mulheres escoIhem a praça como palco representativo de suas dores. Como elas podem ser presas por agrupamento ilegal, decidem caminhar em torno do obelisco central da praça. A repetição dessa ação no decorrer dos anos transforma essa caminhada circular em ato de memória, um gesto ritual, que leva o mundo todo a ter conhecimento dessa causa. Caminhar para essas mães é uma forma de se manterem próximas de seus filhos.

As passeatas das Mães da Praça de Maio, os escraches de H.I.J.O.S e os panelaços têm sido ações que, pela sua repetição e capacidade de convocar, converteram- 
-se em gestus simbólicos da sociedade civil, em rituais coletivos de participação cidadã, privilegiando as estratégias corporais e configurando uma nova linguagem que desautomatizou as tradicionais formas de protestos (CABALLERO, 2011, p. 122).

A autora enfatiza a importância de as ações poderem ser descoladas dos atores sociais que as performam, de modo que essas ações podem ser aprendidas e refeitas por outras pessoas. São ações simples, transmitidas por uma forma de "contágio". Conforme Taylor, à medida em que uma pessoa tem contato com essa dor, ela imediatamente a incorpora, responsabilizando-se por passar a limpo fatos passados, exigindo mudanças sociais e culturais. Voltando para nossa hipótese de que as intervenções e performances contemporâneas que se aproximam do real - pela inscrição no espaço urbano e pela implicação dos corpos em deslocamento - dispõem de um potencial pedagógico, podemos dizer que nesses formatos de protestos, esse potencial se apresenta pelo compartilhamento da dor. Vem da capacidade de cada um de se colocar no lugar do outro, de se perceber a partir do outro e de compreender que somos todos atores sociais envolvidos na escrita de uma história comum.

Quando a ação foi proibida pelos militares, um ícone toma conta do espaço: a imagem do lenço branco sem rosto, pintado por elas no chão da Plaza, como um ato de reivindicação daquele espaço, de demarcação de suas presenças e da ausência de seus filhos. Quando lleana Diéguez Caballero analisa essa ação, afirma que "o silêncio se converteu em discurso" (CABALLERO, 2011, p. 124). Ao adicionar os cartazes com as fotos de seus filhos sobre seus corpos, essas mulheres apelaram para mais um recurso icônico, que transformava seus corpos em "arquivos vivos", como atesta Diana Taylor. Com a volta da democracia em 1983, as avós e mães da Plaza passam a caminhar atrás de uma enorme faixa na qual acusam o governo de impunidade. Tais passeatas são emblemáticas da capacidade dessas performances de transmitirem a memória traumática de um povo, segundo Taylor. De fato, o que acontece é que o trauma as move; elas usam o trauma como inspiração para seu ativismo político. Para essa autora, ao utilizar a forma da performance para protestar, essas pessoas lidam com o trauma individual e coletivo, sendo que tanto a performance quanto o trauma são característicos por suas repetições. O trauma está localizado num espaço específico e "ambos se fazem sentir afetiva e visceralmente no presente" (TAYLOR, 2013, p.235). Trata-se de um gesto ao mesmo tempo de expurgo do sofrimento e de denúncia política, quando o estético dá suporte para uma revisão e um acerto de contas com o ético.

A memória traumática frequentemente conta com a performance interativa e ao vivo para sua transmissão. Até mesmo estudos que enfatizam a ligação entre o trauma e a narrativa evidenciam em sua própria análise que a transmissão da memória traumática da vítima para a testemunha inclui o ato, compartilhado e participativo, de contar e ouvir, que se associa com a performance ao vivo. Dar testemunho é um processo ao vivo, um fazer, um evento que acontece em tempo real, na presença de um ouvinte que "passa a ser um participante e coproprietá- 
rio do acontecimento traumático" (Ibid. p. 235).

A autora enfatiza a importância de as ações poderem ser descoladas dos atores sociais que as performam, de modo que essas ações podem ser aprendidas e refeitas por outras pessoas. São ações simples, que se transmitem por uma forma de "contágio". Conforme Taylor, à medida em que uma pessoa tem contato com essa dor, ela imediatamente a incorpora, responsabilizando-se por passar a limpo fatos passados, exigindo mudanças sociais e culturais. Voltando para nossa hipótese de que as intervenções e performances contemporâneas que se aproximam do real - pela inscrição no espaço urbano e pela implicação dos corpos em deslocamento - dispõem de um potencial pedagógico, podemos dizer que nesses formatos de protestos, esse potencial se apresenta pelo compartilhamento da dor. Vem da capacidade de cada um de se colocar no lugar do outro, de se perceber a partir do outro e de compreender que somos todos atores sociais envolvidos na escrita de uma história comum.

Diante da dor dos outros (citando Susan Sontag), penso no quanto o Brasil é carente de conhecimentos sobre a própria história e quanto ações que trouxessem à tona os mortos da nossa Ditadura seriam um importante exercício pedagógico e, ao mesmo tempo, político. Quando cidadãos contemporâneos, que viveram há menos de cinquenta anos uma Ditadura Militar, vão às ruas pedindo intervenção militar é prova de que vivemos em um sistema anestésico, silenciador e alienado. Cerca de 500 crianças nascidas entre 1976 e 1983 na Argentina continuam desaparecidas. Mesmo que no país vizinho o número de desaparecidos seja superior ao número de desaparecidos durante a ditadura brasileira, os movimentos sociais argentinos são reveladores de um passado histórico, formando as novas gerações. No Brasil, onde o golpe que instituiu a Ditadura Militar foi anterior à ditadura argentina, apenas recentemente houve a abertura dos arquivos da época e a instauração de uma Comissão da Verdade. Ao fim e ao cabo, ouve-se muito pouco a respeito de nossos mortos. Em ambos os países, trata-se de uma história muito recente; em menos de três gerações, a população já dá sinais públicos de esquecimento desse momento trágico de nossa história. Penso nas crianças desaparecidas na Argentina: algumas elas têm a mesma idade que eu, ou seja, pertencemos à mesma geração de crianças latino-americanas. A partir dessa aproximação temporal, elas parecem mais próximas de nós do que podemos imaginar.

Diana Taylor, considera as "crianças desaparecidas", aquelas nascidas nos campos de concentração argentinos e adotadas pelas famílias dos militares, enquanto aquelas que nasceram antes dos pais serem raptados são consideradas por ela como os "filhos dos desaparecidos". Entre as Avuelas, Madres e Hijos há uma herança genética, não apenas do DNA biológico, mas também no que se refere à performance. "O DNA funciona como uma espécie de arquivo, armazenando e transmitindo códigos que marcam a especificidade de nossa existência tanto como espécie quanto como indivíduos" (TAYLOR, 2013, p. 243). Além das fotografias, o exame de DNA torna-se um documento importante para o rastreamento so- 
bretudo dos netos desaparecidos, pois nos casos das mulheres que foram raptadas grávidas é bastante provável que essas crianças estivessem vivas e que nem tivessem conhecimento de sua verdadeira origem.

Taylor considera tanto as transferências testemunhais quanto os protestos performáticos, que podem ser apreendidos e repetidos, como "formas de comportamento social expressivo", enquadrando-se no que ela categorizou como "repertório". A ele se opõe a ideia de "arquivo", algo que dura mais do que os limites do "ao vivo" (Ibid. p. 244). Entre repertório e arquivo há uma diferença entre o que é efêmero e o que é permanente. Ou seja, o arquivo tem uma materialidade específica, que permite armazenamento, enquanto o repertório é

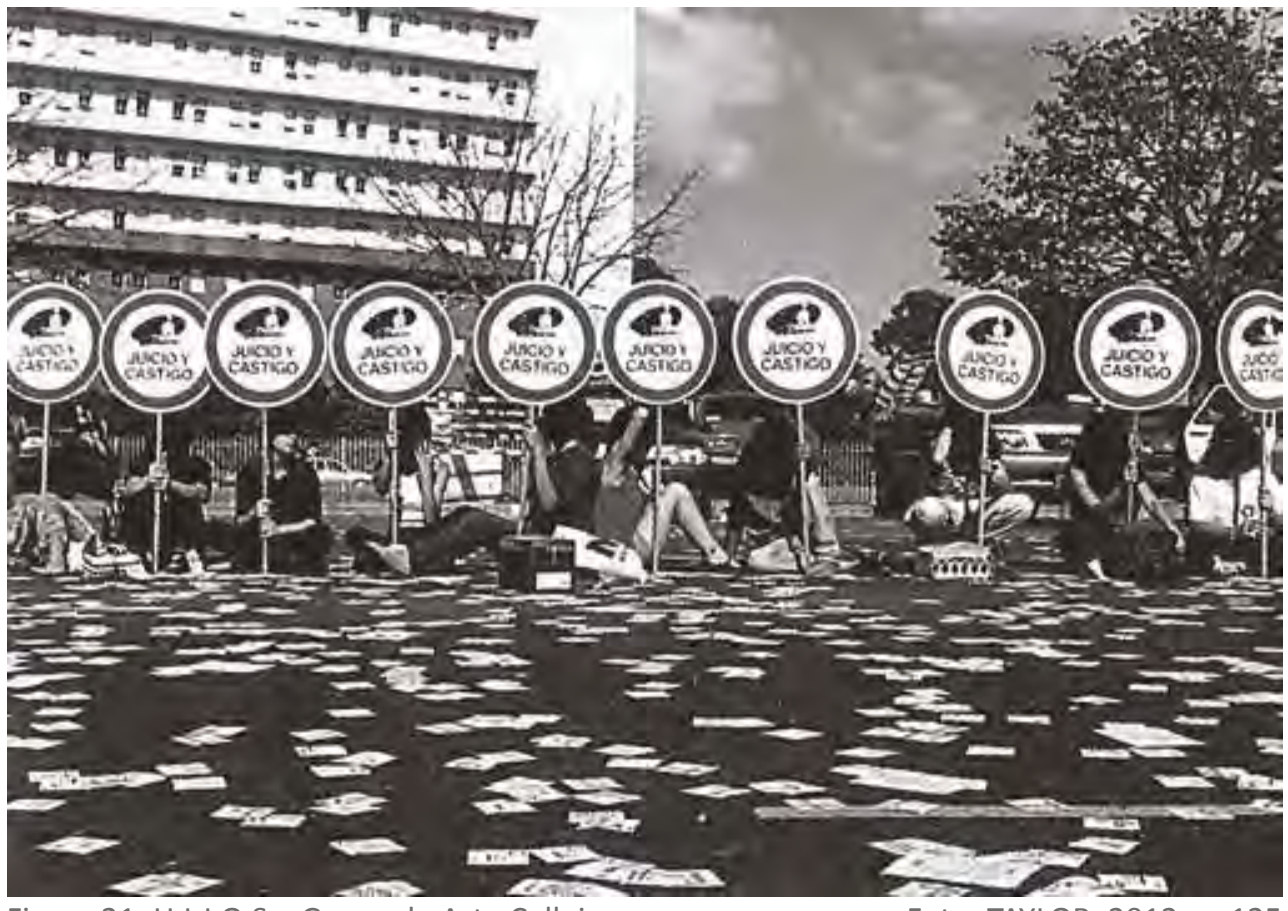

Figura 21: H.I.J.O.S e Grupo de Arte Callejero escrache
Foto: TAYLOR, 2012, p. 125

toda imagem ou comportamento que podem ser transmitidas por meio da performance. Fotografias e exames de DNA são arquivos tanto no contexto da performance, quanto no contexto das investigações policiais. Não por acaso, os militares argentinos somem com todas as imagens de arquivos dos indivíduos considerados subversivos raptados durante a ditadura. Como se não bastasse, suas casas são invadidas e as fotografias das vítimas igualmente roubadas para serem destruídas. Dessa forma, fotografias são provas, capazes inclusive de atestar sua existência.

A fotografia e o DNA certamente oferecem provas radicalmente diferentes de "presença", pois cada uma torna visível o que é totalmente inacessível à outra. Não podemos testar o DNA de uma fotografia, do mesmo modo que não podemos reconhecer fisionomias ao olhar para os nossos genes. Porém, tanto o DNA quanto as fotografias transmitem informações altamente codificadas (Ibid. p. 248). 
Enquanto as madres vestem as fotografias "como segundas peles" (expressão de Diana Taylor), encenando o arquivo sobre o próprio corpo, as abuelas - além de usar os exames de DNA como uma forma de estabelecer as relações genéticas entre os sobreviventes e os desaparecidos - encontram outras estratégias para o uso da fotografia. Exemplo disso é uma exposição organizada por elas em 2001 no Centro Cultural da Recoleta, em Buenos Aires, na qual elas posicionam fotografias das mães e pais desaparecidos ao lado de espeIhos nas mesmas dimensões das fotos. O propósito dessas composições era identificar seus netos desaparecidos. Segundo as abuelas "Encontrarlos es encontrarnos" [Encontrá-los é encontrar-nos]. Mais uma comprovação do quanto essas mulheres se referem a fatos recentes, pois elas buscam atualmente por volta de 500 adultos de no máximo 40 anos.

Nas ações propostas pelos H.I.J.O.S também há uma ênfase na questão da memória, uma vez que eles se baseiam na consanguinidade biológica (sem se restringir a ela) e utilizam um repertório similar àquele utilizado por essas mães e avós. Usam frequentemente a faixa longa e horizontal contendo o nome do grupo, grandes ampliações das fotos dos desaparecidos e realizam suas ações nas ruas, como forma de marcar publicamente sua luta contra o esquecimento. Todos reagem a uma perda, no entanto enquanto as mães expõem seu luto em um ritual em praça pública, os filhos apelam para uma criação carnavalesca e alegre. Ao ato de execração pública que eles cometem, dá-se o nome de escraches (escrachar, expor, por em evidência) ${ }^{26}$. Fazem parte do grupo H.I.J.O.S, os coletivos Etcétera e Grupo de Arte Callejero ( $G A C)$, que realizam atos de indignação e protesto nas ruas de Buenos Aires. Ambos desenvolvem suas obras como produções simbólicas contestatórias, exigindo "juicio y castigo" [julgamento e castigo] para os militares e todos aqueles que foram coniventes com eles no rapto, tortura e morte de seus pais.

Os escraches são destinados à participação de todos; não são eventos para serem olhados, mas para serem experimentados como os happenings. "São manifestações espalhafatosas, festivas e móveis, que reúnem de 300 a 500 pessoas" (TAYLOR, 2013, p. 232). Contudo, esses protestos performáticos apropriam-se de táticas de guerrilha, como por exemplo ocupar durante um mês ou mais os bairros onde os criminosos vivem ou centros clandestinos usados durante a ditadura, mostrando fotografias e conversando com a população local. Trata-se de uma ação ao mesmo tempo artística e política, que irrompe no espaço público, de modo similar aos situacionistas.

Tomando emprestado um vocabulário situacionista, podemos sem dúvida falar de uma psicogeografia da insurreição tal qual se manifesta no ritual das marchas contestatórias, a súbita instabilidade dos desconhecidos e dos muros, as ruas e as praças negras do mundo, a exaltação que acompanha a esperança de liberdade e que é o sinal indubitável de que a imaginação ao menos quebrou suas correntes.

26 De acordo com Diana Taylor, "a palavra escrache é etimologicamente relacionada a scracè = expectorar" (2013, p. 254). 
"Os momentos revolucionários são carnavais onde a vida individual comemora sua unificação com uma sociedade regenerada", declara o situacionista Raoul Vaneigem. (SOLNIT, 2002, p. 297) ${ }^{27}$.

Segundo Caballero, os escraches podem ser considerados como situações construídas, por se tratarem de "momentos da vida construídos concreta e deliberadamente para a organização coletiva de um ambiente unitário e de um jogo de acontecimentos" (2011, p. 130). 0 que a ação dos hijos promove é um deslocamento de foco dos desaparecidos para aqueles que o fizeram ou contribuíram para seu desaparecimento. São denunciados além de militares, "médicos que ajudaram nas sessões de tortura (...), a C.I.A e o seu plano Plano Condor, uma rede de ditaduras do Cone Sul, e a Escola das Américas que, financiada pelos Estados Unidos, treinou torturadores" (TAYLOR, 2012, p. 128) ${ }^{28}$. Esse movimento foi iniciado pelas

Figura 22: H.I.J.O.S

e Grupo de Arte Callejero - escrache

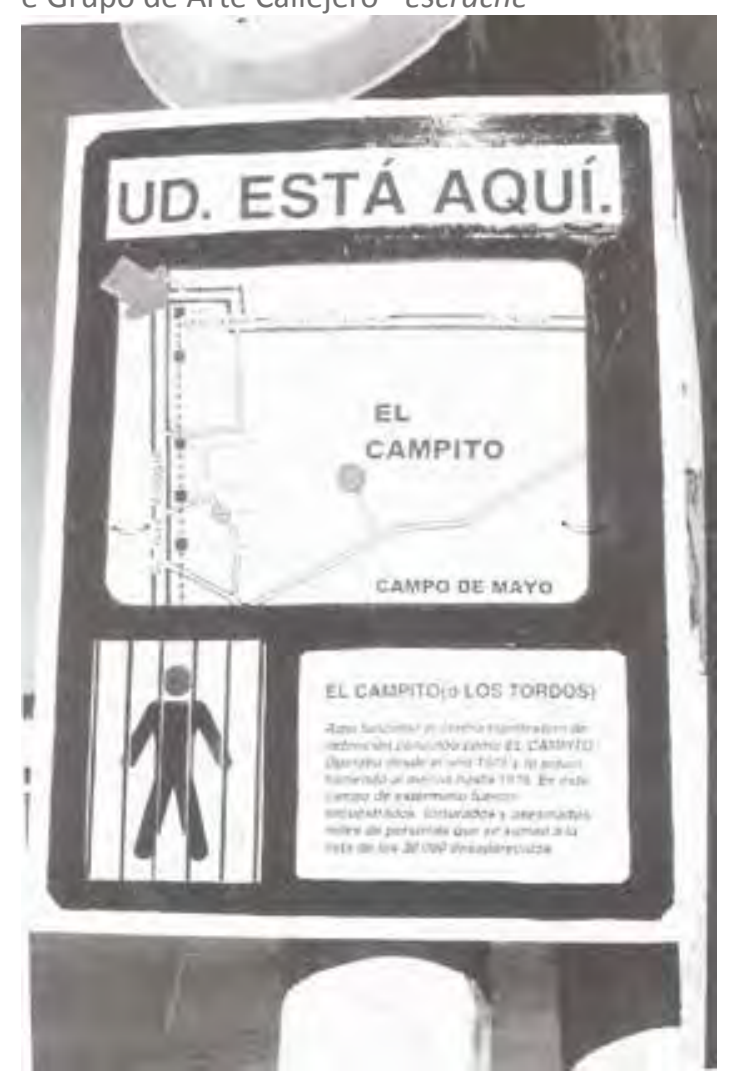

Foto: TAYLOR, 2013, p. 236 mães e avós da praça, que após o final da ditadura começaram a cobrar a impunidade dos crimes cometidos durante a "Guerra Suja". No entanto, essas mulheres eram obrigadas a permanecer na centralidade da praça, no local mais visível da cidade. Caso contrário, seriam rapidamente desaparecidas ${ }^{29}$. Enquanto isso, os hijos desafiam os criminosos expondo suas

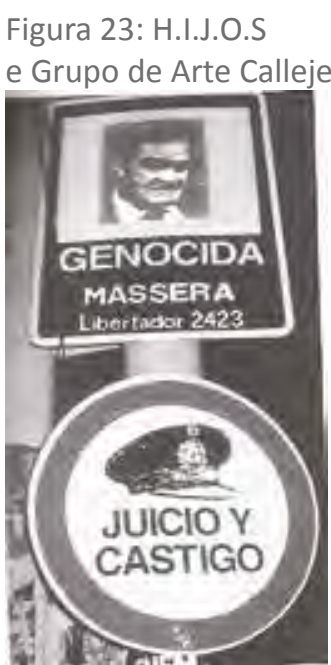

Foto: TAYLOR, 2013, p. 235

${ }_{27}$ Empruntant au vocabulaire situationniste, on peut sans doute parlerd'une psychogéographie de l'insurrection telle qu'elle se manifeste dans le rituel des marches contestataires, la soudaine volubilité des inconnus et des murs, les rues et les places noirs de monde, la griserie qui accompagne l'espoir de liberté et qui est le signe indubitable que l'imagination au moins a brisé ses chaînes. "Les moments révolutionnaires sont des carnavals où la vie individuelle fête son unification avec une société régénérée", déclare le situationniste Raoul Vaneigem (tradução minha).

${ }^{28}$ [...] a los médicos que asistían a las sesiones de tortura [...], a C.I.A. y su Plano Cóndor, y la Escuela de las Américas que, financiada por los Estados Unidos, entrenó a los torturadores (tradução minha).

29 Vale lembrar o caso do militar Alfredo Astiz, conhecido como "Anjo Loiro da Morte", que se infiltrou no grupo das Madres e matou 14 delas. Em 2011, ele foi condenado à prisão perpétua, por crimes, torturas e sequestros na época da Ditadura Militar argentina. 
identidades, perseguindo-os e fazendo que eles também se sintam observados e inseguros. Sua luta se volta para a condenação pública dos militares envolvidos no exército do terror. Por isso, sintetizam sua atuação na seguinte frase: "Si no hay justicia, hay escrache" [Se não há justiça, há escrache].

O escraches têm o objetivo de aumentar a consciência pública de que tais crimes, criminosos e organizações criminosas impunes continuam a existir no contexto de uma suposta volta à democracia. As políticas econômicas neoliberais da América Latina, segundo eles, simplesmente continuam as políticas econômicas da ditadura em aparência mais moderna (TAYLOR, 2013, p. 255).

Dentre as ações empreendidas pelos H.I.J.O.S serão destacadas ações que dão continuidade ao uso de fotografias ou que se valem de dispositivos para localizar os torturadores. Os hijos subvertem o uso da fotografia de suas antepassadas e expõem a imagem dos torturadores. Segundo Taylor, agora são os repressores militares que destroem as próprias fotografias, como se assim apagassem as suas pegadas, seus documentos de identificação. Entretanto, os participantes do movimento os seguem e tiram fotografias deles quando menos esperam. Assim, participantes do movimento têm acesso a imagens mais recentes dos torturadores, uma vez que interessa a eles que esses homens sejam reconhecidos hoje por onde quer que passem.

Antes de realizarem os escraches, há um período de preparação da comunidade para a ação, que consiste basicamente em conversar com pessoas diretamente, mostrando fotografais, ou em percorrer as ruas do bairro com um carro de som, narrando a história do criminoso e indagando os vizinhos com frases como: "Vocês sabem que um torturador mora por aqui?" ou "Vocês sabem que moram ao lado de um campo de concentração?". Desse modo, todos os procedimentos utilizados visam tornar o criminoso conhecido e condenável, num movimento parecido ao dos militares que faziam a população condenar as pessoas perseguidas pelo regime militar. No dia marcado para o escrache, muitos vizinhos resolvem participar da ação que pode se resumir na escrita do nome do criminoso na calçada da casa ou da instituição, seguido da lista de crimes cometidos por ele. Ainda usando fotografias, alguns escraches propõem a exposição das fotografias dos militares em placas coladas aos postes (figura 23), juntamente com seu endereço e a inscrição: "genocida". Em outros casos, são afixados cartazes com o mapa da região investigada, indicando onde mora um torturador ou onde havia um campo de concentração (figura 22). Parodiando as placas que informam pontos turísticos, o hijos denunciam de forma sarcástica o que todos no fundo já sabem, embora medidas concretas não sejam tomadas. Para essas ações mais plásticas, contam com a colaboração dos artistas do Grupo de Arte Callejero (GAC).

Os cortejos dos H.I.J.O.S. são alegres e provocativos, apesar dos discursos sérios. Ao longo das travessias dos bairros, eles andam de mãos dadas e em círculos, mantendo a herança 
circular das madres e avuelas. Entre deslocamentos e paradas estratégicas, eles dançam, cantam e agregam pessoas, mas muito atentos para não deixarem entrar infiltrados da polícia. Como as datas dos escraches são públicas, a polícia sempre aparece ou os espera nos locais em que acontecerão as intervenções. Contudo, a atitude dos artivistas é realizar a tarefa de tornar visíveis essas denúncias de maneira persistente e pacífica.

O fato de se revoltar - de bom humor e coletivamente, ocupando a rua - não era mais a partir deste momento um meio servindo a um objetivo, mas um fim em si mesmo. Visto sob esse ângulo, a diferença entre festa e revolução perde sua consistência, pois, em um mundo onde o isolamento é a regra, a festa torna-se fundamentalmente revolucionária. (SOLNIT, 2002, p. 298) ${ }^{30}$.

Mesmo quando a manifestação é mais festiva, como ocorre no carnaval, caminhar junto é um modo potente de ocupar e de (co)habitar o espaço público. Da festa de rua aos desfiles, fúnebres ou militares, passando pelas mais diversas manifestações políticas e marchas em defesa de diferentes causas, ocupar a cidade coletivamente é uma postura política. Quando o espaço urbano se encontra esvaziado é um sintoma de que os processos de compartiIhamento do bem público estão ameaçados. A rua se encontra vazia quando há toque de recolher, quando é transformada em passagem privada, em suma, quando venceu a cultura da mercadoria, do medo e da propriedade privada.

\footnotetext{
${ }_{30}$ Le seul fait de révolter - dans la bonne humeur et collectivement, en occupant la rue-n’était plus désormais un moyen servant un objectif, mais une fine $n$ soi. Vue sous cet angle, la différence entre fête et révolution perde sa consistance, car, dans un monde où l'isolement est la règle, la fête devient fondamentalement révolutionnaire (tradução minha).
} 


\section{> capítulo seis: depois de caminhar - rastros, vestígios e desdobramentos da prática performativa}

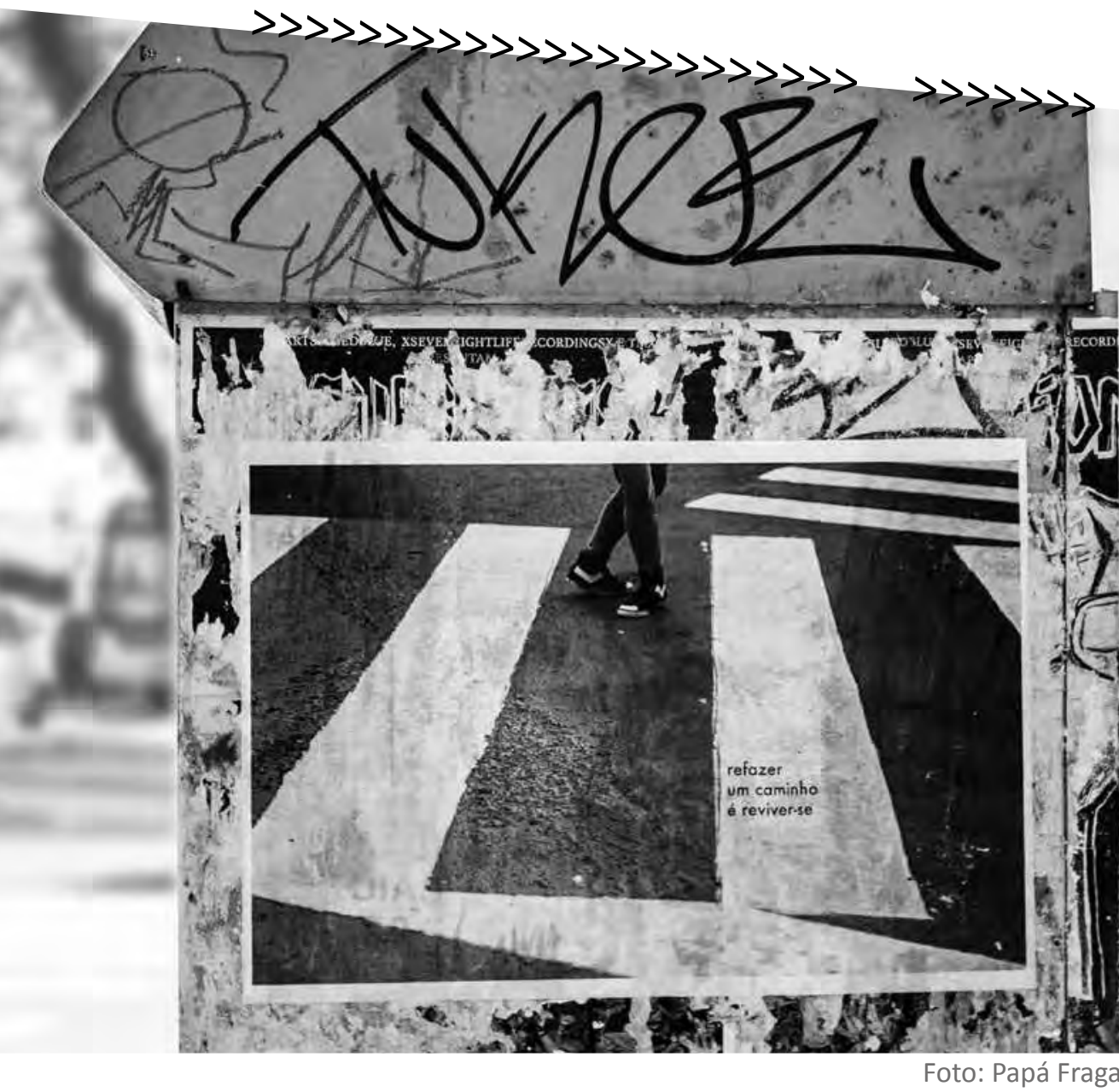

[nota sobre o capítulo: Neste capítulo, toda produção realizada a partir de performances, ou melhor, depois de caminhar, está em destaque. São fotografias, vídeos, desenhos, narrativas, mas também acontecimentos instaurados e outras performances, como desdobramento da primeira. A presença dessas outras materialidades reforça o entendimento de performance como ação expandida, pois além dela, há os rastros ou vestígios, bem como acontecimentos instaurados e desdobramentos de programas de ações performativas que podem ser realizados por toda e qualquer pessoa. $\mathrm{O}$ artista revela seu programa de ação e ao mesmo tempo produz, voluntariamente ou não, restos e cria "efeitos colaterais" provenientes de sua ação no mundo. À medida em que o artista revela seu modo de fazer, ele apresenta pistas para o espectador se localizar em um território no qual as referências se dissolvem. 
Uma performance se expande quando resulta em fotografia ou em vídeo, sem no entanto, que tais materialidades sejam reduzidas à função de registro de uma prática efêmera e precária. Dessa forma, não se trata de analisar ações performáticas a partir de seus registros, mas de observar performances que se destinam para as câmeras, com a intenção de gerar documentos em outros formatos. Há ainda a possibilidade de a ação performativa instaurar um acontecimento, um debate público ou uma situação que se confunde com o real, gerando desdobramentos que independem da presença do artista. O presente capítulo se encerra com uma discussão a respeito da livre circulação dos programas de performance - num movimento que autoriza toda e qualquer pessoa a explorar programas criados por artistas que estão menos interessados na preservação de direitos autorais do que na disseminação de práticas que ultrapassam o fazer artístico - em prol do investimento em outros modos de vida possíveis.]

A palavra performance faz referência a uma ampla gama de comportamentos e práticas corporais, que podem ser realizadas por uma pessoa sozinha ou por um grupo de participantes, com ou sem a presença de público e ainda com e para uma câmera. Neste caso, pode-se dizer que a performance se destina a um espectador ausente. A inclusão da câmera na história da performance vem da necessidade de registrar tais ações, como se ao produzirem vestígios, os artistas encontrassem não apenas meios de atestar sua existência, mas de assegurar outras configurações para o mesmo ato. Se tomarmos como referência a vertente dos estudos da performance que atribui às artes visuais os primórdios dessa linguagem, observamos um movimento que leva da produção de pinturas, esculturas, objetos ou instalações à criação de performances. Da produção do objeto à ação, é nítida a confluência para o desaparecimento físico da obra.

\footnotetext{
Esse fim aparentemente radical, o desaparecimento físico da obra, é algo tangível numa parcela significativa da produção dos artistas caminhantes, e pode se traduzir, até, na suspensão da criação, passo definitivo e extremo que tem sido dado com certa frequência, na segunda metade do século passado, por artistas engajados politicamente, inconformados com a incapacidade das ações artísticas de dar conta da complexidade dos problemas sociopolíticos e de contribuir para sua resolução. A própria evolução da Internacional Situacionista, que de grupo eminentemente artístico acabou dissolvendo-se em movimento exclusivamente político, é um ótimo exemplo desse processo (VISCONTI, 2014, p.55).
}

O autor citado reforça a dissolução da materialidade física da obra sobretudo na produção dos artistas caminhantes, aproximando a discussão do nosso recorte temático. $\mathrm{O}$ ato de caminhar, quando explorado no contexto urbano, sugere pelo simples uso do espaço público, uma abordagem política. Caminhar na cidade é atitude, opção e posicionamento político, ainda que essas ações artísticas deambulatórias não consigam contribuir para a resolução da complexidade dos problemas sociopolíticos identificáveis na rua. Por um lado, há a inclu- 
são do corpo na execução da ação; por outro, há o prolongamento dessas ações no tempo, por meio justamente da produção de outras materialidades derivadas da performance.

Com a inclusão do corpo nas artes visuais, não apenas como meio de produção da obra, mas como gesto, movimento e exibição do fazer, a ação é colocada em relevo. Nesse contexto, não basta observar o gesto aparente na pincelada sobre a tela (como em Van Gogh, por exemplo), nem perceber que o jato de tinta decorre de um grande movimento corporal (como em Pollock). Os artistas visuais que aderiram à performance, como já foi dito, promoveram a saída das galerias e se negaram a produzir objetos, passando a investir na criação de ações que exibissem seus corpos no próprio ato do fazer artístico. Datam desse momento histórico, os primeiros happenings e aquilo que Richard Martel nomeou de arte da ação.

Para mostrar o fazer, os artistas passaram não só a deixar, mas a fabricar vestígios de suas ações. Essa fabricação de vestígios, em diferentes materialidades, dá o testemunho do ocorrido, configura-se como prova de algo que não se repete, nem se materializa. Na medida em que tais vestígios são elaborados, eles se tornam parte integrante da ação, sendo impossível separar a performance da fotografia, por exemplo. Elas se tornam indissociáveis, como carne e osso. Diana Taylor, ao apresentar as noções de arquivo e repertório (já mencionadas no capítulo anterior) como "dois sistemas heurísticos", que não correspondem à dicotomia biológico e performativo, refere-se ao DNA da performance como uma conjunção dessas duas noções. A autora recusa a ideia "de que o arquival e biológico [seja] mais duradouro ou exato do que a prática performática incorporada" (TAYLOR, 2013, p. 244).

\footnotetext{
Sistemas de conhecimento e de memória intermediários ou em sobreposição constituem um amplo espectro, que pode combinar as operações do "permanente" e do "efêmero" de maneiras diferentes. Cada sistema de conter e transmitir conhecimento excede as limitações do outro. $O$ "ao vivo" nunca pode ser contido no arquivo; o arquivo dura mais do que os limites do "ao vivo". (Ibid., grifos meus).
}

Taylor recorre à contribuição de Richard Dawkins - aos memes como replicadores culturais, correlatos dos genes na biologia - para discutir formas genéricas e culturais de transmissão. O termo meme evoca imitação, memória e também a palavra fracesa même [mesmo], tendo a mesma sonoridade que gene. Os memes são "práticas incorporadas e formas de conhecimento", que a autora associa a repertório. Assim como Dawkins, a autora questiona a valorização do arquivo acima do repertório. O cientista afirma que nem os materiais genéticos nem os meméticos duram mais do que três gerações. Essa discussão nos interessa, pois o que se propõe aqui é um jogo entre arquivo e repertório, colocando em fricção essas duas instâncias. 
Nos exemplos que serão abordados a seguir, observo os vestígios da ação efêmera como arquivos capazes de acionar repertórios. Algumas ações já foram analisadas nos capítulos anteriores e serão retomadas aqui, com o enfoque na sua produção de rastros e vestígios. De um lado, há a produção de materialidades distintas que não se restringem apenas à função de registrar, como um subproduto da performance. De outro, há a exploração prática do arquivo, de modo a criar desdobramentos do repertório.

\section{$>$ I. quando a performance resulta em outras materialidades}

Tanto no campo do teatro quanto no campo da performance, a efemeridade das ações é uma característica frequentemente destacada quando se discute a produção de registros dessas experimentações artísticas. É recorrente, portanto, que se defenda que nenhum documento decorrente de uma peça de teatro ou performance seja suficientemente representativo do que se apresenta de fato nessas ocasiões (vide citação anterior de Diana Taylor). Exemplo disso é a manifestação dos artistas preconizadores dos happenings ao considerarem esse tipo de material como restos lacunares de um evento infinitamente mais complexo. Jean-Jacques Lebel fala na natureza irreprodutivel dos happenings e Allan Kaprow afirma que eles não podem ser reproduzidos. E nesse caso, Kaprow se refere tanto à impossibilidade de um happening ser rejogado, quanto da dificuldade de se obter uma imagem representativa do evento como um todo. Esse autor redigiu uma curta nota sobre as fotografias, publicada em livro de 1966, na qual concede uma grande autonomia às imagens, que segundo ele, não existem para atestar a existência de um fato, mas para provocar a imaginação do espectador. Em outro texto de mesmo ano, Kaprow destaca uma questão ideológica importante: "para esses artistas, no que diz respeito a esses acontecimentos, eles não poderiam jamais se confundir com sua representação, sem a qual suas tentativas de borrar os limites entre experiência humana e experiência estética encontrariam-se anuladas" (DELPEUX, 2010, p.10)ํ․․

Segundo Sophie Delpeux no livro supracitado ${ }^{2}$, a questão colocada por Kaprow reforça essa proibição de deixar a representação confundir-se com a ação em si. Nesse sentido, a fotografia não poderia ser tomada como o ato da performance, nem o registro como documentação direta do evento. O que Rebecca Schneider, citada por Delpeux, defende é que por mais que se capte algo ao vivo de uma performance, há algo que sempre escapará dessa tentativa de fixação da realidade efêmera. Essa autora critica o lugar da fotografia nas artes da ação e considera as imagens um meio concreto de retomar um acontecimento passado. Delpeux também cita Kristin Stiles para evocar os objetos que restam como interfaces

\footnotetext{
${ }_{1}$ [...] il s'agit pour ces artistes que jamais l'événement ne puisse se confondre avec sa représentation, sans quoi leurs tentatives de brouiller les limites entre expérience humaine et expérience esthétique s'en trouveraient annulées (tradução minha).

${ }^{2}$ Le corps-caméra: Le performer et son image (Éditions Textuel, 2010).
} 
capazes de fazer reviver a ação, o que autorizaria um tipo de ligação ininterrupta com a performance, que poderia, por sua vez, ser reatualizada ao infinito. Em todos esses autores citados há um mesmo pressuposto norteador: "a participação ou a empatia são as modalidades de compreensão das artes da ação" (Ibid., p. 11) .

Na contracorrente dos autores citados acima por Delpeux, a performer Gina Pane postula a equivalência entre seu corpo e seu corpo fotografado. Para ela, não existe diferença entre ver uma imagem e presenciar o acontecimento que foi fotografado. Aparece aqui uma crença na transparência da fotografia, como se ela fosse capaz de tornar uma presença infinita. Amelia Jones, do mesmo modo, ao analisar uma ação de Carolee Schneemann defende que ter contato físico direto com a artista no ato de sua performance "não garante 'conhecimento' de sua subjetividade ou intencionalidade, nada mais do que assistir um filme ou uma imagem dessa atividade, ou olhar para uma pintura que tenha sido feita como resultado de uma ação" (JONES, 1997, p. 13)4. Nesse contexto, fica evidente que a discussão sobre a documentação em performance coloca em questão a noção de presença, assunto que será retomado mais adiante, evocando mais uma vez as operações entre o efêmero e o permanente desenvolvidas por Taylor.

Rebecca Solnit discorre sobre a atividade de três fotógrafos que percorrem as ruas antes e depois da guerra escolhendo o que enquadrar, como se ao fixar uma imagem escolhessem o que recolhem da realidade. Antes da guerra, a primeira artista fotografa os imóveis da cidade. Depois da guerra, a segunda fotografa crianças brincando nas ruas e o terceiro retrata o submundo, as prostitutas nos furgões da polícia. "Imaginamos esses três fotógrafos caminhando pelas ruas com a vigilância de caçadores-colhedores primitivos, e preenchendo seus aparelhos de imagens recolhidas, a fim de nos deixar não a narrativa de seus passeios, como os poetas, mas os frutos desses passeios" (SOLNIT, 2002, p. 253) ${ }^{5}$. Ao meu ver, fotografias e vídeos, assim como os desenhos, são igualmente narrativas, de modo que eu não vejo uma distinção entre a atividade do fotógrafo e do poeta. Entretanto, o que Solnit parece querer marcar é a diferença entre descrever, simplesmente reportar um fato, e reagir a ele, produzindo algo que não seja a mímese da "coisa", mas um olhar sobre a "coisa".

Diante de práticas afeitas ao desaparecimento, nos dois campos estudados aqui (do teatro e da performance) há uma tentativa das bibliotecas e arquivos de reunir em seus acervos materiais adjacentes a essas formas efêmeras e imateriais. No caso do teatro são os mate-

3 [...] la participation et/ou l'empathie sont les modalités de compréhension des arts de l'action (tradução minha).

${ }^{4}$ [...] does not ensure 'know/wdge' of her subjectivity or intentionality any more than does looking at a film or picture of this activity, or looking at a painting that was made as the result of such an action (tradução minha).

5 On imagine ces trois photographes marcher dans les rues avec la vigilance des chasseurs-cueilleurs primitifs, et remplir le panier de leur appareil des images récoltées, afin de nous laisser, non le récit de leurs promenades, comme les poètes, mais les fruits de ces promenades (tradução minha). 
riais utilizados pela crítica genética - flyers, programas, críticas, relatos sobre os processos de criação, entrevistas com artistas, bem como fotografias e vídeos - que são reunidos na busca por dar corpo às encenações que não são suficientemente contempladas sem o uso de imagens e da descrição desses eventos. A partir do momento em que as encenações passam a ser estudadas como acontecimentos paralelos e impossíveis de serem apreendidas pelo acesso exclusivo à literatura dramática surgem, por exemplo, as teatrotecas. Além disso, acervos de artistas, de teatros e centros culturais, assim como de escolas especializadas, ganham relevância. Embora nosso foco nessa pesquisa não se volte para a preservação da memória nas artes cênicas, essa discussão tangencia o recorte temático proposto nesse capítulo, uma vez que se discute a produção de materialidades adjacentes à criação cênica e performática.

\section{_ a fotografia como documento primário da performance}

No campo da performance, portanto, a fotografia é considerada um documento primário dessa produção, pois a representação caminha paralelamente à fabricação dos rastros ou vestígios dessa prática. A respeito dessa fabricação de rastros, Sophie Delpeux menciona uma passagem irônica escrita por David Briers, principal autor do catálogo de uma exposição apresentada em Londres em 1986, na qual ele afirma que a ausência de um fotógrafo ao lado de um performer tornou-se tão impensável quanto prescindir dessa figura em um casamento. Não por acaso, a exposição citada acima intitula-se "A fotografia como performance".

Em "Diante da Dor dos Outros", Susan Sontag questiona o impacto da fotografia sobre nossa percepção dos acontecimentos históricos e contemporâneos. Em dado momento, ela afirma que "o problema não é que as pessoas lembrem por meio das fotos, mas que só se lembrem das fotos. Essa lembrança por meio das fotos ofusca outras formas de compreensão e de recordação"(SONTAG, 2005, p. 75). No contexto dessa afirmação, a autora discute a profusão de imagens às quais somos confrontados diariamente e o poder que as imagens têm de criar "memórias", o que ela considera, no fim das contas, como uma ficção. Num cenário político-social mais recente (início de 2015), a fotografia do menino sírio-curdo morto à beira-mar, após uma tentativa mal sucedida de atravessar o Mediterrâneo em busca de melhores condições de vida, ficou impregnada nas mentes de todos aqueles que acompanharam os noticiários a respeito dos refugiados sírios. A ampla divulgação dessa imagem foi internacionalmente debatida e condenada por muitos, por mostrar algo em excesso.

Embora se trate de contextos completamente diferentes - a fotografia como documento do real, da guerra e de acontecimentos históricos e a fotografia como documento da perfor- 
mance - o mundo no qual tais imagens se inserem é o mesmo, assim como a relação que se estabelece com as imagens nesse mundo. Prova disso é que Sontag mais adiante nesse mesmo texto afirma que "lembrar, cada vez mais, não é recordar uma história, e sim ser capaz de evocar uma imagem"(Ibid., p.75). Nesse sentido, parece oportuno e até mesmo sintomático que os artistas da performance optem por direcionar suas ações às câmeras, como forma de preservar algum substrato de sua criação, uma vez que as performances evocam imagens e ideias sintéticas e raramente se apoiam em narrativas. Desse modo, pode-se afirmar que a opção pelo suporte fotográfico coloca em relevo a possibilidade de desaparecimento do acontecimento - da performance em si, priorizando sua representação.

\footnotetext{
O fluxo incessante de imagens (televisão, vídeo, cinema) constitui o nosso meio circundante, mas, quando se trata de recordar, a fotografia fere mais fundo. A memória congela o quadro; sua unidade básica é a imagem isolada. Numa era sobrecarregada de informação, a fotografia oferece um modo rápido de apreender algo e uma forma compacta de memorizá-lo. A foto é como uma citação ou uma máxima ou provérbio. Cada um de nós estoca, na mente, centenas de fotos, que podem ser recuperadas instantaneamente (Ibid., p.23).
}

Diante desse cenário, a fotografia deixa de ser considerada um simples registro da performance e passa a ser considerada um documento primário decorrente dessa linguagem. Regina Melim quem lança essa discussão, questionando em que medida a fotografia seria sempre uma fonte secundária que descreve algo já ocorrido ou se poderia ser pensada como parte constitutiva, um ponto ou linha de união entre a performance e o seu testemunho (MELIM, 2008) ${ }^{6}$. Para tanto, a autora diferencia os artistas que nas décadas de 1960 e 1970 registravam suas ações no ato mesmo de sua exibição para o público, com o intuito de preservá-las, daqueles que passam a endereçar suas ações para a câmera.

Tal dispositivo é comumente associado à imprensa, ao seu poder de divulgação e uso da imagem, seja para manipular informações, seja para denunciar, incriminar ou defender alguém. Por isso, a câmera também pode intimidar as pessoas, que se sentem vigiadas por ela, reagindo a essa invasão com a proibição de certos registros. O cidadão contemporâneo zela por sua própria imagem, discute e reivindica o direito sobre ela. Nunca no mundo, os habitantes das cidades se (pre)ocuparam tanto com as representações de suas (auto) imagens. Os homens e mulheres desse tempo se colocam nas miras das câmeras, sob a ilusão de que todos têm o poder de mirar - de olhar através da câmera - mas na verdade, tais imagens são manipuladas por um grupo restrito de pessoas. A partir do advento da internet, todos têm a impressão de deter os meios para a ampla circulação da informação. Doce ilusão: as redes sociais são controladas por algoritmos que configuram combinações

\footnotetext{
6 MELIM, Regina. "A fotografia como documento primário e performance nas artes visuais", de 2008, disponível em: http://www.portaldeperiodicos.unisul.br/index.php/Critica_Cultural/issue/view/16, acesso em: 5 Dez. 2016.
} 
inferiores ao seu suposto número de amigos. O território a que temos direito de circular na internet é efetivamente uma micro comunidade, que pertence aos poucos detentores dos patrimônios, das mercadorias e do capital. Nesse tempo de alta produção de selfs, de preocupação com direito de imagem, de elevação do estatuto da imagem, a produção de performance não passaria ilesa à nossa capacidade de documentar.

Impossível, portanto, nesse caso não aceitar a Fotografia como documento primário da Performance, uma vez que é o resultado direto de uma ação orientada para esse meio, e a sua audiência se dará a partir do mesmo. Vale dizer: a Performance só é acessível ao público a partir de sua documentação. Ou ainda, somente através da sua documentação que a Performance existe como Performance (MELIM, 2008).

Por isso, fotografar performance corresponde, em larga escala, a produzir provas da realização de algo, mas também de expansão da noção de performance, à medida em que se usa outras plataformas para criar. Assim, a câmera se torna testemunha da ação, ela não apenas registra, ela narra, cria uma ficção. A câmera se torna um dispositivo de criação de ficção, tanto no campo da arte, quanto na vida cotidiana e, por consequência, no campo da história.

\section{_quando a ação performativa se destina pra um espectador ausente}

Abro um parêntese aqui para sugerir algo que será retomado no final do presente capítulo: o papel do espectador dessas ações. Essa figura que parece dissolvida em algumas manifestações artísticas recentes, como apontado no primeiro capítulo, oscila nessas produções como coautora, participante e pesquisadora em potencial. O campo da performance se abre de tal modo para o espectador, que lhe propõe outros usos e fruições. Engajando o corpo, despertando o interesse, compartilhando os programas e os processos de produção dessas ações, as performances já não se restringem ao que se presencia, mas se apresentam ao espectador como um jogo complexo, engendrando diferentes plataformas e interagindo frequentemente com o real. Dessa forma, quanto mais o interlocutor se dedica ou se interessa por uma ação, mais pistas ele encontra para desfrutá-la.

A tomada da fotografia como fonte primária da performance ocorre, em grande medida, pela modificação da relação entre performance e audiência. À medida em que a fotografia não se volta mais para o registro do encontro com o espectador, há uma modificação de sua função dentro desse evento. Quando a performance passa a ser endereçada para a câmera, ela passa a prescindir da presença do espectador, pois a execução da ação não coincide necessariamente com a presença do público. Ou então, ela se relaciona diferentemente com quem a presencia (por exemplo, os passantes ocasionais) e com quem está ausente 
(o espectador pesquisador, potencial, futuro). No caso das performances urbanas, mesmo que a ação prescinda da presença do público, ela se instaura como acontecimento dentro de um espaço/tempo já habitado. A cidade não se esvazia para que a performance se inscreva nela; ao contrário, ela faz conviver modos diversos e complexos de sociabilização, comunicação e visibilidade. Essa profusão de plataformas de contato, de interatividade e de atenção, incluindo o corpo como explorador dessa experiência, promove outras possibilidades e outras qualidades de presença.

Do mesmo modo como falamos no capítulo quatro sobre a criação de efeitos de presença nas experimentações cênicas e performáticas, esse efeito se desloca para a relação com os espectadores. A execução da performance não será necessariamente concomitante à sua recepção. Mediante esse adiamento da recepção, a fotografia e outras materialidades distintas daquelas associadas às artes efêmeras e imateriais ganham relevância no campo da performance e das artes da cena. Não se trata de transmitir uma performance ao vivo, via streaming, entendendo que o espectador pode estar presente mesmo ausente fisicamente. Muitas vezes, a performance se realiza para um espectador ausente e não apenas virtual. Trata-se de alguém que entrará em contato com a ação futuramente, sem que o artista estabeleça qualquer grau de convivência com esse espectador.

De certo modo, é possível afirmar que a câmera, em inúmeros casos, substitui a presença concreta e imediata do espectador. Nesses casos, os artistas passam a endereçar suas ações para a câmera, cuja presença modifica o modo de realizar a ação. Portar uma câmera na rua é dispor de um dispositivo não apenas associado ao registro, mas igualmente associado ao controle, à segurança e à defesa. Embora a grande maioria das pessoas atualmente possa ter uma câmera acoplada em seu telefone celular, quem porta uma câmera em um espaço público ainda detém um tipo de poder. Essa presença modifica o modo das pessoas agirem, pois elas se sentem vigiadas e, como afirmava Roland Barthes, "objetificadas", como se o olhar da câmera transformasse o sujeito em objeto. "[...] para dizer a verdade, não sou nem um sujeito nem um objeto, mas antes um sujeito que se sente tornar-se objeto: vivo então uma microexperiência da morte (do parêntese): torno-me verdadeiramente espectro" (1984, p.27). Ainda sobre o desconforto de estar diante de uma câmera, o autor afirma que diante de uma objetiva, ele não sabe como do interior dele mesmo agir sob sua pele.

[...] a partir do momento que me sinto olhado pela objetiva, tudo muda: ponho-me a 'posar', fabrico-me instantaneamente um outro corpo, metamorfoseio-me antecipadamente em imagem. Essa transformação é ativa: sinto que a Fotografia cria meu corpo ou o mortifica, a seu bel-prazer (Ibid., p.22).

Esse deslocamento do espectador presencial para a câmera ganha um impulso ainda maior com o advento da internet. A maioria dos estudos de performance acontecem a partir de bases de dados e buscas na internet, sem que tal experimentação tenha sido presenciada 
fisicamente pelo pesquisador. Em 1997, Amelia Jones é convidada a escrever um artigo para a revista Art Journal e percebe que ela é a única especialista que não experimentou diretamente as ações sobre as quais pesquisa. Ao constatar que tal número dessa revista tinha como premissa a importância de estar presente em carne e osso diante da performance para melhor apreendê-la, a autora decide colocar em pé de igualdade o testemunho e o historiador. Para justificar essa atitude provocadora, Jones afirma que tanto aquele que testemunha, quanto o historiador, devem interrogar o passado com suficiente recuo e para isso, ambos precisam recorrer aos documentos. Endossando sua argumentação, a pesquisadora ressalta a dissolução de seus objetos de estudo e a visão crítica destinada aos possíveis documentos, não sem antes estabelecer uma linha do tempo na qual revela sua idade (entre 3 e 15 anos) quando as performances que compõem o corpus de sua pesquisa foram realizadas. Ela afirma ter iniciado seus estudos somente aos 30 anos, portanto não poderia ter tido acesso presencialmente a tais performances.

A partir desse dado autobiográfico, a autora de Presence in absentia: Experiencing Performance as Documentation [Presença na ausência: Experimentando Performance como Documentação] ${ }^{7}$ defende o uso da documentação em performance como uma fonte legítima de estudo e análise dessas ações. Jones apresenta duas acepções de performance art: uma mais ampla, que remonta ao dadaísmo e considera performance qualquer exploração de teatralidade da parte de um artista visual e outra mais estreita, que considera performance algo que ocorre diante de um público. A essas acepções, a autora contrapõe a noção de body art ou bodywork, modalidade que independe da presença de espectadores. Dessa forma, ela não considera a presença do público uma premissa para a realização de uma performance.

Quando uma performance se dirige para uma câmera, o resultado foto ou videográfico (isto é, sua documentação) ganha outra dimensão, cumpre outro papel no campo da performance. Não se trata apenas de um registro, mas de um meio de expressão, uma extensão, um prolongamento da performance em outras materialidades. Parafraseando Susan Sontag, que afirmava que quando há fotos, uma guerra se torna real (SONTAG, 2005, p. 87); podemos afirmar que a fotografia faz o mesmo com a performance: ela atribui à ação um certificado de existência, de realidade. É assim que o ato de documentar passa a integrar o ato de performar. Se tomarmos como referência a acepção de Richard Schechner, a performance pode ser compreendida a partir de três operações: ser/estar (being), ou seja, se comportar (to behave); fazer (doing), como a atividade de tudo o que existe, e mostrar o que se faz (showing doing), que consistiria em dar-se em espetáculo, em mostrar ou se mostrar (SCHECHNER, 2006, p.28). Nesse contexto, o "mostrar" aferido por Richard Schechner se desloca

\footnotetext{
7 JONES, Amelia. "Presence in Absentia. Experiencing Performance as documentation". Art Journal, v.56, n.4, 1997, pp.11-18, disponível em: <http://art.usf.edu/file_uploads/presence.pdf>. Acesso em: 5 dez. 2016.
} 
do público para a câmera. Ou seja, se anteriormente o estatuto de uma performance era definido pela presença de uma audiência; a partir da expansão desse campo para outras materialidades, é a presença da câmera que passa a definir tal estatuto.

Conforme Roland Barthes, a fotografia anuncia uma ausência; ela se apresenta onde o sujeito já não está ou no lugar onde ele não alcança. O autor defende que a fotografia "desrealiza completamente o mundo humano dos conflitos e dos desejos, sob o pretexto de ilustrá-lo"(BARTHES, 1984, p.174). Pensando em termos de performance, a fotografia proveniente dessa ação não apenas ilustra, mas testemunha sua realização. No entanto, esse suporte ainda assim anuncia a ausência do ato, prorrogando o encontro com o espectador, que será, ele sim, separado do evento. Quando alguém tem acesso a uma performance via fotografia, essa pessoa está necessariamente à parte do evento. Ela acessa os rastros, os vestígios, sem no entanto sentir os cheiros, observar o antes e o depois, ou as interações precisas estabelecidas com um ou outro espectador. O documento não permite tampouco que o espectador se confunda com aquilo que acontece, ele permanece de fora. Nesse mesmo sentido, Barthes afirma que não pode "aprofundar, penetrar a Fotografia. Posso apenas varrê-la com o olhar, como uma superfície imóvel. A Fotografia é chã, em todos os sentidos da palavra [...]" (Ibid., p. 157). E acrescenta, citando Maurice Blanchot:

\footnotetext{
[...] a essência da imagem é estar toda fora, sem intimidade, e no entanto mais inacessível e misteriosa do que o pensamento de foro íntimo; sem significação, mas invocando a profundidade de todo sentido possível; irrevelada e todavia manifesta, tendo essa presença-ausência que faz a atração e o fascínio das Sereias. (BLANCHOT apud BARTHES, 1984, p. 157).
}

Se a noção de performance quando se aproxima da body art é associada à entrega do corpo do artista sem mediação, sem intermediários, tomando o corpo como material primário, Amelia Jones em texto supracitado rejeita tais princípios. A ideia de que a performance ou a body art seja a única forma de arte capaz de garantir a presença do artista - colocando em jogo sua vida real, suas experiências e suprimindo a mediação - colabora, segundo Jones, para a exaltação do "status da representação", ao invés de confirmar sua prioridade ontológica (1997, p. 13).

Os aspectos representacionais deste trabalho - seu "jogo dentro da arena do simbólico" e, eu acrescentaria, sua dependência da documentação para atingir status simbólico dentro do âmbito da cultura - expõem a impossibilidade de atingir pleno conhecimento de si por meio da proximidade do corpo. Ter contato físico direto com uma artista que puxa um pergaminho de seu canal vaginal não garante mais conhecimento de sua subjetividade ou intencionalidade do que assistir um filme ou observar uma imagem dessa atividade, ou ainda olhar uma pintura 
Jones se refere no trecho acima à conhecida performance de Carolee Schneemann, Interior Scroll, de 1975, para destacar a insuficiência do corpo na articulação de seus significados, pois dependem do contexto no qual ele se expõe, do intercâmbio entre artista e espectadores, bem como do ato de documentar a ação. Nesse sentido, a fotografia seria considerada como um suplemento do corpo do artista, tanto como prova visível de sua existência quanto como prolongamento sem fim.

A autora se vale das ideias de Derrida para afirmar que o suplemento representa uma ameaça, pois indica uma falta, uma ausência. De modo similar ao que afirma Barthes, para Derrida, o suplemento também se configura como a primeira e mais eficiente proteção contra essa ameaça. Na defesa dos suplementos, esse autor afirma que a body art [leia-se: a performance] iniciou uma corrente infinita derivada do corpo em si - a narrativa falada, a fotografia, o vídeo e outros textos - como forma de explicar o equívoco da centralidade do corpo no discurso artístico modernista e pós-modernista. O que Jones irá defender a partir das ideias de Derrida é que a body art exacerba a suplementaridade do corpo do artista, cuja exposição não é garantia de presença.

O corpo complementa o evento da performance e cumpre seu papel de representação dentro da arena do simbólico. "Ao invés de confirmar a coerência ontológica do corpo-como-presença, a body art depende da documentação, confirmando - e até mesmo exacerbando - o caráter suplementar do corpo em si" (Ibid., p. 15) ${ }^{9}$. Dessa maneira, Jones considera que a body art não expõe o corpo apenas no momento da comunicação e da troca com o público, mas também por meio dos diferentes modos de (re)apresentá-lo.

\section{_quando a performance resulta em fotografia}

Narrativas podem nos levar a compreender. Fotos fazem outra coisa: nos perseguem. Susan Sontag

O primeiro exemplo que gostaria de evocar é a conhecida obra de Yves Klein, Salto no vazio, de 1960. Aos 34 anos, o artista realiza seu ato fotográfico: sua imagem saltando

\footnotetext{
8 The representational aspects of this work - its "play within the arena of the symbolic" and, I would add, its dependence on documentation to attain symbolic status within the realm of culture-expose the impossibility of attaining full knowledge of the self through bodily proximity. [...]. Having direct physical contact with an artist who pulls a scroll from her vaginal canal does not ensure "knowledge" of her subjectivity or intentionality any more than does looking at a film or picture of this activity, or looking at a painting that was made as the result of such an action (tradução minha).

9 "Rather than confirming the ontological coherence of the body-as-presence, body art depends on documentation, confirming - even exacerbating - the supplementarity of the body itself'(tradução minha).
} 
destemidamente pela janela de um edifi-

cio, de peitos e braços abertos, o que se tornaria um dos seus trabalhos mais conhecidos. O retrato do falso suicídio é por si só performativo. Quando alguém compõe uma imagem que declara algo tão convictamente, de modo a enganar seu interlocutor, a performatividade do ato é revelada. Jorge Glusberg atribui a essa experiência de Klein o ato seminal da arte da performance: “(...) era o protagonista da obra, e, nesse sentido, a obra em si" (GLUSBERG, 2016, p. 11). Klein lançou-se de fato pela janela, mas no momento em que executou tal ação, havia um grupo com um tecido elástico a postos para recepcioná-lo no final de sua queda e uma pessoa fotografando o salto. $O$ artista sobrepôs a imagem de seu salto, posteriormente, à foto do espaço no qual saltou, sem o grupo reunido embaixo da janela. Desse modo, a fotografia anuncia seu gesto destemido, como se ele tivesse realmente acontecido. A fotografia performa seu desafio à gravidade, sem que o artista tenha colocado sua vida em risco.

Antes de passar aos próximos exemplos, gostaria de destacar a diferença existente entre a câmera que registra um evento e a câmera que interage com o performer. No primeiro caso, ela é sujeito da ação, ela documenta o que se passa, construindo um discurso. Pode-se dizer que ela mostra seu ponto de vista sobre a ação observada. A câmera pode, portanto, ser considerada a voz enunciadora, aquela que fabula, que apresenta os fatos. No segundo caso, a câmera é o objeto da ação

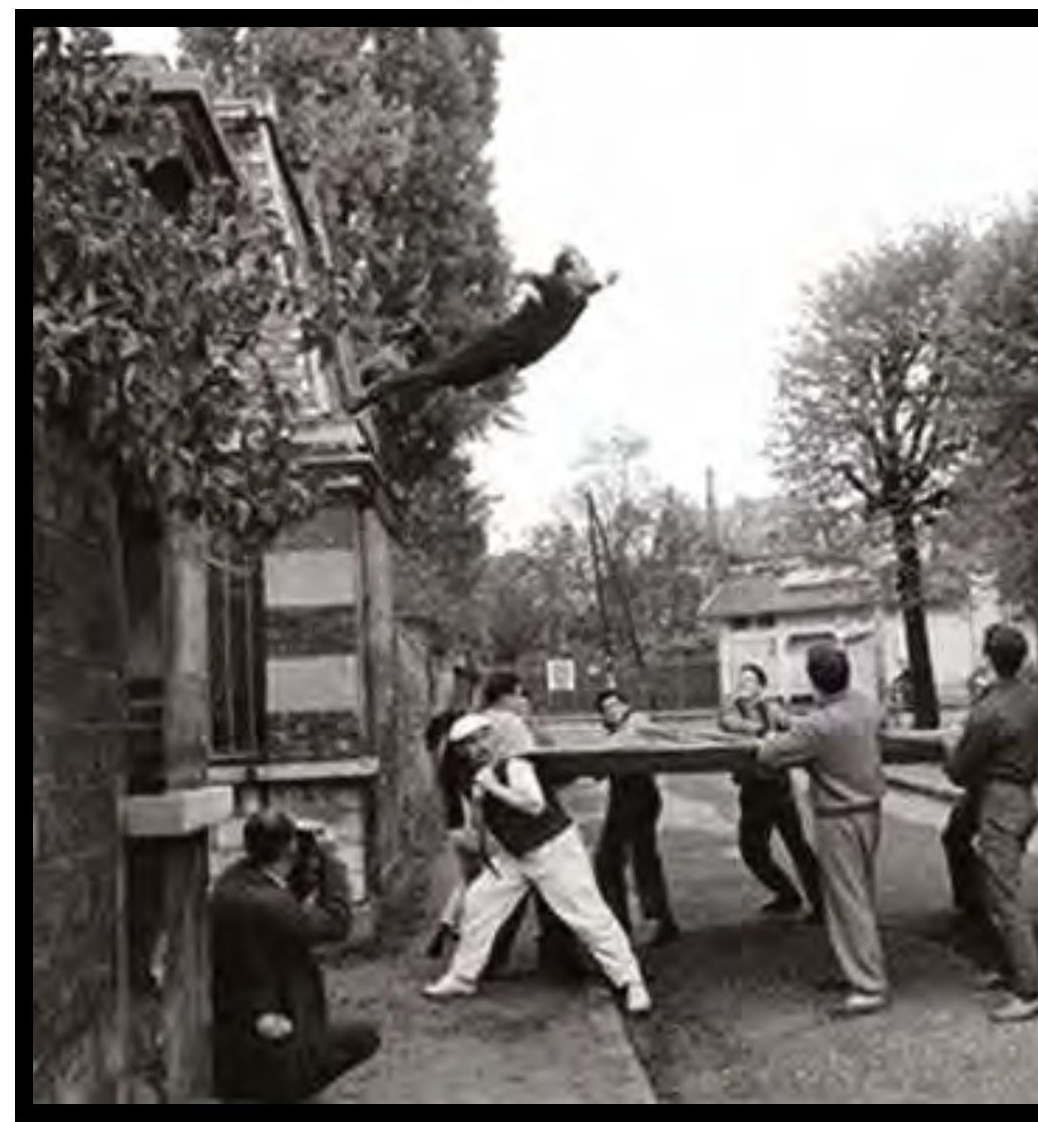

Figura 2: Foto: Disponível em: <http://www.e-farsas.com/ Yves Klein - wp-content/uploads/salto_para_vazio.jpg>. Salto no Vazio Acesso em: 29 mar. 2017.

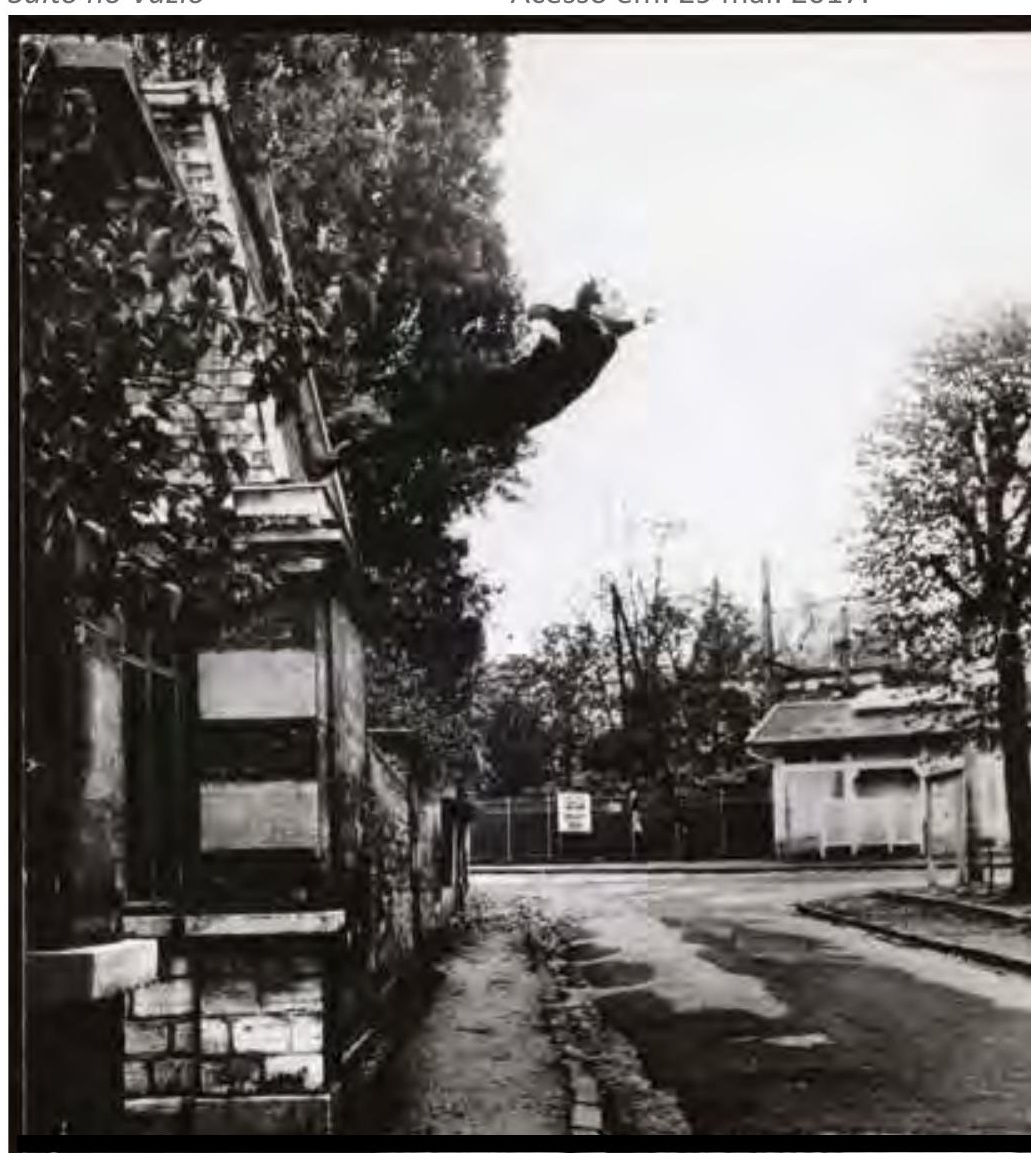


do performer. Como o discurso é endereçado a ela, é o performer que dispõe de seu controle, posicionando-a e tomando todas as decisões a respeito da captação da performance. Em muitos casos, essa tarefa não é realizada por uma artista sozinho; muitas parcerias entre performers e fotógrafos são seladas com o objetivo de organizar a ação em função do olhar da câmera e vice-versa. Dessa forma, esse dispositivo se torna o meio de comunicação do artista, que deixa de organizar um evento para receber o público e passa a organizar uma outra situação, direcionada para o registro: a captação da performance.

O direcionamento da performance para a câmera oculta o papel de registro que lhe era inicialmente atribuído e coloca em evidência seu papel de suspensão do tempo e do espaço da ação, deslocando a performance do aqui e agora. Dito de outro modo, ao direcionar a performance para uma câmera, o artista adia o encontro com o outro, deixa de agir diretamente no presente e opera ao mesmo tempo em materialidades distintas. Por mais que a performance se caracterize por uma ação realizada por um corpo no presente ou pelo simples ato de um corpo se propor a fazer algo, a presença da câmera modifica o corpo e o desloca de seu espaço-tempo inicial. A performance transforma a câmera no outro e o virtualiza, tornando possível se comunicar com corpos de outros territórios e temporalidades. Há nessa mudança de enfoque - da câmera que olha para a câmera que é olhada - uma operação que desterritorializa a ação para em seguida reterritorializá-la.

Apresentarei a seguir dois exemplos de performances que resultam em fotografia. 0 primeiro deles não se direciona exclusivamente para a câmera. Há espectadores passantes desavisados que acabam por integrar um acontecimento promovido por uma intervenção urbana. Neste caso, quem está em movimento é justamente esse espectador transeunte, surpreendido em seu percurso cotidiano por visões da miséria humana. As fotografias resultantes dessa ação incluem esses passantes como testemunhas de um momento histórico e, ao mesmo tempo, pulverizam a imagem de uma Argentina em crise no início do século XXI. Por meio dessas fotografias, outras pessoas terão acesso a essa intervenção, e não somente aquelas que fortuitamente se depararam com ela. Trata-se de Filoctetes: Lemnos em Buenos Aires, intervenção realizada pelo coletivo argentino El periférico de objetos ${ }^{10}$, em 2002.

Nessa intervenção, vinte e três bonecos hiper-realistas, reproduzindo o formato e as dimensões de corpos humanos inertes, são instalados em locais estratégicos da cidade. Para sua realização, o El Periferico conta com uma equipe de sessenta pessoas, de especialidades diversas: fotógrafos, dramaturgos, atores, músicos, dançarinos, artistas plásticos, entre ou-

\footnotetext{
${ }^{10}$ El Periferico de objetos é um grupo argentino coordenado por Emilio Garcia Wehbi, oriundo do teatro de bonecos; desde sua formação, em 1989, utiliza objetos como protagonistas em suas criações.
} 


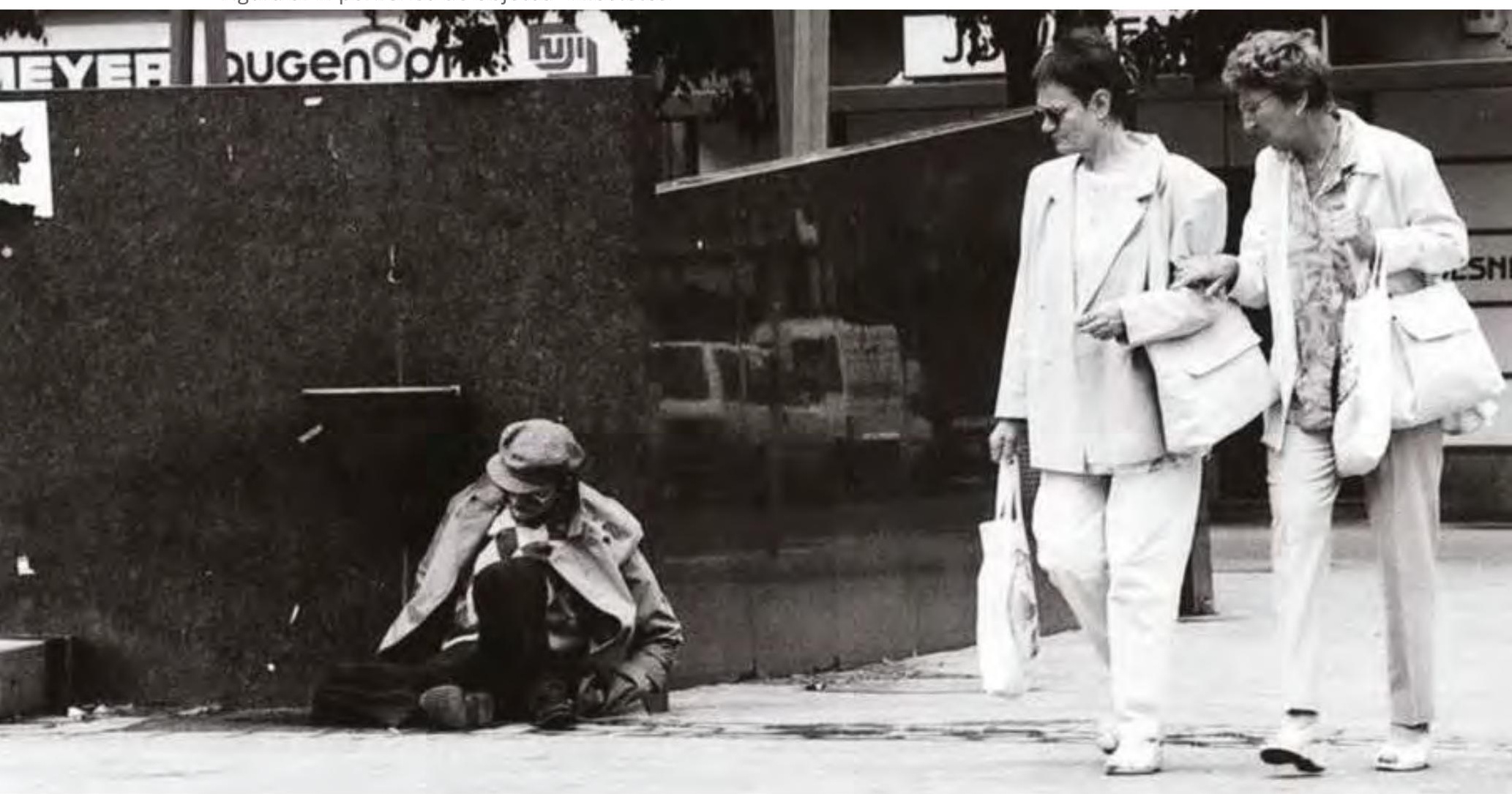

Foto: Disponível em: <https://www.facebook.com/GarciaWehbi/photos>. Acesso em: 17 jun. 2013.

tros, ocupados em promover o entrecruzamento entre o real e o artístico. Filoctetes $^{11}$ ocupa as ruas de Buenos Aires um ano após a crise econômica e social que aconteceu na Argentina em 2001, deixando um grande número de desempregados e pessoas em estado de imensa pobreza. Ao espalhar corpos inertes no espaço público, a experiência transbordou a esfera artística, atingindo diretamente os cidadãos daquele país.

A ação pretende provocar os cidadãos, interrogando-os sobre os vínculos que seriam estabelecidos entre eles e os corpos

${ }^{11}$ O nome Filoctetes remete ao mito de um herói grego afastado de uma expedição rumo à Troia, por causa de suas feridas. O subtítulo: Lemnos en Buenos Aires ressalta a metáfora que coloca a cidade sul-americana como a polis que suportou a fetidez e a dor de Filoctetes.
Figura 4:

El periférico de objetos - Filoctetes

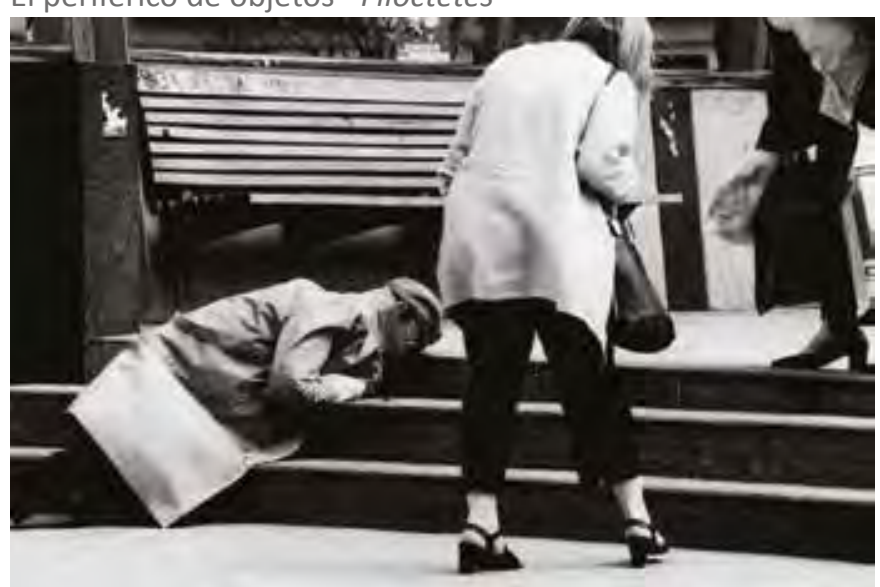

Foto: Disponível em: <https://www.facebook. com/GarciaWehbi/photos>. Acesso em: 17 jun. 2013.

Figura 5:

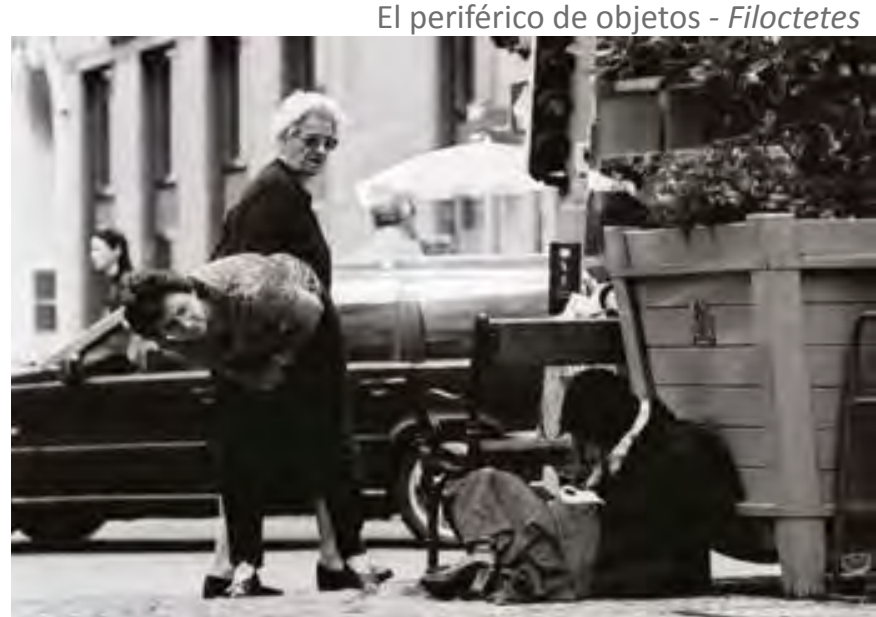

Foto: Disponível em: <https://www.

facebook.com/GarciaWehbi/photos>. 
jogados na rua. Parece fundamental, portanto, que a ação tenha resultado em materiais em diferentes suportes. Além da ação performática, que envolve o encontro de cada boneco com espectadores casuais, a intervenção foi amplamente documentada. Mesmo que a intervenção não se endereçasse exclusivamente para a câmera, as fotografias derivadas dessa intervenção não podem ser consideradas documentos secundários. Elas são tão importantes quanto a ação performática ao vivo e in situ, pois criam documentos visuais que revelam encontros entre espectadores e bonecos, provavelmente presenciados por um número muito restrito de pessoas. Em todas as cidades em que a intervenção é realizada ${ }^{12}$, é comum que os bonecos sejam confundidos com corpos reais em estado de miséria, desfalecidos ou mortos.

Se tomamos como referência a noção de teatralidade adotada por Jorge Dubatti, como algo identificável nas estruturas conviviais da vida cotidiana (DUBATTI, 2003, p. 9), pode-se dizer que a experiência proveniente de Filoctetes depende mais de uma situação de convívio, do que da linguagem em si. Segundo o autor, as práticas de convívio se referem "à reunião de pessoas num determinado espaço e tempo para compartilhar um rito de sociabilidade no qual se distribuem e alternam papéis"(Ibid., 2003, p.17). Por mais que o passante não reconheça imediatamente o que ocorre como um acontecimento poético ou de linguagem, quando finalmente percebe que se tratam de bonecos, esse acontecimento poético se revela e o passante reconhece sua função de espectador. Inicialmente, ele não consegue separá-lo da ordem da vida e por isso não tem consciência de que é espectador. No entanto, a partir do momento em que ele se deixa afetar pelo corpo presente, suspende seu isolamento, sai de si e vai ao encontro do outro, o passante experimenta uma confusão sensorial, na qual realidade e ficção seguem embaralhadas. Tal situação de convívio é efêmera e provavelmente não se repetirá.

Ao expandir a ação performática para o suporte da fotografia, Filoctetes atinge também o espaço virtual, onde atualmente acontecem as situações de convívio. Tais fotografias não se constituem como meros registros, elas são criação em outra linguagem, pois os elementos que caracterizam essa linguagem foram devidamente articulados. A câmera nessa intervenção é posicionada de modo que os passantes não percebam sua presença. $A$ intervenção acontece em duas instâncias: na instalação dos corpos na cidade e na captação de uma série de fotografias que documenta os encontros dos bonecos com os passantes, como vestígios ou rastros conscientemente produzidos pelos artistas.

O segundo exemplo também tem lugar no contexto urbano, em deambulação e é presenciado por espectadores passantes. No entanto, a ação é tão sutil que pode ser confundida com uma experimentação obsessiva de um fotógrafo que resolve fazer alguns testes enquanto

${ }_{12}$ Filoctetes foi realizada também em Berlim e Viena, no ano de 2004. 
se desloca pela rua. Dificilmente, alguém resolverá seguir o artista tendo a impressão de que se trata de uma performance. Neste caso o "fazer" se separa da ação de "mostrar"; a ação de fotografar fica isolada, confinada em uma esfera quase íntima. Prova disso é que o próprio corpo do artista é invisibilizado na resultante fotográfica da performance, que, por sua vez, desloca o protagonismo da ação para o enquadramento da cidade. As fotos documentam um percurso, apresentando os pontos de vista de quem percorre a cidade, sem revelar sua identidade. Trata-se de Blinks (do inglês: "piscada" ou "piscadela"), performance realizada em Nova York por Vito Acconci, em 1969.

Nessa ação, o artista transforma-se em corpo-câmera, pois efetivamente traça um percurso em Nova York e o documenta por meio de fotografias. O protocolo da ação consiste em carregar uma câmera fotográfica pronta para tirar uma foto. Enquanto caminha em uma linha contínua pela rua, o artista tenta não piscar. Todavia, quando seus olhos não resistem e piscam, ele apoia no gatilho da câmera e tira uma foto. É evidente que nesse momento a câmera usada por Acconci não é digital, o que torna seu feito ainda mais artesanal e instantâneo. Dessa proposta, decorre um desejo de não perder nenhum aspecto do caminho percorrido. Não no sentido de ter uma visão ampla e globalizante, mas como forma de viver intensamente um percurso, sem deixar passar sequer um elemento de sua observação única e particular.

\footnotetext{
Para mim, o órgão do Fotógrafo não é o olho (ele me terrifica), é o dedo: o que está ligado ao disparador da objetiva, ao deslizar metálico das placas (quando a máquina ainda as tem). [...] Para mim, o barulho do Tempo não é triste: gosto dos sinos, dos relógios - e lembro-me de que originalmente o material fotográfico dependia das técnicas da marcenaria e da mecânica de precisão: as máquinas, no fundo, em relógios de ver, e talvez em mim alguém muito antigo ainda ouça na máquina fotográfica o ruído vivo da madeira (BARTHES, 1984, p.30).
}

É interessante notar que no caso de Acconci, o artista concentra em seu próprio corpo o papel de performer e fotógrafo, o que não acontece em todos os casos nos quais a fotografia é tida como documento primário. Na medida em que a fotografia deixa de se constituir como uma simples operação de registro e memória a serviço da performance, a fotografia passa a ser investigada nas artes da ação como experimentação artística. Ou seja, não é apenas a fotografia que modifica a performance, mas esta também enriquece e modifica a fotografia. É nesse sentido, que Philippe Dubois afirma que a fotografia deixa de ser uma ferramenta para as artes da ação e se torna um modelo para essas artes. Por esse motivo, as preocupações do artista parecem multiplicadas, pois ele investiga como proceder, como realizar tal ação e, ao mesmo tempo, como documentá-la. O gesto artístico aparece, a partir de então, como disposição do corpo em imagem.

Retomo aqui o conceito de infra-mince, proposto por Marcel Duchamp e já utilizado no 
capítulo anterior, para invocar a obra do artista tcheco Jiri Kovanda. Em 1977, em um contexto de repressão política em Praga, sob forte vigilância, o artista realiza a ação Contact, na qual caminha pelas ruas em busca de estabelecer contatos físicos ínfimos e efêmeros com passantes anônimos. Nesse momento, sob o domínio soviético, era ilegal tocar-se publicamente. A ação consiste em caminhar até encontrar o momento adequado para roçar - tocar ligeiramente o outro - de modo que a obra se restringe a esse momento, a esse toque leve

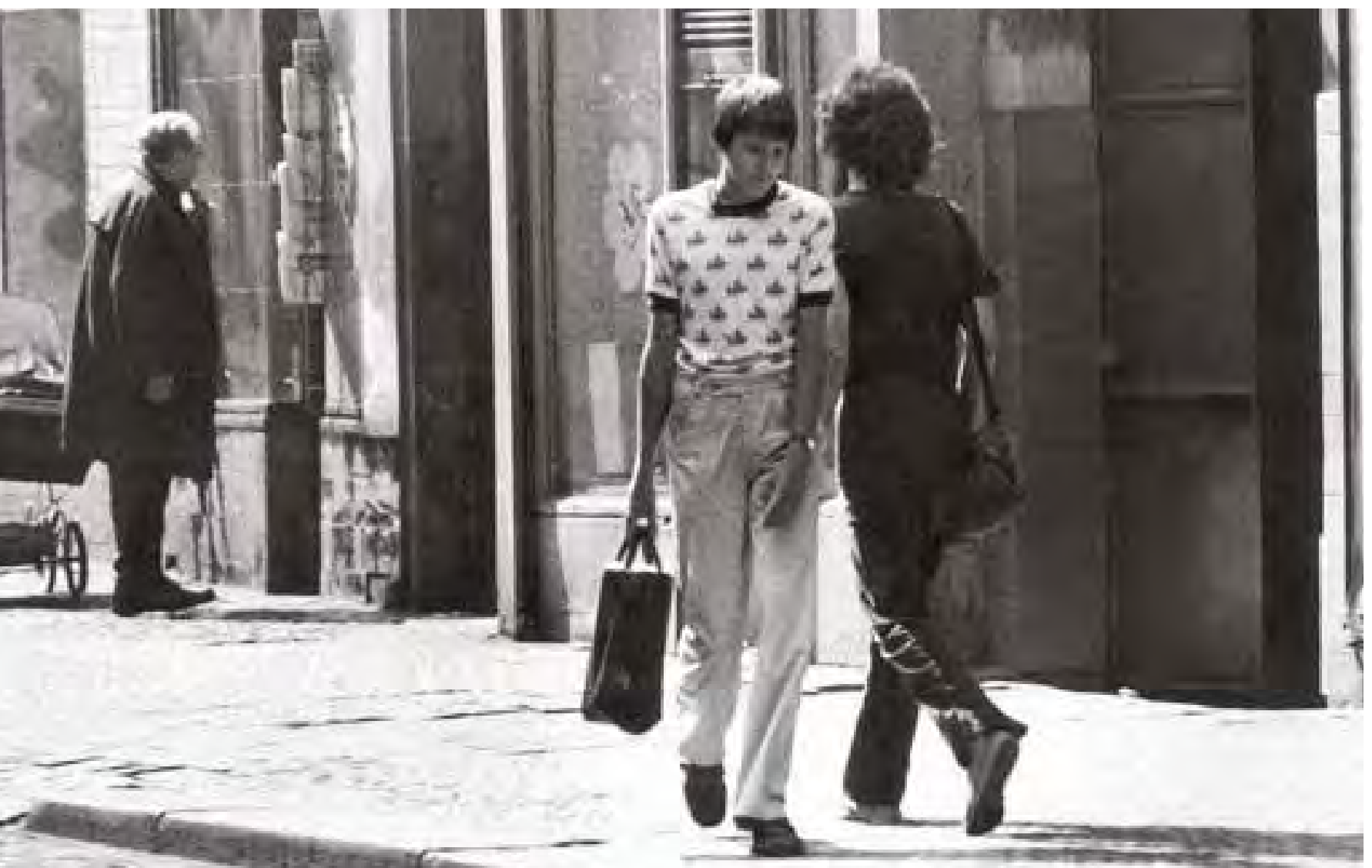

Figura 6: Jiri Kovanda - Contact

Foto: Disponível em: <http://london.czechcentres.cz/public/galleries/88/87977/001-contact-jiri-kovanda-prague-1977-low-res.jpg?c7dae77bfb3f740ac7779edb47a6a092>. Acesso em 29 mar. 2017

entre dois caminhantes que não se encontrarão jamais. As obras de Kovanda se encontram nessa camada ultrafina, imperceptível, mas muito reveladora das forças ideológicas que moldam o espaço público. Realizadas na década de 70, o único traço da existência dessas ações são as fotografias que testemunham o ato de sua existência. Pode-se dizer que tais obras subsistem por meio das fotografias. Como micro-ações no contexto urbano, elas contestam modos de vida de maneira quase invisível e silenciosa e criam pequenas resistências afetivas, embora sejam inapreensíveis para a maioria dos passantes (tocados ou não pelo artista).

Anos depois, em setembro de 1977, o artista realiza outra ação (sem título) que se passa 
em escadas rolantes frequentadas por muitos usuários. Ele sobe uma escada rolante cheia de gente e no meio do trajeto volta-se para todas as pessoas presentes ali, olhando-as nos olhos. Ninguém sequer se dá conta de que isso está acontecendo. É uma ação que ocorre no intervalo, no delay e em looping, pois se repete insistentemente, sem que ninguém a

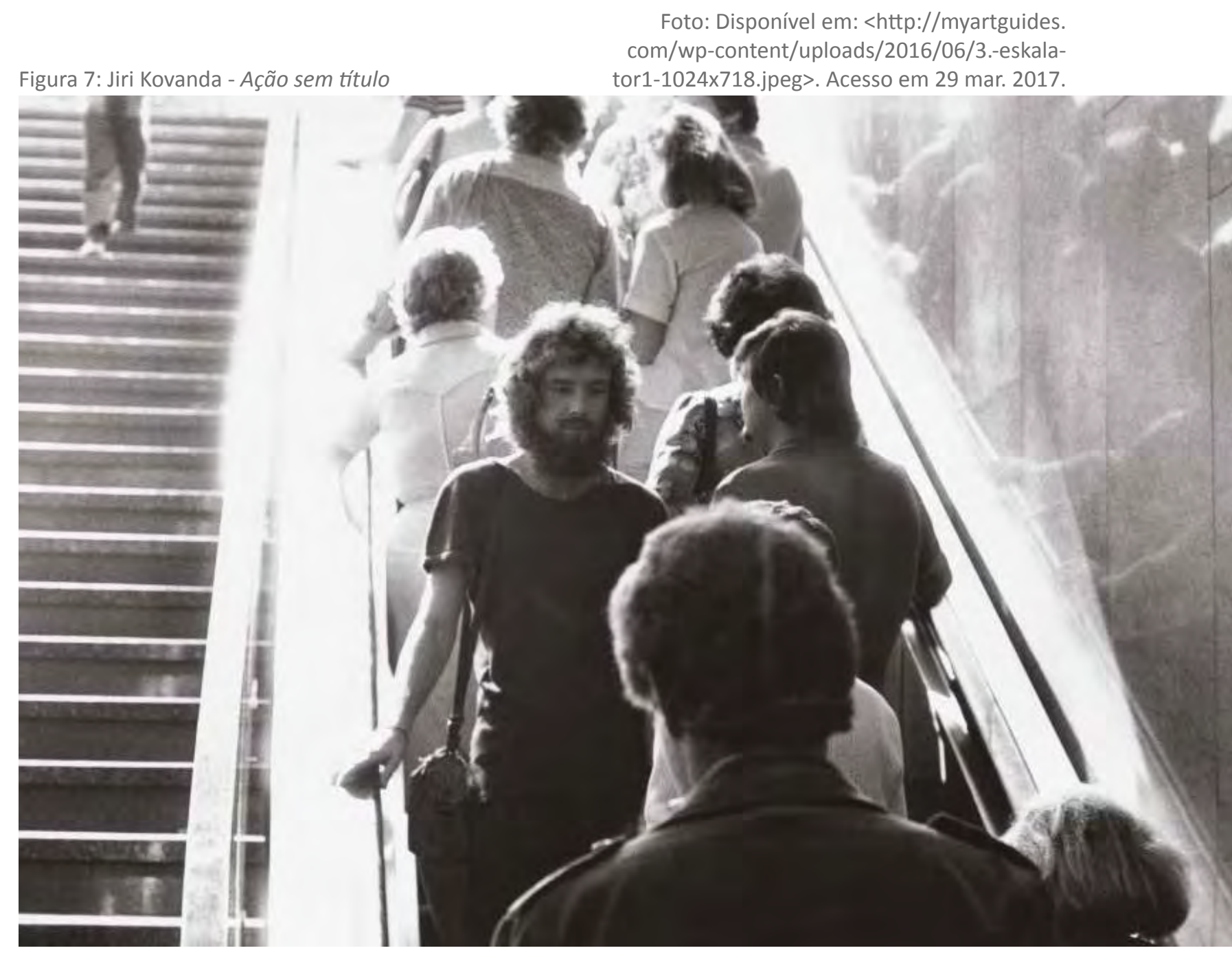

perceba. Não é possível perceber a obra enquanto ela ocorre; é a partir de sua passagem para outra linguagem, de sua expressão em outra materialidade, que a obra passa a existir. Diante das ações desse artista, o termo infra-mince é um conceito operatório fundamental, pois possibilita que se discuta a fenomenologia das coisas imperceptíveis. Marcel Duchamp escreveu 46 notas sobre esse conceito, entre 1935 e 1945, tendo se dedicado mais a esse assunto que à ideia de ready made, paradoxalmente, seu conceito mais conhecido. Dessa forma, Duchamp discutiu a invisibilidade como uma prática possível e convocou, de maneira indireta, os artistas a buscarem o infra-mince como resposta a um mundo tão sobrecarregado de informações, de ideias, de referências e de imagens impactantes.

Curiosamente, o que torna visíveis as ações compostas na lógica do infra-mince é a fotografia, o documento decorrente da performance. O que ocorre nesse movimento de reprodu- 
ção ou representação de ações efêmeras e imateriais em suporte fotográfico é que o arquivo tem uma tendência a se emancipar de seu estatuto puramente documental. Ou seja, ele tem a possibilidade de se tornar um material artístico independente da performance, ainda que seu processo de produção seja profundamente marcado pela experiência vivida. Dessa forma, ação performativa e fotografia convivem como produções paralelas considerando a evolução processual e conceitual da arte desde a década de 1960.

Ao discutir os documentos decorrentes das criações dos Acionistas Vienenses, Philip Auslander discorre sobre a hegemonia da documentação de performance sobre a performance em si. Ele considera o público inicial da performance irrelevante; para ele, o que conta é o espectador ausente, aquele que tem acesso ao documento da performance. Retomando uma performance discutida anteriormente na modalidade passeio: Vienna Walk, realizada pelo austríaco Günter Brus, pode-se afirmar que o público que se deparou com essa performance não teve nenhum acesso à ação. Trata-se de um público desinformado.

\footnotetext{
"Por um público desinformado, quero dizer, pessoas que se constituem como público simplesmente por estarem numa dada localização em um dado momento, em oposição ao convidado, público esteticamente sofisticado das performances de Nova York (por exemplo, da Judson Memorial Church) ou mesmo dos eventos do estúdio Acionista (WIDRICH, 2014, p. 55-56). ${ }^{13}$
}

Assim como Auslander discorre sobre a performatividade da documentação em performance, Rebecca Schneider pressupõe que "estamos lendo o arquivo como um ato" (SCHNEIDER apud WIDRICH, 2014, p.57) ${ }^{14}$. Nesse sentido, ela argumenta que o documento dá acesso ao passado, estabelecendo uma relação com a história. Portanto, a leitura da performance não deve ser exclusivamente associada com o efêmero, nem baseada em documento, pois a primeira não pode ser dissociada do segundo. Performance e documento são como carne e osso, o que Widrich compara com a relação entre o filme e o celuloide. Do mesmo modo como afirmamos que aquilo que vemos projetado na tela é um filme, o celuloide onde ele se encontra também pode ser considerado o filme.

Parece relevante, contudo, ressaltar que para Widrich a fotografia não apenas reporta um evento, ela concede imagens históricas para nosso imaginário, além de revelar modos de performar para a câmera. Todo esse material contribui igualmente para experimentações que se faz no presente. Para embasar suas hipóteses, ela recorre a duas performances de VALIE EXPORT com a colaboração de Peter Weibel, amplamente documentadas. Na primeira delas, já mencionada no capítulo um, Portfolio of Doggedness (1969), a artista leva Weibel para passear, preso por uma coleira. Ela está vestida de casaco de pele e ele, de

\footnotetext{
${ }_{13}$ "By an uninformed audience I mean persons who constitute an audience simple by being in a given location at a given time, as opposed to the invited, aesthetically sophisticated audiences of New York performance (e.g. at the Judson Memorial Church) or even Actionist Studio events" (tradução minha).

${ }^{14}$ We are reading the archive as an act (tradução minha).
} 
camisa e gravata. O próprio nome da ação, que se constitui como um portfólio (uma lista ou coleção de imagens), denota a importância dada à documentação. Nesse caso, a câmera não captura apenas a ocorrência do ato, mas a reação do público. Conforme Widrich, há nos projetos colaborativos de EXPORT e Weibel muitas camadas de mediação, literal e me-

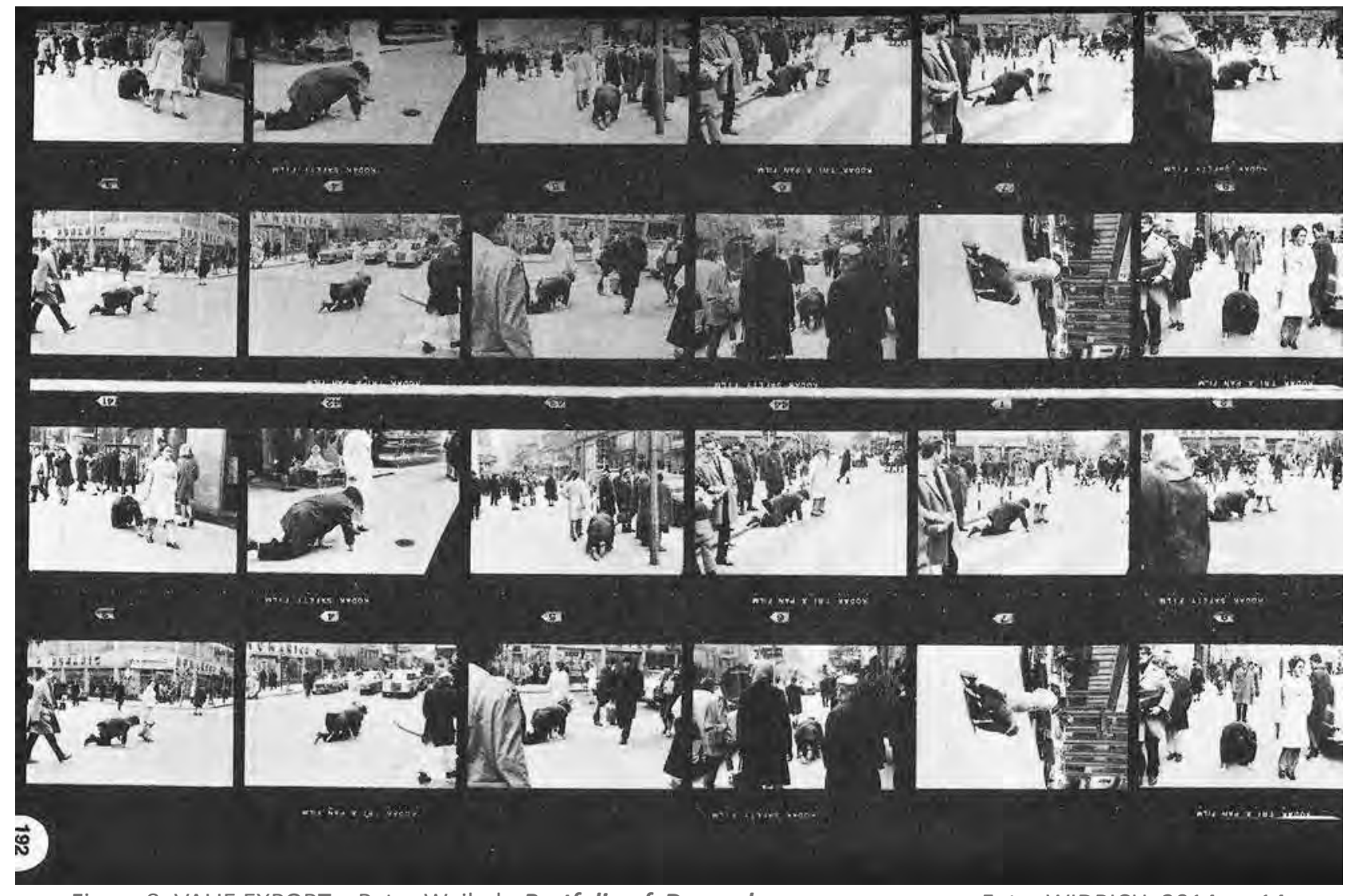

Figura 8: VALIE EXPORT e Peter Weibel - Portfolio of Doggedness

Foto: WIDRICH, 2014, p. 14

tafórica, de tal modo que o material produzido em decorrência da performance se constitui ele mesmo em ação (Ibid., p. 61).

EXPORT estava especialmente dedicada à documentação da performance ao vivo - não para comprovar que a ação realmente ocorreu no espaço público e não num estúdio (como forma de atestar que não se trata de uma fotomontagem) - pois interessa-se pela reação dos passantes às suas ações. A opção por estruturar os resquícios de Doggedness em um portfólio revela a intenção de EXPORT de operar em um momento posterior à ação propriamente dita. Ela se vale do portfólio como ferramenta, assim como se vale da documentação em vídeo como meio de dissecar a ação e afirmá-la como um corpo expandido, capaz de ser representativo em diferentes mídias. A manipulação dessas materialidades decorrentes da ação chega ao seu ápice em outra performance realizada pela dupla: Touch Cinema $(1968)^{15}$.

\footnotetext{
${ }^{15}$ A performance foi realizada por VALIE EXPORT em Viena, Munique, Colônia, Zurique, Amsterdã e Londres, em instituições de arte e em festivais de cinema.
} 


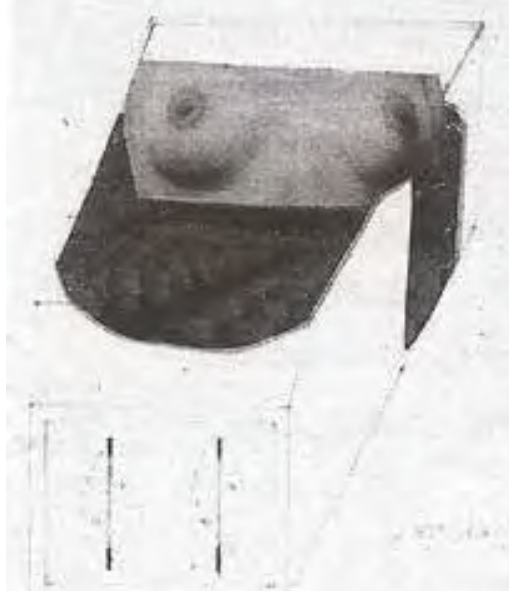

Foto: WIDRICH, 2014, p. 72
A artista cobre os seios nus com uma maquete de uma caixa cênica, com cortinas vermelhas na frente, e caminha pelo espaço público portando esse proscênio em miniatura acoplado ao seu torso. Enquanto caminha, os passantes são convocados pela voz de Peter Weidel, ampliada por um megafone, para participarem da ação, tocando o que se esconde por trás da cortina. Durante um tempo cronometrado (uma variação de 15 a 30 segundos), alguns voluntários colocam as mãos dentro do dispositivo e tocam os seios da performer. A substituição da tela do cinema pela pele de uma mulher é considerada por Widrich como uma analogia pública à privacidade erótica da sala escura (2014, p.65). Nesse jogo entre público e privado, entre presença e mediação, a sensação de intimidade com o seio alheio é invadida pelo olhar de VALIE EXPORT, que insiste em manter um contato visual com a pessoa

que a toca. A figura do voyeur cinematográfico passa de observador a "tateador" do objeto erótico, ao mesmo tempo em que é assistido por uma pequena multidão que se aglomera em torno da performer. O que tal ação propõe é a quebra de um tabu, que segundo VALIE EXPORT representa o primeiro passo de uma mulher de objeto a sujeito. Em uma das ocasiões na qual a performance foi realizada, um festival de cinema, a dupla propõe uma crítica a esse mundo, majoritariamente masculino. Touch cinema é também uma reivindicação feminista a outros postos para as mulheres que não seja o papel de objeto sexual. Nesse caso é a mulher que olha diretamente nos olhos de quem a apalpa e que consente que seus seios sejam não apenas observados, mas tocados ${ }^{16}$. Tal ação coloca em questionamento o ser ativo e passivo, o ver e o agir e também o corpo crítico e o corpo sensível.

No entanto, o que merece atenção no que tange à questão da documentação em performance é o trabalho realizado pelos performers a posteriori. Inicialmente documentada em vídeo, foram as fotografias da performance que mais circularam pela grande mídia. E o detalhe mais intrigante está no fato de a própria EXPORT ter selecionado e autorizado a reprodução de suas imagens, mesmo junto aos artigos que questionavam o teor de sua representação. A ação foi interpretada por alguns como castradora, chegando a ser retratada em caricaturas que mostravam as cortinas se transformando em guilhotinas que cortam as mãos de quem toca seus seios. A performer não exclui o debate sobre a desigualdade de

\footnotetext{
16 VALIE EXPORT é uma pioneira no cinema de vanguarda da Áustria, além de único membro feminino a participar da fundação da Cooperativa de Cineastas daquele país.
} 
gênero de sua proposta, nem reduz a ação a essa única problemática. "Mais que infringir um certo número de tabus, a peça nos interroga sobre os seios de Valie Export como o lugar de encontro entre dois indivíduos" (DELPEUX, 2010, p. 144) ${ }^{17}$. Tal afirmação só reforça a relação de cumplicidade que a performer busca estabelecer com o espectador por meio de sua entrega corporal nesse ambiente velado, atrás do qual somente os dois sabem exatamente o que se passa.

As imagens escolhidas para documentar a ação, essas mesmas fotografias que tanto circularam, compõem uma narrativa a partir das reações do público inicial (as pessoas que oca-

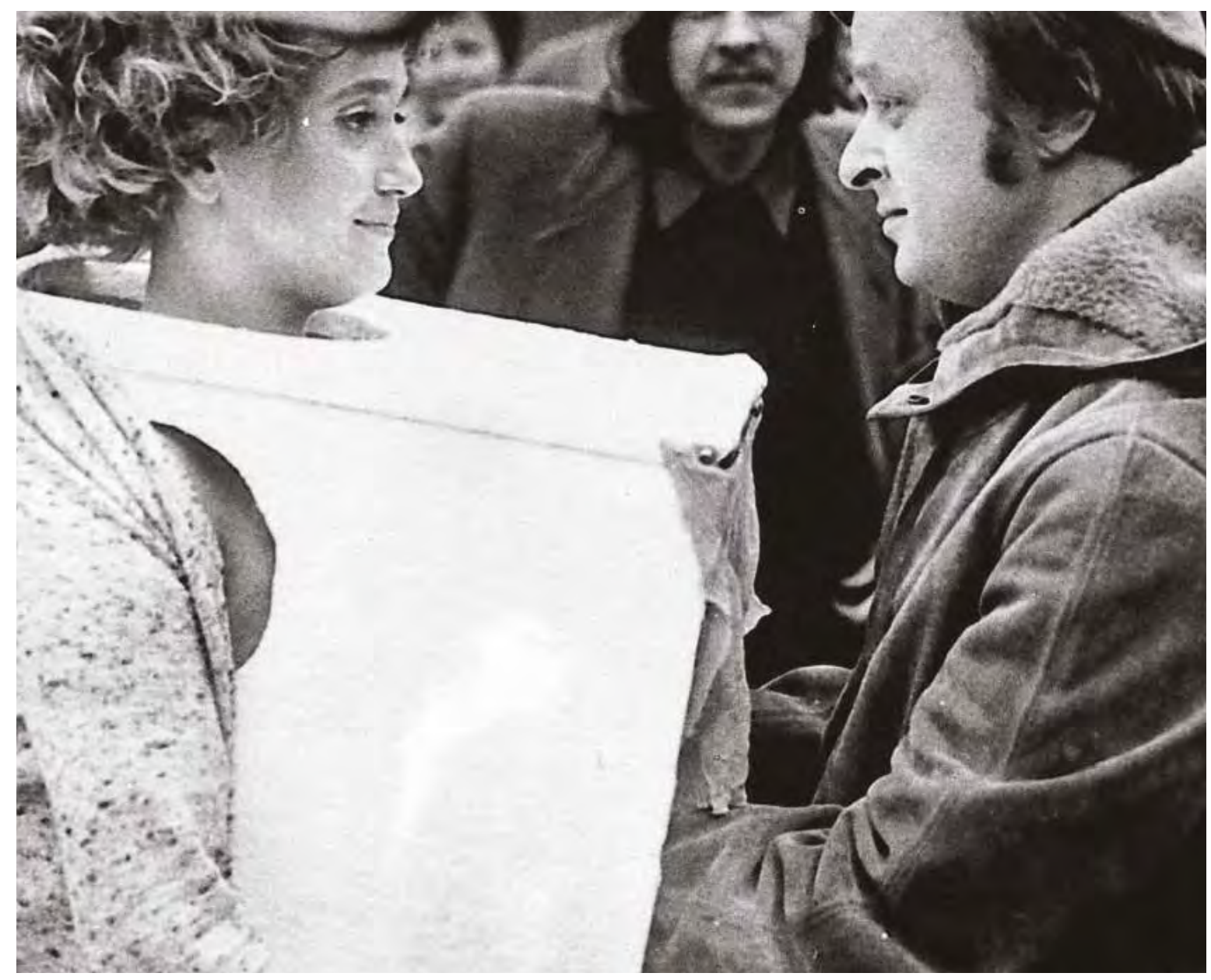

Figura 10: VALIE EXPORT e Peter Weibel - Touch Cinema

Foto: DELPEUX, 2014, p. 143

sionalmente se encontravam ali). Embora EXPORT não tenha dirigido a filmagem da ação, ela selecionou as imagens de dois homens como público modelo, justamente por sintetizarem o espírito da performance. O cuidado com o documento indica o quanto a ação não se encerra na sua ocorrência ao vivo, à presença da artista na cidade como experiência única, mas continua na conjugação de camadas de significado acrescentadas na manipulação de

${ }^{17}$ En plus d'enfreindre un certain nombre de tabous, la pièce nous interroge sur ce lieu de rencontre entre deux individus que devient la poitrine de Valie Export. 
um conjunto de fotografias.

Não por acaso, os sujeitos escolhidos para integrar o triângulo mulher - invasor - voyeur são dois cineastas: Ed Sommer (um tipo "classe trabalhadora) e Werner Nekes (um tipo intelectual). Conforme revela Widrich, o primeiro representa o toque masculino, enquanto o segundo, olhar masculino (2014, p. 71). Enquanto Sommer toca os seios de EXPORT na primeira foto, Nekes os observa e sua disposição central no enquadramento chama atenção de quem observa a foto (figura 10). Nekes olha fixamente para EXPORT e a câmera que documenta a ação captura seu voyeurismo, posicionando a performer na distância exata entre ela e Nekes. Tal composição causa a impressão de que Nekes também nos vê, a nós, espectadores ausentes, que nesse jogo assumem o lugar da câmera. Outro aspecto interessante dessas fotos é a diferença no olhar de EXPORT, que olha nos olhos de Sommer com certo desconforto enquanto é tocada por ele e que ri, olhando na direção em que estaria seu parceiro Peter Weidel, enquanto Nekes a toca. Tal observação revela o protagonismo da performer, que se reafirma na posição de sujeito, apesar de oferecer-se como objeto para o toque alheio.

É possível observar uma performatividade no documento, desde a escolha dos colaboradores, que estão efetivamente envolvidos com a ação, até o fato de ser possível apreender significados no documento, que não estão colocados na ação ao vivo. Esses dois homens são passantes ideais que poderiam ser qualquer um de nós, porém suas identidades se mantêm veladas a quem têm acesso apenas às imagens. Tal artifício revela o quanto a criação

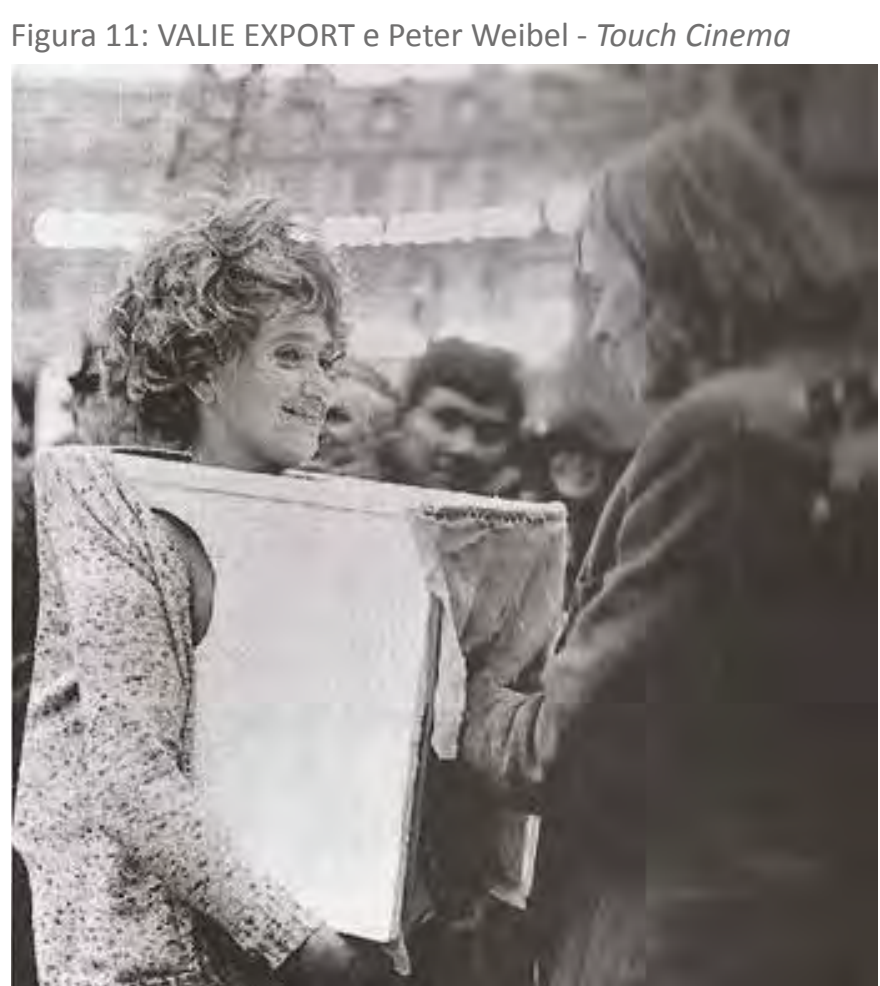

Foto: Werner Schulz WIDRICH, 2014, p. 65 de EXPORT ocorre a partir da sobreposição de significados, que serão desvelados na medida em que o espectador recorre aos documentos, sejam eles fotografias, textos, reportagens de jornal.

No caso da performance de VALIE EXPORT, que propõe uma visão confusa das relações de poder e evidencia as desigualdades de gênero no espaço público, o uso das fotografias em outros suportes e composições foi um meio de defender as posições da artista frente ao uso hostil de suas imagens por parte da imprensa austríaca e alemã. Na verdade, a grande difusão das imagens de EXPORT, mesmo quando afirmam que se trata de uma jovem bonita e a criticam por deixar seus seios disponíveis, 
acabou colocando sua produção no centro da discussão. Fato este que não ocorreu com nenhum outro artista ligado ao acionismo vienense. Em uma colagem conceitual realizada pela artista, 4 anos após a execução da performance, ela posiciona a foto de seus seios no lugar da tela de um cinema, disposto lado a lado com a foto de Sommer tocando seus seios. Dessa forma, ela coloca seus seios simbolicamente dentro e na arquitetura e não como objeto da performance (figura 9). Essas outras materialidades decorrentes de Touch Cinema enfatizam o aspecto comunicacional da performance, que oferece o corpo da artista mediado, expandido na forma de tela tocável - a síntese de um erotismo masculino - cujo desejo é insistentemente acionado pelo gesto de olhar corpos femininos reduzidos a objetos. Cada reconfiguração dessa proposta articulada por VALIE EXPORT ressalta a posição da artista como sujeito crítico e também carregado de desejo.

\begin{abstract}
Contrariamente ao que afirma o pós-modernismo de que o evento não importa, uma vez que somos capazes de experimentar somente através de imagens, defendo que não apenas precisamos de um evento, real ou imaginado, para experimentá-lo imaginativamente, como precisamos frequentemente nos direcionar para a presença corporal de audiências prévias, como forma de experimentar um ato anárquico que acontece ao ar livre - geralmente vemos as fotografias, afinal, de volta às paredes brancas da galeria. Mas isso, também, está implícito: mais, isso está implícito na performance. Olhar para essas imagens é o mesmo que lê-las, com a mesma contribuição de nosso imaginário de quando lemos um livro. Mas em contraste com o livro, temos mais do que apenas um documento, mais do que o substrato de um material sobre o qual a performance opera, uma vez que o artista da performance trabalha em diferentes tempos: pelas escolhas feitas na hora da performance, pela direção da captação [de fotografia ou vídeo], pela impressão e venda de algumas imagens e não de outras, pelas entrevistas concedidas e permissões para publicar. $\mathrm{O}$ emaranhado das camadas de respostas do público diz respeito historicamente à natureza efêmera da performance: elas constituem não a sua vida posterior, mas sua vida em exibições, rumores e textos históricos da arte. Performers, pelos documentos que divulgam, tornam-se atores e escritores de sua própria história - embora não tão infalivelmente. (WIDRICH, 2014, p. 72-73) ${ }^{18}$.
\end{abstract}

O ponto de vista da autora apresenta três pontos bastante interessantes para nossa discus-

\footnotetext{
${ }_{18}$ Against postmodernism claims that the event does not matter, as we are able to experience only through images, I argue that not only do we need an event, actual or imagined, in order to imaginatively experience it, we often need to be pointed towards the bodily presence of prior audiences in order to experience an anarchic act taking place out of doors - we usually see the photographs, after all, back within the white walls of the gallery. But that, too, is implicit: more, it is implicit in the performance. For looking at its images is reading them, with as much of our own imaginative input as reading a book. But in contrast to a book, we have more than just a document, more than one material substrate on which the performance operates, as the performance artist works in distinct temporal stages: by choices made at the time of performance, by directing the shooting, by printing and selling some images and not others, by giving interviews and permission to publish. The resulting tangled layers of public response are the historical nature of ephemeral performance: they constitute not its afterlife but its life in exhibitions, rumors, and art-historical texts. Performers, through the documents they release, become both actors and writers of their own history though of course, not infallibly so (tradução minha).
} 
são. Primeiramente, ela não só enfatiza a importância do público inicial, como aquele que efetivamente experimenta "um ato anárquico" em local comum, provavelmente público, mas também reconhece a produção de vestígios como constitutiva do ato performativo. Para ela, não se trata nem de eliminar o evento enquanto situação de encontro, nem de deixar de produzir materialidades distintas da efemeridade da performance. É como se a ação precisasse de produções paralelas para concretizar seu caráter imaterial.

Depois, Widrich aproxima o contato com a performance de uma experiência de leitura, para qual nosso imaginário também é solicitado, não apenas como exercício de decodificação da linguagem. Não se trata de uma leitura para a qual precisamos conhecer os signos, mas de uma leitura que não se encerra na decodificação; ela exige uma contribuição de cada imaginário que se confronta com a obra. A essa leitura, eu acrescentaria uma situação de estudo, tendo em mente a perspectiva apresentada por Amelia Jones. O acesso aos restos da performance, pode ser tão ou mais intrigante do que a frequentação da performance ao vivo. Quando se estuda performance, o retorno ao material é quase obrigatório. Mesmo tendo presenciado o ato, faz-se necessária a consulta aos arquivos, pois eles são pistas deixadas pelo artista.

Por último, ela afirma que a organização dos vestígios da performance por parte do artista é parte constituinte do ato performativo. Isso fica claro na criação de VALIE EXPORT que manipula com eficiência os materiais decorrentes de suas experimentações. Os performers, que segundo ela assumem o papel de escritores da própria história, assumem, pela divulgação desses documentos, também o papel de escritores da história da performance. Para tanto, diversos suportes são utilizados, como por exemplo a fotografia e o vídeo, mas também o desenho e a escrita textual, não só na forma de relatos sobre o processo de criação, como também em formas literárias.

\section{_quando a performance resulta em vídeo}

Quando o documento resultante da ação performática é um vídeo, inúmeras questões se colocam e a discussão fica ainda mais complexa. A câmera busca incessantemente reproduzir o real, uma vez que a imagem é capturada em movimento, ainda que, em certa medida, o movimento também esteja presente no suporte fotográfico. No entanto, a fotografia será sempre uma representação, um átimo, uma cristalização de um momento ou de um movimento. Perpetuando instantes isolados e não uma ação em continuidade, a fotografia não seria capaz de substituir ou se confundir com o ato performático, apenas integrá-lo. Existem lacunas entre um registro fotográfico e outro e essas lacunas são, no meu ponto de vista, essenciais para que o espectador - tendo ele vivenciado ou não a ação ao vivo - com- 
plete com seu imaginário as lacunas entre uma foto e outra. Há um risco no suporte videográfico de o documento ser tomado como a representação da totalidade da experiência, uma vez que o vídeo busca causar impressão de realidade. Dessa forma, parece limitador reduzir a leitura de uma performance a apenas um ponto de vista sobre a ação, aquele de quem filma.

Há na fotografia outra lacuna que, ao meu ver, contribui para a documentação de performance: a ausência do som. Assim como a fala é associada ao pensamento, o som revela a ambiência, o contexto no qual a ação foi captada e a situação na qual a ação se insere. O som é um elemento muito importante na representação do real; sem ele, não somos inteiramente mergulhados em determinado contexto. Por esse motivo, a ausência de som na imagem fotográfica pode ser observada como uma vantagem em relação ao vídeo, pois o silêncio nos mantém minimamente distanciados do evento. De certo modo, o que se apresenta em imagem e som em vídeo é excessivamente próximo, no que diz respeito à ideia de registro, do que se passa numa ação performativa. A falta de distanciamento entre o vídeo e a performance impediria a configuração dessa materialidade visual (o vídeo) na forma de documento; ela permaneceria, na maior parte das vezes, como registro. Ou seja, dificilmente um vídeo poderia se tornar um documento de performance, a não ser que a ação fosse realizada expressamente para a captação de uma câmera, o que acontece muito frequentemente em performances atuais. Nesses casos, o artista está de comum acordo com quem capta as imagens ou é ele mesmo o responsável pela edição e montagem do vídeo, reconhecendo nesse suporte a forma final de sua criação.

Embora eu reconheça a fotografia como o suporte mais rico na documentação de performance, não poderia me isentar de apresentar nesse texto formas bastante originais e inventivas de usar o vídeo na documentação de performance. Em muitos casos, o que ocorre não é a captação de imagens videográficas com o intuito de documentar amplamente a performance, mas o uso do vídeo para a produção de outros materiais relacionados ao ato performativo. É o que acontece com os teasers e mesmo com os gifs produzidos pelos artistas a partir de suas ações efêmeras ${ }^{19}$.

Observando a documentação de ações performativas em vídeo, notamos grande interesse dos artistas pelas novas tecnologias desenvolvidas para a captação de imagens em tempo real, o mesmo movimento que acontece historicamente na interface entre arte e tecnologia. Na medida em que as câmeras de vídeo se tornam mais leves e mais difundidas em diferentes meios sócio-econômicos, a captação da performance em movimento passou

19 Teasers são vídeos curtos que visam divulgar a performance, sintetizando-a para alguém que não chegou a presenciá-la, ou convidando espectadores para estarem presentes no ato de sua realização. Gifs são combinações de imagens compactadas em um único arquivo, que, ao ser visualizado, causa a impressão de movimento. São formatos que tem curta duração, diferente do que ocorre com uma criação em um stop motion, por exemplo. 
por diferentes etapas. Três delas podem ser evocadas como significativas para exemplificar essa evolução. A primeira delas, anterior à invenção do digital, configurou-se a partir da década de 1980 como um campo autônomo de criação : a vídeo arte. A segunda, pode ser associada à popularização das câmeras, nesse momento já digitais, quando elas passam a integrar as ferramentas dos telefones celulares mais básicos (nesse aspecto, a fotografia caminha lado a lado com o vídeo). A terceira etapa coincide com a possibilidade de vídeos serem difundidos em tempo real pela internet, ferramenta que hoje em dia está disponível inclusive nas redes sociais. Passo agora à apresentação de um exemplo de performance que resulta em vídeo ou se vale desse suporte para organizar sua criação como ferramenta de expansão das artes da ação.

No caso da performance Matrimônios, realizada pelo Desvio Coletivo, em São Paulo em novembro de 2016, a resultante videográfica tem duas funções distintas. Num primeiro momento, o vídeo é usado como meio de comunicação imediata com um público ausente fisicamente, mas que acompanha a performance em tempo real. Ou seja, a performance é filmada e transmitida ao vivo, por um canal comunicado previamente para o público desse coletivo, por meio de uma plataforma na internet. Philip Auslander discorre sobre a transmissão ao vivo afirmando que "os performers e os espectadores estão presentes temporalmente uma vez que os últimos são testemunhas da performance no momento exato no qual ela se produz, mas eles não estão presentes fisicamente" (AUSLANDER in FÉRAL e

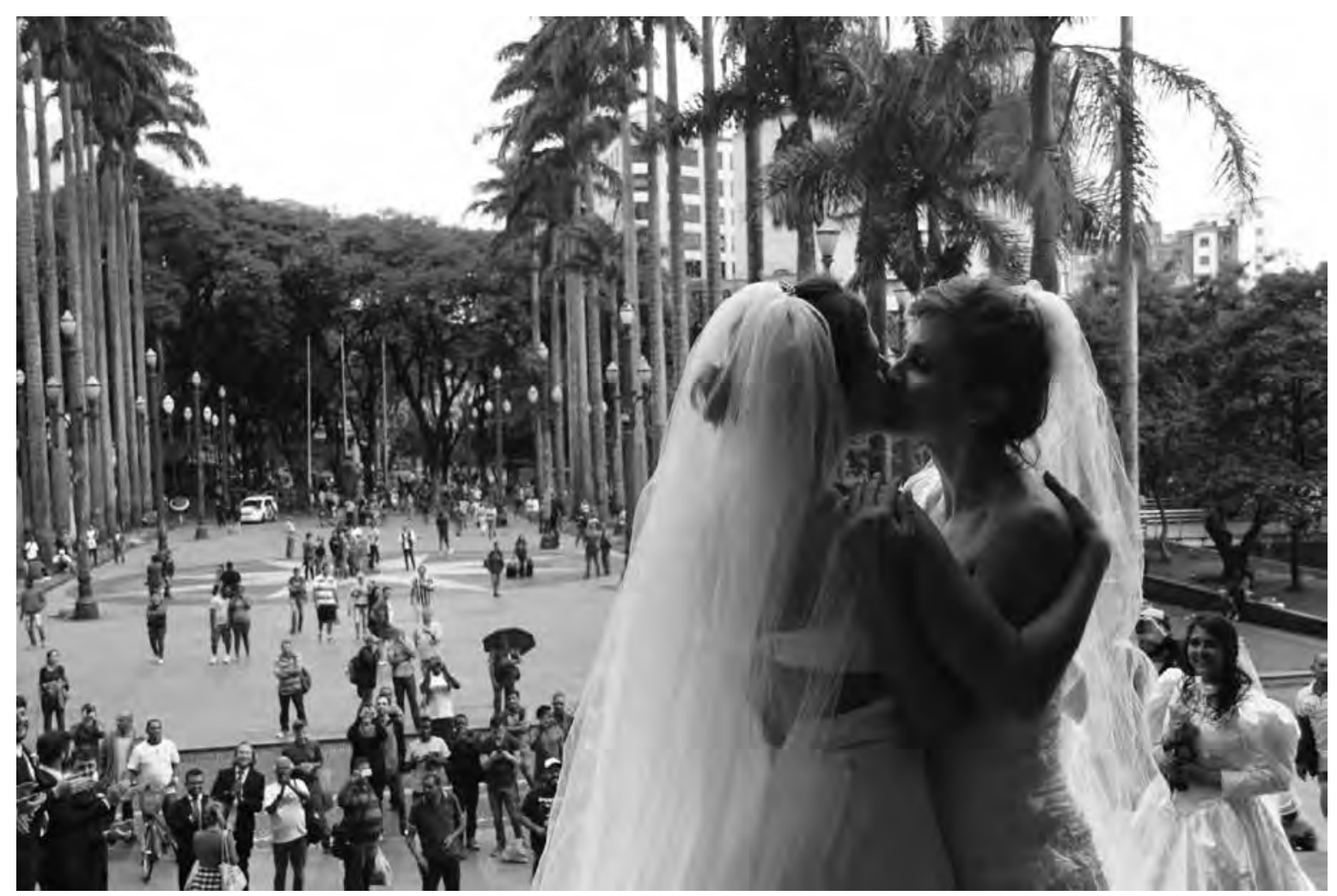


PERROT, 2013, p.64) ${ }^{20}$. Estar presente ou estar ausente quando o assunto é performance ou intervenção urbana passa a ser relativo, na medida em que se utiliza de novas tecnologias para a transmissão e comunicação com o público. Quando uma ação é transmitida ao vivo, ela encurta distâncias e causa a impressão de que nos encontramos no local onde ela acontece. Por isso, Auslander considera esses espectadores virtuais como testemunhas da performance, ainda que não estejam presentes fisicamente. $O$ recurso da transmissão ao vivo possibilita outros tipos de relação com a ação artística.

Num segundo momento, um vídeo curto, na forma de teaser (com aproximadamente 4 minutos), é produzido reunindo trechos dessa performance e alguns comentários de passantes que se deparam com essa ação em plena Praça da Sé, em São Paulo. No feriado da proclamação da República, quando vários militares se encontram reunidos ali, um cortejo de noivas e noivos percorre a praça. Diante dessa primeira aparição, composta por casais aparentemente heterossexuais, espectadores fortuitos aplaudem a chegada dos noivos, gritando "Viva os noivos!". No teaser é possível observar comentários como: "ainda bem que é homem e mulher, macho e fêmea [...]", "Graças a Deus". Os casais seguem um percurso previamente definido, caminhando em direção à igreja e cortejando-se mutuamente. De braços dados, cada casal se beija ao chegar ao topo da escadaria que dá acesso à igreja. Em seguida, se separam e formam linhas organizando-se em outras configurações de gênero ou mesmo em outros tipos de agrupamento (a três ou a quatro). Quando esses novos casais, fora do padrão heteronormativo, começam a se beijar, os comentários de aprovação e elogio ao casamento se transformam em agressões aos performers.

A experiência coloca uma lupa no conservadorismo popular, ao expor na rua um comportamento que foge aos padrões oficialmente estabelecidos. Muitas pessoas se exaltam, gritam e xingam os performers, ao se depararem com casais homossexuais se beijando ou com representações grupais de poli amor. Matrimônios transforma o espaço público numa ágora onde se debate gênero e sexualidade. Com ânimos exaltados, os mais conservadores bradam a quem quiser ouvir suas regras de comportamento, enquanto as pessoas que se identificam ou apoiam essas configurações amorosas também se manifestam, defendendo a liberdade de cada pessoa decidir como opera sua subjetividade. No teaser produzido pelo Coletivo, vemos uma amostra desse embate público produzido pela performance. Há testemunhos de senhoras que acham estranho ver um homem beijando outro homem e que não estão acostumadas a ver isso na igreja; há pessoas que consideram esses comportamentos "normais", alegando que cada um tem o direito de viver como quer e que o dever de todos é respeitar a escolha do outro; há também quem analise a situação como teatro, como ideia original que mostra o casamento a partir de outros pontos de vista.

\footnotetext{
${ }^{20}[. .$.$] les performeurs et les spectateurs sont présents les uns aux autres temporellement puisque les derniers$ sont témoins de la performance au moment exact où elle se produit, mais ils ne sont pas présents les uns aux autres physiquement (tradução minha).
} 
Essa performance causa um efeito de acontecimento em praça pública, confrontando opiniões e convidando os cidadãos a discutirem sobre os tipos de relações amorosas que são oficialmente aceitas nessa sociedade. Esse efeito de acontecimento presente na performance será debatido ainda nesse capítulo, mas o que interessa destacar nesse momento é a exposição desse material na ágora virtual representada pela internet. Nesse caso, a opção pelo suporte do vídeo pode ser justificada pela importância dada aos testemunhos, uma vez que o que se coloca em jogo nessa ação é o calor do debate. Evidentemente, o público inicial dessa performance faz parte de sua realização. Trata-se de uma situação de convívio, uma representação de um casamento coletivo - diante do maior símbolo da igreja católica dessa cidade - no qual todas as configurações são possíveis. Se Matrimônios resultasse em fotografia, o espectador ausente ou virtual não teria acesso à reação das pessoas, à maneira pela qual o debate se disseminou nesse recorte da cidade, em decorrência da intervenção cênica. $O$ debate sobre gênero não se encerra nos caminhos traçados por cada dupla, trio ou quarteto amoroso pelas ruas do centro de São Paulo; o debate continua virtualmente, por meio do vídeo que se configura como uma reportagem do evento ocorrido.

Jonathan Lamy, em artigo publicado no livro Le réel à l'épreuve des technologies: Les arts de la scène et les arts médiatiques [O real à prova das tecnologias: as artes da cena e as artes midiáticas], faz o seguinte questionamento: quantas pessoas estavam presentes na Galeria F Space, onde Chris Burden, no dia 19 de novembro de 1971, voluntariamente, levou um tirou no braço? Essa pergunta desencadeia uma série de reflexões sobre a documentação de performance, pois certamente a quantidade de observadores que assistiu ao vídeo de Chris Burden, ou teve conhecimento do enunciado de sua performance, é muito maior do que as pessoas que efetivamente presenciaram o ato. Por isso, Lamy não considera as fotografias, vídeos ou textos decorrentes de uma performance apenas arquivos, rastros materiais que permitem a reconstituição dos fatos, pois eles transmitem a performatividade da ação.

Essas imagens, mais que arquivos, permitem não somente aos espectadores entrar em relação com essas performances após sua realização, mas elas se constituem uma parte intrínseca da obra. Como se cada obra de performance compreendesse uma dimensão imediata (o desenvolvimento enquanto tal da ação com caráter artístico) e um "ao redor", composto de imagens (croquis, fotografias, vídeos), narrativas (abordagem do artista, entrevistas, relatórios) e por vezes outros documentos (registros sonoros, cartazes). O que contorna a performance faz parte de certo modo da performance (LAMY in FÉRAL e PERROT, 2013, p.179). ${ }^{21}$

Lamy ressalta o quanto a ação se confunde com as materialidades que a testemunham,

${ }^{21}$ Ces images, bien plus que des archives, permettent non seulement aux spectateurs d'entrer en relation avec ces performances après leur réalisation, mais elles constituent une part intrinsèque de l'œuvre. Comme si chaque œuvre de performance comprenait une dimension immédiate (le déroulement comme tel de l'action à caractère artistique) et un "autour", composé d'images (croquis, photographies, vidéos), de récits (démarche de l'artiste, entrevues, comptes rendus) et parfois d'autres documents (enregistrements sonores, affiches). Ce qui entoure la performance fait en quelque sorte partie de la performance (tradução minha). 
motivo pelo qual a performance se constitui, pelo próprio caráter de sua prática, como um campo expandido de criação. Decorrem desse mesmo fato, as múltiplas origens atribuídas à história da performance, que podem ser observadas a partir das artes cênicas, das artes performáticas ou dos estudos antropológicos. De acordo com Lamy, trata-se de uma prática artística que dispõe de uma dimensão viva e de uma dimensão visual, de onde vêm igualmente sua riqueza e sua complexidade. Nos casos em que a performance abdica da presença do público no ato de sua execução, destinando-se exclusivamente para a câmera, há uma redução da ação à sua representação. Assim, a imagem substituiria a ação performativa. Paradoxalmente, quando a imagem veicula a ação, há uma expansão de seus domínios, pois mais pessoas terão acesso a ela, em espaços e tempos que não abrangem o ato de sua execução.

\section{_quando a performance resulta em desenhos, textos e outras narrativas}

Provenientes das artes visuais, muitos performers utilizam-se de desenhos para criar rastros ou vestígios de suas ações. Tais desenhos são inevitavelmente documentados pelo intermédio de fotografias ou vídeos, meios que detêm atualmente a visualidade das ações performáticas. Prova disso é que, em geral, temos acesso a essas ações pelas imagens difundidas pela internet. Em inúmeras ações, muitas delas citadas nos capítulos anteriores, Francis Alÿs ${ }^{22}$ explorou a dimensão gráfica de suas caminhadas. Exemplos disso são as linhas ou fios de tinta usados pelo artista para demarcar percursos como em The Leak, realizada em São Paulo (1995) e em Paris (2003), além da travessia The Green Line (2004), na qual marcou a divisa entre Israel e Cisjordânia. No caso dessas ações de Alÿs, os desenhos acontecem em decorrência de sua deambulação, sendo que o chão é usado como suporte para inscrição de seus traços. É interessante destacar que no primeiro caso, não há uma elaboração do que se desenha; a marca visível dessa caminhada é fruto do acaso. No segundo caso, o performer demarca com sua linha uma antiga fronteira, apagada pela expansão do território de Israel. Nesses dois exemplos, trata-se de um fio de tinta vazando de uma lata furada.

De acordo com Francesco Careri, os artistas da land art transformam o espaço geográfico em espaço cartográfico, usando o chão como superfície de escrita. Para os artistas caminhantes, é recorrente que as performances sejam documentadas ou partam da criação de mapas. Dentre as obras que ultrapassam a representação da caminhada e que se configuram como o resultado de um processo, o vestígio de uma caminhada, destacam-se as ações

\footnotetext{
${ }_{22}$ É interessante destacar que Francis Alÿs escolhe uma fotografia de cada ação realizada por ele para produzir cartões postais sobre seus deslocamentos pela cidade e enviar para pessoas relacionadas ao mundo das artes. Essa proposta se configura não apenas como uma forma de vender e divulgar seus trabalhos, mas também como um prolongamento de sua ação, que viaja para além do tempo e do espaço percorrido.
} 
dos ingleses Richard Long e Hamish Fulton, muito conhecidas no campo da land art. No caso do primeiro, cuja ação já foi apresentada no capítulo anterior, $\boldsymbol{A}$ line made by walking (1967), na qual uma linha é desenhada pelo efeito de uma caminhada repetitiva sobre um terreno gramado, a ação é conhecida por meio de um registro fotográfico. O registro perenizado pela fotografia é a marca do deslocamento, do objeto criado pela ação de um corpo que já não se encontra mais presente.

No segundo caso, as ações realizadas por Hamish Fulton resultam igualmente em imagem fotográfica e, menos frequentemente, em vídeo. As imagens criadas na natureza não são modificadas pela presença de um corpo, mas de uma coletividade. Nesse caso é a ação que é sutil, quase imperceptível. São passos muito lentos, uma caminhada que acontece com um grande intervalo entre um passo e outro. Desse modo, mesmo quando a ação é filmada, tem-se a impressão de que se trata de uma sequência de fotografias. Sem espectadores convidados a ação é inteiramente desenvolvida a partir de uma convocatória para centenas de pessoas realizarem um ato conjunto. Dessa forma, o artista elabora um postulado sobre sua arte: o ato de caminhar não se configura como um objeto ou material artístico, ele é vivido como experiência. Apesar de documentar suas ações em fotografias e vídeos, ele defende que não se trata de land art, são experiências significativas para quem faz. Essas ações podem acontecer nas mais diversas praias, bastando reunir um grande agrupamento de pessoas compondo filas que se aproximam e se distanciam do mar. Water (2012) é uma experiência ao mesmo tempo meditativa e política.

Fulton acredita na arte como a única resultante da experiência de caminhar e defende a ideia de que esse ato tem um valor artístico por si só, sem necessitar da produção de outros trabalhos artísticos para certificá-lo. Considera o corpo o instrumento perceptivo e realiza mapas abstratos a partir de suas experiências, assim como coleciona sons (ruído do vento, canto de passarinhos e o pulso dado pelo próprio passo) e frases curtas que remetem aos espaços visitados. Quando se apresenta em galerias, exibe em suas exposições uma espécie de "poesia geográfica", usando as palavras de Careri. Hamish Fulton desenvolve o que Elie Faure - um dos primeiros autores a escrever sobre cinema - qualificou como cineplástica (já mencionado na capítulo três). Diferente da mera mobilidade, a cineplástica condiciona uma plasticidade vinculada ao movimento. Tanto Richard Long quanto Hamish Fulton são artistas que desenham ou esculpem percursos. Ambos partem de uma mobilidade simples, um deslocamento entre dois pontos, para compor um caminho em forma de desenho que será melhor observado se o ponto de vista for aéreo. O historiador da arte Thierry Davila os considera agrimensores da paisagem.

Nas ações da land art, a ênfase na ação acaba imprimindo no terreno o desenho de um percurso. Em A line made by walking, realizada por Richard Long em 1967 ou em A walk of hour and four circles, de 1972, o artista percorre determinado percurso inúmeras ve- 


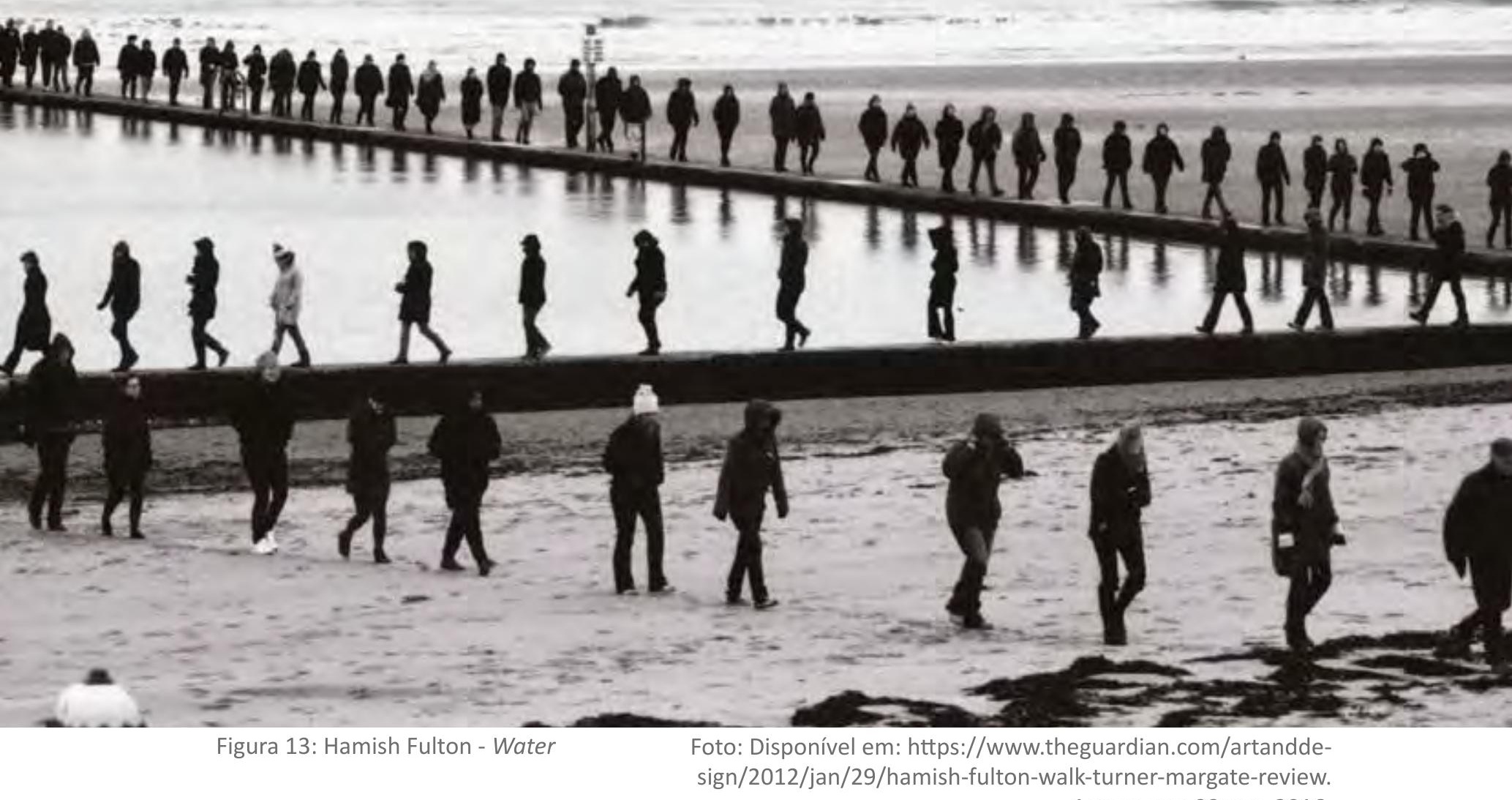

Acesso em: 23 nov. 2016.

zes, sem que ninguém presencie sua ação. No primeiro caso, o percurso é uma linha reta traçada sobre a grama, no segundo, são círculos desenhados pelo efeito de uma hora de caminhada ininterrupta sobre um terreno. Essas ações afirmam a ausência do corpo em performance, uma vez que elas resultam em desenho, tendo a terra como suporte para o traço. Ou antes, mais do que um desenho disposto entre céu e terra, tais ações resultam em fotografia do desenho ou efeito do ato de caminhar.

Yoko Ono, em seu livro Grapefruit: A Book of Instruction and Drawings by Yoko Ono 23 reúne uma série de programas de ações que podem ser realizados, posteriormente, por outras pessoas. O livro está dividido em nove partes - música, pintura, evento, poesia, objeto, filme, dança e peças de arquitetura - com pequenas instruções para a execução de ações relacionadas a essas diferentes linguagens. Porém, ao articular esses textos, Yoko Ono embaralha os procedimentos dessas linguagens e age com muita liberdade na proposição de dispositivos para o jogo. Exemplo disso são as seguintes proposições: "PEÇA DE PAREDE PARA ORQUESTRA para Yoko Ono. Bata numa parede com sua cabeça."; "PEÇA DE RELÓGIO. Roube todos os relógios de mesa ou de pulso do mundo. Destrua-os." e "POEMA TÁTIL III. Realize uma reunião de poema tátil em algum lugar distante ou num endereço fictício num dia fictício." e "PINTURA PARA SER CAMINHADA. Deixe um pedaço de tela ou uma pintura terminada no chão ou na rua." É interessante como a autora integra o corpo em proposi-

${ }^{23}$ Usei a tradução para o português: Grapefruit: o livro de instruções e desenhos de Yoko Ono, realizada por Giovanna Viana Martins e Mariana de Matos Moreira Barbosa, através do Programa de Bolsa de Iniciação Científica FAPEMIG/UEMG, em Belo Horizonte. 
ções relacionadas à música ou à poesia, assim como se utiliza de objetos e da vida cotidiana como matéria para seu fazer artístico.

Ao final do livro, ela apresenta alguns folders de suas exposições ou eventos, além de revelar como alguns desses programas foram realizados. Muito provavelmente, nem todos saíram do papel dado seu aspecto poético, sendo apenas imaginados; outros eram impossíveis de serem realizados, dado seu aspecto absurdo. O mais curioso é que ela apresenta esse relato final da execução das performances na forma de um documento intitulado: "Gravação de 13 concertos de peças performáticas". A artista afirma que a maioria das peças são curtas, constituem-se apenas de um título e algumas instruções e descreve em poucas palavras como algumas ações foram experimentadas. Há muitos aspectos desse livro que interessam à presente pesquisa: desde o modo de articular os programas (um exercício quase obsessivo da artista), passando pela experimentação em diferentes linguagens (em especial a ideia de evento), até sua proposição de compartilhamento desses programas com toda e qualquer pessoa. Por hora, gostaria de destacar duas peças igualmente intituladas City Pieces [Peças da Cidade], criadas em 1961 e 1963, e outras intituladas Map Pieces [Peças de Mapa], criadas em 1962 e 1964. Retomarei os outros aspectos do livro mencionados acima ao longo do capítulo.

Antes de passar às ações propriamente ditas, gostaria de ressaltar que a primeira delas, relativa à cidade se encontra na parte do livro dedicada à música, enquanto a segunda, que trata de mapas, se encontra na parte de eventos. De maneira poética, Yoko Ono propõe misturas de linguagens e de modos de fruição, sem preocupar-se excessivamente com os nexos ou com o significado de suas propostas. É interessante notar como os temas se repetem e se modificam, de acordo com a reformulação da instrução e o quanto tais programas são performativos, ainda que inicialmente se configurem como produções literárias.

As City Pieces apresentam diferentes configurações, ao lado de proposições musicais que vão desde peças gravadas (um convite a gravar sons cotidianos), passando por escutar o som do relógio, do sino e do coração, fazer um passeio de bicicleta em silêncio e caminhar atrás de uma pessoa por quatro horas. Da percepção sonora do mundo ao próprio pulso, a autora propõe uma brincadeira de esconde-esconde como quem faz ou ouve música. A primeira peça de cidade, composta no inverno de 1961 resume-se a: "Caminhe por toda a cidade com um carrinho de bebê vazio" (ONO, 2009, p. 55) ${ }^{24}$. Na segunda, do outono de 1963, a artista recomenda que se passe por todos os atoleiros da cidade.

Dentre as Map Pieces, há pelo menos duas versões. Uma delas, datada da primavera de 1964, restringe-se à: "desenhe um mapa para perder-se". A outra, do verão de 1962, é mais

${ }^{24}$ A edição brasileira do livro data de 2009, mas a publicação original é de 1964. 
extensa, mas parte do mesmo princípio que a anterior: desenhar um mapa imaginário e percorrê-lo na cidade real.

\author{
PEÇA DE MAPA \\ Desenhe um mapa imaginário. \\ Marque um ponto no mapa aonde \\ deseja ir. \\ Caminhe em uma rua verdadeira segundo \\ seu mapa. \\ Se não existe rua onde deveria haver \\ Segundo o mapa, faça uma colocando \\ de lado os obstáculos. \\ Quando alcançar a meta, pergunte o nome \\ da cidade e dê flores à primeira \\ pessoa que conhecer. \\ O mapa precisa ser seguido exatamente, \\ ou o evento deverá ser totalmente abandonado. \\ Peça aos amigos que escrevam mapas. \\ Dê mapas aos amigos. (Ibid., p.126)
}

As ações apresentadas a seguir resultam em de-

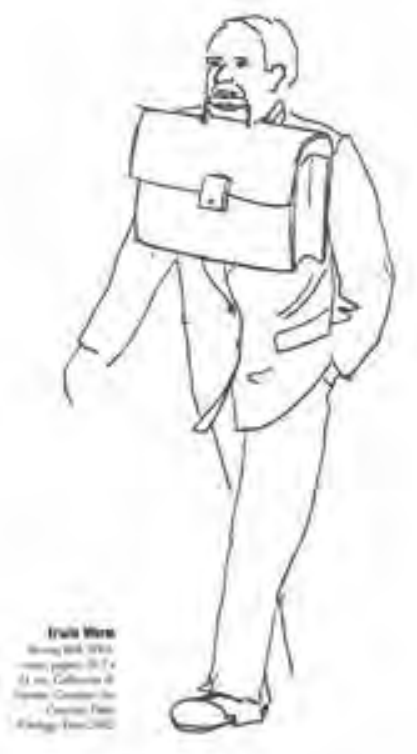

Desenho: DAVILA, 2002, p. 6 senho e têm no papel seu suporte primordial, concretizando-se ora como planos das ações (realizados previamente), ora como vestígios desses deslocamentos. Em Morning walk (2001), Erwim Wurm propõe um programa destinado a uma caminhada profissional e matinal composto por cinco desenhos diferentes, que sugerem cinco roteiros possíveis. Neste caso, o desenho opera como uma prévia da caminhada, pois a descrição do modo de caminhar não parece suficiente ao artista. Assim, o desenho se configura como uma instrução, o esclarecimento de uma iniciativa. $\mathrm{O}$ artista austríaco apresenta em cada um desses esboços de modos de caminhar, um homem de terno (daí a ideia do "profissional") experimentando carregar sua maleta com uma parte inusitada do corpo. Em um dos desenhos, a maleta encontra-se sobre sua cabeça e em outro, ela é carregada pela boca do homem, que ao invés de carregá-la com uma de suas mãos, morde sua alça.

Os Dessins Marchés realizados por Sylvie Cotton em Toronto no Canadá (2003) são fruto da deambulação da artista na companhia de desconhecidos. Durante uma residência artística 
na cidade, a artista propõe uma ação simples e convivial; ela prevê passar no mínimo três horas com uma pessoa encontrada por um artista parceiro pela internet e por anúncios na arte. As seis pessoas que atenderam o chamado de Cotton decidem se passam esse tempo em silêncio ou se a artista teria seus olhos vendados ao longo de todo o encontro. Em seu programa de ação, a cada dia, depois desse período de convivência com pessoas desconhecidas, a artista faz a narrativa do dia por meio de um desenho da trajetória percorrida e de escritas sobre o encontro. No final dessa semana, a artista convida todos os participantes

para verem os desenhos, lerem os textos e trocarem impressões sobre as materialidades produzidas a partir do encontro com cada acompanhante.

Promenade invisible, promovido pela mesma artista, também resulta em desenho dos trajetos percorridos pela cidade (2002). Nessa ação, na qual procura descobrir hábitos e trajetos de passantes, Sylvie Cotton segue pessoas escolhidas ao acaso na rua, durante uma semana. Depois da perseguição, realizada sem que a pessoa perceba, a artista desenha o percurso realizado por ela em busca desse outro. Tal ação foi a primeira dentro da trajetória da artista na qual ela desenha uma performance. Conforme Cotton, tais iniciativas propõem uma (re)descoberta da cidade. Diferente das ações apresentadas dentro da modalidade fugas e perseguições, há aqui a produção de um mapa afetivo e de uma narrativa sobre suas impressões enquanto se desloca pelos caminhos do outro. Nos demais casos analisados, a resultante da perseguição era sempre a fotografia. 


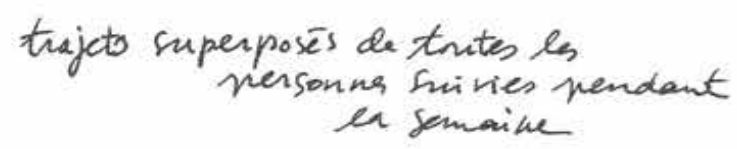

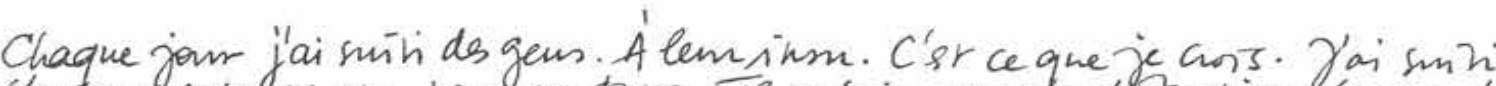
claque persolve un pen, pas trop. Je ne sin pas une défective. (royez la

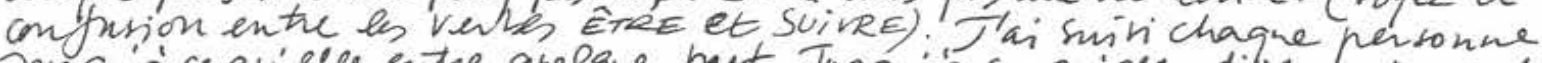
jujgn'à ce quille entre queque put. Jusquià ce quiele dispahaisse et Coin. Apies je dersinars. les gen miont mence cher Jean Contr, ou grichet, duez IGA, an parking ou à la librovirie. Panfois à lem domicile. L' avis. je hai parté à personne. En fait, je ne les ai mesque pas vas. Je venx die tem is sage. Je niai vu que lewi derrière. Des dos, des ungur, des jerres,

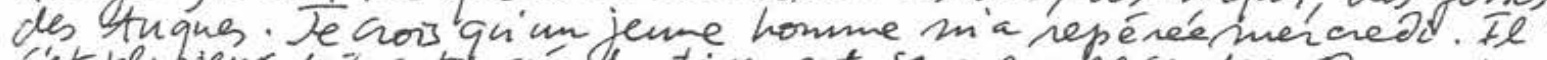
s'st plusiens fois retourné gurtivement saus me he garder. On ne s'st

Figura 16: Silvye Cotton - Promenade invisible

Imagem: Disponível em: <http://www. sylviecotton.ca/projets/b1w-mq2SWr3yF1ab7j_TIN/representations/aqGqKg2SOr3y-

F1ab7j_TIN>. Acesso em: 29 mar. 2017.

\section{> II. quando a performance provoca um efeito de acontecimento}

"Toda vez que eu dou um passo, o mundo sai do lugar"

No dia 30 de outubro de 1938, uma transmissão de rádio da rede CBS (Columbia Broadcasting System), anunciando uma suposta invasão de marcianos na Terra, causou pânico em pelo menos três cidades nos Estados Unidos. O modo como a transmissão foi realizada articulava a linguagem do rádio nos mesmos moldes de um programa jornalístico, como se tratasse de uma "notícia em edição extraordinária". O que ocorria, na verdade, era a difusão de uma peça de radioteatro baseada no livro de ficção científica "A Guerra dos Mundos", do inglês Herbert George Wells de 1897. Quem está por trás da adaptação do romance para a rádio, responsabilizando-se pela direção e pela interpretação do papel de professor da Universidade de Princeton que lidera a resistência à invasão marciana, é o então desco- 
nhecido ator e diretor de cinema Orson Welles. Com 20 e poucos anos, Welles combinou os elementos específicos da rádio novela com os noticiários da época e converteu o relato futurista em realidade ${ }^{25}$.

O programa de apenas 1 hora de duração, transmitido na véspera do Halloween, marcou a história da mídia no século 20, além de tornar Orson Welles mundialmente conhecido. A notícia extraordinária relata a chegada de centenas de marcianos a bordo de naves extraterrestres na cidade de Grover's Mill, no estado de Nova Jersey. Usando a forma de um programa jornalístico, a transmissão conta com reportagens externas, depoimentos de pessoas que vivenciam o acontecimento, entrevistas com peritos e autoridades, além de efeitos sonoros, sons ambientes, gritos e muita emoção da parte de quem narra e comenta a situação. A emissora de rádio calcula que uma média de seis milhões de pessoas sintoniza o programa, sendo que metade o faz após os informes de que se trata da novela de rádio transmitida semanalmente. A criação primorosa de Orson Welles (o $17^{\mathrm{a}}$. programa de um série de adaptações) causa a impressão de uma transmissão ao vivo, levando mais de um milhão de pessoas a acreditar que se trata de um fato real. Há pânico generalizado, sobrecarregando linhas telefônicas, causando congestionamentos e aglomerações de pessoas que tentam fugir da invasão marciana ${ }^{26}$.

O caso metaforiza o poder dos meios de comunicação sendo articulados por pessoas com alto grau de conhecimento. Inicialmente, há a escrita jornalística e bastante atual para sua época do romance de H.G. Wells, em seguida, a adaptação do jovem Orson Welles, que domina brilhantemente a linguagem da rádio novela e, por fim, o laço estreito entre a ficção e a realidade. Nesse momento em que o rádio é o meio mais potente de difusão de informações, os mesmos elementos utilizados na composição de um noticiário são usados na composição de um roteiro de fiç̧ão científica, resultando em desespero nos ouvintes. A linha tênue entre a realidade e a ficção levanta muitos questionamentos que se expandem até os dias de hoje, desde a crença depositada pelas pessoas nos meios de comunicação, que costumam associar a informação à verdade, até o fato de que a História se escreve do mesmo modo que se escreve uma ficção. A História é uma versão dos fatos, contada pelos vencedores e tão marcante e significativa quanto maior o mérito de seu roteirista.

No âmbito dessa pesquisa, o caso da "Guerra dos mundos" introduz a discussão acerca da possibilidade de um acontecimento ser instaurado por uma performance. É recorrente nesse campo, a confusão entre realidade e ficção, seja quando a ação artística inventa algo na esfera do real, seja quando ela se insere no espaço do real e promove debates relacionados ao contexto atual. Francis Alÿs, um dos artistas mais interessantes da contemporaneidade,

\footnotetext{
${ }^{25}$ Ouça um trecho da transmissão: https://pt.wikipedia.org/wiki/A_Guerra_dos_Mundos_(livro).

${ }^{26}$ Mais informações em: <http://www.dw.com/pt-br/1938-p\%C3\%A2nico-ap\%C3\%B3s-transmiss\%C3\%A3ode-guerra-dos-mundos/a-956037>.
} 
não por acaso citado inúmeras vezes nesse trabalho, cria em Tlayacapan, no México, em 1999, uma ação intitulada The Rumour [O Rumor], documentada pelo intermédio de fotografias. Trata-se, grosso modo, do ato de espalhar um boato em uma pequena comunidade do sul do México. Uma pessoa diz algo para alguém, que em seguida repete para uma outra, depois outra, e outra, até que no final do dia, não se fala em outra coisa, sendo que a fonte da notícia terá se perdido ao longo do caminho percorrido pela anedota. A partir desse procedimento simples e altamente difundido não somente em pequenos agrupamentos de pessoas, Alÿs espalha um boato nessa pequena cidade do México, com a ajuda de três habitantes locais.

A notícia, que reúne realidade e ficção, consiste na história de "uma pessoa que teria deixado o hotel na véspera para caminhar e não teria retornado" (GODFREY et al., 2010, p.89) ${ }^{27}$. A anedota se espalha rapidamente graças à imaginação popular e, aos poucos, esse personagem fictício adquire identidade: uma fisionomia, um sexo e uma idade relativamente fixos, bem como uma história para explicar seu desaparecimento. Prova disso é que três dias após a disseminação do boato, a polícia local divulga um retrato falado da pessoa desaparecida, dando corpo ao personagem dessa fiç̧ão secreta. The Rumour explora a dinâmica dos circuitos sociais ativados pela fofoca, ressaltando assim o interesse do artista pela produção de mitos pelas comunidades, o que seria, para ele, um elemento bastante significativo de coesão social (Ibid.).

Tal ação resulta na criação de um efeito de acontecimento. Mais do que comprovar os laços estreitos entre fiç̧ão e realidade e explicar esta última como uma versão ficcional dos fatos, interessa aqui destacar o papel do artista como inventor de supostos acontecimentos. Yoko Ono também propôs em seu livro de instruções e desenhos, uma ação similar a um boato, na qual opera no estreito limiar entre vida e morte. A artista joga com o fato de ser uma figura pública e anuncia a própria morte a cada mudança de endereço, desafiando os meios de comunicação como os grandes articuladores da história oficial.

\author{
PEÇA DE AVISO I \\ Faça anúncios fúnebres cada vez que se \\ mudar, em vez de anunciar a \\ mudança de endereço. \\ Envie o mesmo anúncio quando morrer.
}

Verão de 1962

PEÇA AVISO II

Anuncie mudança de endereço cada vez

que morrer.

Verão de 1963 (ONO, 1964, p.123)

\footnotetext{
${ }_{27}$ "une personne qui aurait quitté l'hôtel la veille pour aller marcher mais ne serait pas revenue" (tradução minha).
} 
Erika Fischer- Lichte dedica todo um capítulo de seu livro "Ästhetik des Performativen" [Estética do Performativo ${ }^{28}$ para discutir a realização cênica como acontecimento, decorrente do desmantelamento da oposição entre arte e realidade. Conforme a autora, tal desmantelamento teria acarretado o fim de outras oposições, tais como o estético e o social e o estético e o político, observado por ela na análise de inúmeras ações performativas recentes. A autora afirma que tanto os performers quanto os espectadores encontram-se em um limiar, mesmo quando estes últimos oscilam entre o status de espectador e participante. Nessas performances, o espectador é colocado em uma situação de crise, uma vez que ele não pode recorrer aos padrões de comportamento de que tem conhecimento.

A autora fala em laço ou espiral de retroalimentação autopoiético [bucle de retroalimentación autopoiético] para tratar dos problemas ocasionados pela transformação do cidadão em espectador, quando a distinção entre realidade e ficção não está clara, quando não é nítida a transição entre o mundo cotidiano e a realização cênica, quando não se nota a clivagem entre o meio habitual e o plano da ação artística. Nesse contexto, a performance passa de evento artístico a evento social, do qual pode-se mais uma vez apreender o desdobramento político e pedagógico. Se consideramos que o processo de conhecimento se dá de maneira cíclica, entre a ação e a experiência, podemos afirmar que o espectador continua reagindo aos estímulos da ação performativa, mesmo depois de seu encerramento.

\begin{abstract}
A experiência estética não se produz somente a partir de acontecimentos excepcionais, mas também a partir da percepção do ordinário. Tenho insistido com diversos argumentos em que durante as realizações cênicas se têm experiências que coincidem em alguns aspectos com as vivências cotidianas do espectador, apesar de tais experiências estarem à margem do discurso oficial; tenho insistido que nelas se percebem corpos, ações, movimentos, objetos, sons e odores cotidianos que ao mesmo tempo aparecem como extraordinários, como transfigurados; tenho insistido que o singular das realizações cênicas é precisamente sua capacidade de converter o ordinário em chamativo [...]. Quando o cotidiano se converte em extraordinário, as dicotomias se desmoronam e as coisas se transformam em seu oposto, o espectador experimenta então a realidade como "encantada". É este encantamento o que o coloca em um estado de liminaridade que pode transformá-lo (FISCHER-LICHTE, 2011, p. 356-357) ${ }^{29}$.
\end{abstract}

\footnotetext{
${ }_{28}$ Tive acesso a tal publicação por intermédio da tradução espanhola, datada de 2011.

29 La experiencia estética no se produce solamente a partir de acontecimientos excepcionales, sino también a partir de la percepción de lo ordinario. He insistido con diversos argumentos en que durante las realizaciones escénicas se tienen experiencias que coinciden en algunos aspectos con vivencias cotidianas del espectador, a pesar de que tales experiencias están al margen del discurso oficial; he insistido en que en ellas se perciben cuerpos, acciones, movimientos, objetos, sonidos y olores cotidianos que al mismo tiempo aparecen como extraordinarios, como transfigurados; he insistido en que lo singular de las realizaciones escénicas es precisamente su capacidad de convertir lo ordinario en llamativo [...]. Cuando lo cotidiano se convierte en extraordinario, las dicotomías se desmoronan y las cosas se transforman en su opuesto, el espectador experimenta entonces la realidad como "encantada". Es este encantamiento el que lo pone en un estado de liminaridad que puede transformarlo (tradução minha).
} 
Para articular esse ideia de realização cênica como acontecimento, a autora alemã se vale da noção de liminaridade, segundo a acepção de Victor Turner, que por sua vez, se volta aos rituais para delinear esse conceito. A liminaridade é um espaço-tempo de suspensão, de afastamento dos procedimentos convencionais da ação social e por isso as situações consideradas liminares são capazes de criar communitas. Ou seja, um sentimento intenso de comunidade capaz de eliminar as barreiras que separam os indivíduos participantes de um ritual. A liminaridade tem uma função purificadora e pedagógica por instaurar um período de mudanças, estando associada à realização de uma experiência e à prática da inversão ou suspensão do tempo comum. llena Diéguez Caballero, que também se utiliza desses conceitos de Turner, afirma que "as instâncias liminares, concebidas como situações intersticiais, constituem espaços potenciais nos quais são tecidas estetizações da política e politizações do artístico" (CABALLERO, 2011, p. 188, grifo da autora). Ela afirma a seguir que "nos acontecimentos liminares que fundam communitas são colocadas em prática - consciente ou não - as estratégias situacionistas" (Ibid.).

Ao retomar as estratégias (ou táticas, considerando o ponto de vista de Certeau) situacionistas, Caballero ressalta a intersecção entre realidade e ficção e a quebra do estatuto entre quem realiza e quem vê uma ação artística. Desse modo, os artistas não se colocam como representantes de "grandes verdades", eles tornam visíveis as estruturas sociais que já incluem, por exemplo, representações de poder, divisão de grupos de acordo com a condição social, além de revelar outras desigualdades, como as de gênero e etnia. Se tomarmos como referência os fluxos de pessoas no espaço público, rapidamente observaremos diversas camadas de representação: os que se deslocam em transportes públicos e os que se deslocam em transportes particulares, os que se deslocam em veículos motorizados e os quem vão a pé, os mais velozes e os mais lentos, além daqueles que se deslocam nos espaços intersticiais (entre os carros e os ônibus, seja para ganhar velocidade munidos de motocicletas, seja para fazer circular as mercadorias que são vendidas para os passageiros dos carros nos sinais). Podemos observar ainda os adultos e as crianças, os jovens e os velhos, os homens e as mulheres, os habitantes da cidade e os policiais, os executivos e os vendedores ambulantes e muitas outras categorias de atores sociais. É interessante destacar como a cidade não para, nem se esvazia, para que as ações artísticas aconteçam. Imersos nos espaços públicos, os artistas convivem e dialogam com convenções sociais e legais, com relações de poder, além de experimentarem outros regimes de atenção. Eles ainda investigam outras densidades de presença e vivem sob outras condições sanitárias, históricas e emocionais.

Retomando a proposição de Fischer-Lichte na qual reconhece a realização cênica como acontecimento e tendo em vista as questões expostas anteriormente, pergunto-me se realmente podemos afirmar que intervenções e performances urbanas podem ser 
consideradas acontecimentos. Recorro a um exemplo de algo que ocorreu em plena Avenida do Estado, na ocasião em que me preparava pra realizar uma deriva com o Coletivo Teatro Dodecafônico. Uma mulher se joga no rio Tamanduateí, na corrente de água limitada pelo concreto. Ela passa um tempo observando o rio, depois pula a mureta que separa o rio da passagem dos carros e, em seguida, entrega seu corpo para as águas fétidas do rio. Caminha e se deixa levar por ele, carregando um livro nas mãos, talvez uma bíblia. Ao longo de sua ação, muitas pessoas se mobilizam e a cidade ao redor daquele nódulo, daquela ilha de desordem, começa a parar. Coincidentemente ou não, ela resolve realizar sua ação em frente a um dos prédios da guarda municipal. Eles são os primeiros a socorrer a mulher, tentando dissuadi-la de tal feito. Sem resposta e depois da primeira corda perdida para o rio, outras instâncias são acionadas: os bombeiros, a polícia e a CET (Companhia de Engenharia de Tráfego). Aos poucos, nosso ponto de encontro se enche de curiosos, de carros e um grande congestionamento se forma, enquanto a mulher já fora da água, permanece altiva, sentada em uma brecha de sol onde ainda é possível se esquentar de seu banho-acontecimento.

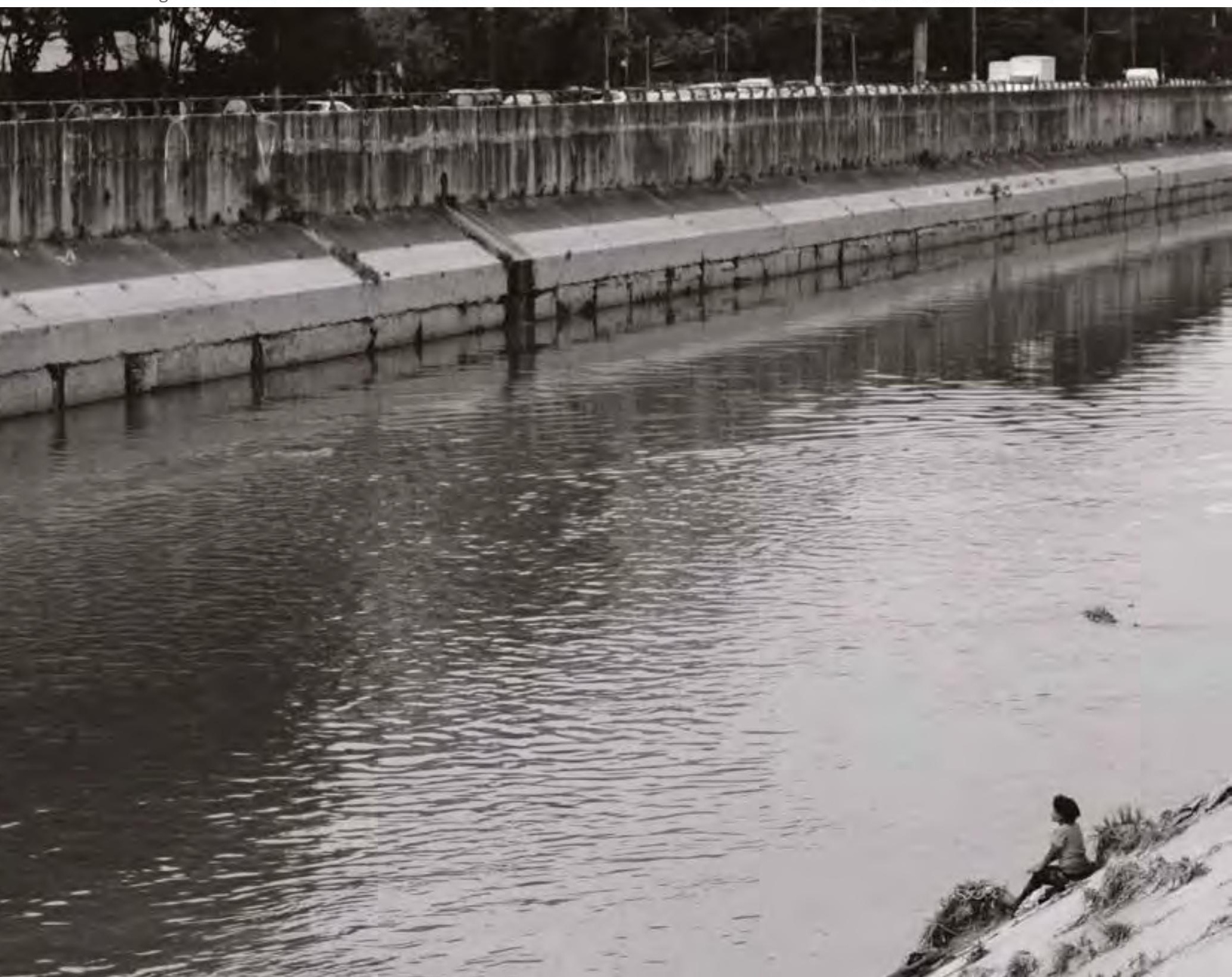


Muito provavelmente essa mulher não tem a menor ideia dos efeitos gerados por sua ação, nem o quanto eu me ocupo de pensar em sua imagem ao contemplar o rio no qual acabou de se banhar, nem o quanto a cidade para ao seu redor. Como se estranhamente, São Paulo se curvasse para sua habitante menos relevante. Esse exemplo é para mim o retrato de um acontecimento, que segundo Vladimir Safatle, em entrevista concedida a Maria Rita Kehl, é evento complexo, rico, naquilo que produz, seja na forma de surpresa poética, seja na forma de catástrofe. Segundo o filósofo, um acontecimento é equivalente ao trágico na vida política, por isso, tudo o que tentamos fazer é que um acontecimento não ocorra. Ele afirma que criamos mundos onde acontecimentos são completamente impossíveis e complementa: "não que eles não ocorram, mas porque desenvolvemos toda uma capacidade de não percebê-los ou só percebê-los como catástrofes iminentes". A partir da contribuição de Safatle, podemos constatar que a ação dessa mulher tem um aspecto trágico; inúmeros são os motivos que poderiam levá-la a provocar tal acontecimento e todos eles remetem às terríveis condições de vida que muito provavelmente ela leva. Essa mulher, portanto, é o retrato do rio, seu espelhamento; ela manifesta no seu próprio corpo a condição das águas para as quais se entregou. Não se trata de uma jovem da classe média, nem de uma dona de casa; trata-se de uma mulher-bruta, uma mulher-bicho, uma mulher-criatura sem perspectivas, tentando se salvar pelo contato com a água e o repouso ao sol. Um retorno desesperado para uma natureza que já não há mais.

Diante dessa visão que a cidade de São Paulo me proporcionou, não acredito que a arte possa criar acontecimentos. Nada que seja programado, que tenha o mínimo de representação pode se comparar ao gesto dessa mulher. $O$ que talvez responda a essa questão sobre a capacidade da performance de criar um efeito de acontecimento é, ao meu ver, a noção de situação construída proposta por Debord e os Situacionistas. Nesse caso, fica nítida a proposição de algo que não tem a ver com o impossível, com o imponderável, com o inesperado. Uma situação construída é uma ação programada - leia-se: um programa de ação, um protocolo, uma instrução sobre algo que deve ocorrer como sobreposição ao que já acontece na cidade. É provável que uma situação construída não pare uma cidade e que ela possa, inclusive, não ser percebida, a não ser pelas pessoas que a realizam. Um acontecimento é, como disse Safatle, algo do qual nos protegemos, que preferimos que não aconteça e que nos preparamos a cada dia para não perceber.

Por outro lado, podemos afirmar que, ao espectador atento, aquele que por um motivo ou outro, percebe que algo incomum e fora da norma está se produzindo, uma intervenção ou performance urbana será sempre um acontecimento. Em oposição a essa noção, Roman Ondák propôs um 'não-acontecimento', no meio de um espaço de exposição intitulado Teaching to walk [Ensinando a andar]. Uma moça chega com seu filho de 18 meses e permanece no espaço de exposição, ensinando seu filho a andar. Ela ocupa esse espaço todos 
os dias. Só perceberá que se trata de uma ação quem frequentar a exposição e notar que todos os dias essa moça se encontra lá, brincando com seu filho real e ensinando-o a andar.

Apresento, por fim, uma ação realizada pelo Coletivo Teatro Dodecafônico, intitulada Responda Sim ou Não $(2014)^{30}$, na qual duas mulheres caminham pela rua com pequenas caixas de som conectadas a microfones, fazendo perguntas sobre a posição da mulher na sociedade contemporânea, suas possibilidades de trabalho e suas relações com a cidade. Ao que uma terceira mulher responde sim ou não. Aos poucos, uma delas começa a direcionar as perguntas para os passantes que também são convidados a responder sim ou não. A ação foi inspirada em uma cena do filme One plus one, no qual Jean-Luc Godard mescla imagens da gravação da música Sympathy for the Devil, dos Rollings Stones, com cenas disjuntas relacionadas a temáticas políticas. Revelando o processo de trabalho do grupo, Godard desconstrói o mito do gênio criador e apresenta - na cena que serviu de inspiração - uma equipe de filmagem seguindo um jornalista que entrevista uma moça desimportante. O papel atribuído a moça desimportante é extremamente significativo para a instauração do jogo no espaço público. É ela quem revela o dispositivo e possibilita que os passantes sejam incluídos no jogo.

Em certa medida, o jogo causa um efeito de acontecimento, pois propõe um debate público a respeito das desigualdades de gênero. Toda proposição se realiza em deambulação, com pequenas pausas para fazer perguntas a pessoas que eventualmente não estejam em deslocamento pela cidade, como por exemplo frequentadores e vendedores de bares, lanchonetes e lojas, fixas ou ambulantes. O caminhar constante, típico do errante nômade, muito praticado pelos moradores das grandes cidades, combina com o questionamentos como: "Estou no caminho certo?"; "Você gosta de andar sozinha na rua?"; "Já passou por aqui antes?". Outra característica do jogo de Godard, destacada pelo Dodecafônico, é o enunciado constantemente repetido "responda sim ou não", toda vez que o entrevistado tenta explicar sua resposta. Cabe a tal regra a função de instauração de um debate, que inevitavelmente se desenvolve na medida em que a performance atravessa o contexto urbano. Como nem sempre as respostas mais adequadas a essas perguntas se resumem a sim ou não, o jogo infiltra em certos agrupamentos de pedestres o desejo de discutir a temática proposta. Frequentemente, sobretudo quando tocamos em assuntos políticos, as perguntas despertam muitas respostas, inclusive de pessoas para as quais as perguntas não foram endereçadas.

No atual contexto político do Brasil, perguntar se a pessoa votaria em uma mulher para Presidente da República pode gerar muitas polêmicas. Quando uma mulher responde não,

\footnotetext{
${ }^{30}$ De início, a ação foi realizada no centro de São Paulo, depois na Parada LGBT de Buenos Aires (2014) e no SESC Santana (2016), além de ter sido integrada à intervenção urbana Atos íntimos contra o embrutecimento, no SESC Bauru (2014), no Festival Danza Fuera em de La Plata, na Argentina (2014), na Virada Cultural da cidade de São Paulo (2015) e no Centro, na Avenida Paulista e no bairro do Bixiga com o apoio do Prêmio Funarte Artes de Rua (2015).
} 
No caso dessa ação, os dispositivos usados são caixa de som e microfone, além das perguntas que também podem ser consideradas dispositivos. No entanto, eles estão confusamente distribuídos, de modo a causar um estranhamento nos pedestres. Se por um lado o passante se sente importante por alguém querer saber sua opinião, por outro, o dispositivo microfone não é dado a ele; é a voz de quem pergunta que é amplificada. Suas respostas não são anotadas, não vão integrar nenhuma base de dados, nem contribuirão para nada externo àquele encontro. Assim sendo, responder sim ou não só serve para colocar em estado de reflexão a pessoa que responde ou aquelas que eventualmente escutam a pergunta e aguardam a resposta que um(a) passante dará. Numa escala um pouco maior, a voz amplificada da entrevistadora espalha perguntas pelo ar, poluindo o ambiente sonoro da cidade de questionamentos, de dúvidas e incertezas. No fundo nenhuma pergunta é tão óbvia, nem responder se é homem ou mulher; nenhuma pergunta tem apenas uma resposta possível, homens e mulheres são iguais, sim e não. O conjunto de perguntas transita entre as esferas social e íntima, questionando sobre os espaços do trabalho, sobre a liberdade de ir e vir e os espaços de lazer, passando pelas práticas desenvolvidas por cada um(a) e a abertura para se discutir sobre os prazeres sexuais. Tal ação tem revelado que a sexualidade feminina é inversamente proporcional à sexualização de seu corpo. Por mais que se invista insistentemente na aparência sexualizada da mulher, raramente é dado a ela o direito de falar sobre o que lhe dá prazer, e assuntos como a masturbação continuam sendo um tabu para a mulher, sobretudo no espaço público.

\section{>> III. quando a performance se desdobra e, depois, se multiplica}

Observando os desdobramentos em outras materialidades decorrentes da prática da performance, ressaltamos até aqui a importância desses rastros ou vestígios das ações para o estudo e a pesquisa nesse campo do conhecimento. Os materiais provenientes dessas práticas, sejam fotografias, vídeos ou textos, possibilitam uma prática muito difundida pedagogicamente nessa área: a re-performance. Sem o acesso a essa documentação visual e audiovisual, dificilmente algumas ações seriam retomadas e o ensino e o estudo da performance teriam tomado outros rumos. A fecundidade dessa produção, sua rápida difusão por meio da internet e a facilitação do acesso por parte dos artistas a esses materiais faz com que muitas ações sejam re-performadas. Desse modo, nenhum jovem performer concluirá sua formação sem ter experimentado pelo menos um programa de ação formulado por um artista tomado por ele como referência.

A questão da repetição é recorrente quando o assunto é performance. Richard Schechner fala em comportamento restaurado e Josette Féral afirma que a repetição é uma ideia-cha- 
ve do conceito de performatividade. Esses autores reforçam a produção de performance como um segundo olhar, como se fosse impossível fazer performance sem incluir de algum modo a repetição: seja pelo comportamento restaurado ou repetido em outro contexto, diferente do cotidiano; seja a repetição da performance de outro artista; seja a proposição de ações cuja repetição não só é autorizada, como recomendada.

Tanto Schechner quanto Féral se valem dos estudos de J. L. Austin sobre o ato performativo no campo da Lingüística. Os estudos de Austin sobre o performativo são precursores nessa área, porém se restringem às palavras que ao invés de dizer, fazem algo. Exemplo disso é a expressão: "Eu os declaro marido e mulher", pronunciada em uma cerimônia, que possui valor performativo, pois define, modifica um status quo, e portanto, age (FÉRAL, 2009, p. 67). Austin denomina tais verbos de performativos, conceito retomado por John R. Searle, na teoria dos atos da fala. Ambos restringem a utilização do termo aos atos de enunciação. É Jacques Derrida quem inicialmente questiona a aplicabilidade do performativo estritamente às situações relacionadas à fala. Ele afirma que freqüentemente as ações evocadas em enunciados performativos fracassam, ou seja, podem ou não ser eficazes; mesmo quando se trata de uma ação em si, ela pode não atingir seu objetivo e fracassar. Assim, Derrida retira a performatividade da restrição ao campo da Lingüística e a transforma em ferramenta teórica transferível para outras áreas, podendo atribuí-la a qualquer processo de escritura.

\footnotetext{
A partir disso, é fácil afirmar que a performatividade acompanha necessariamente o surgimento de significados múltiplos e que ela oscila entre o reconhecimento e a ambigüidade dos significados. Ela aparece como sinônimo de fluidez, instabilidade, abertura do campo de possibilidades, lá onde a teatralidade teria a ver com signos. Ela seria aquilo que permite fazer escapar numa obra as fragilidades do pensamento linear e unívoco moderno. Ela vai ao encontro do "um" para fazer emergir o "plural". Aberta e instável, a escrita é, portanto, performativa. Ela é multissignificante e, portanto, decodificável. Porque se ela é código, bem estabelecido em sistema e reprodutível certamente ao infinito, o significado desses códigos, ao contrário, bem como sua composição, não é um, mas são plurais (FÉRAL in MOSTAÇO et al, 2009, p. 73-74).
}

Por esse motivo, todo o tipo de repetição que possa ocorrer em performance será bem-vinda, pois a cada circunstância que um programa é refeito, ele tem a oportunidade de ser revisto e ressignificado. No terreno movediço e plural do performativo, há uma tendência ao fragmento, à montagem em forma de colagem, ao invés de uma composição centrada no binômio causa e efeito. No performativo, a repetição aparece como uma figura de estilo. No contexto teatral, a repetição também aparece como ensaio e preparação para o encontro com o público. No contexto da performance não há ensaios, no entanto, a repetição ainda persiste. Ela está presente mesmo em um programa de ações realizado pela primeira vez, pois tudo o que possa ser feito já foi realizado, de uma forma ou de outra, no âmbito da 
vida; trata-se sempre de segunda vez. "A performance em termos de comportamento restaurado significa que nunca foi realizada pela primeira vez, mas sempre pela segunda vez e pela enésima vez: um comportamento repetido" (SCHECHNER, 2003, p. 29).

Para a prática da re-performance, a documentação é uma ferramenta indispensável. Em alguns casos, é o artista que convida outras pessoas, do meio artístico ou não, para refazerem suas ações. Em outros, os programas circulam e pessoas desconhecidas, mesmo sem autorização, refazem a performance de alguém e ainda há casos em que é o próprio artista que as refaz. Este é o caso de Yoko Ono, que em 2003, refez sua performance Cut Piece, realizada anteriormente na década de 1960. A artista optou por re-performá-la em um pequeno teatro parisiense como protesto contra a guerra do Iraque.

\footnotetext{
Re-performance pode nos ajudar a ver como a história desempenha um papel na arte da performance na medida em que atinge os fundamentos da performance desafiando o que costumava ser considerado o valor central desse suporte: sua dependência do encontro autêntico entre artista e público. Se quisermos fazer justiça ao modo pelo qual a arte da performance tem sido re-performada, precisamos reconsiderar seus fundamentos como forma de arte cuja vida não se encerra simplesmente com sua ocorrência, mas que nos permite voltar ao evento, para pensar e discutir sobre ele - em suma, para re-imaginá-lo pelo exercício de sua memória (WIDRICH, 2014, p. 13-14). ${ }^{31}$
}

Yoko Ono foi pioneira nesse entendimento de que a performance não se encerra em sua execução e do quanto sua vida depende da utilização de outros suportes, de outras linguagens artísticas. Como podemos perceber em uma das muitas instruções publicadas no já comentado livro Grapefruit: “PINTURA PARA EXISTIR SOMENTE QUANDO COPIADA OU FOTOGRAFADA. Deixe que as Pessoas copiem ou fotografem suas pinturas. Destrua os originais. Primavera de 1964" (ONO, 1964, p. 84). Nesse programa, a artista deixa claro também sua intenção de compartilhar sua arte, sem preocupar-se excessivamente com a questão da autoria. Prova disso é que a última instrução de seu livro é: "Favor queimar este livro depois de ler. Y.O." (ibid., p.325). É interessante notar o ponto de vista de Ono em um momento em que os artistas estavam bastante preocupados em deixar sua marca. Na parte de seu livro na qual se dedica aos filmes, ela declara que "estas informações foram impressas e colocas à disposição de quem estava interessado, no momento ou posteriormente, em fazer suas próprias versões dos filmes, desde que esses filmes, por sua natureza, somente se tornem realidade quando forem repetidos e realizados por outros cineastas" (Ibid., p. 212).

${ }_{31}$ Re-performance can help us see how history plays a role in performance art as such, for it strikes at the foundations of performance by challenging what used to be considered the core value of the medium: its dependence on the 'authentic' encounter between artist and audience. If we want to do justice to performance art as it is being re-performed, we need to reconsider this foundations as an art form the life of which does not simply 'end' with its taking place, but one which allows us belatedly to refer back to this event, to think and argue about it - in short to re-imagine it by exercising one's memory (tradução minha). 
Yoko Ono convida toda e qualquer pessoa que tenha interesse para realizar suas ações, incluindo também a filmagem de seus roteiros de cinema. O livro em sua integridade é dedicado para a exploração do leitor, que não deve apenas lê-lo, mas praticá-lo. Dessa forma, o livro será mais bem sucedido à medida em que mais pessoas experimentarem, ainda que secretamente, essas ações sugeridas em seus cotidianos.

\begin{abstract}
Assim o happening, a body art, a performance, frutos da idade do gesto autorizado pela fotografia, comprometem como ela a noção de original. Esta última qualidade, certamente paradoxal, que Rosalind Krauss define como específica da fotografia volta à "desconstruir o sistema do modelo e da cópia, e do original e do falso, da primeira cópia e da segunda". (DELPEUX, 2010, p.17) ${ }^{32}$.
\end{abstract}

Como uma mulher à frente de seu tempo, Ono agia no mundo como se a internet já existisse e podemos dizer que ela antecipou uma prática que ficou conhecida no mundo pós-internet como flash mob. Em uma de suas instruções, ela pede ao leitor que mande uma libra para o FESTIVAL DE DANÇA FAÇA-VOCÊ-MESMO, que teria a duração de 13 dias. "[...] com a sua libra, durante 13 dias, você irá receber um cartão diário com instruções de dança marcando a hora para fazer a performance daquela peça, então todos iremos fazer a performance ao mesmo tempo" (Ibid., p.227). É evidente que nos dias de hoje, uma proposta como esta seria bem mais facilmente desenvolvida pelo intermédio da internet, no entanto, a artista já propunha ações extremamente participativas usando o meio que tinha a seu dispor: o correio. Ela complementa a instrução acima, dizendo que as pessoas que não tiverem uma libra para enviar, podem enviar o equivalente em flores e 13 selos.

Nos Performance Studies, que discutem inclusive o comportamento humano, a repetição se dá na rotina e no treinamento para quase tudo o que se pretende fazer. A repetição é o

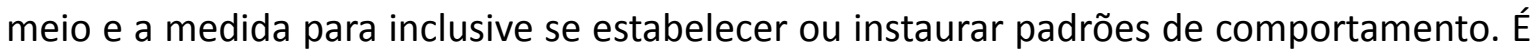
repetindo que se aprende desde criança as ações mais simples relacionadas à sobrevivência e também às convenções sociais e às tradições. "As performances - artísticas, rituais ou da vida ordinária - são feitas de comportamentos duplamente agidos, comportamentos restaurados, ações performadas que as pessoas treinam para executar, que praticam e ensaiam" (SCHECHNER, 2003, p. 22). A repetição é uma figura de estilo associada às ideias de citação ou paródia e que também faz pensar na ideia de plágio suscitada por Guy Debord. Em seus estudos sobre o performativo, Derrida recorre a dois conceitos complementares para responder às ideias de Austin: a iterabilidade e a citacionalidade.

Derivada do sânscrito itara, "outro", a iterabilidade é a propriedade do signo de

\footnotetext{
${ }^{32}$ Ainsi le happening, le body art, la performance, fruits de l'âge du geste autorisé par la photographie, compromettent comme elle la notion d'original. Cette dernière qualité, certes paradoxale, que Rosalind Krauss définit comme spécifique à la photographie revient à "déconstruire le systhème du modele et de la copie, de l'original et du faux, de la première copie et de la seconde" (tradução minha).
} 
ser sempre outro na sua mesmidade, a repetição na alteração; a citacionalidade é a propriedade do signo de ser retirado do seu contexto "original" e deslocado para outro, produzindo por isso mesmo, significado. Derrida argumenta que tais propriedades não são eventuais ou acidentais, mas constitutivas dos signos, portanto, dos atos de fala, e, delas, os atos retiram sua força (PINTO, 2013, p.36).

Nesse sentido, a iterabilidade está presente quando o próprio artista refaz sua performance, em outro espaço-tempo. Ou seja, cada vez que o artista reperforma seu programa de ação, ela fica diferente, embora o programa permaneça o mesmo. A citacionalidade, por sua vez, está presente quando qualquer pessoa refaz a performance proposta por um outro. Ou seja, ao ser deslocado do seu contexto original, um determinado signo produzirá outro significado. Se pensarmos nos documentos decorrentes da performance, também podemos utilizar esses dois conceitos.

Em seu artigo sobre os H.I.J.O.S, as mães e as avós da Plaza de Mayo (aos quais nos dedicamos no capítulo anterior), Diana Taylor examina "várias iterações de performances de protesto que incluem a fotografia e que aconteceram nos últimos 25 anos" (TAYLOR, 2013, p. 237). Para ela, esta é uma estratégia que revela tanto a continuação quanto a transformação de materiais culturais. Fotografia e exame de DND, nesse contexto, tem a mesma função de identificação de pessoas desaparecidas. Entre as mães, as fotografias davam identidade aos desaparecidos, num gesto de denúncia, que carecia de um documento comprobatório. No caso dos hijos, quem geralmente os procura são suas avós, pois aqueles cujos pais morreram e foram adotados por famílias de militares, podem ser identificados por elas por intermédio da fotografia. Esta última é a versão rudimentar daquilo que o exame de DNA é capaz de garantir atualmente.

O interessante disso tudo é perceber que a repetição e a iteração são recursos muito eficazes no contexto da performance. O uso da fotografia, a repetição dessa mesma materialidade, tem um papel importante tanto na identidade do DNA dessas performances (conforme Taylor), quanto no rastreamento de laços de parentesco que envolvem as pessoas desaparecidas. Desse modo, esses materiais passam a se constituir como ferramentas políticas, capazes de interferir diretamente na vida de pessoas reais. "Os movimentos pelos direitos humanos por toda a América Latina, no Oriente Médio, na Antiga União Soviética e em outras áreas começaram a carregar fotografias de seus desaparecidos" (TAYLOR, 2013, p. 245). Isso prova o quanto os repertórios são passíveis de serem "memetizados" e que esses desdobramentos mantêm as iniciativas das performances vivas. Tratam-se de modos de apropriar-se simbolicamente de materialidades que estão disponíveis no mundo real para agir na esfera da ficção, numa época em que essas duas instâncias - o real e o ficcional - já não se configuram como dicotomias. Ao contrário, são infiltrações capazes de promover ações concretas no contexto real, ainda que numa escala pequena e ao alcance das comunidades em torno das quais a ação se apresenta. 
Quando se fala em desdobramento de ações performáticas, em muitos dos casos citados acima, evoca-se a participação dos espectadores, ou melhor, trata-se de uma arte se constitui como "espetáculo sem espectador", nas palavras de Claire Bishop. Em suma, a autora problematiza a questão da participação, desassociando-a do coletivismo e afirmando que a arte participativa - aquela que em sua expressão mais restrita suprime o espectador, transformando-o em produtor da ação - não se configura necessariamente como arte ativista ou socialmente engajada. Ao contrário, de acordo com Bishop, "a participação não tem um alinhamento político determinado: trata-se de uma estratégia que pode ser igualmente associada ao fascismo italiano, ao comunismo bolchevique e à negação anárquica da política" (2016, s.p.). Para ela, em cada um desses momentos históricos a arte participativa assume uma forma diferente, sendo que depois de 1989, frente a uma ausência de alternativas de esquerda, a participação se aproxima mais do capitalismo neoliberal, mesmo que os artistas pretendam se posicionar contra ele.

Essa nova proximidade entre espetáculo e participação, ao meu ver, ressalta a necessidade de manter uma tensão entre as críticas artística e social. Os projetos mais contundentes que compõem a história da arte participativa destituem todas as polaridades nas quais esse discurso é fundado (individual/coletivo, autor/ espectador, ativo/passivo, vida real/arte), mas não com o objetivo de fazê-los desabar. Ao fazer isso, eles mantêm tensionadas as críticas artística e social (Ibid.).

Vale lembrar que em 1968, participar correspondia a ser livre ; ser participante era o contrário de ser consumidor. A mudança de perspectiva em relação à participação, no entanto, não a deslegitima, apenas coloca ressalvas para o modo como ela se realiza e o contexto no qual ela acontece. A participação por si só não é garantia de posicionamento político a favor do bem comum, do investimento no espaço público, de diminuição das desigualdades sociais e de direitos iguais para todos. Claire Bishop afirma, desse modo, que a arte, caso queira atingir alguma mudança social, deve conduzir a outras instituições, pois "não basta continuar produzindo arte ativista". Por esse motivo, as interfaces entre arte e social, arte e educação, arte e vida não devem ser "reconciliados ou derrubados" (como diz Bishop), mas mantidos em tensão contínua.

A arte participativa não é um meio político privilegiado, tampouco uma solução ready-made para uma sociedade do espetáculo, mas algo tão incerto e precário quanto a própria democracia; nenhuma delas é legitimada de antemão, mas precisam ser performadas e testadas continuamente em cada contexto específico (Ibid.).

Algumas ações artísticas observadas nesta pesquisa, no entanto, parecem abrir espaços no pensamento, pois propõem visões de um mundo por vir ou dão a ver o que oficialmente não se tem visto. Elas subvertem os usos dos aparatos urbanos e convidam à fruição de uma experiência de corpo presente. Ao colocar o corpo em movimento, implicando-o 
diretamente na ação, elas deslocam pontos de vista e partilham tempo de vida. Segundo Bishop, a arte que usa as pessoas como meio comunica "os paradoxos que são reprimidos no discurso cotidiano, além de extrair experiências perversas, perturbadoras e agradáveis que ampliam nossa capacidade de imaginar o mundo e nossas relações de uma nova maneira" (Ibid.). Exemplo disso é a ação proposta pelo grupo chileno CADA, na qual uma pessoa podia encontrar um folheto caindo do céu anunciando que "Cada homem que trabalha para a ampliação, ainda que seja mental, de seus espaços de vida, é um artista". Essa ação - atirar folhetos de seis aviões pequenos - foi realizada em plena ditadura militar no Chile, enquanto Pinochet controlava o céu das cidades. (TAYLOR, 2012, p. 45).

Numa proposição que restaura comportamentos, o projeto Where we come from [De onde nós viemos], de Emily Jacir realizado entre 2001 e 2003 consiste numa série de idas e vindas entre Estados Unidos e Palestina. Aproveitando sua dupla cidadania, a artista pergunta aos seus compatriotas que já não vivem na Palestina, exilados no Líbano, na Síria, na Europa e nos Estados Unidos: "se eu pudesse fazer algo por vocês, em qualquer lugar na Palestina, o que seria"? Emily Jacir realiza o pedido de cada palestino que responde à sua pergunta e registra todas as suas ações em fotografias sem grande acabamento artístico, mas de grande valor político. Cada fotografia é acompanhada de um texto em inglês e em árabe explicando o pedido e o que impedia que a pessoa realizasse seu desejo ela mesma. A maioria das limitações se deviam a problemas com passaportes e com fronteiras que não podiam atravessar.

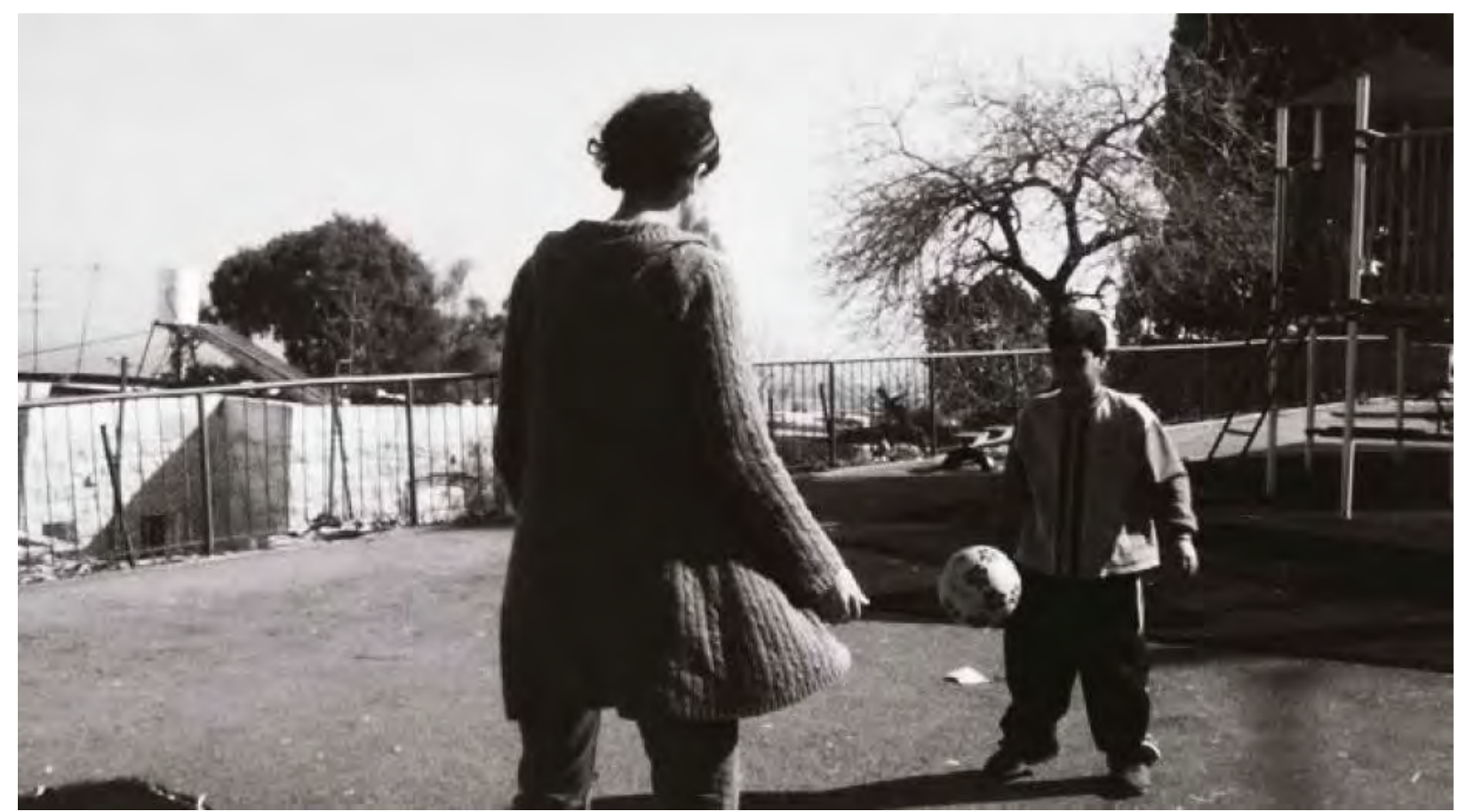

Figura 19: Emily Jacir - Where we come from

Foto: Disponível em: <http://herbalpertawards.org/ sites/default/files/styles/930x516/public/img_ej-11. jpg?itok=eiWfAPjm>. Acesso em: 29 mar. 2017. 
Uma garota pede a Jacir para ir a Haifa e jogar futebol com o primeiro garoto palestino que ela encontrasse na rua. Um homem pede que ela visite o túmulo de sua mãe em Jerusalém, no dia que seria o aniversário dela. Trata-se de uma ação relacional, que coloca em jogo a expansão do corpo da artista. A performer cria um jogo que torna possível o empréstimo do seu corpo para viver o desejo do outro. Jacir não apenas vive situações no lugar do outro, pelo outro, ela dá uma lição de alteridade em tempos áridos, nos quais imperam os individualismos e o reforço das desigualdades sociais, de gênero e de etnia. Diante da impossibilidade de realizar ações tão simples, nesse caso, não são as palavras, mas o gesto que fala em nome de muitas pessoas afastadas de seu país de origem.

A produção dessas materialidades se configura como um desdobramento igualmente político e pedagógico, uma vez que a rua se torna um laboratório de experimentação de outras cidades possíveis. Vale destacar que tais ações colocam a cidade no protagonismo da discussão e investem no ato de caminhar como solução possível para a mobilidade urbana. De maneira direta e simples, elas comprovam que é possível caminhar na cidade, inclusive longas distâncias, independente do gênero, como prática social contra a cultura do medo. Há nessa ocupação da rua um gesto irreverente e uma transformação da cidade em território caminhável. Elas revelam um paradigma no uso da cidade, a associação do carro ao deslocamento urbano e, ao mesmo tempo, apresentam o ato de caminhar como uma solução urbana. Isso não acontece na forma de discurso, não se trata de uma bandeira, de um acionismo, mas de uma experimentação empírica. Ocupar a cidade pelo chão, como pedestre, é essencial para a diminuição de câmeras de vigilância, de guaritas, de muros e portões. Todos esses demarcadores de territórios impedem a livre circulação e esvaziam a rua com o pretexto de que ela é o espaço do perigo. Contrariamente a esse ponto de vista, tais ações adotam o espaço público como o lugar da liberdade, da representatividade e da discussão política. Por mais utópica que essa perspectiva pareça, ao se exporem em deslocamento pelas ruas, essas ações revelam seu potencial político-pedagógico, seu potencial de ofertar outras alternativas, outros pontos de vista, outros modos de vida. 
>>> >> 398 


\title{
caminhar no contexto urbano: um ato de transgressão
}

\author{
Andar e pensar um pouco, \\ que só sei pensar andando. \\ Três passos, e minhas pernas \\ já estão pensando. \\ Aonde vão dar estes passos? \\ Acima, abaixo? \\ Além? Ou acaso \\ se desfazem ao mínimo vento \\ sem deixar nenhum rastro? \\ Paulo Leminski
}

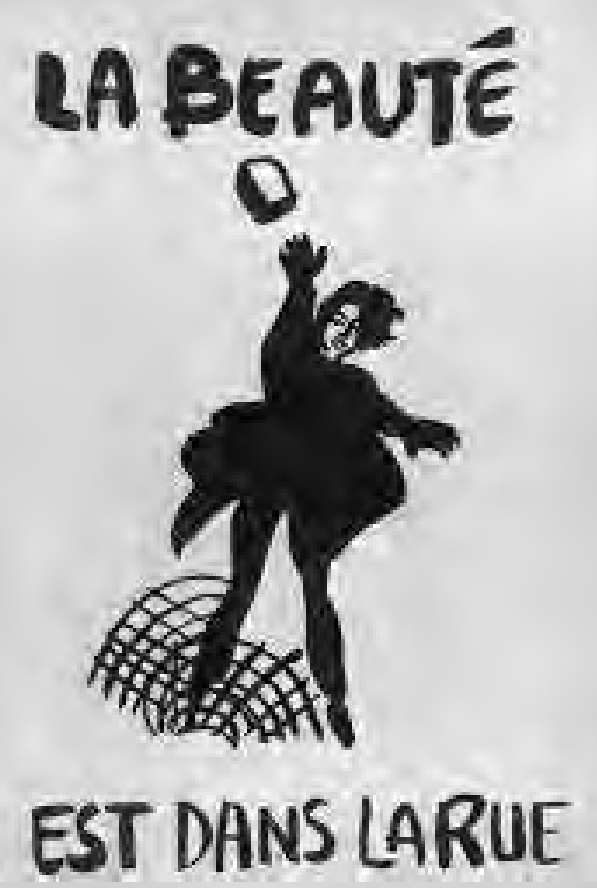

Foto: Disponível em: <http://kurtoglu. deviantart.com/art/La-Beaute-est-dans-laRue-86565308>. Acesso em: 15 mar. 2017
Um passo depois do outro. Não raro, em minha condição de sentada, percebo como os meus pés estão acomodados enquanto escrevo e mudo minhas pernas de posição, como se quisesse acionar os meus pensamentos, mesmo sem caminhar. Minhas pernas teimam em permanecer cruzadas, como se os pés lado a lado não colaborassem para o fluxo de pensamento que escorre do meu corpo/mente, passa pelas minhas mãos e aciona as teclas do computador. Em muitos momentos, escrevi com ambas as pernas cruzadas sobre a cadeira. Em minha casa, coloquei uma pilha de livros grossos no chão, sobre os quais apoio os meus pés e assim consigo permanecer mais tempo com a coluna ereta e os pés paralelos.

Um passo depois do outro não sintetiza o ato de caminhar, pois não se trata de uma alternância mecânica das pernas. Trata-se de uma transferência de peso, de uma negociação nem sempre doce, nem sempre amigável, nem sempre fácil, entre corpo e chão. Ao empurrar o chão, ele nos empurra de volta, devolvendo ao corpo a mesma energia empregada a cada passo. Esse mesmo movimento que aciona o chão deve acionar também as partículas do pensamento, agenciando fluxos de ideias e propondo outras maneiras de enxergar uma mesma questão. Durante todo o tempo desta pesquisa, frequentando experiências deambulatórias, estudando ações de artistas que caminham e propondo derivas e travessias, caminhar tornou-se necessário e urgente em minha vida. 


\section{I. pequeno ato íntimo contra o embrutecimento}

Tornei-me pedestre por opção - ciente de que para a maioria das pessoas não se trata de uma opção - por associar o ato de andar às minhas melhores sensações de liberdade, de autonomia e de experiência compartilhada. Caminhar com as próprias pernas é uma expressão reveladora desse sentimento. Não se trata da descoberta de uma vocação, nem da salvação de uma vida, mas das possibilidades de reinvenção de uma vida. Caminhar mantém vivo o espírito de descobertas, de investigação, de conquista. Caminhar é uma transgressão no contexto atual da cidade onde vivo. Caminhar é resposta à velocidade, à pressa, ao "time is money", à mercantilização da vida. Caminhar encurta as distâncias entre o meu corpo e a minha cidade. Caminhar me expõe no espaço público; é minha demarcação sutil de território; é corpo de mulher no exercício do sem pudores, do sem medos, do vamos juntas ${ }^{1}$. Caminhar é um ato íntimo contra o embrutecimento.

\footnotetext{
Tomei gosto pelo caminhar e hoje ainda não caminho tanto quanto gostaria. Sou mulher, mãe e moro longe de todos os iugares que frequento cotidianamente. Tomo o metrô com frequência e aproveito caronas para poder caminhar, sempre que possivel. Minha condição de mulher muitas vezes me impede de caminhar. Minha condição de mãe também, embora minha filha peça para fazer trajetos a pé. Atualmente, nós duas caminhamos juntas duas manhãs por semana até para suas aulas de natação. Ela se cansa de ficar dentro do carro $e$, infelizmente, é esse o meio de transporte mais usado por ela em seus seis anos de vida. Na sua história, serei eu a introduzir a caminhada em sua vida.
}

Passei a observar de que modo as pessoas que conheço e os artistas que admiro se relacionam com o caminhar. Muitas foram as minhas surpresas ao notar revelações como a que se segue. Questionada por um jornalista sobre como se prepara para enfrentar o público, a cantora e performer Patti Smith respondeu: "perambulo por uma ou duas horas pela rua" (SOLNIT, 2002, p. 249). Para ela, o caminhar é preparatório, é treinamento para o encontro, é aquecimento para a exposição de si, é uma ação meditativa e ritual. Rebecca Solnit afirma que caminhar é ao mesmo tempo o princípio - caminha-se como opção de vida e como ponto de partida para instaurar um acontecimento; o fim - a própria finalidade da caminhada e o meio através do qual se cria, se inscreve na cidade e se relaciona com o espaço e as pessoas encontradas no caminho (Ibid, p. 14).

Não há teoria sobre o caminhar, somente uma consciência do caminhar. Mas pode haver uma certa sabedoria que acompanha o ato de caminhar. Trata-se sobretudo de uma atitude, e essa atitude me convém muito bem. É um estado no qual pode-se estar totalmente atento a tudo o que se passa em nossa visão

\footnotetext{
${ }_{1}^{1}$ Menção à campanha lançada recentemente na internet incentivando a sororidade - uma aliança feminista, que visa o agrupamento de mulheres com o objetivo de fortalecê-las. Quando uma mulher caminha sozinha pela rua e sente em perigo, por qualquer motivo que seja, e ela encontra outra mulher, uma se dirige à outra, perguntando: "vamos juntas?". Assim, as mulheres se protegem, se tornam bando e lutam contra a cultura do medo, que tende a encarcerar os sujeitos do sexo feminino nos espaços internos da casa.
} 
periférica e a tudo o que se ouve e ao mesmo tempo estar perdido nos próprios pensamentos. (ALYS in BIESENBACH e STARKE, 2010, p. 37) $)^{2}$

O trecho acima faz parte de um artigo organizado por dois pesquisadores sobre as ações criadas e realizadas por Francis Alÿs. Trata-se de uma compilação de escritos de diferentes autores usados para ilustrar o trabalho desse artista, conhecido por suas deambulações em diferentes lugares do mundo. Nesse artigo, os autores reúnem pequenos fragmentos textuais a partir de cada letra do alfabeto e o trecho citado acima corresponde à letra $\mathrm{M}$ e se refere à palavra "marche" ["caminhada", em francês]. Durante todo o processo de escrita dessa tese, realizado com minhas pernas paradas, devido à minha posição de pesquisadora sentada, recorri às escritas anteriores ou posteriores aos meus deslocamentos pela cidade. E estou certa de que boa parte das conclusões e reflexões reunidas aqui se construíram enquanto meu corpo estava em movimento. Outras partes pareciam fluir mais dinamicamente após uma pausa, na qual saída para um lanche, ou para uma pequena volta pela biblioteca.

Conforme Alÿs, "a caminhada proporciona um estado de consciência produtiva. Na era do digital é também um dos últimos espaços privados" (Ibid.). É curioso como o artista associa a prática do caminhar ao espaço privado, ainda que seu deslocamento se dê na esfera pública. O alerta do artista é para o fato de que, ao caminhar, podemos estar finalmente sozinhos com nossos pensamentos, sem estar necessariamente conectados quase cem por cento do tempo em rede.

\section{II. um pequeno desvio e os assuntos convergem: a cidade e os seus espaços públicos}

Há alguns meses, no curso de um deslocamento pela cidade ouço na rádio o professor GuiIherme Wisnik discutindo sobre pokemon go: o jogo considerado a febre do momento, por colocar em diálogo o mundo virtual dos aplicativos de celulares e o mundo real da cidade, que se transforma em campo de caça dos personagens do jogo. O professor explica que na década de 1990, o teórico francês Paul Virilio faz uma previsão bastante pessimista sobre os usos do espaço público a partir do advento da internet. Segundo Virilio, a tendência é que esse espaço desapareça, uma vez que a internet possibilita que as pessoas se comuniquem à distância, encomendem produtos e trabalhem de suas casas, diminuindo as necessidades de deslocamento. Sem ser transitada pelas pessoas, a cidade estaria em vias de desapa-

\footnotetext{
2 II n'y a pas de théorie de la marche, juste une conscience de la marche. Mais il peut y avoir une certaine sagesse qui accompagne l'acte de marcher. II s'agit plutôt d'une attitude, et c'est une attitude qui me convient très bien. C'est un état dans lequel on peut être à la fois tout à fait attentif à tout ce qui se passe dans notre vision périphérique et à tout ce que l'on entend et en même temps être tout à fait perdu dans ses propres pensées (tradução minha).
} 
recer. Muito recentemente, esse jogo de videogame tomou as ruas das principais cidades do mundo, contrariando essa previsão de que a internet manteria cada vez mais pessoas dentro de casa.

O que o pokemon go propõe é a saída de uma massa significativa de jovens - mas também de adultos - dos espaços virtuais, ou mais precisamente dos espaços privados, em direção aos espaços públicos. Trata-se de uma ocupação zumbi, composta por corpos que apenas parecem presentes, pois estão alienados ou super-alienados, tão desconectados que estão de si próprios. Esses corpos que passam a ocupar as regiões mais nobres da cidade real - é na Avenida Paulista onde se encontra a maior concentração de pokemons de São Paulo, por exemplo - têm uma percepção torpe do entorno, pois o que os atrai são seres invisíveis a olho nu. Isso é estar alienado, encontrar-se tão ligado a um outro que chega-se a se perder de si mesmo. Nesse ponto, o professor pergunta aos ouvintes algo do tipo: podemos realmente afirmar que haja um desaparecimento do espaço público diante não apenas da invasão desses jogadores, mas tendo em vista outros usos que se faz atualmente desse espaço comum? E ele completa, citando uma longa lista de atividades que passaram a ser praticadas recentemente na cidade: ações lúdicas, manifestações, passeios de bicicleta, frequentação de parques e avenidas fechadas para carros e abertas somente a pedestres.

É certo que muitas das tentativas de manifestar opiniões e valores políticos têm sido sistematicamente minadas pela polícia violenta do Estado de São Paulo. Entre pokebolas, pokemons e bombas de gás, pode-se constatar que o espaço público e urbano está mais vivo do que nunca. É nele que desfilam os modos de vida, as diferenças sociais, os efeitos das políticas públicas e dos modos de funcionamento de um país. Sendo assim, o simples fato dessa massa de sentados passar a circular, ainda que precariamente, pela cidade, caminhando com as próprias pernas, encontrando pessoas reais, tomando sol e correndo riscos, já seria motivo suficiente para se observar uma (re)ativação do espaço público. Desse modo, nem eu, nem o professor citado, gostaríamos de afirmar que esse espaço precise ser ativado; ao contrário, a invasão do espaço público pelo jogo virtual denota que esse espaço ferve, que é lá que a vida acontece e que visionários japoneses descobriram uma maneira de não deixar os pokelovers fora do real espaço da aventura. A rua incendeia e é ela quem me faz entender que faz sentido permanecer aqui sentada, a escrever no branco da biblioteca, pois meus dedos e meu corpo sentado trabalham para reverenciá-la.

Dito de outro modo, parece útil (e não funcional) que se investigue de que maneiras essas (re)ativações lúdicas do espaço público contribuem para alterar o uso desses espaços. Ou ainda, invocam vozes e expressões de uma população que estava aparentemente fechada nos seus espaços privados para ocupar a cidade como último reduto de discussão política não mediatizada. Se os meios de comunicação e difusão de informação são partidários e parciais, se a internet está em toda parte e não concentra mais os indivíduos em espaços 
fechados, a rua aparece como saída para o debate e o embate. Resta saber se o poder público e os mecanismos de controle do Estado estão adequadamente preparados para multidões de seres pensantes que podem ocupar cada vez mais insistentemente a cidade. Assim esperamos ${ }^{3}$.

Diante da realidade atroz, a luta que se trava não é contra seres invisíveis presos nos espaços virtuais; a luta se organiza concretamente, nas ruas, com trincheiras compostas por sacos de lixo montadas contra tropas de choque reais (Penso no início das manifestações pelo Passe Livre em 2013). Os pokemons aparecem, nesse contexto, como preocupação ingênua dentre as experiências possíveis a serem exploradas no espaço urbano. 0 jogo pode ser encarado como um mero passeio entre o real e o virtual. No entanto, vale a pena lembrar a célebre frase de Heiner Müller, evocada aqui no capítulo dois: "A rebelião começa como um passeio". Então, deixemos as massas zumbis ocuparem o espaço público e esperemos para ver o que de concreto acontece. O tipo de experiência detonada nesse contexto está mais próxima de uma travessia de um campo de batalha, no qual as gentes comuns são solicitadas a inventar táticas de sobrevivência para combater estratégias de guerra.

\section{> III. sobre o espectador e o potencial pedagógico presente nas ações teatrais e performa- tivas}

Ao longo da tese muito se discutiu sobre a questão do espectador e seu estatuto dentro da performance e da cena teatral contemporânea. Se em uma acepção mais convencional do teatro, o espectador sabe como deve se comportar, por já ter sido disciplinado para isso, nas modalidades cênicas deambulatórias que ocupam o espaço público, o corpo do espectador passa a ser interpelado de outras formas ${ }^{4}$. No primeiro caso, de modo geral, há

\footnotetext{
3 Poucos meses depois de escrever esse relato, podemos notar que as ações do atual prefeito de São Paulo - João Dória, eleito no primeiro turno das eleições - a partir de janeiro de 2017, foi de apagar não apenas simbólica, mas efetivamente, grafites que deram à cidade o título de uma das três capitais mais importantes em termos de arte urbana no mundo. $O$ atual prefeito decidiu arbitrariamente pintar os muros de São Paulo de cinza. Curiosamente, são nos grafites da cidade que se encontram boa parte dos personagens do jogo pokemon go. Tudo isso pode parecer uma imensa coincidência, mas apenas denota o quanto o espaço público é um espaço de visibilidade, no qual tanto as táticas artísticas e cidadãs, quanto as estratégias políticas emergem como demarcações de territórios. Como resposta à ação do prefeito, laco Viana, um grafiteiro de 34 anos, escreveu o nome "Dória" sobre uma longa faixa de grafites cobertos pela tinta cinza. No protesto, o artista incitava o prefeito a apagar o próprio nome, como forma simbólica de apagar-se a si mesmo, destruindo seu ego. Ao que Dória respondeu, enviando o DEIC (Departamento de Investigações Criminais da polícia) na casa de laco, convocando-o para depor e tentando enquadrá-lo por associação criminosa.

${ }^{4}$ É importante reforçar que não me refiro ao tradicional teatro de rua, pois nesse caso há convenções muito bem estabelecidas, como por exemplo: o chamamento do público anunciando que uma apresentação está prestes a acontecer, a configuração de um círculo em torno do qual os espectadores se organizam, o uso de instrumentos musicais, de técnicas circenses, acrobacias e todo tipo de verticalização dos corpos dos atores.
} 
cadeiras para acomodar o público dentro de um edifício teatral, onde todos devem permanecer em silêncio. No segundo, o espectador precisa se deixar levar até entender o que cabe a ele, onde deverá se posicionar, em que momentos deverá caminhar e como se dará sua interação com a peça. Isso não significa que não haja exceções dentro dos edifícios teatrais, pois cada vez mais os artistas têm explorado outros paradigmas para a relação que se estabelece com o público. O desconforto do espectador diante da cena teatral, no entanto, é contemporâneo das dissoluções dos estatutos teatrais apontados no primeiro capítulo. Conforme Silvia Fernandes, é justamente a indefinição de seu estatuto epistemológico uma das características mais marcantes da cena contemporânea, que, segundo a pesquisadora, passa por uma "crise de identidade" (2011, p.11).

Ao analisar o conceito do teatro prós-dramático em relação à pedagogia teatral, Maria Lúcia Pupo fala da sensação difusa experimentada pelo espectador e o quanto essa cena requisitará dele outra atitude para ampliar e diversificar sua capacidade de leitura.

\footnotetext{
Emerge da natureza dessa cena a necessidade de um estado de espírito inteiramente repensado por parte do espectador. Uma mudança de atitude radical vem a ser solicitada; sua abertura para engendrar liames a partir de uma percepção fragmentada torna-se central. Sentado ou em movimento, em situação de repouso ou sujeito a algum tipo de risco, o espectador é convidado a tecer elos e a configurar relações. Sua intuição e sua imaginação são convocados de modo a preencher as inúmeras lacunas configuradas pelo acontecimento que se desdobra diante de seus sentidos. (PUPO in GUINSBURG e FERNANDES, 2009, p. 225).
}

Vejo nessa solicitação do espectador para se posicionar, não apenas fisicamente, mas como decodificador de um jogo ou criador de elos e enlaces entre os elementos dispostos em cada situação, um potencial pedagógico. Ou seja, o fato da experiência artística colocar o espectador em situação, expondo-o a algo diferente daquilo a que está acostumado, cria uma condição de aprendizagem. Caso o espectador se recuse a tal condição, ele não reconhecerá as pistas capazes de localizá-lo, nem os dispositivos de jogo dos quais dispõe para participar dessa experiência. O potencial pedagógico não deve ser confundido com a explicação da obra, nem tampouco com a ideia de que uma criação artística deve ter uma mensagem a ser decifrada. Não se trata, porém, de algo simples de ser reconhecido, nem explicado, pois há casos em que esse potencial pedagógico existe independentemente do desejo do artista, e muitas vezes, sem que ele tenha consciência disso.

Desse modo, o aspecto pedagógico não está colado à figura do artista, assim como o espectador não se associa ao aprendiz. Trata-se de um processo pedagógico para todos os envolvidos, pois o que o artista promove é uma experimentação de formas organizacionais e relacionais, em contextos que são tanto artísticos, quanto sociais e políticos. É a exploração de "modelos de sociabilidade" - tal qual teoriza Nicolas Bourriaud ao discutir a estética relacional - sem que regras ou normas sejam necessariamente enunciadas. Refiro-me a 
uma prática que ensina e não à dimensão pedagógica relacionada à figura de uma pessoa. Penso em educação como exploração de organizações sociais em oposição a um modo de agir natural. Portanto, não se trata de discutir a recepção da obra, mas de verificar o espaço, a função e as ações atribuídas ao espectador nessas modalidades cênicas.

Quanto mais performáticas são as ações analisadas, mais dissolvida aparece a figura do espectador. Isso ocorre em grande parte das performances analisadas: o público se constitui de espectadores casuais, que se deixam atravessar por uma ação, sem saber inicialmente como distingui-la da esfera do real. Desse modo, em um primeiro momento, o espectador identifica uma camada de invenção no tecido do real, para, em seguida, decifrar o modo operatório da ação. São diversos os casos nos quais o encontro entre espectador e ação acontece apenas virtualmente, sendo que a maioria dos passantes (que seriam espectadores potenciais) não se dá conta de que algo fora do comum acontece e se mantém desinformada sobre aquela situação (termo usado por P. Auslander). Tratam-se de encontros tão efêmeros e pautados por situações tão precárias, que suscitam um tipo de estranhamento nos passantes, sem que tal visão gere algum tipo de reflexão além de um espanto inicial. Do ponto de vista desse passante desinformado, muitas performances se confundem com acontecimentos cotidianos. Desse modo, os vestígios deixados pelas ações, assim como o compartilhamento de seus programas, são peças-chave para a aproximação do espectador dessas modalidades artísticas, contribuindo ainda para o aprofundamento das discussões e reflexões suscitas pela ação. Por esse motivo, é possível constatar que tais ações não se encerram no ato mesmo de sua execução.

Francis Alÿs afirma em seu verbete sobre o caminhar que esta "não é uma técnica, é uma atitude. Caminhar é um meio muito imediato e muito cômodo de interagir e, eventualmente, de interferir em um contexto dado" (ALYS in BIESENBACH e STARKE, 2010, p. 37) $)^{5}$. Assim, tanto para o artista quanto para o espectador, o ato de caminhar se torna algo concreto a fazer, algo que coloca a todos em pé de igualdade, de movimento, de fluxo, para interagir e interferir em dado contexto. Caminhar quebra barreiras, localiza e potencializa o espectador diante do desconhecido. Eleonora Fabião, ao se referir ao espectador de performances afirma que essa operação se resume a uma presença compartilhada, capaz de fundar o que ela nomeia de dramaturgia do espectador.

[...] a performance funda uma cena com características muito particulares uma vez que propõe a realização de ações não-fictícias em tempo "real". Ou ainda, a performance distende a ideia de "cena" propriamente dita: do drama do palco passamos ao drama da sala, da rua, da cidade. [...] É determinante o fato de que o decréscimo ficcional, ilusionista e narrativo implica num acréscimo de presença e participação do espectador. 0 espectador torna-se um elemento fundamental na trama performativa, um agente direto ou indireto, uma testemunha, ou, por

5 La marche n'est pas une technique, c'est une attitude. Marcher c'est un moyen très immédiat et très commode d'interagir et, éventuellement, d'interférer dans un contexte donné (tradução minha). 
vezes, um co-autor da ação proposta pelo performer (FABIÃO in TELLES e FLORENTINO, 2009, pp. 69-70, grifo da autora).

Segundo a autora, a performance convoca o espectador para se posicionar, no aqui e agora e também inspira o teatro a investigar outras maneiras de ativar o público. Nos casos analisados nesta tese, todas as ações, sem distinções entre teatro e performance, tinham em comum o fato de ativarem a mobilidade do espectador. Partimos de exemplos nos quais os espectadores são andarilhos e o ato de andar se torna o elemento detonador de interações do espectador com os artistas, com a cidade e com os demais passantes. É nessa "cena" portadora de ficção, ilusão e narratividade diminutas que identifico um desdobramento pedagógico. É da ausência de elementos como enredo, personagem e ficção - desse contexto instável e desconfortável para o espectador que é a performance - que nasce a necessidade do artista de colocar-se como presença, como sujeito, como corpo, na produção de conhecimentos e de invenções.

É certo que se trata de um problema comumente discutido e enfrentando pela área da mediação cultural, das atividades realizadas pelos monitores das exposições e de toda sorte de procedimentos pedagógicos desenvolvidos para a aproximação do espectador da arte contemporânea. Não nego as vastas possibilidades presentes nessa área, porém minha intenção com este estudo foi observar o "modo de usar" embutido na ação, de maneira mais ou menos explícita. A implicação pedagógica (e às vezes política) possibilita mudanças de paradigmas no uso que o espectador faz da arte, impedindo que a criação se torne um ambiente hermético, intransitável e reservado à fruição exclusiva do artista. Isso nos leva a concluir que não basta o decréscimo ficcional, ilusionista e narrativo para que o espectador se torne presente e participativo. $O$ espectador pode se abrir e o modo de operação proposto não gerar um espaço de troca. Nesses casos, a criação não se completa e o intuito da arte de mobilizar e fortalecer imaginários não se concretiza.

Isso também não significa que se trate de uma incumbência exclusiva dos artistas, ela se refere a todas as pessoas que se interessam e que interagem com a arte, de professores a espectadores, de cidadãos quaisquer e dos críticos de arte, de famílias ao apresentar práticas artísticas aos seus filhos. Cabe às demais pessoas envolvidas na ação artística a identificação dos dispositivos apresentados na ação ou decorrentes dela. Ou seja, o espectador também pode ele mesmo inventar dispositivos para se relacionar com a criação e subverter ou apropriar-se de iniciativas disponibilizadas pelos artistas. Por exemplo, o simples fato do artista divulgar o programa da performance já é uma forma de se aproximar do seu processo de criação, o que nos leva a concluir que o "modo de usar" uma criação artística estará sempre implícito no seu "modo de fazer".

Explico-me: há casos nos quais a ação performática faz-se invisível aos olhos da cidade. É o 
que ocorre em muitos exemplos de passeios, derivas, perseguições e travessias analisados respectivamente nos capítulos dois, três e cinco. Neles, o espectador terá acesso à ação posteriormente, pela internet, por meio de pelo menos duas vias: documentos audiovisuais produzidos em decorrência da ação e seus respectivos programas. Assim que o espectador tem acesso ao programa da performance e percebe que para realizar tal ação ele não precisa dispor de nenhum conhecimento específico ou qualidade especial, reconhece que ele também pode se aventurar na execução de determinada ação. Isso é nítido nos casos das ações analisadas na modalidade percursos, pois toda e qualquer pessoa dispõe de itinerários próprios e pode optar por lidar com eles de maneira poética. Notamos assim a diluição do imperativo do talento e a expansão da atividade artística para todos. Assim, a arte se torna verdadeiramente revolucionária, pois amplia as possibilidades de movimento e de criação de mundo, pelo exercício comum do imaginário.

Quando notamos nesses exemplos dos capítulos mencionados acima que o desdobramento pedagógico da ação se desloca para as outras materialidades produzidas em decorrência de uma ação primeira não espetacularizada, não ficcional e sem outros elementos de mediação (portanto, altamente confundidas com a esfera da vida), a ideia de arte precisa ser reconfigurada. As fotografias, os vídeos, os relatos e os desenhos produzidos a partir da ação, bem como seu programa, passam a ser facilmente apropriados e reperformados. Dessa forma, o espectador não tem acesso apenas a um produto artístico, mas a todo um dossiê sobre a ação artística, um vasto material de estudo sobre ela; é o processo que passa a ser compartilhado. Ao saber que Laurent Malone e Denis Adams atravessaram Nova York a pé fotografando a cidade objetiva e subjetivamente, propus-me a atravessar Paris a pé com meu companheiro, em seus dois eixos axiais. Essa travessia amorosa me fez lembrar da travessia complementar que Marina Abramovic e Ulay fizeram ao se despedirem de anos de relacionamento sobre as Muralhas da China. Quando Beatriz Cruz soube que Eleonora Fabião "conversava sobre qualquer assunto", ela se propôs no quadro da Ocupação Mulheres, Performance e Gênero ${ }^{6}$ a conversar, num banco de praça, sobre ser mulher. E o mais curioso é constatar que Papá Fraga criou seu Caracol (ação em que rasteja pela rua vagarosamente como um molusco) sem conhecer as ações de rastejamento de William Pope L. Do mesmo modo, Natalia Coehl propôs-se a andar de quatro, sendo levada para passear puxada por uma coleira, sem saber que há quarenta anos atrás VALIE EXPORT levava seu companheiro pela coleira, também de quatro, pelas ruas frias de Viena.

O que pretendo afirmar com isso, é que o programa de uma performance é suficientemente simples não somente para ser reperformado e apropriado, como para ser idealizado, de maneiras muito similares, por pessoas de contextos diferentes. Isso se deve ao fato de

\footnotetext{
6 Ocupação de 16 horas realizada a partir de uma residência artística proposta pelos Coletivos Teatro Dodecafônico e Rubro Obsceno, com a colaboração de Andrea Caruso, na Oficina Cultural Oswald de Andrade, entre março e abril de 2016.
} 
que uma performance será sempre um comportamento restaurado, na acepção de Richard Schechner. Não se trata de um texto ou de uma proposta de encenação cuja complexidade impede sua reprodução sem que pensemos em plágio. Observar a simplicidade de um programa de performance não implica considerá-lo pejorativamente como algo simplório. Acontece que o programa é uma iniciativa da qual depende o modo pelo qual uma ação será executada e também o modo pelo qual ela será documentada e narrada. Não por acaso Fabião afirma que a extinção da ficção não implica necessariamente na extinção das narrativas.

\section{> IV. entre a superação da arte e o que queremos, contemporaneamente, que a arte seja}

Todo movimento anti-arte abre inevitavelmente um novo capítulo dentro da História da Arte. Theodor Adorno

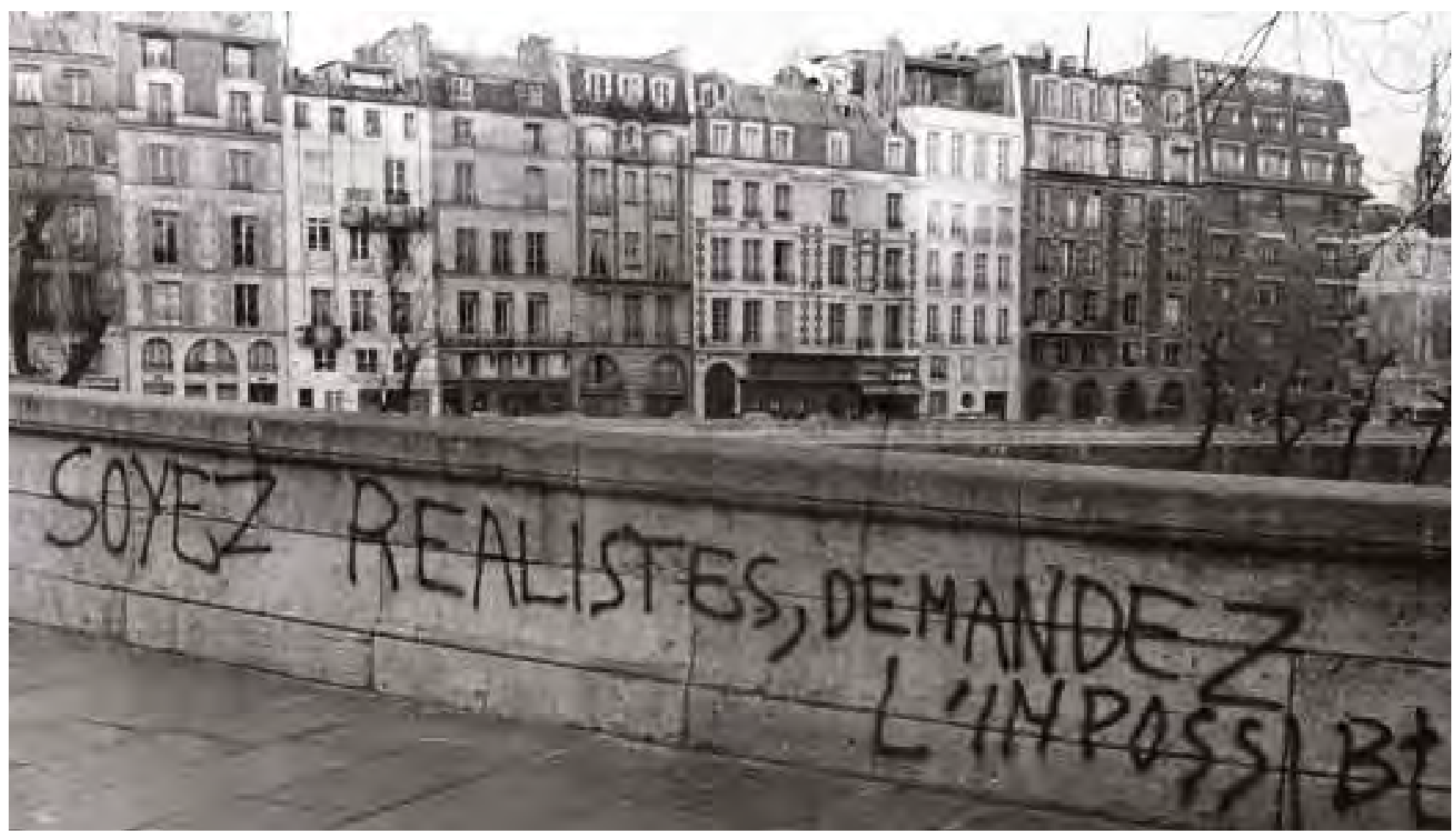

Figura 2: Slogan maio 1968

Foto: Disponível em: <http://www.gettyimages.pt/evento/gammaweekly-bucket-481105319\#slogan-be-realistic-ask-for-the-impossible-inparis-france-on-may-3-picture-id480831863>. Acesso em: 15 mar. 2017

Pelo menos desde as vanguardas artísticas do início do século XX, passando pelo Movimento Situacionista, que culminou nas manifestações e ocupações estudantis realizadas em Maio de 1968 em Paris, discute-se a superação da arte. Para Claire Bishop esses dois momentos históricos, associados à queda do muro de Berlim em 1989, contextualizam retornos ao social dentro da história da arte contemporânea. Esses momentos são frequente- 
mente acompanhados por reflexões utópicas acerca da arte e suas relações, em particular seu potencial político, reconsiderando-se os modos pelos quais a arte é produzida, consumida e debatida (BISHOP, 2012). Se tomarmos como exemplo alguns slogans de Maio de 1968, notamos ideais utópicos que reivindicam a aproximação entre desejo e realidade, que convocam os cidadãos a sonhar com transformações que julgam impossíveis e que propõem o fim da arte em benefício do usufruto da vida cotidiana. "Je prends mes désirs pour la réalité car je crois en la réalité de mes désirs" [Tomo meus desejos pela realidade, pois creio na realidade dos meus desejos], "Soyez réalistes, demandez l'impossible" [Sejam realistas, exijam o impossível] - figura 2 - e L'art est mort, libérons notre vie quotidienne [A arte está morta, liberemos nossa vida cotidiana].

Ao problematizar a arte e sua função no âmbito da presente pesquisa, muitos assuntos emergem, tais como: a arte como representação, a irrupção do real na arte e a participação. Nas ações analisadas nesse estudo não há uma intenção de representar a realidade, mas de invocar e acessar o real. Os espaços institucionais convencionalmente associados à arte foram substituídos pela rua. Artistas e espectadores são na maioria dos casos colocados em pé de igualdade por adotarem todos a mesma atividade pedestre: a caminhada. Muitas dessas ações se configuram de maneira invisível ao olho do passante, sendo que em alguns casos, o espectador é convidado a agir, acionando ele mesmo os dispositivos organizados pelo artista. Não podemos dizer que nesses casos, o real se apresente como irrupção (como diria Maryvonne Saison), pois ele não invade, nem perfura o tecido da ficção. A situação que se constrói, a partir de uma iniciativa artística, está completamente imersa no real, confundindo-se com ele e recolhendo da vida cotidiana os elementos para a sua composição. Para Eleonora Fabião, é nesse ponto que se encontra a força da performance, em um ato de des-automatização da relação do cidadão com a polis. A autora nos convida a refletir menos sobre o que significa uma performance e mais "sobre o que move [um]a performance e o que [um] performance é capaz de mover" (FABIÃO in TELLES e FLORENTINO, 2009, p.63). Ela evoca uma questão que poderia ter sido lançada aos situacionistas, quando questiona não apenas o que é "a arte contemporânea, mas o que queremos, contemporaneamente, que a arte seja" (Ibid. p. 61).

Não se trata, portanto, de suprimir a arte e transformar essas experiências em recortes da vida, nem de suprimir a arte para que uma revolução aconteça, mas em manter a tensão entre essas duas esferas. É certo que a função da arte atual não é ornamentar, nem produzir luxo ou beleza; ela já não se propõe a refletir o real de maneira mimética. A arte também não se limita a uma operação que visa difundir ideias e conhecimentos, mensagens políticas e morais. Walter Moser afirma que a arte já assumiu muitas funções dentro de sua história ocidental, porém ela não esgota suas possibilidades de interação com o mundo do qual ela faz parte. E para além de representá-lo, cabe à arte intervir no real, inventando ou- 
tros mundos possíveis, criando "mundos alternativos que permitam lançar um olhar crítico sobre o que se apresenta como a única realidade possível" (MOSER in FERAL e PERROT, 2013, p. 93) 7 .

Diante das inúmeras transformações às quais a "arte" já foi submetida, Walter Moser apresenta dois requisitos mínimos para que a arte seja definida como tal. O primeiro é de natureza pragmática e consiste em dizer "isto é arte", que o autor define como staging (encenação) e que independe de um espaço tradicionalmente vinculado ao fazer artístico. O segundo requisito, de natureza ôntica (relativa ao fenômeno, ao que os sentidos nos mostram) e não ontológica (relativa ao ser) - o framing (enquadramento) - consiste em submeter a modalização "como se", o que poderia atenuar sua responsabilidade civil, política, moral, possibilitando uma grande liberdade de expressão. Tal modalização, segundo o autor, não atenuaria a intensidade estésica com a qual os diversos componentes de uma obra de arte podem interpelar o aparelho sensorial do espectador. Segundo Moser, "ao observar a aplicação dessas duas condições, torna-se evidente que a fronteira entre arte e não-arte é movediça e deve ser redefinida com a mudança dos contextos históricos" (Ibid. p. 96) ${ }^{8}$.

Em entrevista recente à Eric Nepomuceno, a poeta portuguesa Matilde Campilho fala sobre o que seria para ela a função da arte $^{9}$, relembrando um momento epifânico que vivenciou ao se deparar com uma pintura de Pollock quando era criança. Para ela, se existe alguma função na arte é a de salvar certos momentos, descrevendo a sensação de beleza e espanto que teve diante de algo desconhecido, ao mesmo tempo em que sentiu os joelhos fraquejarem um pouquinho. Segundo ela, cabe à arte tirar a atenção da dor e quando for preciso colocar a atenção na dor também, pois andamos distraídos demais. Fico me perguntando depois de ouvir Matilde Campilho, quantas vezes realmente senti os joelhos fraquejarem e quanto as condições para que essa sensação se instale em nossos corpos independe do espaço institucional, do artista virtuose e de condições adequadas de pressão e temperatura.

Exemplo disso, são os decretos conceituais espalhados por Paulo Nazareth em diferentes pontos da cidade de Belo Horizonte, declarando que "Aqui é Arte". Em um decreto datado de 05 de dezembro de 2005, ele atesta que um buraco na parede da Avenida Dr. Otacílio Negrão de Lima, de onde pode-se ver o mato crescer no período da chuva é arte. Em outro, do mesmo dia e ano, ele declara que entre às $4 \mathrm{~h}$ e às $7 \mathrm{~h}$ da manhã, sob a barragem da Pampulha (entre as avenidas Presidente Antonio Carlos e D. Pedro I), se você se colocar sobre o escoadouro do córrego do Onça, um pássaro passará por baixo dos seus pés e que esse instante é arte (NAZARETH, 2012, s.p.).

\footnotetext{
7 [...] mondes alternatifs qui permettent de jeter un regard critique sur ce qui se donne comme la seule réalité possible (tradução minha).

8 À observer l'application des ces deux conditions, il devient évident que la frontière entre art et non-art est mouvante et doit être redéfinie avec le changement des contextes historiques (tradução minha).

9 Disponível em: <https://www.youtube.com/watch?v=UFI1YOMNuEo>. Acesso em: 27 fev. 2017.
} 


\section{AQUI É ARTE}

Decreto conceitual de 05 de dezembro de 2005

$\mathrm{Na}$ Avenida Dr. Otacilio Negrão de Lima , número 17397 Pampulha, Belo Horizonte MG / Brasil; há um muro com um buraco por onde vocé pode ver o mato crescer no periodo da chuva.

$$
\text { Data }
$$

Validado

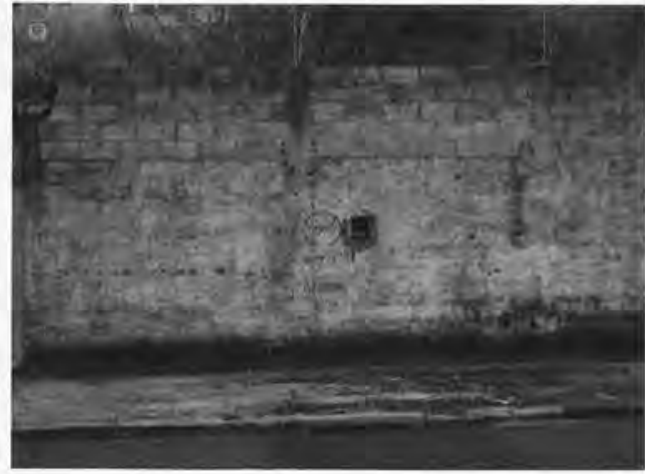

\section{AQUI É ARTE}

Decreto conceitual de 05 de dezembro de 2005 Dat validade

Entre as 4:00 e 7:00 da manhã, vá á barragem da Pampulha entre as Avenidas Presidente Antonio Carlos e D.Pedro I, Belo Horizonte MG / Brasil.Coloque-se exatamente em cima do escoadouro que dá para o corrego do Onça,um passaro irá passar por baixo de seus pés
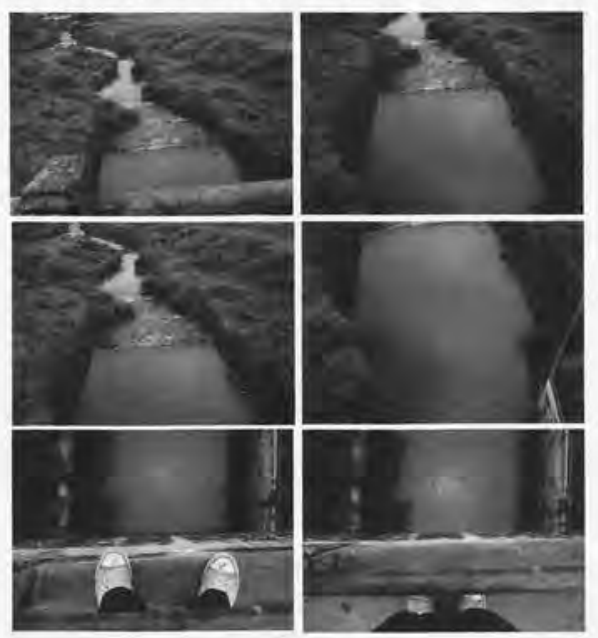

O que todos os autores evocados até aqui sugerem é que a arte é capaz de colocar em contato elementos que se mantém separados na ordem dada ao mundo e induzir uma desordem exploratória (para usar uma expressão de Moser). Esse autor afirma que diferentes discursos, práticas, experiências e categorias de objetos articulados de maneira experimental permitem que a arte não se restrinja à tradicional função mimética e se assuma funções cognitivas, críticas e utópicas (MOSER in FERAL e PERROT, 2013, p. 94).

Jacques Rancière, por sua vez, afirma que "não há o que compreender", diante da suposta dificuldade de entendimento relacionada à arte contemporânea. Conforme o autor, o que existem são encontros que podem ou não acontecer. A ideia de emancipação está apoiada na suposição de que todos são capazes, não há uma superioridade de inteligência entre o mestre e o aprendiz, assim como ela não existe entre o artista e o espectador. Nesse sentido, Maria Lúcia Pupo ressalta, em artigo sobre o espectador, essa noção-chave na obra de Rancière: a ideia de tradução, na qual a autora identifica um deslocamento da fruição da cena de uma aquisição intelectual para a formulação de correspondências. Ela insiste que cada pessoa poderá traduzir à sua maneira o que apreende de uma cena, lembrando que Rancière estabelece uma relação entre tradução e aventura, pois "nenhuma aventura se parece com a outra" (2012, p. 95).

Parece relevante destacar que embora eu afirme que a arte contemporânea prescinda de mediação, as outras materialidades decorrentes das criações em performance apresentadas ao longo do último capítulo da tese podem ter uma função mediadora da relação com o público. Isso não significa que a fruição dessas ações dependa das materialidades apon- 
tadas, mas sim que essas últimas são constitutivas do ato performativo. Desse modo, fotografias, vídeos, desenhos e relatos produzidos pelos artistas, bem como os programas de performance, identificados como primeiros elementos portadores de um potencial pedagógico, são capazes de mobilizar desdobramentos e invenções da parte de toda e qualquer pessoa que se deixar tocar por determinada ação. São esses vestígios da produção artística contemporânea que me levam a criar programas nos quais eu sigo mulheres e me coloco em seus lugares, refletindo sobre as desigualdades de gêneros no espaço público. São eles também que me fazer caminhar pelas ruas em busca de buracos nas paredes, brechas ou fendas nos muros que mostrem visões da cidade que não posso ter enquanto me desloco de carro ou ônibus. Foi assim, por exemplo, que durante uma deriva, o Coletivo Teatro Dodecafônico descobriu uma porção de mata atlântica sob um viaduto, atravessado por carros em alta velocidade. Ao lado do trilho do trem, cercado por antigas construções de galpões atualmente abandonados, o mato cresceu como se nenhuma civilização tivesse chegado em pleno centro de São Paulo.

\section{> V. caminhar como prática estética e política}

Criar não é a tarefa do artista, sua tarefa é a de mudar o valor das coisas. Yoko Ono

Nas ações que nos levam a percorrer a cidade a pé, o ato de caminhar é ação estética e ao mesmo tempo gera a produção de outras materialidades. Levando-se em conta o espaço estriado (Deleuze e Guattari), luminoso (Milton Santos) e cheio (Careri) da cidade, estrategicamente planejado e constituído, caminhar no contexto dessas ações cria territórios nômades e se configura como tática de transgressão de padrões de comportamento. Essas ações não buscam representar a organização político-social da cidade, elas a questionam e a reinventam, propõem modos de se relacionar com os transeuntes e criam intervenções ou turbulências na estrutura urbana. Observar uma ação artística como tática pressupõe a reconfiguração temporária, e apenas temporária, da cidade real. Por mais que seu campo de atuação seja o espaço urbano concreto e que essas ações emerjam como acontecimentos aos olhos dos passantes, seu investimento está no campo do imaginário. A cidade é hoje um lugar de fluxos muito intensos, de aglomeração e de presença massiva de pessoas. A maior parte dos usuários da cidade passam mais tempo fora do que dentro de casa, no entanto a rua não pode ser considerada como o inverso dos espaços interiores, pois à história que se inscreve nela correspondem a organizações sociais que se instalam dentro de nossas casas. Desse modo, caminhar é tática, resistência a estratégias de um sistema de poder.

Depois de apresentar no primeiro capítulo dessa tese o cenário de dissolução da cena te- 
atral contemporânea - o que segundo Eleonora Fabião corresponde a abdicar "de muitos (senão de todos) os elementos ditos constitutivos da cena dramática" - e da constatação da ausência desses elementos no campo da performance, passei à distinção de diferentes modalidades do caminhar em ações com fins artísticos, poéticos e políticos. Ao realizar as análises das encenações e performances deambulatórias foi possível perceber que muitas ações poderiam servir de exemplo para diferentes modos do caminhar. Caminhar em suas múltiplas facetas: uma errância atenta, uma vagabundagem experimental, uma deambulação ritual, um nomadismo poético. Caminhar torna-se uma ação artística em si, uma ação estética (para Careri), uma atitude (para Francis Alÿs), outro modo de sociabilidade (pensando nas ideias de Bourriaud), uma tática de encontro e de apropriação da cidade. Aliás, classificar tais ações não era meu objetivo final, mas sim colocar modos distintos do caminhar em comparação, investigando detalhadamente as implicações desses deslocamentos urbanos objetivos ou subjetivos, artísticos ou cotidianos, mais ou menos visíveis, solitários ou coletivos.

Ao reunir modalidades artísticas diversas, unidas pela ideia de que há um índice de performatividade em todas essas ações fundadas sobre o caminhar, acabei produzindo uma cartografia de ações deambulatórias realizadas nos últimos 60 anos. Esse estudo me mostrou que há nessas ações um potencial transformador dos corpos e transgressor das regras vigentes no contexto urbano.

\footnotetext{
"Todos na rua" é o grito de guerra dos cidadãos revoltados, pois é na rua que se exerce o poder do povo. Lugar tumultuoso onde se opera a grande mistura da vida citadina, a rua é por esta razão mesmo tão perigosa e fascinante quanto um curso de água turbulenta (SOLNIT, 2002, p. 236). ${ }^{1}$
}

Após uma deriva realizada com o Dodecafônico, Sandra Ximenez escreveu: "A cidade acende desejos" ${ }^{\prime 2}$, catalisando uma porção de sensações que os nossos corpos acumulam. Nos últimos quatro anos, lancei-me na cidade com o propósito de estudar, de entender e perceber sua estrutura, seus fluxos, suas densidades. Raramente estamos disponíveis para percebê-la enquanto circulamos por ela, tão absortos que nos encontramos entre um compromisso e outro, entre o trabalho e a casa, entre um encontro e uma entrevista de emprego. Todos os itinerários tendem a ser ocupados por preocupações ou tentativas de tornar os tempos úteis, numa luta constante pela sobrevivência. Todas as táticas para perder-se organizadas junto com o Coletivo Teatro Dodecafônico, bem como todas as explorações do espaço público que realizamos nos colocam repetidamente para reconsiderar nossa relação com a cidade. São táticas que nos posicionam efetivamente no corpo-a-corpo com a cidade,

\footnotetext{
1 "Tous dans la rue" est le cri de ralliement des citadins révoltés, car c'est dans la rue que s'exerce le pouvoir du peuple. Lieu tumultueux où s'opère le grand brassage de la vie citadine, la rua est pour cette raison même aussi dangereuse et fascinante qu'un cours d'eau tourbillonnant (tradução minha).

2 Essa frase entrou na composição da música "Um lugar chamado cidade", realizada a partir de escritas automáticas pós derivas.
} 
refletindo sobre ela e como a (re)construímos a cada itinerário.

Estudar o caminhar como princípio, como meio e como fim para ações artísticas me fez reservar trajetos de vida para serem apreciados. Primeiramente, com as escritas prévias, depois com escritas automáticas em reação a percursos que realizo recorrentemente e, por último, incluindo trajetos para serem percorridos a pé na minha vida cotidiana. Essa escoIha não se justifica simplesmente como uma alternativa ao transporte público ou individual, configura-se como uma proposta política. É importante percorrer as ruas com o próprio corpo, como forma de viver e perceber a cidade, é ativismo, é artivismo. É assim que construímos percursos, (re)conhecemos pessoas, integramos fluxos, percebemos as necessidades e as urgências das cidades. Quanto mais nos fechamos, nos deixamos transportar e evitamos pisar as calçadas, mais investimos na cultura do medo, na exaltação dos espaços privados, na concepção de que a rua é perigosa para as mulheres, na impossibilidade de se brincar na rua e de ocupar os espaços públicos com atividades de cultura e de lazer.

Em última instância, arrisco afirmar que uma ação artística só poderá ser verdadeiramente política e transformadora para quem a realiza ou para quem acessa as ferramentas para sua fruição. Por isso, quando programas performativos são disponibilizados para toda e qualquer pessoa, os efeitos dessas ações são ampliados, por permitirem que mais pessoas experimentem seus corpos em condições distintas daquelas exploradas usualmente. E para que mais pessoas possam viver tais experiências dependemos da manutenção e da criação de programas públicos de educação e cultura, pois a arte sozinha, sem dar os braços para outros sistemas de mobilização e produção de conhecimento, não pode ser responsabilizada pela retirada da população de um certo estado de anestesia. Ciente do quanto as grandes transformações sociais implicam em mudanças estruturais e definitivas nos sistemas políticos, para que haja menos pessoas em estado de sobrevivência, aposto nessas experiências artísticas fundadas no caminhar como atos de transgressão do sistema vigente.

Arrisco também afirmar que - fora os casos nos quais o sujeito experimenta ele mesmo, com seu próprio corpo, uma ação artística - nem sempre o encontro presencial com uma performance é o mais impactante. $\mathrm{O}$ acesso aos seus desdobramentos pode se constituir uma operação muito mais complexa que a primeira observação de um evento, pois desse encontro, muitas perspectivas podem ser abertas. Entendo a rua como campo de experiência legítima e como espaço de exploração de outros modos de sociabilidade e de convívio. Por isso, ao fazer do caminhar uma prática estética, inventamos não apenas micro-poéticas na esfera da vida, mas também micropolíticas do devir. 


\section{>> referências bibliográficas}

AGAMBEN, Giorgio. O que é contemporâneo? Chapecó: Argos, 2009.

Qu'est-ce qu'un dispositif? Paris: Payot et Rivages, 2007.

AGRA, Lúcio. Autor/autores - performance no coletivo ou de como a reencenação da performance é um fator estratégico para sua pedagogia. Revista Sala Preta, São Paulo, n. 8, p. 247-252, 2008.

. O que chamamos de performance? Conceição/Conception, Campinas, v. $1, \quad$ n. 1, p.75-85, dez. 2012.

ARAGON. Le paysan de Paris. Paris: Gallimard, 1953.

ARAÚJO, Antonio. A encenação no coletivo: desterritorializações da função do diretor no processo colaborativo. 2008. Tese (Doutorado em Artes Cênicas) - Escola de Comunicações de Artes, Universidade de São Paulo, 2008.

A encenação performativa. Revista Sala Preta, São Paulo, n. 8, p. 253-257, 2008.

ARDENNE, Paul. Un art contextuel: Création artistique en milieu urbain, en situation, d'intervention, de participation. Paris: Flammarion, 2002.

AUSTIN, John. Quando dizer é fazer. Porto Alegre: Artes Médicas, 1990.

BARTHES, Roland. A câmara clara. Rio de Janeiro: Nova Fronteira, 1984.

BAUDELAIRE, Charles. Paraísos Artificiais, Porto Alegre: L\&PM, 1998.

.Sobre a modernidade: o pintor da vida moderna. Rio de Janeiro: Paz e Terra, 1997.

BAUMAN, Zygmunt. Vida em fragmentos. São Paulo: Jorge Zahar, 2011.

BHABHA, Homi K. El lugar de la cultura. Buenos Aires, Manantial, 2002.

BENJAMIN, Walter. CEuvres III. Paris: Gallimard, 2000.

. Magia e técnica, arte e política: ensaios sobre literatura e história da cultura. 7. ed. São Paulo: Brasiliense, 1994. v. 1.

Rua de mão única. São Paulo: Brasiliense, 1987.

BIRCH, Anna; TOMPKINS, Joanne. Performing site-specific theatre: Politics, Place, Practice. London: Palgrave Macmillan, 2012.

BISHOP, Claire. Artificial hells: participatory art and the politics of spectatorship. London: Verso, 2012.

Participação e espetáculo: Em que ponto estamos agora? Revista Celeuma, São Paulo, n. 5, jun. 2016. Disponível em: <http://www.mariantonia.prceu.usp.br/celeuma/?q=revista/5/participa\%C3\%A7\%C3\%A3o-e-espet\%C3\%A1culo-em-que-ponto-estamos-agora $>$. Acesso em: 30 jun. 2016. 
BOURRIAUD, Nicolas. Esthétique relationnelle. Monts: Les presses du réel, 1998.

CABALLERO, lleana Diéguez. Cenários liminares: teatralidades, performances e política. Uberlândia: EDUFU, 2011.

.Cenários Liminares: teatralidades, performances e política. 2. ed. rev. e ampl. Uberlândia: EDUFU, 2016.

CALLE, Sophie. Des histoires vraies. Arles: Actes Sud, 2013.

Suite vénitienne. Paris: Éditions de l'Étoile / Cahiers du cinéma, 1983.

CAMART, Cécile. Sophie Calle, de dérives en filatures: un érotisme de la séparation. ESSE Dérives II, Montréal, n. 55, automne 2005.

CANDELA, Iria. Sombras de la ciudad. Arte y transformación urbana en Nueva York, 19701990. Madrid: Alianza, 2004.

CARASSO, Jean-Gabriel. Nos enfants ont-ils droit à l'art et à la culture? Toulouse: Éditions de l'Attribut, 2011.

CARDIFF, Janet; SCHAUB, Mirjam. Janet Cardiff : the walk book. New York: Public Art Found, 2005. Disponível em: <https://issuu.com/tba21/docs/the_walk_book_complete>. Acesso em: 5 jan. 2017.

CARERI, Francesco. Walkscapes: o caminhar como prática estética. São Paulo: G. Gili, 2013.

CARREIRA, André (Org.). Teatralidade e Cidade. Cadernos do Urdimento. Florianópolis: UDESC, 2011.

CERTEAU, Michael de. A invenção do cotidiano. Petrópolis: Vozes, 2014. v.1.

COELHO, Teixeira. A cultura e seu contrário. São Paulo: lluminuras / Observatório Itaú Cultural, 2008. 2008.

(Org.). A cultura pela cidade. São Paulo: Iluminuras e Observatório Itaú Cultural,

COHEN, Renato. Performance como linguagem. São Paulo: Perspectiva, 2007.

. Work in progress na cena contemporânea. São Paulo: Perspectiva, 1998.

CRUZ, Beatriz Silva. O corpo na deriva. 2016. Monografia (TCC) - Pontifícia Universidade Católica, São Paulo, 31 mar. 2016.

DAVILA, Thierry. Marcher, créer. Déplacements, flâneries, dérives dans l'art de la fin du XXe siècle. Paris : Éditions du Regard, 2002.

DEBORD, Guy. A Sociedade do espetáculo. Rio de Janeiro: Contraponto, 1997.

. Le marquis de Sade a des yeux de fille. Paris: Fayard, 2004.

. Cuvres. Paris: Éditions Gallimard, 2006.

DELEUZE, Gilles. Crítica e clínica. São Paulo: Editora 34, 2011.

DELEUZE, Gilles; GUATTARI, Félix. Mil platôs: capitalismo e esquizofrenia, São Paulo: Editora 34, 1995. v. 1. 
. Mil platôs: capitalismo e esquizofrenia. São Paulo: Editora 34, 1996. v. 3.

Mil platôs: capitalismo e esquizofrenia. São Paulo: Editora 34, 1997. v. 5.

DELPEUX, Sophie. Le corps-caméra. Le performer et son image. Paris: Textuel, 2010.

DESGRANGES, Flávio. A inversão da olhadela: alterações no ato do espectador teatral. São Paulo: Hucitec, 2012.

A pedagogia do espectador. São Paulo: Hucitec, 2003.

DORWART, Laura. Revisiting Janet Cardiff's Central Park Audio Walk as an Ophelian Performance and Representation. Liminalities: A Journal of Performance Studies, v. 12, n. 2, 2016. Disponível em: <http://liminalities.net/12-2/cardiff.pdf>. Acesso em: 05 jan. 2017.

DUBATTI, Jorge (Coord.). Micropoéticas II. Buenos Aires: Centro Cultural de la Cooperación, 2003.

DUBOIS, Philippe. O ato fotográfico e outros ensaios. Campinas: Papirus, 1993.

FABIÃO, Eleonora. Ações: Eleonora Fabião. Rio de Janeiro: Tamanduá Arte, 2015.

Performance e Teatro: poéticas e políticas da cena contemporânea. Revista Sala Preta, São Paulo, n. 8, p. 235-246, 2008.

Programa Performativo: o corpo-em-experiência. ILINX Revista do LUME, Campinas, n. 4, 2013. Disponível em: <http://gongo.nics.unicamp.br/revistadigital/index.php/ lume/article/view/276/256>. Acesso em: 01 jun. 2016.

FERNANDES, Silvia. Teatralidades Contemporâneas. São Paulo: Perspectiva, 2010.

Teatralidade e performatividade na cena contemporânea. Revista Camarim, São Paulo, ano 15, n. 46, p.20-29, 2012.

FÉRAL, Josette. Além dos limites. Teoria e Prática do Teatro. São Paulo : Perspectiva, 2015.

Les paradoxes de la théâtralité. Théâtre Public : du théâtral et du performatif, Montreuil, p. 8-11, juil.-sept. 2012.

. Performance e Performatividade: o que são os Performance Studies? In: MOSTAÇO, Edélcio et al. (Org.). Sobre performatividade. Florianópolis: Letras Contemporâneas, 2009. p. 49-85.

Por uma poética da performatividade: o teatro performativo. Revista Sala Preta, São Paulo, n. 8, p. 197-210, 2008.

(Org.). Pratiques performatives: BodyRemix. Rennes: Presses Universitaires de Rennes; Québec: Presses de l'Université du Québec, 2012.

.Théorie et pratique du théâtre. Au-delá des limites. Paris: L’Entretemps, 2011.

FÉRAL, Josette; PERROT, Edwige (Org.). Le réel à l'épreuve des technologies: Les arts de la scène et les arts médiatiques. Rennes: Presses Universitaires de Rennes; Québec: Presses de I’Université du Québec, 2013.

FERRIER, Nicolas. Situations avec spectateurs. Recherches sur la notion de situation. Paris: Presses de l'Université Paris-Sorbonne, 2012. 
FINTER, Helga. A Teatralidade e o teatro: espetáculo do real ou realidade do espetáculo? Revista Camarim, São Paulo, ano 10, n. 39, p. 8-19, 2007.

FISCHER-LICHTE, Erika. Estética de lo performativo. Madrid: Abada, 2011.

FRIED, MICHAEL. Arte e objetidade. Revista Arte e Ensaios, Rio de Janeiro, n. 9, p. 130-147, 2002. Tradução de Milton Machado.

GENET, Jean. L’atelier d'Alberto Giacometti. Paris: L’Arbalète / Gallimard, 1995.

GLUSBERG, Jorge. A arte da performance. 2.ed. São Paulo : Perspectiva, 2016.

GODFREY, Mark et al. (Org.). Francis Alÿs: a story of deception. New York: The Museum of Modern Art, 2010.

GOLDBERG, Roselee. A Arte da performance: do Futurismo ao Presente. São Paulo: Martins Fontes, 2006.

GONON, Anne. Tout ouïe: la création musicale et sonore en espace public. Montpellier: Éditions l’Entretemps, 2016.

GROS, Frédéric. Petite bibliothèque du marcheur. Paris: Flammarion, 2011.

GUATTARI, Félix; ROLNIK, Suely. Micropolítica: cartografias do desejo. Petrópolis: Vozes, 1986.

GUÉNOUN, Denis. 0 teatro é necessário? São Paulo: Perspectiva, 2004.

GUINSBURG, Jacó; FERNANDES, Silvia (Orgs.). O pós-dramático: um conceito operativo? São Paulo: Perspectiva, 2009.

GUY, Emmanuel; LE BRAS, Laurance (Org.). Guy Debord: un art de la guerre. Paris: Bibliothèque nationale de France / Gallimard, 2013.

HAMIDI-KIM, Bérénice. Les cités du théâtre politique en France depuis 1989. Montpellier: L’Entretemps, 2013.

HARVEY, David. Cidades rebeldes. São Paulo: Martins Fontes, 2014.

HOUAISS, Antônio ; VILLAR, Mauro de Salles. Dicionário Houaiss da Língua Portuguesa. Rio de Janeiro: Objetiva, 2001.

HUIZINGA, Johan. Homo ludens: o jogo como elemento da cultura. São Paulo: Perspectiva, 2012.

JACQUES, Paola Berenstein. Apologia da Deriva. Escritos situacionistas sobre a cidade. Rio de Janeiro: Casa da Palavra, 2003.

Elogio aos errantes. Salvador: Editora da Universidade Federal da Bahia, 2012.

JONES, Amelia. Presence in absentia. Experiencing performance as documentation. Art Journal, New York, v. 56, n. 4, p. 11-18, 1997. Disponível em: <http://art.usf.edu/file_uploads/presence.pdf>. Acesso em: 5 dec. 2016.

KASTRUP, Virgínia. O funcionamento da atenção no trabalho do cartógrafo. Psicologia \& Sociedade, Rio de Janeiro, v. 19, n. 1, p. 15-22, jan./abr. 2007. 
KAPELUSZ, Anyssa. Quitter la communauté? L'écoute au casque dans les dispositifs théâtraux contemporains. Théâtre Public - Penser le spectateur, Montreuil, p. 124-128, avril/ juin 2013.

http://www.critical-stages.org/7/le-point-de-vue-du-spectateur/KAYE, Nick. Site-specific art: performance, place and documentation. London: Routledge, 2008.

LARROSA, Jorge. Tremores: Escritos sobre experiência. Belo Horizonte: Autêntica, 2014.

LEBEL, Jean-Jacques. Happenings ou l'insoumission radicale. Paris: Hazan, 2009.

LE BRETON, David. Elogio del caminar. Madrid: Siruela, 2011.

LEFEBVRE, Henri. Espaço e política. O direito à cidade II. 2.ed. Belo Horizonte: Editora da UFMG, 2016.

LEHMANN, Hans-Thies. Teatro pós-dramático. São Paulo: Cosac \& Naify, 2007.

LEPECKI, André. Coreopolítica e coreopolícia. Ilha, Florianópolis, v. 13, n. 1, p. 41-60, jan./ jun. 2012.

LUCET, Sophie. Mémoires et pouvoirs du spectateur. Théâtre Public - Penser le spectateur, Montreuil, n. 208, p. 98-102, avril/juin 2013.

MARCOLINI, Patrick. Le mouvement situationniste: une histoire intellectuelle. Montreuil: Éditions L’Echappée, 2013.

MARTEL, Richard (Org.). Art action: 1958 a 1998. Québec : Intervention, 2001.

MELIM, Regina. A fotografia como documento primário e performance nas artes visuais. Crítica Cultural, Tubarão, v. 3, n. 2, 2008. Disponível em: <http://www.portaldeperiodicos. unisul.br/index.php/Critica_Cultural/issue/view/16>.Acesso em: 5 dez. 2016.

Performance nas artes visuais. Rio de Janeiro: Jorge Zahar, 2008.

MERCIER, Luc. Archives situationnistes, documents traduits (1958-1970). Paris: Contre-Moule/Parallèles, 1997. v. 1.

MERVANT-ROUX, Marie-Madeleine. Figurations du spectateur: une réflexion par l'image sur le théâtre et sur sa théorie. Paris : L’Harmattan, 2006.

MONNET, Nadja. Flanâncias femininas e etnografia. Revista Redobra: Laboratório Urbano, Salvador, n. 11, ano 4, p. 218-234, 2013.

MÜLLER, Heiner. Quatro textos para teatro: Mauser, Hamlet-máquina, A Missão, Quarteto. São Paulo: Hucitec, 1987.

NAZARETH, Paulo. Paulo Nazareth, Arte Contemporânea/LTDA. Rio de Janeiro: Cobogó, 2012.

NEVEUX, Olivier. Politique du spectateur: les enjeux du théâtre politique aujourd'hui. Paris: La Découverte, 2007.

Une conception tactique et stratégique du spectateur ? Quatre proposition sur la politique et le théâtre. Théâtre Public : penser le spectateur, Montreuil, n. 208, p. 25-29, avril-juin 2013.

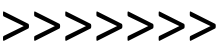


OITICICA, Hélio; OITICICA FILHO, Cesar; COELHO, Frederico (Org.). Conglomerados newyorkaises (1939-1980). Rio de Janeiro : Beco do Azougue, 2013.

O'ROURKE, Karen. Walking and mapping: artists as cartographers. London: The MIT Press, 2013.

ONO, Yoko. Grapefruit : a book of instruction and drawings by Yoko Ono. New York: Simon \& Schuster, 1964.

PAVIS, Patrice. A análise dos espetáculos. São Paulo: Perspectiva, 2005.

Dicionário de Teatro. São Paulo: Perspectiva, 1999.

2014.

Dictionnaire de la performance et du théâtre contemporain. Paris: Armand Colin,

La mise en scène contemporaine. Paris: Armand Colin, 2010.

. Le point de vue du spectateur, Critical Stages, Paris, n. 7, dez. 2012. Disponível em: $<$ http://www.critical-stages.org/7/le-point-de-vue-du-spectateur/>. Acesso em: 29 mar. 2017.

PATO, Ana et al (org.). Liminaridade. São Paulo: Parole, 2015

PELBART, Peter Pál. Biopolítica. Revista Sala Preta, São Paulo, n. 7, p. 57-65, 2007.

PINTO, Joana Plaza. O percurso da performatividade. Revista Cult, São Paulo, n. 185, ano 16, p.35-37, nov. 2013.

PRECIADO, Beatriz. Aimer une ville. Libération, Paris, 04 dez. 2015. Disponível em: <http:// www.liberation.fr/debats/2015/12/04/aimer-une-ville_1418398>. Acesso em: 20 jan. 2017.

. O feminismo não é um humanismo. O Povo, Fortaleza, 24 nov. 2014. Disponível em: <http://www20.opovo.com.br/app/colunas/filosofiapop/2014/11/24/noticiasfilosofiapop,3352134/o-feminismo-nao-e-um-humanismo.shtml>. Acesso em: 24 mar. 2016.

Manifesto contrasexual. Práticas subversivas de identidade sexual. São Paulo: n-1 edições, 2014.

PRECIOSA, Rosane. Rumores discretos da subjetividade: sujeito e escritura em processo. Porto Alegre: Editora da UFRGS, 2010.

POE, Edgar Allan. Nouvelles histoires extraordinaires. Paris: Gallimard, 2006. Tradução de Charles Baudelaire.

PUPO, Maria Lúcia. Alteridade em cena. Revista Sala Preta, São Paulo, v. 12, n. 1, p. 4657, jun. 2012.

.Création et action théâtrales à São Paulo. Horizons/Théâtre, Bordeaux, n. 2, p. 116-129, oct. 2012/mars 2013.

2001.

. O lúdico e a construção do sentido. Revista Sala Preta, São Paulo, v. 1, p. 181-187,

Por uma arte do espectador. A[L]BERTO Revista da SP Escola de Teatro, n. 3, p. 90- 
96, primavera de 2012.

RANCIÈRE, Jacques. O espectador emancipado. São Paulo: Martins Fontes, 2012.

. Les scènes de l'émancipation: entretien avec Jacques Rancière. Théâtre Public : penser le spectateur, Montreuil, p. 8-15, avril-juin 2013.

A partilha do sensível: Estética e Política. São Paulo: Editora 34, 2012.

SALLES, Cecília Almeida. Gesto inacabado: Processo de criação artística. São Paulo: Editora da FAPESP, 1998.

Redes da criação: construção da obra de arte. Vinhedo: Horizonte, 2008.

RAMOS, Luiz Fernando. Mimesis Performativa: a margem da invenção possível. São Paulo: Annablume, 2015.

SAISON, Maryvonne. Les théâtres du réel. Paris: L'Harmatan, 1998.

SARRAZAC, Jean-Pierre. (Org.). Léxico do drama moderno e contemporâneo. São Paulo : Cosac \& Naify, 2012.

SCHECHNER, Richard. O que é performance? Revista Percevejo, Rio de Janeiro, n. 12, ano 11, p. 25-50, 2003.

Performance. Expérimentation et théorie du théâtre aux USA. Montreuil-sousBois: Éditions Théâtrales, 2008.

Performance studies: an introduction. New York, Routledge, 2006.

Performer. Revista Sala Preta, São Paulo, v. 9, p. 333-365, 2009.

SOLNIT, Rebecca. L’art de marcher. Arles: Actes Sud, 2002.

SONTAG, Susan. Contra a Interpretação. Porto Alegre: L\&PM, 1987.

Diante da dor dos outros. São Paulo: Companhia das Letras, 2005.

Sobre fotografia. São Paulo: Companhia das Letras, 2004.

TAYLOR, Diana. O Arquivo e o repertório: performance e memória cultural nas Américas. Belo Horizonte: UFMG, 2013.

Performance. Buenos Aires : Asunto Impreso Ediciones, 2012.

TELLES, Narciso e FLORENTINO, Adilson (Org.). Cartografias do ensino do teatro. Uberlândia: EDUFU, 2009.

TRAVERSO, Enzo. Siegfried Kracauer: itinéraire d'un intellectuel nomade. Paris : Éditions la Découverte, 1994.

THOREAU, Henry David. Andar a pé. Rio de Janeiro : W. M. Jackson Inc, 1950. Disponível em: <http://www.ebooksbrasil.org/adobeebook/andarape.pdf>. Acesso em: 22 set. 2016.

TURCOT, Laurent. Le promeneur à Paris au XVIIlème siècle. Paris: Gallimard, 2007.

VELOSO, Verônica G. O teatro em fuga ou quando o teatro escapa de si mesmo. Revista Sala Preta, São Paulo, vol. 13, n. 2, p. 105-120, 2013. 
VISCONTI, Jacopo Crivelli. Novas Derivas. São Paulo: Martins Fontes, 2014.

WIDRICH, Mechtild. Performative Monuments: The rematerialisation of public art. Manchester: Manchester University Press, 2014.

ZACARIAS, Gabriel Ferreira. Expérience et représentation du sujet: une généalogie de l'art et de la pensée de Guy Debord. 2014. Tese (Doutorado) - Université de Perpignan/Università Degli Studi di Bergamo, 2014.

ZUMTHOR, Paul. Performance, Recepção e Leitura. São Paulo: Cosac Naify, 2007.

YEE, Lydia; URSPRUNG, Philip. Laurie Anderson, Trisha Brown, Gordon Matta-Clark: Pioneers of the Downtown Scene, New York 1970s. London: Prestel/Barbican Art Gallery, 2011.

\section{Catálogos:}

- Coletivo Política do Impossível. Cidade Luz: uma investigação-ação no centro de São Paulo. São Paulo: Editora PI, 2008.

- 8‥ Encontro do Hemispheric Institute. Instituto Hemisférico de Performance \& Política. São Paulo, 2013.

- Obra e Documento: Arte/Ação e 3nós3. São Paulo: Centro Cultural São Paulo, Curadoria de Artes Visuais, 2012.

- OPOVOEMPÉ. “A Máquina do Tempo (ou Longo Agora)”, 2012. 